\title{
On the Diplectroninae and Hydropsychinae (Trichoptera) of India, with related taxa. A tribute to Fernand Schmid
}

\author{
J. OLÁH ${ }^{1}$, G. VINÇON ${ }^{2}$ \& K.A. JOHANSON ${ }^{3}$ \\ ${ }^{1} J a ́ n o s$ Oláh,Tarján u. 28, H-4032 Debrecen, Hungary.E-mail: profolah@gmail.com \\ ${ }^{2}$ Gilles Vinçon, 55 Bd Joseph Vallier, F-38100 Grenoble,France.E-mail: gvincon@gmail.com \\ ${ }^{3}$ Kjell Arne Johanson, Swedish Museum of Natural History, Department of Zoology, \\ Box 50007, SE-10405 Stockholm, Sweden.E-mail: kjell.arne.johanson@nrm.se
}

\begin{abstract}
The overall declining state of the western taxonomy is clearly documented by the present fate of the extremely high valued and huge unidentified caddisfly material collected in India and deposited in the Canadian National Collection. Due to the general lack of both financial and scientific resources in taxonomy, this huge collection remained almost untouched during the last 70 years after its collection. With a tribute to the collector, Fernand Schmid, the great caddisfly collector and taxonomist we have reconstructed his collecting activities of the five years in India by geolocalization and elaborated about ten percent of his undetermined Hydropsychidae in the Diplectroninae and Hydropsychinae subfamilies. Description of 145 new species from this small fragment of the huge unidentified collection demonstrates a pronounced underestimation of the biodiversity in general, routinely measured by gross phenomics. During this study we have reinstated the species status of seven taxa: Diplectrona kirimaduhela Schmid, 1958, stat. restit., Cheumatopsyche rienga Oláh \& Johanson, 2008, stat. restit., Cheumatopsyche amurensis Martynov, 1934, stat. restit., Cheumatopsyche banksi Mosely, 1942, stat. restit., Cheumatopsyche processuata (Martynov, 1927), stat. restit., Potamyia klakahana (Ulmer, 1951), stat. restit., Potamyia proboscida Li \& Tian, 1996, stat. restit., and raised the subspecies status to species rank of Diplectrona stigmatica Banks, 1937, stat. nov. Furthermore, we have etablished four new species groups, sixteen new species complexes and described 145 new species as follows: Diplectrona aurovittata new species group: D. hasada new species complex: $D$. bandara sp. nov., D. borghata sp. nov., D. chiangma sp. nov., D. chingsa sp. nov., D. daotama sp. nov., D. grimona sp. nov., $D$. jaraina sp. nov., D. khopurna sp. nov., D. khumyara sp. nov., $D$. kualagomba sp. nov., $D$. kurlingha sp. nov., $D$. lyngkota sp. nov., D. mawkhapa sp. nov., D. mirgona sp. nov., D. muktapura sp. nov., D. mynsoa sp. nov., D. nongina sp. nov., $D$. nongra sp. nov., $D$. nongronga sp. nov., $D$. sirkasha sp. nov., $D$. sironga sp. nov., D. sumatrana sp. nov., D. tairenpokpa $\mathrm{sp}$. nov., D. tungpa sp. nov., D. tamdaophila new species complex: $D$. aisahka sp. nov., D. beluma sp. nov., D. dhampa sp. nov., $D$. dhankuta sp. nov., D. huishua sp. nov., D. khasiaca sp. nov., D. khasigupta sp. nov., D. madonga sp. nov., D. meghalaya sp. nov., D. mopaenga sp. nov., D. parala sp. nov., D. rumkhenga sp. nov., D. sitahoana sp. nov., D. sohra sp. nov., $D$. coalescens species group: $D$. hongkonga sp. nov., D. kattalaimala sp. nov., D. shimoga sp. nov., D. gombak new species group: D. albofasciata new species complex, $D$. fasciata new species complex: D. buitenzorga sp. nov., D. panaona sp. nov., $D$. simalura sp. nov., $D$. tonkulana $\mathrm{sp}$. nov., $D$. wailima $\mathrm{sp}$. nov., $D$. gentinga new species complex: $D$. gentinga $\mathrm{sp}$. nov., $D$. gombak new species complex: $D$. barisana sp. nov., D. merangira sp. nov., D. phanoma sp. nov., D. temengora sp. nov., $D$. tengaha sp. nov., D. taprobanes new species group: D. abmaka sp. nov., D. kambaita sp. nov., D. kamikarka sp. nov., $D$. koda sp. nov., D. komadia sp. nov., D. madhya sp. nov., D. satanwada sp. nov., D. sirtranga sp. nov., D. tienmua sp. nov., $D$. umlanga sp. nov., Cheumatopsyche lepida species group: C. assamha sp. nov., C. fordula sp. nov., C. madpradha sp. nov., $C$. manimapa sp. nov., C. pondora sp. nov., C. puramukta sp. nov., C. purmapa sp. nov., C. sohkha sp. nov., C. swampa sp. nov., $C$. dubitans species group: $C$. mawpya sp. nov., $C$. excisa species group: $C$. chuga sp. nov., $C$. costalis species group: $C$. dangchura sp. nov., C. kamposka sp. nov., C. lagaironga sp. nov., C. mawjana sp. nov., C. mawprana sp. nov., C. nonga sp. nov., C. nongajra sp. nov., C.oinamla sp. nov., $C$. salaka sp. nov., C. yunnana sp. nov., C. concava species group: $C$. haflonga sp. nov., C. kambirona sp. nov., C. khasia sp. nov., C. korosa sp. nov., C. myntanga sp. nov., C. nongrima sp. nov., C. chinensis species group: $C$. bandarkhala sp. nov., C. delhia sp. nov., C. hanoia sp. nov., C. hotaya sp. nov., C. pega sp. nov., C. quangchua sp. nov., C. tamda sp. nov., C. tongoma sp. nov., C. holzschuhi species group: C. apuma new species complex: C. apuma sp. nov., C. nyukma sp. nov., Potamyia czekanovskii species group: $P$. flavata new species complex: $P$. binhoa sp. nov., P. chitwana sp. nov., P. congsa sp. nov., P. moccha sp. nov., P. nikalandugola species complex: P. hasalaka sp. nov., $P$. tamilnada sp. nov., $P$. chinensis species group, $P$. flava species group: $P$. dinamla sp. nov., $P$. trenhona species group: $P$. barata sp. nov., $P$. jinhongensis new species complex: $P$. dhauliana sp. nov., $P$. yunnanica new species complex: $P$. namha sp. nov., P. namkhana sp. nov., $P$. topali sp. nov., $P$. umbaso sp. nov., $P$. vietnama sp. nov., Hydromanicus hermosus species group: H. flavoguttatus species complex: H. bukit sp.nov., H. mawpyut sp. nov., H. mawshun sp. nov., $H$.
\end{abstract}




\begin{abstract}
luctuosus species group nom. nov.: H. asor new species complex: H. shilliang sp. nov., H. eleasar new species complex: $H$. kambaitiensis sp. nov., H. kamengensis sp. nov., H. kashong sp. nov., H. sikkimensis sp. nov., $H$. tibetensis sp. nov., $H$. inferior new species complex: H. darban sp. nov., H. hasad sp. nov., H. jakhand sp. nov., H. khalband sp. nov., H. mattiyang sp. nov., H. mynso sp. nov., H. nondeng sp. nov., H. luctuosus species complex: H. fureses sp. nov., H. garhwal sp. nov., $H$. khopum sp. nov., H. laitlyn sp. nov., H. manilon sp. nov., H. mapum sp. nov., $H$. pufok sp. nov., H. thangrain sp. nov., $H$. tharauyang sp. nov., H. tiyang sp. nov., H. tungnath sp. nov., H. umbonatus new species complex: H. kover sp. nov., $H$. manisir sp. nov., $H$. ronghongkung sp. nov., $H$. sirohis sp. nov., $H$. spatulatus species group: $H$. rahung sp. nov., $H$. spatulatus species cluster.
\end{abstract}

Keywords. Geolocalization, Fernand Schmid, India, Diplectroninae, Hydropsychinae, new species.

\section{INTRODUCTION}

$\mathrm{W}$ e have carried out this study on a very small fragment of hydropsychid specimens from Schmid's collection of Indian Trichoptera with description of 145 new species with our fine phenomics in order to demonstrate its huge diversity and extremely high scientific value. First and foremost we wish to thank for this hydropsychine material we have elaborated in this paper and to express our acknowledgement to Fernand Schmid (1924, Sion, Switzerland 1998, Ottawa, Canada), the Great Trichopterologist, the Ultimate Collector of caddisflies and the teacher of the first author. Soon after completing his groundbreaking research, synthesis and revision, on Limnephilidae family (Weaver \& Nimmo 1999), he made several long-lasting and wide-ranging collecting expeditions to Pakistan (1953-1954), Ceylon (1954: Sri Lanka), Iran (1955-1956), and to India (1958-1962). His expeditions were often lengthy. He spent at least nine months of the year in the field for four years straight in India, except for 1960, when he was there for seven months (Lonsdale 2000).

\section{TRIBUTE TO FERNAND SCHMID}

This entire decade of the intensive field work between 1953 and 1962 was organised through the University of Lausanne, Switzerland, and resulted in an enormous catch of research material. The vast amount of the unidentified materials is deposited in the Canadian National Collection of Insects in Ottawa and still waiting for taxonomists to be elaborated. This will be a hard job, especially to handle the pinned fragile microcaddisflies of a few milimeters. There are two cabi- nets full of pinned, unidentified Trichoptera and much more unspecified specimens are scattered throuhout the collection that was sorted to genus by Fernand Schmid himself (Lansdale 2018). Who will elaborate this extremely rich material with its ultimate scientific value?

The realy high value of Schmid's unidentified Trichoptera collection is documented by the results of the present study. There have been elaborated only about ten percent of the unidentified specimens of the Diplectroninae and Hydropsychinae subfamilies, out of the about 40 families or subfamilies and described over 100 new species. It does not mean however, that we have to multiply 100 by 200 in order to estimate the real potential of the $c a .20$ thousands of Trichoptera species in and around the Indian subcontinent. Actually Schmid has estimated the total number of the South West Asian Trichoptera species about 40 thousands (Schmid 1984). According to Malicky (1993) this high number may be an overestimate even for South East Asia.

It is a shame and an axiomatic failure of our western culture that this high-valued material, collected by ultimate talent, devotion and enthusiasm of a great man, is still almost untouched after 70 years of its collection. However, this is not a surprise! This is the symptomatic result of the depressing scenario created by the declining state of the Western taxonomy. The decline of taxonomy, the basic science of sciences, has started by degrading the phenotype with the conflation of systematics and beanbag genetics that is by the "modern synthesis". This sinister product of scientism is assimilated and adopted in the new systematics of Huxley (1940) and Mayr (1942). 
With this ideology and science policy all the resources are drained from taxonomy and channelled into the "modern synthesis". This decline is supported by the virtual, "modern" analytic philosophy and logical positivism; by the underestimation of empiricism against rationalism and by degrading experience of phenomenology against logics of virtual analysis. All these are resulted in the lack of taxonomists to effectively describe biodiversity; in the lack of adaequate sampling density and frequency; and especially in lack of population sampling, the key momentum in the contemporary perspectives of species level taxonomy. Our teacher in taxonomy, Fernand Schmid is turning in his grave!

Unlike to trips in Sri Lanka, Pakistan and Iran, Schmid has not published any general survey or mapping of his trips to India. We have started to study this small fragments of his hydropsychine specimens relying on the locality names printed on the pinned labels. However, names are shortliving things which may change rapidly for politics and transliteration (Malicky 2018). Therefore we have decided to search the coordinates for Schmid's collecting sites by reconstructing on maps his daily movement during his five years long collecting activities in India. Our maps and tables with figured sites help our present study to identify the distribution character states of species described in this paper. Furthermore, it provides basic geo-localisation for the specimens and may help in giving some impetus for future studies on the huge undetermined caddisfly material collected by Fernand Schmid in India.

\section{Geo-localisation of the Schmid collecting sites in India}

The geo-localization of Schmid's collecting localities was based on the great work of Lonsdale (2020) concerning the Schmid Trichoptera collection in India, and, at a lesser degree on the faunistic list given by Aubert (1966), regarding the Stoneflies collected by Schmid in the same Indian regions. Schmid's Indian activities and localities were hand written in several notebooks but without detailed localization except the name of a village or hamlet followed by its elevation. All these notebooks are already retranscribed by Malicky (2018). Moreover, one manuscript of Schmid is also directly available on the WEB «Field Notes and Taxonomic Observations of Trichoptera in India from 1958 to 1962» (https://archive.org/details/fieldnotestaxon1schm). It is a scan of the original notebook of the $\mathrm{Ku}$ maon region (NW India, Uttarakhand), completed by ecological notes: type of water course, name of the river, aquatic or surrounding vegetation, current speed, type of substratum. These two works are the basis of our reseach work to geolocate the Schmid collecting localities, a hard task since Schmid didn't give any route map for his indian collecting trips and since many indian locality names have changed, as explained by Malicky (2018) and Lonsdale (2020).

For the geo-localization, we have mainly used two motor reseaches (Google Map and Open Street Map) and in some cases the indications given by Lonsdale (2020) who has already located some of them. For a few high elevation sites of difficult access, the locality names are not known on the main motor reseaches, but some of them can be found elsewhere on the WEB. For instance, it is the case of Theulocha and Muguthang, in the heights of the Sikkim mountains (4500 $\mathrm{m}$ asl.) that we found on a trecker's map on an advertisement site (http://www.worldmarco polo.com/site_map.html)

Most localities of Schmid have been located though their names are often slightly different from the one given by Schmid (phonetic script). In case of two different names, we give first the name written in the Schmid's notebook and then the current name found on our maps. To plot the Schmid's localities on a map has helped us to find some names with their new orthography when it corresponds to a localitity placed between two others on the Schmid route. However, some localities remain unknown but for interested researchers, an approximative position can be deduced between the two closest known localities, by interpolation. Lacking numbers on the maps correspond to these unknown localities but more 
often to some localities that are already ploted on the map, when Schmid has returned several times at the same place or at different elevations in the same place, as it is the case for many localities (for instance on the Manipur map, Sirohi Kashong: $14,15,16,17,29,41,42)$. On some maps, we use different colours to separate the different trips of Schmid in the same area, to make the map more readable.

For a better visualisation of the whole collecting effort made by Schmid in India, a first global map (Map 1) shows the 8 main indian regions carefully visited by Schmid: Uttarakhand Map 2), Sikkim and North Western Bengal (Map 3), Assam (Map 4), Meghalaya (Map 5), Manipur + Mizoram (Map 6), Kerala (Map 7a), Tamil Nadu (Map 7b). This global map also shows how Schmid has carefully prepared his successive collecting trips in India, in the great purpose to give to Science a most complete tribute to the Indian Trichoptera as well as to other insects orders also collected by him for his colleagues (Plecoptera, Diptera, ...). It is probably the most considerable effort ever made to prospect a land nearly as big and complex as Europa.

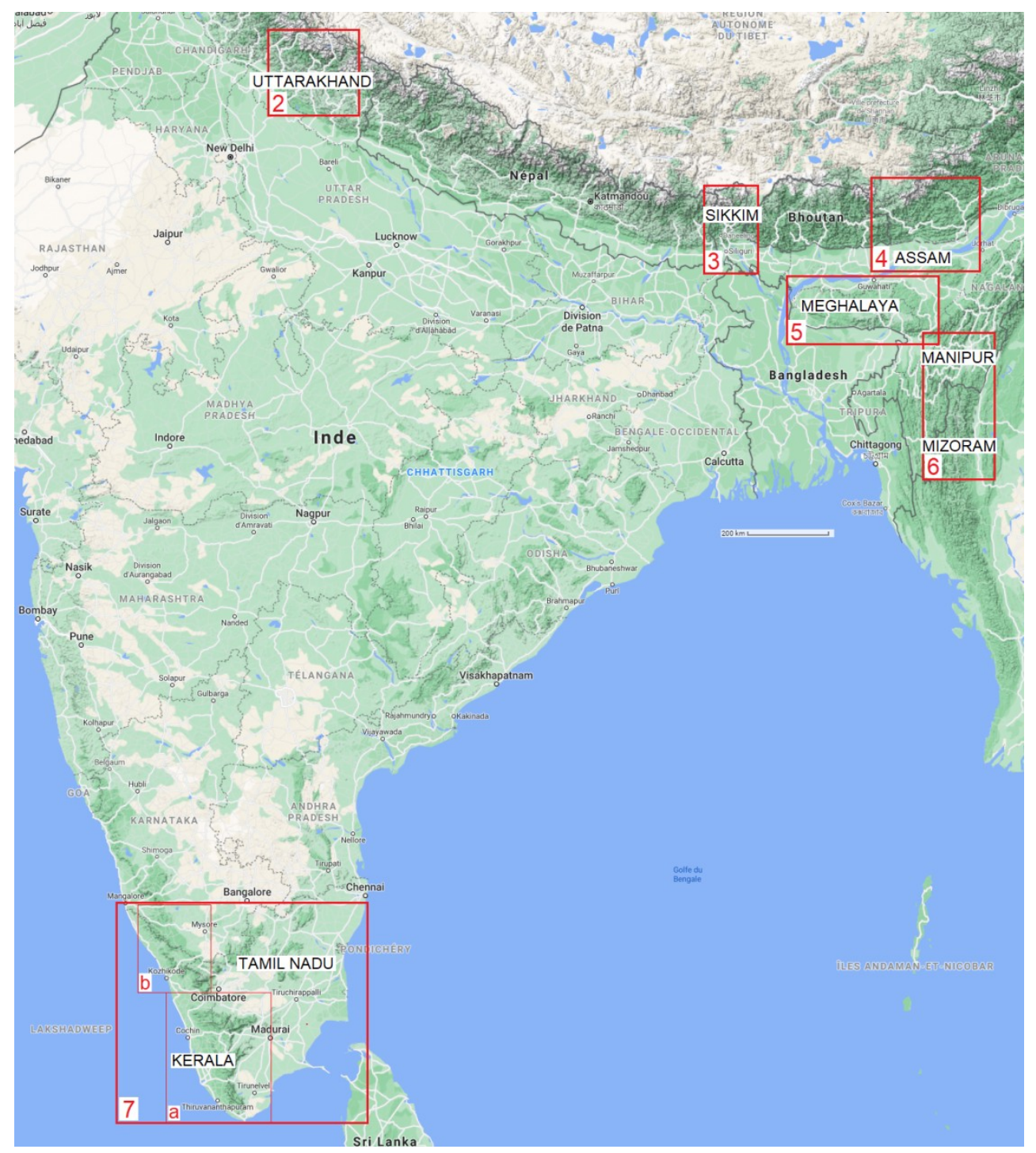

Map 1. The 8 main indian regions visited by Schmid. 


\section{North West India $($ Uttarakhand $)=$ Kumaon 1958 (Map 2)}

This high moutainous region of north western India, named under its old appellation «Kumaon» by Schmid, nowdays named Uttarakhand, is placed westward the Nepal and southward the Tibet (Map 1). The ecological notes given for many localities were written at the end of the Kumaon's notebook of Schmid.

1 Dera Dun $=$ Dehra Dun, $30^{\circ} 18^{\prime} 04.8^{\prime \prime} \mathrm{N} 78^{\circ} 07^{\prime}$ 02.4"E

2 U.P. Rishikesh, $1200 \mathrm{ft}$, Gange River and lateral brooks and springs, $30^{\circ} 05^{\prime} 16.7^{\prime \prime} \mathrm{N} 78^{\circ} 17^{\prime}$ 22.8"E, 25-31.03.1958

3 Nasendranagar $=$ Narendranagar, $2200 \mathrm{ft}$, small river and lateral tributaries in narrow valley, $30^{\circ} 09^{\prime} 36.9^{\prime \prime} \mathrm{N} 78^{\circ} 17^{\prime 2} 24.4^{\prime \prime} \mathrm{E}, 4.04 .1958$

4 Agra $=$ Agrakhal (Lonsdale 2020), 3000-5000 $\mathrm{ft}$, small brook with mosses tributary of Huini River, $30^{\circ} 12^{\prime} 50^{\prime \prime} \mathrm{N} 78^{\circ} 19^{\prime} 41^{\prime \prime} \mathrm{E}, 5-6.04 .1958$

5 Birnu, $4000 \mathrm{ft}$, small brook with mosses, 7.04.1958

6 Katkor $=$ Katkot, $3500 \mathrm{ft}$, small brook, 30 $34^{\prime}$ 08.5"N 78²0'53.9"E, 7.04.1958

7 Ampata, $2500-3500 \mathrm{ft}$, small river tributary of Huini River, $30^{\circ} 16^{\prime} 6^{\prime \prime} \mathrm{N} 78^{\circ} 22^{\prime} 18^{\prime \prime} \mathrm{E}, 10.04$. 1958

8 Rampur, Northwards Bhandargaon, 3000-5000 $\mathrm{ft}$, small torrent tributary of Huini River, $30^{\circ}$ 17'23.6"N 78²2'03.6"E, 11-12.04.1958

9 Tipli $=$ Teepali, $3000 \mathrm{ft}$, hygropetric habitat below a cascade, $30^{\circ} 17^{\prime} 26.7^{\prime \prime} \mathrm{N} 78^{\circ} 21^{\prime} 27.5^{\prime \prime} \mathrm{E}$, 13.04.1958

10 Nagani = Nagani Sera, $4000 \mathrm{ft}$, small river tributary of Huini River, $30^{\circ} 18^{\prime} 41.9^{\prime \prime} \mathrm{N} 78^{\circ}$ 20'29.9"E, 13.04.1958

11 Dobalgaon $=$ Dobhalu $\mathrm{Ka}=$ Than (the locality indicated in Lonsdale (2020) is wrongly assigned to the Schmid itinerary since it is much too far from the road taken by Schmid), 5000$6000 \mathrm{ft}, 2$ small torrents, $30^{\circ} 19^{\prime} 49.7^{\prime \prime} \mathrm{N} 78^{\circ} 23^{\prime}$ 32.5"E, 14.04.1958

12 Jaspur, $3500-4500 \mathrm{ft}$, small torrent in bushes, $30^{\circ} 23^{\prime} 34.7^{\prime \prime} \mathrm{N} 78^{\circ} 25^{\prime} 21.4^{\prime \prime} \mathrm{E}, 15.04 .1958$

13 Teri $=$ Tehri Garhwal District, 2500-5000 ft, small torrent tributary of Bhillangana River and hygropetric habitat, $30^{\circ} 22^{\prime} 13.7^{\prime \prime} \mathrm{N} 78^{\circ} 25^{\prime}$ 55.4"E, 16-21.04.1958

14 Pau Kal = Paukhal Gaon, 4000-5000 ft., river tributary of Bhillangana River and hygropetric habitat, 30²1'48.9"N 78³6'36.7"E, 21-23.04. 1958

15 Jakhanr = Jahkand, $3500 \mathrm{ft}$, below the village, small river tributary of Alaknanda River, $30^{\circ}$ 19'49.4"N 78³9'20.9"E, 24.04.1958

16 Dangchura $=$ Dang Chaunra, 3000-3200 ft, 2 small brooks tributary of Takali Gad, $30^{\circ}$ $15^{\prime} 55.8^{\prime \prime} \mathrm{N} 78^{\circ} 43^{\prime} 02.2^{\prime \prime} \mathrm{E}, 25.04 .1958$

17 Rudraprayag, 1900-2300 ft, small river tributary of Alaknanda and hygropetric habitat, $30^{\circ}$ 17'08.7"N 7858'58.3"E, 28.04.1958

18 Rampur (the locality indicated in Lonsdale (2020) is wrongly assigned to the Schmid itinerary since it is much too far from the road taken by Schmid, while our locality named Rampur is just placed between the previous and next localities on the Schmid's route), 2100-3000 ft, small river and hygropetric habitat, $30^{\circ} 22^{\prime} 01.7^{\prime \prime} \mathrm{N} \quad 78^{\circ} 59^{\prime} 12.7^{\prime \prime} \mathrm{E}, 29.04$. 1958

19 Barakot, 2450-3000 ft, medium size river and hygropetric habitat, $30^{\circ} 23^{\prime} 58.9^{\prime \prime} \mathrm{N} 79^{\circ} 01^{\prime} 32.2^{\prime \prime}$ E, 30.04.1958

20 Chandrapuri, $2500-3500 \mathrm{ft}$, small river in forest and hygropetric habitat, $30^{\circ} 25^{\prime} 36.0^{\prime \prime} \mathrm{N}$ 7904'02.9"E, 1.05 .1958

21 Gupta Kashi = Guptkashi, 3200-4000 ft, 2 small brooks very steep, $30^{\circ} 31^{\prime} 31.3^{\prime \prime} \mathrm{N} 79^{\circ} 05^{\prime}$ 20.0"E, 2.05.1958

22 Khumyara = Khumera (Lonsdale 2020), 4300 $5000 \mathrm{ft}, 2$ small brooks in bushes and hygropetric habitat, $30^{\circ} 33^{\prime} 15^{\prime \prime} \mathrm{N} 79^{\circ} 03^{\prime} 44^{\prime \prime} \mathrm{E}$, 3-4.05.1958

23 Barasu, 5000-6000 ft, small torrent, Mandakini tributary, in dense forest, $30^{\circ} 36^{\prime} 5^{\prime \prime} \mathrm{N} 79^{\circ}$ 1 '45"E, 5.05 .1958

24 Tarsali, $6000-7000 \mathrm{ft}$, torrent in dense forest, $30^{\circ} 35^{\prime} 40^{\prime \prime} \mathrm{N} 79^{\circ} 2^{\prime} 1{ }^{\prime \prime} \mathrm{E}, 6.05 .1958$

25 Akhrotkoti, $5700 \mathrm{ft}$, wonderful forest river, Mandakini tributary, 8.05.1958

26 Gaurikund, 6400-7200 ft, small torrent, Mandakini tributary, in bushes, $30^{\circ} 39^{\prime} 11.2^{\prime \prime} \mathrm{N}$ 7901'37.0"E, 9-11.05.1958 


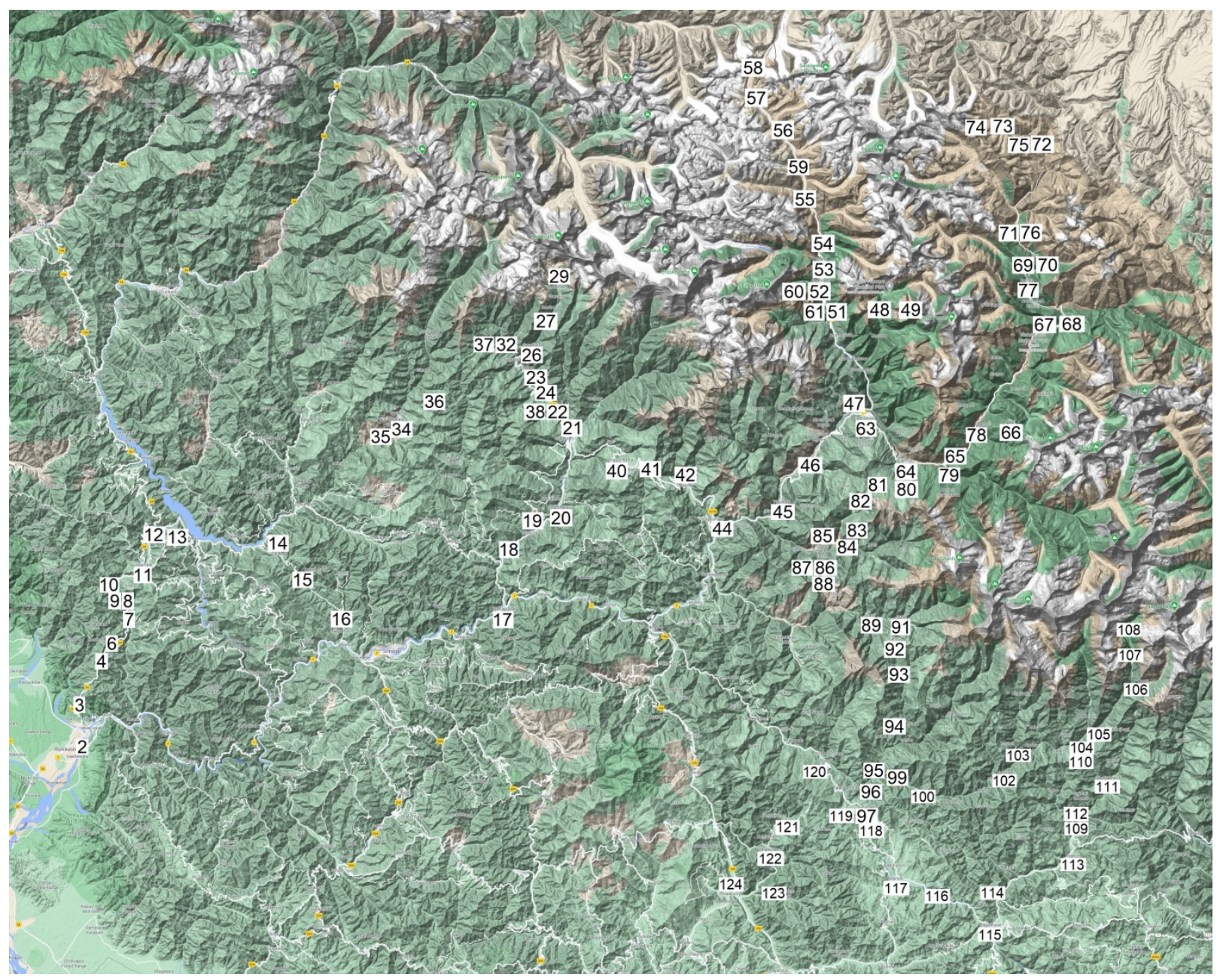

Map 2. Schmid's road in Uttarakhand.

27 Jungal Chatti $=$ Jungle Chatti, $8000-8500 \mathrm{ft}$, torrent and hygropetric habitat below a high cascade, $30^{\circ} 40^{\prime} 49.6^{\prime \prime} \mathrm{N} 79^{\circ} 02^{\prime} 39.2^{\prime \prime} \mathrm{E}, 11.05$. 1958

28 Ukhal, $9500 \mathrm{ft}$, torrent, brooks and springs, 16.05.1958

29 Kedarnath, 11800-13000 ft, torrent below a snowfield and brooks, $30^{\circ} 44^{\prime} 4^{\prime \prime} \mathrm{N} 79^{\circ} 4^{\prime} 1^{\prime \prime} \mathrm{E}$, 13-16.05.1958

30 Idem 28, Ukhal, 9500 ft, 16.05 .1958

31 Idem 25, Akhrotkoti, $5700 \mathrm{ft}, 17-18.05 .1958$

32 Trijugi $=$ Trijuginarayan, $7000 \mathrm{ft}$, small brook with mosses, in rhododendron forest, $30^{\circ} 38^{\prime}$ $48.8^{\prime \prime} \mathrm{N} 78^{\circ} 59^{\prime} 18.2^{\prime \prime} \mathrm{E}, 19.05 .1958$

33 Manghu Chatti, 9000-9270 ft, nice brooks in bushes and fields, 20-21.05.1958
34 Yawana = Gawana Malla, $6000 \mathrm{ft}$, small river tributary of Bhichangana, $30^{\circ} 32^{\prime} 18.9^{\prime \prime} \mathrm{N} 78^{\circ}$ 48'35.9"E, 22-24.05.1958

35 Ghuttu, $5000 \mathrm{ft}, 30^{\circ} 31^{\prime} 43.0^{\prime \prime} \mathrm{N} 78^{\circ} 47^{\prime} 22.6 " \mathrm{E}$, 23.05.1958

36 Panwalli = Panwali Kantha (Bugyal) Bhinlgana range, $11000 \mathrm{ft}$, small brook in forest, $30^{\circ} 34^{\prime} 07.9^{\prime \prime} \mathrm{N} 78^{\circ} 51^{\prime} 58.8^{\prime \prime} \mathrm{E},(22), 25.05 .1958$

37 idem 32, Trijugi = Trijuginarayan, $7000 \mathrm{ft}$, 26.05.1958

38 idem 22, Khumyara, 4300-5000 ft, 27-28. 05.1958

39 Ugsara, $4500 \mathrm{ft}$, small steep brook, 29.05.1958

40 Dogalbeta $=$ Dogalbhita $=$ Duggal Bittha, $7000-8300 \mathrm{ft}, 2$ steep brooks with mosses in forest, $30^{\circ} 29^{\prime} 10.1^{\prime \prime N} 79^{\circ} 11^{\prime} 23.3 " \mathrm{E}, 30.05 .1958$ 
41 Tungnath, $9000 \mathrm{ft}$, brook with mosses in forest, $30^{\circ} 28^{\prime} 41.9^{\prime \prime} \mathrm{N} 79^{\circ} 12^{\prime} 43.9^{\prime \prime} \mathrm{E}, 1.06 .1958$

42 Mandoli = Mandal, $7500 \mathrm{ft}, 30^{\circ} 27^{\prime} 38.2^{\prime \prime} \mathrm{N} 79^{\circ}$ 16'33.2"E, 1.06.1958

43 Duldhar, $4500 \mathrm{ft}$, big torrent and small brook, 2.06.1958

44 Chamoli, $3800 \mathrm{ft}$, along the Gange River, $30^{\circ}$ 24'16.1"N 79¹9'46.6"E, 3.06.1958

45 Pipalkoti, $4400 \mathrm{ft}$, small steep brook, $30^{\circ} 25^{\prime}$ 58.0"N 79²5'58.9"E, 6.06.1958

46 Hilang, = Hailang = Helong, 5000-7500 ft, along the Gange River, $30^{\circ} 31^{\prime} 25.0^{\prime \prime} \mathrm{N} 79^{\circ} 30^{\prime}$ 16.6"E, 6-7.06.1958

47 Phaia = Chaien, $5780 \mathrm{ft}$, along Alaknanda River, 30³4'03.3"N 79³2'54.8"E, 11.06.1958

48 Gangrea $=$ Ghangria $=$ Ghangaria, $7500-10000$ $\mathrm{ft}$, big torrent and small brook, $30^{\circ} 41^{\prime} 54.5^{\prime \prime} \mathrm{N}$ 79³5'19.3"E, 12-15.06.1958

49 Lokpal, $14000 \mathrm{ft}$, glacial lake, 30 $41 ' 59.3 " \mathrm{~N}$ 79³6'56.0"E, 13.06.1958

50 Binaik Chatti, 7000-7500 ft, steep torrent, 16.06.1958

51 Hanuman Chatti, $9000 \mathrm{ft}$, brooklets in grassland, $30^{\circ} 41^{\prime} 41^{\prime \prime} \mathrm{N} 79^{\circ} 30^{\prime} 51^{\prime \prime} \mathrm{E}, 17.06 .1958$

52 Badrinath, $10100-11000 \mathrm{ft}$, torrent, brooks and springs, $30^{\circ} 44^{\prime} 45.6^{\prime \prime} \mathrm{N} \quad 79^{\circ} 29^{\prime} 33.7^{\prime \prime E}, \quad 18-$ 19.06.1958

53 Mana, $10300 \mathrm{ft}$, brooks and springs, with mosses, 3046'21.0"N 79²9'39.7"E, 20.06. 1958

54 Moussa Pani, brooks and springs, with mosses, $11800 \mathrm{ft}, 30^{\circ} 47^{\prime} 31.7^{\prime \prime N} 79^{\circ} 29^{\prime} 29.6 " \mathrm{E}, 21.06$. 1958

55 Nag Tal, $13100 \mathrm{ft}$, springs and lake, $30^{\circ} 51^{\prime} 22.8^{\prime \prime} \mathrm{N} 79^{\circ} 28^{\prime} 07.1^{\prime \prime} \mathrm{E}, 22.06 .1958$

56 Phurunda, $15000 \mathrm{ft}$, Saraswati River, brooks and springs in grassland, $30^{\circ} 56^{\prime} 35.7^{\prime \prime} \mathrm{N} 79^{\circ} 25^{\prime}$ 57.5"E, 24.06.1958

57 Saraswati, $16000 \mathrm{ft}$, Saraswati River, 30 $39^{\prime}$ $14.3^{\prime \prime N} 79^{\circ} 23 ' 22.0 " \mathrm{E}, 25-26.06 .1958$

58 Jagrao, $17300 \mathrm{ft}$, Saraswati River, $31^{\circ} 02^{\prime} 03.6^{\prime \prime}$ N 79²2'02.5"E, 26.06.1958

59 Chamrao, $14200 \mathrm{ft}$, brooks and springs with mosses, $\quad 30^{\circ} 54^{\prime} 15.5^{\prime \prime} \mathrm{N} \quad 7^{\circ} 27^{\prime} 35.3^{\prime \prime} \mathrm{E}$, 27.06.1958

60 Idem 52, Badrinath 10100-11000 ft, torrent, brooks and springs, $30^{\circ} 44^{\prime} 45.6^{\prime \prime} \mathrm{N} 79^{\circ} 29^{\prime} 33.7^{\prime \prime}$ E, 28-29.06.1958
61 idem 51, Hanuman Chatti, $9000 \mathrm{ft}$, brooklets in grassland, $30^{\circ} 41^{\prime} 41^{\prime \prime} \mathrm{N} 79^{\circ} 30^{\prime} 51^{\prime \prime} \mathrm{E}, 30.06 .1958$

62 idem 50, Binaik Chatti, 7000-7500 ft, steep torrent, 2.07.1958

63 Jashimath = Joshimath = Jyotirmath, $7100 \mathrm{ft}$, at the light of the Rest House, 30 $32^{\prime} 55.0^{\prime \prime} \mathrm{N}$ 79³3'43.2"E, 3-4.07.1958

64 Tapoban $=$ Tapoban Joshimat $=$ Tapovan, 7300 $\mathrm{ft}$, river and steep brooks under bushes, $30^{\circ}$ 29'05.3"N 79³7'28.3"E, 5.07.1958

65 Lata, $7500 \mathrm{ft}$, along the Dauli Ganga River and brooklet, $30^{\circ} 29^{\prime} 56.0^{\prime \prime} \mathrm{N} \quad 79^{\circ} 42^{\prime} 49.2^{\prime \prime} \mathrm{E}, 6.07$. 1958

66 Phagti $=$ Fagti, $7874 \mathrm{ft}$, along the Dauli Ganga River, 30³3'34.8"N 7945'58.7"E, 7.07.1958

67 Kosa, $9219 \mathrm{ft}$, along the Dauli Ganga River and brooklet, $30^{\circ} 40^{\prime} 31.5^{\prime \prime} \mathrm{N} 79^{\circ} 51^{\prime} 39.0^{\prime \prime} \mathrm{E}, 8$. 07.1958

68 Malari, 10000-11000 ft, nice torrent, brooks and springs with mosses, $30^{\circ} 41^{\prime} 00.4^{\prime \prime} \mathrm{N} 79^{\circ}$ 53'23.2"E, 9-10.07.1958

69 Gamsali, = Gamshali, $11000 \mathrm{ft}$, big glacial torrent, $30^{\circ} 45^{\prime} 18.0^{\prime \prime} \mathrm{N} \quad 79^{\circ} 49^{\prime} 24.9^{\prime \prime} \mathrm{E}, 11.07$. 1958

70 Timarsan, $11122 \mathrm{ft}$, along the Dhauli Ganga River, lateral torrent and brooks, $30^{\circ} 45^{\prime} 52.5^{\prime \prime} \mathrm{N}$ 7950'54.7"E, 12-14.07.1958

71 Siunti, $12260 \mathrm{ft}$, along the Dhauli Ganga River and Dhamian Nadi torrent, $30^{\circ} 48^{\prime} 36.3^{\prime \prime} \mathrm{N} 79^{\circ}$ 48'04.4"E, 15.07.1958

72 Ganesh Ganga, $14400 \mathrm{ft}$, steep brooklet, $30^{\circ}$ $55^{\prime} 58.0^{\prime \prime} \mathrm{N} 79^{\circ} 50^{\prime} 44.1 " \mathrm{E}, 16.07 .1958$

73 Khar Yongma, $16000 \mathrm{ft}, 30^{\circ} 57^{\prime} 22.9^{\prime \prime} \mathrm{N} 79^{\circ}$ 46'56.5"E, 17.07.1958

74 Khar Todma, $17000-18000 \mathrm{ft}, 30^{\circ} 57^{\prime} 26.0^{\prime \prime} \mathrm{N}$ 7944'45.1"E, 18-19.07.1958

75 Geldhung, $14600 \mathrm{ft}$, big glacial torrent, $30^{\circ}$ $56^{\prime} 01.9 " \mathrm{~N} 79^{\circ} 50^{\prime} 08.8^{\prime \prime} \mathrm{E}, 20.07 .1958$

76 Gothing, $12400 \mathrm{ft}$, brooklet in grassland, $30^{\circ}$ 49'01.9"N 7948'28.4"E, 21.07.1958

77 Bampa, $10500 \mathrm{ft}$, along the Dhauli Ganga River, 3044'21.1"N 7949'48.4"E, 23.07.1958

78 Suraithota, $7200 \mathrm{ft}$, along the Dhauli Ganga River and lateral brooklet, $30^{\circ} 31^{\prime} 52.2^{\prime \prime} \mathrm{N}$ 7944'38.5"E, 25.07.1958

79 Rini, $7000 \mathrm{ft}$, big torrent and brooklet in bushes, $30^{\circ} 28^{\prime} 19.2^{\prime \prime} \mathrm{N} \quad 79^{\circ} 42^{\prime} 21.5^{\prime \prime} \mathrm{E}, 27.07$. 1958 
80 idem 64, Tapoban, $7300 \mathrm{ft}$, brooks in forest, 28.07.1958-2.08.1958

81 Kulara = Khullara Camp Site, 12000 ft, small torrent in grassland with trees, $30^{\circ} 27^{\prime} 35.2^{\prime \prime} \mathrm{N}$ 79³5'08.0"E, 3-4.08.1958

82 Dakwani = Dhakwani (on the path to the Kuari Pass), 9300-10950 ft, steep torrent in forest, $30^{\circ} 26^{\prime} 26.5^{\prime \prime} \mathrm{N} 79^{\circ} 33^{\prime} 41.8^{\prime \prime} \mathrm{E}, 5-9.08 .1958$

83 Pana, $8200 \mathrm{ft}, 3$ brooks in bushes, 30 $233^{\prime} 27.2^{\prime \prime}$ N 79³3'20.5"E, 10.08.1958

84 Pagna Malla = Pagana, $5955 \mathrm{ft}$, steep brook in grassland, $30^{\circ} 22^{\prime} 15.7^{\prime \prime} \mathrm{N} 79^{\circ} 32^{\prime} 34.7^{\prime \prime} \mathrm{E}, 11.08$. 1958

85 Ghona Tal = Gohna Lake, $5580 \mathrm{ft}$, torrent in forest flowing in the lake, $30^{\circ} 22^{\prime} 24.3^{\prime \prime} \mathrm{N} 79^{\circ}$ 31'31.4"E, 12.07.1958

86 Begar Nala, $6560 \mathrm{ft}, 2$ torrents in forest, $30^{\circ} 20^{\prime} 33.7^{\prime \prime} \mathrm{N} 79^{\circ} 30^{\prime} 09.7^{\prime \prime} \mathrm{E}, 13.08 .1958$

87 Tarak Tal $=$ Taraktal, $7540 \mathrm{ft}, 30^{\circ} 20^{\prime} 35.5^{\prime \prime} \mathrm{N}$ $79^{\circ} 29^{\prime} 04.2^{\prime \prime} \mathrm{E}, 14.08 .1958$

88 Ramni = Ramani, $8200 \mathrm{ft}$, torrent, $30^{\circ} 18^{\prime}$ 55.4"N 79³0'21.2"E, 15.08.1958

89 Gery $=$ Gairi $=$ Gari, $6290 \mathrm{ft}$, river, torrent and brook in bushes, $30^{\circ} 16^{\prime} 21.7^{\prime \prime} \mathrm{N} 79^{\circ} 33^{\prime} 44.3^{\prime \prime} \mathrm{E}$, 16.08.1958

90 Dhar, $7220 \mathrm{ft}$, Nandakini tributary, river in forest and lateral canals, 17.08.1958

91 Sutol, $7250 \mathrm{ft}$, meeting of 2 rivers in forest, $30^{\circ} 16^{\prime} 13.1^{\prime \prime} \mathrm{N} 79^{\circ} 37^{\prime} 24.5^{\prime \prime} \mathrm{E}, 18.08 .1958$

$92 \mathrm{Kanol}, 8530 \mathrm{ft}$, springs and brooklets with mosses, $30^{\circ} 15^{\prime} 05.8^{\prime \prime} \mathrm{N}$ 79³5'51.4"E, 19.08. 1958

$93 \mathrm{Wan}, 7880 \mathrm{ft}$, torrents in bushes, $30^{\circ} 12^{\prime} 13.6^{\prime \prime} \mathrm{N}$ 79³7'06.6"E, 20.08.1958

94 Lohajang = Lohjang = Loha Jung, $6070 \mathrm{ft}$, along the Gyan Ganga River, 30 $07^{\prime} 10.1 " \mathrm{~N}$ 79³6'30.1"E, 21.08.1958

95 Salkhola $=$ Ichchholi Laga Silkhola, $4240 \mathrm{ft}$, junction of Pindar and Kail Ganga Rivers, and lateral brooklets, 30.057177, 79.584542, 22. 08.1958

96 Koti $=$ Kothi, $4200-5500 \mathrm{ft}$, steep brooklets in forest, $30^{\circ} 01^{\prime} 52.2^{\prime \prime} \mathrm{N} 79^{\circ} 34^{\prime} 04.9^{\prime \prime} \mathrm{E}, 23.08 .1958$

97 Gwaldam, 6000-6400 ft, small torrent in bushes and brook in forest with mosses, 2429.08.1958

98 Koti, idem 96, 4200 ft, 30.08.1958
99 Palwara, $4300 \mathrm{ft}$, torrent, Pindar tributary, in forest, $30^{\circ} 02^{\prime} 39.9^{\prime \prime} \mathrm{N} \mathrm{79} 36^{\prime} 48.0^{\prime \prime} \mathrm{E}, 1.09 .1958$

100 Lingari $=$ Lingadi, $4400 \mathrm{ft}$, brooks and springs, $30^{\circ} 01^{\prime} 22.8^{\prime \prime} \mathrm{N} \quad 79^{\circ} 39^{\prime} 59.3^{\prime \prime} \mathrm{E}, \quad 1.09$. 1958

101 Maupata, $4500 \mathrm{ft}$, along the Pindar River, 2.09.1958

102 Harmal, $5100 \mathrm{ft}$,torrent, Pindar tributary, $30^{\circ} 03^{\prime} 16.8^{\prime \prime} \mathrm{N} 79^{\circ} 47^{\prime} 16.5^{\prime \prime} \mathrm{E}, 4-5.09 .1958$

103 Bilap, $5500 \mathrm{ft}$, River in forest, $30^{\circ} 04^{\prime} 30.4^{\prime \prime} \mathrm{N}$ 7948'38.5"E, 6.09.1958

104 Dhur $=$ Dhoor Village, $7400 \mathrm{ft}$, steep brooks in forest, $30^{\circ} 05^{\prime} 13.9^{\prime \prime} \mathrm{N} 79^{\circ} 54^{\prime} 33.5^{\prime \prime} \mathrm{E}, 8-9.09$. 1958

105 Khati, 7700-8000 ft, along the Pindar River and brooks with mosses, $30^{\circ} 06^{\prime} 18.4^{\prime \prime} \mathrm{N} 79^{\circ}$ 56'33.7"E, 10-11.09.1958

106 Dwali, $8410 \mathrm{ft}$, torrent and brooks, $30^{\circ} 10^{\prime}$ 34.0"N 79०59'31.2"E, 12-16.09.1958

107 Phurkia, $8510 \mathrm{ft}$, big torrent and brooklets in forest, $30^{\circ} 12^{\prime} 58.3^{\prime \prime} \mathrm{N} 79^{\circ} 59^{\prime} 50.6^{\prime \prime} \mathrm{E}, 13.09 .1958$

108 Rata, $11000 \mathrm{ft}$, brooklets in grassland and Rhododendron bushes, with mosses, $30^{\circ} 15^{\prime}$ 05.8"N 7959'39.1"E, 14.09.1958

109 Saran, $7200 \mathrm{ft}$, torrent and nice brooks in forest, with mosses, $30^{\circ} 01^{\prime} 07.7^{\prime \prime} \mathrm{N} \quad 79^{\circ} 52^{\prime}$ 43.3"E, 17.09.1958

110 Dhakuri Guest House, $9000 \mathrm{ft}$, brooks in forest, with mosses, $30^{\circ} 04^{\prime} 37.5^{\prime \prime} \mathrm{N} \quad 79^{\circ} 55^{\prime}$ 06.4"E, 18.09.1958

111 Loharkhet, $5770 \mathrm{ft}$, torrent, $30^{\circ} 02^{\prime} 11.0^{\prime \prime} \mathrm{N}$ 7956'13.9"E, 19.09.1958

112 Sarju, $5700-4000 \mathrm{ft}, 2$ rivers, steep brooks in bushes and hygropetric habitat, $29^{\circ} 59^{\prime} 16.7^{\prime \prime} \mathrm{N}$ 7954'53.1"E, 21.09.1958

113 Kapkot, $3700 \mathrm{ft}$, river tributary of Sarju, $29^{\circ} 56^{\prime} 18.3^{\prime \prime} \mathrm{N} 79^{\circ} 54^{\prime} 06.2^{\prime \prime} \mathrm{E}, 21.09 .1958$

114 Chhana, $3500 \mathrm{ft}$, nice river, lateral hygropetric habitat, $29^{\circ} 53^{\prime} 00.2^{\prime \prime} \mathrm{N} 79^{\circ} 46^{\prime} 31.4^{\prime \prime} \mathrm{E}$, 22.09.1958

115 Bagheswar = Bageshwar, $3200 \mathrm{ft}$, Sarju River and small river tributary with mosses, $29^{\circ}$ 50'33.3"N 7946'32.0"E, 23.09.1958

116 Bamrari, $3700 \mathrm{ft}$, Gornati River and brooklets in forest, lateral hygropetric habitat, $29^{\circ}$ $52^{\prime} 40.7 " \mathrm{~N} 79^{\circ} 40^{\prime} 50.2^{\prime \prime} \mathrm{E}, 24.09 .1958$

117 Bajnath = Baijnath, $3800 \mathrm{ft}$, Gornati River, $29^{\circ} 54^{\prime} 22.8^{\prime \prime} \mathrm{N} 79^{\circ} 36 ' 52.2^{\prime \prime} \mathrm{E}, 25.09 .1958$ 
118 Sirkot, $4200 \mathrm{ft}$, river and brooks in bushes, $29^{\circ} 58^{\prime} 42.3^{\prime \prime} \mathrm{N} 79^{\circ} 34^{\prime} 16.3^{\prime \prime} \mathrm{E}, 26.09 .1958$

119 Idem 97, Gwaldam, 6000 ft, 27-30.09.1958

120 Simra $=$ Simar Pul, $5800 \mathrm{ft}$, nice rivers in forest, $30^{\circ} 03^{\prime} 28.7^{\prime \prime} \mathrm{N} \quad 79^{\circ} 29^{\prime} 37.4^{\prime \prime} \mathrm{E}, 1-2.10$. 1958

121 Nail, 5000-6000 ft, swampy brooklets, $29^{\circ}$ $58^{\prime} 37.6^{\prime \prime} \mathrm{N} 79^{\circ} 26^{\prime 2} 26.9^{\prime \prime} \mathrm{E}, 3.10 .1958$

122 Chulera Sim = Chulerasim, 3800 ft, Ramganga River and lateral steep torrent, $29^{\circ} 55^{\prime}$ 59.4"N 79²4'33.0"E, 4.10.1958

123 Tarag Tal $=$ Tarag lake, $3900 \mathrm{ft}$, toorents flowing in a lake, $29^{\circ} 53^{\prime} 01.0^{\prime \prime} \mathrm{N} 79^{\circ} 25^{\prime} 25.0^{\prime \prime} \mathrm{E}$, 5.10 .1958

124 Chaukhutia, $3050 \mathrm{ft}$, along Ramganga River, $29^{\circ} 53^{\prime} 12.3^{\prime \prime} \mathrm{N} 79^{\circ} 21^{\prime} 00.6 " \mathrm{E}, 6.10 .1958$
$125 \mathrm{Sat}$ Tal, $4100 \mathrm{ft}$, several lakes, 11.10 .1958

126 Naukucchiya Tal = Naukuchia Taal, 4100 ft, lake, 12.10.1958

127 Ranibagh, $1778 \mathrm{ft}$, torrent, $29^{\circ} 17^{\prime} 14.0^{\prime \prime} \mathrm{N} 79^{\circ}$ 33'00.6"E, 13.10 .1958

\section{Sikkim and North Western Bengal localities, 1959 (Map 3)}

This high mountainous region is surrounded westward by the Nepal, northward by the Tibet and eastward by the Bhoutan (Map 1).

North Western Bengal

1 Singtam, $2625 \mathrm{ft}, 27^{\circ} 03^{\prime} 48.5^{\prime \prime} \mathrm{N} 88^{\circ} 13^{\prime} 02.6^{\prime \prime} \mathrm{E}$, 11.03 .1959

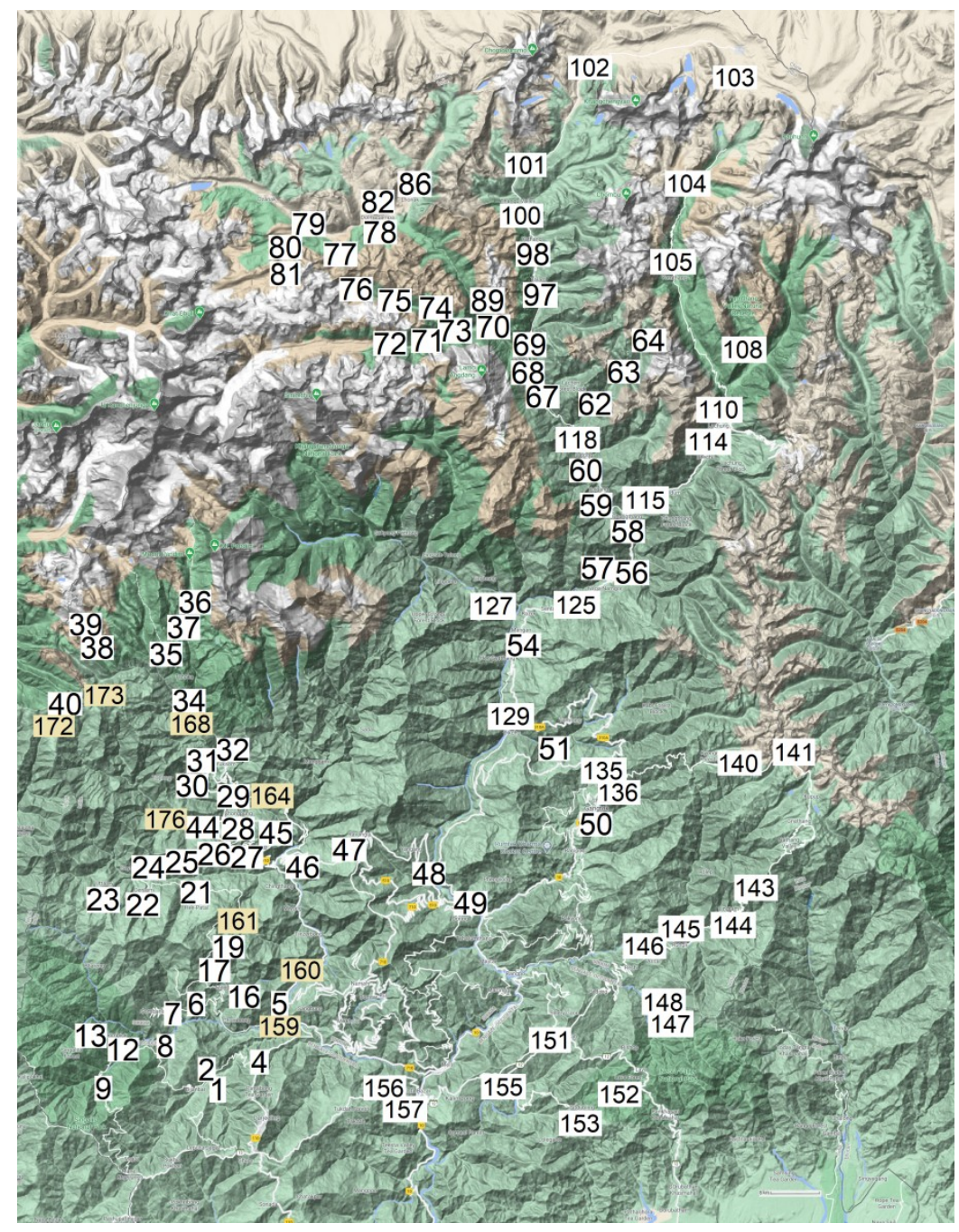

Map 3. Schmid's road in Sikkim and North Western Bengal. 
2 Pul Bazar = Pulbazar, $2400 \mathrm{ft}, 27^{\circ} 04^{\prime} 29.7^{\prime \prime} \mathrm{N}$ 88 $12^{\prime} 11.9^{\prime \prime} \mathrm{E}, 12.03 .1959$

3 Dhangia Bazar, $3280 \mathrm{ft}, 13.03 .1959$

4 Takvar = Tukvar, $1760 \mathrm{ft}, 27^{\circ} 05^{\prime} 50.0^{\prime \prime} \mathrm{N} 88^{\circ}$ 15'28.3"E, 14.03.1959

\section{Sikkim}

5 Naya Bazar, $1060 \mathrm{ft}, 27^{\circ} 08^{\prime} 49.6^{\prime \prime} \mathrm{N} 88^{\circ} 16^{\prime} 46.6^{\prime \prime}$ E, 15-16.03.1959

6 Tharpu, $2625 \mathrm{ft}, 27^{\circ} 08^{\prime} 43.5^{\prime \prime} \mathrm{N} 88^{\circ} 11^{\prime} 41.0^{\prime \prime} \mathrm{E}$, 17.03.1959

7 Dharmdin = Daramdin, 2854-3200, 2708'03.6" N 8809'49.1"E, 18.03.1959

North Western Bengal

8 Bara Hala = Berea?, $4920 \mathrm{ft}, 27^{\circ} 06^{\prime} 20.5^{\prime \prime} \mathrm{N} 88^{\circ}$ 09'18.7"E, 19.03.1959

9 Dilpa, $6260 \mathrm{ft}, 27^{\circ} 04^{\prime} 44.1^{\prime \prime N} 88^{\circ} 05^{\prime} 12.8^{\prime \prime} \mathrm{E}, 20$. 03. 1959

10 Dilpa, $5500 \mathrm{ft}, 27^{\circ} 04^{\prime} 31.9^{\prime \prime} \mathrm{N} 88^{\circ} 05^{\prime} 19.6^{\prime \prime} \mathrm{E}, 21$. 03.1959

11 Bara Hata $=$ Berea, $5000 \mathrm{ft}, 27^{\circ} 06^{\prime} 20.5^{\prime \prime} \mathrm{N} 88^{\circ}$ 09'18.7"E, 22.03.1959

12 Rimbik, $6560 \mathrm{ft}, 27^{\circ} 07^{\prime} 11.6^{\prime \prime} \mathrm{N} 88^{\circ} 06^{\prime} 17.3^{\prime \prime} \mathrm{E}$, 23.03.1959

13 Shepi = Sepi Gaon, $7200 \mathrm{ft}, 27^{\circ} 07^{\prime} 38.4^{\prime \prime} \mathrm{N} 88^{\circ}$ 05'52.9"E, 23.03.1959

14 Phedigaon, $7000 \mathrm{ft}, 25.03 .1959$

\section{Sikkim}

15 idem 5, Naya Bazar, $1060 \mathrm{ft}, 27^{\circ} 08^{\prime} 49.6^{\prime \prime} \mathrm{N} 88^{\circ}$ 16'46.6"E, 28.03.1959

16 Chakung, $4920 \mathrm{ft}, 27^{\circ} 09^{\prime} 12.5^{\prime \prime} \mathrm{N} 88^{\circ} 14^{\prime} 37.8^{\prime \prime} \mathrm{E}$, 29.03.1959

17 Samdong $=$ Chota Samdong, $3600 \mathrm{ft}, 27^{\circ} 10^{\prime}$

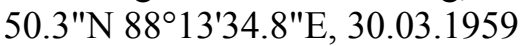

18 Samdong = Chota Samdong, $4100 \mathrm{ft}, 27^{\circ} 10^{\prime}$ 50.3"N 88¹3'34.8"E, 31.03.1959

19 Dethang = Deythang, $4000 \mathrm{ft}, 27^{\circ} 12^{\prime} 03.5^{\prime \prime} \mathrm{N}$ $88^{\circ} 13^{\prime} 17.6 " \mathrm{E}, 1.04 .1959$

20 Rapham, $5250 \mathrm{ft}, 2.04 .1959$

$21 \mathrm{Hi}=\mathrm{Hee}, 4200-5500 \mathrm{ft}, 27^{\circ} 15^{\prime} 19.7^{\prime \prime} \mathrm{N} 88^{\circ}$ 10'54.4"E, 3.04.1959

22 Dentham $=$ Dentam, $4500 \mathrm{ft}, 27^{\circ} 15^{\prime} 37.4^{\prime \prime} \mathrm{N} 88^{\circ}$ 08'24.9"E, 4.04.1959

23 Uttare = Uttarey, $6950 \mathrm{ft}, 27^{\circ} 15^{\prime} 36.3^{\prime \prime} \mathrm{N} 88^{\circ} 05^{\prime}$ 55.1"E, 5.04.1959
24 Srinagi, $4920 \mathrm{ft}, 27^{\circ} 16^{\prime} 11.7^{\prime \prime} \mathrm{N} 88^{\circ} 08^{\prime} 54.1^{\prime \prime E}$, 6.04 .1959

25 Bongteng = Bangten, $5800 \mathrm{ft}, 27^{\circ} 16^{\prime} 31.7^{\prime \prime} \mathrm{N}$ 8809'39.6"E, 6.04.1959

26 Sardong, $2600 \mathrm{ft}, 27^{\circ} 17^{\prime} 05.9^{\prime \prime N} 88^{\circ} 11^{\prime} 42.6^{\prime \prime} \mathrm{E}$, 6.04.1959

27 Tikjak = Tikjya, $4900 \mathrm{ft}, 27^{\circ} 17^{\prime} 25.1^{\prime \prime} \mathrm{N} 88^{\circ}$ 13'43.3"E, 7.04.1959

28 Chongpung, $5000 \mathrm{ft}, 27^{\circ} 19^{\prime} 34.8^{\prime \prime} \mathrm{N} 88^{\circ} 14^{\prime}$ 09.8"E, 8.04.1959

29 Tinglin $=$ Thingle, $2950 \mathrm{ft}, 27^{\circ} 20^{\prime} 31.9^{\prime \prime} \mathrm{N} 88^{\circ}$ 13'45.9"E, 8.04.1959

30 Kechoiperi $=$ Khechiperi $=$ Khecheopalri Lake, $5900 \mathrm{ft}, 27^{\circ} 21^{\prime} 07.3^{\prime \prime} \mathrm{N} 88^{\circ} 11^{\prime} 25.8^{\prime \prime} \mathrm{E}, 9.04 .1959$

31 Chojo = Tsozo, $3980 \mathrm{ft}, 27^{\circ} 21^{\prime} 58.5^{\prime \prime} \mathrm{N} 88^{\circ}$ 12'21.5"E, 10.04.1959

32 Yoksam = Yuksom, $5600 \mathrm{ft}, 27^{\circ} 22^{\prime} 20.6^{\prime \prime} \mathrm{N}$ 88¹3'21.0"E, 10.04.1959

33 Zomphuk, $6500 \mathrm{ft}, 11.04 .1959$

34 Bakkim = Bakhim Guest House, $6890 \mathrm{ft}$, $27^{\circ} 25^{\prime} 41.9^{\prime \prime} \mathrm{N} 88^{\circ} 11^{\prime} 10.3 " \mathrm{E}, 12-13.04 .1959$

35 Dzongri, $13222 \mathrm{ft}, 27^{\circ} 28^{\prime} 39.0^{\prime \prime} \mathrm{N} 88^{\circ} 09^{\prime} 48.8^{\prime \prime} \mathrm{E}$, 14.04.1959

36 Tangshing $=$ Thangsing Trekkers's hut, 12200 $\mathrm{ft}, 27^{\circ} 30^{\prime} 59.3^{\prime \prime} \mathrm{N} 88^{\circ} 11^{\prime} 07.5^{\prime \prime} \mathrm{E}, 17.04 .1959$

37 Churong $=$ Kukchurung Trekkers's hut, 12460 $\mathrm{ft}, 27^{\circ} 30^{\prime} 12.1^{\prime \prime} \mathrm{N} 88^{\circ} 10^{\prime} 31.1^{\prime \prime} \mathrm{E}, 18.04 .1959$

38 Tikipchu $=$ Tipik chu, $13800 \mathrm{ft}, 27^{\circ} 28^{\prime} 37.0^{\prime \prime} \mathrm{N}$ $88^{\circ} 05^{\prime} 11.0 " \mathrm{E}, 19.04 .1959$

39 Tikipchu, $15000 \mathrm{ft}, 27^{\circ} 29^{\prime} 47.3^{\prime \prime N} 88^{\circ} 04^{\prime} 16.4^{\prime \prime}$ E, 20.04.1959

40 Gopetang = Gonpatang (Népal close to the Indian border), $12200 \mathrm{ft}, 27^{\circ} 25^{\prime} 44.9^{\prime \prime} \mathrm{N} 88^{\circ} 03^{\prime}$ 27.9"E, 21.04.1959

41 Chunjom, $6800 \mathrm{ft}, 23.04 .1959$

42 Ramtang, $5780 \mathrm{ft}, 24.04 .1959$

43 Palam, $5100 \mathrm{ft}, 25.04 .195,9$

44 Singbeng = Singyang, $4920 \mathrm{ft}, 27^{\circ} 19^{\prime} 09.7^{\prime \prime} \mathrm{N}$ $88^{\circ} 12^{\prime} 41.6^{\prime \prime E}, 26.04 .1959$

45 Pemayangtse, $5600 \mathrm{ft}, 27^{\circ} 18^{\prime} 14.7^{\prime \prime} \mathrm{N} 88^{\circ} 15^{\prime}$ 12.8"E, 27.04.1959

46 Ligship = Likship, $1700 \mathrm{ft}, 27^{\circ} 16^{\prime} 13.5^{\prime \prime} \mathrm{N} 88^{\circ}$ 17'34.8"E, 28.04.1959

47 Doling, $5900 \mathrm{ft}, 27^{\circ} 17^{\prime} 20.6^{\prime \prime} \mathrm{N} 88^{\circ} 20^{\prime} 41.9^{\prime \prime} \mathrm{E}$, 29.04.1959

48 Mangalbarey = Manglay Bazaar, $2800 \mathrm{ft}, 27^{\circ}$ 16'10.7"N 88²5'27.3"E, 30.04.1959 
49 Sirwani, $1150 \mathrm{ft}, 27^{\circ} 14^{\prime} 29.0^{\prime \prime} \mathrm{N} 88^{\circ} 28^{\prime} 56.8^{\prime \prime} \mathrm{E}$, 1.05 .1959

50 Gangtok, $5570 \mathrm{ft}, 27^{\circ} 19^{\prime} 54.9^{\prime \prime} \mathrm{N} 88^{\circ} 36^{\prime} 48.5^{\prime \prime E}$, 3.05 .1959

51 Lingdok, $4600 \mathrm{ft}, 27^{\circ} 23^{\prime} 14.8^{\prime \prime} \mathrm{N} 88^{\circ} 34^{\prime} 21.0^{\prime \prime} \mathrm{E}$, 7.05.1959

52 Nantpung, 3980 ft, 8.05.1959

53 Dakchu, $2300 \mathrm{ft}, 9.05 .1959$

54 Mangang = Mangan, $3600 \mathrm{ft}, 27^{\circ} 29^{\prime} 42.2^{\prime \prime} \mathrm{N}$ $88^{\circ} 31^{\prime} 45.9^{\prime \prime}$ E, 9.05.1959

55 Masin, $4920 \mathrm{ft}, 10.05 .1959$

$56 \mathrm{Nanga}=$ Naga falls, $5000 \mathrm{ft}, 27^{\circ} 32^{\prime} 24.2^{\prime \prime} \mathrm{N} 88^{\circ}$ 37'51.1"E, 12.05.1959

57 Teng $=$ Tung bridge on Lachung River, 4600 $\mathrm{ft}, 27^{\circ} 32^{\prime} 58.6^{\prime \prime} \mathrm{N} \mathrm{88^{ \circ } 3 8 ^ { \prime } 4 3 . 0 ^ { \prime \prime } \mathrm { E } , 1 2 . 0 5 . 1 9 5 9}$

58 Chumtang = Chungthang, $5120 \mathrm{ft}, 27^{\circ} 36^{\prime} 14.0^{\prime \prime}$ N 88³8'44.9"E, 13.05.1959

59 Yugang = Yuigang, $5700 \mathrm{ft}, 27^{\circ} 37^{\prime} 45.7^{\prime \prime} \mathrm{N}$ $88^{\circ} 37^{\prime} 02.5^{\prime \prime} \mathrm{E}, 14.05 .1959$

60 Lathong = Latong, $6560 \mathrm{ft}, 27^{\circ} 39^{\prime} 35.4^{\prime \prime} \mathrm{N} 88^{\circ}$ 36'08.7"E, 15.05.1959

61 Benshoi, $7550 \mathrm{ft}, 16.05 .1959$

$62 \mathrm{Chachu}=$ Tarum Chachu Hot Spring, $9950 \mathrm{ft}$, $27^{\circ} 42^{\prime} 30.4^{\prime \prime} \mathrm{N} 88^{\circ} 366^{\prime} 35.4^{\prime \prime} \mathrm{E}, 17.05 .1959$

$63 \mathrm{Gey}, 11650 \mathrm{ft}, 27^{\circ} 44^{\prime} 41.9^{\prime \prime} \mathrm{N} 88^{\circ} 38^{\prime} 34.5^{\prime \prime} \mathrm{E}, 18$. 05.1959

64 Gey, 13200 ft, 2746'18.5"N 88³9'48.1"E, 19. 05.1959

65 Gey, $12000 \mathrm{ft}, 20.05 .1959$

66 idem 62, Chachu = Tarum Chachu Hot Spring, 9900 ft, 27²4'30.4"N 88³6'35.4"E, 21.05. 1959

67 Chateng = Chaten, $8700 \mathrm{ft}, 27^{\circ} 32^{\prime} 24.2^{\prime \prime} \mathrm{N} 88^{\circ}$ 37'51.1"E, 22.05.1959

68 Lachen, $8930 \mathrm{ft}, 27^{\circ} 43^{\prime} 45.0^{\prime \prime} \mathrm{N} 88^{\circ} 33^{\prime} 02.3^{\prime \prime} \mathrm{E}$, 23.05.1959

69 Zema, $8900 \mathrm{ft}, 27^{\circ} 45^{\prime} 18.8^{\prime \prime} \mathrm{N} 88^{\circ} 32^{\prime} 32.9^{\prime \prime} \mathrm{E}$, 24.05.1959

70 Yedang, $10600 \mathrm{ft}, 27^{\circ} 46^{\prime} 47.8^{\prime \prime} \mathrm{N} 88^{\circ} 30^{\prime} 04.1^{\prime \prime} \mathrm{E}$, 25.05.1959

71 Thomrachen, $11900 \mathrm{ft}, 27^{\circ} 46^{\prime} 11.4^{\prime \prime} \mathrm{N} 88^{\circ} 26^{\prime}$ 12.9"E, 26.05.1959

72 Yahuk = Yabuk, $13050 \mathrm{ft}, 27^{\circ} 45^{\prime} 53.2^{\prime \prime} \mathrm{N} 88^{\circ}$ 23'30.7"E, 27.05.1959

73 Yagtang= Yakthang, $11200 \mathrm{ft}, 27^{\circ} 46^{\prime} 31.1^{\prime \prime} \mathrm{N}$ $88^{\circ} 28^{\prime} 04.4^{\prime \prime}$ E, 28.05.1959

74 Thomphyak, $12800 \mathrm{ft}, 27^{\circ} 47^{\prime} 00.3^{\prime \prime} \mathrm{N} 88^{\circ} 26^{\prime}$ 57.9"E, 29.05.1959
75 Theuchung, $14100 \mathrm{ft}, 27^{\circ} 48^{\prime} 28.4^{\prime \prime} \mathrm{N} 88^{\circ} 23^{\prime}$ 30.1"E, 30.05.1959

76 Theulocha $=$ Thieulacha, $14900 \mathrm{ft}, 27^{\circ} 48^{\prime}$ $59.9^{\prime \prime} \mathrm{N} 88^{\circ} 21^{\prime} 52.9^{\prime \prime} \mathrm{E}, 30.05 .1959$

77 Langbos = Langbo, $14750 \mathrm{ft}, 27^{\circ} 51^{\prime} 21.9^{\prime \prime} \mathrm{N}$ $88^{\circ} 21^{\prime} 25.5^{\prime \prime} \mathrm{E}, 31.05 .1959$

78 Dolkhasampat = Dolma Sampa, $14700 \mathrm{ft}, 27^{\circ}$ $53^{\prime} 02.5^{\prime \prime} \mathrm{N} 88^{\circ} 23^{\prime} 00.0^{\prime \prime} \mathrm{E}, 1.06 .1959$

79 Lungma, $15320 \mathrm{ft}, \quad 27^{\circ} 52^{\prime} 06.7^{\prime \prime} \mathrm{N} \quad 88^{\circ} 19^{\prime}$ 39.0"E, 2.06.1959

80 Changsang $=$ Changsang glacier, $15750 \mathrm{ft}$, $27^{\circ} 52^{\prime} 11.2^{\prime \prime} \mathrm{N} 88^{\circ} 17^{\prime} 44.7^{\prime \prime} \mathrm{E}, 2.06 .1959$

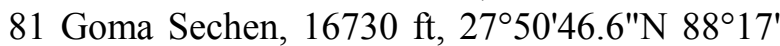
00.1"E, 3.06.1959

82 idem 78, Dolamsampa = Dolma Sampa, 14700 $\mathrm{ft}, 27^{\circ} 53^{\prime} 02.5^{\prime \prime} \mathrm{N} 88^{\circ} 23^{\prime} 00.0$ "E, 5.06.1959

83 Kora Chamna, $16250 \mathrm{ft}, 6.06 .1959$

84 Kora La Cho, $16700 \mathrm{ft}, 6.06 .1959$

85 Siling, $14900 \mathrm{ft}, 6.06 .1959$

86 Mugutang = Muguthang $=$ Lhonak, $14750 \mathrm{ft}$, $27^{\circ} 53^{\prime} 56.5^{\prime \prime} \mathrm{N} 88^{\circ} 25^{\prime} 01.4^{\prime \prime} \mathrm{E}, 7.06 .1959$

87 Sase, $14170 \mathrm{ft}, 7.06 .1959$

88 Rongsha, $14400 \mathrm{ft}, 8.06 .1959$

89 idem 70, Yedang, $10600 \mathrm{ft}, 27^{\circ} 46^{\prime} 47.8^{\prime \prime} \mathrm{N}$ $88^{\circ} 30^{\prime} 04.1$ "E, 9.06.1959

90 idem 70, Yedang, $9680 \mathrm{ft}, 27^{\circ} 46^{\prime} 47.8^{\prime \prime} \mathrm{N} 88^{\circ}$ 30'04.1"E, 10.06.1959

91 idem 69, Zema = Zemu chu River, $8900 \mathrm{ft}$, $27^{\circ} 45^{\prime} 19.2^{\prime \prime} \mathrm{N} 88^{\circ} 32^{\prime} 32.4^{\prime \prime} \mathrm{E}, 11.06 .1959$

92 idem 67, Chateng $=$ Chaten, $8700 \mathrm{ft}, 27^{\circ}$ $32 ' 24.2^{\prime \prime} \mathrm{N} 88^{\circ} 37 ' 51.1 " \mathrm{E}, 12.06 .1959$

93 idem 68, Lachen, $8900 \mathrm{ft}, 27^{\circ} 43^{\prime} 45.0^{\prime \prime} \mathrm{N}$ $88^{\circ} 33^{\prime} 02.3$ "E, 13.06.1959

94 idem 69, Zema, $9100 \mathrm{ft}, 27^{\circ} 45^{\prime} 18.8^{\prime \prime} \mathrm{N} 88^{\circ}$ 32'32.9"E, 14.06.1959

95 Yunga, $10000 \mathrm{ft}, 14.06 .1959$

96 Tombu, $10450 \mathrm{ft}, 15.06 .1959$

97 Talam, $11300 \mathrm{ft}, 27^{\circ} 49^{\prime} 28.6^{\prime \prime} \mathrm{N} 88^{\circ} 33^{\prime} 07.2^{\prime \prime} \mathrm{E}$, 16.06.1959

98 Yagtang = Yathang, $11650 \mathrm{ft}, 27^{\circ} 51^{\prime} 46.5^{\prime \prime} \mathrm{N}$ $88^{\circ} 32^{\prime} 42.2^{\prime \prime} \mathrm{E}, 17.06 .1959$

99 Kalip, 12100 ft, 18.06.1959

100 Tanggu $=$ Thangu, $12800 \mathrm{ft}, 27^{\circ} 54^{\prime} 36.8^{\prime \prime} \mathrm{N}$ $88^{\circ} 42^{\prime} 42.2^{\prime \prime} \mathrm{E}, 19.06 .1959$

101 Taling, $13800 \mathrm{ft}, 27^{\circ} 55^{\prime} 50.7^{\prime \prime N} 88^{\circ} 32^{\prime} 08.4^{\prime \prime E}$, 21.06.1959

102 Denkung, $15750 \mathrm{ft}, 28^{\circ} 01^{\prime} 13.8^{\prime \prime} \mathrm{N}$ 88³6' 06.3"E, 22.06.1959 
103 Cho Lhamo = Tso Lhamo Lake, $16700 \mathrm{ft}$, $28^{\circ} 00^{\prime} 25.5^{\prime \prime} \mathrm{N} 88^{\circ} 45^{\prime} 21.9^{\prime \prime} \mathrm{E}, 25.06 .1959$

104 Yume Samdong = Yumesodong, $15110 \mathrm{ft}$, $27^{\circ} 54^{\prime} 36.8^{\prime \prime} \mathrm{N} 88^{\circ} 42^{\prime} 42.2^{\prime \prime} \mathrm{E}, 26.06 .1959$

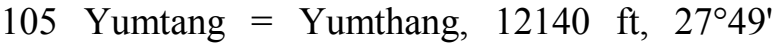
35.4"N 88०41'41.0"E, 27.06.1959

106 Chachu, $11500 \mathrm{ft}, \quad 29.06 .1959$

107 Phune Kongma, 11150 ft, 30.06.1959

108 Shingba $=$ Shingba Rhododendron Sanctuary, $10400 \mathrm{ft}, 27^{\circ} 45^{\prime} 02.6^{\prime \prime} \mathrm{N} 88^{\circ} 46^{\prime} 25.7^{\prime \prime} \mathrm{E}, 30.06$. 1959

109 Namnasa, $10000 \mathrm{ft}, 1.07 .1959$

110 Lachung $=$ Lachung bridge on the Lachung River, $8610 \mathrm{ft}, 27^{\circ} 41^{\prime} 26.8^{\prime \prime N} 88^{\circ} 44^{\prime} 44.5^{\prime \prime} \mathrm{E}, 2-$ 13.07.1959

111 Chumyomoi Chaka, $11800 \mathrm{ft}, 8.07 .1959$

112 Namnasa, $10000 \mathrm{ft}, 11.07 .1959$

113 Namnasa, 9500 ft, 12.07.1959

114 Bichu = Beechu, 8000-8500, 27³9'34.4"N 884' $44.3^{\prime \prime E}, 14.07 .1959$

115 Bop, $5950 \mathrm{ft}, 27^{\circ} 36^{\prime} 58.5^{\prime \prime} \mathrm{N}$ 88³9'34.0"E, 15.07.1959

116 idem 58, Chumtang = Chungthang, $5120 \mathrm{ft}$, $27^{\circ} 36^{\prime} 14.0^{\prime \prime} \mathrm{N} 88^{\circ} 38^{\prime} 44.9^{\prime \prime} \mathrm{E}, 16-23.07 .1959$

117 idem 59, Yugang = Yuigang, $5700 \mathrm{ft}, 2^{\circ} 37^{\prime}$ 45.7"N 88³7'02.5"E, 24.07.1959

118 idem 60, Lathang = Latong, $6500 \mathrm{ft}, 2^{\circ} 39^{\prime}$ 35.4"N 88³6'08.7"E, 26.07.1959

119 Selep, $7000 \mathrm{ft}, 27.07 .1959$

120 idem 67, Chateng = Chaten, $8000 \mathrm{ft}, 27^{\circ}$ $32^{\prime} 24.2^{\prime \prime} \mathrm{N} 88^{\circ} 37^{\prime} 51.1 " \mathrm{E}, 28.07 .1959$

121 idem 58, Chumtang= Chungthang, $5120 \mathrm{ft}$, $27^{\circ} 36^{\prime} 14.0^{\prime \prime} \mathrm{N} 88^{\circ} 38^{\prime} 44.9^{\prime \prime} \mathrm{E}, 30.07 .1959$

122 Teng, $4600 \mathrm{ft}, 1.08 .1959$

123 Tung, $4500 \mathrm{ft}, 2.08 .1959$

124 idem 56, Nanga $=$ Naga falls, $5000 \mathrm{ft}, 27^{\circ}$ $32^{\prime} 24.2^{\prime \prime} \mathrm{N} 88^{\circ} 37^{\prime} 51.1^{\prime \prime E}, 5000 \mathrm{ft}, 3-4.08 .1959$

$125 \mathrm{Manu}=$ Manul, $4900 \mathrm{ft}, 27^{\circ} 31^{\prime} 14.3^{\prime \prime} \mathrm{N} 88^{\circ} 35^{\prime}$ 24.9"E, 5.08.1959

126 Singhik = Singchit, $3700 \mathrm{ft}, 27^{\circ} 31^{\prime} 30.7^{\prime \prime} \mathrm{N}$ 88॰35'01.5"E, 6-19.08.1959

127 Lingtham $=$ Lingthem, $5250-6500 \mathrm{ft}, 27^{\circ} 31^{\prime}$ $34.8^{\prime \prime} \mathrm{N} 88^{\circ} 30^{\prime} 17.0^{\prime \prime} \mathrm{E}, 8-10.08 .1959$

128 idem 54, Mangang = Mangan, $3600 \mathrm{ft}$, $27^{\circ} 29^{\prime} 42.2^{\prime \prime} \mathrm{N} 88^{\circ} 31^{\prime} 45.9^{\prime \prime} \mathrm{E}, 11.08 .1959$

129 Dikchu = bridge on the Dik Chuu River, 2300 $\mathrm{ft}, 27^{\circ} 24^{\prime} 05.8^{\prime \prime} \mathrm{N} 88^{\circ} 31^{\prime} 25.6^{\prime \prime} \mathrm{E}, 12.08 .1959$

130 Dikchu, $2200 \mathrm{ft}, 27^{\circ} 23^{\prime} 41.0^{\prime \prime} \mathrm{N} 88^{\circ} 30^{\prime} 50.7^{\prime \prime E}$, 13.08.1959
131 Dikchu, $2080 \mathrm{ft}, 27^{\circ} 23^{\prime} 41.0^{\prime \prime} \mathrm{N} 88^{\circ} 30^{\prime} 50.7^{\prime \prime} \mathrm{E}$, 14.08 .1959

132 Kambur, 3280 ft, 15.08 .1959

133 Nampung, 3280 ft, 16.08.1959

$134=51$, Lingdok, $4000 \mathrm{ft}, 27^{\circ} 23^{\prime} 12.2^{\prime \prime} \mathrm{N} 88^{\circ} 34^{\prime}$ 18.8"E, 17.08.1959

135 Penlang $\mathrm{La}=$ Penlong La (Pass), $6200 \mathrm{ft}$, $27^{\circ} 21^{\prime} 59.7^{\prime \prime} \mathrm{N} 88^{\circ} 37^{\prime} 00.1 " \mathrm{E}, 18.08 .1959$

136 Rongne $=$ Rongneck, $6200 \mathrm{ft}, 27^{\circ} 20^{\prime} 15.2^{\prime \prime} \mathrm{N}$ $88^{\circ} 37^{\prime} 44.2^{\prime \prime}$ E, 21.08.1959

137 Karponang, 8100 ft, 22.08.1959

138 Karponang, 9900 ft, 23.08 .1959

139 Chamiteng, $9900 \mathrm{ft}, 24.08 .1959$

140 Tsomgo = Tsongmo Lake, $9900-12500 \mathrm{ft}$, $27^{\circ} 22^{\prime} 26.9^{\prime \prime} \mathrm{N} 88^{\circ} 45^{\prime} 24.2^{\prime \prime} \mathrm{E}, 26.08 .1959$

141 Sherabtong = Sarathang, $13200 \mathrm{ft}, 27^{\circ} 22^{\prime}$ 40.5"N 8849'10.7"E, 27.08.1959

142 Sherabtong = Sarathang, $12700 \mathrm{ft}, 27^{\circ} 22^{\prime}$ 40.5"N 8849'10.7"E, 28.08.1959

143 Padamchen, $7060 \mathrm{ft}, 27^{\circ} 14^{\prime} 38.5^{\prime \prime} \mathrm{N} 88^{\circ} 46^{\prime}$ 14.3"E, 29.08.1959

144 Lingtam, $4600 \mathrm{ft}, \quad 27^{\circ} 13^{\prime} 41.8^{\prime \prime} \mathrm{N} \quad 88^{\circ} 44^{\prime}$ 27.0"E, 2.09.1959

145 Rangli = Rongli, $2550 \mathrm{ft}, 27^{\circ} 12^{\prime} 11.7^{\prime \prime} \mathrm{N} 88^{\circ}$ 42'05.5"E, 3.09.1959

146 Aritar, $4920 \mathrm{ft}, 27^{\circ} 11^{\prime} 17.7^{\prime \prime} \mathrm{N} 88^{\circ} 40^{\prime} 28.8^{\prime \prime} \mathrm{E}$, 5.09.1959

North Western Bengal

147 Rhenok = Rhenok forest, $1900-3200 \mathrm{ft}$, $27^{\circ} 07^{\prime} 41.0^{\prime \prime} \mathrm{N} 88^{\circ} 41^{\prime} 07.8^{\prime \prime} \mathrm{E}, 5.09 .1959$

148 Lingsoka $=$ Lingsaykha Khasmahal, $3930 \mathrm{ft}$, $27^{\circ} 08^{\prime} 17.5^{\prime \prime} \mathrm{N} 88^{\circ} 40^{\prime} 34.5^{\prime \prime} \mathrm{E}, 7.09 .1959$

149 Lingsoka = Lingsaykha Khasmahal, $4270 \mathrm{ft}$, 9.09.1959

150 Lingsoka $=$ Lingsaykha Khasmahal, $4500 \mathrm{ft}$, 10.09.1959

151 Labha, $5000 \mathrm{ft}, 27^{\circ} 06^{\prime} 30.0^{\prime \prime} \mathrm{N} 88^{\circ} 33^{\prime 2} 29.7^{\prime \prime} \mathrm{E}$, 11.09.1959

152 Samabeong $=$ Samabiyong, $4540 \mathrm{ft}, 27^{\circ} 03^{\prime}$ 06.2"N 88०38'20.5"E, 12.09.1959

153 Git Dabling = Git Dubling, 4900-5100 ft, $27^{\circ} 02^{\prime} 38.3^{\prime \prime N} 88^{\circ} 36^{\prime} 35.8^{\prime \prime E}, 13-15.09 .1959$

154 Khani, $2050 \mathrm{ft}, 16.09 .1959$

155 Pudung, $3280 \mathrm{ft}, 27^{\circ} 04^{\prime} 00.5^{\prime \prime} \mathrm{N} 88^{\circ} 31^{\prime} 01.3$ "E, 17.09.1959

156 Bara Mangwa = Bara Mungwa, $720 \mathrm{ft}$, $27^{\circ} 03^{\prime} 50.7^{\prime \prime} \mathrm{N} 88^{\circ} 24^{\prime} 38.2^{\prime \prime E}, 18.09 .1959$ 
157 Peshok, 780-850 ft, $27^{\circ} 04^{\prime} 18.4^{\prime \prime} \mathrm{N} 88^{\circ} 24^{\prime}$ 13.9"E, 19-20.09.1959

\section{Sikkim}

158 Manghitar, $930 \mathrm{ft}, 21.09 .1959$

159 idem 5, Naya Bazar, 1060 ft, 2708'49.6"N 88¹6'46.6"E, 22.09.1959

160 Mabong, $1148 \mathrm{ft}, \quad 27^{\circ} 10^{\prime} 31.4^{\prime \prime} \mathrm{N} \quad 88^{\circ} 18^{\prime}$ 10.0"E, 23.09.1959

161 Rishi, $1470 \mathrm{ft}, 27^{\circ} 13^{\prime} 13.0^{\prime \prime} \mathrm{N} 88^{\circ} 13^{\prime} 55.2^{\prime \prime} \mathrm{E}$, 24.09.1959

162 idem 46, Ligship = Likship, $1700 \mathrm{ft}, 27^{\circ} 16^{\prime}$ $13.5^{\prime \prime} \mathrm{N} 88^{\circ} 17^{\prime} 34.8^{\prime \prime} \mathrm{E}, 25.09 .1959$

163 idem 28, Chongpung, $4920 \mathrm{ft}, 27^{\circ} 19^{\prime} 34.8^{\prime \prime} \mathrm{N}$ $88^{\circ} 14^{\prime} 09.8^{\prime \prime} \mathrm{E}, 27.09 .1959$

164 idem 29, Tinglin = Thingle, $2950 \mathrm{ft}, 27^{\circ} 20^{\prime}$ $31.9^{\prime \prime} \mathrm{N} 88^{\circ} 13^{\prime} 45.9^{\prime \prime} \mathrm{E},=28.09 .1959$

165 Tashigang $=$ Tashigang Resort, Yangtey, $3120 \mathrm{ft}, 27^{\circ} 17^{\prime} 49.1^{\prime \prime N} 88^{\circ} 16^{\prime} 18.2^{\prime \prime E}, 29.09$. 1959

166 idem 32, Yoksam = Yuksom, $5600 \mathrm{ft}$, $27^{\circ} 22^{\prime} 20.6^{\prime \prime} \mathrm{N} 88^{\circ} 133^{\prime} 21.0^{\prime \prime} \mathrm{E}, 30.09 .1959$

167 Zonphuk, $6500 \mathrm{ft}, 1.10 .1959$

168 idem 34, Bakkim = Bakhim Guest House, $6890 \mathrm{ft}, 27^{\circ} 25^{\prime} 41.9^{\prime \prime} \mathrm{N} 88^{\circ} 11^{\prime} 10.3$ "E, 2.10.1959

169 idem 36, Tangshing $=$ Thangsing Trekkers's hut, $12200-14100 \mathrm{ft}, 27^{\circ}, 30^{\prime} 59.3^{\prime \prime} \mathrm{N} 88^{\circ} 11^{\prime}$ 07.5"E, 5-6.10.1959

170 idem 37, Churong $=$ Kukchurung Trekkers's hut, $12460 \mathrm{ft}, 27^{\circ} 30^{\prime} 12.1^{\prime \prime} \mathrm{N} \quad 88^{\circ} 10^{\prime} 31.1^{\prime \prime} \mathrm{E}$, 8.10 .1959

171 Yangsap, $13120 \mathrm{ft}, 9.10 .1959$

172 idem 40, Gopetang = Gonpatang (Népal close to the Indian border), $12299 \mathrm{ft}, 27^{\circ} 25^{\prime} 44.9^{\prime \prime} \mathrm{N}$ 88०03'27.9"E, 10.10.1959

173 Lakchmi Pokri = Lachmi Pokhri, $14000 \mathrm{ft}$, $27^{\circ} 26^{\prime} 03.5^{\prime \prime} \mathrm{N} 88^{\circ} 05^{\prime} 06.2^{\prime \prime} \mathrm{E}, 11.10 .1959$

174 idem 41, Chungjom, $6800 \mathrm{ft}, 12.10 .1959$

175 idem 42, Ramtang, 5780 ft, 13.10 .1959

176 idem 44, Singbeng = Singyang, $4920 \mathrm{ft}$, $27^{\circ} 19^{\prime} 09.7^{\prime \prime} \mathrm{N} 88^{\circ} 12^{\prime} 41.6^{\prime \prime} \mathrm{E}, 14.10 .1959$

177 idem 45, Pemayangtse, $5600 \mathrm{ft}, 27^{\circ} 18^{\prime} 14.7^{\prime \prime} \mathrm{N}$ $88^{\circ} 15^{\prime} 12.8^{\prime \prime} \mathrm{E}, 15.10 .1959$

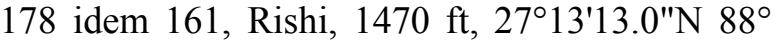
13'55.2"E, 16.10.1959

179 idem 160, Mahong = Mabong, $1148 \mathrm{ft}$, $27^{\circ} 10^{\prime} 31.4^{\prime \prime} \mathrm{N} 88^{\circ} 18^{\prime} 10.0^{\prime \prime} \mathrm{E}, 17.10 .1959$
180 idem 5, Naya Bazar, $1060 \mathrm{ft}, 27^{\circ} 08^{\prime} 49.6^{\prime \prime} \mathrm{N}$ 88¹6'46.6"E, 17.10.1959

\section{North western Assam (23.09.1960 - 21.10.1961) (Map 4)}

This high mountainous region is surrounded westward by the Bhutan and northward by the Tibet (Map 1).

1 Lalaghat, $50 \mathrm{ft}, 24^{\circ} 33^{\prime} 08.7^{\prime \prime} \mathrm{N} 92^{\circ} 37^{\prime} 37.7^{\prime \prime E}, 23$. 09.1960

2 Gauhati = Guwahati, $100 \mathrm{ft}, 26^{\circ} 08^{\prime} 39.4^{\prime \prime} \mathrm{N} 91^{\circ}$ 44'05.9"E, 26.09.1960

3 Foothills, $700 \mathrm{ft}, 26^{\circ} 56^{\prime} 58.7^{\prime \prime} \mathrm{N} 92^{\circ} 22^{\prime} 06.5^{\prime \prime} \mathrm{E}$, 25.02.1961

4 Chapai, $700 \mathrm{ft}, 26^{\circ} 27^{\prime} 52.3^{\prime \prime} \mathrm{N} 92^{\circ} 01^{\prime} 32.8^{\prime \prime} \mathrm{E}, 26$. 02.1961

5 Dhekiajuli, $400 \mathrm{ft}, 26^{\circ} 42^{\prime} 31.2^{\prime \prime} \mathrm{N} 92^{\circ} 29^{\prime} 10.1 " \mathrm{E}$, 28.02.1961

6 Bhairabkunda, $700-1000 \mathrm{ft}, 26^{\circ} 53^{\prime} 10.2^{\prime \prime} \mathrm{N} 92^{\circ}$ 07'28.2"E, 3-8.03.1961

7 Amatulla, $1250-2000 \mathrm{ft}, 26^{\circ} 55^{\prime} 42.9^{\prime \prime} \mathrm{N} 92^{\circ} 07^{\prime}$ 19.3"E, 9-11.03.1961

8 Ankalling = Ankalin, $2100 \mathrm{ft}, 27^{\circ} 01^{\prime} 30.2^{\prime \prime} \mathrm{N}$ $92^{\circ} 08^{\prime} 37.9^{\prime \prime} \mathrm{E}, 12.03 .1961$

9 Bokhar, $2200 \mathrm{ft}, 13.03 .1961$

10 Lungdur, $2800 \mathrm{ft}, 27^{\circ} 03^{\prime} 26.1^{\prime \prime N} 92^{\circ} 08^{\prime} 40.4^{\prime \prime} \mathrm{E}$, 14.03.1961

11 Lifakpo = Liphakpu, $3100 \mathrm{ft}, 27^{\circ} 04^{\prime} 35.6^{\prime \prime} \mathrm{N}$ $92^{\circ} 07^{\prime} 15.3 " \mathrm{E}, 15.03 .1961$

12 Kalaktang, $4000 \mathrm{ft}, 27^{\circ} 06^{\prime} 14.5^{\prime \prime} \mathrm{N} 92^{\circ} 06^{\prime} 49.9^{\prime \prime}$ E, 16-22.03.1961

13 Brukpataenchu $=$ Brokpalangchen, 3750-4000 $\mathrm{ft}, 27^{\circ} 05^{\prime} 02.1 " \mathrm{~N} 92^{\circ} 06^{\prime 22} .6^{\prime \prime} \mathrm{E}, 17-18.03 .1961$

14 Warongpang $=$ Warrangpam, 4250-5000 ft, $27^{\circ} 06^{\prime} 22.6^{\prime \prime} \mathrm{N} 92^{\circ} 05^{\prime} 01.3 " \mathrm{E}, 19-21.03 .1961$

15 idem 12, Kalaklang = Kalaktang, 4000-5500 $\mathrm{ft}, 27^{\circ} 06^{\prime} 17.4^{\prime \prime} \mathrm{N} 92^{\circ} 06^{\prime} 49.7^{\prime \prime} \mathrm{E}, 23.03 .1961$

16 Jhum La, 7200-8000 ft, 15-22.09.1961

17 Talung Deong, $7000 \mathrm{ft}, 26.03 .1961$

18 Domkho, $6950 \mathrm{ft}, 27^{\circ} 09^{\prime} 58.2^{\prime \prime N} 92^{\circ} 13^{\prime} 49.4 " \mathrm{E}$, 27.03.1961

19 Shergaon, $6200-6600 \mathrm{ft}, 27^{\circ} 07^{\prime} 26.2^{\prime \prime} \mathrm{N} 92^{\circ} 15^{\prime}$ 18.4"E, 28-30.03.1961

20 Gigaon = Jigaon, $6000 \mathrm{ft}, 27^{\circ} 10^{\prime} 05.7^{\prime \prime} \mathrm{N} 92^{\circ} 20^{\prime}$ 14.8"E, 31.03.1961 


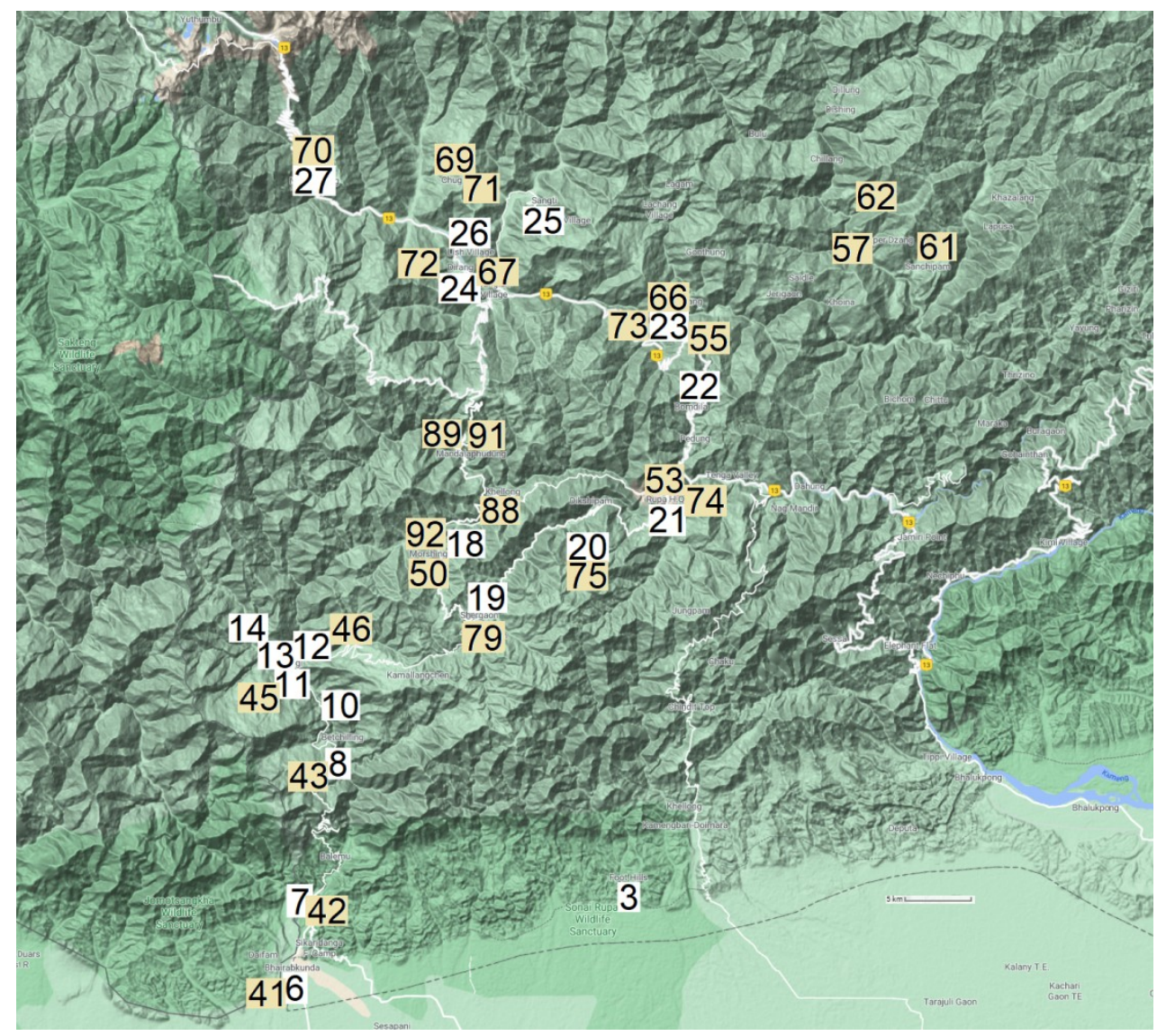

Map 4. Schmid's road in Assam.

21 Rupa, 5200-6000ft, 27²12'10.6"N 92²3'55.1" E, 1-3.04.1961

22 Bomdi La $=$ Bomdila, $8800 \mathrm{ft}, 27^{\circ} 16^{\prime} 21.3^{\prime \prime} \mathrm{N}$ $92^{\circ} 25^{\prime} 07.2^{\prime \prime} \mathrm{E}, 4-7.04 .1961$

23 Rahung, $5200 \mathrm{ft}, 27^{\circ} 18^{\prime} 46.2^{\prime \prime} \mathrm{N} 92^{\circ} 23^{\prime} 43.8^{\prime \prime} \mathrm{E}$, 8.04.1961

24 Dirang Dzong, $5300 \mathrm{ft}, 27^{\circ} 20^{\prime} 37.0^{\prime \prime} \mathrm{N} 92^{\circ} 16^{\prime}$ 22.8"E, 9-11.04.1961

25 Sangti, $5500 \mathrm{ft}, 27^{\circ} 24^{\prime} 20.3^{\prime \prime N} 92^{\circ} 18^{\prime} 15.6 " \mathrm{E}$, 12.04.1961

$26 \mathrm{Lih}=\mathrm{Lish}, 5500 \mathrm{ft}, 27^{\circ} 22^{\prime} 16.2^{\prime \prime} \mathrm{N} 92^{\circ} 14^{\prime}$ 14.7"E, 13.04.1961

27 Nyukmadong, $6600-8000 \mathrm{ft}, 27^{\circ} 24^{\prime} 32.5^{\prime \prime} \mathrm{N} 92^{\circ}$ 07'57.3"E, 18-23.04.1961

28 idem 24, Dirang Dzong, 5300 ft, 27²0'37.0"N $92^{\circ} 16 ' 22.8^{\prime \prime} \mathrm{E}, 24.04 .1961$

29 idem 23, Rahung, $5200 \mathrm{ft}, 27^{\circ} 18^{\prime} 46.2^{\prime \prime} \mathrm{N}$ $92^{\circ} 23^{\prime} 43.8^{\prime \prime} \mathrm{E}, 25.04 .1961$

30 idem 19, Bomdi $\mathrm{La}=$ Bomdila, $8800 \mathrm{ft}$, $27^{\circ} 16^{\prime} 15.2^{\prime \prime N} 92^{\circ} 25^{\prime} 59.0 " \mathrm{E}, 26-30.04 .1961$
31 idem 21, Rupa, 5200-6000ft, 27 $12^{\prime} 10.6^{\prime \prime} \mathrm{N}$ $92^{\circ} 23^{\prime} 55.1 " \mathrm{E}, 2-3.05 .1961$

32 idem 20, Gigaon = Jigaon, $6000 \mathrm{ft}, 27^{\circ}$ $10^{\prime} 05.7^{\prime \prime} \mathrm{N} 92^{\circ} 20^{\prime} 14.8^{\prime \prime} \mathrm{E}, 4.05 .1961$

33 idem 19, Shergaon, 6100-6600 ft, $27^{\circ} 07^{\prime}$ 26.2"N 92 $15^{\prime} 18.4 " \mathrm{E}, 5-10.05 .1961$

34 idem 18, Domkho, $6900 \mathrm{ft}, 27^{\circ} 09^{\prime} 58.2^{\prime \prime} \mathrm{N} 92^{\circ}$ 13'49.4"E, 11.05.1961

35 idem 17, Talung Dzong, $7000 \mathrm{ft}, 12.05 .1961$

36 idem 16, Jhum La, 7800 ft, 13-14.05.1961

37 idem 12, Kalaktang, $4000 \mathrm{ft}, 27^{\circ} 06^{\prime} 17.4^{\prime \prime} \mathrm{N}$ 92 06'49.7"E, 14.05.1961

38 idem 11, Lifakpo = Liphakpu, $3100 \mathrm{ft}, 27^{\circ} 04^{\prime}$ 35.6"N 9207'15.3"E, 15.05.1961

39 idem 10, Lungdur, $2800 \mathrm{ft}, 27^{\circ} 03^{\prime} 26.1^{\prime \prime} \mathrm{N} 92^{\circ}$ 08'40.4"E, 16.05.1961

40 idem 7, Amatulla, $1800 \mathrm{ft}, 26^{\circ} 55^{\prime} 42.9^{\prime \prime} \mathrm{N} 92^{\circ}$ 07'19.3"E, 17.05.1961

41 idem 6 Bhairabkunda, $700-1000 \mathrm{ft}, 26^{\circ} 53^{\prime}$ 10.2"N 9207'28.2"E, 18-22.05.1961 
42 idem 7, Amatulla, 1300-2000 ft, 26 $6^{\circ} 55^{\prime} 42.9^{\prime \prime} \mathrm{N}$ $92^{\circ} 07^{\prime} 19.3 " \mathrm{~B}, 23-25.05 .1961$

43 idem 8, Ankaling = Ankalin, $2100 \mathrm{ft}, 2^{\circ} 01^{\prime}$ $30.2^{\prime \prime} \mathrm{N} 92^{\circ} 08^{\prime} 38.3^{\prime \prime} \mathrm{E}, 26.05 .1961$

44 idem 9, Bokhar, 2200-2500 ft, 27-28.05.1961

45 idem 11, Lifakpo = Liphakpu, $3100 \mathrm{ft}, 27^{\circ} 04^{\prime}$ $35.6^{\prime \prime} \mathrm{N} 92^{\circ} 07^{\prime} 15.3 " \mathrm{E}, 29.05 .1961$

46 idem 12, Kalakpang = Kalaktang, $4000 \mathrm{ft}$, $27^{\circ} 06^{\prime} 17.4^{\prime \prime} \mathrm{N} 92^{\circ} 06^{\prime} 49.7^{\prime \prime} \mathrm{E}, 31.05 .1961$

47 idem 16, Jhum La, 9000 ft, 31.05.1961

48 idem 16, Jhum La, $7800 \mathrm{ft}, 1-2.06 .1961$

49 idem 17, Talung Dzong, 7000-7800 ft, 3-6. 06.1961

50 Moshing $=$ Morshing, $7800 \mathrm{ft}, 27^{\circ} 09^{\prime} 53.7^{\prime \prime} \mathrm{N}$ $92^{\circ} 12^{\prime} 56.7^{\prime \prime} \mathrm{E}, 7.06 .1961$

51 idem 18, Dorukho = Domkho, $6500 \mathrm{ft}, 27^{\circ} 09^{\prime}$ 56.4"N 92॰13'49.7"E, 8.06.1961

52 Bilo La, 5800-6000 ft, 9-10.06.1961

53 idem 21, Rupa, 5500-6000 ft, 27²1'10.6"N 92 $23 ' 55.1 " \mathrm{E}, 11-12.06 .1961$

54 idem 22, Bomdi $\mathrm{La}=$ Bomdila, $8800 \mathrm{ft}$, $27^{\circ} 16 ' 21.3^{\prime \prime} \mathrm{N} 92^{\circ} 25^{\prime} 07.2^{\prime \prime} \mathrm{E}, 13-21.06 .1961$

55 Salari, $4000 \mathrm{ft}, 27^{\circ} 18^{\prime} 32.8^{\prime \prime} \mathrm{N} 92^{\circ} 24^{\prime} 41.4^{\prime \prime} \mathrm{E}$, 22.06.1961

56 But, $5800 \mathrm{ft}, 23.06 .1961$

$57 \mathrm{Nafra}, 3500 \mathrm{ft}, 27^{\circ} 22^{\prime} 15.0^{\prime \prime} \mathrm{N} 92^{\circ} 32^{\prime} 41.9^{\prime \prime} \mathrm{E}$, 24-25.06.1961

$58 \mathrm{Nafra}, 4000 \mathrm{ft}, 27^{\circ} 22^{\prime} 31.7^{\prime \prime} \mathrm{N} 92^{\circ} 33^{\prime} 02.3^{\prime \prime E}$, 26.06.1961

59 Nyong, $4800 \mathrm{ft}, 27.06 .1961$

60 Kujjalong, $4500 \mathrm{ft}, 28-30.06 .1961$

61 Khelang = Khellong, $6000 \mathrm{ft}, 27^{\circ} 22^{\prime} 11.2^{\prime \prime} \mathrm{N}$ 92³6'19.4"E, 1-2.07.1961

62 Nakhu, 3800-4800 ft, $27^{\circ} 24^{\prime} 11.1^{\prime \prime} \mathrm{N} 92^{\circ} 33^{\prime}$ 35.8"E, 3-6.07.1961

63 idem 56, But, $4000 \mathrm{ft}, 7-8.07 .1961$

64 idem 55, Salari, 4000-4300 ft, $27^{\circ} 18^{\prime} 32.8^{\prime \prime} \mathrm{N}$ $92^{\circ} 24 ' 41.4 " \mathrm{E}, 9-10.07 .1961$

65 idem 22, Bondi La $=$ Bomdila, $8800 \mathrm{ft}, 27^{\circ}$ $16^{\prime} 21.3^{\prime \prime} \mathrm{N} 92^{\circ} 25^{\prime} 07.2^{\prime \prime} \mathrm{E}, 11-15.07 .1961$

66 idem 23, Rahung, $6500-7000 \mathrm{ft}, 27^{\circ} 18^{\prime} 46.2^{\prime \prime} \mathrm{N}$ $92^{\circ} 23^{\prime} 43.8^{\prime \prime E}, 16-17.07 .1961$

67 idem 24, Dirang Dzong, 5300-6500 ft, 27 $20^{\prime}$ $37.0^{\prime \prime} \mathrm{N} 92^{\circ} 16^{\prime} 22.8^{\prime \prime} \mathrm{E}, 18-22.07 .1961$

68 idem 26, Lih $=$ Lish, $5500 \mathrm{ft}, 27^{\circ} 22^{\prime} 16.2^{\prime \prime} \mathrm{N}$ $92^{\circ} 14^{\prime} 14.7^{\prime \prime} \mathrm{E}, 24.07 .1961$

69 Chug, 6800-7300 ft, 27²5'07.7"N 92 $14^{\circ} 01^{\prime \prime}$ E, 25-31.07.1961
70 idem 27, Nyukmadong, 6600-8000ft, 27²4' $32.5^{\prime \prime} \mathrm{N} 92^{\circ} 07 ' 57.3 " \mathrm{E}, 1.08 .1961$

71 idem 69, Chug, 7150-7300 ft, 27²5'07.7"N $92^{\circ} 14^{\prime} 01 " \mathrm{E}, 9-13.08 .1961$

72 idem 24, Dirang Dzong, $5300 \mathrm{ft}, 27^{\circ} 20^{\prime} 37.0^{\prime \prime} \mathrm{N}$ $92^{\circ} 16^{\prime} 22.8^{\prime \prime} \mathrm{E}, 15.08 .1961$

73 idem 23, Rahung, $7000-7300$ ft, $27^{\circ} 18^{\prime} 46.2^{\prime \prime} \mathrm{N}$ $92^{\circ} 23^{\prime} 43.8^{\prime \prime} \mathrm{E}, 16-17.08 .1961$

74 idem 21, Rupa, $5500 \mathrm{ft}, 27^{\circ} 12^{\prime} 10.6^{\prime \prime} \mathrm{N} 92^{\circ} 23^{\prime}$ 55.1"E, 26.08.1961

75 idem 20, Gigaon = Jigaon, $6000 \mathrm{ft}, 27^{\circ}$ $10^{\prime} 05.7 " \mathrm{~N} 92^{\circ} 20^{\prime} 14.8^{\prime \prime} \mathrm{E}, 27.08 .1961$

76 idem 19, Shergaon, $6100 \mathrm{ft}, 27^{\circ} 07^{\prime} 26.2^{\prime \prime} \mathrm{N}$ $92^{\circ} 15^{\prime} 18.4 " \mathrm{E}, 28.08 .1961$

77 idem 19, Shergaon, $6200 \mathrm{ft}, 27^{\circ} 07^{\prime} 26.2^{\prime \prime N ~} 92^{\circ}$ 15'18.4"E, 29.08.1961

78 idem 19, Shergaon, 6400-6500 ft, 2707' 26.2"N 92 $15^{\circ} 18.4^{\prime \prime} \mathrm{E}, 30-31.08 .1961$

79 idem 19, Shergaon, $6800 \mathrm{ft}, 27^{\circ} 07^{\prime} 26.2^{\prime \prime} \mathrm{N}$ $92^{\circ} 15^{\prime} 18.4 " \mathrm{E}, 1.09 .1961$

80 Tarupa La, $9000 \mathrm{ft}, 2.09 .1961$

81 idem 18, Domkho, 6970 ft, $27^{\circ} 09^{\prime} 58.2^{\prime \prime} \mathrm{N}$ $92^{\circ} 13^{\prime} 49.4^{\prime \prime} \mathrm{E}, 3.09 .1961$

82 idem 50, Moshing = Morshing, $6800 \mathrm{ft}, 27^{\circ} 09^{\prime}$ 53.7"N 92०12'56.7"E, 4-7.9.1961

83 idem 50, Moshing = Morshing, 7000-7500 ft, $27^{\circ} 09^{\prime} 53.7^{\prime \prime N} 92^{\circ} 12^{\prime} 56.7 " \mathrm{E}, 8-10.9 .1961$

84 idem 17, Talung Dzong, 7000-7800 ft, 11-13. 09.1961

85 idem 16, Jhum La, 7200-8000 ft, 15-22.09. 1961

86 idem 18, Domkho, $6500 \mathrm{ft}, 27^{\circ} 09^{\prime} 58.2^{\prime \prime} \mathrm{N} 92^{\circ}$ 13'49.4"E, 23.09.1961

87 idem 52, Bilo La, 5800 ft, 24.09.1961

88 Kelong $=$ Khellong, $6000-6200 \mathrm{ft}, 27^{\circ} 12^{\prime}$ $28.2^{\prime \prime} \mathrm{N} 92^{\circ} 16^{\prime} 21.8^{\prime \prime} \mathrm{E}, 25-26.09 .1961$

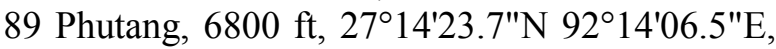
27-28.09.1961

90 Phutang, $7200-7300 \mathrm{ft}, 27^{\circ} 14 ' 35.8^{\prime \prime} \mathrm{N} 92^{\circ} 14^{\prime}$ 24.6"E, 1-4.10.1961

91 Prudong = Mandalaphudung, $11000 \mathrm{ft}, 27^{\circ}$ $14^{\prime} 00.7^{\prime \prime} \mathrm{N} 92^{\circ} 14^{\prime} 56.2^{\prime \prime} \mathrm{E}, 5.10 .1961$

92 idem 50, Moshing = Morshing, $9000 \mathrm{ft}, 27^{\circ}$ 09'53.7"N 92॰12'56.7"E, 6.10.1961

93 idem 50, Moshing = Morshing, $6800 \mathrm{ft}, 27^{\circ}$ 09'53.7"N 92॰12'56.7"E, 7.10.1961

94 idem 16, Jhum La, 9000 ft, 8.10.1961 
95 idem 12, Kalaktang, $4000 \mathrm{ft}, 27^{\circ} 06^{\prime} 17.4^{\prime \prime} \mathrm{N}$ 9206'49.7"E, 9-10.10.1961

96 idem 10, Lungdur, $2800 \mathrm{ft}, 27^{\circ} 03^{\prime} 26.1^{\prime \prime} \mathrm{N} 92^{\circ}$ 08'40.4"E, 11-12.10.1961

97 idem 9, Bokhar, $2000 \mathrm{ft}, 13.10 .1961$

98 idem 8, Ankaling = Ankalin, $5000 \mathrm{ft}, 27^{\circ}$ $01^{\prime} 30.2^{\prime \prime} \mathrm{N} 92^{\circ} 08^{\prime} 38.3 " \mathrm{E}, 14.10 .1961$

99 idem 7, Amatulla, $2000 \mathrm{ft}, 26^{\circ} 55^{\prime} 42.9^{\prime \prime} \mathrm{N}$ 9207'19.3"E, 16.10.1961

100 idem 7, Amatulla, 1500-1800 ft, 26 ${ }^{\circ} 55^{\prime}$ 42.9"N 9207'19.3"E, 17-19.10.1961

101 idem 6, Bhairabkunda, $1000 \mathrm{ft}, 26^{\circ} 53^{\prime} 10.2^{\prime \prime} \mathrm{N}$ $92^{\circ} 07 ' 28.2^{\prime \prime} \mathrm{E}, 20.10 .1961$

102 idem 6, Bhairabkunda, $700 \mathrm{ft}, 26^{\circ} 53^{\prime} 10.2^{\prime \prime} \mathrm{N}$ $92^{\circ} 07 ' 28.2^{\prime \prime} \mathrm{E}, 21.10 .1961$

\section{Meghalaya and southern Assam, 1959-1960 (Map 5)}

Meghalaya was named United Jaintia and Khasi Hills (UJKH) in the Schmid's notebook. This moutainous region is rather isolated southward the wide Brahmapoutre River and northward the Bangladesh (Map 1).

1 Pinursla $=$ Pynursla, $3750 \mathrm{ft}, 25^{\circ} 18^{\prime} 34.7^{\prime \prime} \mathrm{N} 91^{\circ}$ 54'06.8"E, 30.11.1959

2 Mawpran = Mawpran Nonglyndiang, $3500 \mathrm{ft}$, $25^{\circ} 17^{\prime} 52.9^{\prime \prime} \mathrm{N} 91^{\circ} 57^{\prime} 40.4^{\prime \prime} \mathrm{E}, 1.12 .1959$

3 Pynter, $2800 \mathrm{ft}, 2^{\circ} 15^{\prime} 49.9^{\prime \prime N} 91^{\circ} 57^{\prime} 33.6^{\prime E} \mathrm{E} 2$. 12.1959

4 Mawshun, $1500 \mathrm{ft}, 25^{\circ} 14^{\prime} 46.7^{\prime \prime} \mathrm{N} 91^{\circ} 58^{\prime} 21.2^{\prime \prime} \mathrm{E}$, 4.12.1959

5 Shnongpdeng, 200-1000 ft, $25^{\circ} 12^{\prime} 27.0^{\prime \prime} \mathrm{N} 92^{\circ}$ 00'28.4"E, 5.12.1959

6 idem 5, Shnongpdeng, $500 \mathrm{ft}, 25^{\circ} 12^{\prime} 27.0^{\prime \prime} \mathrm{N} 92^{\circ}$ 00'28.4"E, 6.12.1959

7 Sohkha = Sohkha Shnong, 200-300 ft, 25 $12^{\prime} 59.3^{\prime \prime} \mathrm{N} \mathrm{92}{ }^{\circ} 01^{\prime} 55.0 " \mathrm{E}, 7.12 .1959$

8 Dawki, $200 \mathrm{ft}, 25^{\circ} 11^{\prime} 21.1^{\prime \prime N} 92^{\circ} 01^{\prime} 12.2^{\prime \prime E}, 8$. 12.1959
9 Ronghongkung $=$ Rhongkum, $200 \mathrm{ft}, 25^{\circ} 10^{\prime}$ 49.4"N 92॰05'01.5"E, 9.12.1959

10 Sohkharim, $200 \mathrm{ft}, 10.12 .1959$

11 Muktapur, $200 \mathrm{ft}, 25^{\circ} 09^{\prime} 48.6^{\prime \prime N} 92^{\circ} 07^{\prime} 45.4^{\prime \prime} \mathrm{E}$, 11-12-12.1959

12 Syndai, $700 \mathrm{ft}, 25^{\circ} 10^{\prime} 34.6^{\prime \prime} \mathrm{N} 92^{\circ} 07^{\prime} 46.7^{\prime \prime} \mathrm{E}$, 14.12.1959

13 Syndai, $700-2500 \mathrm{ft}, 25^{\circ} 11^{\prime} 29.2^{\prime \prime} \mathrm{N} 92^{\circ} 08^{\prime}$ 31.5"E, 15.12.1959

14 Syndai, $800 \mathrm{ft}, 25^{\circ} 11^{\prime} 29.2^{\prime \prime N} 92^{\circ} 08^{\prime} 31.5^{\prime \prime E}, 16$. 12.1959

15 Laremshiap = Laremshyiap, $1800 \mathrm{ft}, 25^{\circ} 10^{\prime}$ $44.5^{\prime \prime} \mathrm{N} 92^{\circ} 11^{\prime} 54.1$ "E, 17.12.1959

16 Laremshiap = Laremshyiap, $1500 \mathrm{ft}, 25^{\circ} 10^{\prime}$ 39.7"N 92॰11'46.4"E, 18.12.1959

17 Borghat, $200 \mathrm{ft}, 25^{\circ} 09^{\prime} 50.0^{\prime \prime} \mathrm{N} 92^{\circ} 15^{\prime} 13.4^{\prime \prime} \mathrm{E}$, 19-22.12.1959

18 Purnasampara, $500 \mathrm{ft}, 23-24.12 .1959$

19 idem 12, Syndai, $700 \mathrm{ft}, 25^{\circ} 10^{\prime} 34.6^{\prime \prime N} 92^{\circ} 07^{\prime}$ 46.7"E, 25-26.12.1959

20 Tarangblang, $2000 \mathrm{ft}, 25^{\circ} 11^{\prime} 24.4^{\prime \prime} \mathrm{N} 92^{\circ} 12^{\prime}$ 34.2"E, 27.12.1959

21 Mawpang, $2500 \mathrm{ft}, 28.12 .1959$

22 Tkentalong, $2500 \mathrm{ft}, 29-31.12 .1959$

23 idem 20, Tarangblang, $2000 \mathrm{ft}, 25^{\circ} 11^{\prime} 24.4^{\prime \prime} \mathrm{N}$ $92^{\circ} 12^{\prime} 34.2^{\prime \prime} \mathrm{E}, 1.01 .1960$

24 idem 17, Borghat, $200 \mathrm{ft}, 25^{\circ} 09^{\prime} 50.0^{\prime \prime} \mathrm{N} 92^{\circ} 15^{\prime}$ 13.4"E, 2-3.01.1960

25 Lakadong, $1500 \mathrm{ft}, 25^{\circ} 10^{\prime} 50.4^{\prime \prime} \mathrm{N} \quad 92^{\circ} 16^{\prime}$ 55.1"E, 4.01.1960

26 Umlong, $500 \mathrm{ft}, 25^{\circ} 10^{\prime} 19.7^{\prime \prime} \mathrm{N} 92^{\circ} 20^{\prime} 13.1 " \mathrm{E}$, 5.01 .1960

27 Umpuh, 2000 ft, 6.01.1960

28 Musianglamare $=$ moo sianglamare, $2700 \mathrm{ft}$, $25^{\circ} 13^{\prime} 13.5^{\prime \prime} \mathrm{N} 92^{\circ} 21^{\prime 2} 20.7^{\prime \prime E}, 7-9.01 .1960$

29 Tharauyang, $2900 \mathrm{ft}, 10.01 .1960$

30 Myndihati = Byndihati, $3000 \mathrm{ft}, 25^{\circ} 19^{\prime} 09.4^{\prime \prime} \mathrm{N}$ $92^{\circ} 22^{\prime} 12.7^{\prime \prime} \mathrm{E}, 11.01 .1960$

31 Pynter, $1700 \mathrm{ft}, 25^{\circ} 15^{\prime} 17.2^{\prime \prime} \mathrm{N} 91^{\circ} 57^{\prime} 46.6^{\prime \prime} \mathrm{E}$, 19.01.1960 


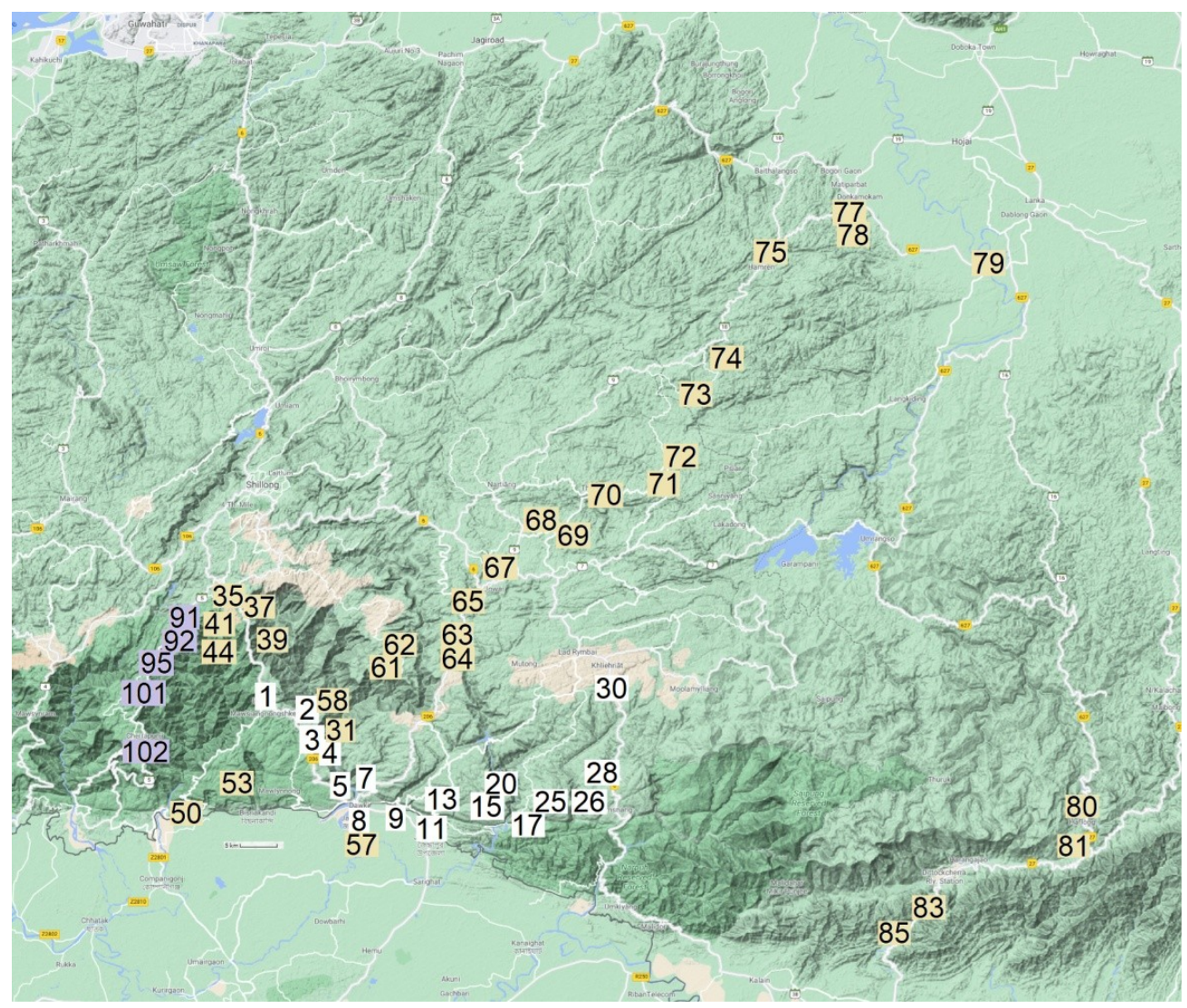

Map 5. Schmid's road in Meghalaya.

32 Pynter, $500 \mathrm{ft}, 25^{\circ} 15^{\prime} 18.2^{\prime \prime} \mathrm{N} 91^{\circ} 58^{\prime} 43.8^{\prime \prime} \mathrm{E}, 20$. 01.1960

33 Pynter, 200-300 ft, $25^{\circ} 15^{\prime} 18.2^{\prime \prime} \mathrm{N} 91^{\circ} 58^{\prime} 43.8^{\prime \prime}$ E, 21-23.01.1960

34 idem 4, Mawshun, $2000 \mathrm{ft}, 24.01 .1960$

35 Laitlyngkot, $4800 \mathrm{ft}, 25^{\circ} 26^{\prime} 39.0^{\prime \prime} \mathrm{N} 91^{\circ} 50^{\prime} 40.8^{\prime \prime}$ E, 14.03 .1960

36 Laitlyngkot, $4000-4500 \mathrm{ft}, 25^{\circ} 26^{\prime} 39.0^{\prime \prime} \mathrm{N} 91^{\circ}$ 50'40.8"E, 15.03.1960

37 Laitlyngkot, $3000-3500 \mathrm{ft}, 25^{\circ} 25^{\prime} 51.2^{\prime \prime} \mathrm{N} 91^{\circ}$ 52'58.5"E, 16.03.1960

38 Laitlyngkot, $2000-2300 \mathrm{ft}, 25^{\circ} 24^{\prime} 42.9^{\prime \prime} \mathrm{N} 91^{\circ}$ 54'35.4"E, 17.03.1960

39 Mawkhap, $1500 \mathrm{ft}, 25^{\circ} 23^{\prime} 15.5^{\prime \prime} \mathrm{N} 91^{\circ} 54^{\prime} 14.0^{\prime \prime}$ E, 18.03.1960

40 Mawkhap, $2000 \mathrm{ft}, 25^{\circ} 23^{\prime 2} 27.7^{\prime \prime} \mathrm{N} 91^{\circ} 53^{\prime} 59.0^{\prime \prime}$ E, 19.03.1960

41 Rumkheng $=$ Ramkheng, $5500 \mathrm{ft}, 25^{\circ} 23^{\prime} 20.0^{\prime \prime}$ N 9150'01.1"E, 20-23.03.1960

42 Rumkheng $=$ Ramkheng, $4500 \mathrm{ft}, 25^{\circ} 23^{\prime} 07.2^{\prime \prime}$ N 9150'12.8"E, 24.03.1960
43 Rumkheng = Ramkheng, $3000 \mathrm{ft}, 25^{\circ} 21^{\prime} 55.4^{\prime \prime}$ N 91 ${ }^{\circ} 50 ' 24.4 " \mathrm{E}, 25.03 .1960$

44 Rumkheng = Ramkheng, $2000 \mathrm{ft}, 25^{\circ} 21^{\prime} 11.8^{\prime \prime}$ N 91 50 '17.3"E, 26.03.1960

45 Nongrim = Nongtraw?, $1800 \mathrm{ft}, 25^{\circ} 22^{\prime} 09.9^{\prime \prime} \mathrm{N}$ $91^{\circ} 45^{\prime} 48.2^{\prime \prime} \mathrm{E}, 27.03 .1960$

46 Nongrim = Nongtraw?, $3000 \mathrm{ft}, 25^{\circ} 22^{\prime} 09.9^{\prime \prime} \mathrm{N}$ $91^{\circ} 45^{\prime} 48.2^{\prime \prime} \mathrm{E}, 28.03 .1960$

47 Mawshnid, $1400 \mathrm{ft}, 29.03 .1960$

48 Mawja, $550 \mathrm{ft}, 30.03 .1960$

49 Nongjri $=$ Hat Nongjri, $350 \mathrm{ft}, 25^{\circ} 10^{\prime} 18.4^{\prime \prime} \mathrm{N}$ 914' 54.9"E, 31.03.1960

50 Nongjri $=$ Hat Nongjri, $300 \mathrm{ft}, 25^{\circ} 10^{\prime} 18.4^{\prime \prime} \mathrm{N}$ 914ㄴ'54.9"E, 1.04 .1960

51 Therria, $200 \mathrm{ft}, 2.04 .1960$

52 Barpunji, $200 \mathrm{ft}, 3.04 .1960$

53 Hat Nongshken = Nongshken, $200 \mathrm{ft}, 25^{\circ}$ $12^{\prime} 39.0^{\prime \prime} \mathrm{N} \mathrm{91}{ }^{\circ} 51^{\prime} 44.9 " \mathrm{E}, 4.04 .1960$

54 Umkaram, 1000 ft, 5.04.1960

55 idem 4, idem 34, Mawshun, $1500 \mathrm{ft}, 6.04 .1960$

56 Shuongpdeng, $1000 \mathrm{ft}, 7.04 .1960$ 
57 idem 8, Dawki, $200 \mathrm{ft}, 25^{\circ} 11^{\prime} 21.1^{\prime \prime N} 92^{\circ}$ 01'12.2"E, 8.04.1960

58 idem 2, Mawpran = Mawpran Nonglyndiang, $3500 \mathrm{ft}, 25^{\circ} 17^{\prime} 52.9^{\prime \prime} \mathrm{N} 91^{\circ} 57^{\prime} 40.4^{\prime \prime} \mathrm{E}, 8.04 .1960$

59 Mawpran = Mawpran Nonglyndiang, $2000 \mathrm{ft}$, $25^{\circ} 18 ' 27.3^{\prime \prime} \mathrm{N} 91^{\circ} 58^{\prime} 05.7 " \mathrm{E}, 9.04 .1960$

60 Mawpran = Mawpran Nonglyndiang, $900 \mathrm{ft}$, $25^{\circ} 18^{\prime} 43.0^{\prime \prime} \mathrm{N} 91^{\circ} 59^{\prime} 15.6^{\prime \prime} \mathrm{E}, 10.04 .1960$

61 Syntung, $4000 \mathrm{ft}, 25^{\circ} 21^{\prime} 12.2^{\prime \prime} \mathrm{N} 92^{\circ} 03^{\prime} 08.0^{\prime \prime} \mathrm{E}$, 11.04.1960

62 Mawlang, $4000 \mathrm{ft}, 25^{\circ} 21^{\prime} 30.3^{\prime \prime} \mathrm{N} 92^{\circ} 04^{\prime} 15.1$ "E, 12.04.1960

63 Jarain, $2800 \mathrm{ft}, 25^{\circ} 22^{\prime} 23.7^{\prime \prime} \mathrm{N} 92^{\circ} 08^{\prime} 58.9^{\prime \prime} \mathrm{E}$, 13.04.1960

64 Mawpyut, $4000 \mathrm{ft}, 25^{\circ} 22^{\prime} 20.7^{\prime \prime} \mathrm{N} 92^{\circ} 09^{\prime} 03.7^{\prime \prime}$ E, 14.04.1960

65 Demphring = Demthring, $3800 \mathrm{ft}, 25^{\circ} 26^{\prime} 09.5^{\prime \prime}$ $\mathrm{N} 92^{\circ} 10^{\prime} 08.0 " \mathrm{E}, 16.04 .1960$

66 Tadlaskein, $4250 \mathrm{ft}, 17.04 .1960$

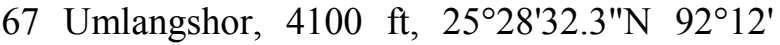
49.0"E, 18.04.1960

68 Nongjni $=$ Nongjngi, $3750 \mathrm{ft}, 25^{\circ} 32^{\prime} 21.1^{\prime \prime} \mathrm{N}$ $92^{\circ} 16^{\prime} 12.4^{\prime \prime} \mathrm{E}, 19.04 .1960$

69 Mynso = Mynsoo, $3500 \mathrm{ft}, 25^{\circ} 33^{\prime} 43.5^{\prime \prime} \mathrm{N} 92^{\circ}$ 19'37.5"E, 20.04.1960

70 Shilliang Myntang = Shiliangmyntang, 3500 $\mathrm{ft}, 25^{\circ} 33^{\prime} 55.6^{\prime \prime} \mathrm{N} 92^{\circ} 21^{\prime} 32.5^{\prime \prime} \mathrm{E}, 21.04 .1960$

71 Thangrain, $3000 \mathrm{ft}, 25^{\circ} 34^{\prime} 45.1^{\prime \prime} \mathrm{N} \mathrm{92^{ \circ } 2 6 ^ { \prime } 2 6 . 7 ^ { \prime \prime }}$ E, 22.04.1960

72 Barato, $2500 \mathrm{ft}, 25^{\circ} 36^{\prime} 24.1^{\prime \prime N} 92^{\circ} 27^{\prime} 23.1 " \mathrm{E}$, 23.04.1960

United district of Mikir and North Cachar Hills, Assam

73 Nongjrang = Nonjirong, $2700 \mathrm{ft}, 25^{\circ} 41^{\prime} 29.6^{\prime \prime} \mathrm{N}$ $92^{\circ} 28^{\prime} 41.3^{\prime \prime} \mathrm{E}, 25.04 .1960$

74 Umbaso, $2300 \mathrm{ft}, 25^{\circ} 43^{\prime} 46.3^{\prime \prime} \mathrm{N} 92^{\circ} 31^{\prime} 33.5^{\prime \prime} \mathrm{E}$, 26.04.1960

75 Rongkhong = Rongbong Ronghang, $1400 \mathrm{ft}$, $25^{\circ} 51^{\prime} 24.1^{\prime \prime} \mathrm{N} 92^{\circ} 35^{\prime} 17.5^{\prime \prime} \mathrm{E}, 27.04 .1960$

76 Sirtrang, $1400 \mathrm{ft}, 28.04 .1960$

77 Tranggaon $=$ Terang Gaon, $1200 \mathrm{ft}, 25^{\circ} 54^{\prime}$ $57.6 " \mathrm{~N} \mathrm{92} 41^{\circ} 30.2^{\prime \prime} \mathrm{E}, 29.04 .1960$

78 Langtrang = Langang, $500 \mathrm{ft}, 25^{\circ} 54^{\prime} 18.6^{\prime \prime} \mathrm{N}$ 92०41'11.6"E, 30.04.1960

79 Kherani Mokam = Kheroni mökki, $200 \mathrm{ft}$, $25^{\circ} 51^{\prime} 29.8^{\prime \prime} \mathrm{N} 92^{\circ} 53^{\prime} 02.9 " \mathrm{E}, 3.05 .1960$
80 Haflong, $1500 \mathrm{ft}, 25^{\circ} 09^{\prime} 43.8^{\prime \prime N} 93^{\circ} 00^{\prime} 54.3^{\prime \prime} \mathrm{E}$, 5.05 .1960

81 Inchaikang, $800 \mathrm{ft}, 25^{\circ} 07^{\prime} 40.0^{\prime \prime} \mathrm{N} 92^{\circ} 59^{\prime} 52.0^{\prime \prime}$ E, 6.05.1960

82 Nangku, $700 \mathrm{ft}, 7.05 .1960$

83 Bandarkhali = Bandarkhal, $500 \mathrm{ft}, 25^{\circ} 03^{\prime} 31.1^{\prime \prime}$ N 92 $48^{\prime} 02.5 " \mathrm{E}, 8.05 .1960$

84 Bandarkhali $=$ Bandarkhal, $300 \mathrm{ft}, 25^{\circ} 03^{\prime} 31.1^{\prime \prime}$ N 92 $48^{\prime} 02.5 " E, 9.05 .1960$

85 Damchara, $250 \mathrm{ft}, 25^{\circ} 00^{\prime} 44.8^{\prime \prime N} 92^{\circ} 44^{\prime} 57.3^{\prime \prime E}$, 10.05.1960

86 Chabaghan, $100 \mathrm{ft}, 11.05 .1960$

87 Silchar, $50 \mathrm{ft}, 24^{\circ} 50^{\prime} 07.4^{\prime \prime} \mathrm{N} 92^{\circ} 47^{\prime} 10.8^{\prime \prime} \mathrm{E}$, 12.05.1960

88 Lakhipur, $100 \mathrm{ft}, 24^{\circ} 47^{\prime} 48.6^{\prime \prime} \mathrm{N} 93^{\circ} 00^{\prime} 34.5^{\prime \prime} \mathrm{E}$, 14-16.05.1960

89 Telka, $62 \mathrm{ft}, 15.05 .1960$

90 Jirighat, $80 \mathrm{ft}, 24^{\circ} 48^{\prime} 29.4^{\prime \prime} \mathrm{N} 93^{\circ} 06^{\prime} 17.9^{\prime \prime} \mathrm{E}$, 16.05 .1960

Meghalaya (UJKH), Autumn 1960

91 Dympep, 6000 ft, 25²4'40.6"N 91²4'26.7"E, 1.10 .1960

92 Mawrap = Mawrah, $4800 \mathrm{ft}, 25^{\circ} 23^{\prime} 09.8^{\prime \prime} \mathrm{N}$ 914' $53.3 " \mathrm{E}, 2.10 .1960$

93 Serrarim, $5800 \mathrm{ft}, 3.10 .1960$

94 Amsawmat, 4500 ft, 5.10 .1960

95 Serrarim = Sohrarim, $5500 \mathrm{ft}, 25^{\circ} 20^{\prime} 57.8^{\prime \prime} \mathrm{N}$ 914ㄴ'51.3"E, 6-7.10.1960

96 idem 92, Mawrap = Mawrah, $4500 \mathrm{ft}, 25^{\circ}$ $23^{\prime} 09.8^{\prime \prime} \mathrm{N} 91^{\circ} 466^{\prime} 53.3^{\prime \prime} \mathrm{E}, 8.10 .1960$

97 idem 45, Nongrim = Nongtraw?, $2800 \mathrm{ft}, 25^{\circ}$ $22^{\prime} 09.8^{\prime \prime} \mathrm{N} 91^{\circ} 45^{\prime} 41.5^{\prime \prime} \mathrm{E}, 9.10 .1960$

98 idem 46, Nongrim = Nongtraw?, $3500 \mathrm{ft}, 25^{\circ}$ $22^{\prime} 09.8^{\prime \prime} \mathrm{N} 91^{\circ} 45^{\prime} 41.5^{\prime \prime} \mathrm{E}, 10.10 .1960$

99 idem 46, Nongrim = Nongtraw?, $3000 \mathrm{ft}, 25^{\circ}$ $22^{\prime} 09.8^{\prime \prime} \mathrm{N} \mathrm{91}{ }^{\circ} 45^{\prime} 41.5 " \mathrm{E}, 11.10 .1960$

100 Mawshuid, $1400 \mathrm{ft}, 12.10 .1960$

101 Laitryngew, $5000 \mathrm{ft}, 25^{\circ} 19^{\prime} 21.8^{\prime \prime} \mathrm{N} 91^{\circ} 43^{\prime}$ 48.0"E, 13.10.1960

102 Cherrapunji, $4500 \mathrm{ft}, 25^{\circ} 16^{\prime} 08.1^{\prime \prime N} 91^{\circ} 44^{\prime}$ 03.1"E, 14.10.1960

\section{Manipur and Mizoram (Map 6)}

This mountainous region of eastern India is adjacent to the Birman (Myanmar) boarder (Map 1). 


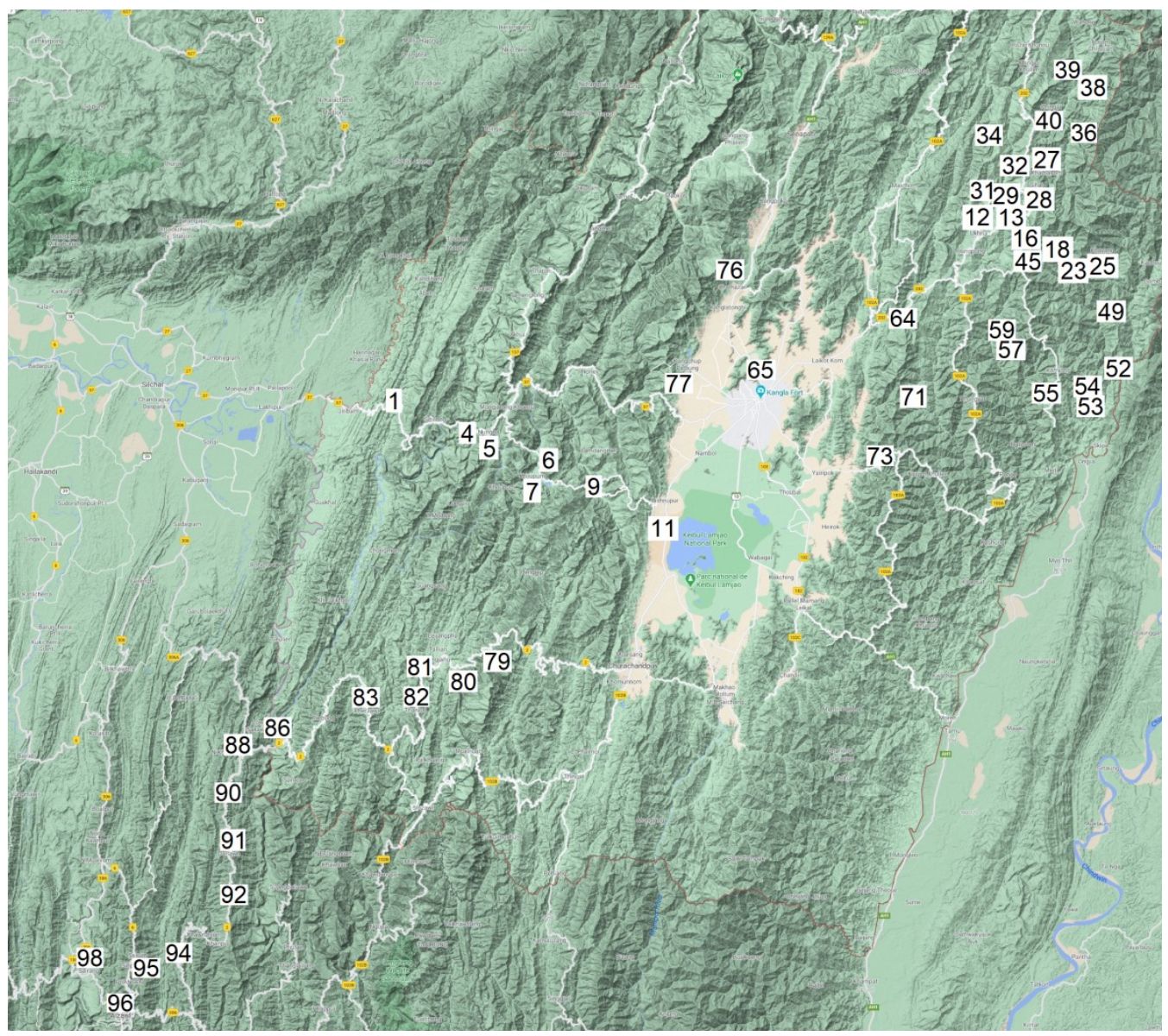

Map 6. Schmid's road in Manipur and Mizoram.

\section{Manipur}

1 Kaiphundai, $100 \mathrm{ft}, 24^{\circ} 47^{\prime} 49.8^{\prime \prime} \mathrm{N} 93^{\circ} 14^{\prime} 14.7^{\prime \prime} \mathrm{E}$, 20.05.1960

2 Vangai Chungpar, $300 \mathrm{ft}, 21.05 .1960$

3 Dinamlong, $300 \mathrm{ft}, 22-23.05 .1960$

4 Kambiron, $1500 \mathrm{ft}, 24^{\circ} 44^{\prime} 46.9^{\prime \prime} \mathrm{N} 93^{\circ} 23^{\prime} 01.7^{\prime \prime} \mathrm{E}$, 24.05 .1960

5 Nungba, $2300 \mathrm{ft}, 24^{\circ} 44^{\prime} 49.3^{\prime \prime} \mathrm{N} 93^{\circ} 24^{\prime} 48.7^{\prime \prime} \mathrm{E}$, 25.05.1960

6 Lagairong, $2500 \mathrm{ft}, 24^{\circ} 42^{\prime} 02.4^{\prime \prime} \mathrm{N} 93^{\circ} 31^{\prime} 55.8^{\prime \prime} \mathrm{E}$, 26.05.1960

7 Khopurn $=$ Khoupum Valley, $2500 \mathrm{ft}, 24^{\circ} 40^{\prime}$ $31.8^{\prime \prime} \mathrm{N} \mathrm{93}{ }^{\circ} 31^{\prime} 07.3^{\prime \prime} \mathrm{E}, 27.05 .1960$

8 Luanglong Khunau $=$ Lubanglong, $2500 \mathrm{ft}$, $24^{\circ}$ $41^{\prime} 08.8^{\prime \prime} \mathrm{N} 93^{\circ} 31 ' 27.2^{\prime \prime} \mathrm{E}, 28.05 .1960$

9 Leimatak River, $1300 \mathrm{ft}, 24^{\circ} 38^{\prime} 48.5^{\prime \prime} \mathrm{N} 93^{\circ} 38^{\prime}$ 03.3"E, 29-30.05.1960
10 Tairenpokpi, $4000 \mathrm{ft}, 24^{\circ} 49^{\prime} 36.7^{\prime \prime} \mathrm{N}$ 93ํำ 14.6"E, 31.05.1960

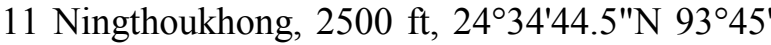
11.1"E, 1.06.1960

12 Ukhrul, $6000 \mathrm{ft}, 25^{\circ} 04^{\prime} 46.3^{\prime \prime} \mathrm{N} 94^{\circ} 21^{\prime} 07.8^{\prime \prime} \mathrm{E}$, 4.06.1960

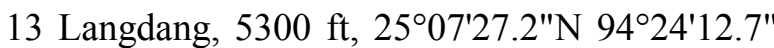
E, 5.06.1960

14 Sirohi Kashong $=$ Siruhi Kashong $=$ Shirui Kashong (peak), 7000-7500 ft, $25^{\circ} 06^{\prime} 44.5^{\prime \prime} \mathrm{N}$ 94²7'35.4"E, 6-7.06.1960

15 Sirohi Kashong = Shirui Kashong (peak), 6800 $\mathrm{ft}, 25^{\circ} 07^{\prime} 06.4^{\prime \prime} \mathrm{N} 94^{\circ} 27^{\prime} 36.6 " \mathrm{E}, 8.06 .1960$

16 Sirohi Kashong = Shirui Kashong (peak), 6000 $\mathrm{ft}, 25^{\circ} 07^{\prime} 39.7^{\prime \prime} \mathrm{N} 94^{\circ} 26^{\prime} 20.6 " \mathrm{E}, 9.06 .1960$

17 Sirohi Kashong = Shirui Kashong (peak), 6200

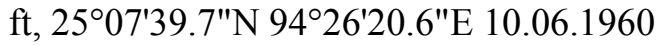


18 Mapum, $5000 \mathrm{ft}, 25^{\circ} 04^{\prime} 55.9^{\prime \prime} \mathrm{N} 94^{\circ} 30^{\prime} 16.9^{\prime \prime} \mathrm{E}$, 11.06.1960

19 Mapum, $3300 \mathrm{ft}, 25^{\circ} 03^{\prime} 23.2^{\prime \prime} \mathrm{N} 94^{\circ} 30^{\prime} 33.5^{\prime \prime} \mathrm{E}$, 12.06.1960

20 Chingsao = Zingsui, 5400 ft., $25^{\circ} 05^{\prime} 43.2^{\prime \prime} \mathrm{N}$ 94³1'56.0"E, 13.06.1960

21 Chingsao $=$ Zingsui, 3800 ft., 14.06 .1960

22 Chingsao $=$ Zingsui, 4500 ft., 5.06 .1960

23 Loni = Roni, $4500-5500$ ft., $25^{\circ} 03^{\prime} 41.8^{\prime \prime} \mathrm{N}$ 943'ㄴ'18.8"E, 16.VI.1960,

24 Mattiyang, $2800 \mathrm{ft}$, the Mattiyang Mount $(1531 \mathrm{~m})$, probably $24^{\circ} 59^{\prime} 02.1^{\prime \prime} \mathrm{N} \mathrm{94^{ \circ } 3 6} 31.9^{\prime \prime}$ $\mathrm{E}$, is the major peak of the range between the Mount Khayang Bung upto Chahang Khunou (Chahong Khunou). The locality Mattiyang was not found but it should be along the road to the Mattiyang Mount near this point according to the altitude, $24^{\circ} 53^{\prime} 16.1^{\prime \prime} \mathrm{N} 94^{\circ} 36^{\prime}$ 49.2"E, 17.06.1960

25 Khaiyang = Khayang, $3200 \mathrm{ft}, 25^{\circ} 03^{\prime} 48.1^{\prime \prime} \mathrm{N}$ 94³6'52.9"E, 18.06.1960

26 Akayam Bum, 7500-5800 ft, 20-23.06.1960

27 Khamasson $=$ Khamasom, $3900 \mathrm{ft}, 25^{\circ} 12^{\prime}$ $05.8^{\prime \prime} \mathrm{N} 94^{\circ} 29^{\prime} 16.4^{\prime \prime} \mathrm{E}, 24.06 .1960$

28 Sihai Khulen $=$ Sihai Khullen, $4700 \mathrm{ft}, 25^{\circ}$

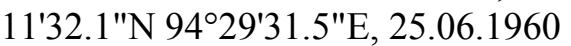

29 Sirohi = Shirui, $4300 \mathrm{ft}, 25^{\circ} 07^{\prime} 42.6^{\prime \prime} \mathrm{N} 94^{\circ} 25^{\prime}$ 14.6"E, 26.06.1960

30 idem 12, Ukhrul, $6000 \mathrm{ft}, 25^{\circ} 04^{\prime} 46.3^{\prime \prime} \mathrm{N} 94^{\circ} 21^{\prime}$ 07.8"E, 28.06.1960

31 Khangairim. It probably corresponds to Khangkhui Khullen, $4145 \mathrm{ft}, 25^{\circ} 05^{\prime} 58.7^{\prime \prime} \mathrm{N} 94^{\circ}$ 23'35.8"E, 29.06.1960,

32 Longhi Khulen $=$ Longpi $=$ Nungbi Khullen, $4500 \mathrm{ft}, 25^{\circ} 12^{\prime} 20.9^{\prime \prime} \mathrm{N} 94^{\circ} 27^{\prime} 10.1^{\prime \prime} \mathrm{E}, 30.06$. 1960

33 Huiahu $=$ Huishu, $4300 \mathrm{ft}, 25^{\circ} 15^{\prime} 07.6^{\prime \prime} \mathrm{N} 94^{\circ}$ 32'23.5"E, 1.07.1960

34 Huiahu = Huishu, $5000 \mathrm{ft}, 25^{\circ} 14^{\prime} 47^{\prime \prime} \mathrm{N}$, 943' $10^{\prime \prime}$ E, 2.07.1960

35 Huiahu $=$ Huishu, $3800 \mathrm{ft}, 25^{\circ} 15^{\prime} 01.4^{\prime \prime} \mathrm{N} 94^{\circ}$ 31'51.8"E, 3.07.1960

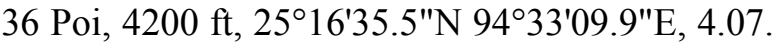
1960

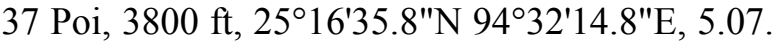
1960

38 Challao $=$ Challow, $3250 \mathrm{ft}, 25^{\circ} 21^{\prime} 30.0^{\prime \prime} \mathrm{N} 94^{\circ}$ 33'06.1"E, 6.07.1960
39 Kongai, $3900 \mathrm{ft}, 25^{\circ} 22^{\prime} 44.7^{\prime \prime} \mathrm{N} 94^{\circ} 32^{\prime} 48.0^{\prime \prime} \mathrm{E}$, 7.07.1960

40 Chingai, $4400 \mathrm{ft}, 25^{\circ} 19^{\prime} 13.2^{\prime \prime} \mathrm{N} 94^{\circ} 30^{\prime} 15.1^{\prime \prime} \mathrm{E}$, 8.07.1960

41 idem 29, Sirohi $=$ Shirui, $4100 \mathrm{ft}, 25^{\circ} 07^{\prime}$ 42.6"N 94²5'14.6"E, 9.07.1960

42 idem 14, Sirohi Kashong = Siruhi Kashong = Shirui Kashong (peak), 7000-7500 ft, $25^{\circ} 07^{\prime}$ $16.8^{\prime \prime} \mathrm{N} 94^{\circ} 27^{\prime} 29.5^{\prime \prime} \mathrm{E}, 11-13.07 .1960$

43 idem 12 \& 30, Ukhrul, $6000 \mathrm{ft}, 25^{\circ} 04^{\prime} 46.3^{\prime \prime} \mathrm{N}$ 94²1'07.8"E, 14-15.07.1960

44 Khanggai, $4828 \mathrm{ft}, 16.07 .1960$

45 Pushing, $6000 \mathrm{ft}, 25^{\circ} 04^{\prime} 27.2^{\prime \prime N} 94^{\circ} 28^{\prime} 00.7^{\prime \prime} \mathrm{E}$, 17.07.1960

46 Pushing, $4800 \mathrm{ft}, 25^{\circ} 03^{\prime} 51.5^{\prime \prime} \mathrm{N} 94^{\circ} 28^{\prime} 37.7^{\prime \prime} \mathrm{E}$, 18.07.1960

47 Lushat, $2800 \mathrm{ft}, 19.07 .1960$

48 Langkae $=$ Lanchah, $5000 \mathrm{ft}, 20.07 .1960$

49 Chattrik, $4300 \mathrm{ft}, 24^{\circ} 58^{\prime} 26.5^{\prime \prime} \mathrm{N} 94^{\circ} 36^{\prime} 52.9^{\prime \prime} \mathrm{E}$, 21.07.1960

50 Chattrik, $1500 \mathrm{ft}, 24^{\circ} 57^{\prime} 35.8^{\prime \prime} \mathrm{N} 94^{\circ} 35^{\prime} 30.7^{\prime \prime} \mathrm{E}$, 22.07.1960

51 Chattrik, $4500 \mathrm{ft}, 24^{\circ} 58^{\prime} 26.5^{\prime \prime} \mathrm{N} 94^{\circ} 36^{\prime} 52.9^{\prime \prime} \mathrm{E}$, 23.07.1960

52 Chaharg Khunon $=$ Chahong Khunou, $1200 \mathrm{ft}$, $24^{\circ} 51^{\prime} 21.3^{\prime \prime N} 94^{\circ} 37^{\prime} 49.4^{\prime \prime} \mathrm{E}, 24.07 .1960$

53 Aishi, $1200 \mathrm{ft}, 24^{\circ} 47^{\prime} 17.3^{\prime \prime} \mathrm{N}$ 94³4'38.1"E, 25.07.1960

54 Lakhan Khuman, $3000 \mathrm{ft}, 24^{\circ} 48^{\prime} 51.1^{\prime \prime} \mathrm{N} 94^{\circ}$ 33'34.6"E, 26.07.1960

55 Bongba Khunou = Bungpa Khunou, $4800 \mathrm{ft}$, $24^{\circ} 49^{\prime} 12.6^{\prime \prime} \mathrm{N} 94^{\circ} 29^{\prime} 13.2^{\prime \prime} \mathrm{E}, 27.07 .1960$

56 Bongba Khulen = Bungpa Khullen, $2500 \mathrm{ft}$, $24^{\circ} 49^{\prime} 49.6^{\prime \prime} \mathrm{N} 94^{\circ} 27^{\prime} 28.6^{\prime \prime} \mathrm{E}, 28.07 .1960$

57 Ningthi, $1800 \mathrm{ft}, 24^{\circ} 51^{\prime} 57.2^{\prime \prime} \mathrm{N} 94^{\circ} 23^{\prime} 58.3^{\prime \prime} \mathrm{E}$, 29.07.1960

58 Ningthi, $2500 \mathrm{ft}, 24^{\circ} 52^{\prime} 48.8^{\prime \prime} \mathrm{N} 94^{\circ} 24^{\prime} 35.5^{\prime \prime} \mathrm{E}$, 30.07 .1960

59 Hanggou $=$ Hangkou, $3300 \mathrm{ft}, 24^{\circ} 55^{\prime} 27.1^{\prime \prime} \mathrm{N}$ $94^{\circ} 23^{\prime} 53.1^{\prime \prime E}, 31.07 .1960$

60 Apong, $3000 \mathrm{ft}, 24^{\circ} 56^{\prime} 14.4^{\prime \prime} \mathrm{N} 94^{\circ} 24^{\prime} 17.0^{\prime \prime} \mathrm{E}$, 1.08 .1960

61 Apong, $2400 \mathrm{ft}, 24^{\circ} 56^{\prime} 18.8^{\prime \prime} \mathrm{N} 94^{\circ} 23^{\prime} 28.3^{\prime \prime} \mathrm{E}$, 2.08.1960

62 Datum, $5000 \mathrm{ft}, 3.08 .1960$

63 Sokpao $=$ Shokvao?, $2700 \mathrm{ft}, 4.08 .1960$

64 Lithan $=$ Litan, $3000 \mathrm{ft}, 24^{\circ} 56^{\prime} 33.5^{\prime \prime} \mathrm{N} 94^{\circ} 12^{\prime}$ 52.4"E, 5.08.1960 
65 Imphal, $2500 \mathrm{ft}, 24^{\circ} 51^{\prime} 04.5^{\prime \prime} \mathrm{N} 93^{\circ} 57^{\prime} 01.6 " \mathrm{E}$, $7-8.08 .1960$

66 idem 64, Lithan, $3000 \mathrm{ft}, 24^{\circ} 56^{\prime} 33.5^{\prime \prime} \mathrm{N} 94^{\circ}$ $12 ' 52.4 " \mathrm{E}, 10.08 .1960$

67 Lithan, $4000 \mathrm{ft}, 24^{\circ} 55^{\prime} 54.6^{\prime \prime} \mathrm{N} 94^{\circ} 13^{\prime} 27.0^{\prime \prime} \mathrm{E}$, 11.08 .1960

67 Yongphu, $4500 \mathrm{ft}, 12.08 .1960$

68 Sinda, $4000 \mathrm{ft}, 13.08 .1960$

69 Marou, $4000 \mathrm{ft}, 14.08 .1960$

70 Singkap, $3800 \mathrm{ft}, 16-17.08 .1960$

71 Tangkhul Hundung, $3000 \mathrm{ft}, 24^{\circ} 48^{\prime} 23.3^{\prime \prime} \mathrm{N}$

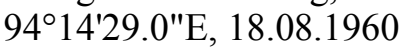

72 Natjang, $4500 \mathrm{ft}, 24^{\circ} 42^{\prime} 42.8^{\prime \prime} \mathrm{N} 94^{\circ} 11^{\prime} 39.9^{\prime \prime} \mathrm{E}$, 19.08.1960

73 Mollen, $3800 \mathrm{ft}, 24^{\circ} 42^{\prime} 25.7^{\prime \prime} \mathrm{N} 94^{\circ} 10^{\prime} 51.7^{\prime \prime} \mathrm{E}$, 20.08 .1960

74 Walthou, $2550 \mathrm{ft}, 21.08 .1960$

75 idem 65, Imphal, $2560 \mathrm{ft}, 24^{\circ} 51^{\prime} 04.5^{\prime \prime} \mathrm{N} 93^{\circ}$ 57'01.6"E, 22-26.08.1960

76 Pangsang, $2750 \mathrm{ft}, 25^{\circ} 01^{\prime} 33.4^{\prime \prime} \mathrm{N} 93^{\circ} 52^{\prime} 60.0^{\prime \prime}$ E, 27.08.1960

77 Khaorang = Kharang, $3750 \mathrm{ft}, 24^{\circ} 50^{\prime} 24.0^{\prime \prime} \mathrm{N}$ 93ํำ'49.9"E, 28.08.1960

78 Phaipbengmun = Phaipheng, $2157 \mathrm{ft}, 24^{\circ} 21^{\prime}$ 04.4"N 93²7'46.6"E, 29.08.1960

79 Phaipbengmun $=$ Phaipheng, $5000 \mathrm{ft}, 24^{\circ} 20^{\prime}$ 31.1"N 9326'03.9"E, 30.08.1960

80 Pamjai = Pamzal, $3500 \mathrm{ft}, 24^{\circ} 18^{\prime} 57.6^{\prime \prime} \mathrm{N} 93^{\circ}$ 22'19.0"E, 31.08.1960

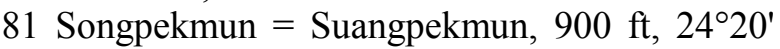
14.3"N 93०17'24.9"E, 1.09.1960

82 Thanlou = Thanlon, $2500 \mathrm{ft}, 24^{\circ} 15^{\prime} 58.6^{\prime \prime} \mathrm{N} 93^{\circ}$ 16'50.9"E, 2.09.1960

83 Pherjol = Pherzawl, $900 \mathrm{ft}, 24^{\circ} 15^{\prime} 47.6^{\prime \prime} \mathrm{N} 93^{\circ}$ 11'12.3"E, 3.09.1960

84 Pherjol = Pherzawl, $1100 \mathrm{ft}, 24^{\circ} 15^{\prime} 47.6^{\prime \prime} \mathrm{N} 93^{\circ}$ 11'12.3"E, 4.09.1960

85 Ptarbung, $3000 \mathrm{ft}, 5.09 .1960$

86 Tipaimukh, $80 \mathrm{ft}, 24^{\circ} 14^{\prime} 06.5^{\prime \prime} \mathrm{N} 93^{\circ} 01^{\prime} 34.1^{\prime \prime} \mathrm{E}$, 6-7.09.1960

Mizoram (Lushai hills)

87 Waiten, $2500 \mathrm{ft}, 8.09 .1960$

88 Thingsat, $3500 \mathrm{ft}, 24^{\circ} 11^{\prime} 49.3^{\prime \prime} \mathrm{N} 92^{\circ} 56^{\prime} 24.3^{\prime \prime E}$, 9.09.1960

89 Thingsat, $2000 \mathrm{ft}, 24^{\circ} 11^{\prime} 49.3^{\prime \prime} \mathrm{N} 92^{\circ} 56^{\prime} 24.3^{\prime \prime} \mathrm{E}$, 10.09.1960

90 Ratu, 3000 ft, 2406'43.2"N 9255'12.8"E, 11.09.1960
91 Darlon = Darlawn, $3500 \mathrm{ft}, 24^{\circ} 01^{\prime} 00.7^{\prime \prime} \mathrm{N} 92^{\circ}$ 55'36.2"E, 12.09.1960

92 Sawleng, $4000 \mathrm{ft}, 2^{\circ} 58^{\prime} 55.7^{\prime \prime N} 92^{\circ} 56^{\prime} 04.3^{\prime \prime} \mathrm{E}$, 13.09.1960

93 Phaileng, $3500 \mathrm{ft}, 14.09 .1960$

94 Sonai = Sonai River, $308 \mathrm{ft}, 23^{\circ} 51^{\prime} 04.2^{\prime \prime N} 92^{\circ}$ 49'45.1"E, 15.09.1960

95 Nausel, 4000 ft, $23^{\circ} 48^{\prime} 58.2^{\prime \prime} \mathrm{N} 92^{\circ} 45^{\prime} 44.3^{\prime \prime} \mathrm{E}$, 16.09 .1960

96 Aijal = Aizwal, $3700 \mathrm{ft}, 23^{\circ} 44^{\prime} 39.5^{\prime \prime} \mathrm{N} 92^{\circ} 44^{\prime}$ 33.9"E, 17.09/1960

97 Sairang, $500 \mathrm{ft}, 23^{\circ} 48^{\prime} 29.8^{\prime \prime} \mathrm{N} 92^{\circ} 39^{\prime} 15.5^{\prime \prime} \mathrm{E}$, 20.09.1960

98 Sairang, $200 \mathrm{ft}, 23^{\circ} 48^{\prime} 39.1^{\prime \prime} \mathrm{N} 92^{\circ} 38^{\prime} 58.6^{\prime \prime} \mathrm{E}$, 21.09 .1960

\section{Southern India (mainly Tamil Nadu and Kerala) 1958-1959 (Map 7a, 7b)}

The southern part of the Indian peninsula is mainly separated into two regions: the Kerala and the Tamil Nadu (named Madras in Schmid's notebook) (Map 1). We cut this wide region in two parts to make the maps more readable (Map $7 \mathrm{a}, 7 \mathrm{~b})$

Penjab

1 Mandkot Cotti, $<2000 \mathrm{ft}, 1.11 .1958$

Madhya Pradesh

2 Satanmara = Satanwada?, $1308 \mathrm{~m}, 25^{\circ} 44^{\prime}$ 9.2" $\mathrm{N} 77^{\circ} 23^{\prime} 48.9^{\prime \prime} \mathrm{E}, 28.11 .1961$

3 Biaora, $1308 \mathrm{ft}, 23^{\circ} 55^{\prime} 07.7^{\prime \prime N} 76^{\circ} 54^{\prime} 17.8^{\prime \prime} \mathrm{E}, 4$. 11.1958

4 Sendhma $=$ Sendhwa, $1308 \mathrm{ft}, 21^{\circ} 41^{\prime} 20.7^{\prime \prime N} 75^{\circ}$ 04'53.1"E, 5.11.1958

Bombay (Mumbai)

5 Chandou, $1308 \mathrm{ft}, 6.11 .1958$

Mysore (Karnataka)

6 Hiriyur, < $1000 \mathrm{ft}, 1^{\circ} 56^{\prime} 58.4^{\prime \prime} \mathrm{N} \mathrm{76} 36^{\circ} 50.1^{\prime \prime} \mathrm{E}$, 9.11.1958

Tamil Nadu (Madras)

7 Kunjankuzhi, 400 ft, 19.11.1958

8 Balamor, $1000 \mathrm{ft}, 20.11 .1958$ 


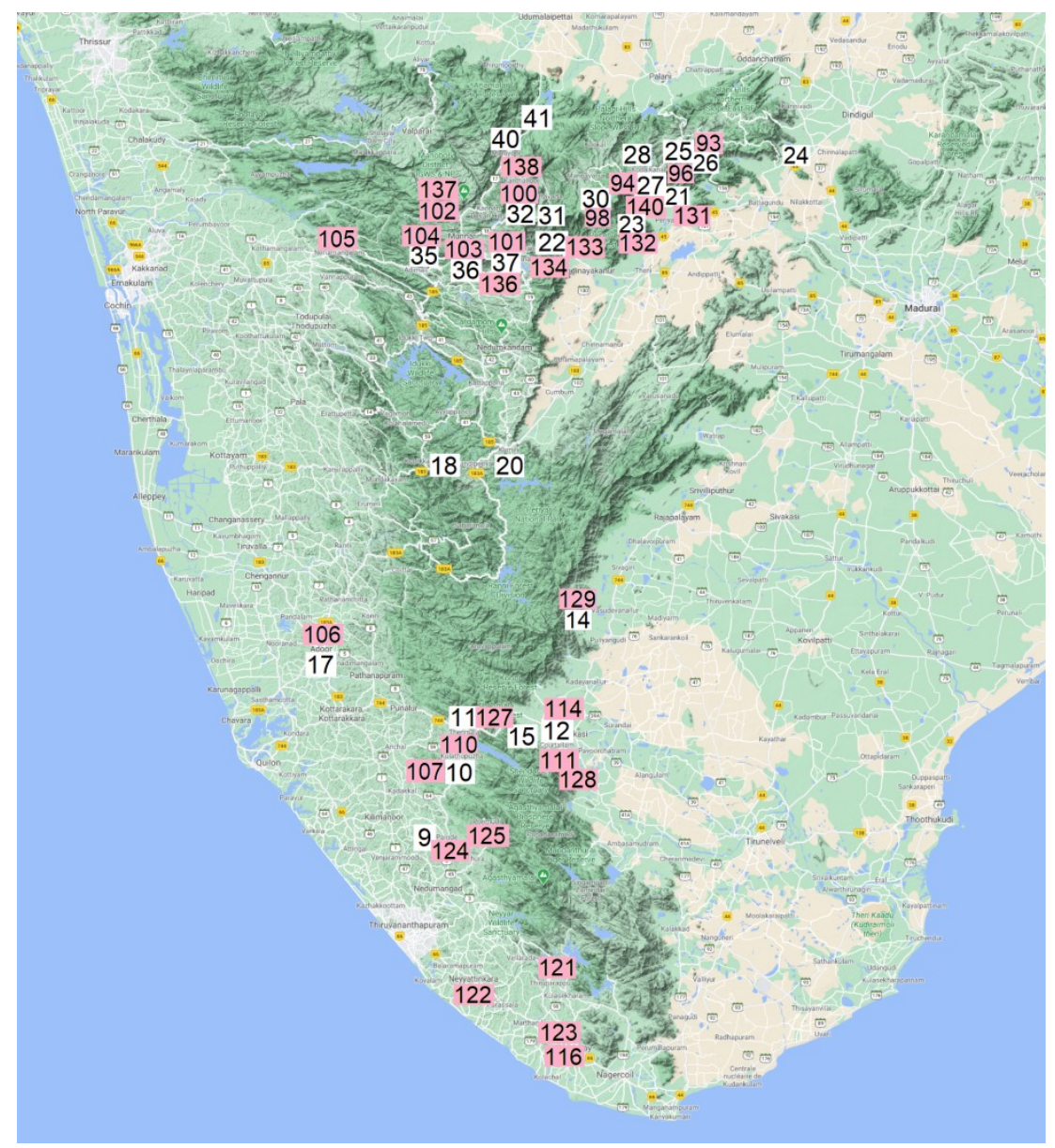

Map 7a. Schmid's road in Kerala.

Kerala

9 Palod = Palode, $400 \mathrm{ft}, 8^{\circ} 43^{\prime} 14.3^{\prime \prime} \mathrm{N} 77^{\circ} 01^{\prime}$ 12.5"E, 21.11.1958

10 Kolattupuzha $=$ Kulathupuzha, $400 \mathrm{ft}, 8^{\circ}$ 54'23.9"N 7703'47.9"E, 21.11.1958

11 Tenmalai $=$ Thenmala, $500-900 \mathrm{ft}, 8^{\circ} 58^{\prime} 07.4^{\prime \prime}$ N 7704'13.7"E, 22.11.1958

\section{Tamil Nadu (Madras)}

12 Kuttalam = Courtallam, 500-1500 ft, $8^{\circ} 55^{\prime}$ $10.4^{\prime \prime} \mathrm{N} 77^{\circ} 15^{\prime} 53.7^{\prime \prime} \mathrm{E}, 23.11 .1958$

13 Aindalai Aruri, 800-1500 ft, 24.11.1958

14 Kattalaimala, in the surroundings of Courtallam and Kannupulimedu, probably corresponds to Kottamalai, $1000 \mathrm{ft}, 9^{\circ} 13^{\prime} 33.3^{\prime \prime N} 77^{\circ}$ 19'06.9"E, 4.11.1958

15 Kannuppali $=$ Kannupulimedu, $800-1500 \mathrm{ft}$, $8^{\circ} 56^{\prime} 28.1^{\prime \prime N} 77^{\circ} 12^{\prime} 10.2^{\prime \prime E}, 25.11 .1958$
Kerala

16 idem 11, Tenmalai $=$ Thenmala, $500-900 \mathrm{ft}$, $8^{\circ} 58^{\prime} 07.4^{\prime \prime N} 77^{\circ} 04^{\prime} 13.7^{\prime \prime E}, 26.11 .1958$

17 Adur = Adoor, $400 \mathrm{ft}, 9^{\circ} 08^{\prime} 42.8^{\prime \prime} \mathrm{N} 76^{\circ} 44^{\prime}$ 06.7"E, 27.11.1958

18 Pirmed $=$ Peermade, $600 \mathrm{ft}, 9^{\circ} 34^{\prime} 40.2^{\prime \prime} \mathrm{N} 77^{\circ}$ 00'56.8"E, 27.11.1958

19 Pirmed = Peermade, $3000-3500 \mathrm{ft}, 9^{\circ} 34^{\prime}$ $00.7^{\prime \prime} \mathrm{N} 77^{\circ} 00^{\prime} 59.9^{\prime \prime} \mathrm{E}, 27.11 .1958$

\section{Tamil Nadu (Madras)}

20 Kumili = Kumily, 2000-2500 ft, 9॰36'10.6"N $77^{\circ} 10^{\prime} 07.6 " \mathrm{E}, 28.11 .1958$

21 Krishnappanayakkan = Krishnappanayakkan Tope (close to Kumbakkarai Falls), $1200 \mathrm{ft}$, $10^{\circ} 10^{\prime} 46.8^{\prime \prime} \mathrm{N} 77^{\circ} 31^{\prime} 51.5^{\prime \prime} \mathrm{E}, 30.11 .1958$

22 Kottagudi $=$ Kottakudi, $2000-2500 \mathrm{ft}, 10^{\circ}$ 04'54.1"N 77¹4'49.1"E, 30.11.1958 
23 Sathuparai $=$ Sothuparai dam, $1500 \mathrm{ft}, 10^{\circ} 07^{\prime}$ 57.0"N 77²7'20.1"E, 1.12.1958

24 Chittayankottai $=$ Sithayankottai, $1000 \mathrm{ft}, 10^{\circ}$ $15^{\prime} 55.1^{\prime \prime} \mathrm{N} 77^{\circ} 50^{\prime} 00.2^{\prime \prime} \mathrm{E}, 2.12 .1958$

25 Perumalmalai, $4000-4500 \mathrm{ft}, 10^{\circ} 15^{\prime} 55.5^{\prime \prime} \mathrm{N}$ 77³2'37.7"E, 3-4.12.1958

26 Senhaganur $=$ Senbahanoor, $5500-6500 \mathrm{ft}$, $10^{\circ} 13^{\prime} 52.3^{\prime \prime N} 77^{\circ} 30^{\prime} 11.6^{\prime \prime E}, 3-8.12 .1958$

27 Kodaikanal, $6500-7200 \mathrm{ft}, 10^{\circ} 12^{\prime} 54.0^{\prime \prime} \mathrm{N} 77^{\circ}$ $28^{\prime} 45.5$ "E, 5-12.12.1958

28 Vilpatti, $6300 \mathrm{ft}, 10^{\circ} 15^{\prime} 58.5^{\prime \prime} \mathrm{N} 77^{\circ} 29^{\prime} 56.7^{\prime \prime} \mathrm{E}$, 9.12.1958

29 Fort Hamilton, 7200-7500 ft, 12-13.12.1958

30 Swamp Hill, $7300 \mathrm{ft}, 10^{\circ} 10^{\prime} 01^{\prime \prime N} 77^{\circ} 22^{\prime} 36 " \mathrm{E}$, 13.12.1958

\section{Kerala}

31 Top Station, $7000 \mathrm{ft}, 10^{\circ} 07^{\prime} 44.8^{\prime \prime} \mathrm{N} 77^{\circ} 14^{\prime}$ 45.4"E, 14.12.1958

32 Ellapatti, $6000 \mathrm{ft}, 10^{\circ} 07^{\prime} 40.7^{\prime \prime} \mathrm{N} 77^{\circ} 12^{\prime} 36.8^{\prime \prime} \mathrm{E}$, 14.12.1958

33 Palar, $5200 \mathrm{ft}, 14.12 .1958$

34 Mumar = Munnar?, 1500-3500 ft, 15.12.1958

35 Vellala Mudi, $3000 \mathrm{ft}, \quad 10^{\circ} 01^{\prime} 47.3^{\prime \prime} \mathrm{N}$ $76^{\circ} 58^{\prime} 50.9^{\prime \prime} \mathrm{E}, 15.12 .1958$

36 Pallivasal, $2500 \mathrm{ft}, 10^{\circ} 03^{\prime} 10.3^{\prime \prime} \mathrm{N} 77^{\circ} 03^{\prime} 32.1^{\prime \prime}$ E, 16.12 .1958

37 Periyakanal $=$ Periakanal, $5000 \mathrm{ft}, 10^{\circ} 02^{\prime}$ 11.4"N 7709'35.1"E, 17.12.1958

38 Craiglamont, $6500 \mathrm{ft}, 18.12 .1958$

39 Talaiyar Maduvakkudi, $4200 \mathrm{ft}, 18.02 .1958$

40 Maraiyur $=$ Marayoor, $3000-4000 \mathrm{ft}, 10^{\circ} 16^{\prime}$ 17.7"N 7709'16.0"E, 19-20.02.1958

41 Chimar = Chinnar Wildlife Sanctuary, $1500 \mathrm{ft}$, $10^{\circ} 20^{\prime} 24.2^{\prime \prime} \mathrm{N} 77^{\circ} 13^{\prime} 05.2^{\prime \prime} \mathrm{E}, 20.12 .1958$

\section{Tamil Nadu (Madras)}

42 Varaiyattu Tittu, $1500 \mathrm{ft}, 21.12 .1958$

43 Vannanturai, $1300 \mathrm{ft}, 22.12 .1958$

44 Attikatti, 2500-3500 ft, 22.12.1958

45 Coibatore $=$ Coimbatore, $1500 \mathrm{ft}, 10^{\circ} 55^{\prime}$ 33.4"N 7654'38.2"E, 23.12.1958

46 Coonoar $=$ Coonoor, $2400-4500 \mathrm{ft}, 11^{\circ} 19^{\prime}$ $52.9^{\prime \prime} \mathrm{N} 76^{\circ} 48^{\prime} 02.8^{\prime \prime} \mathrm{E}, 24.12 .1958$

47 Ootacamund = Udhagamandalam = Ooty, $7200-7300 \mathrm{ft}, \quad 11^{\circ} 24^{\prime} 12.7^{\prime \prime} \mathrm{N} \quad 76^{\circ} 41^{\prime} 42.3^{\prime \prime} \mathrm{E}$, 25.12.1958
48 Avalanche $=$ Avalanche Lake Forest Reserv, $6900-7500 \mathrm{ft}, 11^{\circ} 17^{\prime} 59.3^{\prime \prime N} 76^{\circ} 35^{\prime} 23.9^{\prime \prime} \mathrm{E}, 27-$ 30.12 .1958

49 Makurti $=$ Mukurthi National Park, $4100 \mathrm{ft}$, $11^{\circ} 09^{\prime} 25.2^{\prime \prime} \mathrm{N} \mathrm{76} 30^{\circ} 30.5^{\prime \prime} \mathrm{E}, 1.01 .1959$

50 Pykara, $6900 \mathrm{ft}, 1^{\circ} 28^{\prime} 20.6^{\prime \prime} \mathrm{N} 76^{\circ} 36^{\prime} 13.8^{\prime \prime} \mathrm{E}$, 2.02.1959

51 Gudalur, 4000-6500 ft, $11^{\circ} 29^{\prime} 07.0^{\prime \prime} \mathrm{N} 76^{\circ} 31^{\prime}$ 31.9"E, 6-7.01.1959

52 Devala, $3000 \mathrm{ft}, 11^{\circ} 28^{\prime} 36.6^{\prime \prime} \mathrm{N} 76^{\circ} 22^{\prime} 50.1^{\prime \prime} \mathrm{E}$, 8.01 .1959

Kerala

53 Meppadi, 2800-3500 ft, $11^{\circ} 33^{\prime} 13.8^{\prime \prime} \mathrm{N} 76^{\circ} 08^{\prime}$ 02.7"E, 8-9.01.1959

54 Erumakolli, $3200 \mathrm{ft}, 11^{\circ} 33^{\prime} 58.8^{\prime \prime N} 76^{\circ} 06^{\prime} 35.7^{\prime \prime}$ E, 10.01.1959

Mysore (Karnataka)

55 Kakankote, 2450 ft., 1155'36.0"N 7609'12.6" E, 10.01.1959

56 Piriyapatna, $2800 \mathrm{ft}, 12^{\circ} 20^{\prime} 30.6^{\prime \prime} \mathrm{N} 76^{\circ} 04^{\prime} 59.8^{\prime \prime}$ E, 14.01.1959

Kerala

57 Vittekoli, $2200 \mathrm{ft}, 15.01 .1959$

$58 \mathrm{Urti}, 300 \mathrm{ft}, 15.01 .1959$

59 Mankut, $200 \mathrm{ft}, 15.01 .1959$

Mysore (Karnataka)

60 Mercara, $3400 \mathrm{ft}, 12^{\circ} 25^{\prime} 29.1^{\prime \prime N} 75^{\circ} 43^{\prime} 25.5^{\prime \prime} \mathrm{E}$, 16.01 .1959

61 Katageri $=$ Katakeri, $3000 \mathrm{ft}, 12^{\circ} 25^{\prime} 46.9^{\prime \prime} \mathrm{N} 75^{\circ}$ 41'57.4"E, 16.01.1959

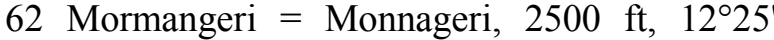
56.4"N 7540'27.5"E, 16.01.1959

63 Yodpai, $2000 \mathrm{ft}, 16.01 .1959$

64 Kunnimotte, 800-1000 ft, 17.01 .1959

65 Uppinangadi, $300 \mathrm{ft}, 12^{\circ} 50^{\prime} 10.7^{\prime \prime} \mathrm{N} 75^{\circ} 14^{\prime}$ 56.9"E, 17.01.1959

66 Malbidu, 800-2300 ft, 18.01 .1959

67 Sakleshpur, $2950 \mathrm{ft}, 12^{\circ} 56^{\prime} 12.0^{\prime \prime} \mathrm{N} 75^{\circ} 47^{\prime}$ 15.1"E, 19.01.1959

68 Honnatlu, $2700 \mathrm{ft}, 20.01 .1959$

69 Kulgunda, 1000-1250 ft, 20-21.01.1959

70 Subrahmanya, $400 \mathrm{ft}, 20.01 .1959$

71 Jannapura, $2959 \mathrm{ft}, 13^{\circ} 05^{\prime} 00.1^{\prime \prime N} 75^{\circ} 41^{\prime} 18.6^{\prime \prime}$ E, 22.01.1959 


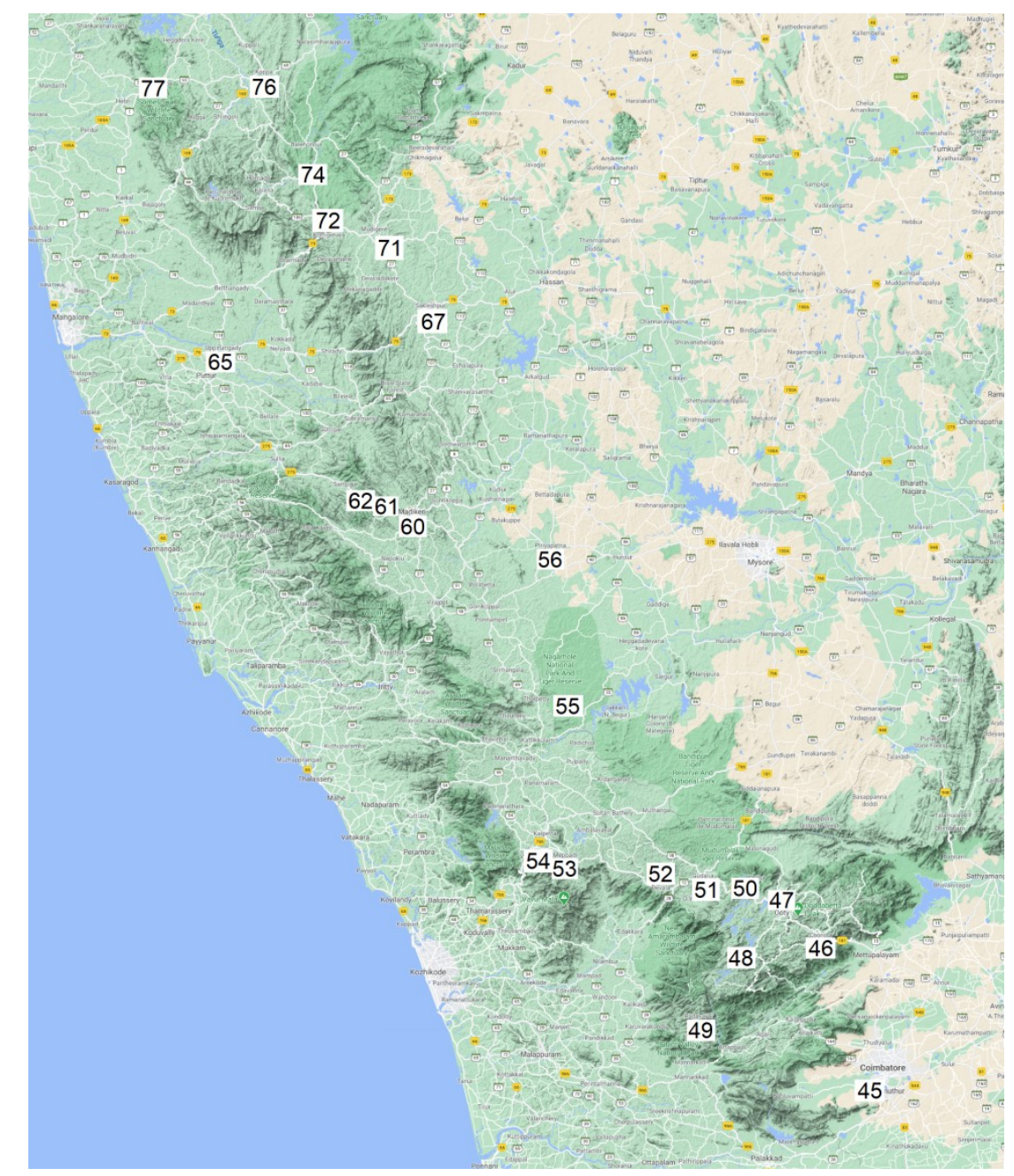

Map 7b. Schmid's road in Tamil Nadu.

72 Kotigehara $=$ Kottigehara, $2900 \mathrm{ft}, 13^{\circ} 07^{\prime}$ 19.2"N 75³1'23.3"E, 23.01.1959

73 Anjadi, $287 \mathrm{ft}, 23.01 .1959$

74 Mahagundi = Magundi, $2350 \mathrm{ft}, 13^{\circ} 16^{\prime} 18.2^{\prime \prime} \mathrm{N}$ 75²9'15.6"E, 24.01.1959

75 Hariharpur, $2043 \mathrm{ft}, 25.01 .1959$

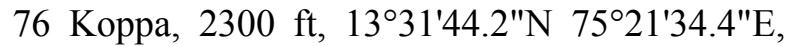
26.01.1959

77 Someshwar $=$ Someshwara Wildlife Sanctuary, $295 \mathrm{ft}, 13^{\circ} 29^{\prime} 26.2^{\prime \prime} \mathrm{N} 75^{\circ} 04^{\prime} 03.4^{\prime \prime} \mathrm{E}, 27.01 .1959$

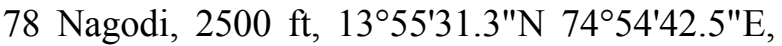
28.01.1959

79 Talguppa, $1941 \mathrm{ft}, 14^{\circ} 12^{\prime} 49.4^{\prime \prime} \mathrm{N} 74^{\circ} 54^{\prime} 25.0^{\prime \prime} \mathrm{E}$, 29.01.1959
80 Yellapur, $1500 \mathrm{ft}, 14^{\circ} 57^{\prime} 08.4^{\prime \prime} \mathrm{N} 74^{\circ} 42^{\prime} 01.3^{\prime \prime} \mathrm{E}$, 30.01 .1959

Bombay (Mumbay)

81 Nandipur, $300 \mathrm{ft}, 1.02 .1959$

82 Rajapur, $300 \mathrm{ft}, 2.02 .1959$

83 Patan, $2500 \mathrm{ft}, 3.02 .1959$

84 Sykes, $2000 \mathrm{ft}, 5.02 .1959$

\section{Madhya Pradesh}

85 Phalghat, $2000 \mathrm{ft}, 6.02 .1959$

86 Guna, $2000 \mathrm{ft}, 24^{\circ} 37^{\prime} 11.7^{\prime \prime} \mathrm{N} 77^{\circ} 16^{\prime} 23.6^{\prime \prime} \mathrm{E}$, 7.02.1959

87 Satanwara = Satanwada, $1308 \mathrm{ft}, 25^{\circ} 44 ' 51.21^{\prime \prime}$ N 77²4'29.44"E, 8.02.1959 
South India 1961-1962

Madhya Pradesh

88 idem 87, Satamara = Satanwada (Lonsdale 2020), $1308 \mathrm{~m}, 25^{\circ} 44^{\prime} 51.21^{\prime \prime} \mathrm{N} 77^{\circ} 24^{\prime} 29.44^{\prime \prime} \mathrm{E}$, 28.11.1961

89 Sarangpur, 2000 ft, 29.11.1961

Bombay (Mumbay)

90 idem 84, Sykes, 2000 ft, 30.11.1961

Mysore (Karnataka)

91 Haveri, $2000 \mathrm{ft}, 14^{\circ} 46^{\prime} 43.4^{\prime \prime} \mathrm{N} 75^{\circ} 23^{\prime} 37.1^{\prime \prime E}, 2$. 12.1961

\section{Tamil Nadu (Madras)}

92 Velor, $1500 \mathrm{ft}, 4.12 .1961$

93 idem 25, Perumalmalai, $4000-4500 \mathrm{ft}, 10^{\circ} 16^{\prime}$ 15.6"N 77³3'55.6"E, 5.12.1961

94 idem 27, Kodaikanal, 7300 ft, $10^{\circ} 12^{\prime} 54.0^{\prime \prime} \mathrm{N}$ $77^{\circ} 28^{\prime} 45.5^{\prime \prime} \mathrm{E}, 6.12 .1961$

95 idem 25, Perumalmalai, 5000-7000 ft, $10^{\circ} 17^{\prime} 52.1^{\prime \prime N} 77^{\circ} 33^{\prime} 53.0^{\prime \prime E}, 5.12 .1961$

96 Senbaganur $=$ Senbahanoor, $5800 \mathrm{ft}, 10^{\circ} 14^{\prime}$ 27.8"N 77³0'42.2"E, 8.12.1961

97 idem 25, Perumalmalai, $5500 \mathrm{ft}, 10^{\circ} 15^{\prime} 55.7^{\prime \prime} \mathrm{N}$ 77³3'14.9"E, 9.12.1961

98 idem 30, Swamp Hill, $7300 \mathrm{ft}, 10^{\circ} 10^{\prime} 01 " \mathrm{~N}$ 77²2'36"E, 10.12.1961

99 Vandaram, $8000 \mathrm{ft}, 11.12 .1961$

\section{Kerala}

100 Kandalur $=$ Kanthalloor, $5500 \mathrm{ft}, 10^{\circ} 12^{\prime}$ 43.2"N 77²12'29.7"E, 12.12.1961

101 idem 37, Periyakanel = Periakanal, $5000 \mathrm{ft}$, $10^{\circ} 02^{\prime} 11.4^{\prime \prime} \mathrm{N} 77^{\circ} 09^{\prime} 35.1 " \mathrm{E}, 13.12 .1961$

102 Silent Valley, $6500 \mathrm{ft}$, according to the elevation, it should be placed northwards the 'Silent Valley' village, in the Eravikulam National Park, $10^{\circ} 08^{\prime} 39.5^{\prime \prime} \mathrm{N} 77^{\circ} 01^{\prime} 57.2^{\prime \prime} \mathrm{E}, 14.12$. 1961

103 idem 34, Munnar, $3500 \mathrm{ft}, 10^{\circ} 05^{\prime} 04.8^{\prime \prime} \mathrm{N} 77^{\circ}$ 04'22.0"E, 15.12.1961

104 idem 35, Vellala Mudi, $3000 \mathrm{ft}, 10^{\circ} 01^{\prime} 56.0^{\prime \prime} \mathrm{N}$ $76^{\circ} 59^{\prime} 06.9^{\prime \prime} \mathrm{E}, 15.12 .1961$

105 idem 100, Kandalur $=$ Kanthalloor, $5500 \mathrm{ft}$, $10^{\circ} 12^{\prime} 43.2^{\prime \prime} \mathrm{N} 77^{\circ} 12^{\prime} 29.7^{\prime \prime E}, 16.12 .1961$

106 Neriyamangalem $=$ Neriamangalam, $800 \mathrm{ft}$, $10^{\circ} 03^{\prime} 07.6^{\prime \prime} \mathrm{N} 76^{\circ} 47^{\prime} 01.5^{\prime \prime} \mathrm{E}, 17.12 .1961$
107 idem 17, Adur $=$ Adoor, $400 \mathrm{ft}, 9^{\circ} 08^{\prime} 57.5^{\prime \prime} \mathrm{N}$ 76²43'58.4"E, 19.12.1961

108 idem 10, Kolattupugha $=$ Kolattupula $=$ Kulathupuzha, $400 \mathrm{ft}, 8^{\circ} 53^{\prime} 47.0^{\prime \prime} \mathrm{N} 77^{\circ} 03^{\prime} 27.4^{\prime \prime}$ E, 19.12.1961

109 Sangalipalam, $475 \mathrm{ft}, 20-21.12 .1961$

110 idem 108, Kolattupugha $=$ Kolattupula, 400 $\mathrm{ft}, 8^{\circ} 53^{\prime} 47.0^{\prime \prime} \mathrm{N} 77^{\circ} 03^{\prime} 27.4^{\prime \prime} \mathrm{E}, 22.12 .1961$

Tamil Nadu (Madras)

111 idem 12, Kuttalam = Courtallam, 500-1500 $\mathrm{ft}, 8^{\circ} 55^{\prime} 10.4^{\prime \prime} \mathrm{N} 77^{\circ} 15^{\prime} 53.7^{\prime \prime} \mathrm{E}, 23.12 .1961$

112 idem 13, Aindalai Aruri, 800-1500ft, 24.12. 1961

113 idem 14, Kattalaimala in the surroundings of Courtallam and Tenkasi probably corresponds to Kottamalai, $1000 \mathrm{ft}, 9^{\circ} 13^{\prime} 33.3^{\prime \prime} \mathrm{N} 77^{\circ} 19^{\prime}$ 06.9"E, 25-26.12.1961

114 Tenkari $=$ Tenkasi, $400 \mathrm{ft}, 8^{\circ} 57^{\prime} 08.5^{\prime \prime} \mathrm{N} 77^{\circ}$ 18'49.5"E, 27.12.1961

Kerala

115 Kughittùai, 200 ft, 30.12.1961

Tamil Nadu (Madras)

116 Neyyur $=$ Neiyyur $=$ Neyyoor, $100 \mathrm{ft}, 8^{\circ} 12^{\prime}$ 52.1"N 77¹8'11.7"E, 31.12.1961

117 Naquroil, 200 ft, 1.01.1962

118 Kunjankhuji, $400 \mathrm{ft}, 2.01 .1962$

119 Balamou, $1500 \mathrm{ft}, 3-4.01 .1962$

120 Ottakada, $350 \mathrm{ft}, 5.01 .1962$

121 Kalial, $200 \mathrm{ft}, 8^{\circ} 23^{\prime} 58.3^{\prime \prime} \mathrm{N} 77^{\circ} 18^{\prime} 00.7^{\prime \prime} \mathrm{E}$, 7.01.1962

\section{Kerala}

122 Neyyartinkara $=$ Neyyattinkara, $200 \mathrm{ft}, 8^{\circ} 24^{\prime}$ 36.9"N 7705'17.1"E, 8.01.1962

Tamil Nadu (Madras)

123 Udayagiri, $200 \mathrm{ft}, 8^{\circ} 14^{\prime} 31.2^{\prime \prime} \mathrm{N} 77^{\circ} 20^{\prime} 19.7^{\prime \prime} \mathrm{E}$, 10.01 .1962

\section{Kerala}

124 idem 9, Palode, $300 \mathrm{ft}, 8^{\circ} 43^{\prime} 21.9^{\prime \prime} \mathrm{N} 77^{\circ} 01^{\prime}$ 30.1"E, 11.01 .1962

125 Ponmudi, $3500 \mathrm{ft}, 8^{\circ} 45^{\prime} 36.2^{\prime \prime} \mathrm{N} 77^{\circ} 06^{\prime} 51.8^{\prime \prime} \mathrm{E}$, 12.01 .1962

126 Kalpatti, $250 \mathrm{ft}, 13.01 .1962$ 
127 Ariankavu $=$ Aryankavu, $750 \mathrm{ft}, 8^{\circ} 58^{\prime} 27.7^{\prime \prime} \mathrm{N}$ 7708'59.3"E, 14.01.1962

\section{Tamil Nadu (Madras)}

128 idem 12, Old Kuttalam Falls = Old Courtallam Falls, $80 \mathrm{ft}, 8^{\circ} 54^{\prime} 04.3^{\prime \prime N} 77^{\circ} 17^{\prime} 47.9^{\prime \prime} \mathrm{E}$, 15.01 .1962

129 idem 14, Kattalaimala in the surroundings of Courtallam and Tenkasi probably corresponds to Kottamalai, $1000 \mathrm{ft}, 9^{\circ} 13 ' 33.3^{\prime \prime} \mathrm{N} 77^{\circ} 19^{\prime}$ 06.9"E, 16-17.01.1962

130 Komadi, 950 ft, 18-19.01.1962

131 idem 21, Krishnappanayakkan = Krishnappanayakkan Tope (close to Kumbakkarai Falls), $1200 \mathrm{ft}, 10^{\circ} 10^{\prime} 46.8^{\prime \prime} \mathrm{N} 77^{\circ} 31^{\prime} 51.5^{\prime \prime} \mathrm{E}, 21.01$. 1962

132 idem 23, Sathuparai = Sothuparai dam, 1200 $\mathrm{ft}, 10^{\circ} 07^{\prime} 48.8^{\prime \prime} \mathrm{N} 77^{\circ} 28^{\prime} 03.2^{\prime \prime} \mathrm{E}, 22.01 .1962$

133 idem 22, Kottagudi = Kottakudi, $2500 \mathrm{ft}$, $10^{\circ} 04^{\prime} 43.9^{\prime \prime} \mathrm{N} 77^{\circ} 15^{\prime} 44.4^{\prime \prime E}, 23.01 .1962$

134 Bodi Mettu = Bodimettu, $3000 \mathrm{ft}, 10^{\circ} 01^{\prime}$ 25.4"N 77²15'50.1"E, 24.01.1962

\section{Kerala}

135 Pannujar, 3000-4000 ft, 24.01.1962

136 idem 37, Perujakanal $=$ Periakanal, $5000 \mathrm{ft}$, $10^{\circ} 02^{\prime} 11.4^{\prime \prime} \mathrm{N} 77^{\circ} 09^{\prime} 35.1^{\prime \prime} \mathrm{E}, 25.01 .1962$

137 idem 102, Silent Valley, $6500 \mathrm{ft}$, according to the elevation, it should be placed much northwards the 'Silent Valley' village, in the Eravikulam National Park, $10^{\circ} 08^{\prime} 39.5^{\prime \prime} \mathrm{N} 77^{\circ}$ 01'57.2"E, 29.01.1962

138 idem 100, Kandalur $=$ Kanthalloor, $5500 \mathrm{ft}$, $10^{\circ} 12^{\prime} 43.2^{\prime \prime} \mathrm{N} 77^{\circ} 12^{\prime} 29.7^{\prime \prime E}, 31.01 .1962$

\section{Tamil Nadu (Madras)}

139 idem 30, Swarup hill = Swamp Hill, $7300 \mathrm{ft}$, $10^{\circ} 10^{\prime} 011^{\prime N} 77^{\circ} 22^{\prime} 36^{\prime \prime} \mathrm{E}, 2.02 .1962$

140 idem 27, Kodaikanal, $7300 \mathrm{ft}, 10^{\circ} 12^{\prime} 54.0^{\prime \prime} \mathrm{N}$ $77^{\circ} 28^{\prime} 45.5^{\prime \prime} \mathrm{E}, 3.02 .1962$

\section{Madhya Pradesh}

141 idem 2, Satanmara= Satanwada?, 1308 m, $25^{\circ} 44^{\prime} 49.2^{\prime \prime} \mathrm{N} 77^{\circ} 23^{\prime} 48.9^{\prime \prime} \mathrm{E}, 6.02 .1962$

\section{DEPOSITORIES}

The Natural History Museum, London, England (BMNH)

Canadian National Collection, Ottawa, Canada (CNC)

Department of Plant Protection, Henan Institute of Science and Technology, Henan, China (DPPHIST)

Hungarian natural History Museum, Budapest, Hungary (HNHM)

Malicky Private Collection, Lunz am See, Austria (MPC).

Museum for Natural History of the Humbolt University of Berlin, Germany (ZMB).

Oláh Private Collection, Debrecen, Hungary. Under national protection by the Hungarian Natural History Museum, Budapest, Hungary (OPC).

Royal Ontario Museum, Toronto, Canada (ROM)

Swedish Museum of Natural History, Stockholm, Sweden (SMNH)

US National Museum, Natural History, Washington DC (USNM)

Zoologisches Museum, Centrum für Naturkunde, Hamburg, Germany (CeNak)

\section{TAXONOMY}

\section{Hydropsychidae Curtis, 1835 \\ Diplectroninae Ulmer, 1951 \\ Diplectrona Westwood, 1840}

The genital structure of the genus Diplectrona is usually blunt, often lack conspicuous characters, and exhibits minor differences requiring careful examination of several specimens to recognise trait stability and the ranges of variability. Combination of following additional body characters may help to differentiate among species: (1) magnitude of eye enlargement; (2) presence or absence of setae on eye; (3) maxillary palp formula; (4) suture and setal wart pattern on head; (5) length of lateral filament, (6) cuticular structures associated with the opening of sternum $\mathrm{V}$ gland; (7) presence or absence and the number of reticulated sacs in abdominal segments; (8) pre- 
sence or absence of fork I on hindwing. However, at the present knowledge we do not know how stable some of these additional body characters are.

We have recorded the shape of paraproct (lateral plate of segment $\mathrm{X}$ ) as well as the lateral profile of the phallotheca and especially the ventral profile of the phallic head rather stable even with minor shape modification of subtle divergences.

It seems, these structures diverge rapidly, subtly and stably in contemporary speciation processes of the Diplectrona genus (Oláh 2013). Moreover, they appear subtle and varying for us if we apply inadequate microscope of low resolution level with unstable angle of observation and without examination of variability and stability ranges, but robust enough for mate recognition of caddisflies in building their reproductive isolation (Oláh 2017).

The discovery of speciation super strait was particularly productive to delineate closely related phylogenetic incipient sibling species in the Hydropsychidae family (Oláh 2018a, 2018b, Oláh \& Jan de Vries 2019). In the hydropsychid Diplectrona atra species complex we have found the lateral profile of the entire phallic organ and the lateral profile of the pair of phallotremal sclerites very diverse, stable and reliable to delineate and establish sibling species in this small species complex (Oláh et al. 2020a).

Based on the principle of "widely varying species of wide distribution", Malicky (2002) has synonymized or listed several taxa with well-discernible divergences in the paraproct and in the phallic organ, under the following species name: D. dilutensis, D. fama, D. kallirrhoe, C. aurovittata, C. sanguana, C. burha, C. hermione, $C$. octomaculata. Malicky's drawings of specimens from different geographic regions exhibit significant divergences representing incipient sibling species and suggest that the genus Diplectrona is very diverse in the Oriental region and that there are probably species complexes represented by only single species names. This hidden diversity is explorable by examining and comparing populations and focusing on details in paraproct and the phallic organ.

The taxonomic history of Diplectrona is accompanied by uncertain determinations. Some authors of species descriptions have declared or remarked the described species with uncertain character states. In order to overcome the unsettled taxonomic position of their described species some have published additional drawings of specimens from different regions (Ulmer 1905a, 1905b,1907, 1909, 1913, 1930, 1951, Schmid 1961, Malicky 2002). Malicky has frequently explained the existing significant character states' divergences with the high variability of the widely distributed species. Here we cite some examples.

Under the species name Diplectrona aurovittata (Ulmer, 1906), a member of the new Diplectrona tamdaophila species complex of the Diplectrona aurovittata species group with various spine formations on the paraproct, Malicky (2002) has listed and drawn three different unknown species and one already known species Diplectrona tamdaophila from four different countries (Thailand, Vietnam, Malaysia, Indonesia).

Under the species name of Diplectrona sanguana Kimmins, 1964, a member of the new Diplectrona tabrobanes species group without spines on the paraproct, Malicky (2002) has listed and drawn from Nepal two species from the Diplectrona tamdaophila and one species Diplectrona hasada new species complexes of the Diplectrona aurovitatta species group characterized by various spine developments on the paraproct.

Similarly, under the species name Diplectrona burha Schmid, 1961, a member of the new Diplectrona tamdaophila species complex of the Diplectrona aurovittata species group with various spine formations on the paraproct, Malicky (2002) has listed one unknown species (Nepal) from the Diplectrona tabrobanes new species group without spines on the paraproct and 
three unknown species (Thailand, Vietnam, Taiwan) from the Diplectrona hasada new species complex of the Diplectrona aurovitatta species group characterized by various spine developments on the paraproct.

In the present study we have delineated four species group for the examined Diplectrona species in the Oriental Region. (1) Diplectrona aurovittata new species group having paraproct (lateral plate of segment X) of a pair of mostly setaless plate-like structure with variously formed pointed spine-like processes in various numbers and usually produced in apicodorsal position. (2) Diplectrona coalescens species group was established as a Diagnostic Species Group by Sun (2017), tacitly contrasting with the expiring epistemic concept of the so called Phylogenetic Species Group. This species group is characterized by the loss of segment X (mesal plate or inner lobe). Segment $X$, the well differentiated mesal plate or inner lobe of segment is highly reduced, almost entirely vestigial, fused to the complex. (3) Diplectrona gombak new species group having paraproct (lateral plate or outer lobe of segment X) of a pair of mostly setaless platelike structure with elongated dorsal and/or lateral profile. (4) Diplectrona taprobanes new species group having paraproct (lateral plate or outer lobe of segment X) of a pair of mostly setaless platelike structure with rounded dorsal or more in lateral profile without any spiny processes.

\section{Diplectrona aurovittata new species group}

Here we group species having paraproct (lateral plate of segment X) of a pair of mostly setaless plate-like structure with variously formed pointed spine-like processes in various numbers and usually produced in apicodorsal position. Most of the Oriental Diplectrona species belong to this group. We have established two species complexes in this group: Diplectrona hasada new species complex and Diplectrona tamdaophila new species complex.

Species of the Diplectrona taprobanes new species group have paraproct produced short and broad in dorsal view as well as Diplectrona gombak new species group have paraproct long and narrow. Both species groups are without spiny processes on the paraproct.

However, there is no clear-cut delineation between the species of the Diplectrona aurovittata group with spiny processes and the $D$. taprobanes new species group with short or D. gombak new species group with long paraproct in horizontal position without spines. Character combination is always incongruent due to the chimerism in the stochastic universe. Phylogenetic tree branching is just the surface. The reality in the deep is always reticulated, forming a complex network with multiple origins due to integrative forces operating and correcting against random effects.

\section{Diplectrona hasada new species complex}

Diplectrona hasada new species complex having paraproct (lateral plate of segment X) of a pair of mostly setaless plate-like structure with doubled pointed spine-like processes in various forms and usually produced in apicodorsal position.

\section{Diplectrona bandara sp. nov.}

(Figures 1-4, Map 5: n 84, Map 8)

Material examined. Holotype: India, Assam, United District of Mikir and North Cachar Hills, Bandarkhal, $300 \mathrm{ft}$., $25^{\circ} 03^{\prime} 31.1^{\prime \prime} \mathrm{N} 92^{\circ} 48^{\prime} 02.5^{\prime \prime} \mathrm{E}$, 9.V.1960, leg. F. Schmid (1 male, CNC).

Diagnosis. This species belongs to the $D i$ plectrona aurovittata species group and to the $D$. hasada species complex. Having double-spined dorsoapical region of the paraproct it is most close to D. muktapura sp. nov. It differs by the more produced lateral spine of the paraproct as well as by the ventral profile of the phallic head.

Description. Male (in alcohol). Light brown animal. Forewings without any pattern. Forewing length is $8 \mathrm{~mm}$, apical fork I present on hindwing. Eyes setaless, not enlarged. Maxillary palp formula I-IV-III-II-V. Abdominal segments without 


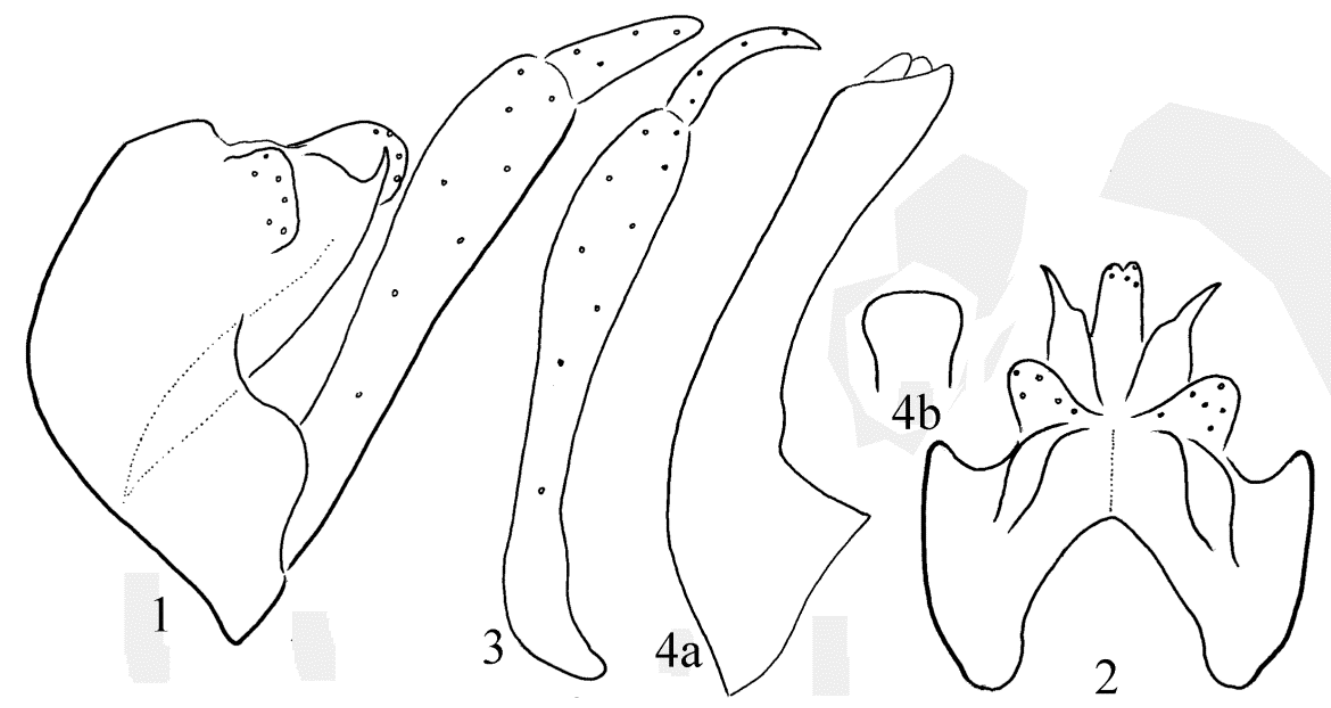

Figures 1-4. Diplectrona bandara sp. nov. Holotype: 1 = male genitalia in left lateral view, $2=$ male genitalia in dorsal view, $3=$ left gonopod in ventral view, $4 \mathrm{a}=$ phallic organ in left lateral view, $4 \mathrm{~b}=$ phallic head in ventral view.

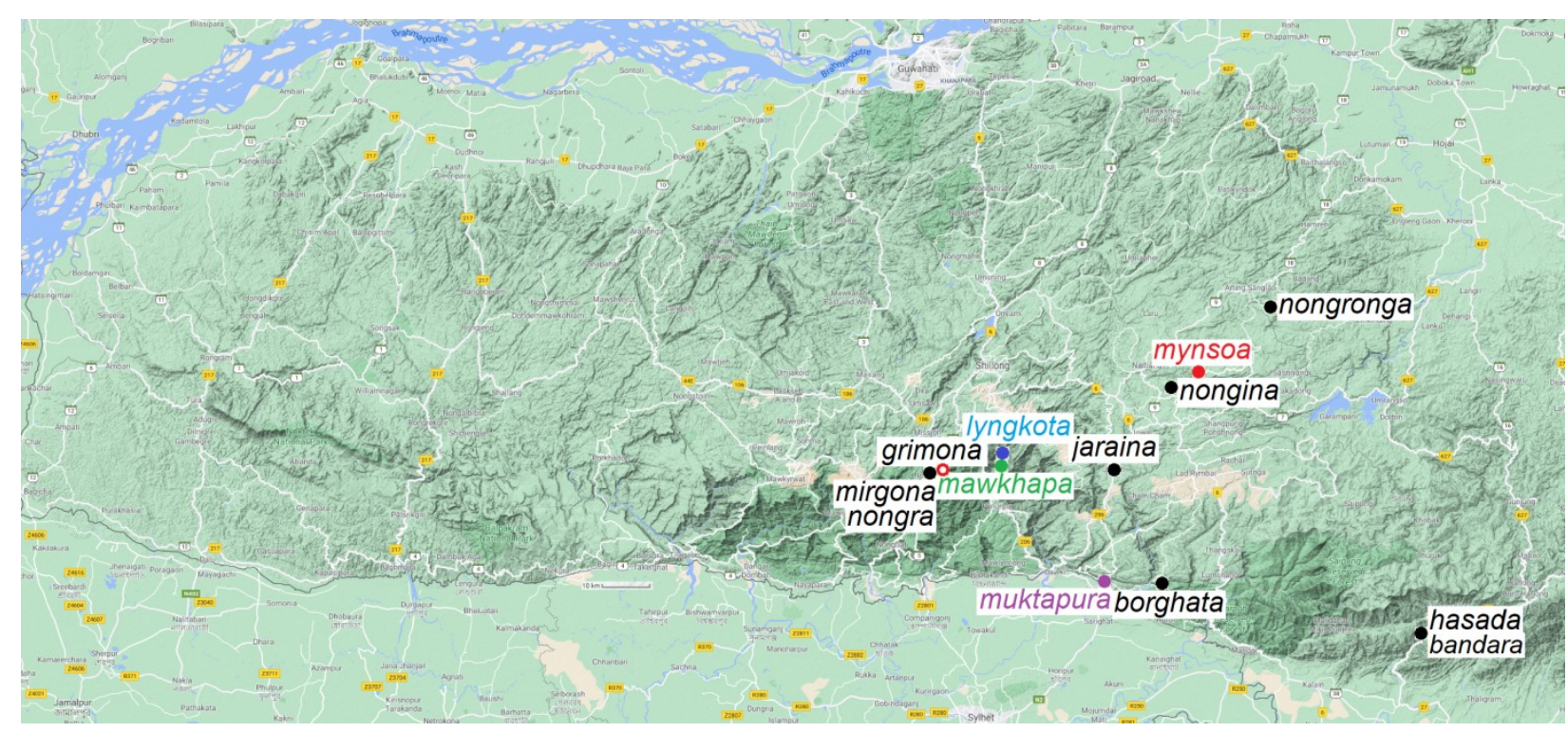

Map 8. Diplectrona hasada complex with only Meghalaya.

any reticulated internal sacs; filament of sternite $\mathrm{V}$ with length of sternite $\mathrm{V}$ and VI.

Male genitalia. Segment IX rounded anterad, dorsum long and flat with a middle depression line, ventrum shorter. Segment $X$ fused to the tergum IX. The dorsoapical setose lobes (inner lobes) of segment $\mathrm{X}$ well-developed, protruded narrow in dorsal view and broad in lateral view; seem bilobed, but tightly adhered. Cerci setose, high and short in lateral view, rounded subtriangularly protruded in dorsal view. Unsetose paraproct (outer lobes or lateral plates of segment X) subtriangular flat plate in lateral view with single upward directed pointed spine-like process; in dorsal profile the lateral spine is produced, the mesal spine less developed. Gonopods robust straight with coxopodite of dilated apical half; harpago mesad turning with sharply ventrad 
pointed head. Phallic apparatus with down curving and broadening basal section and with a longer tube-forming horizontal two thirds with obliquely cut apex in lateral view; two pairs of endothecal processes visible, both with blunt apices in lateral view and pointed triangular in ventral view; dorsal endothecal process bigger; phallotremal sclerite less distinct. The phallic organ with rounded capitate head in ventral view.

Etymology. bandara, named after the name of locus typicus of the holotype.

\section{Diplectrona borghata sp. nov.}

(Figures 5-9, Map 5: n 17, Map 8)

Material examined. Holotype: India, Meghaláya (United Jaintia and Khasi Hills), Borghat, $200 \mathrm{ft}$., 2509'50.0"N 92॰15'13.4"E, 21-22.XII. 1959, leg. F. Schmid (1 male, CNC).

Diagnosis. This species belongs to the Diplectrona aurovittata species group and to the Diplectrona hasada species complex. Having double-spined or pointed dorsoapical region of the paraproct it is most close to D. nongronga sp. nov. It differs by the much longer mesad turning harpago; by the lateral and dorsal profile of the paraproct; by the lower and broader lateral profile of the phallotheca.

Description. Male (in alcohol). Light brown animal. Forewings without pattern. Forewing length is $8 \mathrm{~mm}$, apical fork I present on hindwing. Eyes setaless, not enlarged. Maxillary palp formula I-IV-III-II-V. Abdominal segment VII without any reticulated internal sacs; filament on sternum $\mathrm{V}$ as long as the length of segments $\mathrm{V}$ VI.

Male genitalia. Segment IX rounded anterad with truncated dorsum, dorsum long and flat with a middle depression line, ventrum long. Segment $\mathrm{X}$ fused to the tergum IX. The dorsoapical setose lobes (inner lobes) of segment X well-developed, protruded in dorsal view; seem bilobed, but tightly adhered. Cerci setose rather lobe-like, not just a setose surface both in dorsal and lateral views. Unsetose paraproct (outer lobes or lateral plates of segment $\mathrm{X}$ ) with wide and shallow apical excision; the mesal pointed processes almost disappeared. Gonopods straight with coxopodite of dilated apical half with very broad ventral profile; harpago mesad turning, long digitiform. Phallic apparatus with down curving and broadening basal section and with a longer tube-forming horizontal two thirds with broadened apex in lateral view; two pairs of endothecal processes visible, both with blunt apices in lateral view and pointed triangular in ventral view; dorsal endothecal process bigger; phallotremal sclerite less distinct. The phallic organ with rounded and dilated head in ventral view.

Etymology. borghata, named after the locus typicus of the holotype.

\section{Diplectrona chiangma sp. nov.}

(Map 9)

Diplectrona burha Schmid, 1961: Malicky 2002: 1205-1206. Misidentification.

Material. Syntypes: Malicky, 2002:1206: Thailand, Prov. Mae Hong Son, Ban Huai Hia, $1100 \mathrm{~m}, 19^{\circ} 39^{\prime} 46.4^{\prime \prime} \mathrm{N} 98^{\circ} 14^{\prime} 36.9^{\prime \prime} \mathrm{E}, 15 . \mathrm{IV} .2000$, leg. Malicky, CM: $1 \hat{\jmath} \cdot 14 \hat{\jmath} \widehat{\jmath}$ von 6 Orten in Nord- und Mittel-Thailand, CM, CMU.

Diagnosis. This species having dorsoapicad produced spiny structure on the paraproct belongs to the Diplectrona aurowittata new species group, and supplied with double pointed spines belongs to the Diplectrona hasada new species complex. Has resemblance to Diplectrona sironga sp. nov. described from India, Manipur, but differs by the long and slender harpago, by the more elongated and pointed dorsal profile of the paraproct as well as by the lateral profile of the phallic organ.

Description. Male (Figures: Malicky 2002: Table 14: burha, Chiangmai).

Male genitalia. Segment IX convex anterad, dorsum long and convex with a middle depression line, ventrum long. Segment $\mathrm{X}$ fused to the tergum IX. The dorsoapical setose lobes (inner lobes) of segment X well-developed, protruded 


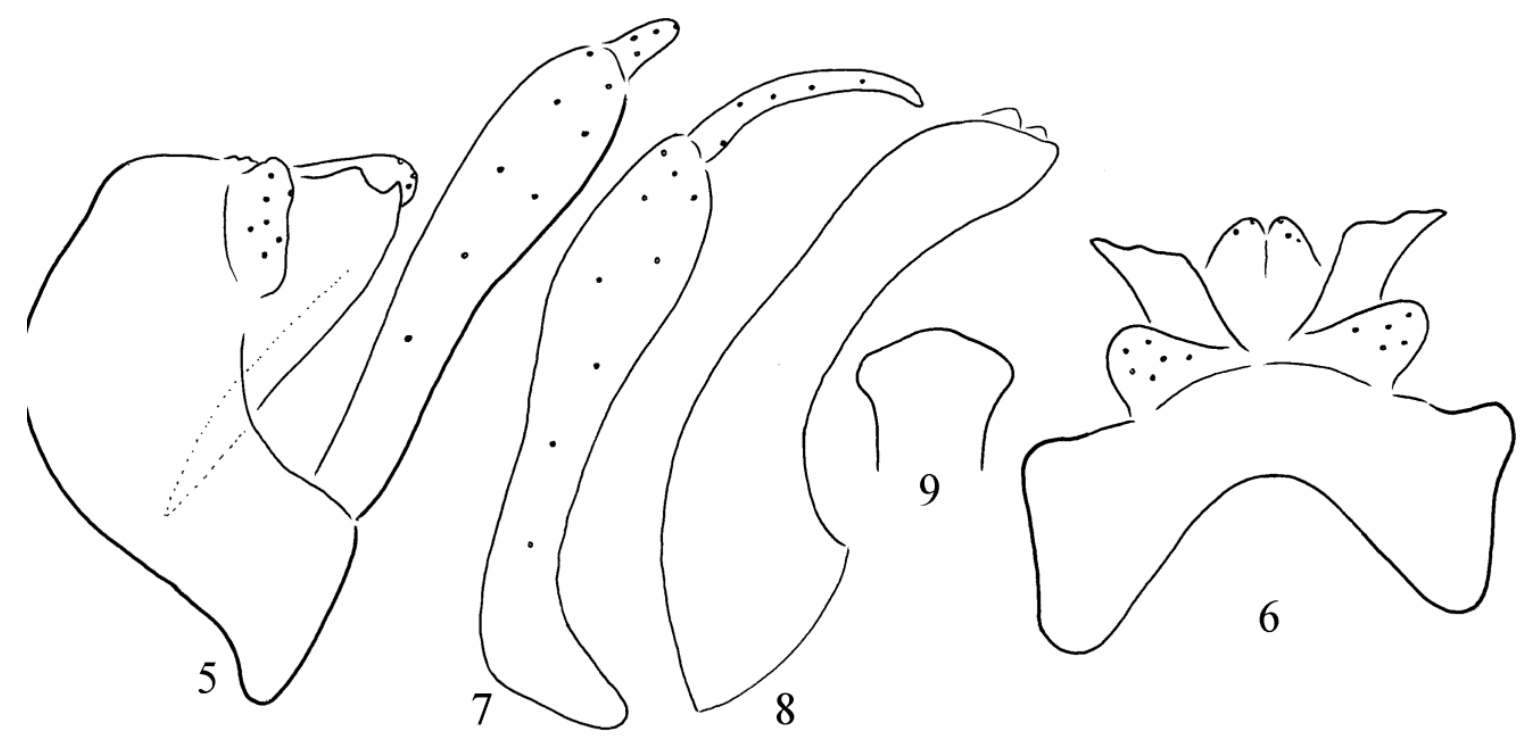

Figures 5-9. Diplectrona borghata sp. nov. Holotype: $5=$ male genitalia in left lateral view, $6=$ male genitalia in dorsal view, $7=$ left gonopod in ventral view, $8=$ phallic organ in left lateral view, $9=$ phallic head in ventral view.

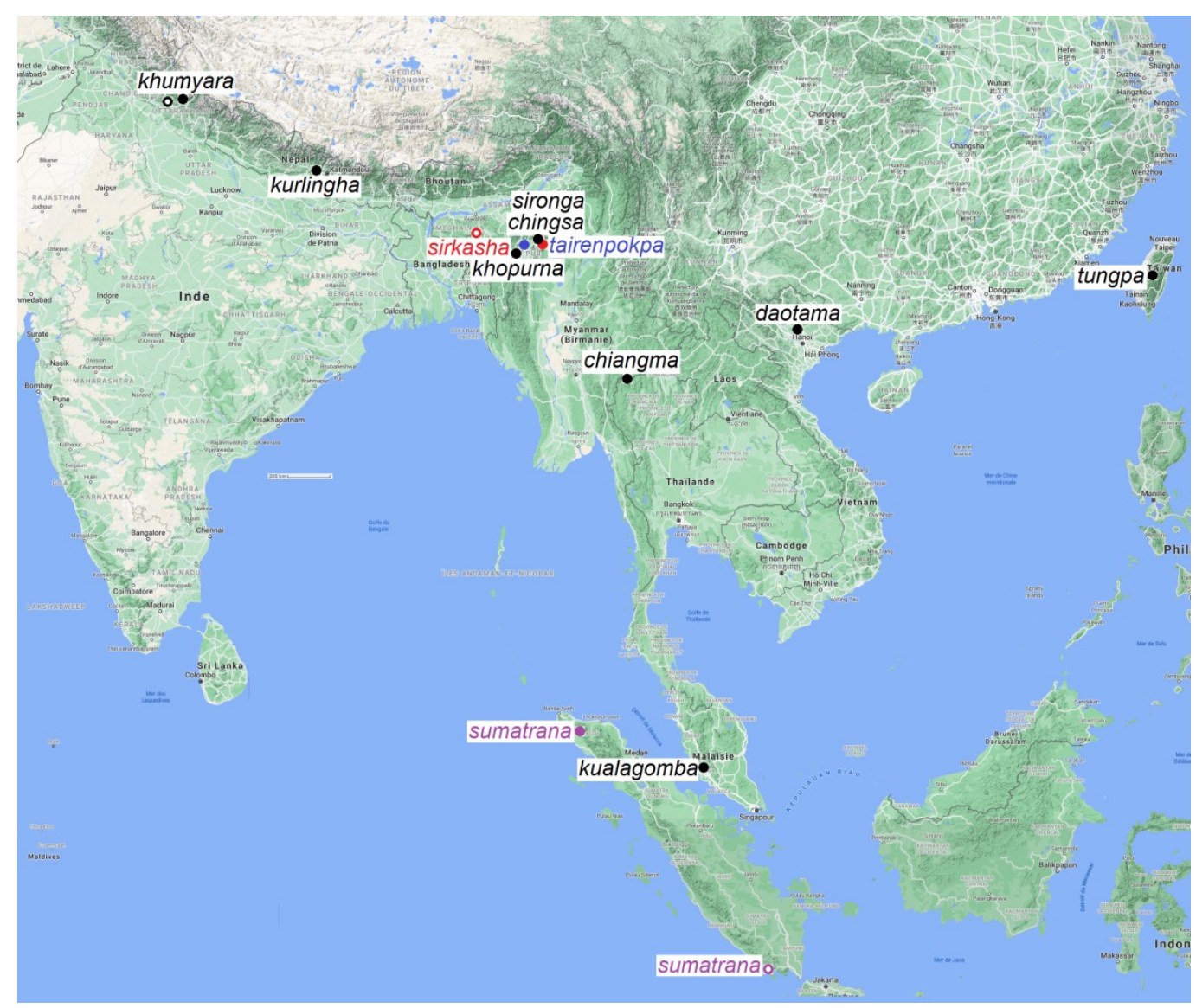

Map 9. Diplectrona hasada complex outside Meghalaya. 
and narrowing apicad, broad in lateral view; seem bilobed, but tightly adhered, as long as the paraproct. Cerci setose, high and short in lateral view, elongated in dorsal view. Unsetose paraproct (outer lobes or lateral plates of segment X) subquadrangular plate with two minute spines in lateral view elongated in dorsal view. Gonopods dilated apicad and their harpago mesad turning and narrowing. Phallic apparatus with head of convex apical margin in ventral view.

Etymology. chiangma, named after the locus typicus of the syntypes. Chiangmai is indicated only on Table 14 !

\section{Diplectrona chingsa sp. nov.}

(Figures 10-14, Map 6: $n^{\circ}$ 20, 23, Map 9)

Material examined. Holotype: India, Manipur, Chingsao [=Zingsui], $5400 \mathrm{ft}, 25^{\circ} 05^{\prime} 43.2^{\prime \prime} \mathrm{N} 94^{\circ}$ 31'56.0"E, 13.VI.1960, leg. F. Schmid (1 male, CNC). Paratypes: same as holotype (1 male, OPC). India, Manipur, Chingsao [=Zingsui], 4500 $\mathrm{ft}, 25^{\circ} 05^{\prime} 43.2^{\prime \prime} \mathrm{N} 94^{\circ} 31^{\prime} 56.0^{\prime \prime} \mathrm{E}, 13 . \mathrm{VI} .1960$, leg. F. Schmid (1 male, CNC). India, Manipur, Loni [=Roni], 4500-5500 ft, 2503'41.8"N 94³4' 18.8" E, 16.VI.1960, leg. F. Schmid (2 males, CNC).

Diagnosis. This species belongs to the Diplectrona aurovittata species group and to the $D$. hasada species complex. Having double-spined or pointed dorsoapical region of the paraproct it is most close to $D$. nongina sp. nov. It differs by the presence of a pair of reticulated sacs in abdominal segment VII, by the shorter ventrum of segment IX, the slender, not robust coxopodite, the small cerci, and the lateral and dorsal shape of the paraproct as well as by the ventral profile of the phallus head.

Description. Male (in alcohol). Light brown animal. Forewings without pattern. Forewing length $8 \mathrm{~mm}$, apical fork I present on hindwing. Eyes setaless, not enlarged. Maxillary palp formula I-IV-III-II-V. Not any filament discernible on segment V. Abdominal segment VII with a pair of reticulated internal sacs.
Male genitalia. Segment IX rounded anterad, dorsum medium long and flat with a middle depression line, ventrum very little longer. Segment $\mathrm{X}$ fused to the tergum IX. The dorsoapical setose lobes (inner lobes) of segment $\mathrm{X}$ welldeveloped, protruded narrowing; seem bilobed, but tightly adhered. Cerci setose rather lobe-like, not just a setose surface both in dorsal and lateral views. Unsetose paraproct (outer lobes or lateral plates of segment $\mathrm{X}$ ) subtriangular flat plate in lateral view with a pair of blunt pointed processes as visible both in lateral and dorsal profiles. Gonopods slender straight with coxopodite of dilated apical half; harpago mesad turning with sharply ventrad pointed head. Phallic apparatus with down curving and broadening basal section and with a longer tube-forming horizontal two thirds with rounded obliquely cut apex in lateral view; two pairs of endothecal processes visible, both with blunt apices in lateral and pointed triangular in ventral view; dorsal endothecal process bigger; phallotremal sclerite less distinct. The phallic organ with slightly convex and dilated head in ventral view.

Etymology. chingsa, coined from the name of locus typicus of the holotype.

\section{Diplectrona daotama sp. nov.}

(Map 9)

Diplectrona burha Schmid, 1961: Malicky 2002:12051206. Misidentification.

Material. Syntypes: Malicky, 2002:1206: Vietnam, Tam Dao, 800-1100m, 21 $27^{\circ} 40.4^{\prime \prime} \mathrm{N}$ 10538'33.7"E, 19.V.-13.VI.1995, leg. Malicky, (14へึ亍, MPC).

Diagnosis. This species having dorsoapicad produced spiny structure on the paraproct belongs to the Diplectrona aurowittata new species group and supplied with double pointed spines belongs to the Diplectrona hasada new species complex. Has resemblance to Diplectrona kurlingha sp. nov. described from Nepal, but differs by the lateral profile of the paraproct with low and not 


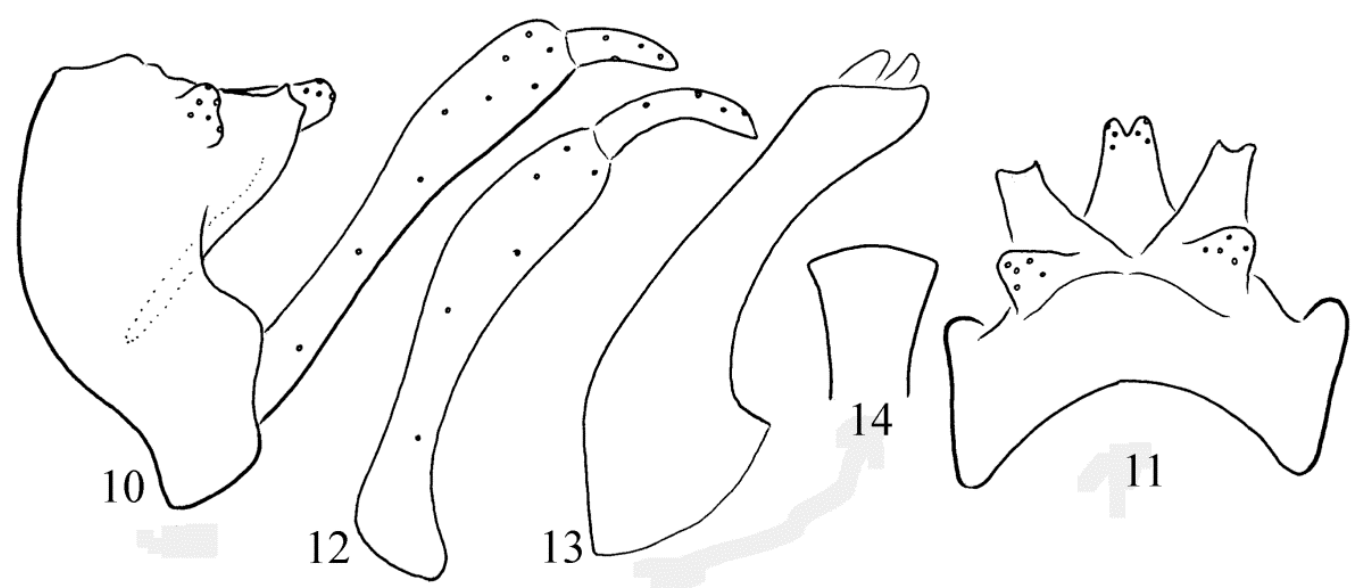

Figures 10-14. Diplectrona chingsa sp. nov. Holotype: $10=$ male genitalia in left lateral view, $11=$ male genitalia in dorsal view, 12 = left gonopod in ventral view, 13 = phallic organ in left lateral view, 14 = phallic head in ventral view.

high apical region; by the lateral profile of the phallic organ and by the ventral profile of the phallic head.

Description. Male (Figures: Malicky 2002: Table 14: burha, Tam Dao).

Male genitalia. Segment IX convex anterad, dorsum long and convex with a middle depression line, ventrum long. Segment $X$ fused to the tergum IX. The dorsoapical setose lobes (inner lobes) of segment $\mathrm{X}$ well-developed, protruded and narrowing apicad, broad in lateral view; seem bilobed, but tightly adhered, longer than the paraproct. Cerci setose, high and short in lateral view, semi-circular in dorsal view. Unsetose paraproct (outer lobes or lateral plates of segment X) subtriangular plate with two blunt spines in lateral view and with more pronounced mesal pointed process in dorsal view. Gonopods robust and their harpago mesad turning with pointed apices. Phallic apparatus with rounded head in ventral view.

Etymology. daotama, named after the locus typicus of the syntypes.

Diplectrona grimona sp. nov.

(Figures 15-19, Map 5: n 46, Map 8)

Material examined. Holotype: India, Meghaláya (United Jaintia and Khasi Hills), Nongrim
[=Nongtraw], $3000 \mathrm{ft}, 25^{\circ} 22^{\prime} 09.8^{\prime \prime} \mathrm{N} \mathrm{91}{ }^{\circ} 4541.5^{\prime \prime}$ E, 28.III.1960, leg. F. Schmid (1 male, CNC).

Diagnosis. This species belongs to the Diplectrona aurovittata species group and to the Diplectrona hasada species complex. It is most close to Diplectrona mirgona sp. nov., but differs by the smaller body size; by regular pointed head of the harpago, not with aviform head; by the different shape of the paraproct both in lateral and dorsal views; as well as by the lateral shape of the phallotheca having low, not high phallobase and by the ventral profile of the phallothecal head with rounded, not triangular lateral lobes.

Description. Male (in alcohol). Light brown animal. Forewings with light spotted pattern. Forewing length is $7 \mathrm{~mm}$, apical fork I present on hindwing. Eyes setaless not enlarged. Maxillary palp formula I-IV-III-II-V. Filament of sternite V indiscernible. Abdominal segments without any reticulated internal sacs.

Male genitalia. Segment IX semicircular anterad, dorsum short and flat with a middle depression line, ventrum shorter than dorsum. Segment $\mathrm{X}$ fused to the tergum IX. The dorsoapical setose lobes (inner lobes) of segment $X$ welldeveloped, rounded broad, short; seem bilobed, but tightly adhered; the ventroapical setose area distinct. Cerci setose, high and long in lateral view, semi-circular in dorsal view. Unsetose para 


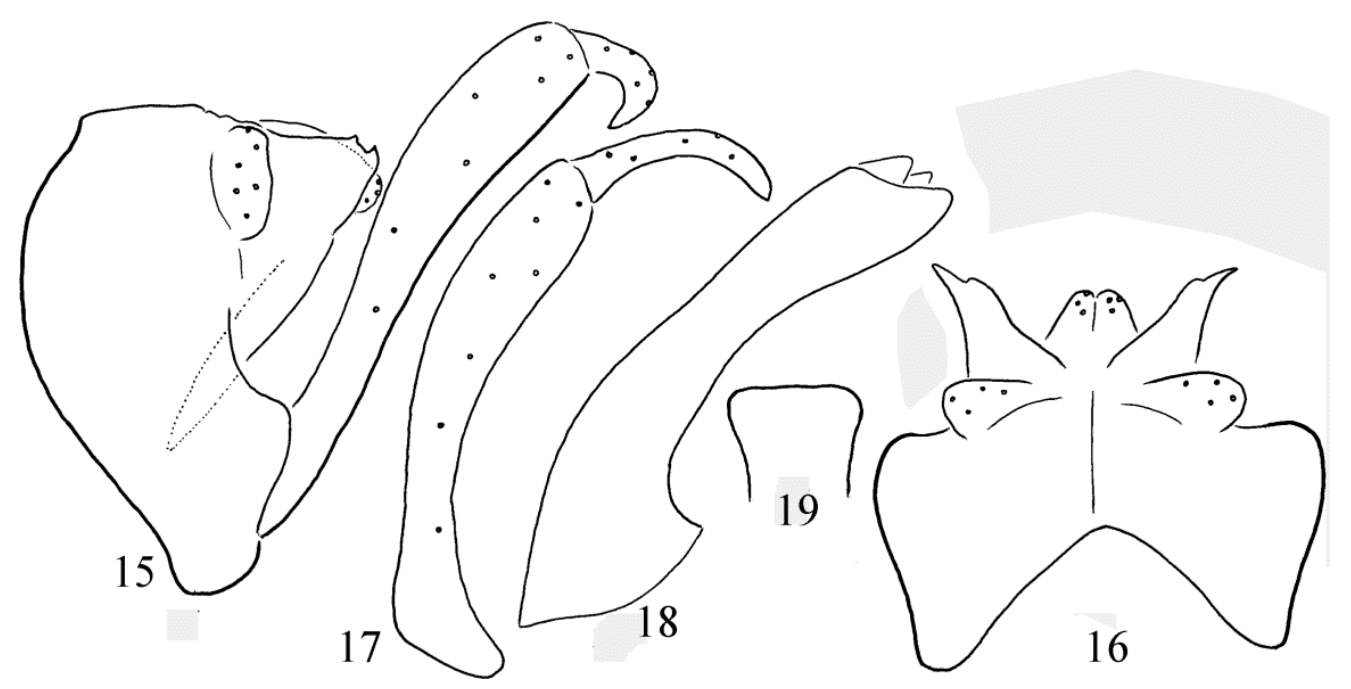

Figures 15-19. Diplectrona grimona sp. nov. Holotype: 15 = male genitalia in left lateral view, $16=$ male genitalia in dorsal view, 17 = left gonopod in ventral view, 18 = phallic organ in left lateral view, $19=$ phallic head in ventral view.

proct (outer lobes or lateral plates of segment X) subtriangular flat plate in lateral view with upward directed pair of less developed pointed processes. Gonopods robust straight and their harpago mesad turning with regular pointed head. Phallic apparatus with highlow down curving and broadening basal section and with a longer tubeforming horizontal two thirds with little constricted middle and rounded obliquely cut apex in lateral view; two pairs of endothecal processes visible, both with blunt apices in lateral view and pointed triangular in ventral view; dorsal endothecal process larger; phallotremal sclerite less distinct. The phallic organ with produced winglike rounded lateral lobes of the head in ventral view.

Etymology. grimona, coined from the name of locus typicus of the holotype.

\section{Diplectrona jaraina sp. nov.}

(Figures 20-24, Map 5: n 63, Map 8)

Material examined. Holotype: India, Meghaláya (United Jaintia and Khasi Hills), Jarain, $25^{\circ} 22^{\prime 2} 23.7^{\prime \prime} \mathrm{N} \mathrm{92} 08^{\prime} 58.9^{\prime \prime E}, 2800 \mathrm{ft}$. 13.IV.1960, leg. F. Schmid (1 male, CNC).
Diagnosis. This species belongs to the Diplectrona aurovittata species group and to the $D$. hasada species complex. Having double-spined dorsoapical region it is most close to D. kismada described from Vietnam. It differs by the character combination of small setaless eyes; without any internal sacs in abdominal segments; anterodorsal filament on sternite $\mathrm{V}$ twice as long as the sternite, presence of fork I on hindwing; short rounded and broad lobes of segment X; enlarged cerci; elongated ventral band of paraproct; almost parallel-sided harpago in ventral view with ventrad pointed head; delta-shaped head of the phallic organ in ventral view. At D. kismada cerci are small, ventral band of paraproct short, head of phallic organ not pronounced delta-shaped in ventral view.

Description. Male (in alcohol). Light brown animal. Forewings without pattern. Forewing length $9 \mathrm{~mm}$, apical fork I present on hindwing. Eyes setaless not enlarged. Maxillary palp formula I-IV-III-II-V. Abdominal segments without any reticulated internal sacs.

Male genitalia. Segment IX convex anterad, dorsum long and flat with a middle depression line, ventrum deformed into a ventral narrowing lobe. Segment $X$ fused to the tergum IX. The 


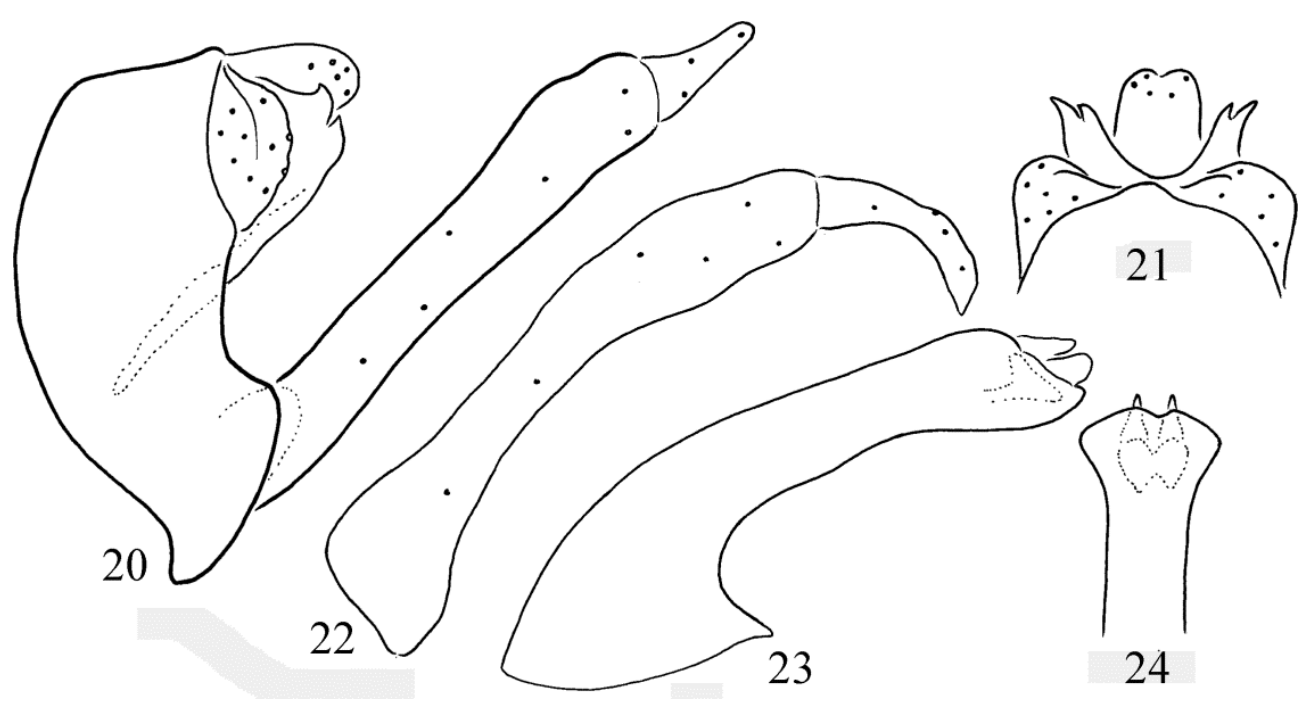

Figures 20-24. Diplectrona jaraina sp. nov. Holotype: $20=$ male genitalia in left lateral view, $21=$ male genitalia in dorsal view, 22 = left gonopod in ventral view, 23 = phallic organ in left lateral view, $24=$ phallic head in ventral view.

dorsoapical setose lobes (inner lobes) of segment $\mathrm{X}$ well-developed, rounded broad, protruded; seem bilobed, but tightly adhered; the ventroapical setose area distinct. Cerci setose, high and long in lateral view, semi-circular in dorsal view. Unsetose paraproct (outer lobes or lateral plates of segment $\mathrm{X}$ ) subtriangular flat plate in lateral view with upward directed pair of pointed processes, narrow in dorsal view. Gonopods robust straight and their harpago mesad turning with sharply pointed head. Phallic apparatus with down curving and broadening basal section and with a longer tube-forming horizontal two thirds with rounded obliquely cut apex in lateral view; two pairs of endothecal processes visible, both with blunt apices in lateral and pointed triangular in ventral view; dorsal endothecal process smaller; phallotremal sclerite less distinct. The phallic organ with produced wing-like triangular delta-shaped head in ventral view.

Etymology. jaraina, named after the locus typicus of the holotype.

\section{Diplectrona khopurna sp. nov.}

(Figures 25-29, Map 6: n 7, Map 9)

Material examined. Holotype: India, Manipur, Khopum [=Khopurn =Khoupum Valley], $2500 \mathrm{ft}$, $24^{\circ} 40^{\prime} 31.8^{\prime \prime} \mathrm{N}$ 9331'07.3"E, 27.V.1960, leg. F. Schmid (1 male, CNC). Paratype: same as holotype (1 male, OPC).

Diagnosis. This species belongs to the Diplectrona aurovittata species group and to the Diplectrona hasada species complex. It is most close to Diplectrona mawkhapa sp. nov. described from Meghalaya, but differs by the uniform forewing without any discernible light spotted pattern; by the small shape modification both in the lateral and dorsal profiles of the paraproct as well as clearly diverged by the head formation of the phallic organ, its ventral profile is rounded, not fan-shaped.

Description. Male (in alcohol). Light brown animal. Forewings without light spotted pattern. Forewing length is $8 \mathrm{~mm}$, apical fork I present on hindwing. Eyes setaless not enlarged. Maxillary palp formula I-IV-III-II-V. Filament of sternite V with length of sternite $\mathrm{V}$ and VI. Abdominal segments without any reticulated internal sacs.

Male genitalia. Segment IX semicircular anterad, dorsum short and flat with a middle depression line, ventrum even shorter. Segment X fused to the tergum IX. The dorsoapical setose lobes (inner lobes) of segment X well-developed, rounded broad, protruded; seem bilobed, but 


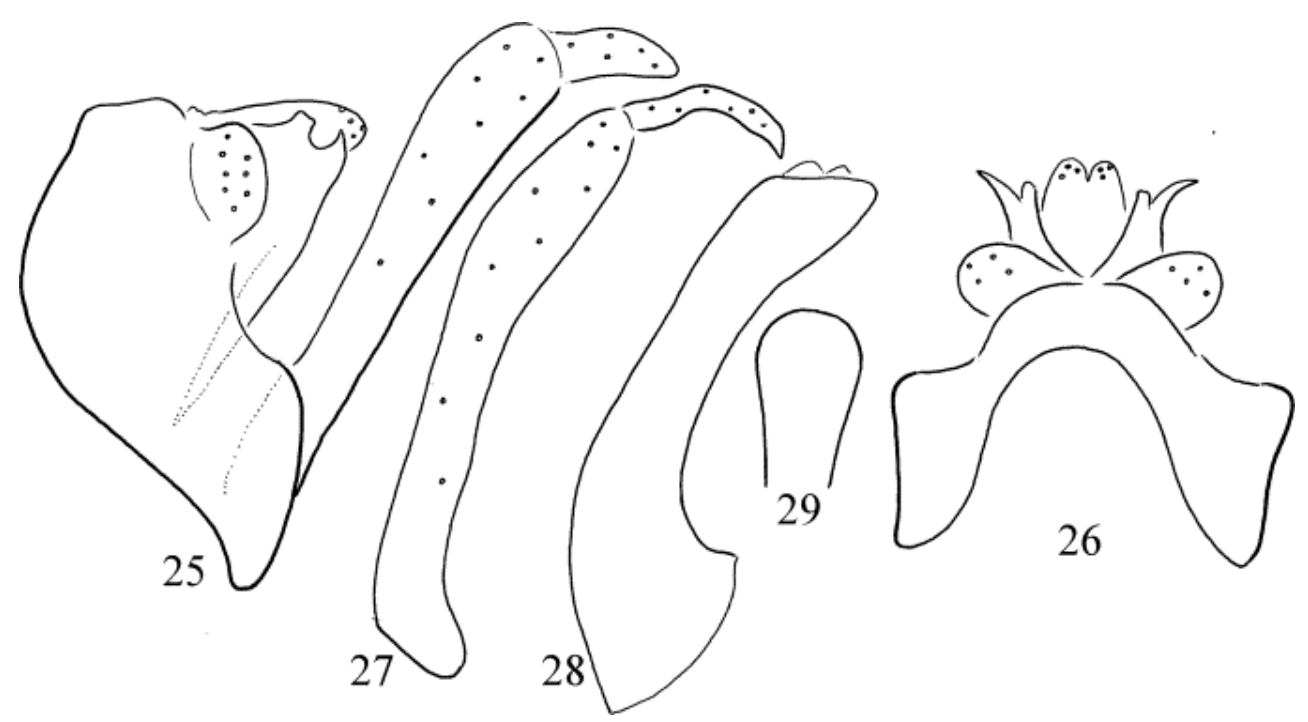

Figures 25-29. Diplectrona khopurna sp. nov. Holotype: 25 = male genitalia in left lateral view, 26 = male genitalia in dorsal view, 27 = left gonopod in ventral view, 28 = phallic organ in left lateral view, $29=$ phallic head in ventral view.

tightly adhered; the ventroapical setose area distinct. Cerci setose, high and long in lateral view, semi-circular in dorsal view. Unsetose paraproct (outer lobes or lateral plates of segment X) subtriangular flat plate in lateral view with upward directed ending with a pointed lateral and a truncated mesal processes; separated with a deep and wide interspine gap visible in lateral view. Gonopods robust straight and their harpago mesad turning with sharply pointed head. Phallic apparatus with low down curving and broadening basal section and with a longer tube-forming horizontal two thirds without pronounced constricted middle and with rounded obliquely cut apex in lateral view; two pairs of endothecal processes visible, both with blunt apices in lateral view and pointed triangular in ventral view; dorsal endothecal process larger; phallotremal sclerite less distinct. The phallic organ with rounded head in ventral view.

Etymology. khopurna, named after the locus typicus of the holotype.

\section{Diplectrona khumyara sp. nov.}

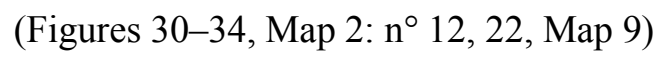

Material examined. Holotype: India, Uttarakhand: Pauri Garhwal, Khumyara [=Khumera ac- cording to Lonsdale (2020)], 2 small brooks in bushes and hygropetric habitat, 30 $33^{\prime} 15.4^{\prime \prime} \mathrm{N} 79^{\circ}$ 03'44.3"E, 4300-5000 ft, 27-28.V.1958, leg. F. Schmid (1 male, CNC). Paratypes: same as holotype (1 male, OPC). India, Pauri Garhwal, Khumyara [probably Khumera], 30 33'15.4"N 7903'44.3"E, 4300-5000 ft, 3-4.V.1958, leg. F. Schmid (4 males, CNC). India, Tehri Garhwal, Jaspur, small torrent in bushes, $30^{\circ} 23^{\prime} 34.7^{\prime \prime} \mathrm{N} 78^{\circ}$ 25'21.4"E, 3500-4500 ft, 15.IV.1958, leg. F. Schmid (3 males, CNC; 1 male, SMNH; 1 male, OPC).

Diagnosis. This species belongs to the Diplectrona aurovittata species group and to the $D$. hasada species complex. Having double-spined dorsoapical region it is most close to D. jaraina sp. nov. described from Meghalaya, India. It differs by the character combination of small setaless eyes; without any internal sacs in abdominal segments; no filament on sternite $\mathrm{V}$ discernible, presence of fork I on hindwing. The genital structure is characterized by short and narrow lobes of segment X; by enlarged cerci; bilobed paraproct blunt, not pointed; elongated and broadened ventral band of paraproct, not elongated and narrow; coxopodite of the gonopods narrowing ventrad, not parallel-sided; harpago with rounded head, not ventrad pointed. 


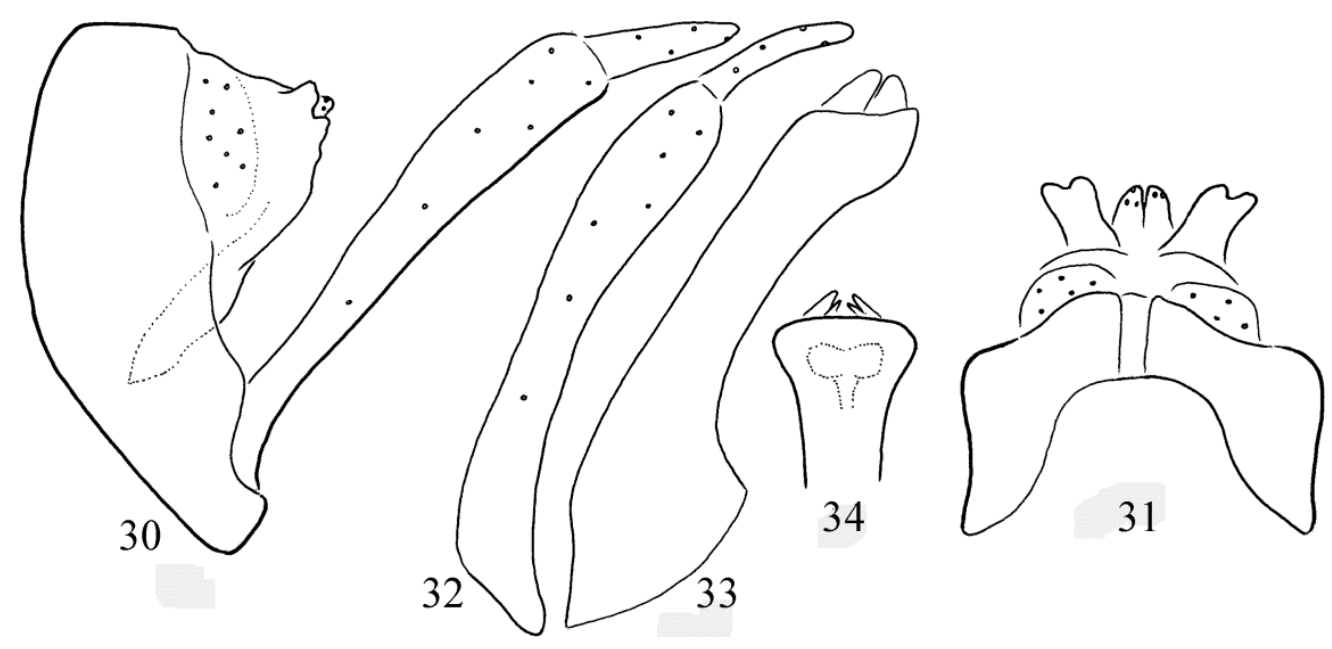

Figures 30-34. Diplectrona khumyara sp. nov. Holotype: $30=$ male genitalia in left lateral view, $31=$ male genitalia in dorsal view, 32 = left gonopod in ventral view, 33 = phallic organ in left lateral view, 34 = phallic head in ventral view.

Description. Male (in alcohol). Light brown animal. Forewings without pattern. Forewing length $5 \mathrm{~mm}$, apical fork I present on hindwing. Eyes setaless not enlarged. Maxillary palp formula I-IV-III-II-V. No filament on segment V present; abdominal segments without any reticulated internal sacs.

Male genitalia. Segment IX convex anterad, dorsum long and flat with a middle depression line, ventrum formed into a narrowing band. Segment $\mathrm{X}$ fused to the tergum IX. The dorsoapical setose lobes (inner lobes) of segment $\mathrm{X}$ narrow slightly protruded, bilobate; the ventroapical setose area distinct. Cerci setose, high and short in lateral view, semi-circular in dorsal view. Unsetose paraproct (outer lobes or lateral plates of segment X) subtriangular flat plate in lateral view with upward directed pair of blunt processes, bilobed also in dorsal view. Gonopods robust straight, narrowing ventrad; their harpago mesad turning, parallel-sided in ventral view with rounded head. Phallic apparatus with down curving and broadening basal section and with a longer tubeforming horizontal section with rounded and obliquely cut apex in lateral view; apicoventrum downward produced; two pairs of endothecal processes visible, both with blunt apices in lateral and pointed triangular in ventral view; phallotremal sclerite distinct. The phallic organ with produced, triangular delta-shaped head in ventral view.
Etymology. khumyara, named after the locus typicus of the holotype.

\section{Diplectrona kualagomba sp. nov.}

(Map 9)

Diplectrona hermione Malicky \& Chantaramongkol, 1992 in Malicky 2002: 1210. Misidentification.

Material. Syntypes: Malicky 2002:1210: Malaysia, Kuala Lumpur, Gombak, 22.V.1996, leg. Trilar, $(7 \hat{\partial} \widehat{\partial}$, one drawn specimen, MPC)

Diagnosis. This species having dorsoapicad produced spiny structure on the paraproct belongs to the Diplectrona aurowittata new species group, and supplied with double pointed spines belongs to the Diplectrona hasada new species complex. Has resemblance to Diplectrona sumatrana sp. nov. described from Indonesia, North and South Sumatra, but differs by the differently shaped dorsal and lateral profiles of the paraproct as well as by the lateral profile of the phallic organ and the ventral profile of the phallic head.

Description. Male (Figures: Malicky 2002: Table 15: hermione, Gombak).

Male genitalia. Segment IX convex anterad, dorsum long and convex with a middle depression line, ventrum short. Segment X fused to the tergum IX. The dorsoapical setose lobes (inner 
lobes) of segment $\mathrm{X}$ well-developed, protruded and narrowing apicad, broad in lateral view; seem bilobed, but tightly adhered basally, slightly longer than paraproct. Cerci setose, high and short in lateral view, semi-circular in dorsal view. Unsetose paraproct (outer lobes or lateral plates of segment $\mathrm{X}$ ) subquadrangular plate with two minute spines in lateral view elongated in dorsal view. Gonopods dilated apicad and their harpago mesad turning and narrowing. Phallic apparatus with head of deeply concave, excised apical margin in ventral view.

Etymology. kualagomba, named after the locus typicus of the syntype.

\section{Diplectrona kurlingha sp. nov.}

(Map 9)

Diplectrona sanguana Kimmins, 1964: Malicky 2002: 1215-1216. Misidentification.

Material. Holotype: Nepal, Trisuli River, Kurlinghat, $380 \mathrm{~m}$, should be near this point: $27^{\circ} 48^{\prime}$ 47.7"N 84०49'58.3"E, according to the altitude along the Trisuli River, 27.X.1995, leg. Sivec (1 male, drawn specimen, MPC).

Diagnosis. This species having dorsoapicad produced spiny structure on the paraproct belongs to the Diplectrona aurowittata new species group and supplied with two pointed spines belongs to the Diplectrona hasada new species complex. Most close to Diplectrona nongronga sp. nov., but differs both by the dorsal and lateral profiles of the paraproct; by the lateral profile of the phallotheca as well as by the ventral profile of the phallic head.

Description. Male (Figures: Malicky 2002: Table 11: sanguana, Kurlinghat). Eyes setaless, not enlarged. Abdominal segments with reticulated internal sacs; filaments on sternite $\mathrm{V}$ present.

Male genitalia. Segment IX convex anterad, dorsum long and convex with a middle depression line, ventrum shorter. Segment $X$ fused to the tergum IX. The dorsoapical setose lobes (inner lobes) of segment $\mathrm{X}$ well-developed, protruded and narrowing apicad, broad in lateral view; seem bilobed, but tightly adhered and longer than paraproct. Cerci setose, high and short in lateral view, semi-circular in dorsal view. Unsetose paraproct (outer lobes or lateral plates of segment X) subquadrangular plate with two dorsoapical elongated spines in lateral view. Gonopods dilated apicad and their harpago mesad turning with ventroapical pointed tiny process. Phallic apparatus with high phallobase and the phallic head with truncated laterad expanding apical margin in ventral view.

Etymology. kurlingha, named after the locus typicus of the holotype.

\section{Diplectrona lyngkota sp. nov.}

(Figures 35-39, Map 5: n 38, Map 8)

Material examined. Holotype: India: Meghalaya (United Jaintia and Khasi Hills), Laitlyngkot, 2000-2300 ft., 2524'42.9"N 91 54'35.4"E, 17.III. 1960, leg. F. Schmid (1 male, CNC).

Diagnosis. This species belongs to the Diplectrona aurovittata species group and the D. hasada species complex. Having double-spined dorsoapical region it is most close to $D$. jaraina sp. nov. but differs by the more produced and curving mesal spine-like process of paraproct, more discernible in lateral view as well as by the small, short and high cerci.

Description. Male (in alcohol). Light brown animal. Forewings without pattern. Forewing length $9 \mathrm{~mm}$, apical fork I present on hindwing. Eyes setaless not enlarged. Maxillary palp formula I-IV-III-II-V. Filaments on sternum V present, its length twice of the segment. Abdominal segments without any reticulated internal sacs.

Male genitalia. Segment IX convex anterad, dorsum long and flat with a middle depression line, ventrum as long as dorsum. Segment X fused to the tergum IX. The dorsoapical setose lobes (inner lobes) of segment $\mathrm{X}$ well-developed, as long as paraproct with rounded apical margin in lateral view and with triangular shape in dorsal view. Cerci setose, small and lobe-like. Unsetose 


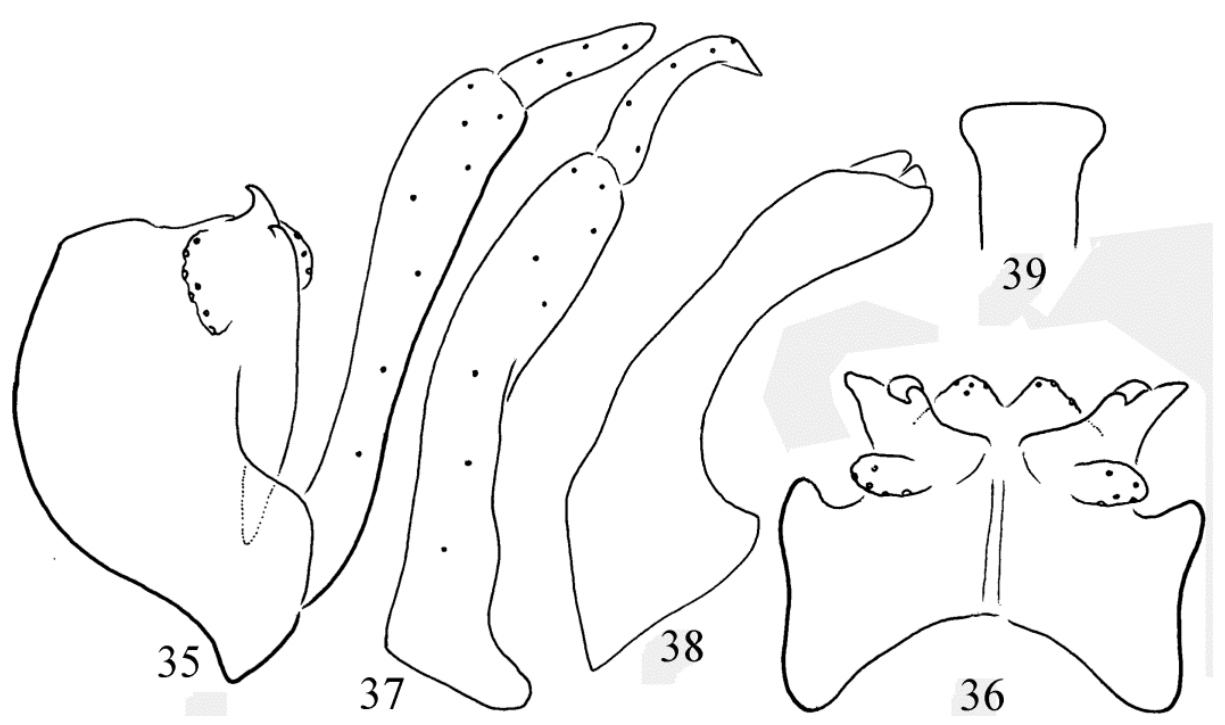

Figures 35-39. Diplectrona lyngkota sp. nov. Holotype: $35=$ male genitalia in left lateral view, $36=$ male genitalia in dorsal view, 37 = left gonopod in ventral view, $38=$ phallic organ in left lateral view, $39=$ phallic head in ventral view.

paraproct (outer lobes or lateral plates of segment $\mathrm{X})$ subtriangular flat plate in lateral view with upward directed pair of pointed processes, narrow in dorsal view; mesal pointed spine-like process more produced and curving in lateral view. Gonopods robust straight and their harpago mesad turning with sharply pointed head. Phallic apparatus with down curving and broadening basal section and with a longer tube-forming horizontal two thirds with rounded obliquely cut apex in lateral view; two pairs of endothecal processes visible, both with blunt apices in lateral and pointed triangular in ventral view; phallotremal sclerite less distinct. The phallic organ with rounded widening apical region in ventral view.

Etymology. lyngkota, coined from the name of the holotype locus typicus.

\section{Diplectrona mawkhapa sp. nov.}

(Figures 40-44, Map 5: n 40, Map 8)

Material examined. Holotype: India, Meghaláya (United Jaintia and Khasi Hills), Mawkhap, 2000 ft., 2523'27.7"N 9153'59.0"E, 19.III.1960, leg. F. Schmid (1 male, CNC). Paratypes: same as holotype (1 male, CNC; 1 male, OPC; 1 male, SMNH).
Diagnosis. This species belongs to the Diplectrona aurovittata species group and to the $D i$ plectrona hasada species complex. It is most close to Diplectrona mirgona sp. nov., but differs by the subquadrangular lateral profile of ventrum IX; by the simple, not aviform head of the harpago; by the tripointed paraproct discernible in lateral view, as well as by the low phallobase of the phallotheca and by the ventral profile of the phallothecal head having very pronounced triangular lateral lobes.

Description. Male (in alcohol). Light brown animal. Forewings with light spotted pattern. Forewing length $10 \mathrm{~mm}$, apical fork I present on hindwing. Eyes setaless not enlarged. Maxillary palp formula I-IV-III-II-V. Filament of sternite V with length of sternite V and VI. Abdominal segments without any reticulated internal sacs.

Male genitalia. Segment IX semicircular anterad, dorsum short and flat with a middle depression line, ventrum longer than dorsum. Segment $\mathrm{X}$ fused to the tergum IX. The dorsoapical setose lobes (inner lobes) of segment X well-developed, rounded broad, protruded; seem bilobed, but tightly adhered; the ventroapical setose area distinct. Cerci setose, high and long in lateral view, semi-circular in dorsal view. Unsetose paraproct (outer lobes or lateral plates of segment X) 


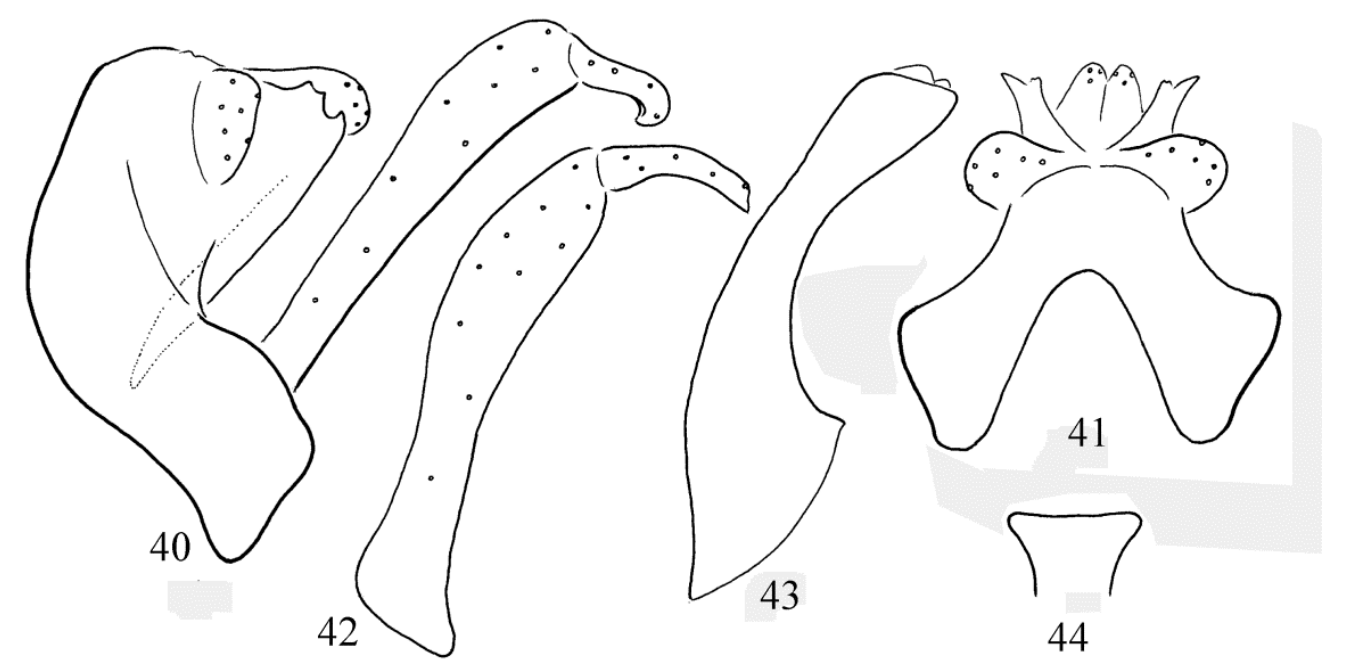

Figures 40-44. Diplectrona mawkhapa sp. nov. Holotype: $40=$ male genitalia in left lateral view, $41=$ male genitalia in dorsal view, 42 = left gonopod in ventral view, 43 = phallic organ in left lateral view, $44=$ phallic head in ventral view.

subtriangular flat plate in lateral view with upward directed tripointed ending; separated with a shallow and wide interspine gap. Gonopods robust straight and their harpago mesad turning with sharply pointed head. Phallic apparatus with low down curving and broadening basal section and with a longer tube-forming horizontal two thirds with constricted middle and rounded obliquely cut apex in lateral view; two pairs of endothecal processes visible, both with blunt apices in lateral view and pointed triangular in ventral view; dorsal endothecal process larger; phallotremal sclerite less distinct. The phallic organ with produced wing-like triangular lateral lobes of the head in ventral view.

Etymology. mawkhapa, coined from the name of locus typicus of the holotype.

\section{Diplectrona mirgona sp. nov.}

(Figures 45-49, Map 5: n 46, Map 8)

Material examined. Holotype: India, Meghaláya (United Jaintia and Khasi Hills), Nongrim

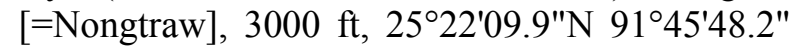
E, 28.III.1960, leg. F. Schmid (1 male, CNC).

Diagnosis. This species belongs to the Diplectrona aurovittata species group and to the Diplectrona hasada species complex. It is most close to Diplectrona nongra sp. nov., but differs by the indistinctly spotted forewing; by the narrow interspine gap of the paraproct well discernible in lateral view, as well as by the lateral shape of the phallotheca and by the ventral profile of the phallothecal head having triangular, not rounded lateral lobes.

Description. Male (in alcohol). Light brown animal. Forewings with light spotted pattern. Forewing length $10 \mathrm{~mm}$, apical fork I present on hindwing. Eyes setaless not enlarged. Maxillary palp formula I-IV-III-II-V. Filament of sternite V with length of sternite V and VI. Abdominal segments without any reticulated internal sacs.

Male genitalia. Segment IX semicircular anterad, dorsum short and flat with a middle depression line, ventrum shorter than dorsum. Segment $X$ fused to the tergum IX. The dorsoapical setose lobes (inner lobes) of segment $\mathrm{X}$ welldeveloped, rounded broad, protruded; seem bilobate, but tightly adhered; the ventroapical setose area distinct. Cerci setose, high and long in lateral view, semi-circular in dorsal view. Unsetose paraproct (outer lobes or lateral plates of segment X) subtriangular flat plate in lateral view with upward directed pair of pointed processes; separated with a narrow interspine gap. Gonopods robust straight and their harpago mesad turning with sharply pointed aviform head. Phallic apparatus 


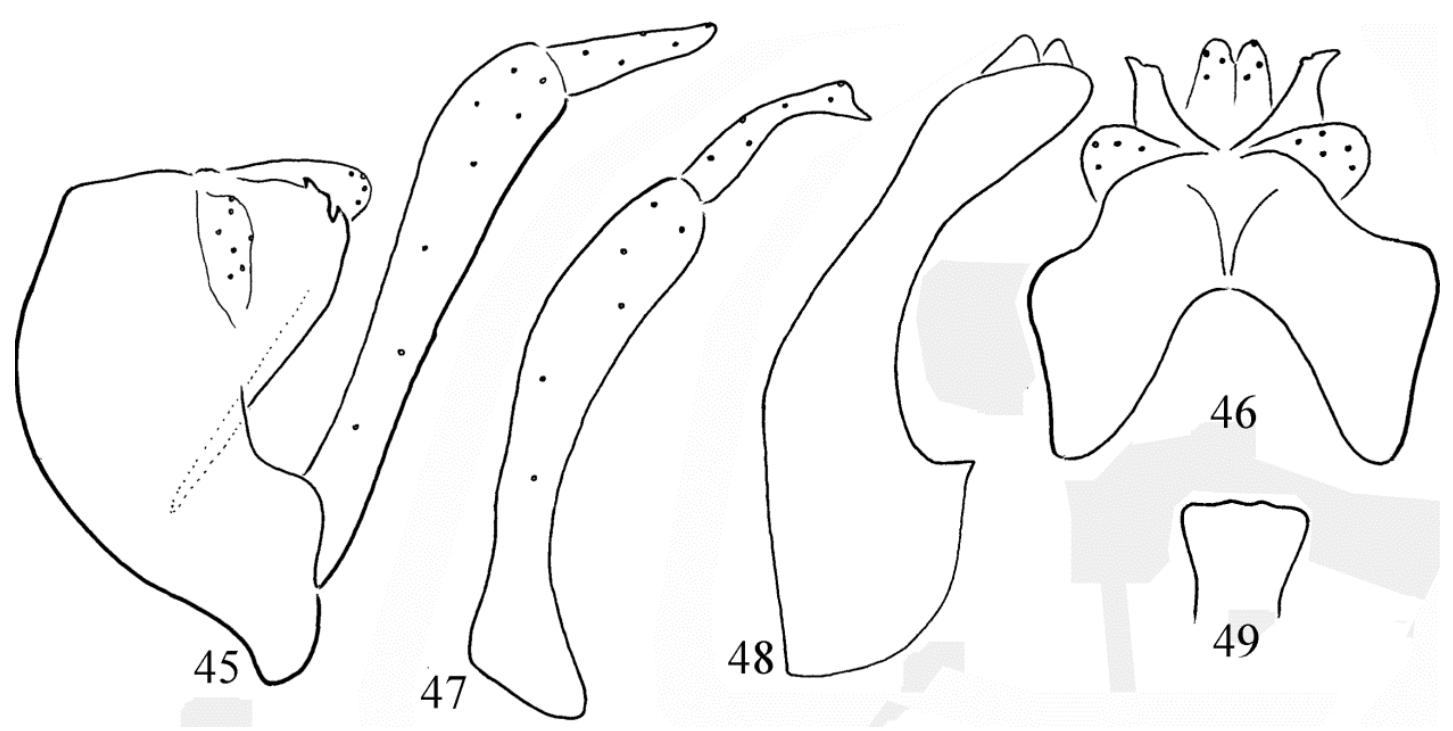

Figures 45-49. Diplectrona mirgona sp. nov. Holotype: 45 = male genitalia in left lateral view, $46=$ male genitalia in dorsal view, 47 = left gonopod in ventral view, 48 = phallic organ in left lateral view, $49=$ phallic head in ventral view.

with high down curving and broadening basal section and with a longer tube-forming horizontal two thirds with constricted middle and rounded obliquely cut apex in lateral view; two pairs of endothecal processes visible, both with blunt apices in lateral view and pointed triangular in ventral view; dorsal endothecal process larger; phallotremal sclerite less distinct. The phallic organ with produced wing-like triangular lateral lobes of the head in ventral view.

Etymology. mirgona, coined from the name of locus typicus of the holotype.

\section{Diplectrona muktapura sp. nov.}

(Figures 50-54, Map 5: $\mathrm{n}^{\circ}$ 11, Map 8)

Material examined. Holotype: India, Meghalaya (United Jaintia and Khasi Hills), Muktapur, 200 ft., 2509'48.6"N 9207'45.4"E, 11-12.XII. 1959, leg. F. Schmid (1 male, CNC). Paratypes: India, Meghaláya (United Jaintia and Khasi Hills), Khasi Hills (Assam, Khasia Hills) McLachlan Coll. B. M. 1938-674 (2 males, BMNH).

Diagnosis. This species belongs to the Diplectrona aurovittata species group and to the $D$. hasada species complex. Having double-spined dorsoapical region of the paraproct, it is most close to $D$. nongina sp. nov. It differs by the upward directed bipointed paraproct in lateral view and the more laterad directed spines in dorsal view; as well as by the shape of the phallic organ, with more produced downward directed phallobase and by the ventral profile of the head of the phallic organ.

Description. Male (in alcohol). Light brown animal. Forewings without any pattern. Forewing length is $8 \mathrm{~mm}$, apical fork I present on hindwing. Eyes setaless, not enlarged. Maxillary palp formula I-IV-III-II-V. Abdominal segments without any reticulated internal sacs; filament of sternite $\mathrm{V}$ with same length of sternite V and VI.

Male genitalia. Segment IX rounded anterad, dorsum long and flat with a middle depression line, ventrum shorter. Segment X fused to the tergum IX. The dorsoapical setose lobes (inner lobes) of segment $\mathrm{X}$ well-developed, protruded narrowing; seem bilobed, but tightly adhered. Cerci setose, high and short in lateral view, rounded subtriangular in dorsal view. Unsetose paraproct (outer lobes or lateral plates of segment X) subtriangular flat plate in lateral view with a pair of two upward directed pointed processes; in dorsal profile the lateral spine is produced, the 


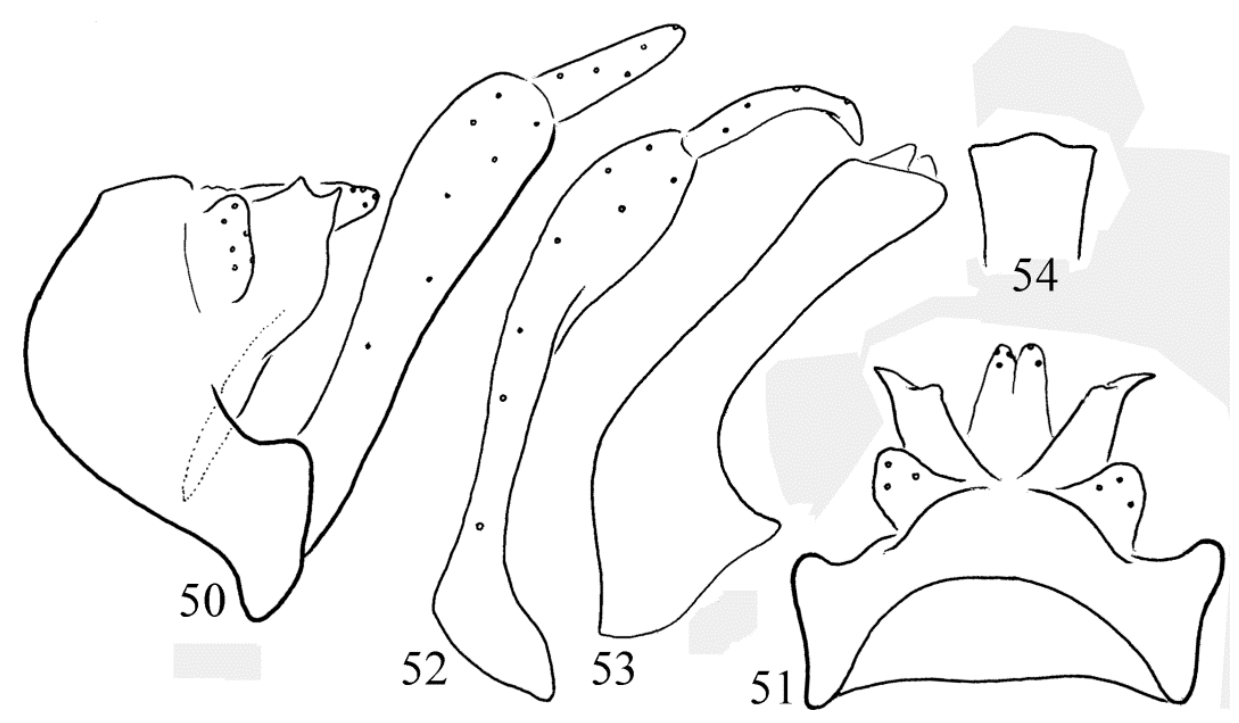

Figures 50-54. Diplectrona muktapura sp. nov. Holotype: $50=$ male genitalia in left lateral view, $51=$ male genitalia in dorsal view, 52 = left gonopod in ventral view, 53 = phallic organ in left lateral view, $54=$ phallic head in ventral view.

mesal spine less developed. Gonopods robust straight with coxopodite of dilated apical half; harpago mesad turning with sharply ventrad pointed head. Phallic apparatus with down curving and broadening basal section and with a longer tube-forming horizontal two thirds with obliquely cut apex in lateral view; two pairs of endothecal processes visible, both with blunt apices in lateral view and pointed triangular in ventral view; dorsal endothecal process bigger; phallotremal sclerite less distinct. The phallic organ without produced wing-like triangular delta-shaped head in ventral view.

Etymology. muktapura, named after the name of locus typicus of the holotype.

\section{Diplectrona mynsoa sp. nov.}

(Figures 55-58, Map 5: n 46, 69, Map 8)

Material examined. Holotype: India, Meghalaya (United Jaintia and Khasi Hills), Mynso = Mynsoo = Kyndong Tuber, $3500 \mathrm{ft}, 25^{\circ} 33^{\prime} 43.5^{\prime \prime} \mathrm{N}$ 92'19'37.5"E, 20.IV.1960, leg. F. Schmid (1 male, CNC). Paratypes: same as Holotype (5 males, CNC, 2 males, OPC; 1 male, SMNH). India, Meghaláya (United Jaintia and Khasi Hills), Nongrim [=Nongtraw], $3000 \mathrm{ft}, 25^{\circ} 22^{\prime} 09.8^{\prime \prime} \mathrm{N}$
914' $41.5^{\prime \prime E}, 28 . I I I .1960$, leg. F. Schmid (1 male, CNC).

Diagnosis. This species having dorsoapicad produced spiny structure on the paraproct belongs to the Diplectrona aurowittata new species group, and based on the somehow bipointed paraproct to the Diplectrona hasada new species complex. However, it has rather unique genital characters of the very small cerci, the subdivided head of the phallic organ. The rather long phallobase relates $D$. mynsoa sp. nov. to D. meghalaya sp. nov. of the $D$. tamdaophila species complex, but differs by the small cerci, by the dorsal elongated profile of the paraproct, by the blunt, not pointed tip of harpago as well as by the head of the phallic organ, that is the very ending of the phallotheca forms a lobe like ventrum. Such a subdivided tube-ending of the phallotheca is unique in the Diplectrona genus.

Description. Male (in alcohol). Dark brown animal. Forewings without discernible pattern. Forewing length is $8 \mathrm{~mm}$, apical fork I present on hindwing. Eyes setaless, not enlarged. Abdominal segments without any reticulated internal sacs; filaments on sternite $\mathrm{V}$ double long than the sternite. 


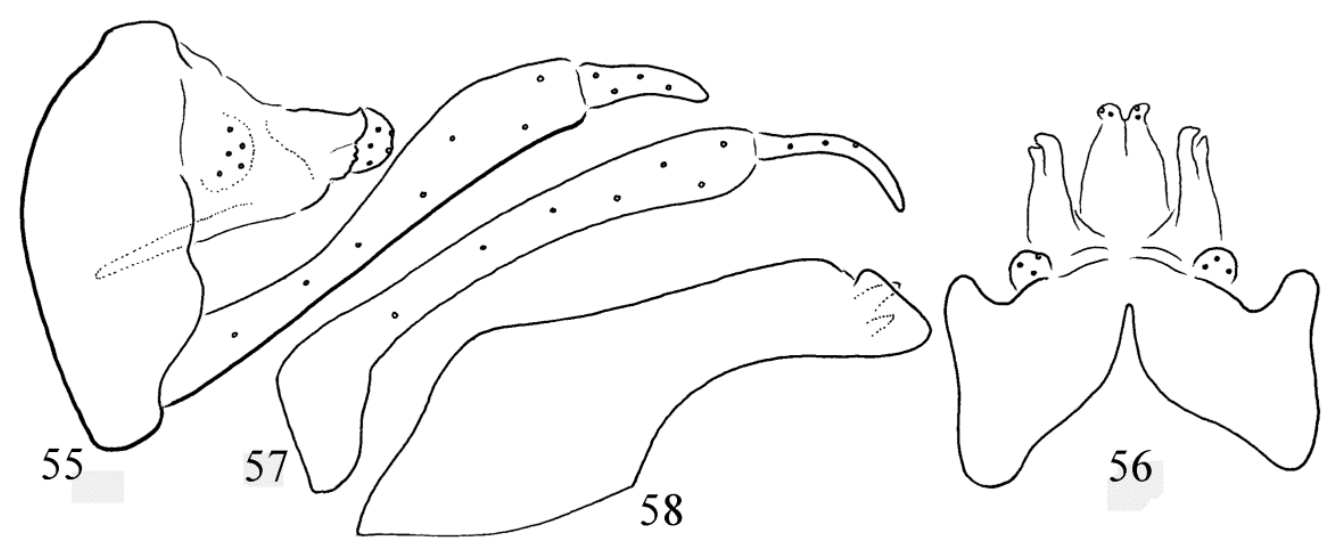

Figures 55-58. Diplectrona mynsoa sp. nov. Holotype: $55=$ male genitalia in left lateral view, $56=$ male genitalia in dorsal view, 57 = left gonopod in ventral view, 58 = phallic organ in left lateral view.

Male genitalia. Segment IX convex anterad, dorsum long and flat with a middle depression line, ventrum short. Segment $\mathrm{X}$ fused to the tergum IX. The dorsoapical setose lobes (inner lobes) of segment $\mathrm{X}$ well-developed, rounded broad protruded in lateral view; laterad directed apical pair of setose lobes in dorsal view. Cerci setose, small short semicircular both in lateral and dorsal views. Unsetose paraproct (outer lobes or lateral plates of segment $\mathrm{X}$ ) long and high plate in lateral view with upward directed pointed spine and slightly elevated middle region, elongated with laterad directed small tip in dorsal view. Gonopods elongated dilating from middle and their harpago mesad turning with blunt tip. Phallic apparatus with down curving and broadening long basal section and with a tube-forming horizontal section with unique subdivided head constituted by ventral lobes; two pairs of endothecal processes discernible, rather pointed in ventral view. In ventral view the phallotheca parallel-sided.

Etymology. mynsoa, named after the locus typicus of the holotype.

\section{Diplectrona nongina sp. nov.}

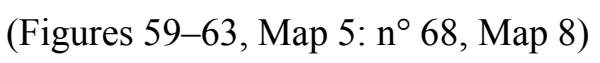

Material examined. Holotype: India, Meghalaya (United Jaintia and Khasi Hills), Nongini [=Nongjngi], $3750 \mathrm{ft}, 25^{\circ} 32^{\prime} 21.1^{\prime \prime} \mathrm{N} 92^{\circ} 16^{\prime} 12.4 " \mathrm{E}$, 19.IV.1960, leg. F. Schmid (1 male, CNC).
Diagnosis. This species belongs to the Diplectrona aurovittata species group and to the $D$. hasada species complex. Having double-spined dorsoapical region of the paraproct it is most close to $D$. jaraina sp. nov. It differs by the rounded anterior margin of segment IX, the more robust coxopodite, by the lateral shape of the paraproct.

Description. Male (in alcohol). Light brown animal. Forewings without pattern. Forewing length $8 \mathrm{~mm}$, apical fork I present on hindwing. Eyes setaless, not enlarged. Maxillary palp formula I-IV-III-II-V. Abdominal segments without any reticulated internal sacs.

Male genitalia. Segment IX rounded anterad, dorsum long and flat with a middle depression line, ventrum little longer. Segment $X$ fused to the tergum IX. The dorsoapical setose lobes (inner lobes) of segment $\mathrm{X}$ well-developed, protruded narrowing; seem bilobed, but tightly adhered. Cerci setose, high and long in lateral view, elongated subtriangular in dorsal view. Unsetose paraproct (outer lobes or lateral plates of segment X) subtriangular flat plate in lateral view with a pair of two pointed processes; in lateral profile the upper pointed tip is smaller. Gonopods robust straight with coxopodite of dilated apical half; harpago mesad turning with sharply ventrad pointed head. Phallic apparatus with down curving and broadening basal section and with a longer tubeforming horizontal two thirds with rounded obliquely cut apex in lateral view; two pairs of endothecal processes visible, both with blunt apices in 
lateral and pointed triangular in ventral view; dorsal endothecal process bigger; phallotremal sclerite less distinct. The phallic organ with produced wing-like triangular delta-shaped head in ventral view.

Etymology. nongina, coined from the name of locus typicus of the holotype.

\section{Diplectrona nongra sp. nov.}

(Figures 64-68, Map 5: n 46, Map 8)

Material examined. Holotype: India, Meghaláya (United Jaintia and Khasi Hills), Nongrim [=Nongtraw], $3000 \mathrm{ft}, 25^{\circ} 22^{\prime} 09.9^{\prime \prime} \mathrm{N} 91^{\circ} 45^{\prime} 48.2^{\prime \prime}$ E, 28.III.1960, leg. F. Schmid (1 male, CNC).

Diagnosis. This species belongs to the Diplectrona aurovittata species group and to the Diplectrona hasada species complex. It is a sibling species of Diplectrona jaraina sp. nov., but differs by the light spotted forewing; by the almost semicircular profile of the anterior margin of segment IX; by the shorter tergum of segment IX, by the wide interspine gap of the paraproct well discernible in lateral view, as well as by the lateral shape of the phallotheca and by the ventral profile of the phallothecal head having rounded lateral lobes, not triangular.

Description. Male (in alcohol). Light brown animal. Forewings with light spotted pattern. Forewing length $9 \mathrm{~mm}$, apical fork I present on hindwing. Eyes setaless not enlarged. Maxillary palp formula I-IV-III-II-V. Abdominal segments without any reticulated internal sacs.

Male genitalia. Segment IX semicircular anterad, dorsum short and flat with a middle depression line, ventrum shorter than dorsum. Segment $\mathrm{X}$ fused to the tergum IX. The dorsoapical setose lobes (inner lobes) of segment X well-developed, rounded broad, protruded; seem bilobed, but tightly adhered; the ventroapical setose area distinct. Cerci setose, high and long in lateral view, semicircular in dorsal view. Unsetose paraproct (outer lobes or lateral plates of segment X) subtriangular flat plate in lateral view with upward directed pair of pointed processes, widely excised, separated with a wide interspine gap, narrow in dorsal view. Gonopods robust straight and their harpago mesad turning with sharply pointed head. Phallic apparatus with down curving and broadening basal section and with a longer tube-forming horizontal two thirds with rounded obliquely cut

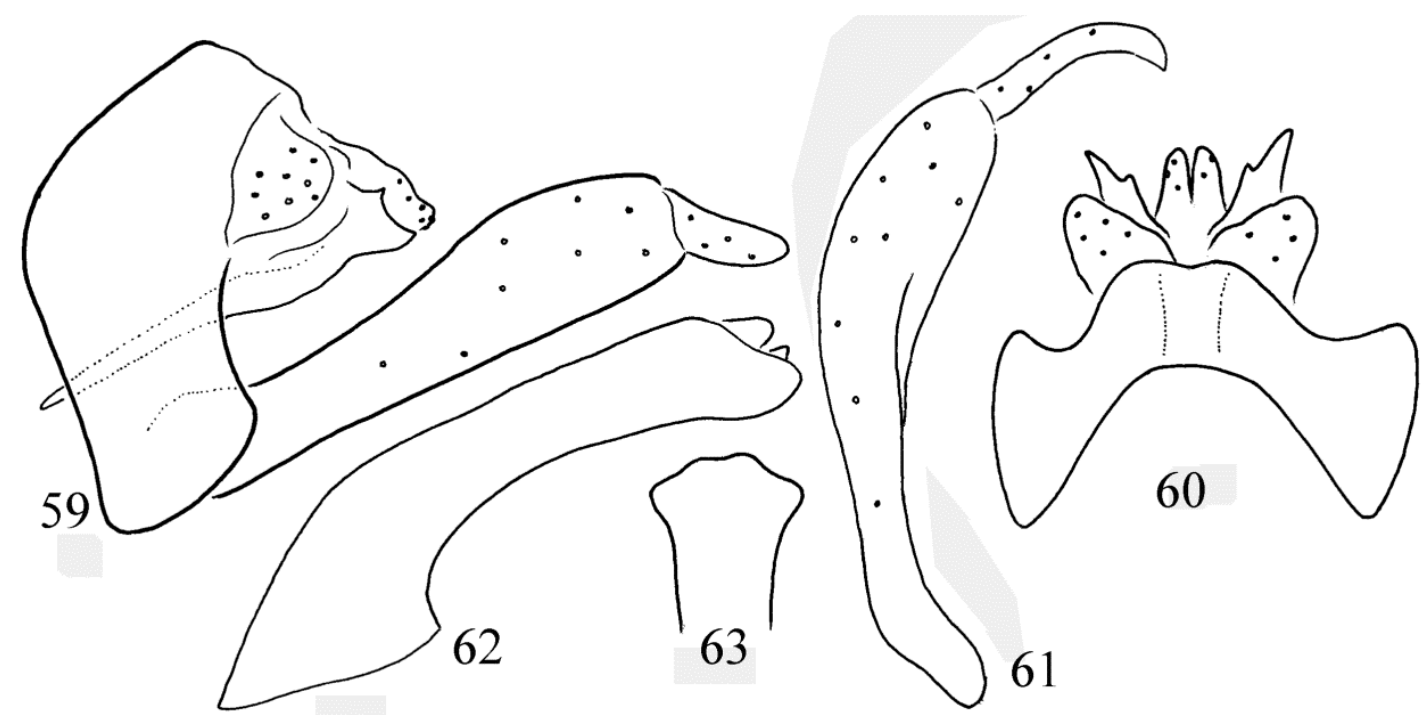

Figures 59-63. Diplectrona nongina sp. nov. Holotype: $59=$ male genitalia in left lateral view, $60=$ male genitalia in dorsal view, 61 = left gonopod in ventral view, 62 = phallic organ in left lateral view, $63=$ phallic head in ventral view. 


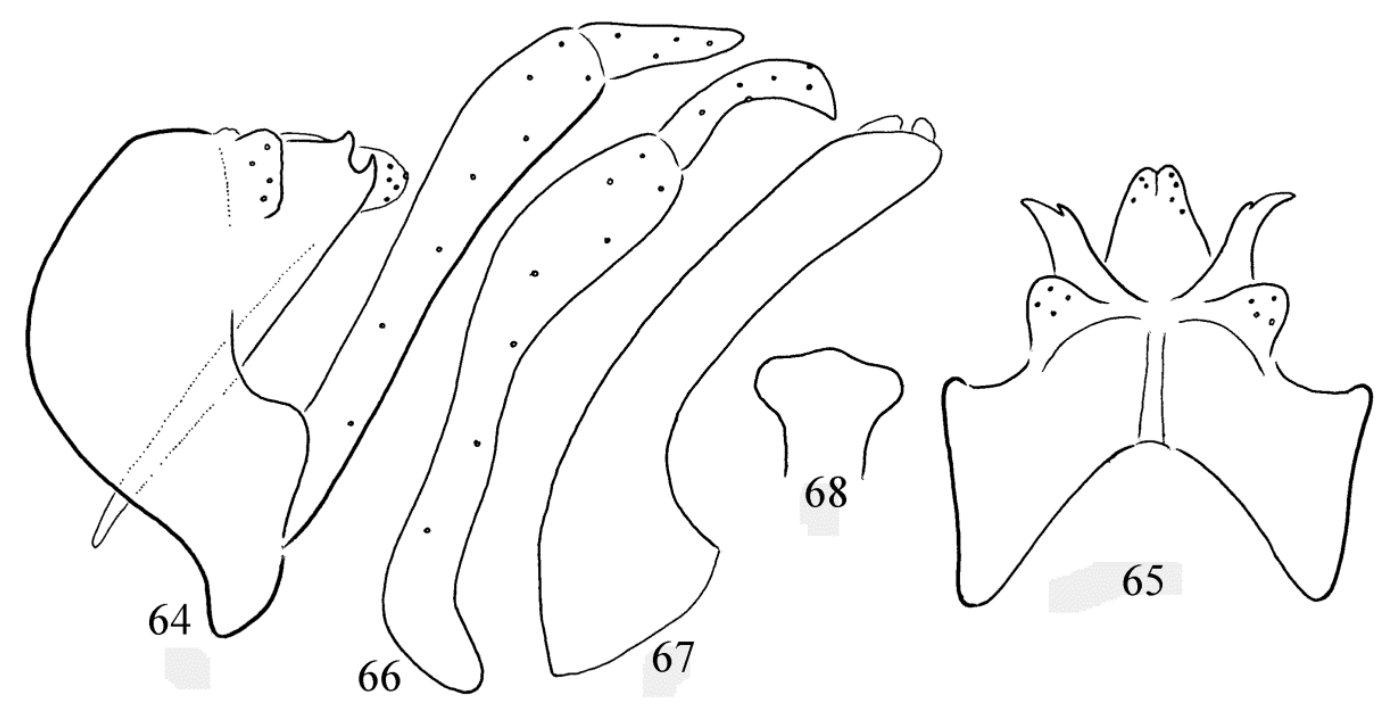

Figures 64-68. Diplectrona nongra sp. nov. Holotype: $64=$ male genitalia in left lateral view, $65=$ male genitalia in dorsal view, $66=$ left gonopod in ventral view, 67 = phallic organ in left lateral view, $68=$ phallic head in ventral view.

apex in lateral view; two pairs of endothecal processes visible, both with blunt apices in lateral and pointed triangular in ventral view; dorsal endothecal process smaller; phallotremal sclerite less distinct. The phallic organ with produced wing-like rounded lateral lobes of the head in ventral view.

Etymology. nongra, coined from the name of locus typicus of the holotype.

\section{Diplectrona nongronga sp. nov.}

(Figures 69-73, Map 5: n 73, Map 8)

Material examined. Holotype: India, Assam, United District of Mikir and North Cachar Hills, Nongjrong [=Nonjirong], $2700 \mathrm{ft}, 25^{\circ} 41^{\prime} 29.6^{\prime \prime} \mathrm{N}$ 92²8'41.3"E, 25.IV.1960, leg. F. Schmid (1 male, $\mathrm{CNC}$ ).

Diagnosis. This species belongs to the Diplectrona aurovittata species group and to the Diplectrona hasada species complex. Having doublespined or pointed dorsoapical region of the paraproct it is most close to $D$. sirkasha sp. nov. It differs by the truncated anterior of tergum IX, by the more lobe-like cerci, by the very broad ventral profile of the apical half of the gonopod, by the abbreviated mesal spine of the bispined head of the paraproct; by the inflated dorsum of the phallic head as well as by the rounded, not truncated ventral profile of the phallic head.

Description. Male (in alcohol). Light brown animal. Forewings without pattern. Forewing length $7 \mathrm{~mm}$, apical fork I present on hindwing. Eyes setaless, not enlarged. Maxillary palp formula I-IV-III-II-V. Abdominal segment VII without a pair of reticulated internal sacs; filament on sternum $\mathrm{V}$ as long as the length of segments VVI.

Male genitalia. Segment IX rounded anterad with truncated dorsum, dorsum long and flat with a middle depression line, ventrum very short. Segment $\mathrm{X}$ fused to the tergum IX. The dorsoapical setose lobes (inner lobes) of segment $X$ welldeveloped, protruded narrowing in dorsal view; seem bilobed, but tightly adhered. Cerci setose rather lobe-like, not just a setose surface both in dorsal and lateral views. Unsetose paraproct (outer lobes or lateral plates of segment $\mathrm{X}$ ) with wide and shallow apical excision; the mesal pointed processes smaller. Gonopods straight with coxopodite of dilated apical half with very broad ventral profile; harpago mesad turning with narrower subapical-apical region. Phallic apparatus with down curving and broadening basal section and 


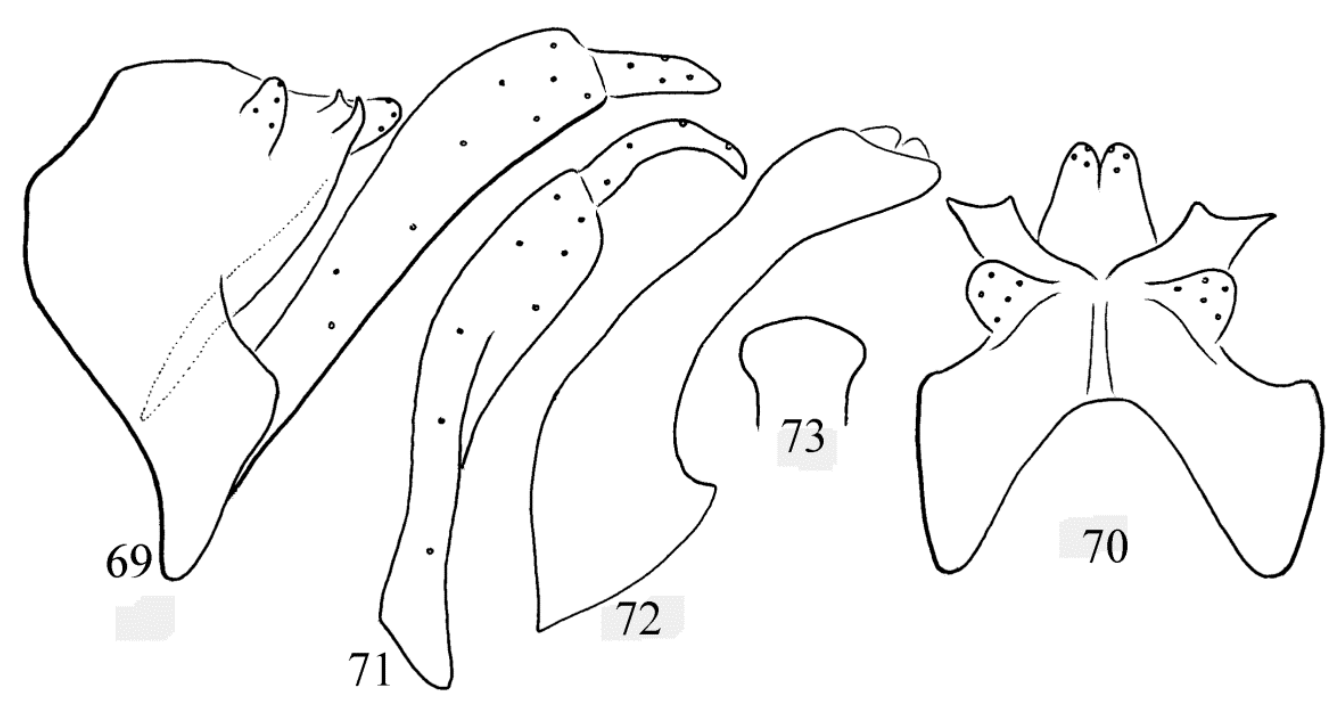

Figures 69-73. Diplectrona nongronga sp. nov. Holotype: $69=$ male genitalia in left lateral view, $70=$ male genitalia in dorsal view, $71=$ left gonopod in ventral view, $72=$ phallic organ in left lateral view, $73=$ phallic head in ventral view.

with a longer tube-forming horizontal two thirds with broadened apex in lateral view; two pairs of endothecal processes visible, both with blunt apices in lateral and pointed triangular in ventral view; dorsal endothecal process bigger; phallotremal sclerite less distinct. The phallic organ with rounded and dilated head in ventral view.

Etymology. nongronga, coined from the name of locus typicus of the holotype.

\section{Diplectrona sirkasha sp. nov.}

(Figures 74-78, Map 6: n 14, Map 9)

Material examined. Holotype: India, Manipur, Sirohi Kashong $[=$ Siruhi Kashong $=$ Shirui Kashong (peak)], 7000-7500 ft, $25^{\circ} 06^{\prime} 44.5^{\prime \prime} \mathrm{N} 94^{\circ} 27^{\prime}$ 35.4"E, 6.-7.VI. 1960, leg. F. Schmid (1 male, CNC). Paratype: India, Meghaláya (United Jaintia and Khasi Hills), Nongrim [=Nongtraw], $3000 \mathrm{ft}$, $25^{\circ} 22^{\prime} 09.9^{\prime \prime} \mathrm{N} 91^{\circ} 45^{\prime} 48.2^{\prime \prime} \mathrm{E}, 28 . I I I .1960$, leg. F. Schmid (1 male, OPC).

Diagnosis. This species belongs to the Diplectrona aurovittata species group and to the $D$. hasada species complex. Having double-spined or pointed dorsoapical region of the paraproct it is most close to $D$. jaraina sp. nov. It differs by the smaller cerci, the wider apical excision with equal pointed mesal and lateral pointed processes on the dorsal profile of the paraproct head as well as by the truncated phallic head in ventral view, not convex with small mesal excision on the apical margin.

Description. Male (in alcohol). Light brown animal. Forewings without pattern. Forewing length $8 \mathrm{~mm}$, apical fork I present on hindwing. Eyes setaless, not enlarged. Maxillary palp formula I-IV-III-II-V. Abdominal segment VII without a pair of reticulated internal sacs; filament on sternum V short.

Male genitalia. Segment IX rounded anterad, dorsum medium long and flat with a middle depression line, ventrum short. Segment $\mathrm{X}$ fused to the tergum IX. The dorsoapical setose lobes (inner lobes) of segment $\mathrm{X}$ well-developed protruded narrowing in dorsal view; seem bilobed, but tightly adhered. Cerci setose rather lobe-like, not just a setose surface both in dorsal and lateral views. Unsetose paraproct (outer lobes or lateral plates of segment $\mathrm{X}$ ) with wide and deep apical excision; the mesal and lateral pointed processes similar, almost equal. Gonopods straight with coxopodite of dilated apical half; harpago sharply mesad turning with ventrad pointed head. Phallic apparatus with down curving and broadening basal section and with a longer tube-forming 


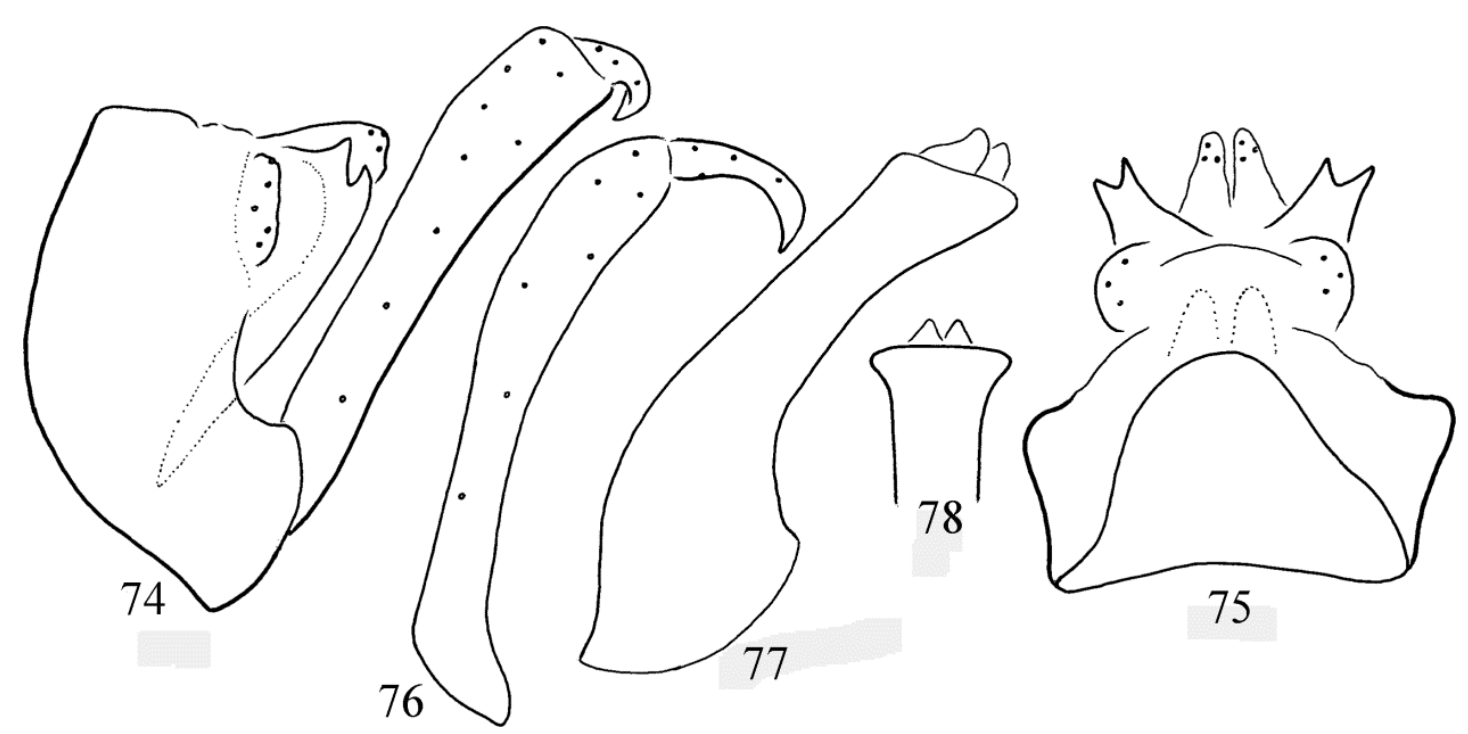

Figures 74-78. Diplectrona sirkasha sp. nov. Holotype: $74=$ male genitalia in left lateral view, $75=$ male genitalia in dorsal view, $76=$ left gonopod in ventral view, $77=$ phallic organ in left lateral view, $78=$ phallic head in ventral view.

horizontal two thirds with obliquely cut apex in lateral view; two pairs of endothecal processes visible, both with blunt apices in lateral and pointed triangular in ventral view; dorsal endothecal process bigger; phallotremal sclerite less distinct. The phallic organ with truncated and dilated head in ventral view.

Etymology. sirkasha, coined from the name of locus typicus of the holotype.

Remarks. The single paratype from Meghaláya has some divergences from the holotype of $D$. sirkasha sp. nov. from Manipur. The phallotheca of the paratype has discernibly more slender middle region on the phallotheca and the harpago is less hooked subapicad. However, these small divergences could be in the range of variabilities. More specimens are required to establish stability of the divergences in order to confirm real species level divergences.

\section{Diplectrona sironga sp. nov.}

(Figures 79-83, Map 6: n 14, Map 9)

Material examined. Holotype: India, Manipur, Sirohi Kashong $[=$ Siruhi Kashong, =Shirui Kashong (peak)], 7000-7500 ft, $25^{\circ} 06^{\prime} 44.5^{\prime \prime} \mathrm{N} 94^{\circ}$
27'35.4"E, 6-7.VI.1960, leg. F. Schmid (1 male, CNC).

Diagnosis. This species belongs to the Diplectrona aurovittata species group and to the $D$. hasada species complex. Having double-spined or pointed dorsoapical region of the paraproct with shallow excision it is most close to D. chingsa $\mathrm{sp}$. nov. It differs by the presence of a pair of reticulated sacs in abdominal segment VII, by the shorter ventrum of segment IX, the slender, not robust coxopodite, the small cerci, and the lateral and dorsal shape of the paraproct as well as by the ventral profile of the phallus head.

Description. Male (in alcohol). Light brown animal. Forewings without pattern. Forewing length $9 \mathrm{~mm}$, apical fork I present on hindwing. Eyes setaless, not enlarged. Maxillary palp formula I-IV-III-II-V. Abdominal sternum V with a short filament and segment VII with a pair of reticulated internal sacs.

Male genitalia. Segment IX rounded anterad, dorsum medium long and flat with a middle depression line, ventrum short. Segment X fused to the tergum IX. The dorsoapical setose lobes (inner lobes) of segment X well-developed, protruded narrowing in dorsal view; seem bilobed, 


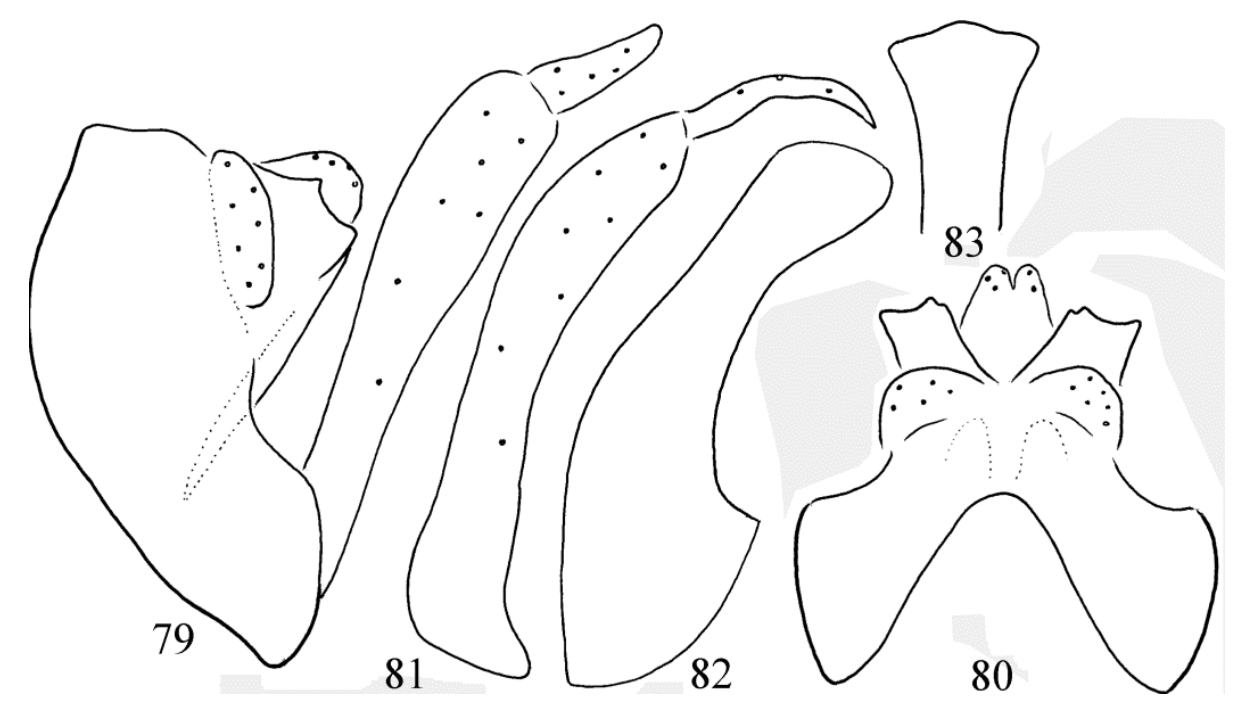

Figures 79-83. Diplectrona sironga sp. nov. Holotype: $79=$ male genitalia in left lateral view, $80=$ male genitalia in dorsal view, 81 = left gonopod in ventral view, 82 = phallic organ in left lateral view, 83 = phallic head in ventral view.

but tightly adhered. Cerci setose rather lobe-like, and high in lateral view. Unsetose paraproct (outer lobes or lateral plates of segment X) subtriangular and truncated flat plate with shallow excision in lateral view and subquadrangular with shallow excision in dorsal view; the mesal pointed corner slightly bilobed. Gonopods slender straight with coxopodite of dilating apical half; harpago very slender and mesad turning with sharply ventrad pointed head. Phallic apparatus with down curving and broadening basal section and with a longer tube-forming horizontal two thirds with rounded obliquely cut apex in lateral view; two pairs of endothecal processes visible, both with blunt apices in lateral and pointed triangular in ventral view; dorsal endothecal process bigger; phallotremal sclerite less distinct. The phallic organ with slightly trilobed convex head in ventral view.

Etymology. sironga, coined from the name of locus typicus of the holotype.

\section{Diplectrona sumatrana sp. nov.}

(Map 9)

Diplectrona hermione Malicky \& Chantaramongkol, in Malicky, 2002:1210. Misidentification.

Material. Syntypes: Malicky 2002: 1210, Indonesia, Sumatra, $15 \hat{\jmath} \widehat{\jmath}$ von 7 Orten, in Aceh und Nord-Sumatra, leg. Diehl, Sivec, Malicky, Tarmann, (15 males, one drawn male genitalia, MPC). Paratype: Indonesia, Sumatra, Danau Ranau, Bukit Barisan Selatan NP, 950m, 30.VI. 2009, leg. Z. Ecsedi (1 male, OPC).

Diagnosis. This species having dorsoapicad produced spiny structure on the paraproct belongs to the Diplectrona aurowittata new species group and supplied with double pointed spines belongs to the Diplectrona hasada new species complex. Has resemblance to Diplectrona kualagomba sp. nov. described from Malaysia, but differs by the differently shaped dorsal and lateral profiles of the paraproct as well as by the lateral profile of the phallic organ and the ventral profile of the shallowly excised phallic head.

Description. Male (Figures: Malicky, 2002: Table 15: hermione, Sipirok).

Male genitalia. Segment IX convex anterad, dorsum long and convex with a middle depression line, ventrum short. Segment $\mathrm{X}$ fused to the tergum IX. The dorsoapical setose lobes (inner lobes) of segment $\mathrm{X}$ well-developed, protruded and narrowing apicad, broad-based; seem bilobed, but tightly adhered basally, slightly shorter than paraproct. Cerci setose, high and short in lateral view, semi-circular in dorsal view. Unsetose para- 
proct (outer lobes or lateral plates of segment X) elongated subquadrangular plate with two minute blunt spines in lateral view elongated in dorsal view. Gonopods dilated apicad and their harpago mesad turning and narrowing. Phallic apparatus with head of shallowly concave, excised apical margin in ventral view.

Etymology. sumatrana, named after the locus typicus of the syntype.

\section{Diplectrona tairenpokpa sp. nov.}

(Figures 84-88, Map 6: $\mathrm{n}^{\circ}$ 10, Map 9)

Material examined. Holotype: India, Manipur, Tairenpokpi, $4000 \mathrm{ft} ., 2^{\circ} 49^{\prime} 36.7^{\prime \prime} \mathrm{N}$ 9348'14.6" E, 31.V.1960, leg F. Schmid (1 male, OPC).

Diagnosis. This species belongs to the Diplectrona aurovittata species group and to the $H$. hasada species complex. Having double-spined and pointed dorsoapical region of the paraproct it is most close to and a sibling species of $D$. chingsa sp. nov. It differs by the more produced cerci, broader dorsoapical setose lobe in lateral view, by the narrow dorsal profile of the paraproct as well as by the high phallobase, slimmer phallothecal shaft and the straight truncated apical end of the phallotheca in ventral view.

Description. Male (in alcohol). Light brown animal. Forewings without pattern. Forewing length $8 \mathrm{~mm}$, apical fork I present on hindwing. Eyes setaless, not enlarged. Maxillary palp formula I-IV-III-II-V. There is a short filament discernible on segment V. Abdominal segment VII with a pair of reticulated internal sacs.

Male genitalia. Segment IX rounded anterad, dorsum medium long and flat with a middle depression line, ventrum shorter. Segment $X$ fused to the tergum IX. The dorsoapical setose lobes (inner lobes) of segment X well-developed, protruded, broad in lateral view; seem bilobed, but tightly adhered. Cerci setose rather lobe-like, not just a setose surface both in dorsal and lateral views. Unsetose paraproct (outer lobes or lateral plates of segment X) subtriangular flat plate in lateral view with a pair of two blunt pointed processes as visible both in lateral and dorsal profiles. Gonopods slender straight with coxopodite of dilated apical half; harpago mesad turning with sharply ventrad pointed head. Phallic apparatus with down curving and broadening high basal section and with a longer tube-forming horizontal two thirds with rounded obliquely cut apex in lateral view; two pairs of endothecal processes visible, both with blunt apices in lateral and pointed triangular in ventral view; dorsal endothecal process bigger; phallotremal sclerite less distinct. The phallic organ with slightly convex and dilated head in ventral view.

Etymology. tairenpokpa, named after the locus typicus of the holotype.

\section{Diplectrona tungpa sp. nov.}

(Map 9)

Diplectrona burha Schmid, 1961: Malicky 2002:12051206. Misidentification.

Material. Syntypes: Malicky 2002: 1206, Taiwan, $11 \hat{\delta} \widehat{\delta}$ von 9 Fundorten aus den Provinzen Taipei, Taitung, Ilan, Tainan, Taichung und Nantou, CM und USNM., (one drawn specimen, MPC).

Diagnosis. This species having dorsoapicad produced spiny structure on the paraproct belongs to the Diplectrona aurowittata new species group, and supplied with double pointed spines belongs to the Diplectrona hasada new species complex. Has resemblance to Diplectrona kallisto Malicky, 2002 described from Malaysia, Sabah, but differs by the blunt, not pointed apex of harpago; by both the lateral and dorsal profiles of the paraproct; as well as by the lateral profile of the phallic organ and by the ventral profile of the phallic head.

Description. Male (Figures: Malicky 2002: Table 14: burha, Tungpu).

Male genitalia. Segment IX convex anterad, dorsum long and convex with a middle depression line, ventrum long. Segment $\mathrm{X}$ fused to the tergum IX. The dorsoapical setose lobes (inner lobes) of segment X well-developed, protruded 


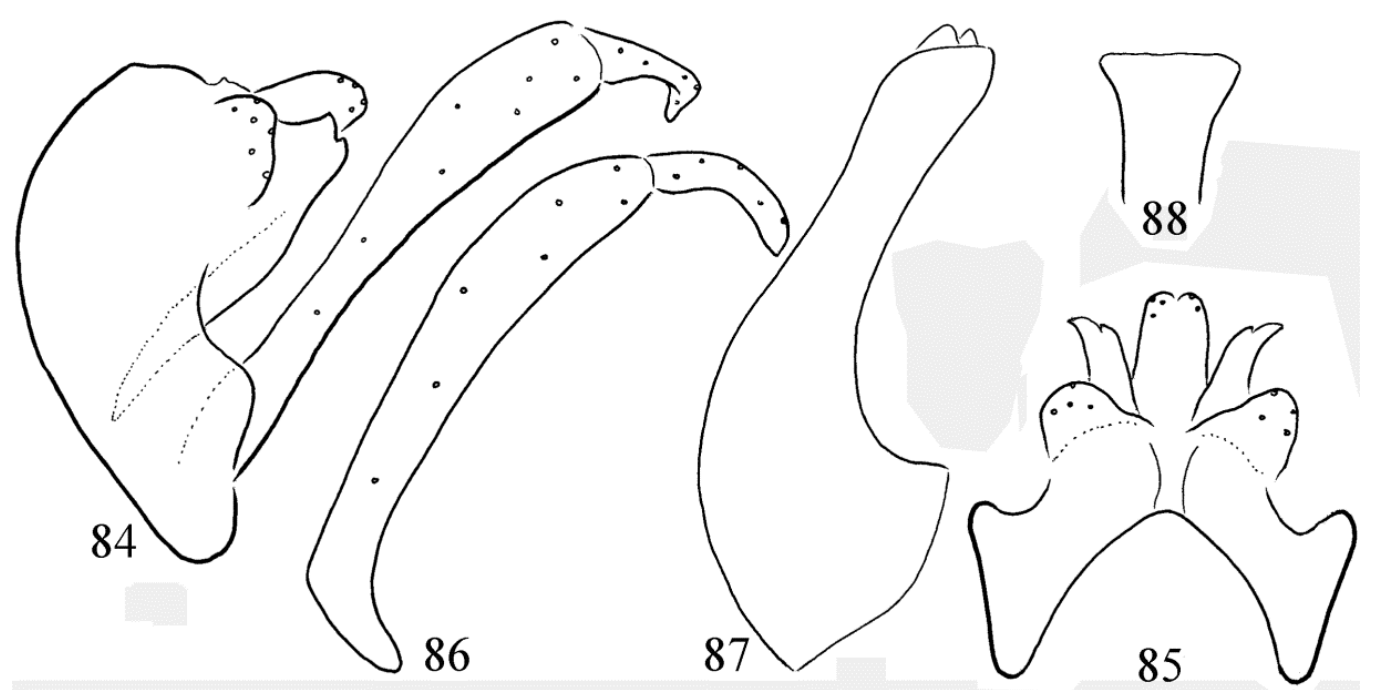

Figures 84-88. Diplectrona tairenpokpa sp. nov. Holotype: $84=$ male genitalia in left lateral view, $85=$ male genitalia in dorsal view, $86=$ left gonopod in ventral view, $87=$ phallic organ in left lateral view, $88=$ phallic head in ventral view.

and narrowing apicad, broad in lateral view; seem bilobed, but tightly adhered, longer than paraproct. Cerci setose, high and short in lateral view, semi-circular in dorsal view. Unsetose paraproct (outer lobes or lateral plates of segment X) upward directed plate with two spines visible both in lateral and dorsal views. Gonopods slender and their harpago mesad turning with blunt apices. Phallic apparatus with rounded, concave head in ventral view.

Etymology. tungpa, named after the locus typicus of the syntype.

\section{Diplectrona tamdaophila new species complex}

Diplectrona tamdaophila new species complex having paraproct (lateral plate of segment X) of a pair of mostly setaless plate-like structure with single pointed spine-like processes in various forms and usually produced in apicodorsal position.

\section{Diplectrona aisahka sp. nov.}

(Figures 89-93, Map 10)

Material examined. Holotype: India, Meghaláya (United Jaintia and Khasi Hills), Khasi Hills (Assam, Khasia Hills) McLachlan Coll. B. M.
1938-674 (1 male, BMNH). Paratypes: same as holotype (1 male, BMNH).

Diagnosis. This species having dorsoapicad produced spiny structure on the paraproct belongs to the Diplectrona aurowittata new species group, and to the Diplectrona tamdaophila new species complex. Most close to the D. khasiaca sp. nov., but differs by the very dilated apical half of the coxopodite; by the dorsal profile of the dorsoapical setose lobes, that is narrowing apicad, not capitate; by the diverged lateral profile of the phallic organ; it is more robust; the phallobase is curving, not subquadratic; the dorsum of the phallotheca gradually curving downward, not straight; the ventral profile of the phallic head is produced laterad rounded, not straight.

Description. Male (in alcohol). Dark brown animal. Forewings without discernible pattern. Forewing length is $8 \mathrm{~mm}$, apical fork I present on hindwing. Eyes setaless, not enlarged. Maxillary palp formula I-III-IV-II-V. Abdominal segments without any reticulated internal sacs; filaments on sternite $\mathrm{V}$ double longer than the sternite.

Male genitalia. Segment IX convex anterad, dorsum long and convex with a middle depression line, ventrum shorter. Segment X fused to the tergum IX. The dorsoapical setose lobes (inner 


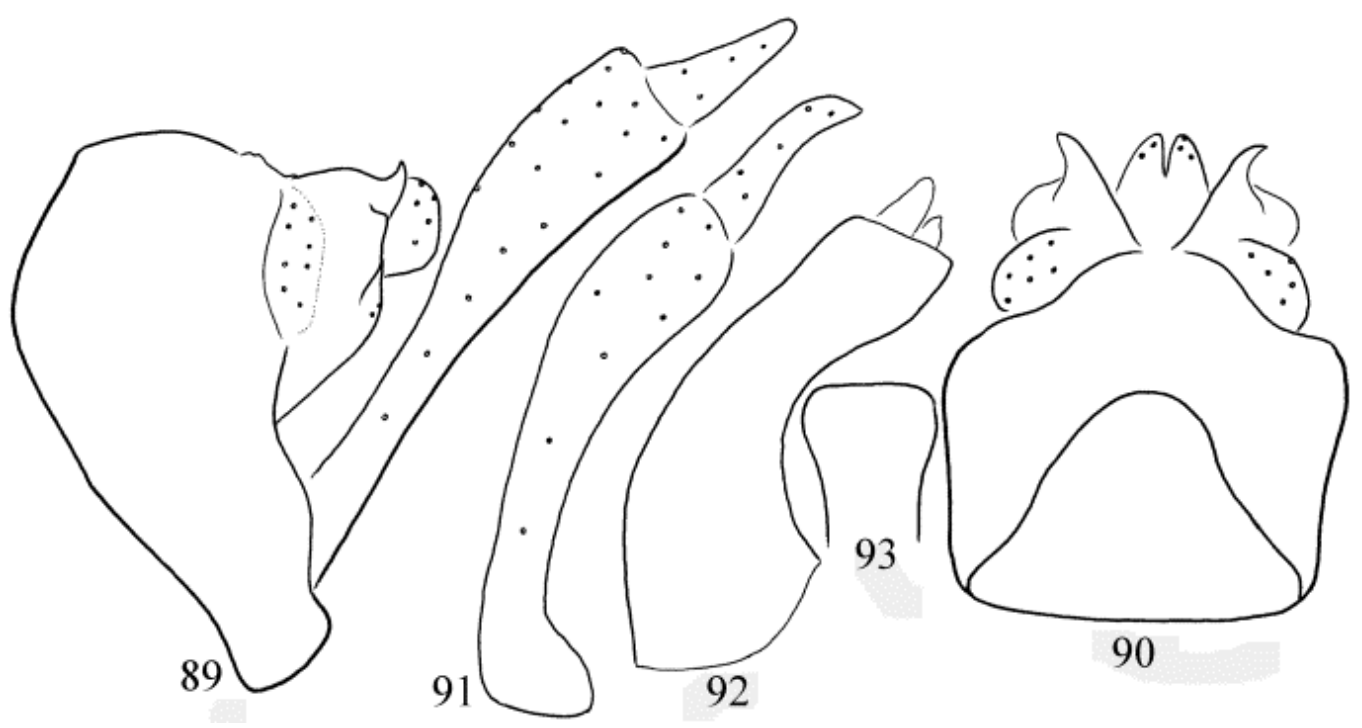

Figures 89-93. Diplectrona aisahka sp. nov. Holotype: $89=$ male genitalia in left lateral view, $90=$ male genitalia in dorsal view, 91 = left gonopod in ventral view, 92 = phallic organ in left lateral view, 93 = phallic head in ventral view.

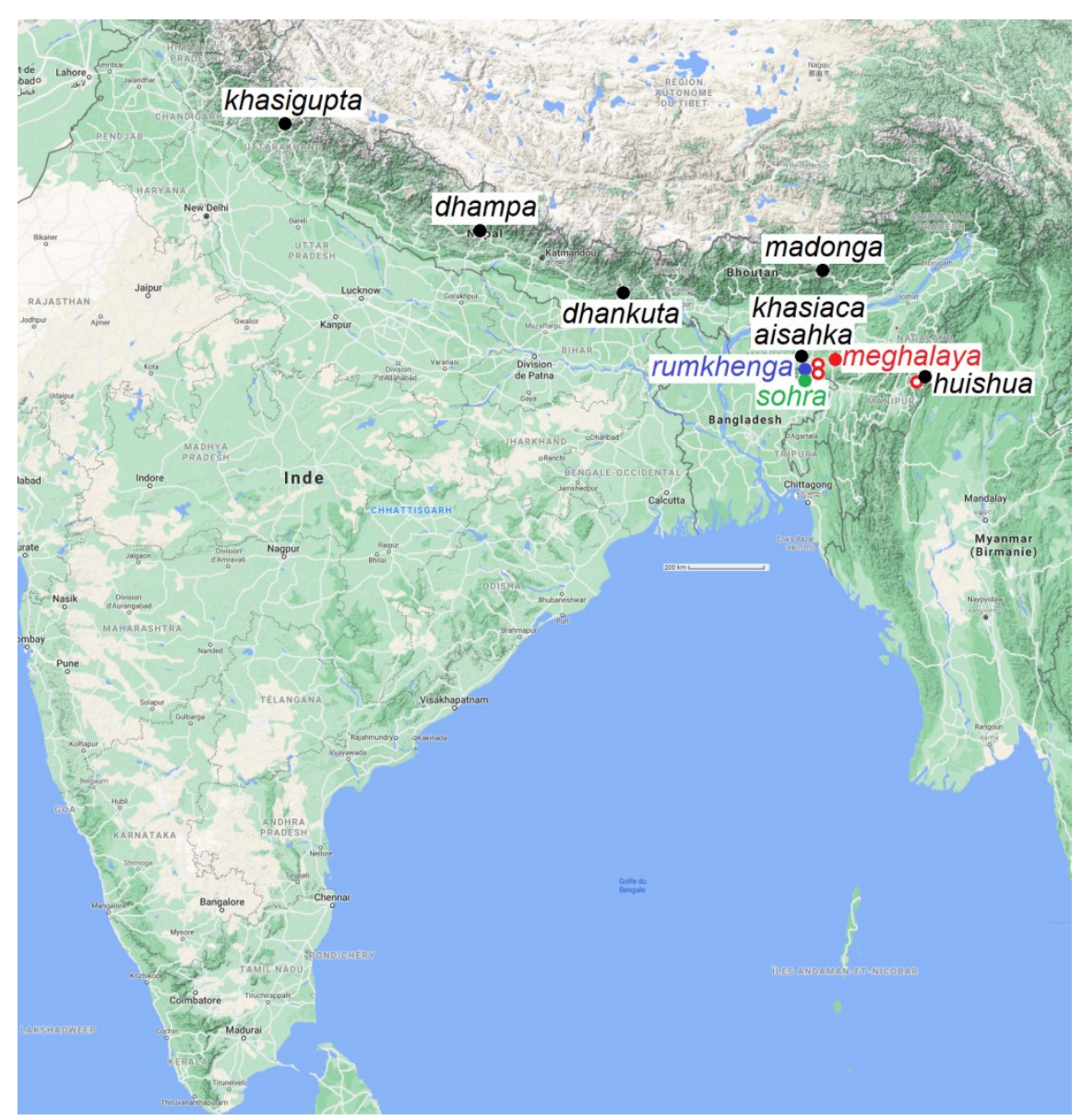

Map 10. Diplectrona tamdaophila complex with only India and Nepal. 
lobes) of segment X well-developed, protruded and narrowing apicad; seem bilobed, but tightly adhered. Cerci setose, high and short in lateral view, semi-circular in dorsal view. Unsetose paraproct (outer lobes or lateral plates of segment X) short and high plate in lateral view with upward directed pointed spine with laterad turning tip. Gonopods very dilated apicad and their harpago mesad turning with ventrad pointed tip. Phallic apparatus very robust with down curving and broadening curving basal section and with a tubeforming horizontal section with downward directed apex in lateral view; one pair of endothecal processes discernible, with blunt apices in lateral and pointed triangular in ventral view; phallotremal sclerite less distinct. In ventral view the head of phallotheca produced rounded laterad.

Etymology. aisahka, coined from the name of the locus typicus of the holotype.

\section{Diplectrona beluma sp. nov.}

(Map 11)

Diplectrona aurovittata Ulmer, 1906: Malicky 2002: 1205. Misidentification.

Material. Syntypes: Malaysia, Hulu, Perak, Belum Expedition, base camp 250m, according to its elevation this locality should placed near this point: $4^{\circ} 37^{\prime} 35.3^{\prime \prime} \mathrm{N} \mathrm{101^{ \circ } 0 9 ^ { \prime } 3 7 . 6 " \mathrm { E } , 2 1 . I I I . - 1 4 . I V .}$ 1994, leg. Sivec, CM: $3{ }^{\widehat{\jmath}}$; do. Sungai Enam, subcamp, 5॰30'57.5"N 101²7'56.2"E, 11.-12.IV. 1994 leg. Sivec, CM: 20ึ đ).

Diagnosis. This species having dorsoapicad produced spiny structure on the paraproct belongs to the Diplectrona aurowittata new species group, and supplied only with a single pointed spine belongs to the Diplectrona tamdaophila new species complex. The additional pairs of small spinules on both plates of the paraproct visible in dorsal view differentiate this species from all the others in the complex.

Description. Male (Figures: Malicky 2002: Table 10: aurovittata, Belum). Eyes setaless, not enlarged. Abdominal segments without any reti- culated internal sacs; filaments on sternite V present.

Male genitalia. Segment IX convex anterad, dorsum long and convex with a middle depression line, ventrum shorter. Segment $X$ fused to the tergum IX. The dorsoapical setose lobes (inner lobes) of segment $\mathrm{X}$ well-developed, protruded and narrowing apicad, broad in lateral view; seem bilobed, but tightly adhered. Cerci setose, high and short in lateral view, semi-circular in dorsal view. Unsetose paraproct (outer lobes or lateral plates of segment $\mathrm{X}$ ) subquadrangular plate with dorsoapical elongated spine in lateral view with additional pair of small spines in dorsal view. Gonopods dilated apicad and their harpago mesad turning and narrowing. Phallic apparatus with head of concave apical margin in ventral view.

Etymology. beluma, named after the locus typicus of the syntypes.

\section{Diplectrona dhampa sp. nov.}

(Map 10)

Diplectrona sanguana Kimmins, 1964: Malicky 2002: 1215-1216. Misidentification.

Material. Holotype: Nepal, Phedi, Nebenbäche bei Dhampus Mailee Hotel, 1200m, according to its elevation, this locality should be placed near this point: $28^{\circ} 18^{\prime} 59.4^{\prime \prime} \mathrm{N} 83^{\circ} 51^{\prime} 27.8^{\prime \prime}$ E. 21. IV.1995, leg. H. Malicky, (1 male, drawn specimen, MPC).

Diagnosis. This species having dorsoapicad produced spiny structure on the paraproct belongs to the Diplectrona aurowittata new species group, and supplied only with a single pointed spine belongs to the Diplectrona tamdaophila new species complex. This species has resemblance to Diplectrona dhankuta sp. nov., but differs both by the dorsal and lateral profiles of the paraproct; by the lateral profile of the phallotheca as well as by the ventral profile of the phallic head.

Description. Male (Figures: Malicky, 2002: Table 11: sanguana, Dhampus Mailee). Eyes setaless, not enlarged. Abdominal segments with reti- 


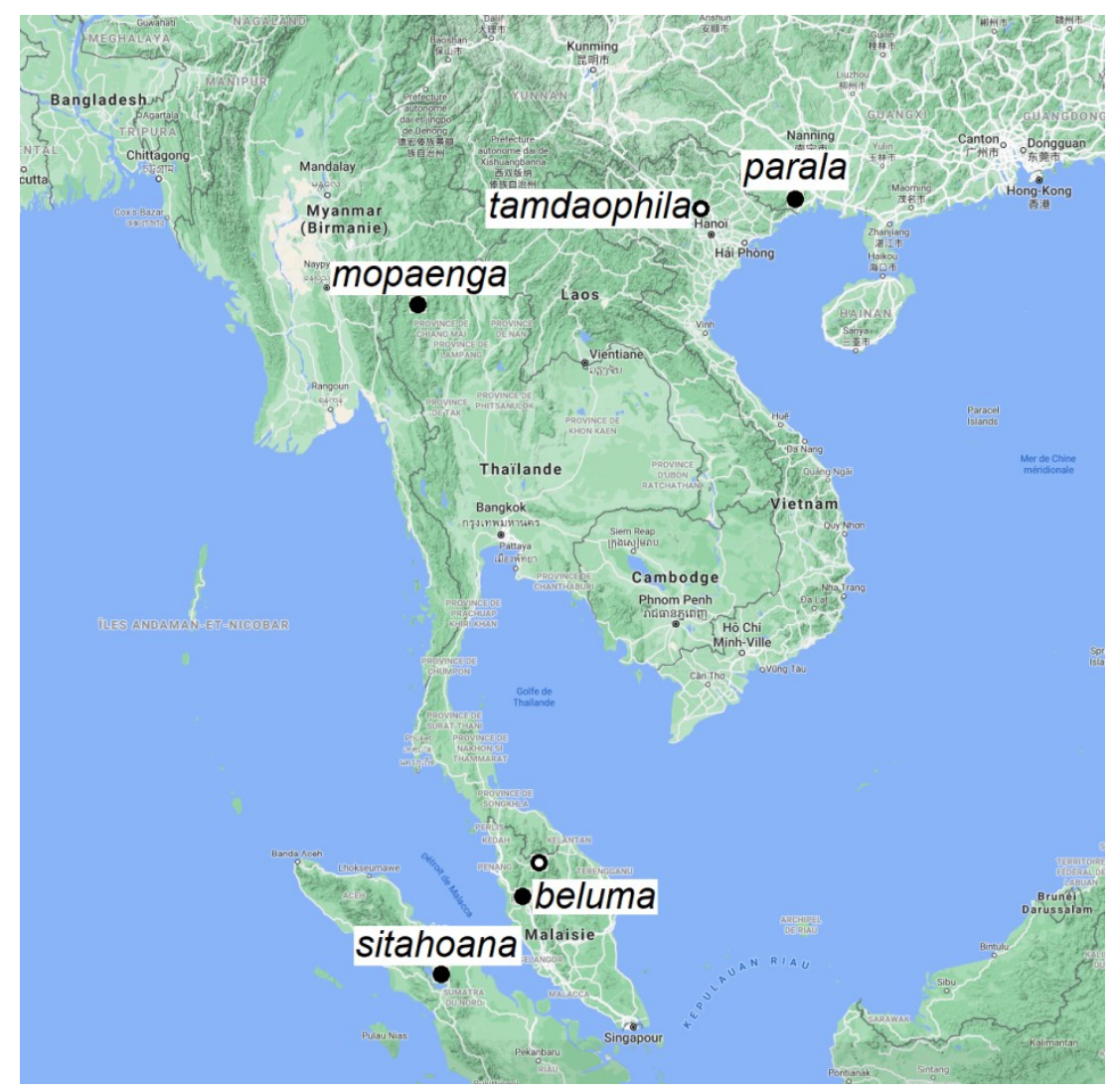

Map 11. Diplectrona tamdaophila complex outside India and Nepal.

culated internal sacs; filaments on sternite V present.

Male genitalia. Segment IX convex anterad, dorsum long and convex with a middle depression line, ventrum shorter. Segment $\mathrm{X}$ fused to the tergum IX. The dorsoapical setose lobes (inner lobes) of segment $\mathrm{X}$ well-developed, protruded and narrowing apicad, broad in lateral view; seem bilobed, but tightly adhered and longer than paraproct. Cerci setose, high and short in lateral view, semi-circular in dorsal view. Unsetose paraproct (outer lobes or lateral plates of segment X) subquadrangular plate with dorsoapical elongated spine in lateral view. Gonopods dilated apicad and their harpago mesad turning with ventroapical pointed tiny process. Phallic apparatus with high phallobase and the phallic head with rounded laterad expanding apical margin in ventral view.

Etymology. dhampa, named after the locus typicus of the holotype.
Diplectrona dhankuta sp. nov.

(Map 10)

Diplectrona sanguana Kimmins, 1964: Malicky 2002: 1215-1216: "Nepal, Dhan Kuta [=Dhankuta], 1500 $\mathrm{m}$, according to its elevation, this locality should be placed near this point: $27^{\circ} 00^{\prime} 29.7^{\prime \prime} \mathrm{N} 87^{\circ} 18^{\prime} 35.4^{\prime \prime} \mathrm{E}$, 30.VI.1991, leg Allen CM: 1ठ, (1 male, CM). Misidentification!

Material. Holotype: Nepal, Dhan Kuta, 1500 m, 30.VI.1991, leg Allen CM: 1ð, (1 male, drawn specimen, MPC).

Diagnosis. This species having dorsoapicad produced spiny structure on the paraproct belongs to the Diplectrona aurowittata new species group, and supplied only with a single pointed spine belongs to the Diplectrona tamdaophila new species complex. This species has resemblance to Diplectrona dhampa sp. nov., but differs both by the 
dorsal and lateral profiles of the paraproct; by the lateral profile of the phallotheca as well as by the ventral profile of the phallic head.

Description. Male (Figures: Malicky 2002: Table 11: sanguana, Dhan Kuta). Eyes setaless, not enlarged. Abdominal segments with reticulated internal sacs; filaments on sternite $\mathrm{V}$ present.

Male genitalia. Segment IX convex anterad, dorsum long and convex with a middle depression line, ventrum little shorter. Segment $\mathrm{X}$ fused to the tergum IX. The dorsoapical setose lobes (inner lobes) of segment $\mathrm{X}$ well-developed, protruded and narrowing apicad, broad in lateral view; seem bilobed, but tightly adhered and longer than paraproct. Cerci setose, high and short in lateral view, semi-circular in dorsal view. Unsetose paraproct (outer lobes or lateral plates of segment X) short subquadrangular plate with dorsoapical elongated spine in lateral view. Gonopods dilated apicad and their harpago mesad turning with ventroapical pointed tiny process. Phallic apparatus with high phallobase and the phallic head with truncated laterad expanding apical margin in ventral view.

Etymology. dhankuta, named after the locus typicus of the holotype.

\section{Diplectrona huishua sp. nov.}

(Figures 94-98, Map 6: $\mathrm{n}^{\circ}$ 34, Map 10)

Material examined. Holotype: India, Manipur, Huiahu, = Huiau in Aubert 1967; according to Lonsdale (2020), this locality corresponds to Huishu, 2514'47"N, 94³3'10"E, 5000 ft. 2.VII. 1960, leg. F. Schmid (1 male, CNC). Paratypes: same as holotype (1 male, OPC).

Diagnosis. This species having dorsoapicad produced spiny structure on the paraproct belongs to the Diplectrona aurowittata new species group, and to the Diplectrona tamdaophila new species complex. It has the character combination of small setaless eyes; without any internal sacs in abdominal segments; anterodorsal filament on sternite V as long as sternite V, VI and VII together, presence of fork I on hindwing; elongated and high rounded lobes of segment X; short cerci; almost parallel-sided harpago with short broad base. Most close to the D. tamdaophila species described from nearby Vietnam but differs by the dorsal pattern of the paraproct.

Description. Male (in alcohol). Dark brown animal. Forewings without discernible pattern. Forewing length $9 \mathrm{~mm}$, apical fork I present on hindwing. Eyes setaless, not enlarged. Maxillary palp formula I-(III, IV)-II-V. Abdominal segments without any reticulated internal sacs; filaments on sternite $\mathrm{V}$ almost triple longer than the sternite.

Male genitalia. Segment IX convex anterad, dorsum long and convex with a middle depression line, ventrum short. Segment X fused to the tergum IX. The dorsoapical setose lobes (inner lobes) of segment $\mathrm{X}$ well-developed, much longer than paraproct which is rounded broad protruded in lateral view; seems bilobed, but tightly adhered and slender in dorsal view. Cerci setose, high and short in lateral view, elongated in dorsal view. Unsetose paraproct (outer lobes or lateral plates of segment X) short and high plate in lateral view with upward directed pointed spine with laterad turning tip; subquadrangular basement in dorsal view. Gonopods robust straight and their harpago mesad turning with short broad base. Phallic apparatus with down curving and broadening basal section and with a tube-forming horizontal section with downward directed apex in lateral view; one pair of endothecal processes discernible, with blunt apices in lateral and pointed triangular in ventral view; phallotremal sclerite less distinct. In ventral view the phallotheca with rounded slightly broadening apex.

Etymology. huishua, named after the locus typicus of the holotype.

\section{Diplectrona khasiaca sp. nov.}

(Figures 99-103, Map 10)

Material examined. Holotype: India, Meghaláya (United Jaintia and Khasi Hills), Khasi Hills (Khasia Hills) McLachlan Coll. B. M. 1938-674 (1 male, BMNH). Paratypes: same as holotype (1 males, BMNH; 1 male, OPC). 


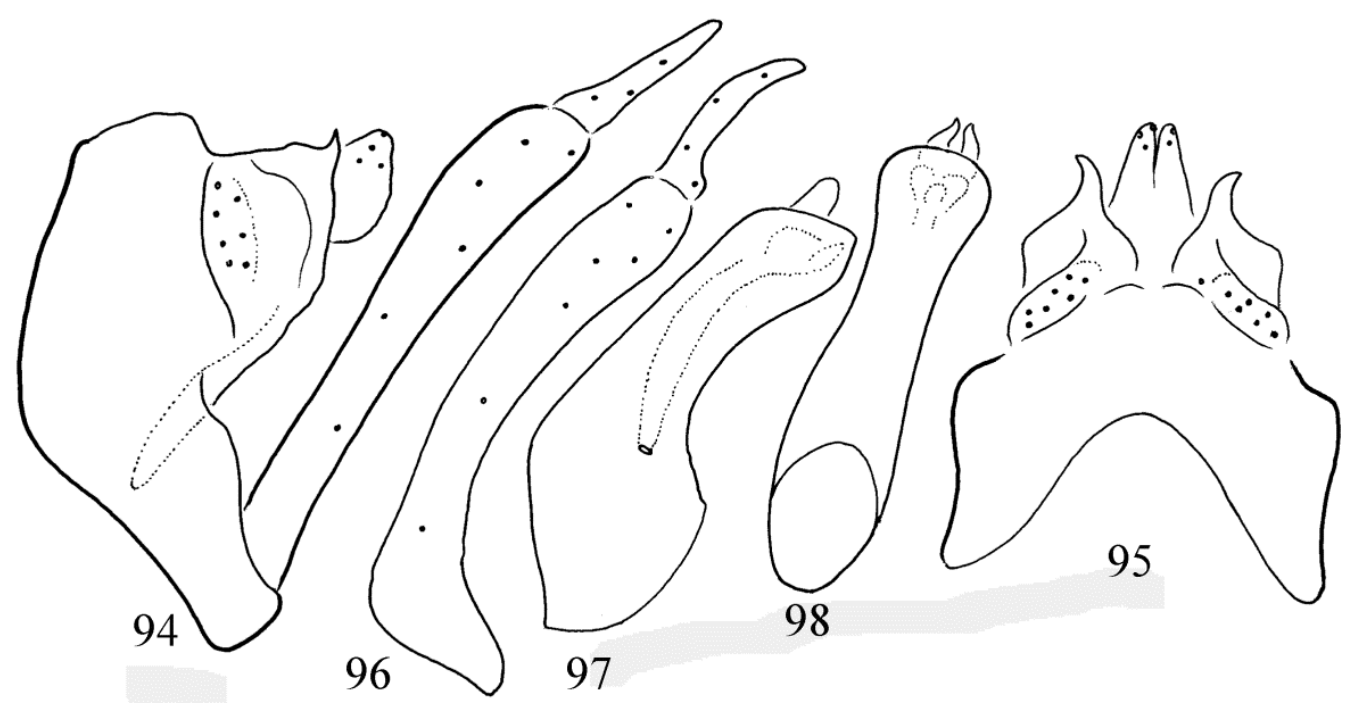

Figures 94-98. Diplectrona huishua sp. nov. Holotype: $94=$ male genitalia in left lateral view, $95=$ male genitalia in dorsal view, 96 = left gonopod in ventral view, 97 = phallic organ in left lateral view, 98 = phallic head in ventral view.

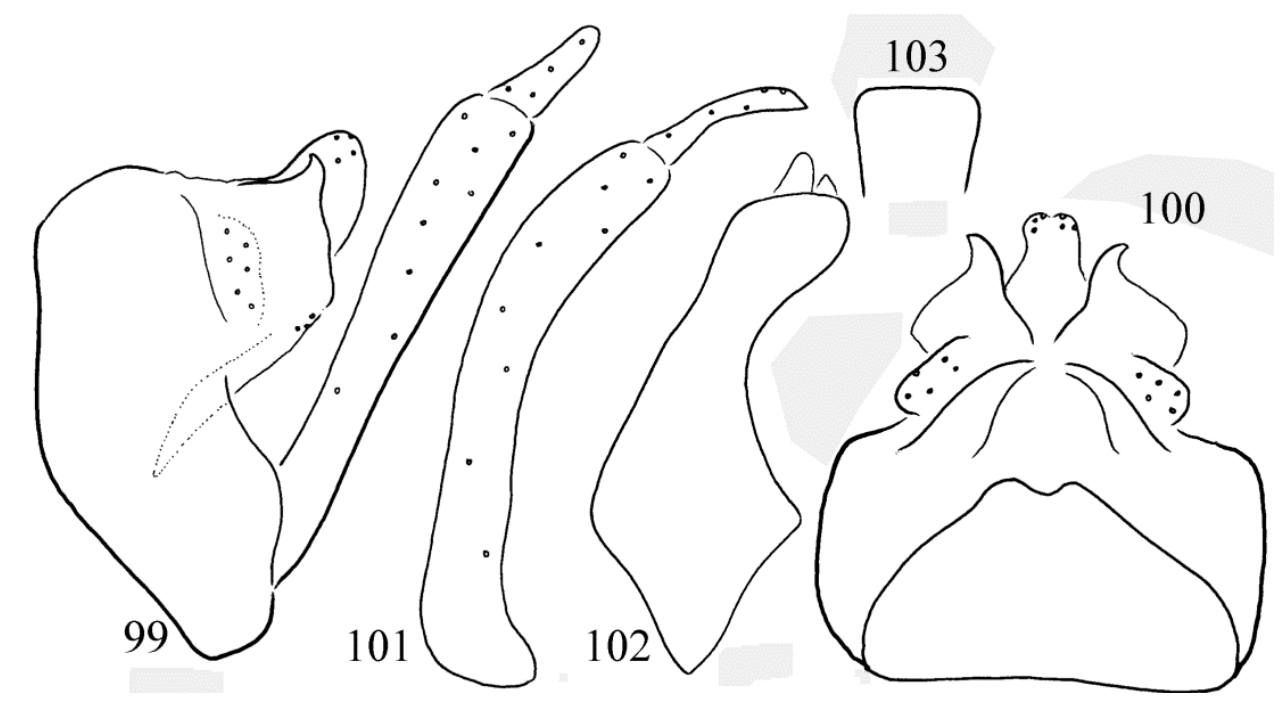

Figures 99-103. Diplectrona khasiaca sp. nov. Holotype: $99=$ male genitalia in left lateral view, $100=$ male genitalia in dorsal view, 101 = left gonopod in ventral view, 102 = phallic organ in left lateral view, $103=$ phallic head in ventral view.

Diagnosis. This species having dorsoapicad produced spiny structure on the paraproct belongs to the Diplectrona aurowittata new species group, and to the Diplectrona tamdaophila new species complex. Most close to D. meghalaya sp. nov., but differs by the dorsal profile of the dorsoapical setose lobes, that is capitate, not narrowing apicad; by the diverged lateral profile of the phallic organ; it is more robust; the phallobase is subquadratic, not curving; the dorsum of the phallotheca straight, not gradually curving downward.

Description. Male (in alcohol). Dark brown animal. Forewings without discernible pattern. Forewing length is $8 \mathrm{~mm}$, apical fork I present on hindwing. Eyes setaless, not enlarged. Maxillary palp formula I-III-IV-II-V. Abdominal segments 
without any reticulated internal sacs; filaments on sternite $\mathrm{V}$ double longer than the sternite.

Male genitalia. Segment IX convex anterad, dorsum long and convex with a middle depression line, ventrum shorter. Segment $\mathrm{X}$ fused to the tergum IX. The dorsoapical setose lobes (inner lobes) of segment $X$ well-developed, rounded broad protruded and capitate; seem bilobed, but tightly adhered. Cerci setose, low and long in lateral view, semi-circular in dorsal view. Unsetose paraproct (outer lobes or lateral plates of segment $X$ ) short and high plate in lateral view with upward directed pointed spine with laterad turning tip. Gonopods robust straight and their harpago mesad turning with sharply ventrad pointed tip. Phallic apparatus with down curving and broadening subquadratic basal section and with a tube-forming horizontal section with downward directed apex in lateral view; one pair of endothecal processes discernible, with blunt apices in lateral view and pointed triangular in ventral view; phallotremal sclerite less distinct. In ventral view the phallotheca is parallel-sided.

Etymology. khasiaca, named after the locus typicus of the holotype.

\section{Diplectrona khasigupta sp. nov.}

(Figures 104-113, Map 2: n²1, 22, Map 10)

Material examined. Holotype: India, Uttarakhand: Pauri Garhwal District, Gupta Khasi = Guptkashi, 2 small brooks very steep, 3800-4000 ft., 30॰31'31.3"N 7905'20.0"E, 2.IV.1958, leg. F. Schmid (1 male, CNC). Paratype: India, Uttarakhand: Pauri Garhwal, Khumyara, probably Khumera according to Lonsdale (2020), 2 small brooks in bushes and hygropetric habitat, 4300-

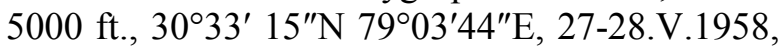
leg. F. Schmid (1 male, OPC).

Diagnosis. This species having dorsoapicad produced spiny structure on the paraproct belongs to the Diplectrona aurowittata new species group, and to the Diplectrona tamdaophila species complex. The dorsal profile of the paraproct of the new species most resembles Diplectrona joannisi described from Vietnam, but the dorsoapical spine directed straight to posterad, not laterad; the cerci vertically elongated, not horizontally; the harpago has a pointed tip, not blunt; the lateral profile of the phallotheca different,

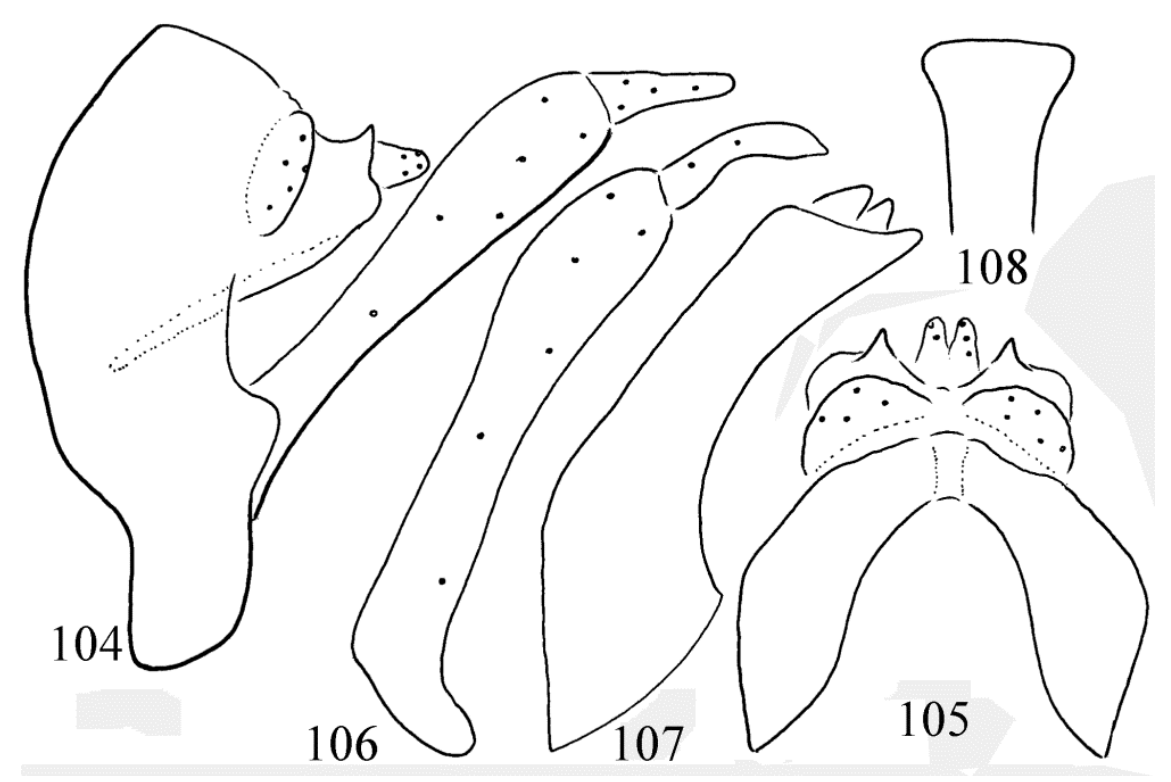

Figures 104-108. Diplectrona khasigupta sp. nov. Holotype: $104=$ male genitalia in left lateral view, $105=$ male genitalia in dorsal view, $106=$ left gonopod in ventral view, $107=$ phallic organ in left lateral view, $108=$ phallic head in ventral view. 


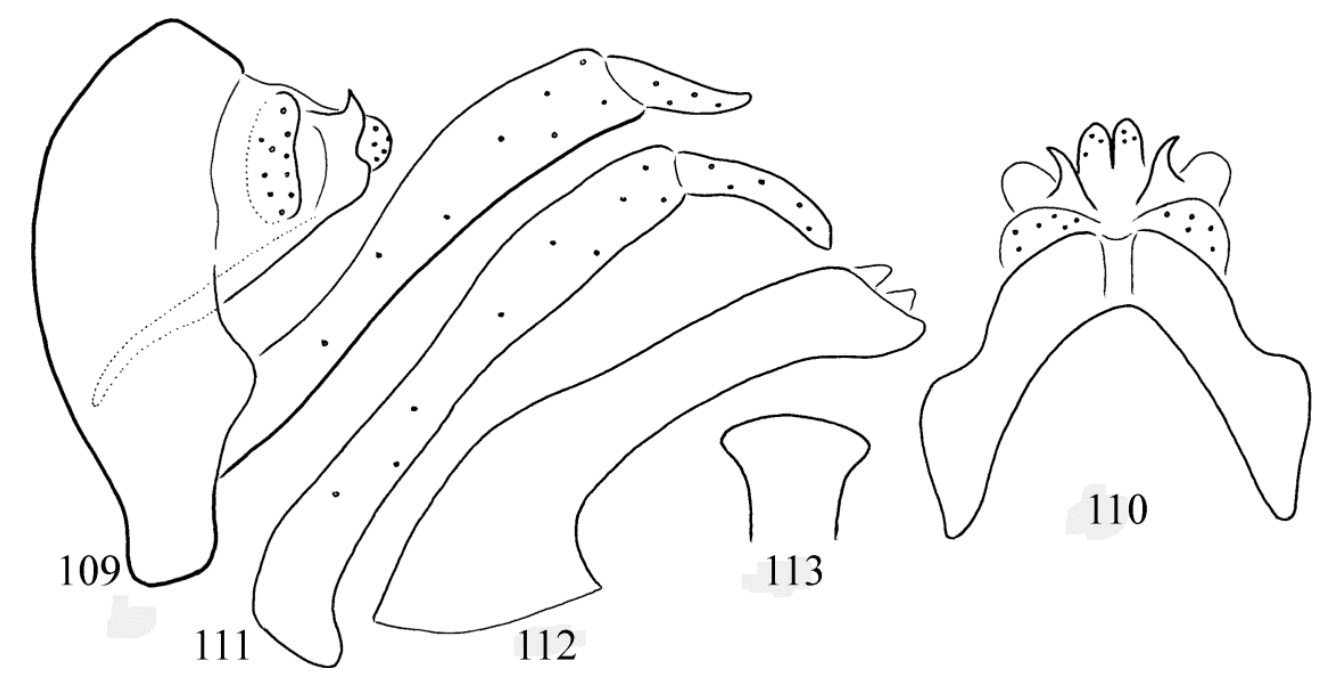

Figures 109-113. Diplectrona khasigupta sp. nov. Paratype: $109=$ male genitalia in left lateral view, $110=$ male genitalia in dorsal view, 111 = left gonopod in ventral view, $112=$ phallic organ in left lateral view, $113=$ phallic head in ventral view.

robust, not slim, its apicoventrum straight and narrowing, not downward directed and broad.

Description. Male (in alcohol). Light brown animal. Forewings without pattern. Forewing length $9 \mathrm{~mm}$, apical fork I present on hindwing. Eyes setaless, not enlarged. Maxillary palp formula I-IV-III-II-V. Abdominal segment VII with two reticulated internal sacs.

Male genitalia. Segment IX convex anterad, dorsum long and flat with a middle depression line, ventrum deformed into a ventral narrowing lobe. Segment $X$ fused to the tergum IX. The dorsoapical setose lobes (inner lobes) of segment $\mathrm{X}$ well-developed, rounded slender, protruded; seem bilobed, but tightly adhered; the ventroapical setose area distinct. Cerci setose, high and short in lateral view, semi-circular in dorsal view. Unsetose paraproct (outer lobes or lateral plates of segment X) subtriangular flat plate in lateral view with upward directed pointed process; straight and posterad directed in dorsal view. Gonopods robust straight and their harpago mesad turning with sharply pointed head. Phallic apparatus with down curving and broadening basal section and with a longer tube-forming horizontal two thirds with rounded obliquely cut apex in lateral view; two pairs of endothecal processes visible, both with blunt apices in lateral and pointed triangular in ventral view; dorsal endothecal process bigger; phallotremal sclerite less distinct. The phallic organ with produced wing-like triangular deltashaped head in ventral view.

Etymology. khasigupta, named after the locus typicus of the holotype.

\section{Diplectrona madonga sp. nov.}

(Figures 114-118, Map 4: n² 27, Map 10)

Material examined. Holotype: India, Arunachal Pradesh (Assam), Kameng, Nyukmadong, 6600-8000 ft., $27^{\circ} 24^{\prime} 32.5^{\prime \prime} \mathrm{N} 92^{\circ} 07^{\prime} 57.3^{\prime \prime E}, 1$. VIII.1961, leg. F. Schmid (1 male, CNC). Paratypes: same as holotype (1 male, OPC; 1 male, SMNH).

Diagnosis. This species having dorsoapicad produced spiny structure on the paraproct belongs to the Diplectrona aurowittata new species group, and to the Diplectrona tamdaophila new species complex. Most close to D. kinulta Oláh \& Li described from China (Tibet), but differs by the short segment $X$, by both the lateral and dorsal profiles of the paraproct as well as by the truncate apex of the phallic organ in ventral view.

Description. Male (in alcohol). Light brown animal. Forewings light spotted brown. Forewing 


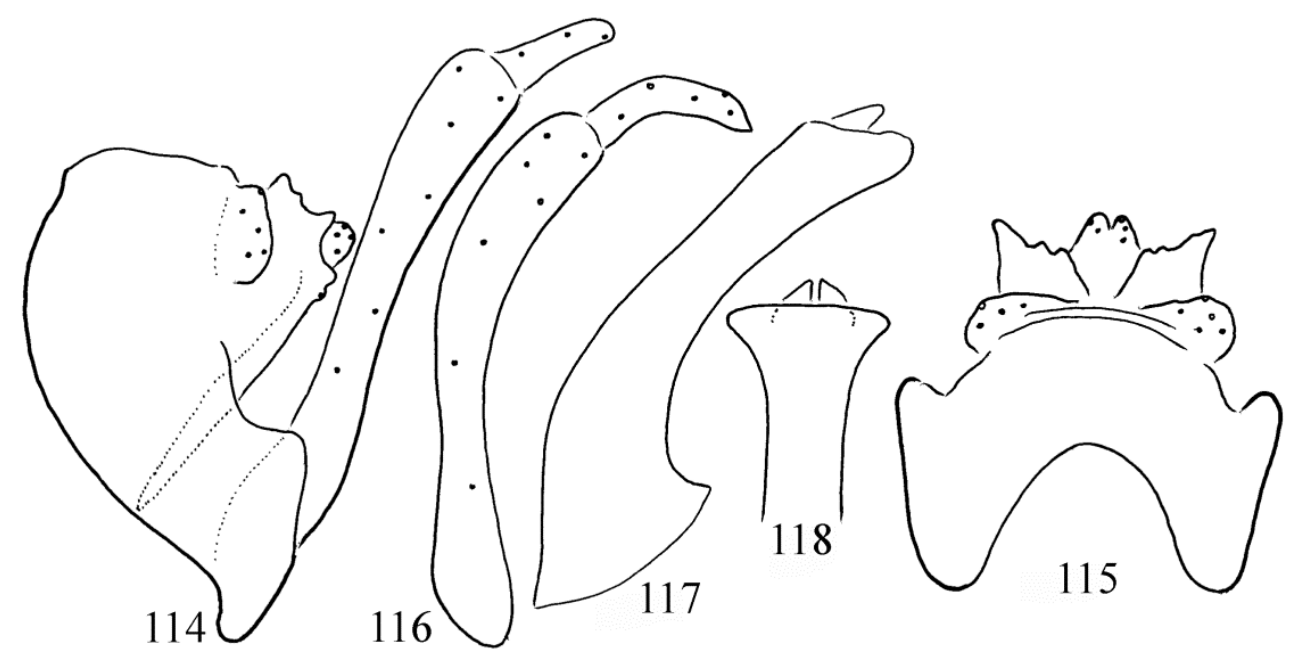

Figures 114-118. Diplectrona madonga sp. nov. Holotype: $114=$ male genitalia in left lateral view, $115=$ male genitalia in dorsal view, 116 = left gonopod in ventral view, 117 = phallic organ in left lateral view, $118=$ phallic head in ventral view.

length is $9 \mathrm{~mm}$, apical fork I present on hindwing. Eyes setaless, not enlarged. Maxillary palp formula I-IV-III-II-V. Anterodorsal filament on sternite V 2.24X as long as the sternite, there are two internal large sacs present in segment VIII.

Male genitalia. Segment IX convex anterad, dorsum long and flat with a middle depression line, ventrum directed anterad. Segment X fused to the tergum IX. The dorsoapical setose lobes (inner lobes) of segment X well-developed, short; seems bilobed, but tightly adhered; the ventroapical setose area distinct. Cerci setose, high and short in lateral view, semi-circular plate-like in dorsal view. Unsetose paraproct (outer lobes or lateral plates of segment X) subquadrangular flat plate in lateral view with five variously sized small outgrowths. Gonopods robust straight and their harpago mesad turning with pointed apex. Phallic apparatus with down curving and broadening basal section and with a longer tube-forming horizontal two thirds with rounded, obliquely cut apex in lateral view; one pair of endothecal processes well discernible, with blunt apices in lateral and pointed triangular in ventral view; phallotremal sclerite less distinct. The phallic organ with much produced wing-like triangular delta-shaped truncated head in ventral view.

Etymology. madonga, coined from the name of the locus typicus of the holotype.

\section{Diplectrona meghalaya sp. nov.}

(Figures 119-123, Map 5: $\mathrm{n}^{\circ}$ 8, 62, 70, Map 6: $\mathrm{n}^{\circ}$ 16, Map 10)

Material examined. Holotype: India, Meghaláya (United Jaintia and Khasi Hills), Shilliang Myntang [=Shiliangmyntang], $3500 \mathrm{ft}, 25^{\circ} 33^{\prime}$ 55.6"N 92²1'32.5"E, 21.IV.1960, leg. F. Schmid (1 male, CNC). Paratypes: same as holotype (1 male, CNC; 1 male, OPC). India, Meghalaya (United Jaintia and Khasi Hills), Mawlang, $4000 \mathrm{ft}$,

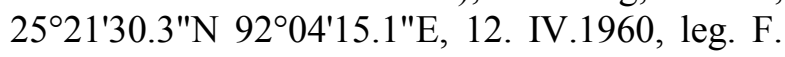
Schmid (1 male, SMNH). India, Meghalaya (United Jaintia and Khasi Hills), Dawki, $200 \mathrm{ft}$, $25^{\circ} 11^{\prime} 21.1^{\prime \prime N} 92^{\circ} 01^{\prime} 12.2^{\prime \prime E}$, 8.XII.1959, leg. F. Schmid (1 male, CNC). India, Manipur, Sirohi = Shirui, $4300 \mathrm{ft}, 25^{\circ} 07^{\prime} 42.6^{\prime \prime} \mathrm{N} 94^{\circ} 25^{\prime} 14.6 " \mathrm{E}, 28$. IX.1960, leg F. Schmid (1 male, CNC).

Diagnosis. This species having dorsoapicad produced spiny structure on the paraproct belongs to the Diplectrona aurowittata new species group, and to the Diplectrona tamdaophila new species complex. Most close to the D. tamdaophila species described from nearby Vietnam as well as to D. parala sp. nov. described from China nearby to Tam Dao of Vietnam. It has the character combination of small setaless eyes; without any internal sacs in abdominal segments; anterodorsal filament on sternite $\mathrm{V}$ as long as sternite $\mathrm{V}$ and VI to 


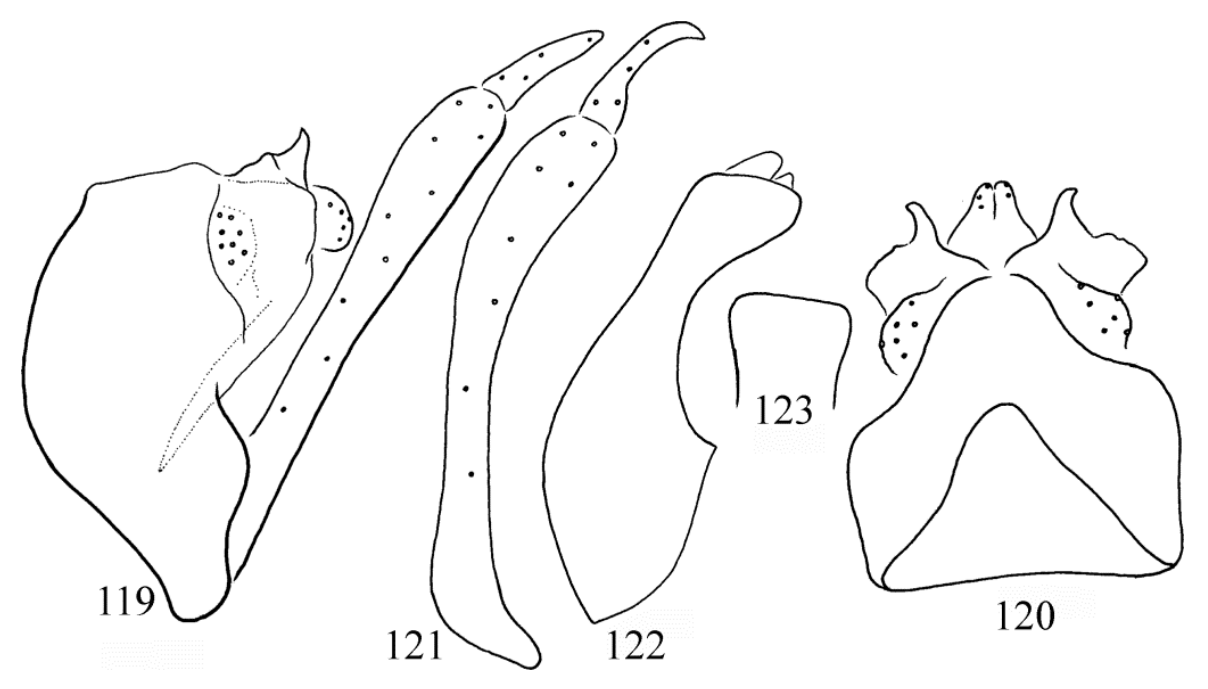

Figures 119-123. Diplectrona meghalaya sp. nov. Holotype: $119=$ male genitalia in left lateral view, $120=$ male genitalia in dorsal view, 121 = left gonopod in ventral view, $122=$ phallic organ in left lateral view, $123=$ phallic head in ventral view.

gether, presence of fork I on hindwing; short and high rounded lobes of segment X; enlarged cerci; almost parallel-sided harpago with ventrad pointed head. But differs by the downward curving head of the phallotheca in lateral view that is parallel-sided at $D$. parala, and less curving at $D$. tamdaophila. The ventral profile of the phallotheca constricted subapicad at D. parala and almost parallel-sided at D. tamdaophila and at $D$. meghalaya sp. nov. D. meghalaya sp. nov. has cerci short and high, low and longer at $D$. tamdaophila.

Description. Male (in alcohol). Dark brown animal. Forewings without discernible pattern. Forewing length is $9 \mathrm{~mm}$, apical fork I present on hindwing. Eyes setaless, not enlarged. Maxillary palp formula I-III-IV-II-V. Abdominal segments without any reticulated internal sacs; filaments on sternite $\mathrm{V}$ double long than the sternite.

Male genitalia. Segment IX convex anterad, dorsum long and convex with a middle depression line, ventrum short. Segment $X$ fused to the tergum IX. The dorsoapical setose lobes (inner lobes) of segment $X$ well-developed, rounded broad protruded; seem bilobed, but tightly adhered. Cerci setose, low and long in lateral view, semi-circular in dorsal view. Unsetose paraproct (outer lobes or lateral plates of segment X) short and high plate in lateral view with upward direct- ed pointed spine with laterad turning tip. Gonopods robust straight and their harpago mesad turning with sharply ventrad pointed tip. Phallic apparatus with down curving and broadening basal section and with a tube-forming horizontal section with downward directed apex in lateral view; one pair of endothecal processes discernible, with blunt apices in lateral and pointed triangular in ventral view; phallotremal sclerite less distinct. In ventral view the phallotheca parallel-sided.

Etymology. meghalaya, named after the locus typicus of the holotype.

\section{Diplectrona mopaenga sp. nov.}

(Map 11)

Diplectrona aurovittata Ulmer, 1906: Malicky, 2002: 1205. Misidentification.

Material. Syntypes: Thailand, Mo Paeng, $19^{\circ}$ 22'43.6"N 98²2'32.8"E, leg. Malicky, Chantaramongkol, Saengpradab, Rausch, (Zahlreiche exemplare, drawn specimen, MPC).

Diagnosis. This species having dorsoapicad produced spiny structure on the paraproct belongs to the Diplectrona aurowittata new species group, and supplied only with a single pointed spine belongs to the Diplectrona tamdaophila new spe- 
cies complex. Most close to the D. aisahka sp. nov. from India, Meghalaya but differs by the longer dorsal profile of the single spine of the paraproct as well as by the slender lateral profile of the phallic organ and the truncated ventral shape of the phallic head.

Description. Male (Figures: Malicky 2002: Table 10: aurovittata, Mo Paeng). Eyes setaless, not enlarged. Abdominal segments without any reticulated internal sacs; filaments on sternite $\mathrm{V}$ present.

Male genitalia. Segment IX convex anterad, dorsum long and convex with a middle depression line, ventrum shorter. Segment $\mathrm{X}$ fused to the tergum IX. The dorsoapical setose lobes (inner lobes) of segment $\mathrm{X}$ well-developed, protruded and narrowing apicad, broad in lateral view; seem bilobed, but tightly adhered. Cerci setose, high and short in lateral view, semi-circular in dorsal view. Unsetose paraproct (outer lobes or lateral plates of segment $\mathrm{X}$ ) subquadrangular plate in lateral view with upward directed pointed spine with laterad turning tip. Gonopods dilated apicad and their harpago mesad turning and narrowing. Phallic apparatus with truncated head in ventral view.

Etymology. mopaenga, named after the locus typicus of the syntypes.

\section{Diplectrona parala sp. nov.}

(Figures 124-127, Map 11)

Diplectrona tamdaophila Mey, 1998: Oláh et al. 2020: 161 Misidentification!

Material examined. Holotype: China, Guangxi Zhuang Autonomous Region, Shangsi County, Shiwandashan Natural Forest Park, Pearl River above tourist route bridge, N21 ${ }^{\circ} 53.913^{\prime} \mathrm{E} 107^{\circ}$ 54.283', 375 m, 27.III.2015(/15), leg. J. Kontschán, J. N. Li, S. Li, W. H. Li, D. Murányi \& G. Q. Wang (1 male, OPC).

Diagnosis. This species having dorsoapicad produced spiny structure on the paraproct belongs to the Diplectrona aurowittata new species group, and to the Diplectrona tamdaophila new species complex. Most close to the D. tamdaophila species described from nearby Vietnam. It has the character combination of small setaless eyes; without any internal sacs in abdominal segments; anterodorsal filament on sternite $\mathrm{V}$ as long as sternite $\mathrm{V}$ and VI together, presence of fork I on hindwing; short and high rounded lobes of segment X; enlarged cerci; almost parallel-sided harpago with ventrad pointed head. But differs by the lateral profile of the phallotheca that is parallel-sided at $D$. parala, constricted middle at D. tamdaophila and by the ventral profile that is constricted subapicad at $D$. parala and almost parallel-sided at $D$. tamdaophila.

Description. Male (in alcohol). Dark brown animal. Forewings without discernible pattern. Forewing length $8 \mathrm{~mm}$, apical fork I present on hindwing. Eyes setaless, not enlarged. Maxillary palp formula I-III-IV-II-V. Abdominal segments without any reticulated internal sacs; filaments on sternite $\mathrm{V}$ double longer than the sternite.

Male genitalia. Segment IX convex anterad, dorsum long and convex with a middle depression line, ventrum short. Segment $X$ fused to the tergum IX. The dorsoapical setose lobes (inner lobes) of segment $\mathrm{X}$ well-developed, rounded broad protruded; seem bilobed, but tightly adhered. Cerci setose, high and short in lateral view, semi-circular in dorsal view. Unsetose paraproct (outer lobes or lateral plates of segment X) short and high plate in lateral view with upward directed pointed spine with laterad turning tip. Gonopods robust straight and their harpago mesad turning with sharply ventrad pointed tip. Phallic apparatus with down curving and broadening basal section and with a longer tube-forming horizontal parallel-sided section with rounded obliquely cut apex in lateral view; one pair of endothecal processes discernible, with blunt apices in lateral and pointed triangular in ventral view; phallotremal sclerite less distinct. In ventral view the phallotheca constricted subapicad.

Etymology. parala, coined form "parallel, párhuzamos" parallel in Hungarian, refers to lateral profile of the phallotheca, having almost parallelsided dorsal and ventral margin. 


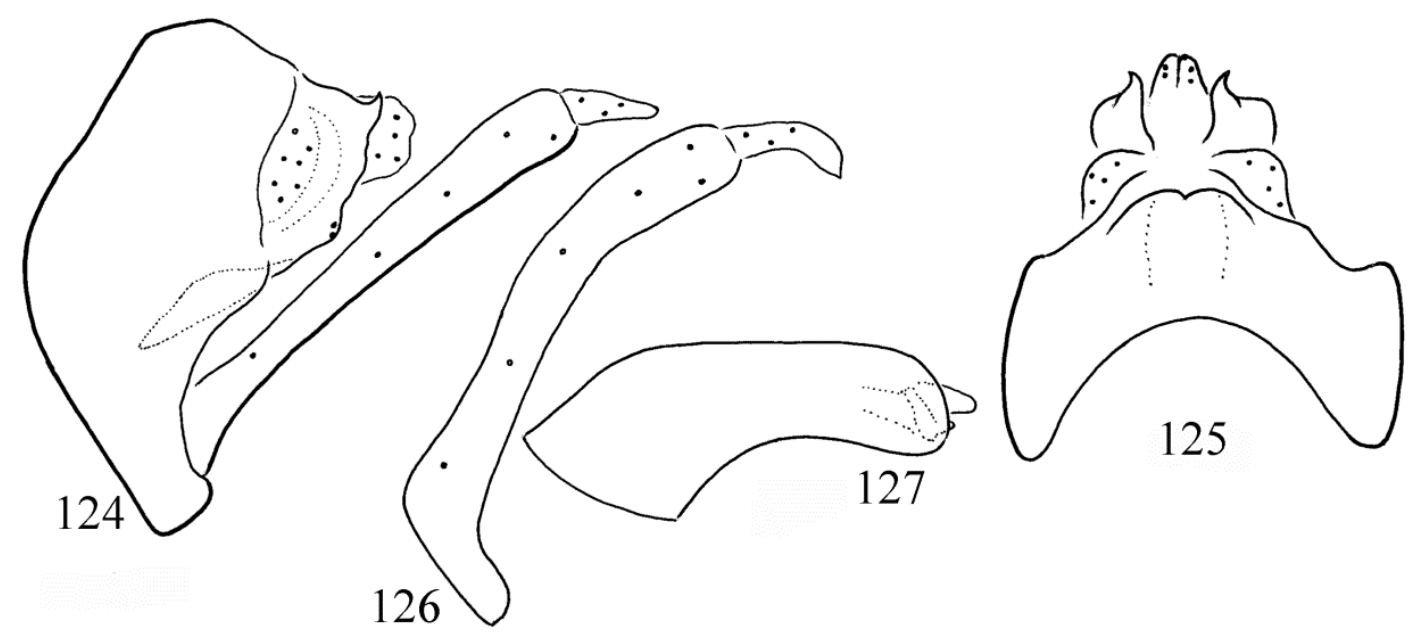

Figures 124-127. Diplectrona parala sp. nov. Holotype: 124 = male genitalia in left lateral view, $125=$ male genitalia in dorsal view, $126=$ left gonopod in ventral view, 127 = phallic organ in left lateral view.

Diplectrona rumkhenga sp. nov.

(Figures 128-132, Map 5: n 41, Map 10)

Material examined. Holotype: India, Meghaláya (United Jaintia and Khasi Hills), Rumkheng [= Ramkheng], $5500 \mathrm{ft} ., 25^{\circ} 23^{\prime} 20.0^{\prime \prime} \mathrm{N} 91^{\circ} 50^{\prime}$ 01.1"E, 20-23.III.1960, leg. F. Schmid (1 male, CNC). Paratypes: same as holotype (1 male, $\mathrm{OPC})$.

Diagnosis. This species having dorsoapicad produced spiny structure on the paraproct belongs to the Diplectrona aurowittata new species group, and to the Diplectrona tamdaophila new species complex. Most close to the D. meghalaya sp. nov. but differs by both the lateral and dorsal profiles of the paraproct as well as by the more robust phallic organ without strongly produced downward directed apical ventrum.

Description. Male (in alcohol). Dark brown animal. Forewings without discernible pattern. Forewing length $9 \mathrm{~mm}$, apical fork I present on hindwing. Eyes setaless, not enlarged. Maxillary palp formula I-III-IV-II-V. Abdominal segments without any reticulated internal sacs; filaments on sternite $\mathrm{V}$ double longer than the sternite.

Male genitalia. Segment IX convex anterad, dorsum long with a middle depression line, ventrum short. Segment X fused to the tergum IX.
The dorsoapical setose lobes (inner lobes) of segment X well-developed, rounded broad protruded; seem bilobed, but tightly adhered. Cerci setose, high and short in lateral view, elongated in dorsal view. Unsetose paraproct (outer lobes or lateral plates of segment $\mathrm{X}$ ) short and high plate in lateral view with upward directed pointed spine with laterad turning tip. Gonopods robust straight and their harpago mesad turning with sharply ventrad pointed tip. Phallic apparatus robust with down curving and broadening basal section and with a tube-forming horizontal section slightly broadening toward the apex in lateral view; one pair of endothecal processes discernible, with blunt apices in lateral view and pointed triangular in ventral view; phallotremal sclerite less distinct. In ventral view the phallotheca parallel-sided, slightly broadening apicad.

Etymology. rumkhenga, named after the locus typicus of the holotype.

Diplectrona sitahoana sp. nov.

(Map 11)

Diplectrona aurovittata Ulmer, 1906: Malicky, 2002: 1205. Misidentification.

Material. Syntypes: Indonesia, Sumatra, Sitahoan, $2^{\circ} 40^{\prime} 09.9^{\prime \prime} \mathrm{N} 98^{\circ} 58^{\prime} 50.7^{\prime \prime} \mathrm{E}$, zahlreiche ex- 


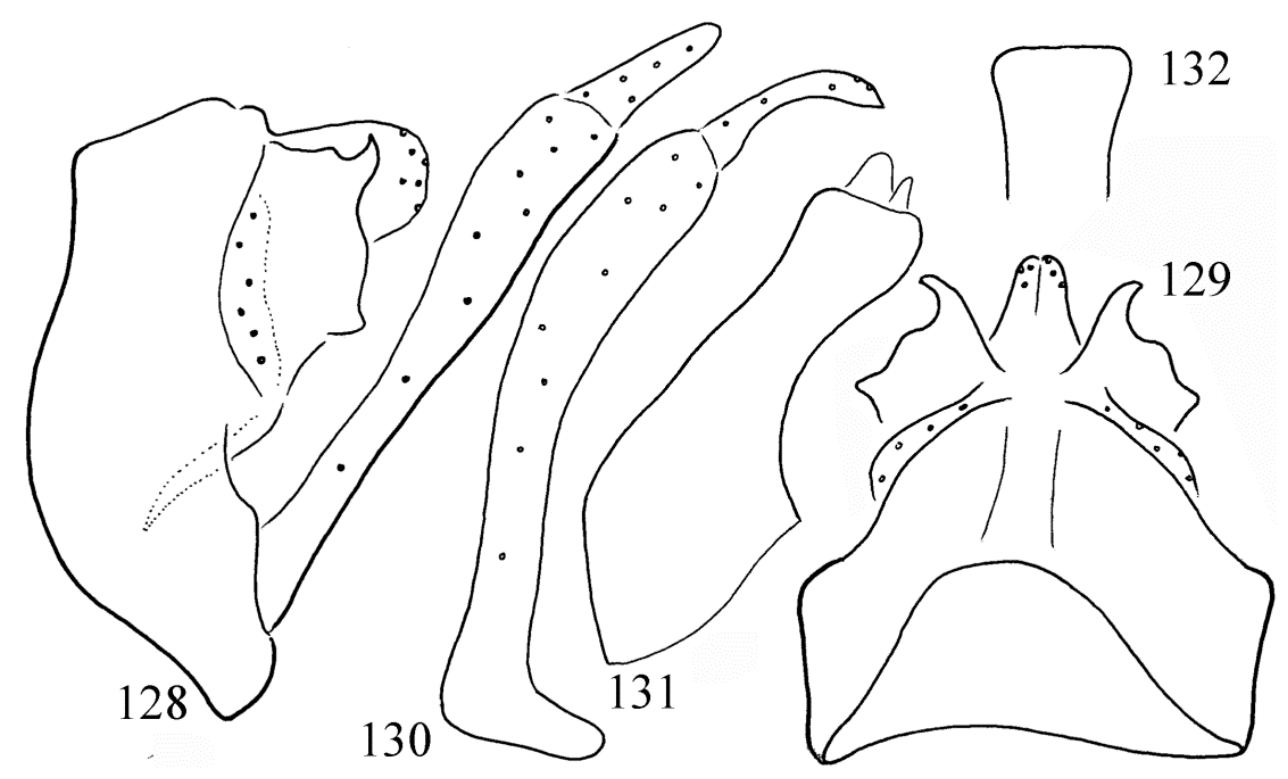

Figures 128-132. Diplectrona rumkhenga sp. nov. Holotype: $128=$ male genitalia in left lateral view, $129=$ male genitalia in dorsal view, 130 = left gonopod in ventral view, 131 = phallic organ in left lateral view, $132=$ phallic head in ventral view.

emplare, leg. Malicky, Diehl, CM. Drawn specimen).

Diagnosis. This species having dorsoapicad produced spiny structure on the paraproct belongs to the Diplectrona aurowittata new species group, and supplied only with a single pointed spine belongs to the Diplectrona tamdaophila new species complex. This species has resemblance to Diplectrona fissilinea Mey, 1999 described from Indonesia, Talaud Island, but differs both by the dorsal and lateral profiles of the paraproct; by the shorter harpago; by the longer dorsoapical setose lobe, as well as by the higher phallobase.

Description. Male (Figures: Malicky 2002: Table 10: aurovittata, Sitahoan). Eyes setaless, not enlarged. Abdominal segments without any reticulated internal sacs; filaments on sternite $\mathrm{V}$ present.

Male genitalia. Segment IX convex anterad, dorsum long and convex with a middle depression line, ventrum shorter. Segment $X$ fused to the tergum IX. The dorsoapical setose lobes (inner lobes) of segment X well-developed, protruded and narrowing apicad, broad in lateral view; seem bilobed, but tightly adhered and longer than paraproct. Cerci setose, high and short in lateral view, semi-circular in dorsal view. Unsetose paraproct (outer lobes or lateral plates of segment X) subquadrangular plate with dorsoapical elongated spine in lateral view. Gonopods dilated apicad and their harpago mesad turning and narrowing. Phallic apparatus with high phallobase and the phallic head with truncate apical margin in ventral view.

Etymology. sitahoana, named after the locus typicus of the syntypes.

\section{Diplectrona sohra sp. nov.}

(Figures 133-137, Map 5: n 102, Map 10)

Material examined. Holotype: India, Meghaláya (United Jaintia and Khasi Hills), Khasi Hills (Assam, Khasia Hills), Cherrapunji, 2516'08.1"N 91 ${ }^{\circ} 44^{\prime} 03.1 " E$, Native Coll., T. B. Fletcher Coll. Brit. Mus. 1936-643 (1 male, BMNH).

Diagnosis. This species having dorsoapicad produced spiny structure on the paraproct belongs to the Diplectrona aurowittata new species group, and to the Diplectrona tamdaophila new species complex. Most close to the D. meghalaya sp. nov., but differs by both the dorsal and lateral 


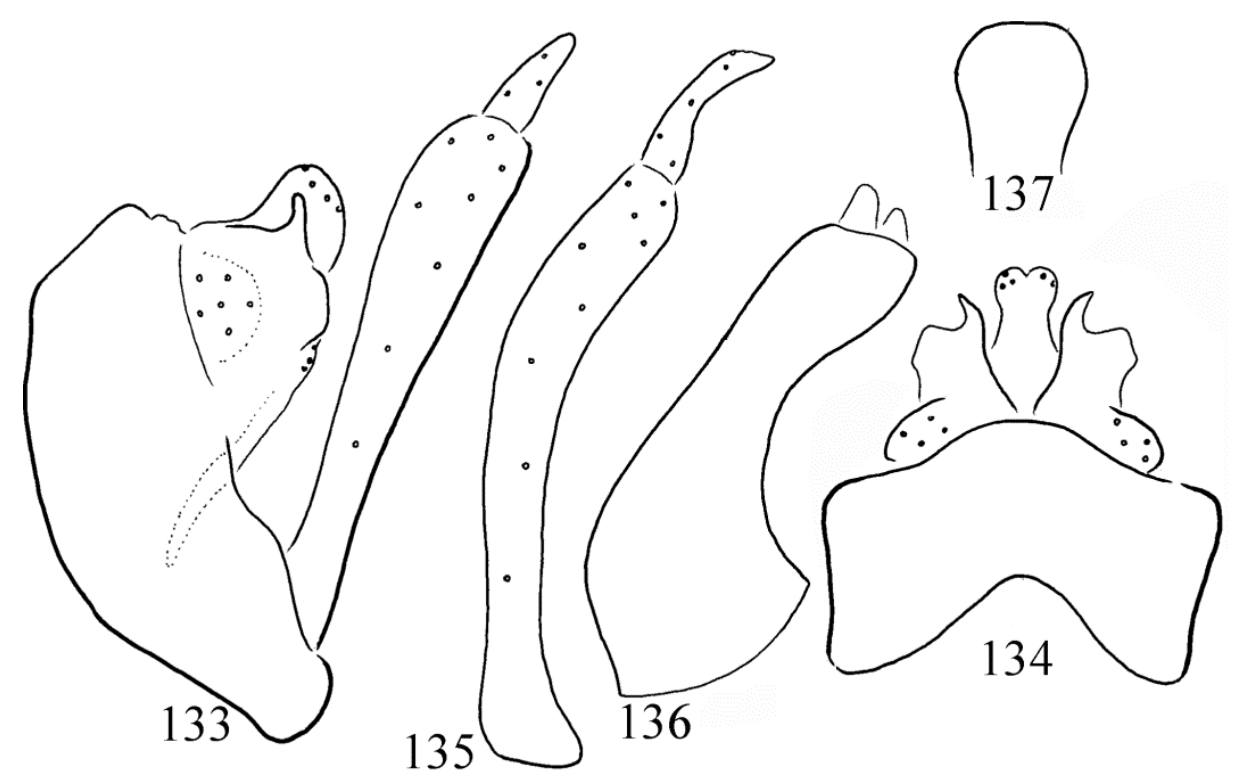

Figures 133-137. Diplectrona sohra sp. nov. Holotype: $133=$ male genitalia in left lateral view, $134=$ male genitalia in dorsal view, 135 = left gonopod in ventral view, 136 = phallic organ in left lateral view, 137 = phallic head in ventral view.

profiles of the dorsoapical setose lobes, that is capitate apicad in dorsal view and upward directed in lateral view; by the diverged lateral profile of the phallic organ; it is more robust; the phallobase is shorter; the ventral profile of the phallic head is regularly rounded, not straight truncated.

Description. Male (in alcohol). Dark brown animal. Forewings without discernible pattern. Forewing length $8 \mathrm{~mm}$, apical fork I present on hindwing. Eyes setaless, not enlarged. Maxillary palp formula I-III-IV-II-V. Abdominal segments without any reticulated internal sacs; filaments on sternite $\mathrm{V}$ double longer than the sternite.

Male genitalia. Segment IX convex anterad, dorsum long and convex with a middle depression line, ventrum shorter. Segment $X$ fused to the tergum IX. The dorsoapical setose lobes (inner lobes) of segment $X$ well-developed, protruded and capitate apicad; seem bilobed, but tightly adhered. Cerci setose, circular in lateral view, semi-circular in dorsal view. Unsetose paraproct (outer lobes or lateral plates of segment X) short and high plate in lateral view with upward directed pointed spine with laterad turning tip. Gonopods straight dilating apicad their harpago mesad turning with ventrad pointed tip. Phallic apparatus very robust with down curving and broadening curving basal section and with a tubeforming horizontal section with downward directed apex in lateral view; one pair of endothecal processes discernible, with blunt apices in lateral view and pointed triangular in ventral view; phallotremal sclerite less distinct. In ventral view the head of phallotheca produced rounded laterad.

Etymology. sohra, the original name of Cherrapunji, named after the locus typicus of the holotype.

\section{Diplectrona tamdaophila Mey, 1998}

(Figures 138-144, Map 11)

Material examined. Vietnam, Tam Dao National Park, Tam Dao City, along the main stream, $1000 \mathrm{~m}, 21^{\circ} 27^{\prime} 17.0^{\prime \prime} \mathrm{N} 105^{\circ} 38^{\prime} 13.7^{\prime \prime E}, 14 . X .1986$, light and singled leg. J. Oláh (13 males, 6 females; OPC). Vietnam, Tam Dao National Park, Tam Dao City, along spring brook of the main stream, 800 m, 10.V.1987, singled leg. J. Oláh (2 males, OPC). Vietnam, Tam Dao National Park, 1994, No. 802 (1 male, HNHM). 


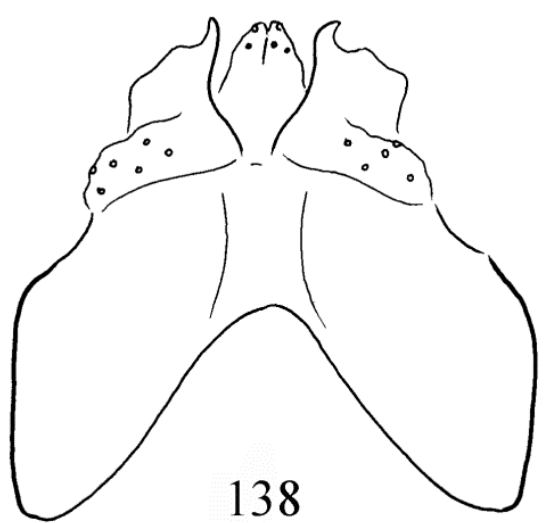

Figures 138. Diplectrona tamdaophila Mey, 1998, male genitalia in dorsal view.
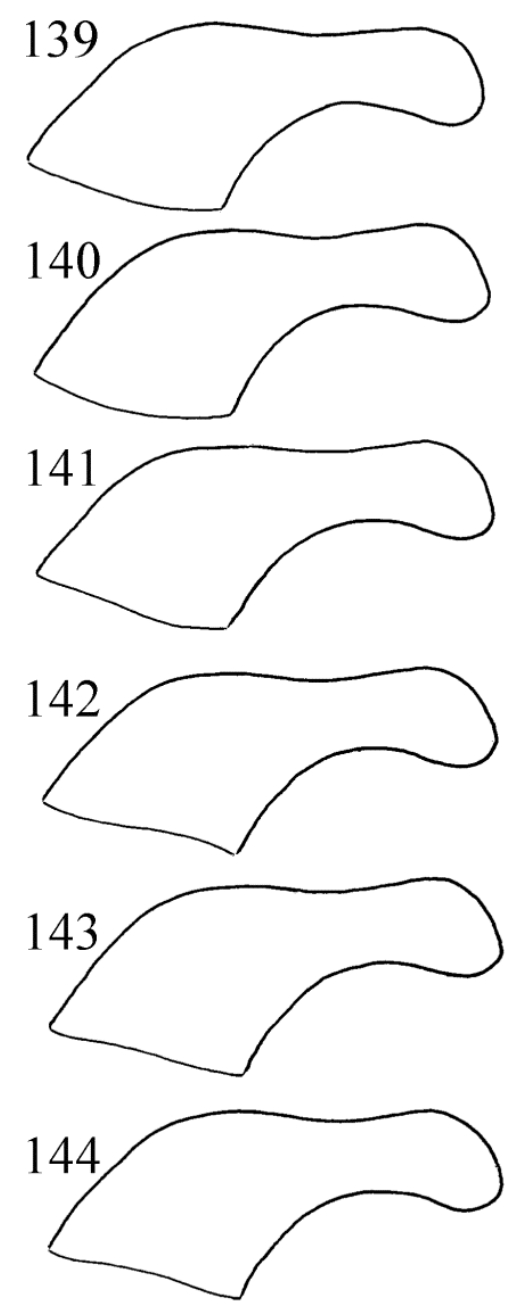

Figures 139-144. Diplectrona tamdaophila Mey, 1998, phallic organ in left lateral view of six specimens from different habitats in Tam dao, Vietnam.
Remarks. This nominate species of the complex differs from Diplectrona meghalaya sp. nov. and $D$. parala $\mathrm{sp}$. nov. by the lateral and ventral profile of the phallic organ as well as from the $D$. huishua sp. nov. by the dorsal pattern of the paraproct. The lateral profile of the phallic organ is very stable in the examined populations of Tam Dao sampled from several habitats a few hundred metres apart.

\section{Diplectrona coalescens species group}

Based on character state combination of setal wart pattern on the head and of the structure of male genitalia the Diplectrona coalescens species group was established as a Diagnostic Species Group by Sun (2017), tacitly contrasting with the expiring epistemic concept of the so called Phylogenetic Species Group.

More than ten years ago, at the peak time of modern scientific hubris dominated by naive simplifying, common sense ideas of objectivism, determinism and reductionism we have accepted the editorial policy of the Zootaxa, an international journal on systematic zoology and established our species groups and clusters in the Hydropsychinae subfamily also as diagnostic species groups and clusters (Oláh et al. 2008). At that time this "modern" distinction between diagnostic (cluster) and phylogenetic (clade) systems of classification was still dominating as a valid epistemic scenario (Oláh et al. 2020b). Today facing the realities of taxonomic/character state incongruences, endless character trees/in a single species tree, and debated dichotomises of analogy/homology, integration/selection, evolution/organisation, branching/ reticulation, monophyletic/chimeric, tree-of-life/ network-of-life, such a hubristic epistemic distinction between diagnostic and phylogenetic taxa has lost theoretical ground. Every classification is artificial, therefore diagnostic!

The Diplectrona coalescens species group is characterized by the basically bilobed fused formation of segment $\mathrm{X}$ and $\mathrm{XI}$ that is the complex of segment X (mesal plate or inner lobe), setose cerci and less setose almost bare paraprocts (late- 
ral plate or outer lobe). Segment X, the well differentiated mesal plate or inner lobe of segment is highly reduced, almost entirely vestigial, fused to the complex.

\section{Diplectrona hongkonga sp. nov.}

(Figures 145-148, Map 12)

Material examined. Holotype: China, HongKong (Island) Mid-Levels, 150m, 20-31.V.1982, actinic trap, leg. J. Robinson, Brit. Mus. 1982-304 (1 male, BMNH).

Diagnosis. This new species having bilobed complex of segment X and XI that is the cerci, the paraproct, the remnant of segment XI and the vestigial segment $X$ fused together is a new member of the Diplectrona coalescens species group. Most close to the nominate species $D$. coalescens sp. nov. described from China, Guang$\mathrm{xi}$, but differs by having the dorsal view of apical head of the bilobed fused complex pointed, not rounded; the lateral profile of the phallic organ more robust and differently shaped; the setaless paraproct laterad pointed. Homologization of the structures is not clear; the setose structure is probably the fused cerci and segment X (inner lobe) and the setaless structure is the paraproct, the remnant of the segment XI.

Description. Male (in alcohol). Dark brown animal. Forewings without pattern. Forewing length is $7 \mathrm{~mm}$, apical fork I present on hindwing. Eyes setaless, not enlarged. Maxillary palp formula I-IV-III-II-V. Anterodorsal filament on sternite $\mathrm{V}$ very small, there are no any internal reticulated sacs present in segment VIII.

Male genitalia. Segment IX convex anterad, dorsum long and flat with a middle depression line. Segment $X$ fused to the tergum IX. The dorsoapical setose lobes (mesal plate or inner lobes of segment $\mathrm{X}$ ) and the setose cerci fused together forming a setose structure narrowing in dorsal view; the setaless paraproct (outer lobes or lateral plates of segment X) pointed. Gonopods are slender, almost straight with slightly dilated apical region; the broad harpago mesad turning. Phallic apparatus very robust with low phallobase; endothecal and phallotremal sclerites withdrawn inside the phallotheca.

Etymology. hongkonga named after the locus typicus of the holotype.

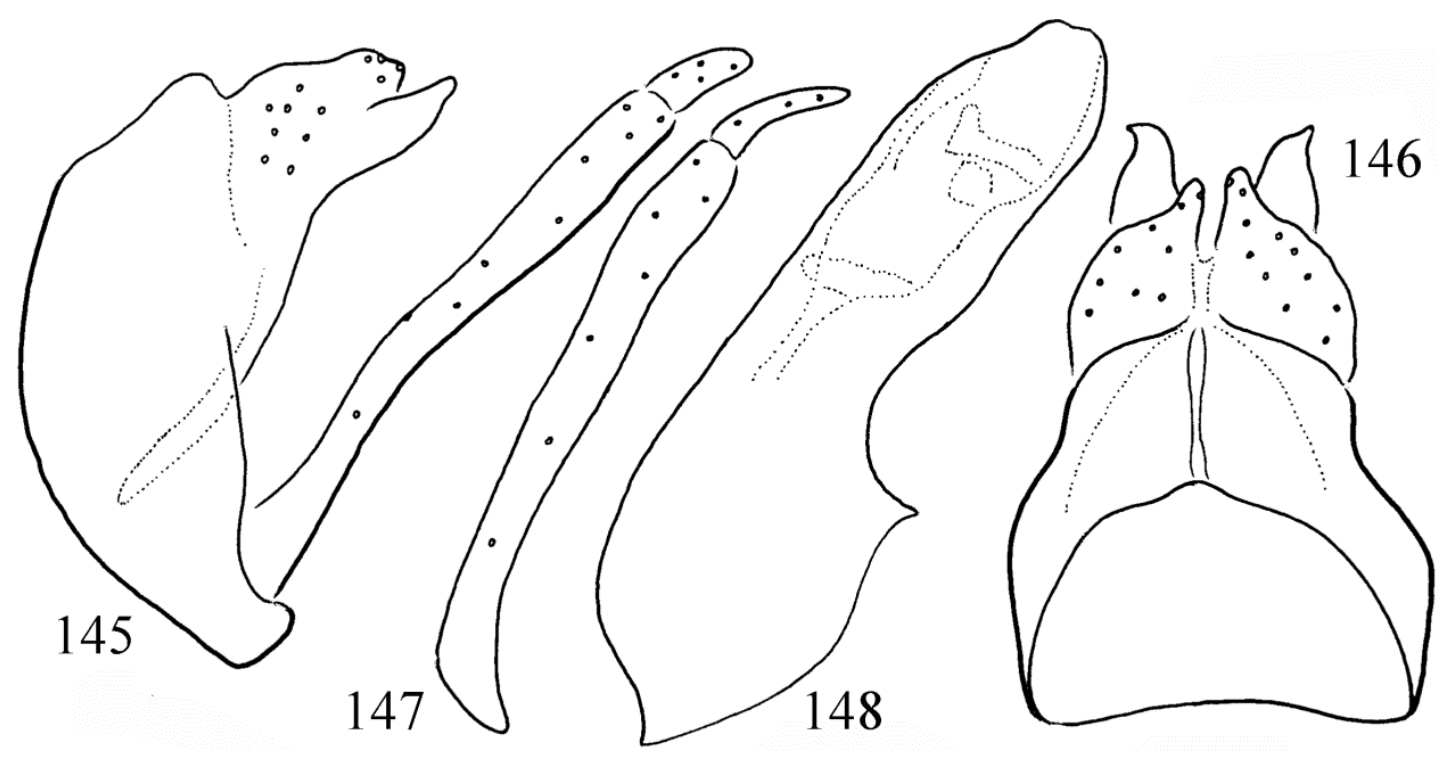

Figures 145-148. Diplectrona hongkonga sp. nov. Holotype: $145=$ male genitalia in left lateral view, $146=$ male genitalia in dorsal view, 147 = left gonopod in ventral view, 148 = phallic organ in left lateral view. 


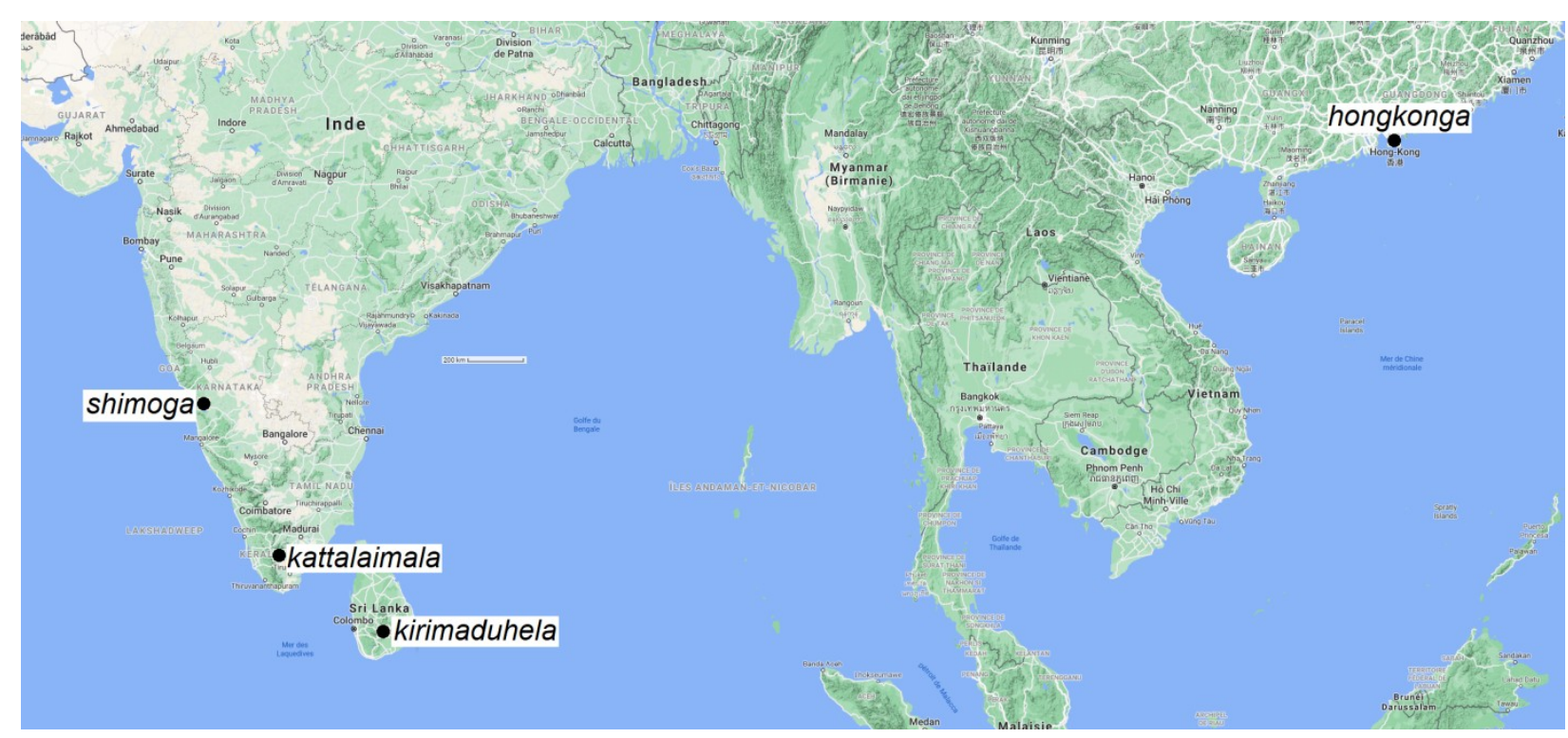

Map 12. Diplectrona coalescens group.

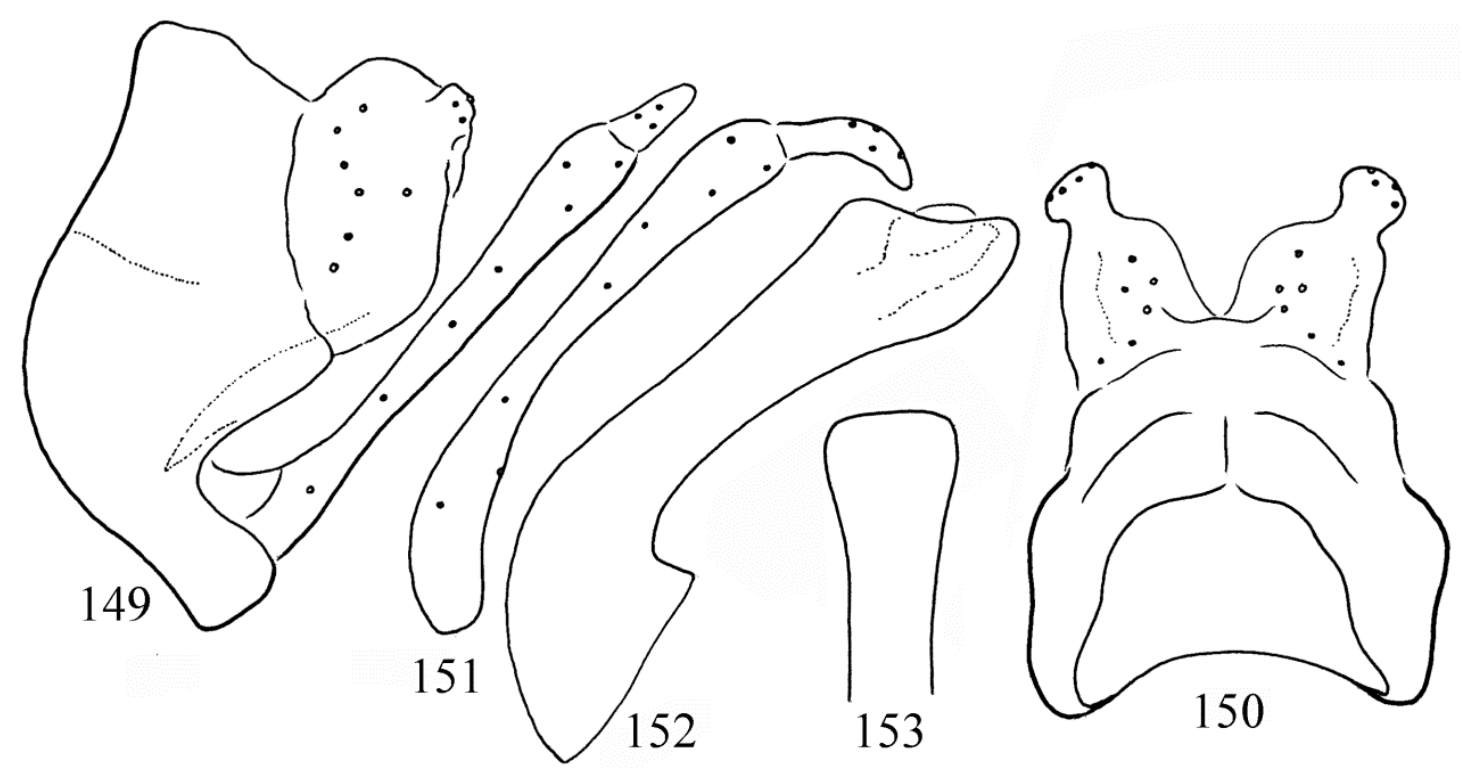

Figures 149-153. Diplectrona kattalaimala sp. nov. Holotype: $149=$ male genitalia in left lateral view, $150=$ male genitalia in dorsal view, 151 = left gonopod in ventral view, $152=$ phallic organ in left lateral view, $153=$ phallic head in ventral view.

\section{Diplectrona kattalaimala sp. nov.}

(Figures 149-153, Map 7a: near n 102, Map 12)

Material examined. Holotype: India, Tamil Nadu (Madras), Kattalaimala, this locality should be in the surroundings of Courtallam and Kannupulimedu, it probably corresponds to Kottamalai,
1000 ft., $9^{\circ} 13^{\prime} 33.3^{\prime \prime} \mathrm{N} \quad 77^{\circ} 19^{\prime} 06.9^{\prime \prime} \mathrm{E}, \quad 16-17 . \mathrm{I}$. 1962, leg. F. Schmid (1 male, CNC).

Diagnosis. This new species having bilobed complex of segment X and XI that is the cerci, the paraproct, the remnant of segment XI and the vestigial segment $X$ fused together is a new mem- 
ber of the Diplectrona coalescens species group. Most close to D. shimoga sp. nov. described from Karnataka, but differs by having the dorsal view of apical head of the bilobed fused complex capitate, not parallel-sided; the lateral profile of the phallic organ differently shaped with more robust, ventroapicad directed produced lobe; its apical margin truncate in ventral view, not rounded.

Description. Male (in alcohol). Dark brown animal. Forewings without pattern. Forewing length $7 \mathrm{~mm}$, apical fork I present on hindwing. Eyes setaless, not enlarged. Maxillary palp formula I-IV-III-II-V. Anterodorsal filament on sternite $\mathrm{V}$ lacking, there are no any internal reticulated sacs present in segment VIII.

Male genitalia. Segment IX convex anterad, dorsum long and flat with a middle depression line. Segment $X$ fused to the tergum IX. The dorsoapical setose lobes (mesal plate or inner lobes) and the unsetose paraproct (outer lobes or lateral plates of segment X) fused together. Cerci form setose area in lateral view, visible both in lateral and dorsal view. Gonopods are robust, almost straight with dilated apical region; the broad harpago mesad turning. Phallic apparatus with slightly downward curving and broadening basal and tube-forming apicad broadening sections; its apicoventrum elongated; two pairs of endothecal processes badly discernible; phallotremal sclerite less distinct.

Etymology. kattalaimala named after the locus typicus of the holotype.

\section{Diplectrona kirimaduhela Schmid, 1958, stat. restit.}

(Map 12)

Diplectrona kirimaduhela Schmid, 1958:117-118. Holotype: Sri Lanka "Horton Plains (C.P., $7000 \mathrm{ft}$ ), $6^{\circ}$ 48'07.2"N 8048'31.6"E, 7-8.III.1954”. A species described from Sri Lanka, close to Diplectrona papillonacea (Hagen, 1859).

non Diplectrona maligna (Hagen, 1859): Flint 2001: 93-94: "The collection of material of both sexes and comparison with the lectotype of $D$. maligna and holotype of D. kirimaduhela confirms the synonymy of these species.

Remarks. Among the material examined (Flint 2001), the holotype, collected by Schmid, the only specimen of this species described on was listed together with a male specimen collected from the same habitat by Flint as well as by 15 other male specimens collected from other habitats. However, the drawings of the genital structure of the lectotype of $D$. maligna (Hagen, 1859) drawn by Flint and the genital structure of the holotype of D. kirimaduhela Schmid, 1958 drawn in the original description by Schmid are extremely different, representing definitely two different species. Therefore here we reinstate the independent species status of Diplectrona kirimaduhela Schmid, 1958 stat. restit.

\section{Diplectrona shimoga sp. nov.}

(Figures 154-158, Map 12)

Material examined. Holotype: India, Karnataka, Shimoge District, Jog Falls, 14¹3'45.4"N $74^{\circ} 48^{\prime} 44.9^{\prime \prime} \mathrm{E}$, on MV lamps at the bungalows, 2.III.1980, leg. Gy. Topal (1 male, OPC).

Diagnosis. This new species having bilobed complex of segment X and XI that is the cerci, the paraproct, the remnant of segment XI and the vestigial segment $X$ fused together is a new member of the Diplectrona coalescens species group. Most close to D. kattalaimala sp. nov. described from Tamil Nadu, but differs by having the dorsal view of apical head of the bilobed fused complex parallel-sided, not capitate; the lateral profile of the phallic organ differently shaped with less robust ventroapical lobe; its apical margin rounded in ventral view, not truncate.

Description. Male (in alcohol). Dark brown animal. Forewings without pattern. Forewing length is $7 \mathrm{~mm}$, apical fork I present on hindwing. Eyes setaless, not enlarged. Maxillary palp formula I-IV-III-II-V. Anterodorsal filament on sternite $\mathrm{V}$ lacking, there are not any internal reticulated sacs present in segment VIII. 


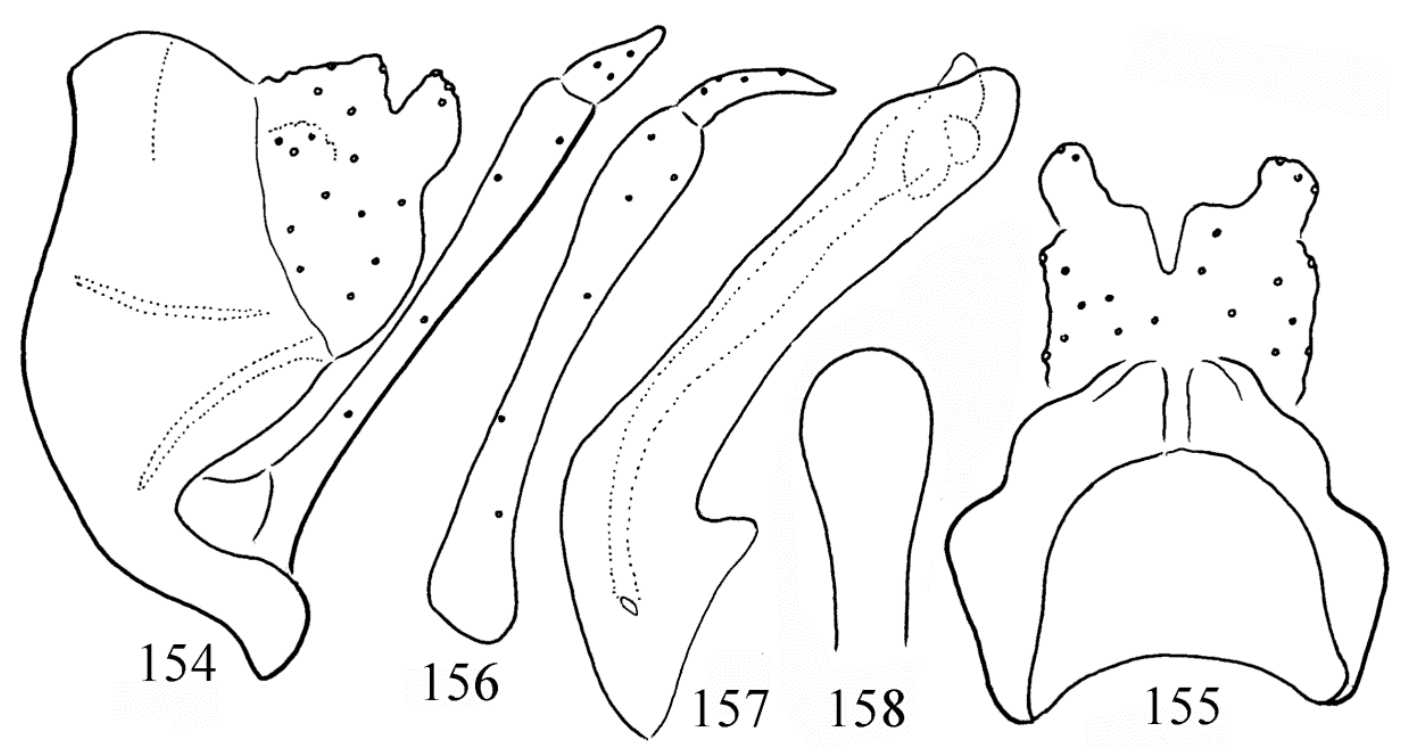

Figures 154-158. Diplectrona shimoga sp. nov. Holotype: $154=$ male genitalia in left lateral view, $155=$ male genitalia in dorsal view, 156 = left gonopod in ventral view, 157 = phallic organ in left lateral view, $158=$ phallic head in ventral view.

Male genitalia. Segment IX convex anterad, dorsum long and flat with a middle depression line. Segment X fused to the tergum IX. The dorsoapical setose lobes (mesal plate or inner lobes) and the unsetose paraproct (outer lobes or lateral plates of segment X) fused together. Cerci form a large setose area in lateral view, visible both in lateral and dorsal view. Gonopods are robust, almost straight with less dilated apical region; the tapering harpago mesad turning. Phallic apparatus with slightly downward curving and broadening basal and tube-forming apicad broadening sections; two pairs of endothecal processes badly discernible; phallotremal sclerite less distinct.

Etymology. shimoga named after the locus typicus of the holotype.

\section{Diplectrona gombak new species group}

Species group having paraproct (lateral plate or outer lobe of segment X) with elongated dorsal profile combined with variously long dorsoapical setose lobes of segment X (mesal plate or inner lobe of segment X). The basic structure of the elongated dorsal profile of the paraproct and the variously blunt apex of the dorsoapical setose lobes are rather stable with a small range of shape divergences. Species delineation in the new species group is based (1) on the lateral and dorsal comparative profiles of the cerci, paraprocts and the dorsoapical setose lobes; (2) on the lateral profile of the phallic organ; (3) on the ventral view of the phallic apex and on the ventral view of the harpago. There are discernible divergences between the species also in the shape of the endothecal processes and the phallotremal sclerite. However these structures are very movable; functional in almost all the three dimensions therefore has no stable and comparable observational view. We have delineated four new species complexes in the Diplectrona gombak new species group: Diplectrona albofasciata new species complex, Diplectrona fasciata new species complex, Diplectrona gentinga new species complex, Diplectrona gombak new species complex.

\section{Diplectrona albofasciata new species complex}

This small new species complex having elongated paraproct belongs to the Diplectrona gombak new species group and is characterized by the laterad produced apicolateral region of the setaless paraproct. Three known species comprise the species complex: D. albofasciata, D. diana, $D$. furia. 


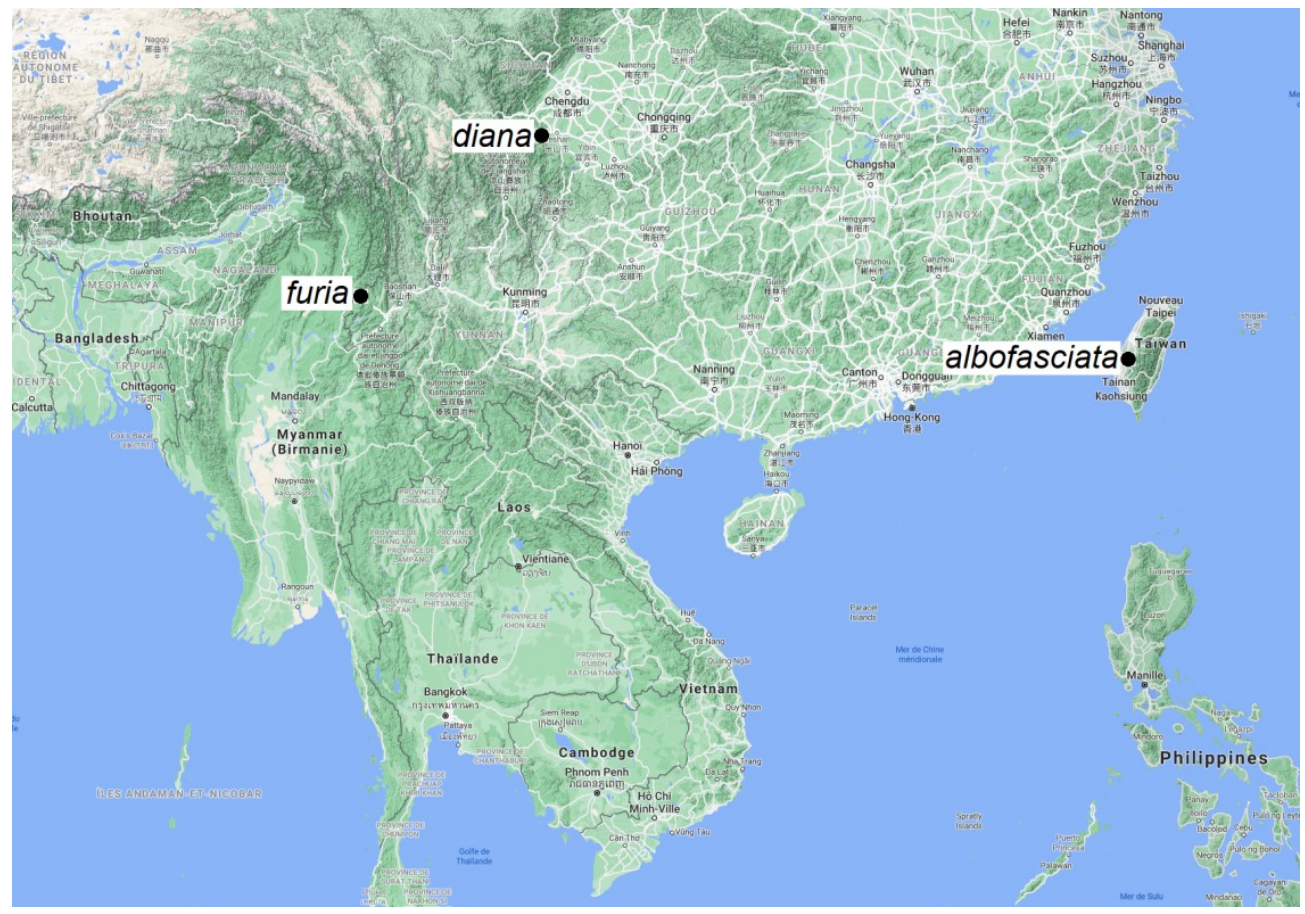

Map 13. Diplectrona albofasciata complex.

\section{Diplectrona albofasciata (Ulmer, 1913)}

(Map 13)

Hydromanicus albofasciatus Ulmer, 1913:49-50, "Formosa. Leg. Hans Sauter. Material: 16 đoㅇ, Taihorinsho, $[=$ currently Dalin of Kagi County, $23.60^{\circ} \mathrm{N}, 120.47^{\circ} \mathrm{E}$, found on: https://zenodo.org/

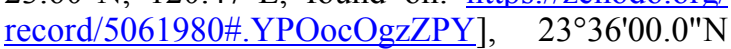
$120^{\circ} 28^{\prime} 12.0 " \mathrm{E}, \mathrm{IX} .-\mathrm{X} .1909$; Taihorin, VIII.1910." "Forderflügel (Figur) graubraun, mit dichter schwarzbrauner Behaarung und drei breiten, oft aus einzelnen Flecken zusammengesetzten, silberwei $\beta$ behaarten Querbinden."

Diplectrona albofasciata (Ulmer, 1913): Malicky 2002:1204. Based on the genital structure Diplectrona albofasciata was related to D. diana Malicky, 2002 from China, Sichuan and to D. furia Malicky, 2002 from Myanmar.

Remarks. Information cited here for mapping the ditribution of the complex.

\section{Diplectrona diana Malicky, 2002}

(Map 13)

Diplectrona diana Malicky, 2002:1206. "Material: China, Setschuan, Qingying Pavilion, Jingshui, E- mei Shan, $180 \mathrm{~km}$ SW Chengdu, 800-1200m, [=Emeishan, in the surrounding of Mount Emei], $29^{\circ}$

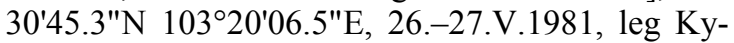
selak, CM: 1 ठ (Holotypus)."

Remarks. Information cited here for mapping the ditribution of the complex.

\section{Diplectrona furia Malicky, 2002}

(Figures 159-163, Map 13)

Diplectrona furia Malicky, 2002:1209. "Material: Myanmar, Kambaiti, $7000 \mathrm{ft}$., [=Kan Paik Ti], 25'24' $22.8^{\prime \prime} \mathrm{N} 98^{\circ} 07^{\prime} 03.8^{\prime \prime} \mathrm{E}, 11 . \mathrm{V} .1934$, leg. Malaise, NRS: $1 \hat{\jmath}$ (Holotypus). Do., 25.V.1934, CM: $1 \hat{\partial}$ (paratypus)."

Material examined. Myanmar, N.E. Burma, Kambaiti, 2000m, 4.V.1934, leg. R. Malaise, Coll. Malaise B.M. 1938-258, (4 males, BMNH). Myanmar, N.E. Burma, Kambaiti, 2000m, 7.9.V.1934, leg. R. Malaise, Coll. Malaise B.M. 1938-258, (4 males, BMNH). Myanmar, N.E. Burma, Kambaiti, 2000m, 16.V.1934, leg. R. Malaise, Coll. Malaise B.M. 1938-258, (1 male, $\mathrm{BMNH}$ ). 


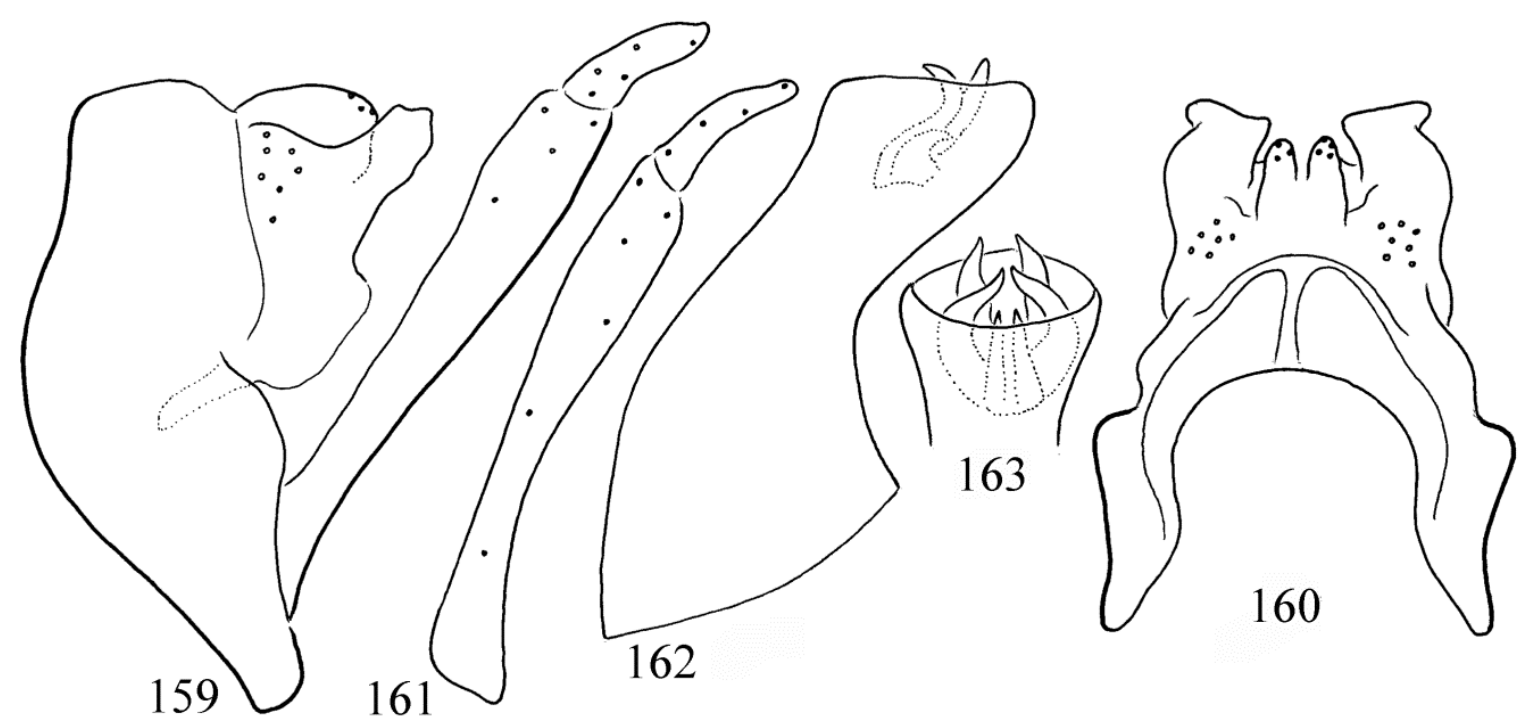

Figures 159-163. Diplectrona furia Malicky, 2002. 159 = male genitalia in left lateral view, 160 = male genitalia in dorsal view, $161=$ left gonopod in ventral view, 162 = phallic organ in left lateral view, $163=$ phallic head in ventral view.

Remarks. We have redrawn a male representing the exact lateral profile of the phallic organ of all the examined nine specimens. It is significantly different from the drawings of Malicky (2002). Particularly the lateral profile of the paraproct head differs as well as the lateral profile of the ventroapical region of the phallic organ is more produced.

\section{Diplectrona fasciata new species complex}

Species of this complex have been described as near to Diplectrona fasciata female holotype. The specific delineation of this colourful female (see Ulmer 1907: Genera Insectorum!) was based on the presence of silverwhite transversal band from costa to postcosta on the forewing before the pterostigma. The true genuine male of this beautiful female has not been associated yet to the $D i$ plectrona fasciata female!

Ulmer $(1930,1951)$ tried to associate and describe Diplectrona fasciata males with the holotype female having light crossvein on forewings from Buitenzorg, Java (Ulmer 1909), from Panaon Island and from Mindanao Island (Tonkulan, Port Banga) of Philippines (Ulmer 1930:399-400) as well as from South Sumatra (Wai Lima), North Sumatra (Simalur Island) and West Sumatra (Fort de Kock) (Ulmer 1930:455-457). However, according to the published drawings they are different species as will be delineated and described here.

\section{Diplectrona buitenzorga sp. nov.}

(Map 14)

Hydromanicus fasciatus Ulmer, 1905a: Ulmer 1909: 138-139. Misidentification.

Material. Syntypes: Indonesia, Java, Buitenzorg (Bogor), 6³5'50.8"S 106²8'20.7"E, Sept. 1907, resp. April 1908, leg. E. Jacobson (2 males, Leidener Museum).

Diagnosis. Diplectrona buitenzorga sp. nov. from Buitenzorg (Bogor), Java, Indonesia, having elongated paraproct belongs to the Diplectrona gombak species group and the silverwhite transversal band on forewing relates it to the Diplectrona fasciata species complex. It has resemblance to Diplectrona wailima sp. nov. described from South Sumatra, but differs by the coneshaped fused dorsoapical setose lobes in dorsal view completely fused, not divided and not rounded. The paraproct robust straight pointed in dorsal view, not slender with mesad turning pointed apices. 


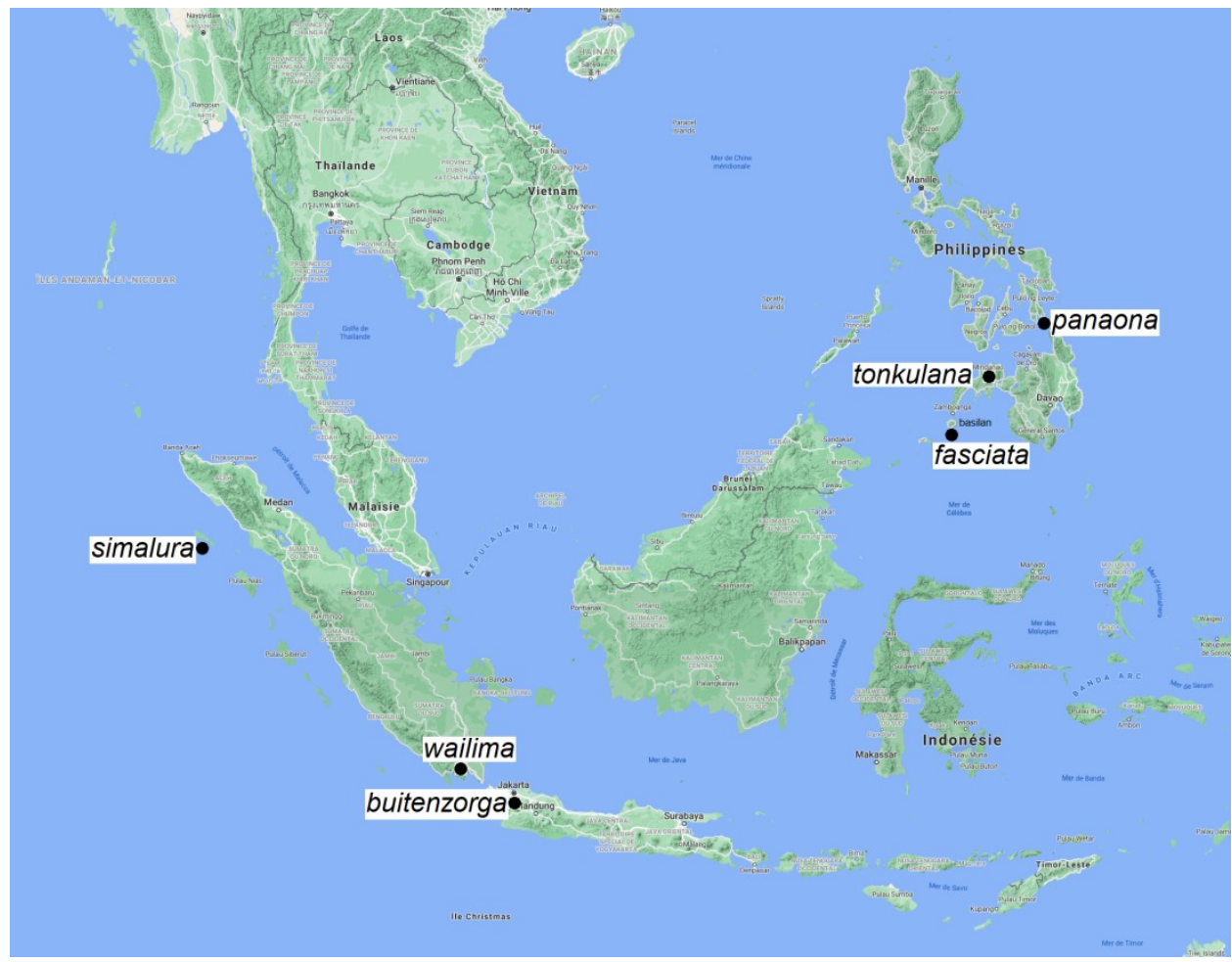

Map 14. Diplectrona fasciata complex.

Description. (Figure: Ulmer, 1909: Figure 13). Antennae two-coloured, the basal region darker, distal region whitish. Forewing steelblue, transversal band sometimes small; body length $6 \mathrm{~mm}$; wingspan $13 \mathrm{~mm}$. Anterodorsal filament on sternite $\mathrm{V}$ long reaching to segment IX.

Male genitalia. Dorsoapical setose lobe (inner lobes) fused and cone-shaped in dorsal view, as long as the paraproct (outer lobes); paraproct straight and sharply pointed in dorsal view, downward directed in lateral view. Phallic head seems rounded truncate in dorsal view and supplied with a pair of fine pointed stuctures.

Etymology. buitenzorga, named after the locus typicus of the syntypes.

\section{Diplectrona fasciata (Ulmer, 1905)}

(Map 14)

Hydromanicus fasciatus Ulmer, 1905a:93. "1 $q$ im Stettiner Museum, bezeichnet: Philippinen, Bazilan. II. III. 98, Doherty."
Hydromanicus fasciatus: Ulmer 1907: “H. fasciatus, Ulmer, Stett. Ent. Zeit. Vol. 66, p. 93 (1905) (Philippinen). Colourful habitus drawing published: table 38, figure 7 .

Remarks. Diplectrona fasciata Ulmer, 1905 was described from a single female collected in Bazilan (Basilan) Island, Philippines. The description and the delineation are based primarily on the forewing pattern with the light, silverwhite transversal band around middle, from costa to postcosta before the pterostigmal area. The Diplectrona fasciata female association with a male from Basilan Island has not been confirmed up to now (Mey 1997).

\section{Diplectrona panaona sp. nov.}

(Map 14)

Hydromanicus fasciatus Ulmer, 1905a: Ulmer 1930: 399-400. Philippines: "Material: 1 ô, leg. Boettcher, in meiner Sammlung: Panaon, 2.XII. 1915." 
Material. Holotype: Philippines, Panaon Island, 2.XII.1915. leg. Boettcher (1 male, CeNak).

Diagnosis. Diplectrona panaona sp. nov. from Panaon Island, Philippines, having elongated paraproct belongs to the Diplectrona gombak species group and the silverwhite transversal band on forewing relates to the Diplectrona fasciata species complex. It has resemblance to Diplectrona buitenzorga sp. nov. described from Java, and to the Diplectrona wailima sp. nov. described from South Sumatra, but differs by the laterad directed paraproct with rounded apices, not straight and pointed like at D. buitenzorga sp. nov. and not mesad directed and pointed like at D. wailima sp. nov.

Description. (Figures: Ulmer 1930: figure 35 and Ulmer 1951: figures 483-485). Antennae one and a half times longer than forewing, the first 23 segment redish yellow others dark brown or black brown. Forewing greybrown, transversal band silverwhite; body length $6 \mathrm{~mm}$; wingspan 13 $\mathrm{mm}$.

Male genitalia. Dorsoapical setose lobe (inner lobes) fused with rounded apex in dorsal view, slightly shorter than the paraproct (outer lobes); paraproct laterad curving with rounded apex, downward located of the inner lobes in lateral view. Phallic head seems robust and complex.

Etymology. panaona, named after the locus typicus of the holotype.

\section{Diplectrona simalura sp. nov.}

(Map 14)

Hydromanicus fasciatus Ulmer, 1905a: Ulmer 1930: 455-457. Misidentification.

Material examined. Syntypes: Indonesia, Sumatra, North Sumatra, Sinabang, Simalur Island, [=Timur, Simeulue, Aceh], 2०28'15.4"N 96 $22^{\prime}$ 04.4"E, VII. 1913. leg. E. Jacobson (2 males, Leidener Museum).

Diagnosis. Diplectrona simalura sp. nov. from Sinabang, Simalur Island, North Sumatra, Indo- nesia, having elongated paraproct belongs to the Diplectrona gombak species group and the silverwhite transversal band on forewing relates it to the Diplectrona fasciata species complex. It has resemblance to Diplectrona buitenzorga sp. nov. described from Java, but differs by the rounded dorsoapical setose lobes in dorsal view that appear with pronounced concave apex, not convex. Dorsoapical setose lobes, the inner lobes of segment X clearly concave, not convex like at $D i$ plectrona panaona $\mathrm{sp}$. nov.

Description. (Figure: Ulmer 1930: Figure 121). Antennae two-coloured, the basal region darker, distal region yellowish. Forewing steelblue with light transversal band; Anterodorsal filament on sternite V long reaching to segment IX.

Male genitalia. Dorsoapical setose lobe (inner lobes) fused with concave apex in dorsal view, shorter than the paraproct (outer lobes); paraproct straight and sharply pointed in dorsal view, downward directed in lateral view. Phallic head seems simple.

Etymology. simalura, named after the locus typicus of the syntypes.

Diplectrona tonkulana sp. nov.

(Map 14)

Hydromanicus fasciatus Ulmer, 1905a: Ulmer 1930: 399-400. Misidentification.

Material examined. Holotype: Philippines, Tonkulan, Mindanao Island, 11.VI.1915. leg. Boettcher (1 male, CeNak).

Diagnosis. Diplectrona tonkulana sp. nov. from Tonkulan, Mindanao Island, Philippines, having elongated paraproct belongs to the $\mathrm{Di}$ plectrona gombak species group and the silverwhite transversal band on forewing relates it to the Diplectrona fasciata species complex. It has resemblance to Diplectrona panaona sp. nov. described from Panaon Island, Philippines, but differs by the clearly subdivided apex of the dorsoapical setose lobe, the inner lobes of segment X, by the length of the inner lobes that are longer 
than paraproct, as well as by the differently patterned apex of the phallic organ.

Description. (Figures: Ulmer 1951: figures 486-487). The first 2-3 segments of antennae redish yellow others dark brown or black brown. Forewing greybrown, transversal band silverwhite; body length $6 \mathrm{~mm}$; wingspan $13 \mathrm{~mm}$.

Male genitalia. Dorsoapical setose lobe (inner lobes) fused with bilobed apex in dorsal view, slightly longer than the paraproct (outer lobes); paraproct straight with rounded apex. Phallic head seems complex.

Etymology. tonkulana, named after the locus typicus of the holotype

\section{Diplectrona wailima sp. nov.}

(Map 14)

Hydromanicus fasciatus Ulmer, 1905a: Ulmer 1930: 455-457. Misidentification.

Material. Syntypes: Indonesia, Sumatra, Wai Lima, 5²5'37.8"S 10501'26.3"E, XI-XII. 1921. No 432, leg. H. Karny (2 males, Leidener Museum)

Diagnosis. Diplectrona wailima sp. nov. from Wai Lima, Sumatra, Indonesia, having elongated paraproct belongs to the Diplectrona gombak species group and the silverwhite transversal band on forewing relates to the Diplectrona fasciata species complex. It has resemblance to Diplectrona buitenzorga sp. nov. described from Java, but differs by the rounded dorsoapical setose lobes in dorsal view that appear divided by a pronounced median keel, not without such a median keel and not cone-shaped. The paraproct slender with mesad turning pointed apices in dorsal view, not robust straight pointed. Phallic head complex, not simple.

Description. (Figure: Ulmer 1930: Figures 122-123). Antennae two-coloured, the basal region darker, distal region yellowish. Forewing steelblue, transversal band sometimes small; body length $6 \mathrm{~mm}$; wingspan $13 \mathrm{~mm}$. Anterodorsal filament on sternite $\mathrm{V}$ long reaching to segment IX.

Male genitalia. Dorsoapical setose lobe (inner lobes) fused and cone-shaped in dorsal view, as long as the paraproct (outer lobes) and armed with a pronounced median keel; paraproct straight and sharply pointed in dorsal view, downward directed in lateral view. Phallic head seems robust and complex.

Etymology. wailima, named after the locus typicus of the syntypes.

\section{Diplectrona gentinga new species complex}

This small complex of species having elongated paraproct belongs to the Diplectrona gombak new species group and delimited by the unique, complex phallic head. Two species are known from this complex: Diplectrona stigmatica Banks, 1937 and the nominate species Diplectrona gentinga sp. nov.

\section{Diplectrona stigmatica Banks, 1937, stat. nov.}

$$
\text { (Map 15) }
$$

Diplectrona fasciata var. stigmatica var. nov. Banks, 1937:164-165. Philippines: "Mindanao, Davo Province, Mount Apo, 659'14.1"N 12516'15.3"E, Mainit River, altitude 6,000 feet, September 7, 10, 14, and 22, October 21; Galog River, altitude 6,000 feet, October 23, November 4 (Clagg): Zamboanga, $7^{\circ} 03^{\prime} 59.4^{\prime \prime N} 122^{\circ} 06^{\prime} 59.9^{\prime \prime E}$ (Clark). Luzon, Mountain Province, Baguio, 16²3'30.5"N 120³7'24.9"E (Baker). Type, M.C.Z. No. 22061."

Diplectrona fasciata stigmatica Banks, 1937: Mey 1997: "The species was described as a variation of D. fasciata (Ulmer, 1905a). The external characters, e.g. wing pattern and body coloration, however, quite distinct. The structure of the genitalia differs from the other known species from the Philippines. At present one can not decide whether it is a valid species or a subspecies or D. fasciata itself (see remarks under D. cinctipennis).

Remarks. Diplectrona fasciata (Ulmer, 1905) was described from Basilan Island of Phillipines based on a female having light transversal band on the forewing. Later, Ulmer and Banks have related several species with some kind of transversal 


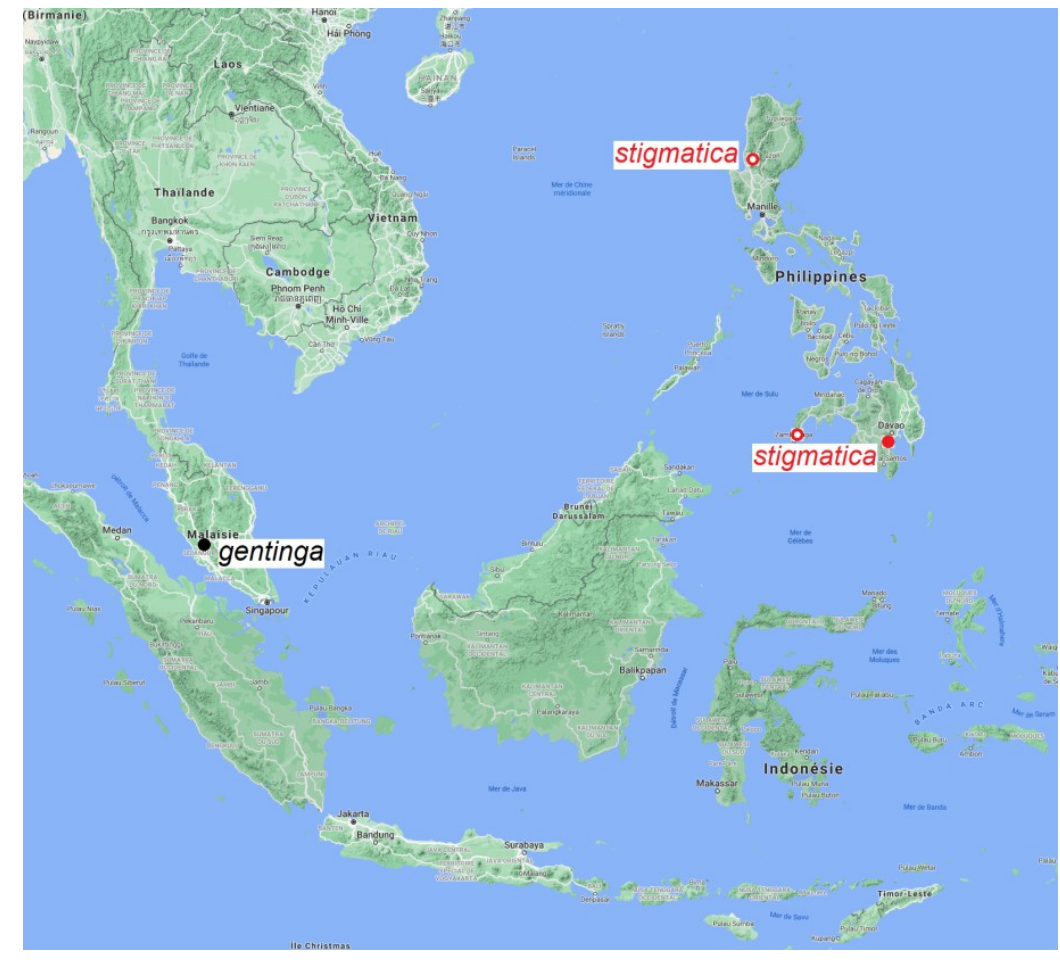

Map 15. Diplectrona gentinga complex.

forewing band from various regions including Diplectrona fasciata var. stigmatica near to Diplectrona fasciata. However, this species has a unique phallic head not any other species of the Diplectrona genus has such phallic divergence in the Palaearctic and Oriental fauna region except our new species Diplectrona gentinga sp. nov. from Malaysia, Pahang. We raise the taxonomic status of this taxon to species rank: Diplectrona stigmatica banks, 1937 stat. nov.

\section{Diplectrona gentinga sp. nov.}

(Figures 164-167, Map 15)

Material examined. Holotype: Malaysia, W. Pahang, Genting Tea Estate, $2000 \mathrm{ft} ., 3^{\circ} 23^{\prime} 43.4^{\prime \prime} \mathrm{N}$ $101^{\circ} 46^{\prime 22} .1^{\prime \prime E}, \mathrm{XI} .1981$, Malaise trap by stream, leg. K. R. Robinson, B.M. 1981-549 (1 male, $\mathrm{BMNH})$.

Diagnosis. This species having elongated dorsal profile of the paraproct with elongated segment X belongs to the Diplectrona gombak spe cies group. Having the rather conservative, stable, less diverging, not diverse structure of the inner and outer lobes it has slight modification compared to other species. However, it has a rather unique phallic head with a complex of various appendages. A single species has somewhat similarly complex phallic head, Diplectrona stigmatica Banks, 1937 stat. nov., but Diplectrona gentinga sp. nov differs by having very stout coxopodite, differently shaped ventral profile of the harpago, different dorsal and lateral profiles of the dorsoapical setose lobes and the paraproct as well as the basically similar phallic head has different fine structure.

Description. Male (in alcohol). Dark brown animal. Forewings without pattern. Forewing length $9 \mathrm{~mm}$, apical fork I present on hindwing. Eyes setaless not enlarged. Maxillary palp formula I-III-II-IV-V. Abdominal segments without any reticulated internal sacs. Filaments on sternite V are very long reaching almost to segment IX.

Male genitalia. Segment IX convex anterad. Segment $\mathrm{X}$ fused to the tergum IX. The dorso- 


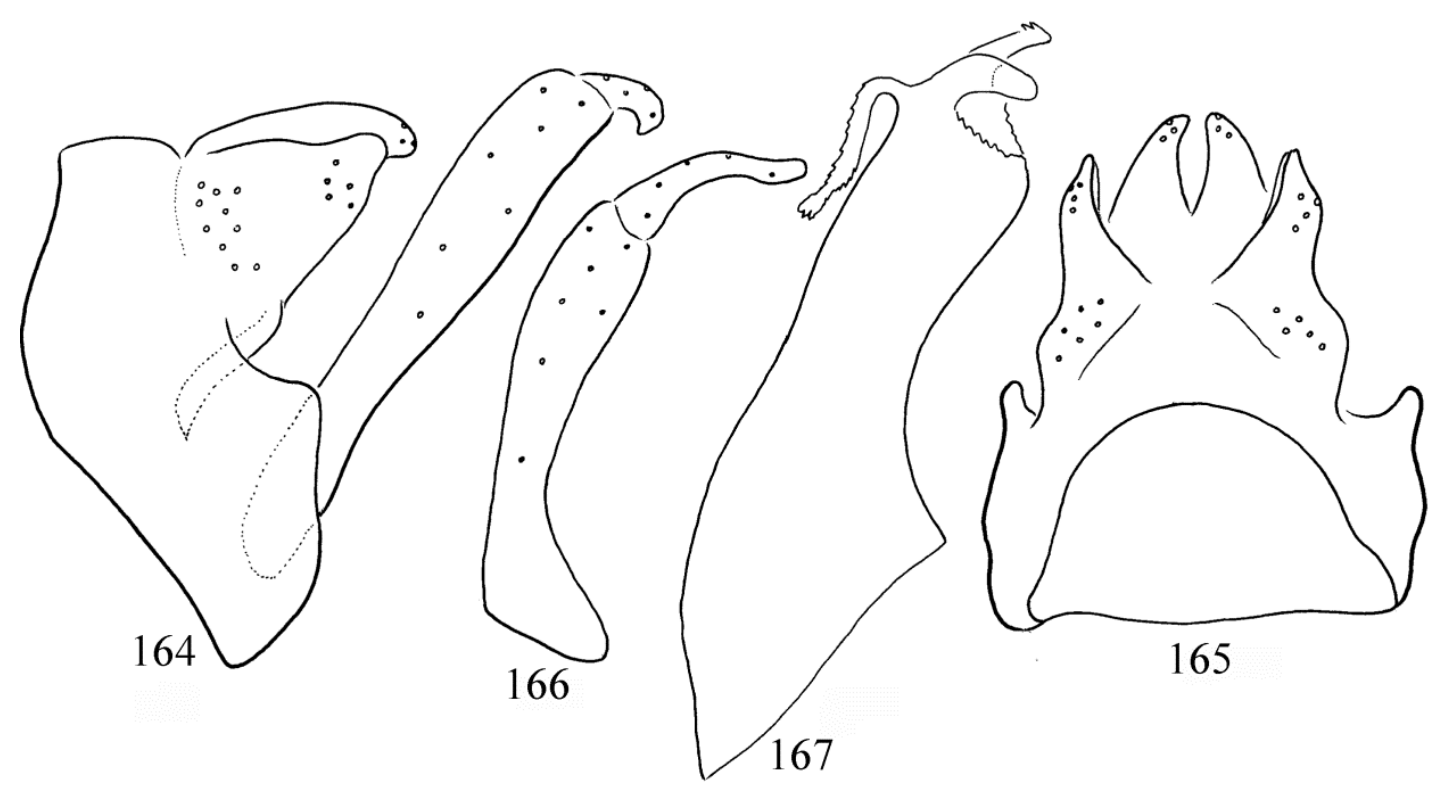

Figures 164-167. Diplectrona gentinga sp. nov. Holotype: $164=$ male genitalia in left lateral view, $165=$ male genitalia in dorsal view, $166=$ left gonopod in ventral view, 167 = phallic organ in left lateral view.

apical setose lobes (inner lobes) of segment X well-developed, broad both in lateral view, tapering and mesad turning in dorsal view; longer than the paraproct. Cerci setose surface shifted basad. Unsetose paraproct (outer lobes or lateral plates of segment X) triangular in lateral and elongated tapering in dorsal view. Gonopods with robust and straight coxopodite; harpago mesad turning with broad base and slightly broadening apical section. Phallic apparatus very robust, head supplied with a dorsal pair of anterad directed long digitiform processes with corrugated surface, a pair of downward turning processes of probably phallothecal origin as well as a single mesad positioned elongation.

Etymology. gentinga, named after the locus typicus of the holotype.

\section{Diplectrona gombak new species complex}

This small complex of species having elongated paraproct belongs to the Diplectrona gombak new species group and is delimited by the upward directed paraproct with narrowing head.
In his treatment on Asian species of the genus Diplectrona Malicky (2002) has identified specimens from Malaysia, Perak, Sarawak, Sabah (Borneo), Indonesia, Kalimantan (Borneo), Sumatra and Thailand as Diplectrona dulitensis as well as specimens from Malaysia: Selangor, $\mathrm{Pa}-$ hang, Johor, Perak, Penang as well as from Thailand as Diplectrona gombak Oláh, 1993. Malicky (2002) himself considered these identifications based on the principles of "species with wide distribution and great variability" as well as on practices of gross phenomics rather doubtful judging from the great shape divergences of the drawn specimens from various localities.

\section{Diplectrona aspersa Ulmer, 1905}

Hydromanicus aspersus Ulmer 1905b:95-96. "2 bez. Java im Stettiner Museum; ferner 4 Exemplare $\left(1 \hat{O}^{\lambda}, 3\right.$ ㅇ $)$ im Wiener Museum, bez. Fruhstorfer. Java, [this locality remains unknown in the Java Island]. 1894;"

Diplectrona aspersa (Ulmer, 1905): Ulmer, 1951: 314-317: "Heimat: Java, Type (ठ) im Museum Wien." Transferred from Hydromanicus genus to the Diplectrona genus. 
Diplectrona aspersa (Ulmer, 1905): Malicky 2002: 1204. "Material: Java 1894, Fruhstorfer, NHMW: $1{ }^{\uparrow}$ (Holotypus)." Partially injured genitalia redrawn.

\section{Diplectrona barisana sp. nov.}

(Figures 168-172, Map 16)

Diplectrona dulitensis Kimmins, 1955: Oláh \& Johanson 2010:18. Misidentification.

Material examined. Holotype: Indonesia, Sumatra, Bukit Barisan Selatan National Park, Barisan Mts., around this point: $3^{\circ} 00^{\prime} 25.3^{\prime \prime S} 102^{\circ} 15^{\prime}$ 03.2"E, Way Pitias, 800m, 17-19.VI.2008, light trap leg. J. Oláh jr. (1 male, OPC). Paratypes: same as holotype (2 males, SMNH; 1 male, OPC). Indonesia, Sumatra, Way Titias, Bukit Barisan Selatan NP, 850 m, 4.VI.2012, UV light trap leg. J. Oláh jr. (1 male OPC).

Diagnosis. This species having elongated dorsal profile of the paraproct with elongated segment X belongs to the Diplectrona gombak species group and the elongated upward directed paraproct relates it to the Diplectrona gombak species complex. It is most close to Diplectrona dulitensis Kimmins, 1955, but differs by the robust broad lateral profile of the paraproct, by pronounced lobe-like cerci, by the sagittaly very flat coxopodite of the gonopods and the harpago with its basal constriction.

Description. Male (in alcohol). Dark brown animal. Forewings without pattern. Forewing length $9 \mathrm{~mm}$, apical fork I present on hindwing. Eyes setaless not enlarged. Maxillary palp formula I-III-II-IV-V. Abdominal segments without any reticulated internal sacs. Filaments on sternite V are very long reaching almost to segment IX.

Male genitalia. Segment IX convex anterad, dorsum longer than ventrum. Segment $\mathrm{X}$ fused to the tergum IX. The dorsoapical setose lobes (inner lobes) of segment $\mathrm{X}$ well-developed, broad in lateral view, digitiform in dorsal view, wellseparated from each others and little longer than the paraproct. Cerci setose, elongated both in lateral and dorsal views. Unsetose paraproct (outer lobes or lateral plates of segment X) upward directed with pointed apex. Gonopods with robust and straight coxopodite, very flat in saggital plane; harpago mesad turning with constricted base. Phallic apparatus with high and long phallobase; phallothecal shaft tube-like; head of phallotheca truncate. Endothecal and phallotremal sclerites withdrawn.

Etymology. barisana, named after the locus typicus of the holotype.

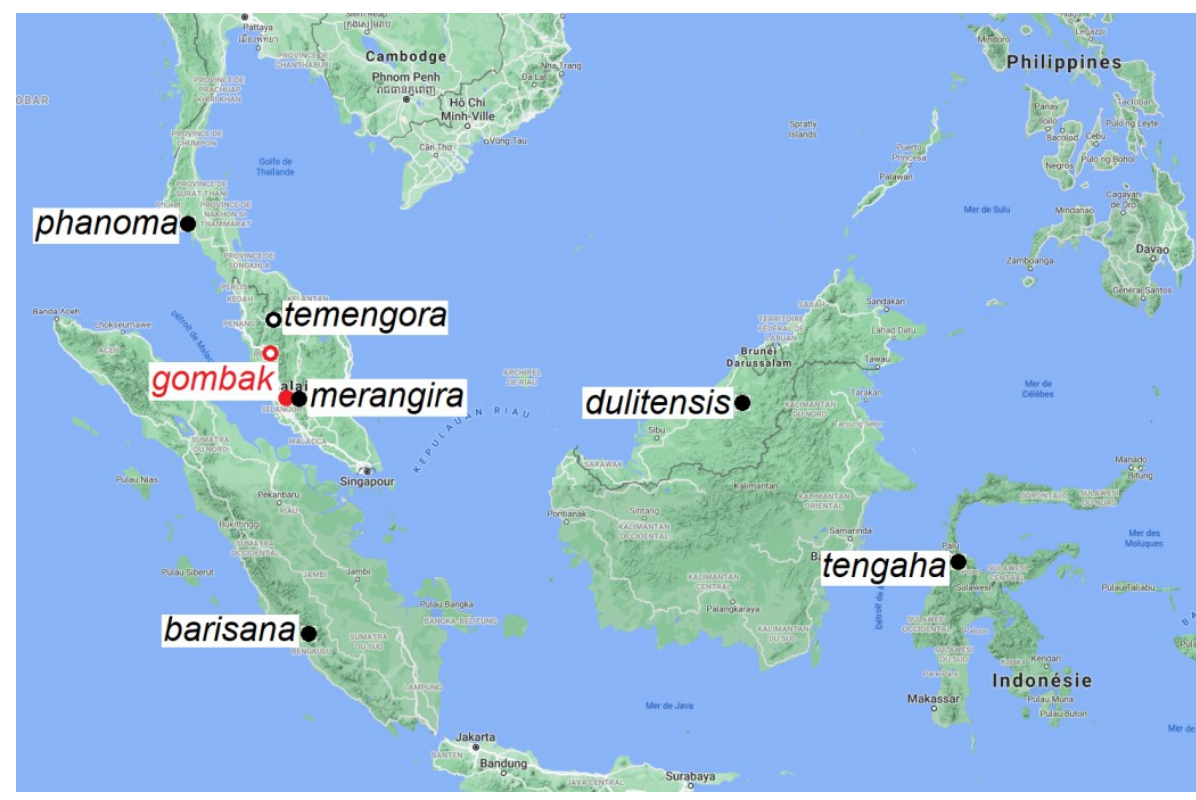

Map 16. Diplectrona gombak complex. 


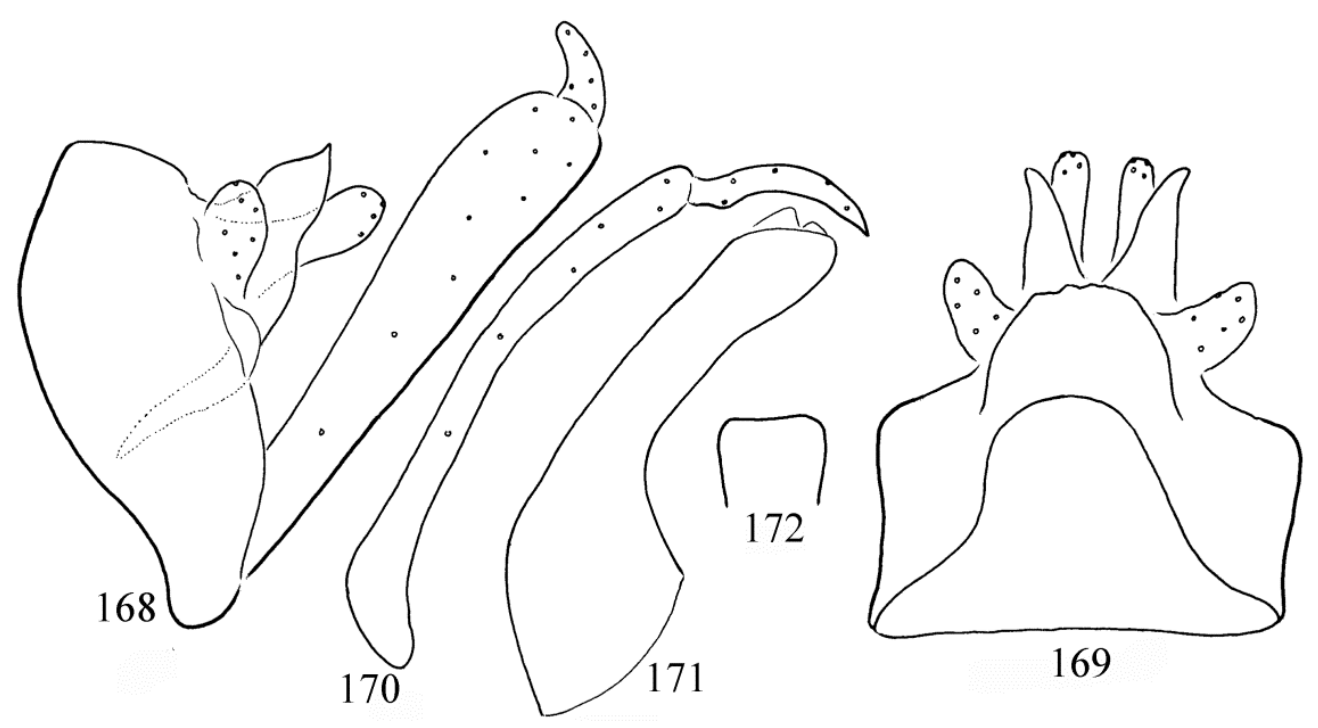

Figures 168-172. Diplectrona barisana sp. nov. Holotype: $168=$ male genitalia in left lateral view, $169=$ male genitalia in dorsal view, $170=$ left gonopod in ventral view, $171=$ phallic organ in left lateral view, $172=$ phallic head in ventral view.

\section{Diplectrona dulitensis Kimmins, 1955}

(Map 16)

Diplectrona dulitensis Kimmins, 1955:393-394. Described from Malaysia, Sarawak." 1 , foot of Mt. Dulit, junction of rivers Tinjar and Lejok, 30.VIII. 1932. 1 J, Mt. Dulit, R. Koyan, 2500 ft., around this point: $3^{\circ} 14^{\prime} 59.0^{\prime \prime} \mathrm{N} 114^{\circ} 14^{\prime} 58.9^{\prime \prime} \mathrm{E}$, primary forest, 19.X.1932." Type depository: BMNH

Diplectrona dulitensis Kimmins, 1955: Malicky 2002: 1206. In his treatment on Asian species of the Diplectrona genus applying the principles of "species with wide distribution and great variability" as well as the practice of gross phenomics, Malicky (2002) has identified specimens from Malaysia, Perak, Sarawak, Sabah (Borneo), Indonesia, Kalimantan (Borneo), Sumatra and Thailand as Diplectrona dulitensis. These are probably different incipient sibling species. Two specimens were drawn with great structural divergences in the shapes of speciation traits. One specimen from North Sumatra described here as Diplectrona merangira sp. nov. an other specimen from Thailand, described here as Diplectrona phanoma sp. nov.

\section{Diplectrona gombak Oláh, 1993}

(Map 16)

Diplectrona gombak Oláh, 1993:99-100: "Holotype đૈ. Tributary of River Sungai Gombak, $30 \mathrm{~km}$ from
Kuala Lumpur, around this point: $3^{\circ} 17^{\prime} 00.4^{\prime \prime} \mathrm{N} 101^{\circ}$ 43'47.5"E, 21.XII.1991. Light collected by Oláh. Paratype ${ }^{\lambda}$. Same as holotype." Described close to Diplectrona dulitensis Kimmins, 1955. Type depository: OPC.

Diplectrona gombak Oláh, 1993 (part.): Malicky 2002: 1209. In his treatment on Asian species of the Diplectrona genus Malicky (2002) has identified several specimens from Malaysia: Selangor, $\mathrm{Pa}-$ hang, Johor, Perak, Penang as well as from Thailand as Diplectrona gombak Oláh, 1993. Only a single specimen was drawn however, it surely represents a still undescribed species. Unfortunately, it is not indicated whether the drawn specimen is from one of the five Malaysian states or from Thailand. Here thus we are unable to describe it.

Material examined. Holotype and paratype: Malaysia, Selangor, Tributary of River Sungai Gombak, $30 \mathrm{~km}$ from Kuala Lumpur, 21.XII. 1991, light leg. J. Oláh (Holotype and 1 male paratype, OPC). Malysia, Perak, Halong stream, IX-XII.1993, light leg. G. S. Robinson (46 males, OPC).

\section{Diplectrona merangira sp. nov.}

(Map 16)

Diplectrona dilutensis Kimmins, 1955: Malicky 2002: 1206. Misidentification. 
Material. Syntype: Malicky 2002:1206. Indonesia, Sumatra, "über 80 ते $\sigma^{\lambda}$ von ca. 20 Ort in Nord-Sumatra von verschiedenen Daten, leg. Diehl, Sivec, Malicky, Heiss (1 male, drawn specimen with cleared genitalia, collected in Dolok Merangir, $3^{\circ} 08^{\prime} 50.0^{\prime \prime} \mathrm{N} \quad 9^{\circ} 07^{\prime} 35.7^{\prime \prime} \mathrm{E}$, North Sumatra, Indonesia, MPC).

Diagnosis. Diplectrona merangira sp. nov. from Dolok Merangir, North Sumatra, Indonesia, having elongated paraproct belongs to the $D i$ plectrona gombak species group and the elongated upward directed paraproct relates to the $D i$ plectrona gombak species complex. It has resemblance to Diplectrona barisana sp. nov. described from South Sumatra, but differs by the lateral profile of the paraproct as well as by the dorsal profile of the dorsoapical setose lobes. Moreover the harpago is broad-based, not constricted basad.

Description. (Figures: Malicky 2002: table 2: under name dulitensis, Dolok Merangir). Cerci setose, long. The dorsoapical setose lobes (inner lobes) of segment $\mathrm{X}$ well-developed, slender in dorsal view, longer than paraproct, divided only at the very apex. Unsetose paraproct (outer lobes or lateral plates of segment X) with long broad basal section in lateral view. Gonopods robust, with straight coxopodite of dilating apical half in lateral view; harpago broad-based, mesad turning with narrowing apex in ventral view. Phallic head truncate in ventral view.

Etymology. merangira, named after the locus typicus of the syntypes.

\section{Diplectrona phanoma sp. nov.}

(Map 16)

Diplectrona dulitensis Kimmins, 1955; Malicky 2002: 1206. Misidentification.

Material. Syntypes: Malicky 2002:1206. Thailand, "über 80 ठิ $\delta$ von 8 Orten in Süd- und Mittel-Thailand, leg. Chantaramongkol, Malicky, Schwendinger (1 male, drawn specimen with cleared genitalia, collected in Khao Phanom, Thailand, MPC, 8 14'23.5"N 9901'26.0"E).
Diagnosis. Diplectrona phanoma sp. nov. from Khao Phanom, Thailand, having elongated paraproct belongs to the Diplectrona gombak species group and the elongated upward directed paraproct relates to the Diplectrona gombak species complex. It has resemblance to Diplectrona gombak Oláh, 1993 described from Malaysia, Selangor, but differs by the lateral profile of the paraproct as well as by the dorsal profile of the dorsoapical setose lobes. Moreover the phallic head is excavated with lateral lobes in ventral view, not truncated.

Description. (Figures: Malicky 2002: table 2: under name dulitensis, Khao Phanom). Cerci setose, long. The dorsoapical setose lobes (inner lobes) of segment X well-developed, slender in dorsal view, longer than paraproct, with widely and deeply divided apex in dorsal view. Unsetose paraproct (outer lobes or lateral plates of segment $\mathrm{X})$ with short slender apical section in lateral view. Gonopods robust, with straight coxopodite of dilating apical half in lateral view; harpago broad-based, mesad turning with narrowing apex in ventral view. Phallic head excavated with lateral lobes in ventral view.

Etymology. phanoma, named after the locus typicus of the syntype.

\section{Diplectrona temengora sp. nov.}

(Figures 173-177, Map 16)

Material examined. Holotype: Malaysia, Perak, Temengor Lake, 5³3'27.2"N 101¹8'57.4"E, 10.XII.1993, light leg. G. S. Robinson. Schmid (1 male, OPC).

Diagnosis. This species having elongated dorsal profile of the paraproct with elongated segment X belongs to the Diplectrona gombak species group and the elongated upward directed paraproct relates to the Diplectrona gombak species complex. It is most close to Diplectrona gombak Oláh, 1993, but differs by the robust laterad curving dorsal profile of the paraproct, by the short and robust as well as by the differently shaped, highly constricted shaft of the phallotheca. 


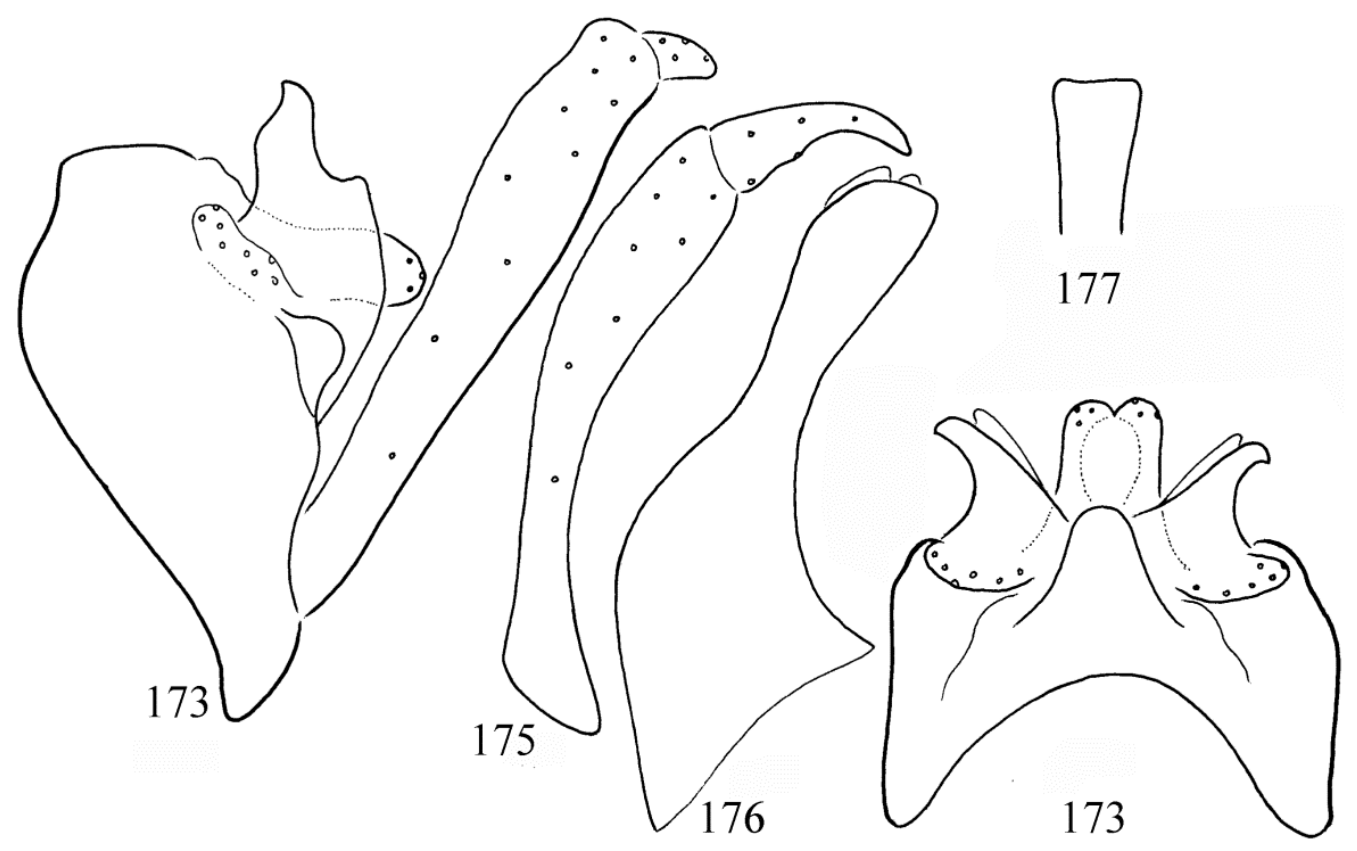

Figures 173-177. Diplectrona temengora sp. nov. Holotype: $173=$ male genitalia in left lateral view, $174=$ male genitalia in dorsal view, 175 = left gonopod in ventral view, $176=$ phallic organ in left lateral view, $177=$ phallic head in ventral view.

Description. Male (in alcohol). Dark brown animal. Forewings without pattern. Forewing length $9 \mathrm{~mm}$, apical fork I present on hindwing. Eyes setaless not enlarged. Maxillary palp formula I-III-II-IV-V. Abdominal segments without any reticulated internal sacs. Filaments on sternite V are very long reaching almost to segment IX.

Male genitalia. Segment IX tripartite posterad, dorsal part fused to segment $\mathrm{X}$, middle part slightly rounded, ventral part smallest; dorsum longer than ventrum. Segment $X$ fused to the tergum IX. The dorsoapical setose lobes (inner lobes) of segment $X$ well-developed, broad both in dorsal and lateral views, little longer than the paraproct. Cerci setose, elongated both in lateral and dorsal views. Unsetose paraproct (outer lobes or lateral plates of segment X) upward directed. Gonopods with robust and straight coxopodite; harpago mesad turning with broad base. Phallic apparatus with high and long phallobase; phallothecal shaft constricted middle; head of phallotheca truncate. Endothecal and phallotremal sclerites withdrawn.

Etymology. temengora, named after the locus typicus of the holotype.

\section{Diplectrona tengaha sp. nov.}

(Map 16)

Diplectrona octomaculata (McLachlan, 1866): Malicky 2002:1215. Misidentification.

Material. Holotype: Malicky, 2002:1215: Indonesia, Sulawesi Tengah: Palolo valley, E. Palu, $800-900 \mathrm{~m}$, around this point: $1^{\circ} 11^{\prime} 08.0^{\prime \prime} \mathrm{S} 120^{\circ}$ 09'37.5"E, 6.X.1985, leg. Weintraub, (1 male, USNM).

Diagnosis. This species having elongated paraproct belongs to the Diplectrona gombak new species group. Has resemblance to Diplectrona octomaculata described from Borneo, but differs by the convex and not deeply concave apical margin of the phallic head in ventral view.

Description. Male (Figures: Malicky 2002: Table 17: octomaculata, Sulawesi).

Male genitalia. Segment IX convex anterad, dorsum long and convex with a middle depression line, ventrum shorter. Segment $X$ fused to the tergum IX. The dorsoapical setose lobes (inner 
lobes) of segment $\mathrm{X}$ well-developed, protruded with knob-like narrowing apicad, broad in lateral view; seem bilobed, but tightly adhered, shorter than paraproct. Cerci setose, high and short in lateral view, semi-circular in dorsal view. Unsetose paraproct (outer lobes or lateral plates of segment X) posterad directed plate in lateral view, and supplied with a subapical lateral lobe in dorsal view. Gonopods slender and their harpago slightly mesad turning with blunt apices. Phallic apparatus with rounded, concave head in ventral view.

Etymology. tengaha, named after the locus typicus of the holotype.

\section{Diplectrona taprobanes new species group}

Species group having paraproct (lateral plate or outer lobe of segment X) with rounded lateral and/or dorsal profile combined with variously long segment $\mathrm{X}$ (mesal plate or inner lobe of segment $\mathrm{X}$ ). Species delineation in the new species group is based (1) on the lateral and dorsal comparative profiles of the cerci and paraprocts; (2) on the lateral profile of the phallic organ; (3) on the ventral view of the phallic apex and on the ventral view of the harpago. There are discernible divergences between the species also in the shape of the endothecal processes and the phallotremal sclerite. However, these structures are very movable; functional in almost all the three dimensions therefore has no stable and comparable observational view.

\section{Diplectrona abmaka sp. nov.}

(Figures 178-182, Map 17)

Material examined. Holotype: Myanmar, North East Burma, Kambaiti, 2000 m, [=Kan Paik

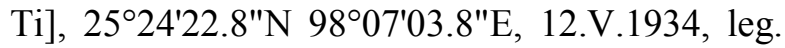
R. Malaise, B.M. 1938-258 (1 male, BMNH). Paratypes: Myanmar, North East Burma, Kambaiti, 2000 m, 18.V.1934, leg. R. Malaise, B. M. 1938-258 (7 males, BMNH). Myanmar, North East Burma, Kambaiti, 7000 ft, 8.VI.1934, leg. R. Malaise, B. M. 1938-258 (1 male, BMNH).

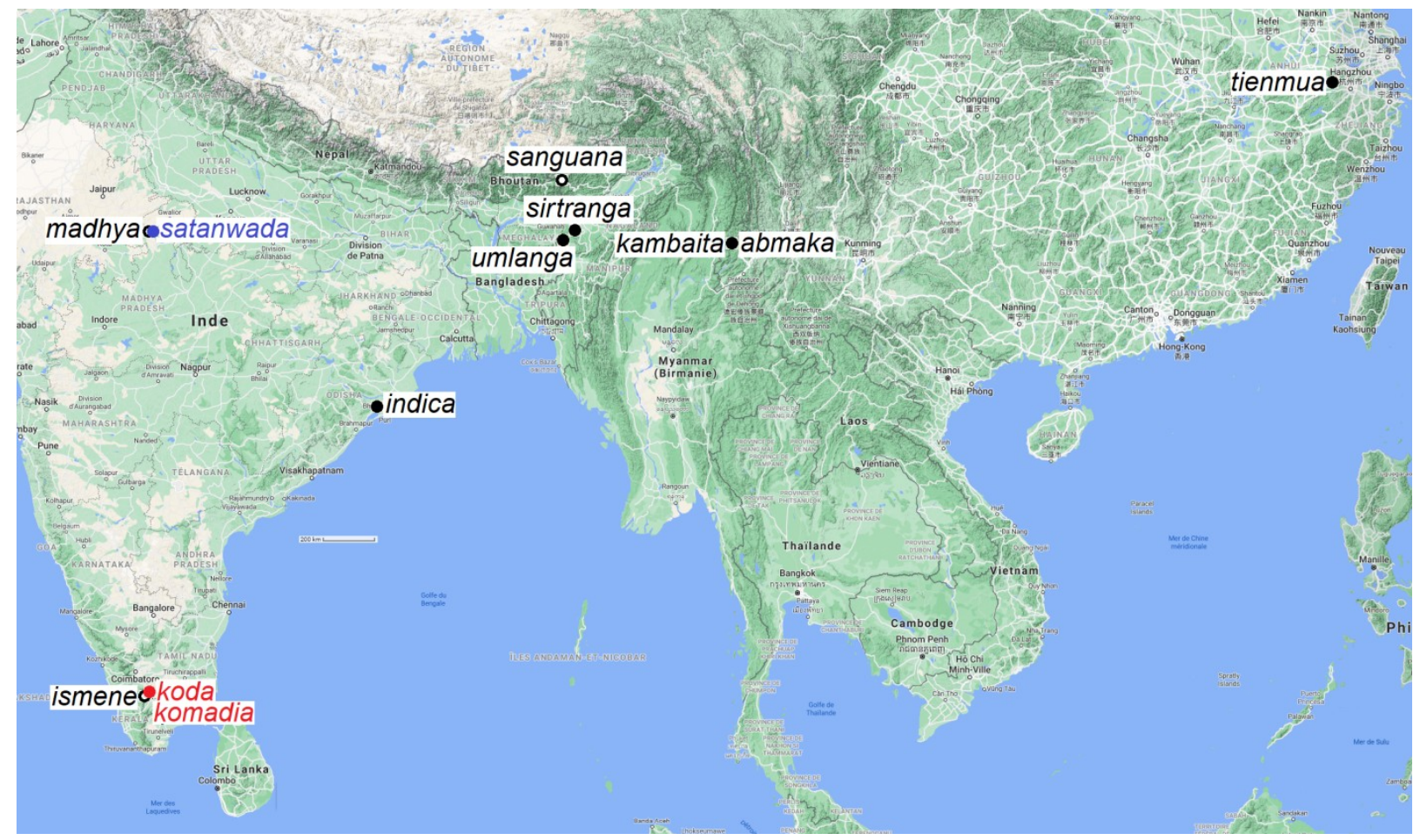

Map 17. Diplectrona taprobanes group. 

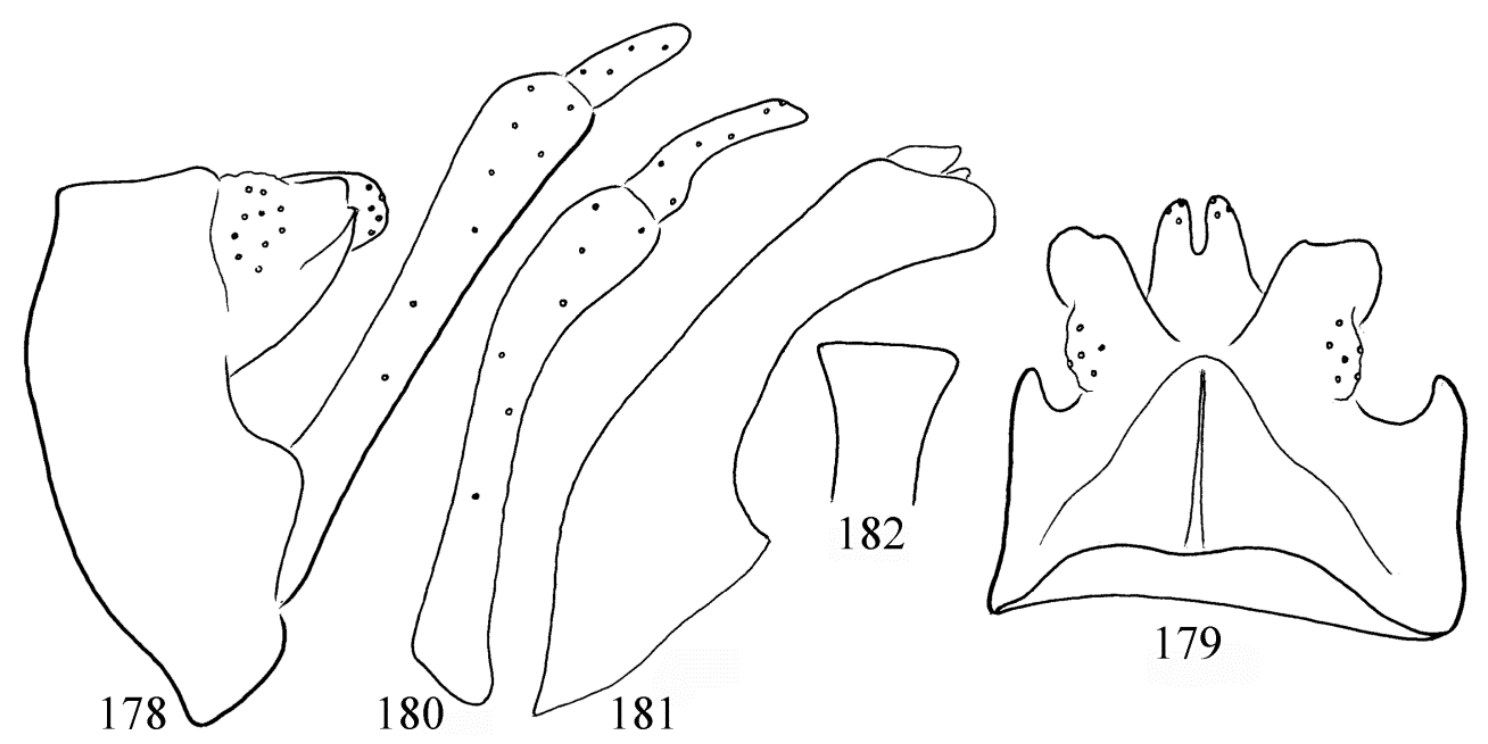

Figures 178-182. Diplectrona abmaka sp. nov. Holotype: $178=$ male genitalia in left lateral view, $179=$ male genitalia in dorsal view, $180=$ left gonopod in ventral view, $181=$ phallic organ in left lateral view, $182=$ phallic head in ventral view.

Diagnosis. This species having rounded broad dorsal profile of the paraproct with elongated segment X belongs to the Diplectrona taprobanes species group. It has similarity to Diplectrona kambaita sp. nov., but differs by the dorsal profile of the paraproct that is less turning laterad and with simple apical margin as well as by the lateral profile of the phallic organ with its less downward directed apicoventrum and by the ventral shape of the phallic head truncated.

Description. Male (in alcohol). Dark brown animal. Forewings without pattern. Forewing length is $9 \mathrm{~mm}$, apical fork I present on hindwing. Eyes setaless not enlarged. Maxillary palp formula I-III-II-IV-V. Abdominal segments without any reticulated internal sacs. Pair of large, elongated sacs present in segment $\mathrm{V}$ and the filaments on sternite $\mathrm{V}$ are long reaching to segment VIII.

Male genitalia. Segment IX convex anterad. Segment $X$ fused to the tergum IX. The dorsoapical setose lobes (inner lobes) of segment $\mathrm{X}$ well-developed, digitiform in dorsal view and rounded in lateral view, slightly longer than the paraproct. Cerci setose, low and short in lateral view. Unsetose paraproct (outer lobes or lateral plates of segment X) long in lateral view and less turning laterad in dorsal view with rounded apical margin. Gonopods robust; coxopodite with dilated apical half; harpago robust, mesad turning. Phallic apparatus with high and long phallobase with less downward curving apicoventrum. Endothecal and phallotremal sclerites withdrawn.

Etymology. abmaka, coined from the inverse name of locus typicus of the holotype.

\section{Diplectrona indica (Mosely, 1931)}

\section{(Map 17)}

Material examined. India, Orissa State [=Odisha State], Chilika Lake, Narayana valley, $19^{\circ} 52^{\prime}$ $22.3^{\prime \prime} \mathrm{N} 85^{\circ} 33^{\prime} 13.8^{\prime \prime} \mathrm{E}, 21 . \mathrm{II} .1987$, singled and light leg. J. Oláh (32 males, OPC).

\section{Diplectrona ismene Malicky, 2002}

$$
\text { (Map 7a: n 100, 101, Map 17) }
$$

Material examined. Holotype: India, Kerala, Kandalur [=Kanthalloor], $5500 \mathrm{ft}, 10^{\circ} 12^{\prime} 43.2^{\prime \prime} \mathrm{N}$ 77'12'29.7"E, 31.I.1962, leg. F. Schmid (1 male, CNC). India, Kerala, Periyakanal [=Periakanal], $5000 \mathrm{ft}, 10^{\circ} 02^{\prime} 11.4^{\prime \prime} \mathrm{N} 77^{\circ} 09^{\prime} 35.1^{\prime \prime} \mathrm{E}, 10^{\circ} 2^{\prime} 4^{\prime \prime} \mathrm{N}$ $77^{\circ} 10^{\prime} 9^{\prime \prime} \mathrm{E}, 25 . \mathrm{I} .1962$, leg. F. Schmid (1 male, $\mathrm{CNC}$; 1 male, OPC). 


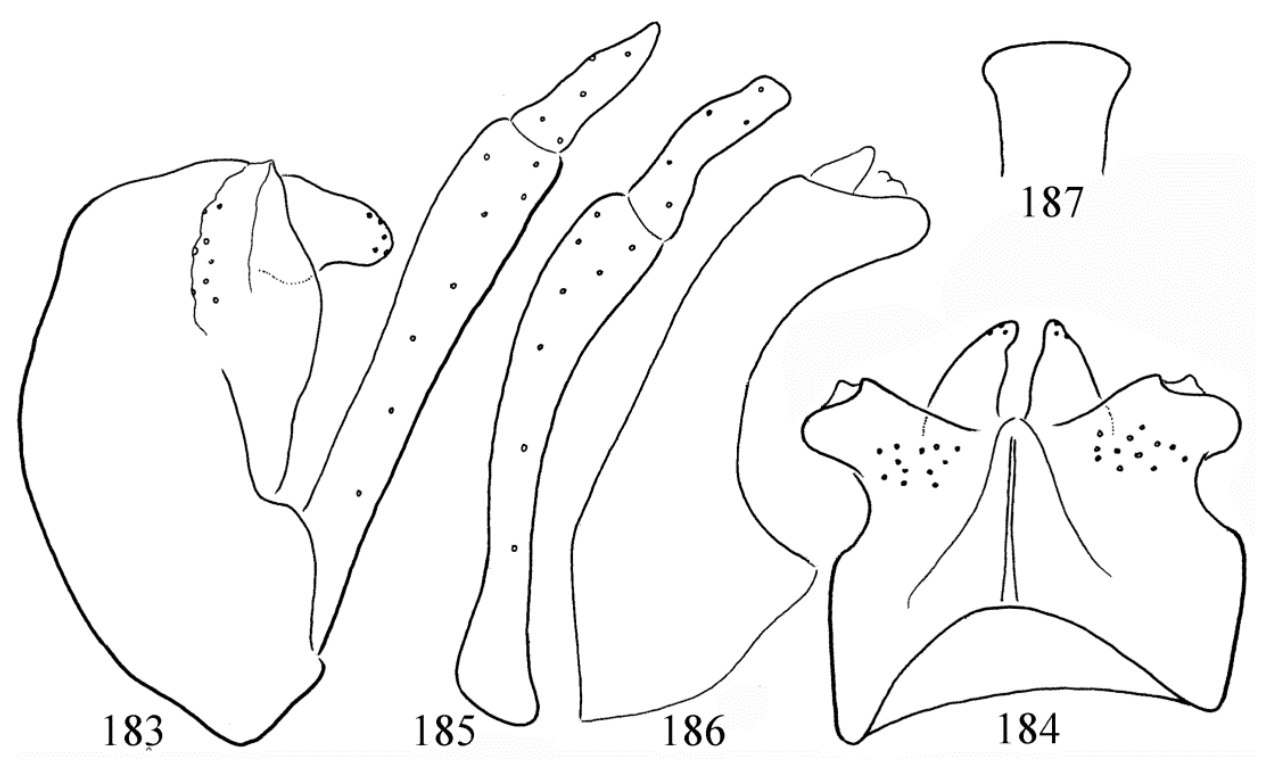

Figures 183-187. Diplectrona kambaita sp. nov. Holotype: $183=$ male genitalia in left lateral view, $184=$ male genitalia in dorsal view, 185 = left gonopod in ventral view, 186 = phallic organ in left lateral view, $187=$ phallic head in ventral view.

\section{Diplectrona kambaita sp. nov.}

(Figures 183-187, Map 17)

Material examined. Holotype: Myanmar, North East Burma, Kambaiti, $7000 \mathrm{ft}$., [=Kan Paik Ti], 2524'22.8"N 9807'03.8"E, 9.V.1934, leg. R. Malaise, B.M. 1938-258 (1 male, BMNH).

Diagnosis. This species having rounded broad dorsal profile of the paraproct with elongated segment X belongs to the Diplectrona taprobanes species group. It is most close to Diplectrona tianmua sp. nov., but differs by the dorsal profile of the paraproct that is more patterned, not simple rounded as well as by the lateral profile of the phallic organ with its downward directed apicoventrum and by the ventral shape of the phallic head broadening apicad.

Description. Male (in alcohol). Dark brown animal. Forewings without pattern. Forewing length $9 \mathrm{~mm}$, apical fork I present on hindwing. Eyes setaless not enlarged. Maxillary palp formula I-III-II-IV-V. Abdominal segments without any reticulated internal sacs. Pair of large, elongated sacs present in segment $\mathrm{V}$ and the filaments on sternite $\mathrm{V}$ are long reaching to segment VIII.
Male genitalia. Segment IX convex anterad. Segment X fused to the tergum IX. The dorsoapical setose lobes (inner lobes) of segment $\mathrm{X}$ well-developed, triangular in dorsal view and rounded in lateral view, significantly longer than the paraproct. Cerci setose, high and short in lateral view. Unsetose paraproct (outer lobes or lateral plates of segment X) short in lateral view and laterad turning in dorsal view with patterned apical margin. Gonopods robust; coxopodite with dilated apical half; harpago robust, mesad turning. Phallic apparatus with high and long phallobase with downward curving apicoventrum. Endothecal and phallotremal sclerites withdrawn.

Etymology. kambaita, named after the locus typicus of the holotype.

\section{Diplectrona kamikarka sp. nov.}

(Map 17)

Diplectrona burha Schmid, 1961: Malicky 2002:12051206. Misidentification.

Material. Syntypes: Malicky, 2002:1206. Nepal, Kamikarna-Südhang, Quellbächlein bei 2600 m, 11.IV.1995, leg. Malicky, (4 males, drawn specimen with cleared genitalia, MPC). 


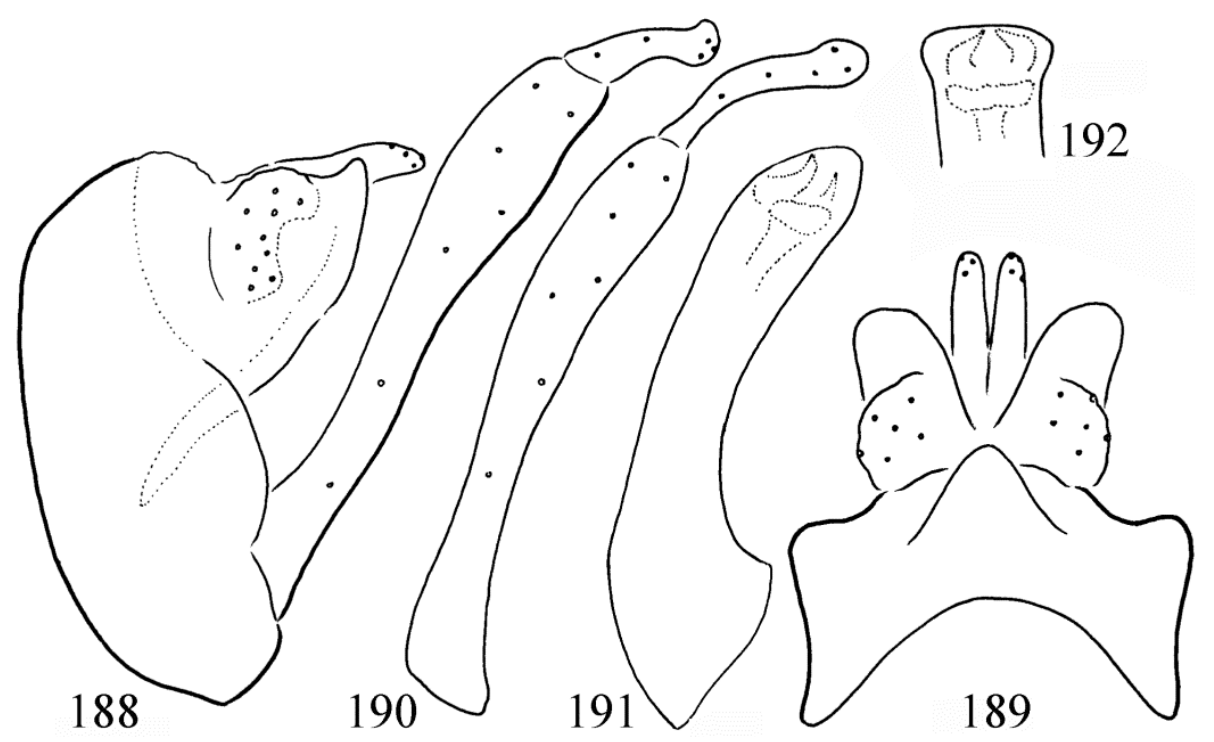

Figures 188-192. Diplectrona koda sp. nov. Holotype: $188=$ male genitalia in left lateral view, $189=$ male genitalia in dorsal view, 190 = left gonopod in ventral view, 191 = phallic organ in left lateral view, 192 = phallic head in ventral view.

Diagnosis. Diplectrona kamikarka sp. nov. from Kamikarna, Nepal, having rounded paraproct belongs to the Diplectrona taprobanes species group. It has resemblance to Diplectrona ismene Malicky, 2002 described from South India, but differs by the parallel-sided, not broad based harpago; by the lateral profile of the paraproct as well as by the dorsal profile of the dorsoapical setose lobes that is longer than paraproct. Moreover the phallic head is rounded, not truncated in ventral view.

Description. (Figures: Malicky 2002: table 14: under name burha, Kamikarna). Cerci setose, long. The dorsoapical setose lobes (inner lobes) of segment X well-developed, slender in dorsal view, longer than paraproct. Unsetose paraproct (outer lobes or lateral plates of segment X) low and small in lateral view. Gonopods robust, with straight coxopodite of slightly dilating apical half in lateral view; harpago almost parallel-sided, mesad turning with narrowing apex in ventral view. Phallic head rounded in ventral view.

Etymology. kamikarka, named after the locus typicus of the syntypes.

\section{Diplectrona koda sp. nov.}

(Figures 188-192, Map 7a: $\mathrm{n}^{\circ}$ 27, Map 17)

Material examined. Holotype: India, Tamil Nadu (Madras), Kodaikanal, 7300 ft., 10¹4'22.4" N, 77²8'45.4"E, 3.II.1962, leg. F. Schmid (1 male, $\mathrm{CNC})$.

Diagnosis. This species having rounded broad dorsal profile of the paraproct with elongated segment X belongs to the Diplectrona taprobanes species group. It is most close to Diplectrona ismene, but differs by the capitate head of the harpago and the longer dorsoapical setose lobes, the inner lobes.

Description. Male (in alcohol). Dark brown animal. Forewings without pattern. Forewing length is $12 \mathrm{~mm}$, apical fork I present on hindwing. Eyes setaless not enlarged. Maxillary palp formula I-III-II-IV-V. Abdominal segments without any reticulated internal sacs. Filaments on sternite $\mathrm{V}$ are very long reaching almost to segment IX.

Male genitalia. Segment IX tripartite posterad, dorsal part fused to segment X, middle part slight- 

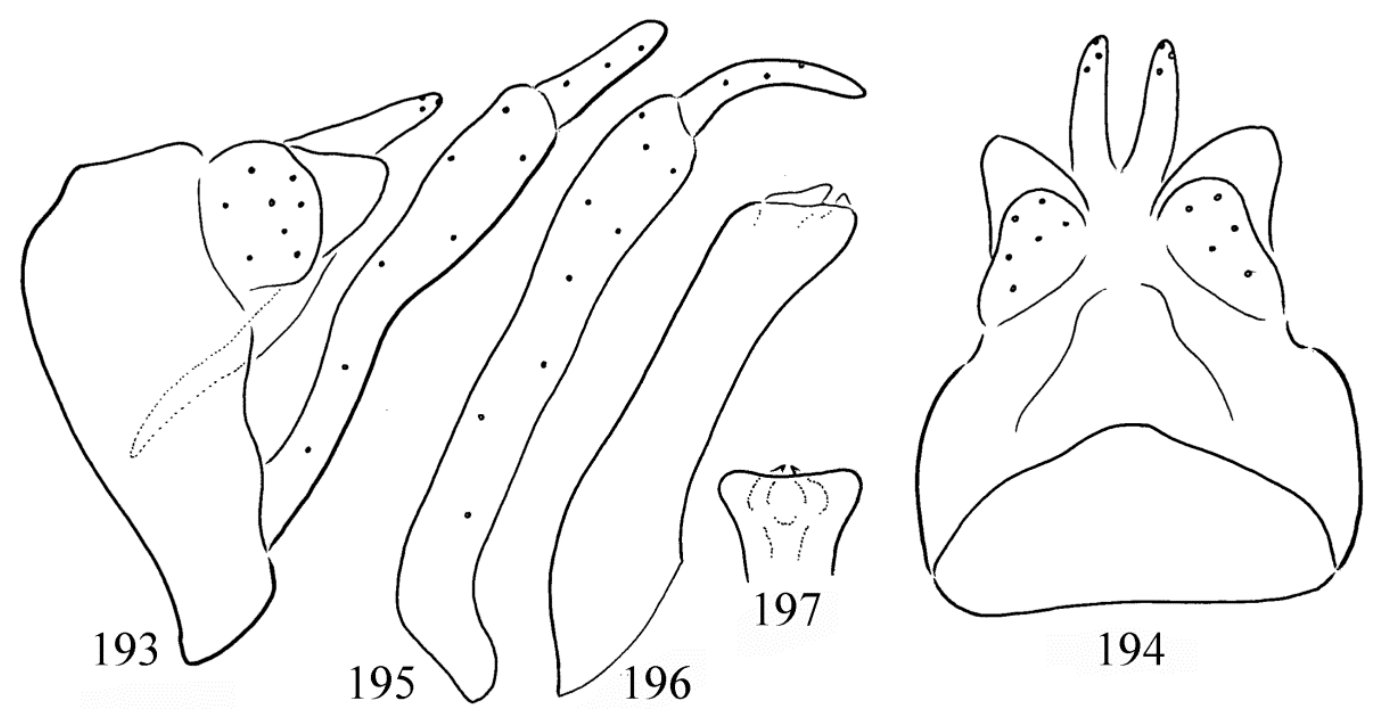

Figures 193-197. Diplectrona komadia sp. nov. Holotype: 193 = male genitalia in left lateral view, $194=$ male genitalia in dorsal view, 195 = left gonopod in ventral view, 196 = phallic organ in left lateral view, $197=$ phallic head in ventral view.

ly rounded, ventral part smallest; dorsum and ventrum with equal length. Segment $\mathrm{X}$ fused to the tergum IX. The dorsoapical setose lobes (inner lobes) of segment X well-developed, slender both in dorsal and lateral views, significantly longer than the paraproct. Cerci setose, fat falciform in lateral and semicircular horizontally in dorsal view. Unsetose paraproct (outer lobes or lateral plates of segment X) subtriangular flat plate in lateral view and rounded in dorsal view. Gonopods robust straight with coxopodite of dilated apical half; harpago mesad turning with capitate head. Phallic apparatus slightly curving tube with narrowing rounded head. Endothecal and phallotremal sclerites withdrawn.

Etymology. koda, coined from the name of locus typicus of the holotype.

\section{Diplectrona komadia sp. nov.}

(Figures 193-197, Map 7a: between $\mathrm{n}^{\circ} 12$ and $\mathrm{n}^{\circ}$ 23, Map 17)

Material examined. Holotype: India, Tamil Nadu, Komadi. This locality remains unkown; it should be placed between Courtallam and Sothuparai, 950 ft., 18.-19.I.1962, leg. F. Schmid (1 male, $\mathrm{CNC}$ ).
Diagnosis. This species having rounded broad dorsal profile of the paraproct with elongated segment X belongs to the Diplectrona taprobanes species group. It is most close to Diplectrona koda sp. nov., but differs by the bigger cerci, longer and slender segment $\mathrm{X}$, as well as by the less curved lateral profile of the phallic organ and the concave, not convex apical ending of the phallic head in ventral view. The harpago is digitate without capitate ending.

Description. Male (in alcohol). Dark brown animal. Forewings without pattern. Forewing length $9 \mathrm{~mm}$, apical fork I present on hindwing. Eyes setaless not enlarged. Maxillary palp formula I-III-II-IV-V. Abdominal segments without any reticulated internal sacs. Pair of large, elongated sacs present in segment $\mathrm{V}$ and the filaments on sternite $\mathrm{V}$ are long reaching to segment VIII.

Male genitalia. Segment IX tripartite posterad, dorsal part fused to segment $\mathrm{X}$, middle part slightly rounded, ventral part smallest; dorsum and ventrum with equal length. Segment $X$ fused to the tergum IX. The dorsoapical setose lobes (inner lobes) of segment $X$ well-developed, very slender both in dorsal and lateral views, significantly longer than the paraproct. Cerci setose, almost circular in lateral view and semicircular horizontally in dorsal view. Unsetose paraproct (outer 


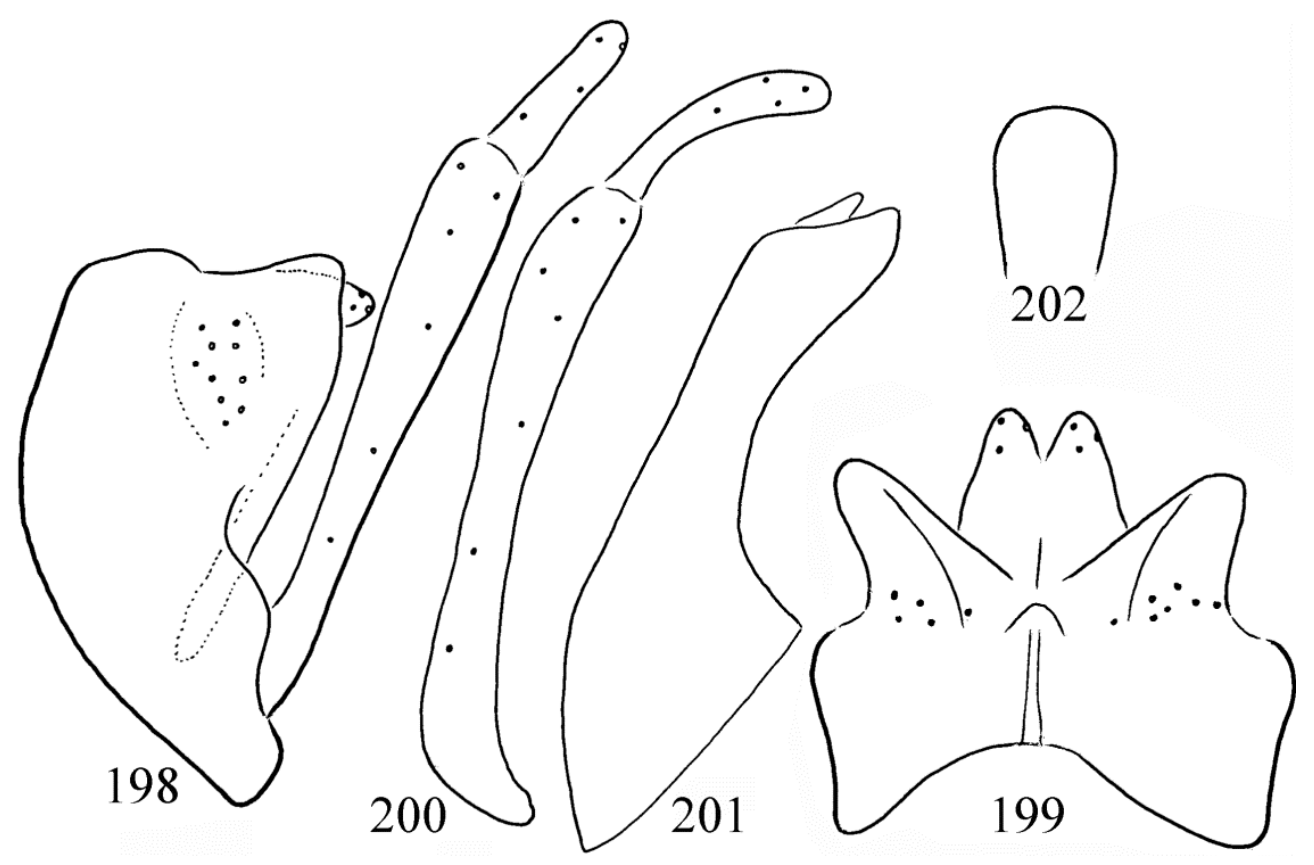

Figures 198-202. Diplectrona madhya sp. nov. Holotype: $198=$ male genitalia in left lateral view, $199=$ male genitalia in dorsal view, 200 = left gonopod in ventral view, 201 = phallic organ in left lateral view, 202 = phallic head in ventral view.

lobes or lateral plates of segment X) subtriangular flat plate both in lateral and dorsal views. Gonopods robust; coxopodite angled in middle with dilated apical half; harpago mesad turning digitate. Phallic apparatus slightly curving tube with narrowing rounded head. Endothecal and phallotremal sclerites withdrawn.

Etymology. komadia, coined from the name of locus typicus of the holotype.

\section{Diplectrona madhya sp. nov.}

(Figures 198-202, Map 7a: n 87, Map 17)

Material examined. Holotype: India, Madhya Pradesh, Satanwara [=Satanwada according to Lonsdale (2020)], $1308 \mathrm{ft}, 25^{\circ} 44^{\prime} 51.21^{\prime \prime} \mathrm{N} 77^{\circ} 24^{\prime}$ 29.44"E, 28.XI.1961, leg. F. Schmid (1 male, $\mathrm{CNC})$.

Diagnosis. This species having rounded broad dorsal profile of the paraproct with elongated segment $\mathrm{X}$ belongs to the Diplectrona taprobanes species group. It is most close to Diplectrona satanwada $\mathrm{sp}$. nov., but differs by the triangular shape of segment $\mathrm{X}$, the more robust paraproct, the smaller cerci as well as both the lateral and ventral shape of the phallotheca.

Description. Male (in alcohol). Dark brown animal. Forewings without pattern. Forewing length $9 \mathrm{~mm}$, apical fork I present on hindwing. Eyes setaless not enlarged. Maxillary palp formula I-III-II-IV-V. Abdominal segments without any reticulated internal sacs. Filaments on sternite $\mathrm{V}$ are very long reaching almost to segment VIII.

Male genitalia. Segment IX tripartite posterad, dorsal part fused to segment $\mathrm{X}$, middle part slightly rounded, ventral part smallest; dorsum little longer that ventrum. Segment $X$ fused to the tergum IX. The dorsoapical setose lobes (inner lobes) of segment $\mathrm{X}$ well-developed, triangular both in dorsal and lateral views, little longer than paraproct. Cerci setose, short. Unsetose paraproct (outer lobes or lateral plates of segment X) subtriangular flat plate in lateral view and rounded in dorsal view. Gonopods robust straight with coxopodite of dilated apical half; harpago mesad turning with broadening apical region. Phallic apparatus slightly curving tube with ventrally e- 


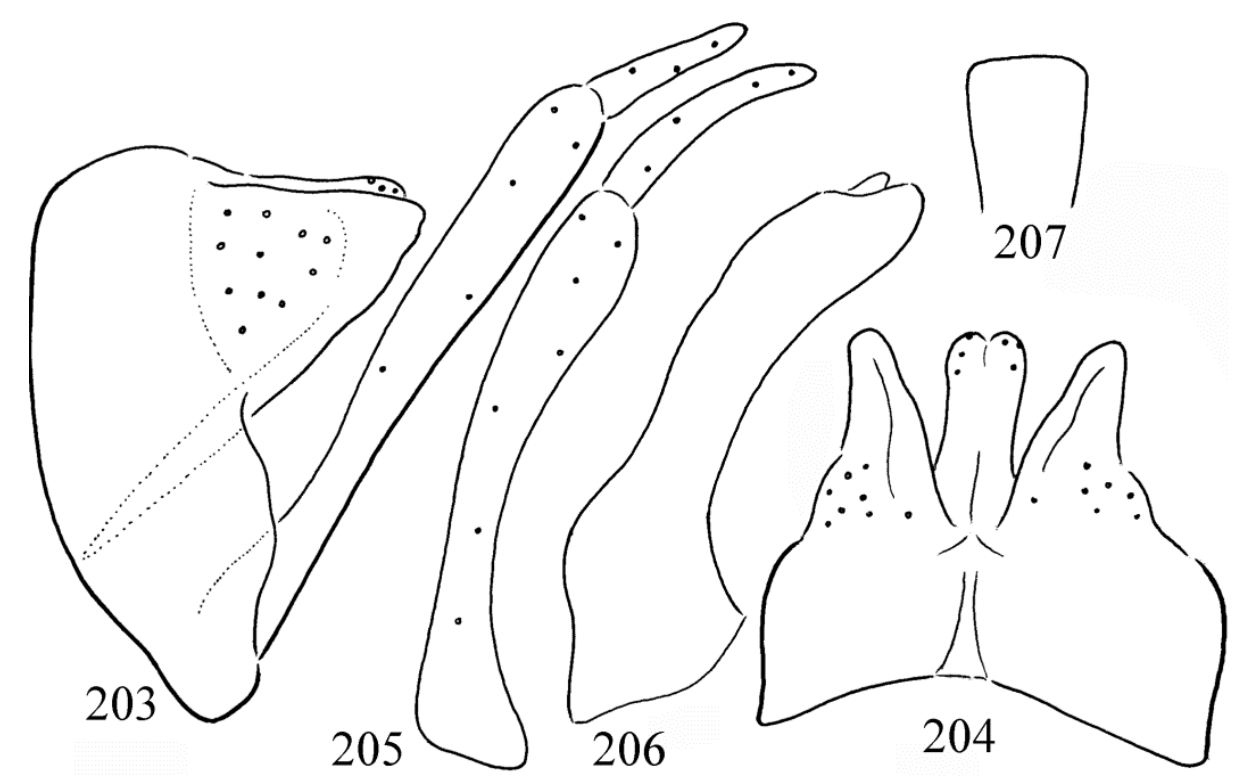

Figures 203-207. Diplectrona satanwada sp. nov. Holotype: 203 = male genitalia in left lateral view, $204=$ male genitalia in dorsal view, 205 = left gonopod in ventral view, 206 = phallic organ in left lateral view, 207 = phallic head in ventral view.

longated lobe in lateral view, the head is rounded in ventral view. Endothecal and phallotremal sclerites withdrawn.

Etymology. madhya, coined from the name of locus typicus of the holotype.

\section{Diplectrona sanguana Kimmins, 1964}

(Map 17)

Diplectrona sanguana Kimmins, 1964:45.

Material examined. India, Arunachal Pradesh (Assam), Kameng, Nyukmadong, 6600-8000 ft., $27^{\circ} 24^{\prime} 32.5^{\prime \prime} \mathrm{N} 92^{\circ} 07^{\prime} 57.3^{\prime \prime E}, 1 . V I I I .1961$, leg. F. Schmid, (1 male, OPC).

\section{Diplectrona satanwada sp. nov.}

(Figures 203-207, Map 7a: n 87, Map 17)

Material examined. Holotype: India, Madhya Pradesh, Satanwara [=Satanwada according to Lonsdale (2020)], $1308 \mathrm{ft}, 25^{\circ} 44^{\prime} 51.21^{\prime \prime} \mathrm{N} 77^{\circ} 24^{\prime}$ 29.44"E, 28.XI.1961, leg. F. Schmid (1 male, CNC).
Diagnosis. This species having rounded broad dorsal profile of the paraproct with elongated segment X belongs to the Diplectrona taprobanes species group. It is most close to Diplectrona madhya sp. nov., but differs by the slender segment $\mathrm{X}$, the slender paraproct, the longer cerci as well as both the lateral and ventral shape of the phallotheca.

Description. Male (in alcohol). Dark brown animal. Forewings without pattern. Forewing length $9 \mathrm{~mm}$, apical fork I present on hindwing. Eyes setaless not enlarged. Maxillary palp formula I-III-II-IV-V. Abdominal segments without any reticulated internal sacs. Filaments on sternite $\mathrm{V}$ are very long reaching almost to segment VIII.

Male genitalia. Segment IX tripartite posterad, dorsal part fused to segment $\mathrm{X}$, middle part slightly rounded, ventral part smallest; dorsum little longer that ventrum. Segment $X$ fused to the tergum IX. The dorsoapical setose lobes (inner lobes) of segment $\mathrm{X}$ well-developed, slender in dorsal view, little shorter than paraproct. Cerci setose, long. Unsetose paraproct (outer lobes or lateral plates of segment $\mathrm{X}$ ) subtriangular flat plate in lateral view and rounded in dorsal view. 


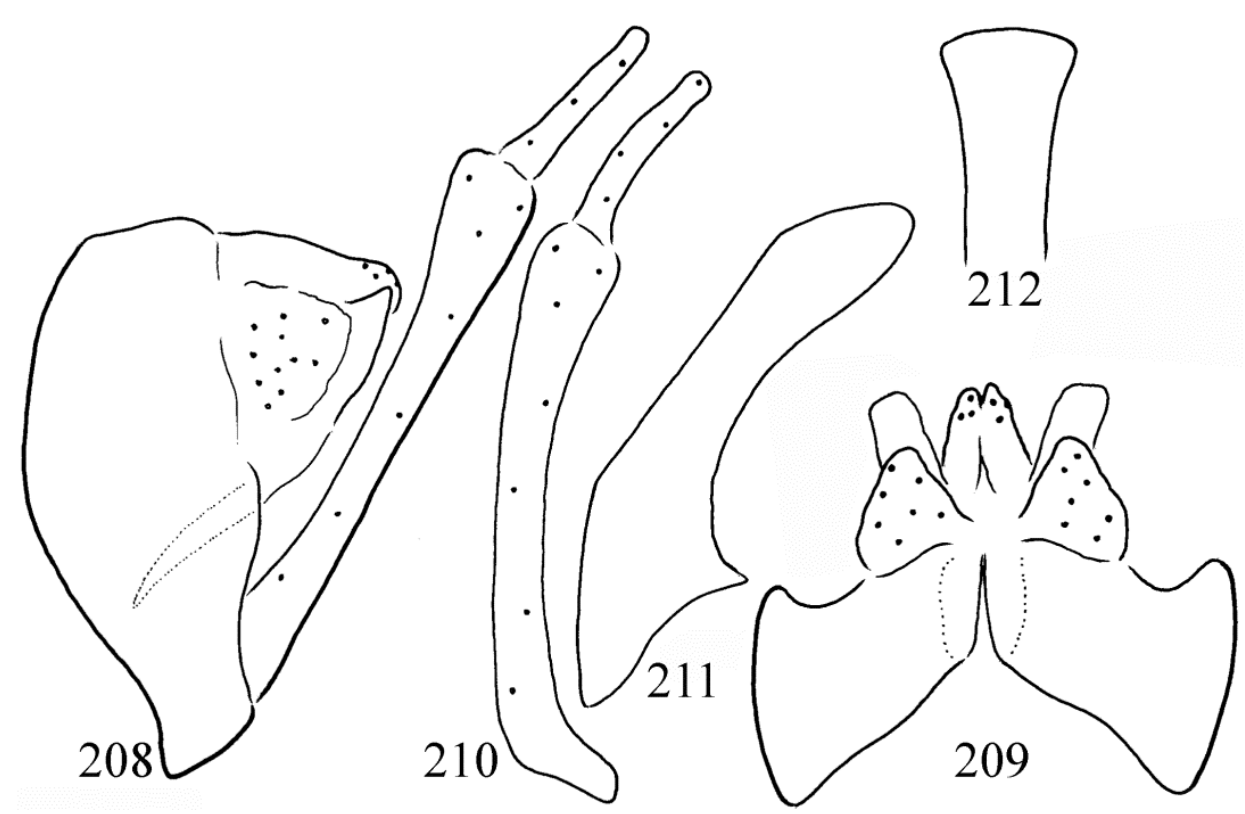

Figures 208-212. Diplectrona sirtranga sp. nov. Holotype: $208=$ male genitalia in left lateral view, $209=$ male genitalia in dorsal view, $210=$ left gonopod in ventral view, $211=$ phallic organ in left lateral view, $212=$ phallic head in ventral view.

Gonopods robust straight with coxopodite of dilated apical half; harpago mesad turning with slightly tapering apical region. Phallic apparatus with waving dorsum, the head is truncated in ventral view. Endothecal and phallotremal sclerites withdrawn.

Etymology. satanwada, coined from the name of locus typicus of the holotype.

\section{Diplectrona sirtranga sp. nov.}

(Figures 208-212, Map 5: between $\mathrm{n}^{\circ} 75$ and $\mathrm{n}^{\circ} 77$, Map 17)

Material examined. Holotype: India, Assam, United District of Mikir and North Cachar Hills, Sirtrang (it should be located between Rongbong Ronghang and Terang Gaon, 1400 ft, 28.IV.1960, leg. F. Schmid (1 male, CNC). Paratypes: same as holotype (1 male, genitalia injured without left gonopod; OPC). India, Assam, United District of Mikir and North Cachar Hills, Nongirong [ $=$ Nonjirong], $2700 \mathrm{ft}, 25^{\circ} 41^{\prime} 29.6^{\prime \prime} \mathrm{N} 92^{\circ} 28^{\prime} 41.3^{\prime \prime} \mathrm{E}, 25$. IV.1960, leg. F. Schmid (2 males, CNC; 1 male, OPC; 1 male, SMNH).
Diagnosis. This species having rounded broad dorsal profile of the paraproct with elongated segment X belongs to the Diplectrona taprobanes species group. It is most close to Diplectrona madhya sp. nov., but differs by the triangular, highly produced cerci, the quadrangular dorsal profile of the paraproct as well as by the truncated, not rounded ventral apical profile of the phallic head.

Description. Male (in alcohol). Dark brown animal. Forewings without pattern. Forewing length is $8 \mathrm{~mm}$, apical fork I present on hindwing. Eyes setaless not enlarged. Maxillary palp formula I-III-II-IV-V. Abdominal segments without any reticulated internal sacs. Filaments on sternite V are long reaching almost to segment VII.

Male genitalia. Segment IX tripartite posterad, dorsal part fused to segment $\mathrm{X}$, middle part slightly rounded, ventral part smallest; dorsum little longer that ventrum. Segment $X$ fused to the tergum IX. The dorsoapical setose lobes (inner lobes) of segment $\mathrm{X}$ well-developed, slender in dorsal view and rounded in lateral view, little longer than paraproct. Cerci setose, produced, triangular both in lateral and dorsal views. Un- 
setose paraproct (outer lobes or lateral plates of segment $\mathrm{X}$ ) subtriangular flat plate in lateral view and rounded quadrangular in dorsal view. Gonopods robust straight with coxopodite of dilated apical region; harpago slightly mesad turning digitiform. Phallic apparatus slightly curving tube with ventrally elongated lobe in lateral view, the head is truncated and widening apicad in ventral view. Endothecal and phallotremal sclerites withdrawn.

Etymology. sirtranga, coined from the name of locus typicus of the holotype.

\section{Diplectrona tienmua sp. nov.}

(Map 17)

Diplectrona kallirrhoe Malicky, 2002:1211-1212. "China, Zhejiang, Tienmu Mt., 30.V.1989, leg. Kyselak, CM: 3 ऽ઼ (Paratypen).” determined as paratype of Diplectrona kallirrhoe Malicky, 2002. Misidentification.

Material. Syntypes: China, Zhejiang Province, Tienmu Mt. [=Thianmu Mt.], $30^{\circ} 21^{\prime} 43.2^{\prime \prime} \mathrm{N} 119^{\circ}$ 30'52.2"E, 30.V.1989 leg. Kyselak, (3 males, drawn specimen, MPC).

Diagnosis. Diplectrona tienmua sp. nov. from the Tienmu Mountains (China) differs from $D$. kallirrhoe described from the Long Wang Mountains (China) having not any spine-like or pointed structures on the paraproct as well as by the ventral profile of the phallic head without pronounced apical widening. Without spine-like processes $D$. tienmua sp. nov. belongs to the Diplectrona taprobanes species group and D. kallirrhoe with bifid, not rounded dorsal profile of the paraproct is a member of Diplectrona aurovittata species group. D. tienmua sp. nov. has the character state of the strongly laterad directed rounded paraproct diverged from all the known members of the species group. Only D. madhya sp. nov. has somewhat, but much less laterad directed paraproct as well as shorter cerci and rounded, not truncate phallic head in ventral view.
Description. (Figures: Malicky 2002: table 8: under names kallirrhoe, Tienmu). Sternum V filament of 1.5-2 segment lengths. Pair of reticulated sacs present in segment VIII. Cerci setose, long. The dorsoapical setose lobes (inner lobes) of segment X well-developed, slender in dorsal view, longer than paraproct. Unsetose paraproct (outer lobes or lateral plates of segment X) subtriangular flat plate in lateral view and rounded, laterad directed without any spine-like processes in dorsal view. Gonopods robust, with straight coxopodite of dilating apicad in lateral view; harpago mesad turning with rounded apex in ventral view. Phallic head truncate in ventral view.

Etymology. tienmua, named after locus typicus of the syntypes.

\section{Diplectrona umlanga sp. nov.}

(Figures 213-217, Map 5: nº 67, Map 17)

Material examined. Holotype: India, United Jaintia et Khasi Hills, Umlangshor, $4100 \mathrm{ft}$., $25^{\circ} 28^{\prime} 32.3^{\prime \prime N} 92^{\circ} 12^{\prime} 49.0^{\prime \prime} \mathrm{E}, 18 . V I .1960$, leg. F. Schmid (1 male, CNC).

Diagnosis. This species belongs to the Diplectrona taprobanes species group, although there is some apparently blunt narrowing structure on the dorsoapical region of the paraproct visible in lateral view. However, that is the result of the transversally flat terminal region of apical ending of the paraproct. Most close to D. madhya sp. nov., but differs by the different dorsal profile of the paraproct and by the rounded, not slightly widening and truncated apex of the phallic organ in ventral view.

Description. Male (in alcohol). Light brown animal. Forewings without pattern. Forewing length is $10 \mathrm{~mm}$, apical fork I present on hindwing. Eyes setaless, not enlarged. Maxillary palp formula I-IV-III-II-V. There is a very long filament on segment V. Abdominal segment VII without any reticulated internal sacs. 


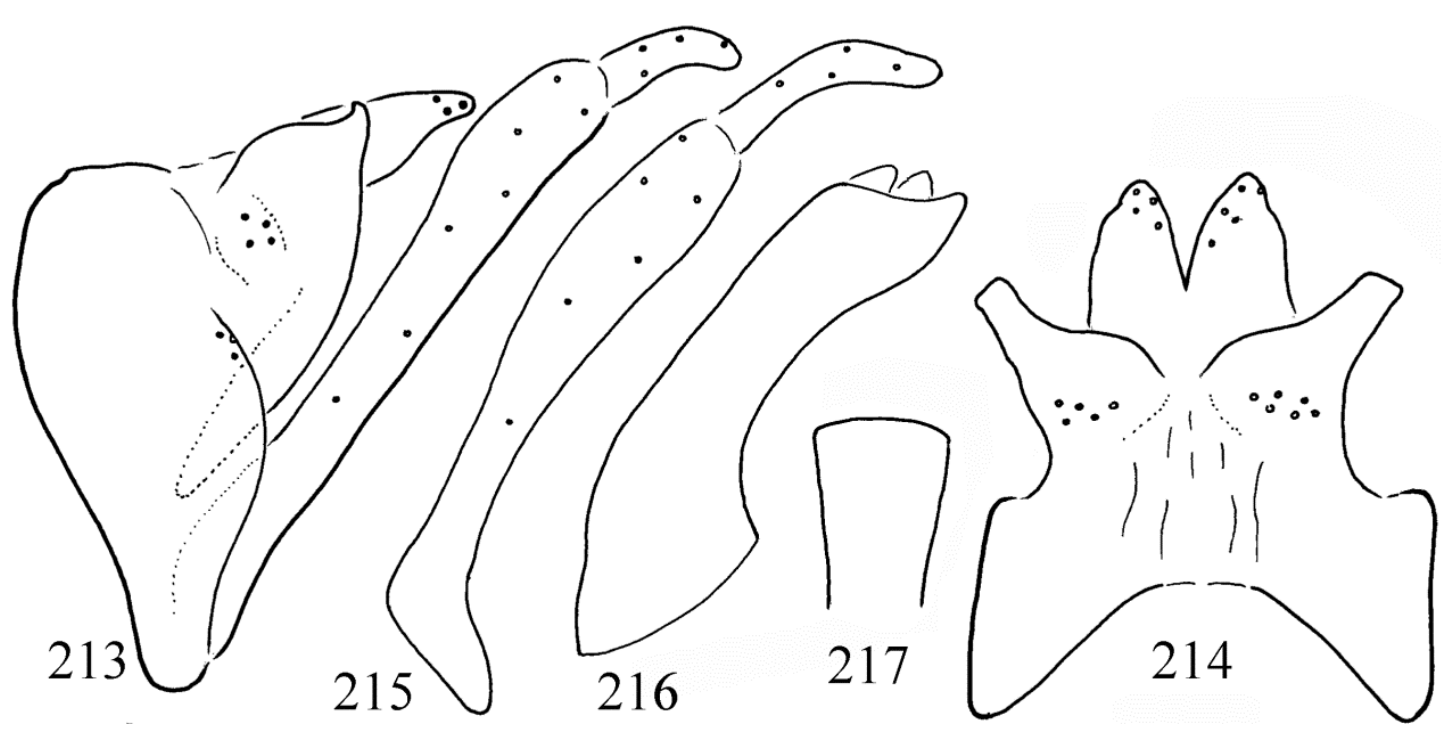

Figures 213-217. Diplectrona umlanga sp. nov. Holotype: $213=$ male genitalia in left lateral view, $214=$ male genitalia in dorsal view, $215=$ left gonopod in ventral view, $216=$ phallic organ in left lateral view, $217=$ phallic head in ventral view.

Male genitalia. Segment IX less convex anterad, dorsum long and flat with a middle depression line, ventrum very short. Segment X fused to the tergum IX. The dorsoapical setose lobes (inner lobes) of segment X well-developed, bilobed, protruded broad based and narrowing apicad. Cerci just a small setose surface both in dorsal and lateral views. Unsetose paraproct (outer lobes or lateral plates of segment X) subtriangular flat plate in lateral view with a blunt pointed process only visible in lateral view. Gonopods slender straight with coxopodite of dilated apical third; harpago mesad turning with rounded head. Phallic apparatus with down curving and broadening basal section and with a longer tubeforming horizontal two thirds with rounded obliquely cut apex in lateral view; two pairs of endothecal processes visible, both with blunt apices in lateral and pointed triangular in ventral view; dorsal endothecal process bigger; phallotremal sclerite less distinct. The phallic organ with slightly convex and dilated head in ventral view.

Etymology. umlanga, coined from the name of locus typicus of the holotype.

\section{Hydropsychinae Curtis, 1835}

\section{Cheumatopsyche Wallengren, 1891}

Cheumatopsyche lepida species group

The morphology of the genitalia in this species group follows the plesiomorphic, ancestral Cheumatopsyche genital plan, although without elongated cerci, but having the most complete processes on the apical region of segment X (Oláh et al. 2008a): the characteristically trilobed segment $X$ with long and upcurving ventroapical setose lobe. The unsetose mesocaudal lobe is mostly well developed, triangular, rounded or quadrangular. This mesocaudal lobe, the third lobe on the apical region of segment $X$, the main distinguishing character state of this species group is sometimes less developed or upward turning, and as a result it is difficult to discern exactly its real extension. Therefore, it is hard to delineate clearly from the species in the Cheumatopsyche dubitans species group having similar long ventroapical setose lobe, but having no or slightly developed mesocaudal lobes. The distribution range of Cheumatopsyche lepida species group covers the Oriental, West Palearctic, East Palearctic and Afrotropical biogeographic regions. 


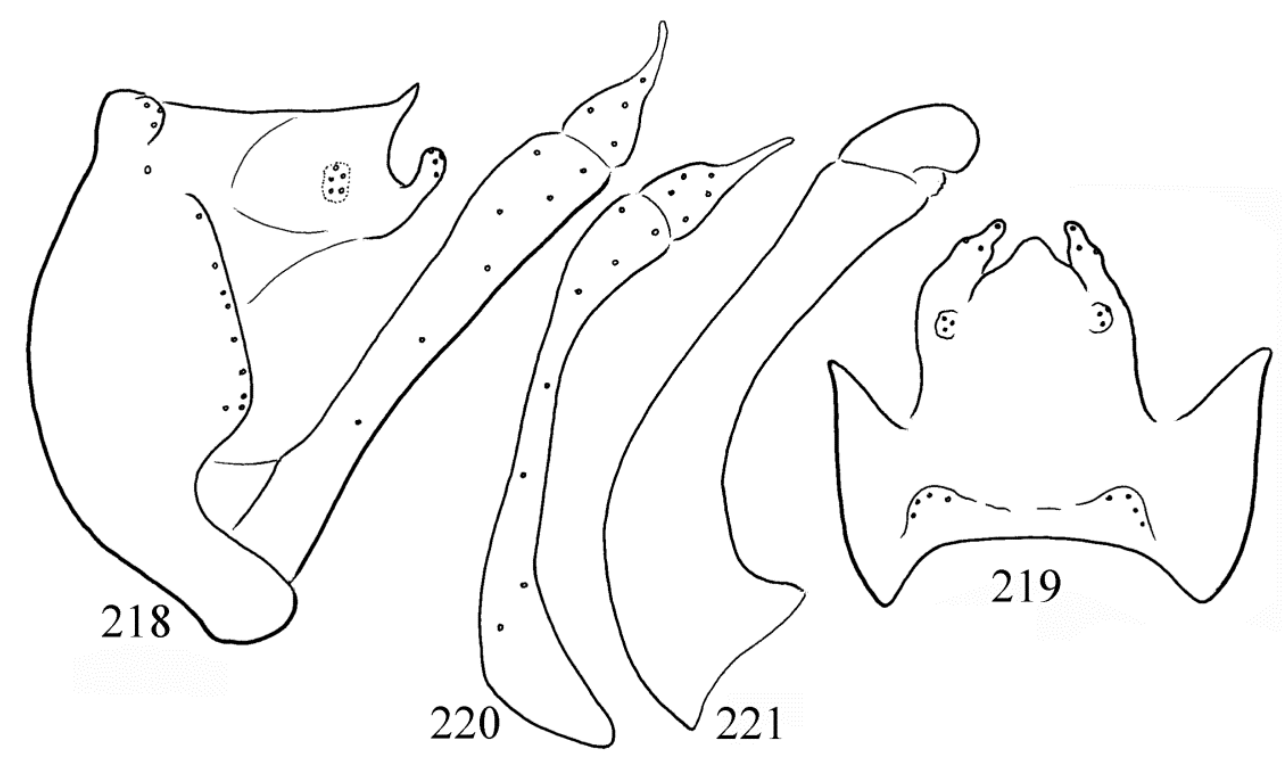

Figures 218-221. Cheumatopsyche assamha sp. nov. Holotype: $218=$ male genitalia in left lateral view, $219=$ male genitalia in dorsal view, $220=$ left gonopod in ventral view, 221 = phallic organ in left lateral view.

\section{Cheumatopsyche assamha sp. nov.}

(Figures 218-221, Map 6: n 8, Map 18)

Material examined. Holotype: India, Assam, United District of Mikir and North Cachar Hills, Haflong, 1500 ft., 2509'43.8"N 9300'54.3"E, 5.V.1960, leg. F. Schmid (1 male, CNC). Paratypes: same as holotype (1 male, CNC; 1 male, OPC; 1 male SMNH). India, Manipur, Luanglong Khunau [= Lubanglong], $2500 \mathrm{ft} ., 24^{\circ} 41^{\prime} 08.8^{\prime \prime} \mathrm{N}$ 9331'27.2"E, 28.V.1960, leg. F. Schmid (1 male, CNC).

Diagnosis. This new species having trilobed segment $X$ with elongated upward directed ventroapical setose lobe belongs to the Cheumatopsyche lepida species group (Oláh et al. 2008a). It has relation to Cheumatopsyche fordula sp. nov. described from Meghalaya, but differs by the wide lateral gap between the ventroapical setose lobe and the unsetose mesocaudal lobe; by the tripartite dorsal profile of the ventroapical setose lobe, by the lateral and ventral shape of harpago as well as by the slender phallic organ.

Description. A uniformly brown coloured small species with forewing length of $5 \mathrm{~mm}$.
Male genitalia. Abdominal segment IX fused annular, short; anterior margin arciform, resulted in a very short dorsum and short but slightly longer ventrum; the ventrum is without spiny ventrocaudal mesal lobe; apical margin is produced into a flat and high lobe above the gonopods, marked with a row of strong spines; intersegmental depression between the ninth and tenth segments low, almost disappeared in lateral view. Body of segment $\mathrm{X}$ longer than high; circular lateral setose area (cerci) in middle position; apicoventral setose lobe discernible as a tripartite setose lobe turning mesad. The basal segment of the gonopods straight in lateral view and curving in ventral view; harpago, the terminal segment of gonopod broad based and filiform on its apical half. Phallic apparatus slender and low with slightly convex dorsum.

Etymology. assamha, coined from the names of the holotype's locus typicus.

\section{Cheumatopsyche fordula sp. nov.}

(Figures 222-225, Map 5: $\mathrm{n}^{\circ}$ 72, Map 18)

Material examined. Holotype: India, Meghalaya (United Jaintia and Khasi Hills), Barato, 


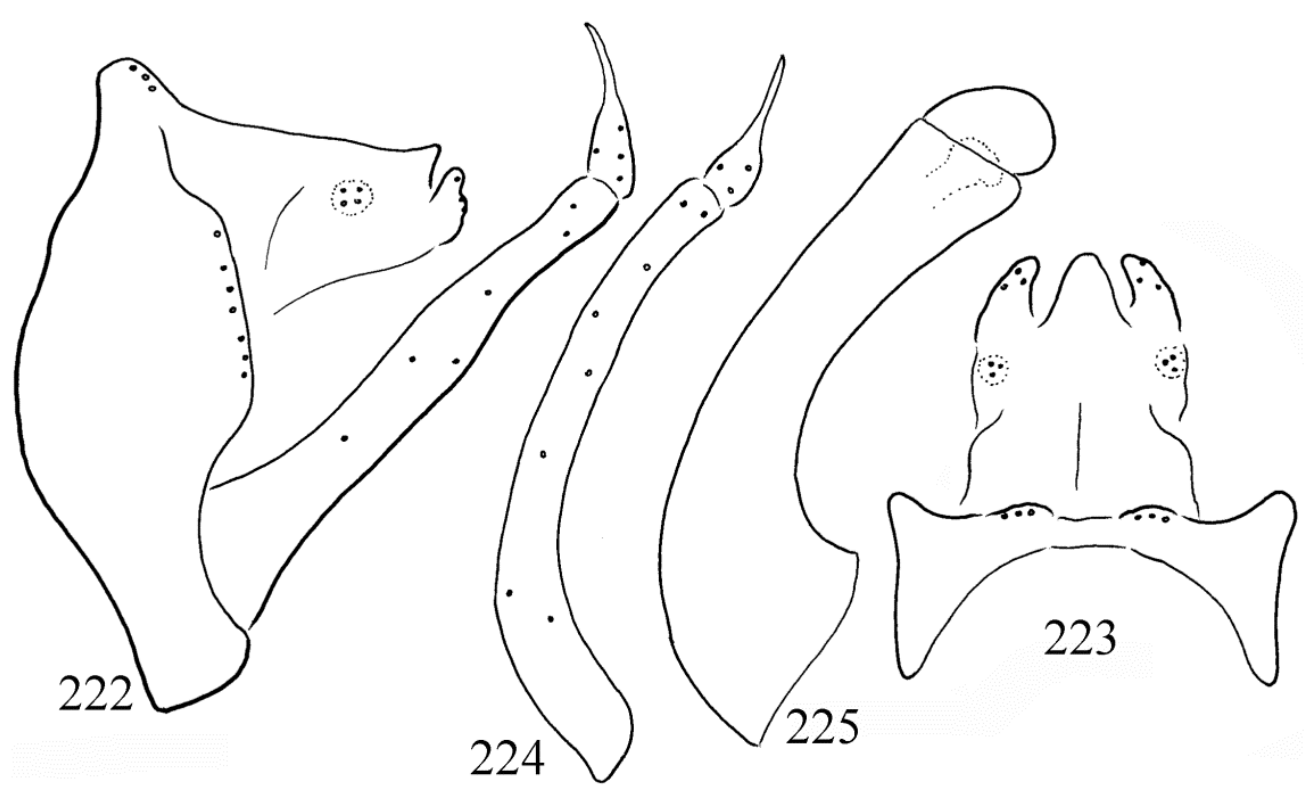

Figures 222-225. Cheumatopsyche fordula sp. nov. Holotype: $222=$ male genitalia in left lateral view, $223=$ male genitalia in dorsal view, 224 = left gonopod in ventral view, 225 = phallic organ in left lateral view.

2500 ft., 2536'24.1"N 92²7'23.1"E, 24.IV.1960, leg. F. Schmid (1 male, CNC). Paratype: same as holotype (1 male, OPC).

Diagnosis. This new species having trilobed segment $\mathrm{X}$ with elongated upward directed ventroapical setose lobe belongs to the Cheumatopsyche lepida species group (Oláh et al. 2008a). It has relation to Cheumatopsyche criseyde described from Thailand and to C. gaia described from Nepal, but differs from both species by the low and robust lateral profile of the phallic organ with convex dorsum and by the long backward (anterad) directed filament representing the apical two thirds of the harpago.

Description. A uniformly brown coloured small species with forewing length of $5 \mathrm{~mm}$.

Male genitalia. Abdominal segment IX fused annular, short; anterior margin arciform, resulted in a very short dorsum and short but slightly longer ventrum; the ventrum is without spiny ventrocaudal mesal lobe; apical margin is produced into a flat and high lobe above the gonopods, marked with a row of strong spines; intersegmental depression between the ninth and tenth segments oblique in lateral view. Body of seg- ment $X$ longer than high; circular lateral setose area (cerci) in middle position; apicoventral setose lobe discernible as a small setose lobe turning mesad. The basal segment of the gonopods straight in lateral view and curving in ventral view; harpago, the terminal segment of gonopod broad based and filiform on its apical two thirds. Phallic apparatus robust and low with convex dorsum.

Etymology. fordula, coined from "vissza forduló, forduló" backward directed in Hungarian, refers to the unique, unusual direction of the harpago.

\section{Cheumatopsyche gaia Malicky, 1997}

$$
\text { (Map 2: } \mathrm{n}^{\circ} \text { 14, Map 18) }
$$

Cheumatopsyche gaia Malicky, 1997:1029. "Holotype: Nepal, Janakpur SE Charikot, 900-1200m, 27 ${ }^{\circ} 37^{\prime}$ 36.0"N 8604'35.0"E, 5.-10.VI.1987, leg. Holzschuh."

Material examined. India, Uttarakhand, Pauri Garhwal, Pau Kal = Paukhal Gaon, 4000-5000ft., river tributary of Bhillangana River and hygropetric habitat, $30^{\circ} 21^{\prime} 48.9^{\prime \prime} \mathrm{N} 78^{\circ} 36^{\prime} 36.7^{\prime \prime} \mathrm{E}, 21 .-$ 23.IV.1958, leg. F. Schmid (1 male, OPC). 


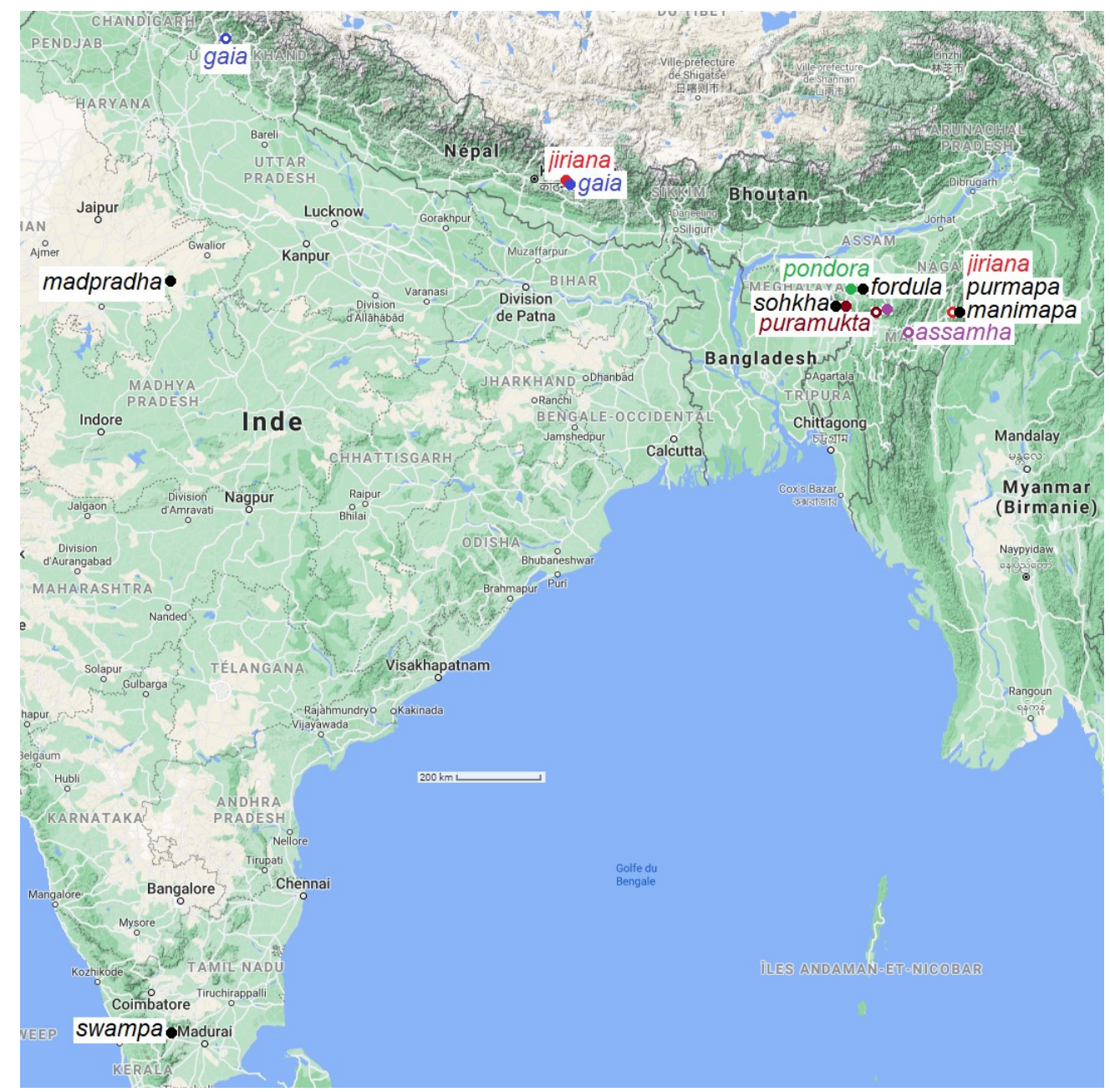

Map 18. Cheumatopsyche lepida group.

\section{Cheumatopsyche jiriana Malicky, 1997}

(Map 6: $\mathrm{n}^{\circ}$ 18, Map 18)

Cheumatopsyche jiriana Malicky, 1997:1026. "HT ô: Nepal, Jiri, 1800m, 27³6'04.6"N 86²'3'35.9"E, 25.V.1991, leg. Allen."

Material examined. India, Manipur, Mapum, 5000 ft., 2504'55.9"N 94³0'16.9"E, 11.VI.1960, leg. F. Schmid (1 male, OPC).

\section{Cheumatopsyche madpradha sp. nov.}

(Figures 226-229, Map 7a: n² 2, Map 18)

Material examined. Holotype: India, Madhya Pradesh, Satanwara $[=$ Satanwada according to
Lonsdale (2020)], $1308 \mathrm{ft}, 25^{\circ} 44^{\prime} 51.21^{\prime \prime} \mathrm{N} 77^{\circ} 24^{\prime}$ 29.44"E, 28.XI.1961, leg. F. Schmid (1 male, CNC).

Diagnosis. This new species having trilobed segment X with elongated upward directed ventroapical setose lobe belongs to the Cheumatopsyche lepida species group (Oláh et al. 2008a). Its dorsal profile of the apicoventral setose lobe has relation to Cheumatopsyche barakambra Oláh \& Johanson, 2008 described from Orissa, but differs by the lateral profile of the phallic organ having long and slender phallobase, not broad and not curving more downward, by the elongated endothecal sclerite, as well as by the very high and flat apical lobe on segment IX, not low and triangular. 


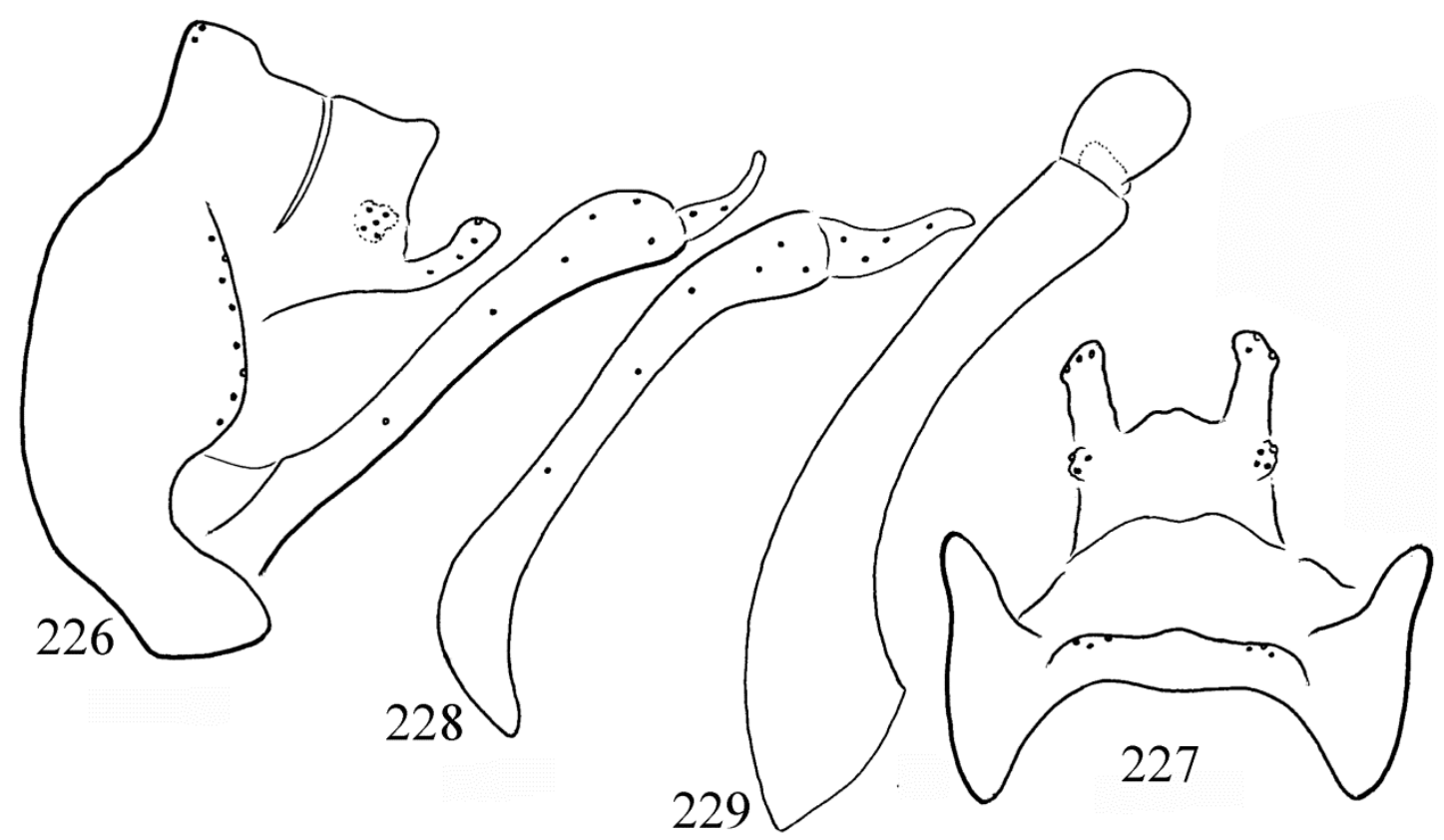

Figures 226-229. Cheumatopsyche madpradha sp. nov. Holotype: $226=$ male genitalia in left lateral view, $227=$ male genitalia in dorsal view, 228 = left gonopod in ventral view, 229 = phallic organ in left lateral view.

Description. A uniformly brown coloured small species with forewing length of $6 \mathrm{~mm}$.

Male genitalia. Abdominal segment IX fused annular, short; anterior margin arciform, resulted in short dorsum and ventrum; the ventrum without spiny ventrocaudal mesal lobe; apical margin produced into a flat and high lobe above the gonopods, marked with a row of strong spines; intersegmental depression between the ninth and tenth segments low and obtuse-angled in lateral view. Body of segment $\mathrm{X}$ subquadrangular both in lateral and dorsal views; circular lateral setose area (cerci) in apical position; apicoventral setose lobe well produced straight, posterad directed with head slightly laterad produced. The basal segment of the gonopods straight with curving and capitate head visible both in lateral and ventral views; harpago, the terminal segment of gonopod broad based, filiform in lateral and S-forming in ventral view. Phallic apparatus with tube shaped along almost the entire length, including phallobase; endothecal sclerite elongated ovoid.

Etymology. madpradha, coined from the name of locus typicus of the holotype.

\section{Cheumatopsyche manimapa sp. nov.}

(Figures 230-233, Map 6: $\mathrm{n}^{\circ}$ 13, 19, Map 18)

Material examined. Holotype: India, Manipur, Mapum, $3300 \mathrm{ft} ., 2^{\circ} 03^{\prime} 23.2^{\prime \prime} \mathrm{N} 94^{\circ} 30^{\prime} 33.5^{\prime \prime} \mathrm{E}, 12$. VI.1960. leg. F. Schmid (1 male, CNC). Paratype: India, Manipur, Langdan, 5300 ft., 5.VI.1960, leg. F. Schmid (1 male, OPC; 1 male, SMNH).

Diagnosis. This new species having trilobed segment $\mathrm{X}$ with elongated upward directed ventroapical setose lobe belongs to the Cheumatopsyche lepida species group (Oláh et al. 2008a). Its dorsal profile of the apicoventral setose lobe has relation to Cheumatopsyche madpradha sp. nov., but differs by the shape of the apicoventral setose lobe broadening apicad in lateral view and narrowing apicad in dorsal view; by the lateral profile of the phallic organ having broad phallobase not slender, by the more elongated endothecal sclerite, as well as by the shape of the harpago both in lateral and ventral views.

Description. A uniformly brown coloured small species with forewing length of $7 \mathrm{~mm}$. 


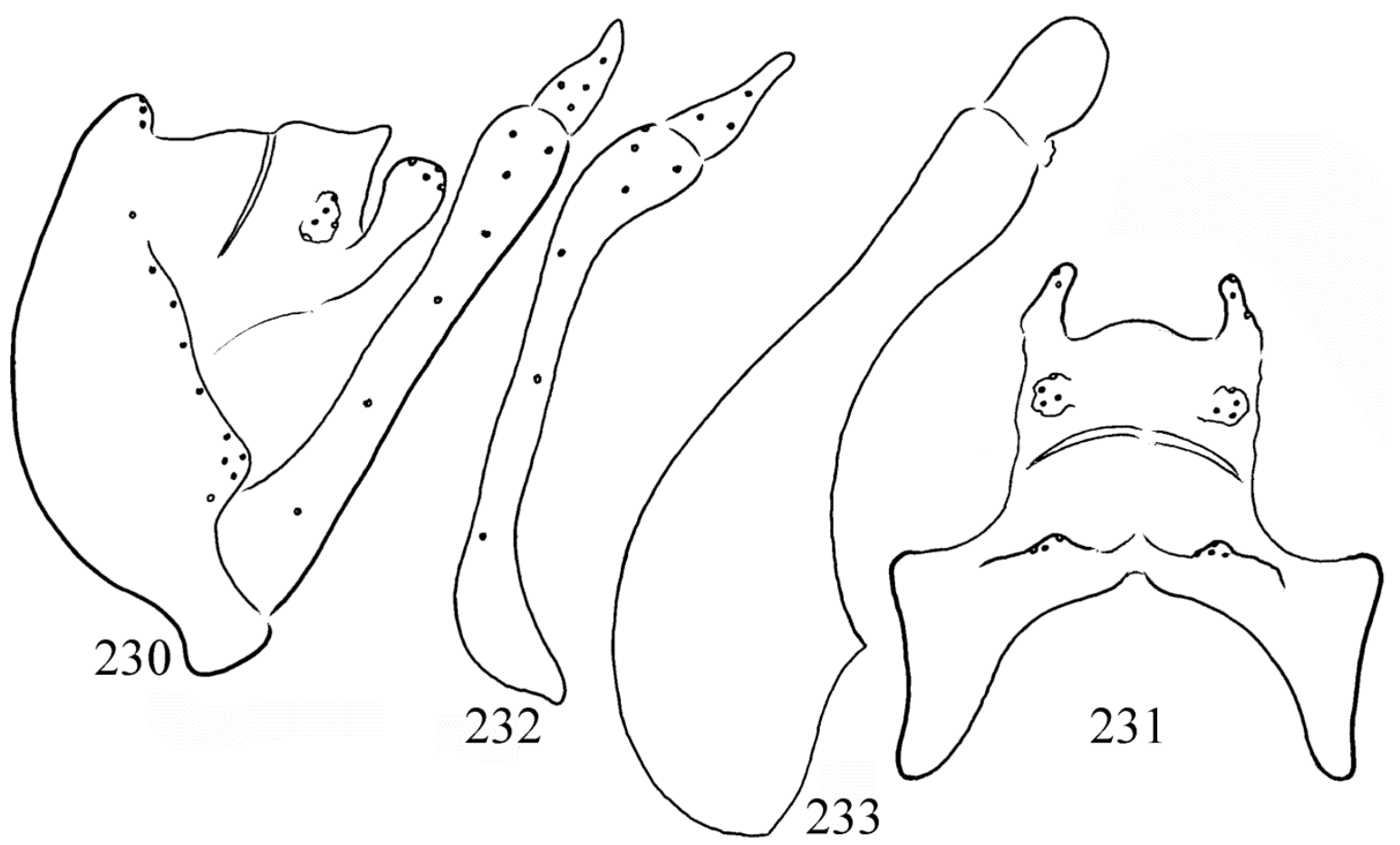

Figures 230-233. Cheumatopsyche manimapa sp. nov. Holotype: $230=$ male genitalia in left lateral view, $231=$ male genitalia in dorsal view, 232 = left gonopod in ventral view, 233 = phallic organ in left lateral view.

Male genitalia. Abdominal segment IX fused annular, short; anterior margin arciform, resulted in short dorsum and slightly longer ventrum; the ventrum without spiny ventrocaudal mesal lobe; apical margin produced into a flat and high lobe above the gonopods, marked with a row of strong spines; intersegmental depression between the ninth and tenth segments low and right-angled in lateral view. Body of segment X subquadrangular both in lateral and dorsal views; circular lateral setose area (cerci) in middle position; apicoventral setose lobe well produced straight, tapering in dorsal and broadening in lateral views. The basal segment of the gonopods regular straight ventrad in lateral view and capitate, mesad turning in ventral view; harpago, the terminal segment of gonopod broad based and tapering apicad. Phallic apparatus with tube shaped along almost the entire length with broad phallobase; endothecal sclerite elongated ovoid.

Etymology. manimapa, coined from the names of locus typicus of the holotype.

\section{Cheumatopsyche pondora sp. nov.}

(Figures 234-237, Map 5: n 68, Map 18)

Material examined. Holotype: India, Meghalaya (United Jaintia and Khasi Hills), Nongjni [=Nongjngi], $3750 \mathrm{ft}, 25^{\circ} 32^{\prime} 21.1^{\prime \prime} \mathrm{N} 92^{\circ} 16^{\prime} 12.4^{\prime \prime} \mathrm{E}$, 19.IV.1960, leg. F. Schmid (1 male, CNC).

Diagnosis. This new species having trilobed segment $\mathrm{X}$ with elongated upward directed ventroapical setose lobe belongs to the Cheumatopsyche lepida species group (Oláh et al. 2008a). It has relation to Cheumatopsyche gaia described from Nepal, but differs by the dorsal pattern of the trilobed structure and especially by the robust and strongly curved lateral profile of the phallic organ.

Description. A uniformly brown coloured small species with forewing length of $5 \mathrm{~mm}$.

Male genitalia. Abdominal segment IX fused annular, short; anterior margin arciform, resulted in a very short dorsum and short but little longer ventrum; the ventrum with a short spiny ventro 


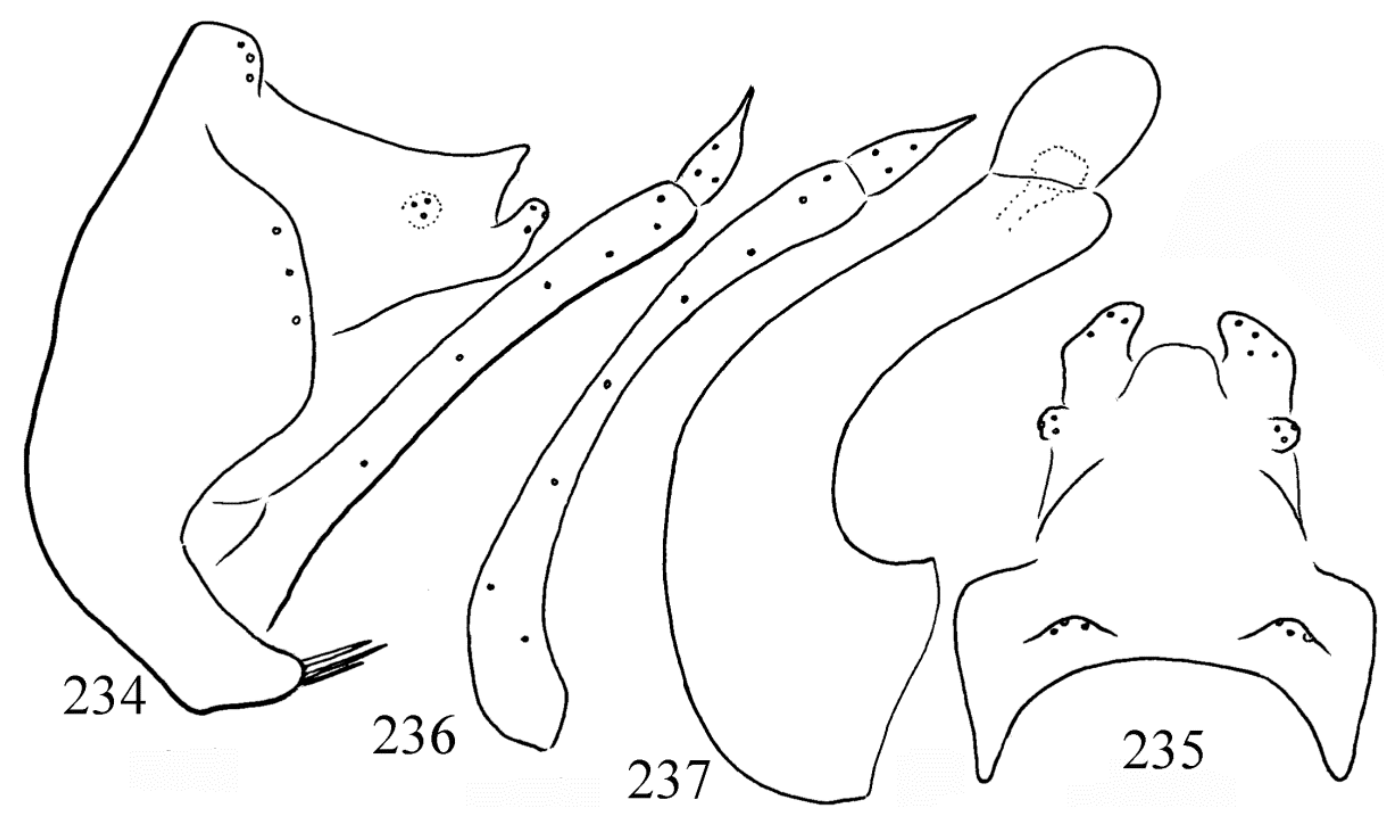

Figures 234-237. Cheumatopsyche pondora sp. nov. Holotype: $234=$ male genitalia in left lateral view, $235=$ male genitalia in dorsal view, 236 = left gonopod in ventral view, 237 = phallic organ in left lateral view.

caudal mesal lobe; apical margin is produced into a flat and high lobe above the gonopods, marked with a row of strong spines; intersegmental depression between the ninth and tenth segments almost right-angled in lateral view. Body of segment $X$ longer than high; circular lateral setose area (cerci) in middle position; apicoventral setose lobe discernible as a small setose lobe turning upward and mesad. The basal segment of the gonopods straight in lateral and curving in ventral view; harpago, the terminal segment of gonopod broad based and filiform on its apical third. Phallic apparatus robust and strongly curving with convex dorsum.

Etymology. pondora, coined from "pöndör" curly in Hungarian, refers to the unique robust and almost re-curving phallotheca.

\section{Cheumatopsyche puramukta sp. nov.}

(Figures 238-241, Map 5: n 11, 84, Map 18)

Material examined. Holotype: India, Meghalaya (United Jaintia and Khasi Hills), Muktapur, 200 ft., $25^{\circ} 09^{\prime} 48.6^{\prime \prime N}$ 9207'45.4"E, 11-12. XII.1959, leg. F. Schmid (1 male, CNC). Para- types: same as holotype (1 male, $\mathrm{CNC}$; 1 male, OPC; 1 male, SMNH). India, Assam, United District of Mikir and North Cachar Hills, Bandarkhal, 300 ft., $25^{\circ} 03^{\prime} 31.1^{\prime \prime} \mathrm{N} 92^{\circ} 48^{\prime} 02.5^{\prime \prime} \mathrm{E}, 9 . \mathrm{V} .1960$, leg. F. Schmid (1 male, OPC).

Diagnosis. This new species having setose bilobed segment $\mathrm{X}$ that is the ventroapical pair of setose lobes with pronounced setaless apicomesal lobe belongs to the Cheumatopsyche lepida species group (Oláh et al. 2008). According to the structure of the apicoventral lobes, it is most close to Cheumatopsyche kurtula described from China (Fujian) but differs by having smaller size; very long harpago, not very short; well developed apicomesal lobe narrowing apicad, lacking in $C$. kurtula; falciform ventroapical setose lobes, not straight; circular endothecal sclerites, not elongated and downward curving.

Description. Small brown animal without any spots on forewing; forewing length of $6 \mathrm{~mm}$.

Male genitalia. Abdominal segment IX fused annular, short; anterior margin bow-shaped, resulted in a short dorsum and ventrum; apical margin is straight vertical marked with a row of 


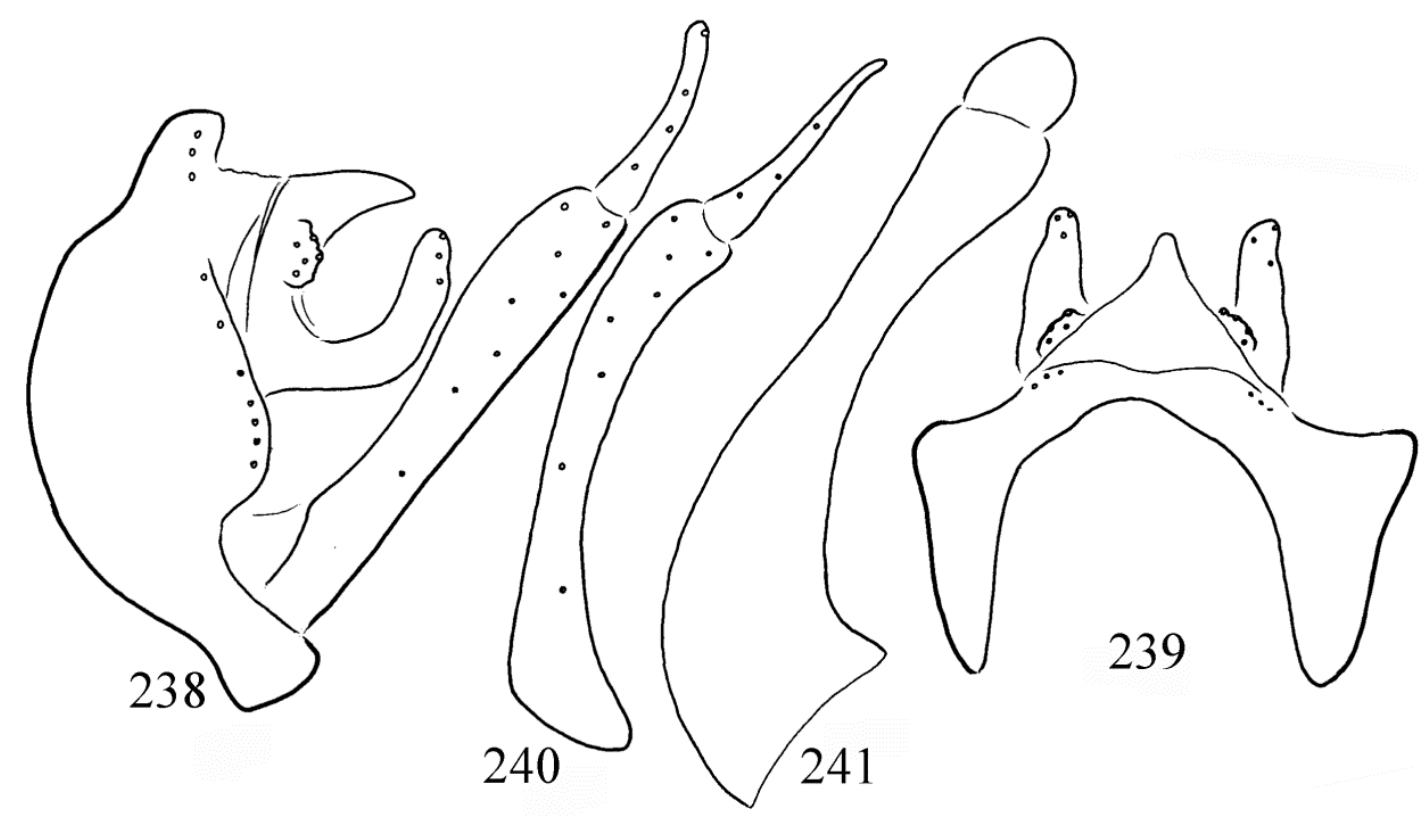

Figures 238-241. Cheumatopsyche puramukta sp. nov. Holotype: $238=$ male genitalia in left lateral view, $239=$ male genitalia in dorsal view, $240=$ left gonopod in ventral view, 241 = phallic organ in left lateral view.

strong spines; intersegmental depression between the ninth and tenth segments deep, right angled in lateral view. Basal body of segment $\mathrm{X}$ very short; lateral setose area (cerci) shifted apicad, forming a short setose process packed with alveoli; apicoventral setose lobe very long, straight in dorsal and falciform in lateral view. The basal segment of the gonopods robust, straight with slightly dilated apical half; the terminal segments long digitiform. Phallic apparatus straight horizontal with middle constriction, phallotremal sclerite pronounced large, endothecal sclerites circular.

Etymology. puramukta, coined from the names of locus typicus of the holotype.

\section{Cheumatopsyche purmapa sp. nov.}

(Figures 242-245, Map 6: $\mathrm{n}^{\circ}$ 19, Map 18)

Material examined. Holotype: India, Manipur, Mapum, $3300 \mathrm{ft}$., 2503'23.2"N 94³0'33.5"E, 12. VI. 1960.leg. F. Schmid (1 male, CNC).

Diagnosis. This new species having trilobed segment $\mathrm{X}$ with elongated upward directed ven- troapical setose lobe belongs to the Cheumatopsyche lepida species group (Oláh et al. 2008a). Its dorsal profile of the apicoventral setose lobe has relation to Cheumatopsyche madpradha sp. nov., but differs by the shape of apicoventral setose lobe more capitate in lateral view; by the lateral profile of the phallic organ having broad phallobase not slender, by the small highly modified endothecal sclerite, as well as by the shape of the harpago slender in ventral view.

Description. A uniformly brown coloured small species with forewing length of $5 \mathrm{~mm}$.

Male genitalia. Abdominal segment IX fused annular, short; anterior margin arciform, resulted in very short dorsum and longer ventrum; the ventrum without spiny ventrocaudal mesal lobe; apical margin produced into a rounded lobe above the gonopods, marked with a row of strong spines; intersegmental depression between the ninth and tenth segments low in lateral view. Body of segment $\mathrm{X}$ subquadrangular both in lateral and dorsal views, supplied with an elaborated pattern of sutures visible in lateral view; circular lateral setose area (cerci) in middle position; apicoventral setose lobe well produced 


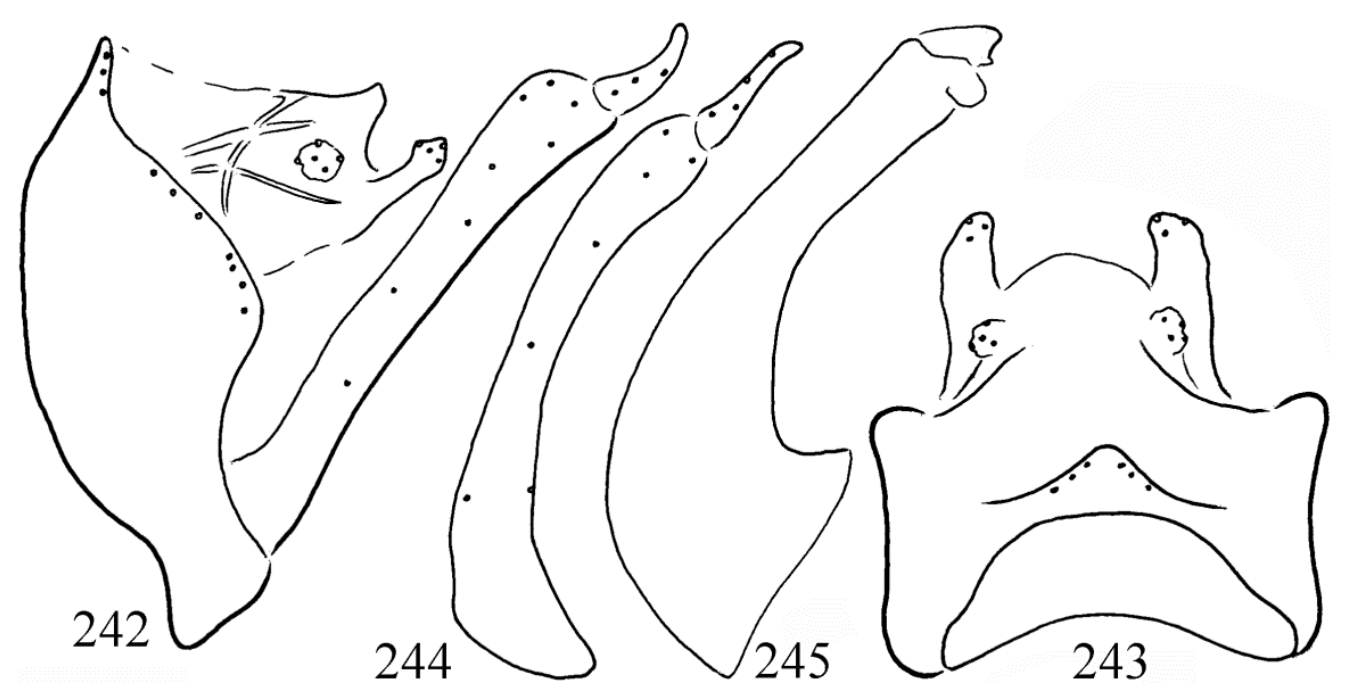

Figures 242-245. Cheumatopsyche purmapa sp. nov. Holotype: $242=$ male genitalia in left lateral view, $243=$ male genitalia in dorsal view, 244 = left gonopod in ventral view, 245 = phallic organ in left lateral view.

straight, tapering and slightly mesad turning in dorsal and capitate in lateral views. The basal segment of the gonopods straight in lateral view; harpago, the terminal segment of gonopod slightly broad based and tapering apicad. Phallic apparatus tube shaped along almost the entire length with broad phallobase; endothecal sclerite reduced in size.

Etymology. purmapa, coined from the names of locus typicus of the holotype.

\section{Cheumatopsyche sohkha sp. nov.}

(Figures 246-249, Map 5: nº 7, Map 18)

Material examined. Holotype: India, Meghaláya (United Jaintia and Khasi Hills), Sohkha [= Sohkha Shnong], 200-300 ft., 25¹2'59.3"N 92 01'55.0"E, 7.XII.1959, leg. F. Schmid (1 male, CNC).

Diagnosis. This new species having setose bilobed segment $X$ that is the ventroapical pair of setose lobes with pronounced setaless apicomesal lobe belongs to the Cheumatopsyche lepida species group (Oláh et al. 2008). According to the structure of the apicoventral lobes most close to Cheumatopsyche puramukta sp. nov., but differs by having unique gopopods with short and broad coxopodite and slender and long harpago; by the indiscernible probably membranous basodorsum of segment X, disappeared during chemical treatment; by the straight not curving ventroapical setose lobes; as well as by the long endothecal sclerites on the phallic organ.

Description. Small brown animal without any spots on forewing; forewing length of $6 \mathrm{~mm}$.

Male genitalia. Abdominal segment IX fused annular, short; anterior margin bow-shaped, resulted in a short dorsum and longer ventrum; apical margin is rounded triangular marked with a row of strong spines; intersegmental depression between the ninth and tenth segments extraordinary deep probably due to dissolution of the membranous basodorsum. Body of segment $\mathrm{X}$ very incomplete; lateral setose area (cerci) shifted apicad; apicoventral setose lobe very long, straight in lateral view and rather flexible mesad turning in dorsal view. The basal segment of the gonopods short, robust, with much dilated apex; harpago long digitiform. Phallic apparatus straight horizontal with slight middle constriction, phallotremal sclerite pronounced large, endothecal sclerites elongated.

Etymology. sohkha, coined from the names of locus typicus of the holotype. 


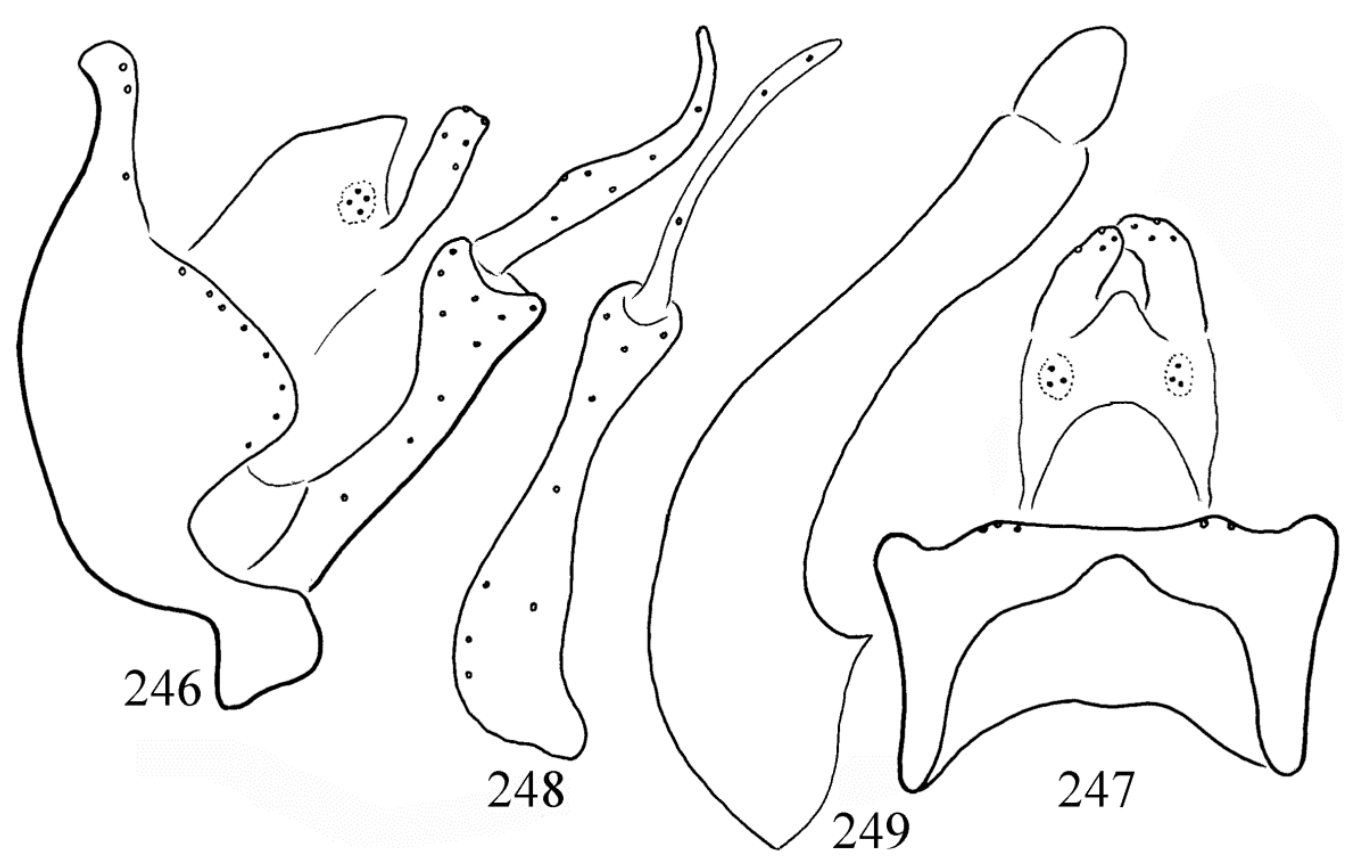

Figures 246-249. Cheumatopsyche sohkha sp. nov. Holotype: $246=$ male genitalia in left lateral view, $247=$ male genitalia in dorsal view, 248 = left gonopod in ventral view, 249 = phallic organ in left lateral view.

\section{Cheumatopsyche swampa sp. nov.}

(Figures 250-253, Map 7a: n 30, Map 18)

Material examined. Holotype: India, Tamil Nadu (Madras), Swamp Hill, South Mannavanur, $7300 \mathrm{ft}$., $10^{\circ} 10^{\prime} 01^{\prime \prime N} 77^{\circ} 22^{\prime} 36^{\prime \prime} \mathrm{E}$, According to Lonsdale (2020), it corresponds to the Swamp Hill where Schmid collected Doloclanes acteon, D. alcmeon, Apsilochorema dakchinam, 2.II.1962, leg. F. Schmid (1 male, CNC).

Diagnosis. This new species having trilobed segment $\mathrm{X}$ with elongated upward directed ventroapical setose lobe belongs to the Cheumatopsyche lepida species group (Oláh et al. 2008a). Its dorsal profile of the apicoventral setose lobe has relation to Cheumatopsyche mariannae and its harpago to $C$. sandrae both described from Karnataka, but differs from both by the lateral profile of the phallic organ having long and broad phallobase, short and narrow at the two Karnatakan species.

Description. A uniformly brown coloured small species with forewing length of $6 \mathrm{~mm}$.
Male genitalia. Abdominal segment IX fused annular, short; anterior margin arciform, resulted in a very short dorsum and longer ventrum; the ventrum is without spiny ventrocaudal mesal lobe; apical margin is produced into a flat and high lobe above the gonopods, marked with a row of strong spines; intersegmental depression between the ninth and tenth segments deep and right-angled in lateral view. Body of segment X longer than high; circular lateral setose area (cerci) in middle position; apicoventral setose lobe well produced slightly and mesad and in right angle upward directed. The basal segment of the gonopods straight in lateral and curving and capitate in ventral views; harpago, the terminal segment of gonopod broad based, curving and filiform. Phallic apparatus with broad and long phallobase; endothecal sclerite elongated ovoid.

Etymology. swampa, named after the locus typicus of the holotype.

\section{Cheumatopsyche dubitans species group}

Species group of bilobed segment $\mathrm{X}$ with long ventroapical lobe (Oláh et al. 2008a). A pair of 


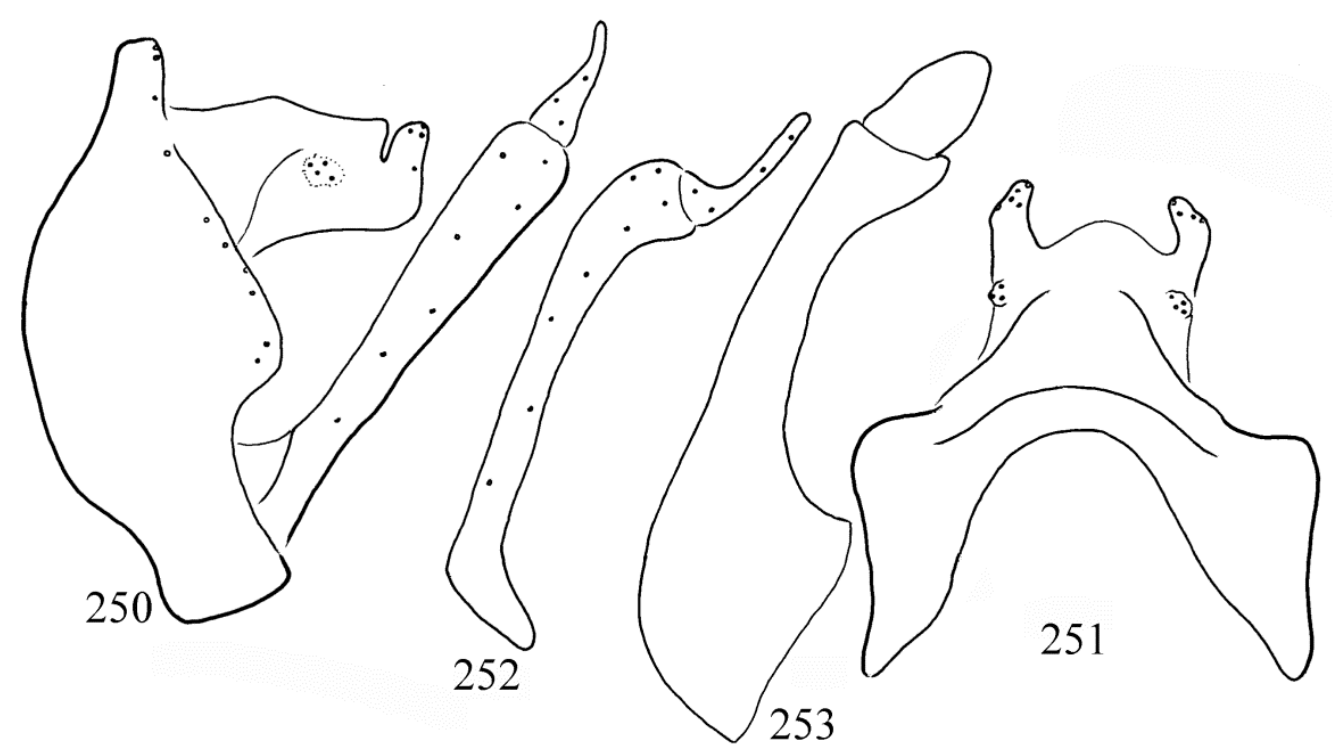

Figures 250-253. Cheumatopsyche swampa sp. nov. Holotype: $250=$ male genitalia in left lateral view, $251=$ male genitalia in dorsal view, 252 = left gonopod in ventral view, 253 = phallic organ in left lateral view.

setose ventroapical lobe produced into a long process straight or mesad curving in dorsal aspect and straight or dorsad curving in lateral aspect, encircling wide and deep dorsal and lateral interlobular gaps in dorsal and lateral aspects while dominating the termination of segment $\mathrm{X}$. The bare unsetose mesocaudal lobe mostly reduced. Some species have patterned forewing membrane.

\section{Cheumatopsyche dubitans Mosely, 1942}

$$
\text { (Map 5: } \mathrm{n}^{\circ} \text { 64, 65, 68, 74, Map 19) }
$$

Cheumatopsyche dubitans Mosely, 1942:352, 354. "One example dated 27.IV.1938; an example already in the British Museum is labelled China only and is lacking an abdomen." The examined specimen, the holotype with description and drawings of both the wings and the genitalia is collected by $\mathrm{Mr}$. M. S. Yang in Foochow = Fuzhou, China: "The locality, in every case, is the vicinity of Foochow, and the only dates available, except in a few particular instances which are indicated, are the years 1935-1936, 1936-1937." Probable approximate collecting site: $26^{\circ} 08^{\prime} 48.0^{\prime \prime} \mathrm{N} 119^{\circ} 17^{\prime} 44.3^{\prime \prime} \mathrm{E}$.

Material examined. India, Meghalaya (United Jaintia and Khasi Hills), Nongjni [= Nongjngi], $3750 \mathrm{ft}, 25^{\circ} 32^{\prime} 21.1^{\prime \prime} \mathrm{N} 92^{\circ} 16^{\prime} 12.4 " \mathrm{E}, 19 . \mathrm{IV} .1960$, leg. F. Schmid (5 males, CNC; 2 males, OPC).
India, Meghalaya (United Jaintia et Khasi Hills),

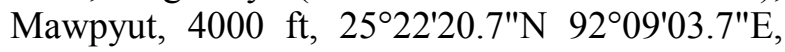
14.IV.1960, leg. F. Schmid (1 male, OPC). India, Meghalaya (United Jaintia et Khasi Hills), Demthring, $3800 \mathrm{ft}, 25^{\circ} 26^{\prime} 09.5^{\prime \prime} \mathrm{N} 92^{\circ} 10^{\prime} 08.0^{\prime \prime} \mathrm{E}, 16$. IV.1960, leg. F. Schmid (1 male, CNC; 1 male, OPC). India, Assam, United District of Mikir and North Cachar Hills, Umbaso, 2300 ft, 254' 46.3"N 92³1'33.5"E, 26.IV.1960, leg. F. Schmid (7 males, 3 females; CNC).

Records. The single specimen from Mawpyut has more scattered pattern on the forewing, but we were unable to find any divergences in the genital structure.

\section{Cheumatopsyche mawpya sp. nov.}

(Figures 254-257, Map 5: n 64, Map 19)

Material examined. Holotype: India, Maghalaya (United Jaintia et Khasi Hills), Mawpyut,

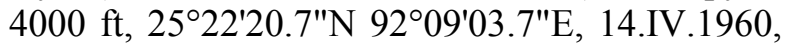
leg. F. Schmid (1 male, OPC).

Diagnosis. This new small species having setose bilobed segment $\mathrm{X}$ that is the ventroapical pair of setose lobes are present and elongated, but the setaless apicomesal lobe reduced, belongs to 


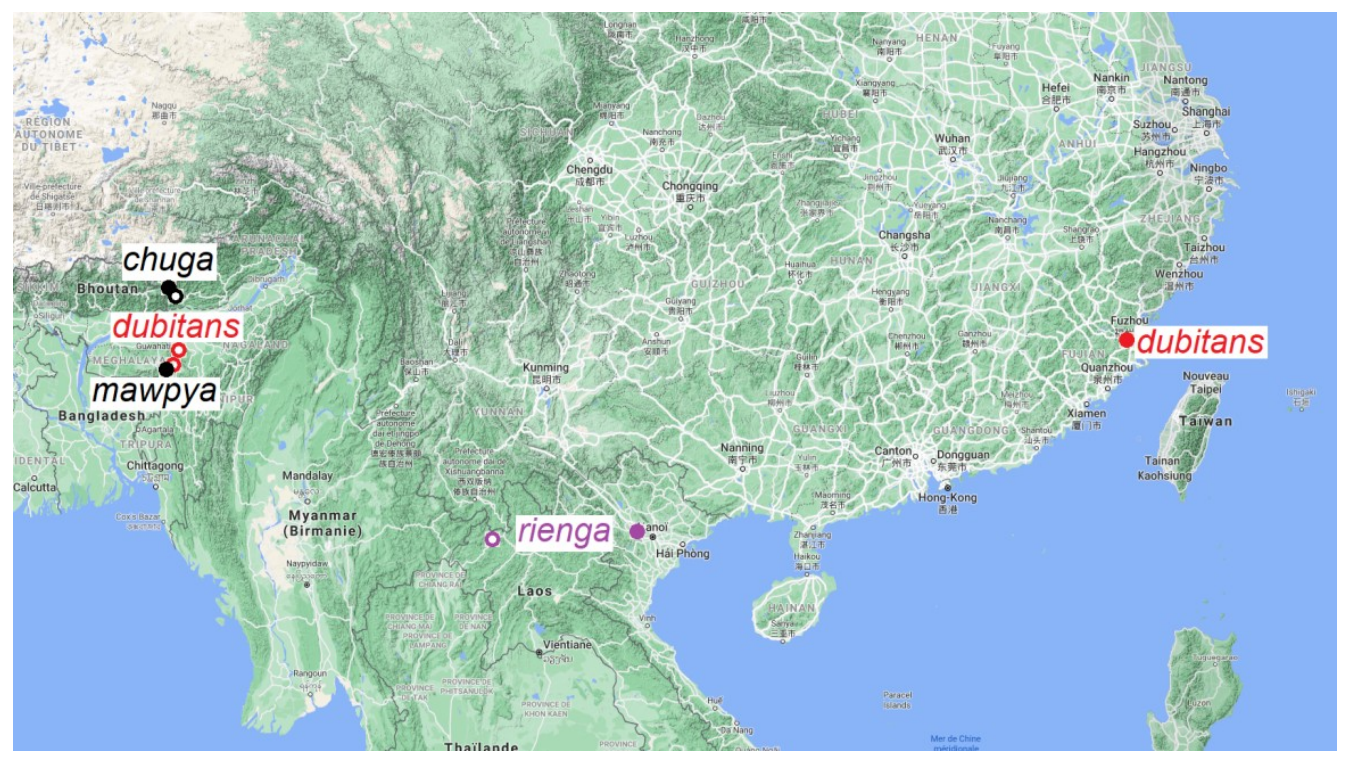

Map 19. Cheumatopsyche dubitans and excisa groups.

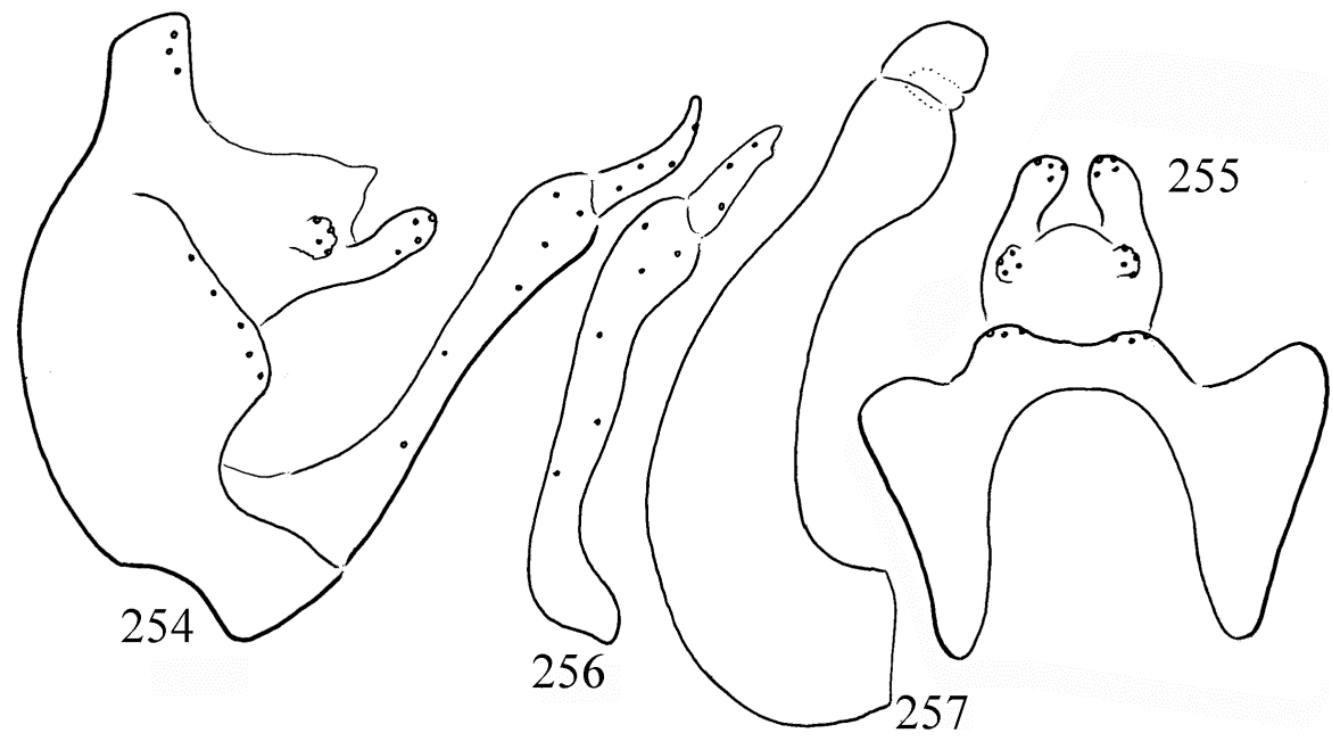

Figures 254-257. Cheumatopsyche mawpya sp. nov. Holotype: $254=$ male genitalia in left lateral view, $255=$ male genitalia in dorsal view, 256 = left gonopod in ventral view, 257 = phallic organ in left lateral view.

the Cheumatopsyche dubitans species group (Oláh et al. 2008). Most close to C. bunkos Oláh, Li \& Oláh, described from China (Guangxi and Fujian Provinces), but differs by having not any spots on forewing, having rounded, but not capitate head of the ventroapical setose lobe in lateral view as well as rounded and not obliquely truncated and mesad turning in dorsal view. The tip of the harpago excised in ventral view, not rounded intact. The lateral profile of the phallic organ is highly convex dorsad, not concave.

Description. A small dark brown animal without any spots on forewing $\mathrm{Sc}$ and $\mathrm{R}$; forewing length is $6 \mathrm{~mm}$.

Male genitalia. Abdominal segment IX fused 
annular, short; anterior margin bow-shaped, resulted in a short dorsum and little longer ventrum; apical margin straight, vertical marked with a row of strong spines; intersegmental depression between the ninth and tenth segments deep vertical in lateral view. Body of segment $\mathrm{X}$ as high as long; lateral setose area (cerci) in middle position forming a short setose process packed with alveoli; apicoventral setose lobe elongated with rounded head in lateral and slightly mesad turning in dorsal view; apicomesal lobe less produced. The basal segment of the gonopods with dilated and downward turning apex; harpago, the terminal segment short with excised apex in ventral view. Phallic apparatus convex dorsad, phallotremal sclerite pronounced large, endothecal processes short and rounded.

Etymology. mawpya, coined from the name of the locus typicus of the holotype.

\section{Cheumatopsyche excisa species group}

Establishment of this species group was based primarily on the bilobed harpago, accompanied by character combination similar to Cheumatopsyche dubitans species group having bilobed segment $\mathrm{X}$ with long ventroapical lobe as well as with less developed unsetose mesal plate on segment $\mathrm{X}$ (Oláh et al. 2008a). The pair of setose ventroapical lobes produced into a long process straight or mesad curving in dorsal aspect and straight or dorsad curving in lateral aspect, encircling the wide and deep dorsal and lateral interlobular gaps in dorsal and lateral views while dominating the termination of segment X. Wart-like lateral setose area, the cerci, the vestigium of preanal appendages located centrally or distad on segment X.

However, several species with bilobed harpago have differently formed ventroapical setose lobe, different unsetose mesal plate and different dorsal interlobular gap. These character state incongruences, like in any other entities, are the result of a reticulated chimeric genesis undermining the naïve religious believe in phylogeny. Reality is rather reticulating than branching in the deep and only superficially discernible directly or even indirectly by human capacity. Retigeny (from rete, reticulum=fishing net, network in Latin, Oláh et al. 2020b), or if we go back thousand years, diktiogeny (from diction=fishing net in old Greek) are behind of any speciation processes (Oláh et al. 2021).

Cheumatopsyche excisa species group created by its bilobous harpago is composed of other characters from several species groups. Most species have long bilobed segment $\mathrm{X}$ without welldeveloped convex mesal plate, a character state of the Cheumatopsyche dubitans species group: $C$. abhugna, C. ceres, C. faniel, C. guadunica, C. rienga, $C$. sara, C. transmutata. Few species have convex mesal plate of Cheumatopsyche lepida species group: C. capronita, C. carna, C. chuga sp. nov. Cheumatopsyche sara has unsetose mesal plate with convex apical margin, a character state of Cheumatopsyche lepida species group. Third and fourth groups of species of bilobed harpago characterized by dorsal interlobular gap very shallow or narrow leading in a few cases to an almost complete fusion of lobes into a monolobed segment X. Shallow dorsal interlobular gap is the character state of Cheumatopsyche costalis species group: C. dangchura sp. nov., C. oinamla sp. nov., C. excisa, C. georgulmeri, C. kamposka sp. nov., $C$. mawprana sp. nov., $C$. nonga sp. nov., $C$. nongajra sp. nov., $C$. salaka sp. nov., $C$. trilari, $C$. triptolemos, C. yunnana sp. nov. Narrow dorsal interlobular gap is the character state of Cheumatopsyche columnata species group: $C$. saltorum, C. stigma. The four types of character combination detected in the Cheumatopsyche excisa species group instantiate that retigenetic chimeric structure of integrative organisation is present and functions not only in species level, but also in higher taxa.

This small species group is distributed both in the Oriental mainland and in the Oriental archipelago of Southeast Asia.

\section{Cheumatopsyche chuga sp. nov.}

(Figures 258-261, Map 4: n 69, 87, Map 19)

Material examined. Holotype: India, Arunachal Pradesh (Assam), Kameng district, Chug, 


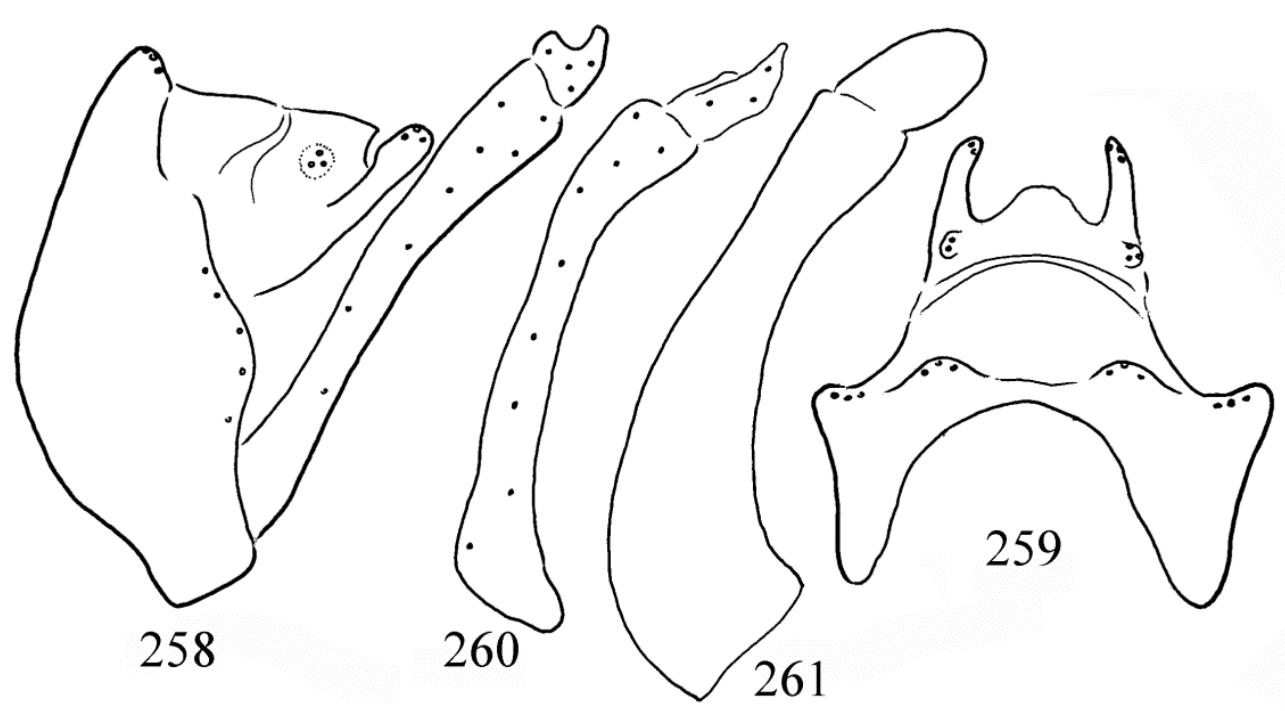

Figures 258-261. Cheumatopsyche chuga sp. nov. Holotype: $258=$ male genitalia in left lateral view, $259=$ male genitalia in dorsal view, $260=$ left gonopod in ventral view, 261 = phallic organ in left lateral view.

$6800-7300 \mathrm{ft} ., 27^{\circ} 25^{\prime} 07.7^{\prime \prime} \mathrm{N} 92^{\circ} 14^{\prime} 01.0^{\prime \prime} \mathrm{E}, 25-$ 31.VII.1961, leg F. Schmid (1 male, CNC). Paratype: same as holotype (1 male, OPC). India, Assam, Kameng, Bilo La, 5800-6000 ft, [according to the road of Schmid, it should be near Domkho], 2709'56.4"N 92॰13'49.7"E, leg. F. Schmid (1 male, ROM).

Diagnosis. This new species having bilobed harpago belongs to the Cheumatopsyche excisa species group. Its trilobed segment $\mathrm{X}$ with elongated upward directed ventroapical setose lobe is a character state of the Cheumatopsyche lepida species group (Oláh et al. 2008a). Most close to C. abhugna Oláh \& Barnard, 2008, but differs by the longer and more slender ventroapical setose lobes; by the less excised harpago and by the elongated ovoid and not drop-shaped endothecal sclerite.

Description. A uniformly brown coloured small species with forewing length of $7 \mathrm{~mm}$.

Male genitalia. Abdominal segment IX fused annular, short; anterior margin arciform, resulted in a very short dorsum and short but slightly longer ventrum; the ventrum lacks spiny ventrocaudal mesal lobe; apical margin produced into a flat and high lobe above the gonopods, marked with a row of strong spines; intersegmental de- pression between the ninth and tenth segments low and oblique in lateral view. Body of segment $\mathrm{X}$ longer than high, subtriangular in lateral view; circular lateral setose area (cerci) in middle position; apicoventral setose lobe long, elongated capitate in lateral view and slender tapering and slightly mesad turning in dorsal view. The basal segment of the gonopods slightly curving both in lateral and ventral views; harpago, the terminal segment of gonopod bilobed, less excised. Phallic apparatus robust and low with convex dorsum, endothecal sclerites ovoid.

Etymology. chuga, named after the locus typicus of the holotype.

\section{Cheumatopsyche rienga Oláh \& Johanson, 2008, stat. restit.}

(Map 19)

Cheumatopsyche rienga Oláh \& Johanson, 2008, in Oláh et al. 2008a:83-84. Holotype: Vietnam (Ha Son Bin Prov. [=Hà Sơn Bình]), Paratype: Laos (Luang Namtha Prov. [=Louang Namtha]).

Cheumatopsyche carna Malicky \& Chantaramongkol, 1997, in Malicky, 1997: Thailand (Tham Than Lod NP, Ban Yang Bong, Mae Rim): Malicky, 2013:48. "Cheumatopsyche carna M\&C $1997=$ C. rienga Oláh \& Johanson, 2008: Die Abbildungen zeigen keinen Unterschid: NOV. SYN.” 
Remarks. Here we cite the original diagnosis of Cheumatopsyche rienga Oláh \& Johanson, 2008 distinguishing this very small species from its sibling species C. carna: "This species is similar to C. carna from Thailand, but the lateral interlobular gaps are very short and narrow, not sinuous; the dorsal interlobular is also short and heart-shaped in dorsal view, not deep; the bilobed harpagones have a long undivided basis, which is very short in C. carna."

We have re-examined the holotype and recorded the same delineating characters between the two species. Moreover, the most distinguishing character created by the differently shaped lateral and dorsal interlobular gaps is the shape of the pair of the long ventrolateral setose lobes. Its lateral profile is clearly capitate and obliquely posterad directed in C. rienga, but narrowing and upward directed in C. carna. The dorsal view confirms these significant divergences between the two species in the shape of the ventrolateral setose lobes. We have also recorded divergences in the position of cerci compared to the positions both to the lateral and dorsal interlobular gaps: gaps are far from cerci in C. rienga and nearby in C. carna. We have experienced again the inadequacy of apophantic nature of creating synonymies by lumpers applying and relying upon the character states of gross phenomics, while not accepting or rather neglecting the reality of fine phenomics, especially the fine phenomics of speciation traits. However, the real knowledge of the exact taxonomic position of $C$. carna and $C$. rienga requires population sampling and research on the whole distributional area, including contact populations. Here we reinstate the species status of Cheumatopsyche rienga Oláh \& Johanson, 2008, stat. restit.

\section{Cheumatopsyche costalis species group}

Species group of bilobed segment $\mathrm{X}$ with shortened ventroapical lobe (Oláh et al. 2008a). A pair of setose ventroapical lobe shortened into a reduced process or just a wart mostly straight both in dorsal and lateral aspects. Interlobular gaps at the termination of segment $X$ very much reduced, visible only in dorsal aspect, usually as a shallow and wide gap. However, the length of the ventroapical setose lobes could be intermediate between short (costalis group) and long (dubitans group). Distributed in South and Southeast Asia, including the Southeast Asian archipelago.

\section{Cheumatopsyche dangchura sp. nov.}

(Figures 262-265, Map 2: n 16, Map 21)

Material examined. Holotype: India, Uttarakhand, Tehri Garhwal, Dangchura = Dang Chaunra, 3000-3200 ft., 2 small brooks tributary of Takali Gad, $30^{\circ} 15^{\prime} 55.8^{\prime \prime N} 78^{\circ} 43^{\prime} 02.2^{\prime \prime} \mathrm{E}, 25 . I V$. 1958, leg. F. Schmid (1 male, CNC). Paratype: same as holotype (1 male, OPC).

Diagnosis. This new species having bilobed segment $X$ with shortened ventroapical lobe belongs to the Cheumatopsyche costalis species group (Oláh et al. 2008a). According to the structure of segment $\mathrm{X}$, the gonopod, especially the harpago and the phallic organ, this small, delicate brown species is most close to the Cheumatopsyche ningmapa but differs by the dorsal and lateral profiles of segment $X$. The setose ventroapical lobes has lost its stalk or stem and resulted in a low (shallow) interlobular gap.

Description. A uniformly brown coloured small species with forewing length of $5 \mathrm{~mm}$.

Male genitalia. Abdominal segment IX fused annular, short; anterior margin arciform, resulted in a very short dorsum and short but slightly longer ventrum; the ventrum is without spiny ventrocaudal mesal lobe; apical margin is produced into a flat lobe above the gonopods, marked with a row of strong spines; intersegmental depression between the ninth and tenth segments oblique and deep in lateral view. Body of segment X longer than high; circular lateral setose area (cerci) in middle position; apicoventral setose lobe discernible as an obliquely positioned slightly elongated structure as visible both in dorsal and lateral views. The basal segment of the gonopods straight dilating apicad in lateral view; harpago, the terminal segment, slender digitate arching in lateral and broad-based in ventral views. Phallic apparatus with constricted middle and broadening 


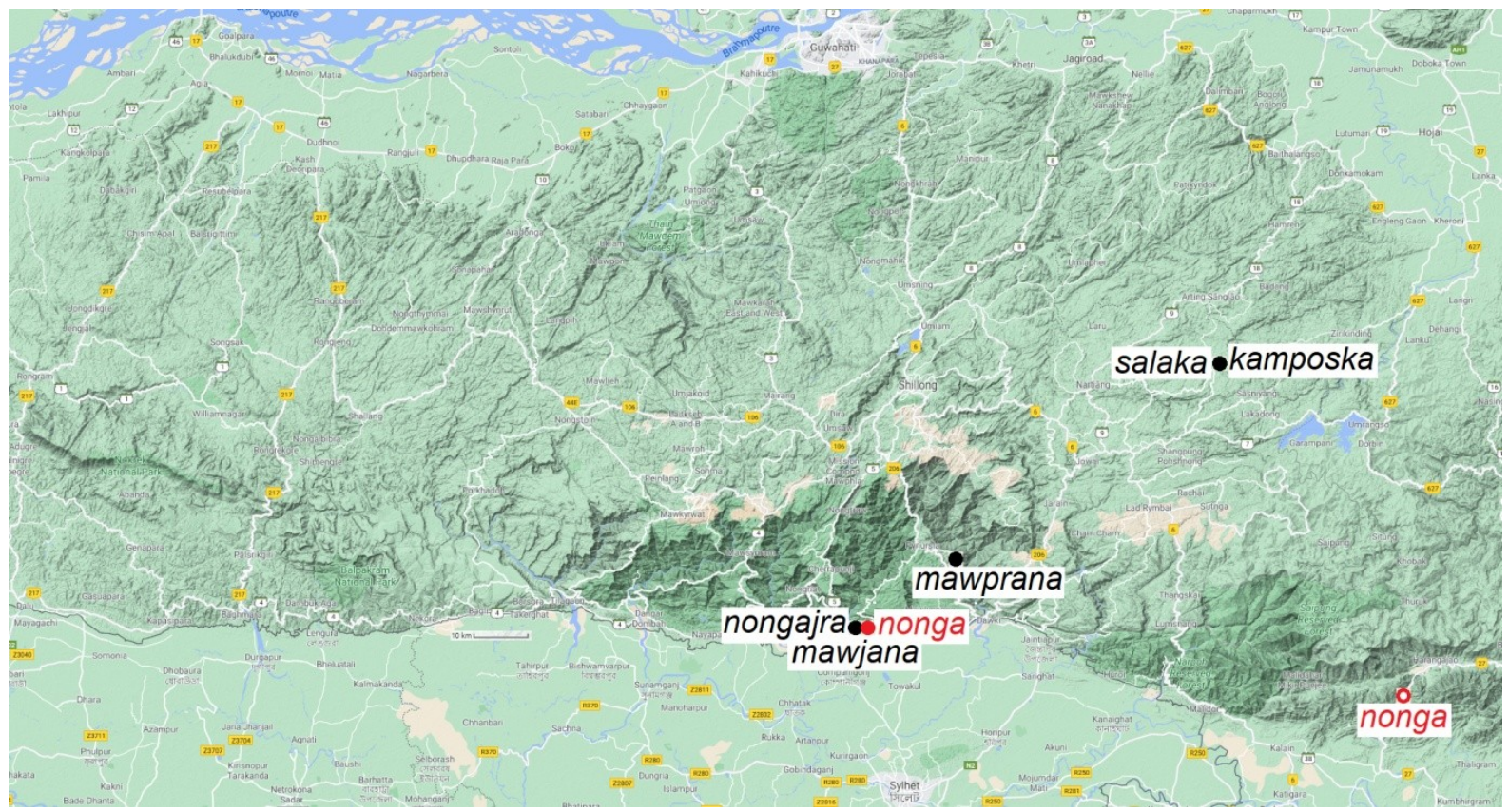

Map 20. Cheumatopsyche costalis group with only Meghalaya.

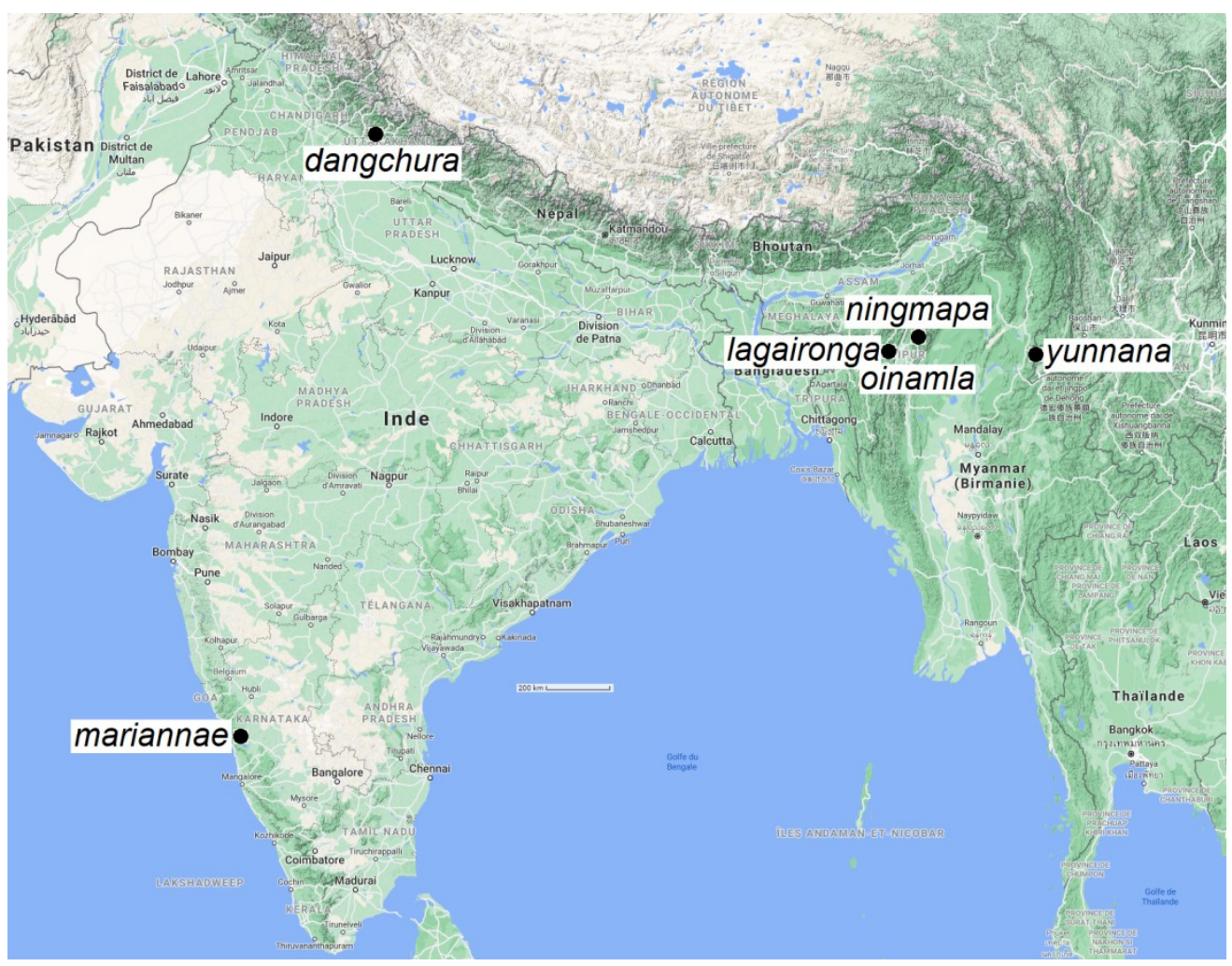

Map 21. Cheumatopsyche costalis group outside Meghalaya. 


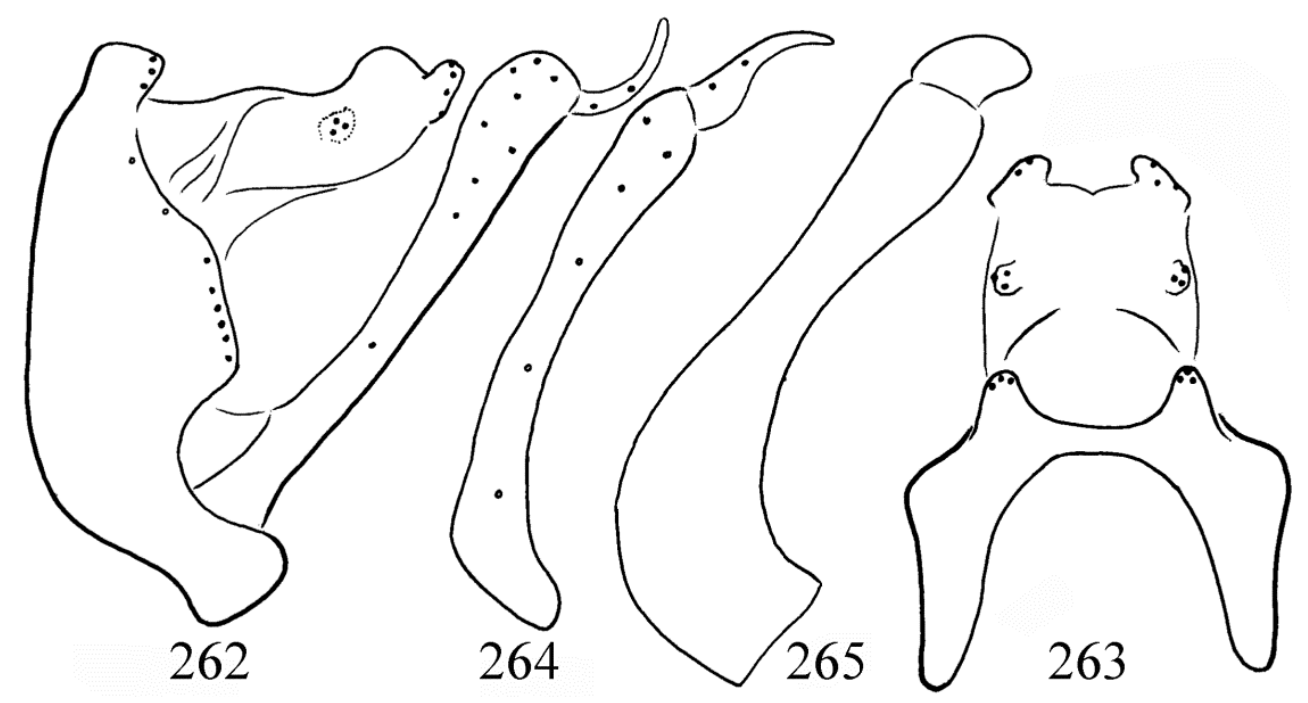

Figures 262-265. Cheumatopsyche dangchura sp. nov. Holotype: $262=$ male genitalia in left lateral view, $263=$ male genitalia in dorsal view, 264 = left gonopod in ventral view, 265 = phallic organ in left lateral view.

apicoventrum; the pair of endothecal sclerites elongated, downward directed.

Etymology. dangchura, named after the locus typicus of the holotype.

\section{Cheumatopsyche kamposka sp. nov.}

(Figures 266-269, Map 5: n 72, Map 20)

Material examined. Holotype: India, Meghalaya (United Jaintia and Khasi Hills), Barato, $2500 \mathrm{ft} ., 25^{\circ} 36^{\prime} 24.1^{\prime \prime} \mathrm{N} 92^{\circ} 27^{\prime} 23.1 " \mathrm{E}, 24 . I V .1960$, leg. F. Schmid (1 male, CNC).

Diagnosis. This new species having bilobed segment $\mathrm{X}$ with shortened ventroapical lobe belongs to the Cheumatopsyche costalis species group (Oláh et al. 2008a). According to the structure of segment $\mathrm{X}$, the gonopod, especially the harpago and the phallic organ, this small delicate brown species most close to the Cheumatopsyche cressida of the Cheumatopsyche concava species group described from Nepal. However, its ventroapical setose lobe clearly enlarged, as visible both in lateral and dorsal views, a character state of the $C$. costalis group and not reduced, not vestigial, a character state of the $C$. concava species group. There are other divergences between the two species. At C. kamposka sp. nov. the coxopodite of gonopods much longer; the hooked endothecal sclerites of the phallic organ much longer as well as the apical region of the phallotheca more produced broad ventrad, than dorsad.

Description. A uniformly brown coloured small species with forewing length of $5 \mathrm{~mm}$.

Male genitalia. Abdominal segment IX fused annular, short; anterior margin arciform, resulted in a very short dorsum and short but slightly longer ventrum; the ventrum is without spiny ventrocaudal mesal lobe; apical margin is produced into a triangular lobe above the gonopods, marked with a row of strong spines; intersegmental depression between the ninth and tenth segments oblique and very shallow in lateral view. Body of segment $X$ longer than high; circular lateral setose area (cerci) in apical position; apicoventral setose lobe discernible as a small rectangular setose lobe as visible both in dorsal and lateral views. The basal segment of the gonopods straight slightly dilating apicad in lateral and more dilated in ventral view; harpago, the terminal segment, slender digitate slightly arching both in lateral and ventral views. Phallic apparatus with constricted middle and broadening apicodorsum and more apicoventrum; the pair of endothecal sclerites hooked, elongated. 


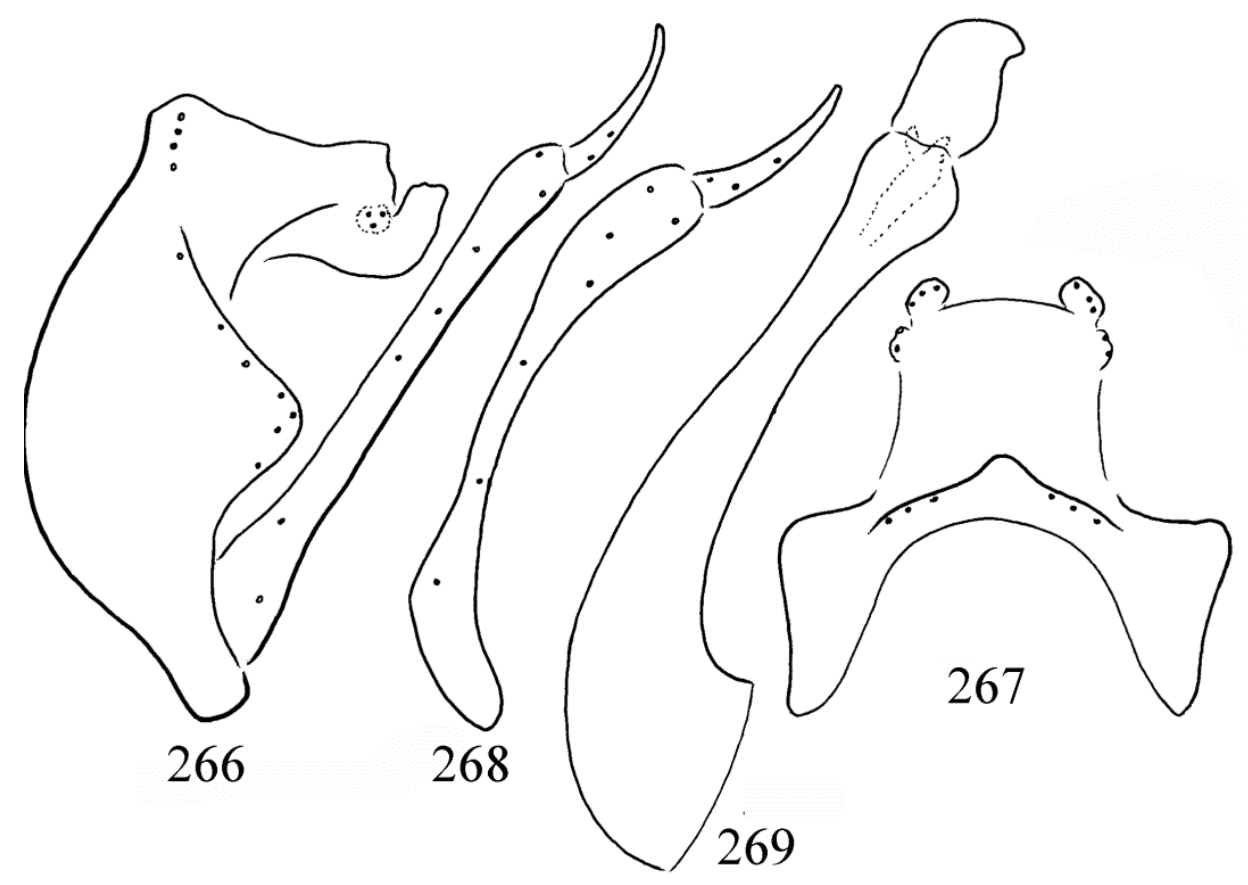

Figures 266-269. Cheumatopsyche kamposka sp. nov. Holotype: $266=$ male genitalia in left lateral view, $267=$ male genitalia in dorsal view, 268 = left gonopod in ventral view, 269 = phallic organ in left lateral view.

Etymology. kamposka, coined from "kampóska" diminutive form of hooked in Hungarian, refers to the hook-shaped endothecal sclerite of the phallic organ.

\section{Cheumatopsyche lagaironga sp. nov.}

(Figures 270-273, Map 6: $\mathrm{n}^{\circ}$ 6, 50, Map 21)

Material examined. Holotype: India, Manipur, Lagairong, 500-1000 ft., 244ㄴ ${ }^{\circ} 02.4^{\prime \prime} \mathrm{N} 93^{\circ} 31^{\prime}$ 55.8"E, 26.V.1960, leg. F. Schmid (1 male, CNC). Paratype: India, Manipur, Chattrik, 1500

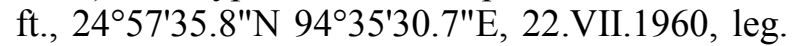
F. Schmid (1 male, OPC).

Diagnosis. This new species having bilobed segment $\mathrm{X}$ with shortened ventroapical lobe belongs to Cheumatopsyche costalis species group (Oláh et al. 2008a). According to the structure of segment $X$ and the phallic organ, this small delicate brown species most close to the Cheumatopsyche salaka sp. nov. described from Meghalaya, but differs by the lateral profile of segment $\mathrm{X}$ having anterad directed hook shaped apicoventral setose lobe, not simple upward turning lobe as well as the endothecal sclerites are short, not long.

Description. A uniformly brown coloured small species with forewing length of $5 \mathrm{~mm}$.

Male genitalia. Abdominal segment IX fused annular, short; anterior margin arciform, resulted in a very short dorsum and longer ventrum; the ventrum without spiny ventrocaudal mesal lobe; apical margin straight vertical, marked with a row of strong spines and ventrad terminated in a blunt triangular lobe above the gonopods; intersegmental depression between the ninth and tenth segments present, right angled in lateral view. Body of segment $\mathrm{X}$ longer than high; circular lateral setose area (cerci) in middle position; apicoventral setose lobe discernible as incompletely fused to the apicoventrum of the segment and present as a small setose lobe with anterad directed hook formation as visible both in dorsal and lateral views. The basal segment of the gonopods straight dilating apicad, both in ventral and dorsal views; harpago, the terminal segment broad basal half slender digitate slightly Sforming in ventral view. Phallic apparatus with 
straight dorsum and broadening ventrum; the pair of endothecal sclerites rounded, slightly longer than high.

Etymology. lagaironga, named after the locus typicus of the holotype.

\section{Cheumatopsyche mariannae Oláh \& Johanson, 2008}

(Map 21)

Cheumatopsyche mariannae Oláh \& Johanson, 2008b: 206-207. „Holotype male: India, Karnataka, Shimoga District, Jog Falls, MV lamp, $14^{\circ} 13^{\prime} 45.4^{\prime \prime} \mathrm{N}$ 7448'44.9"E, 2-8.III.1980."

Material examined. India, Tamil Nadu (Madras), Komadi.

Remarks: This locality remains unkown; it should be placed between Courtallam and Sothuparai, $950 \mathrm{ft}$, 18.-19.I.1962, leg. F. Schmid (1 male, CNC; 1 male, OPC, 1 male SMNH). India, Tamil Nadu (Madras), Kattalaimala, this locality should be in the surroundings of Courtallam and Kannupulimedu, it probably corresponds to Kot- tamalai, $1000 \mathrm{ft}, 9^{\circ} 13^{\prime} 33.3^{\prime \prime} \mathrm{N} 77^{\circ} 19^{\prime} 06.9^{\prime \prime} \mathrm{E}, 16 .-$ 17.I.1962, leg. F. Schmid (1 male, CNC).

\section{Cheumatopsyche mawjana sp. nov.}

(Figures 274-277, Map 5: n $^{\circ}$ 48, 49, Map 20)

Material examined. Holotype: India, Meghaláya (United Jaintia and Khasi Hills), Mawja, 550ft. Remarks: This locality remains unknown but should be close to the next Schmid's locality on its road map (Map 5: $n^{\circ}$ 49): Hat Nongjri, $350 \mathrm{ft}, \quad 25^{\circ} 10^{\prime} 18.4^{\prime \prime} \mathrm{N} \quad 91^{\circ} 46^{\prime} 54.9^{\prime \prime} \mathrm{E}$, 30.III.1960, leg. F. Schmid (1 male, CNC). Paratype: same as holotype (1 male, CNC, 1 male, OPC; 1 male, SMNH). India, Meghalaya (United Jaintia and Khasi Hills), Nongiri [=Hat Nongjri], $350 \mathrm{ft}, 25^{\circ} 10^{\prime} 18.4^{\prime \prime} \mathrm{N} 91^{\circ} 46^{\prime} 54.9^{\prime \prime} \mathrm{E}, 31 . I I I .1960$, leg. F. Schmid (5 males, CNC).

Diagnosis. This new species having bilobed segment X with shortened ventroapical lobe belongs to the Cheumatopsyche costalis species group (Oláh et al. 2008a). According to the structure of segment $\mathrm{X}$, this small, delicate brown species is most close to Cheumatopsyche dang-

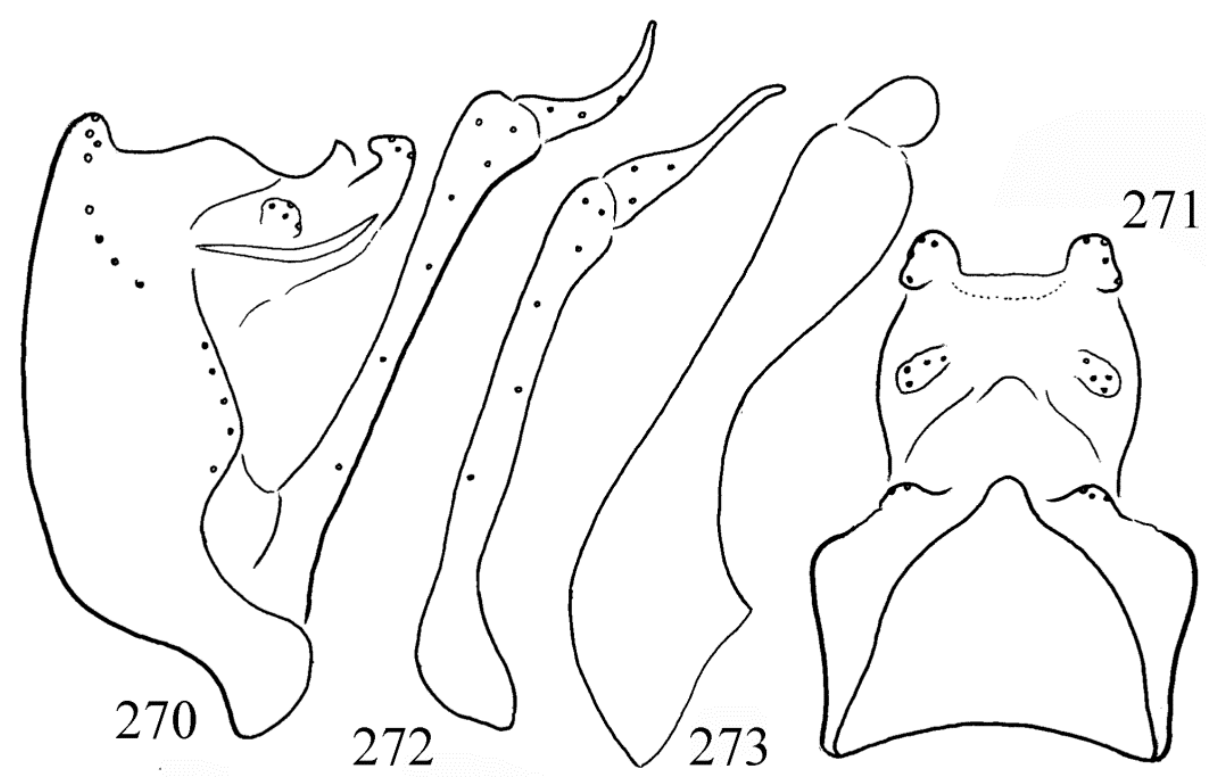

Figures 270-273. Cheumatopsyche lagaironga sp. nov. Holotype: $270=$ male genitalia in left lateral view, $271=$ male genitalia in dorsal view, 272 = left gonopod in ventral view, 273 = phallic organ in left lateral view. 


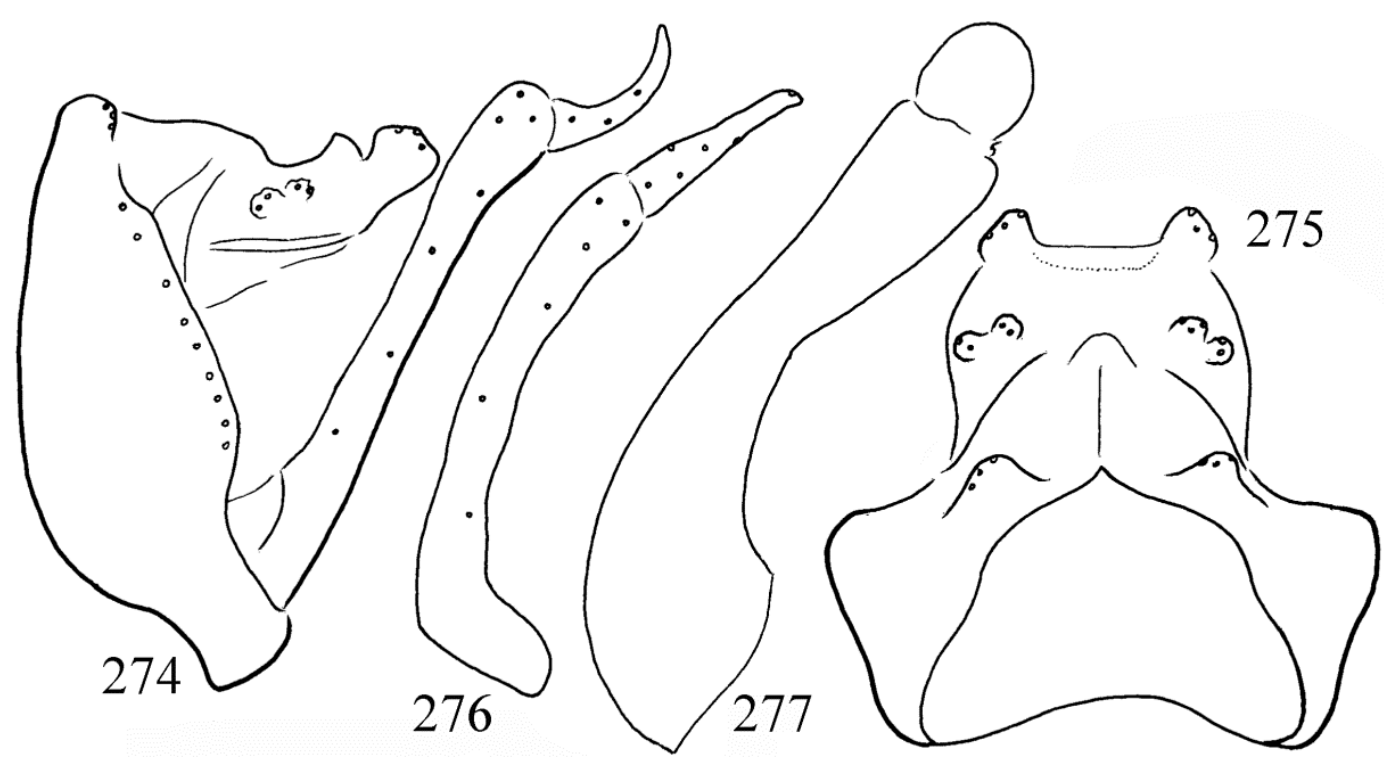

Figures 274-277. Cheumatopsyche mawjana sp. nov. Holotype: $274=$ male genitalia in left lateral view, $275=$ male genitalia in dorsal view, 276 = left gonopod in ventral view, 277 = phallic organ in left lateral view.

chura sp. nov., but differs by the subtle divergences in the dorsal and lateral profiles of segment $\mathrm{X}$ as well as by the entirely diverged ventral shape of the harpago and the completely circular, not downward bending endothecal sclerites of the phallic organ.

Description. A uniformly brown coloured small species with forewing length of $6 \mathrm{~mm}$.

Male genitalia. Abdominal segment IX fused annular, short; anterior margin arciform, resulted in a short dorsum and short but slightly longer ventrum; the ventrum without spiny ventrocaudal mesal lobe; apical margin produced into a flat lobe above the gonopods, marked with a row of strong spines; intersegmental depression between the ninth and tenth segments oblique and deep in lateral view. Body of segment X longer than high; bilobed cerci in middle position; apicoventral setose lobe discernible as a small knob-structure as visible both in dorsal and lateral views. The basal segment of the gonopods straight dilating apicad in lateral view; harpago, the terminal segment, slender digitate, arching in lateral and straight, evenly narrowing in ventral views. Phallic apparatus with constricted middle and broadening apicoventrum; the pair of endothecal sclerites circular.
Etymology. mawjana, named after the locus typicus of the holotype.

\section{Cheumatopsyche mawprana sp. nov.}

(Figures 278-281, Map 5: n 60, Map 20)

Material examined. Holotype: India, Meghaláya (United Jaintia and Khasi Hills), Mawpran, 900 ft., $25^{\circ} 17^{\prime} 21.7^{\prime \prime N} 91^{\circ} 57^{\prime} 57.3 " \mathrm{E}, 10 . I V .1960$, leg. F. Schmid (1 male, CNC).

Diagnosis. This new species having bilobed segment X with shortened ventroapical lobe belongs to the Cheumatopsyche costalis species group (Oláh et al. 2008a). According to the structure of segment $\mathrm{X}$ and the phallic organ this small, delicate brown species is most close to Cheumatopsyche kamposka sp. nov. described from Barato, Meghaláya, but differs by the lateral profile of segment $X$, the intersegmental profile between segments IX and X very deep, not shallow; by the narrowing, almost pointed apical tip of the endothecal sclerites, not hooked and by the shorter digitate harpago.

Description. A uniformly brown coloured small species with forewing length of $5 \mathrm{~mm}$. 


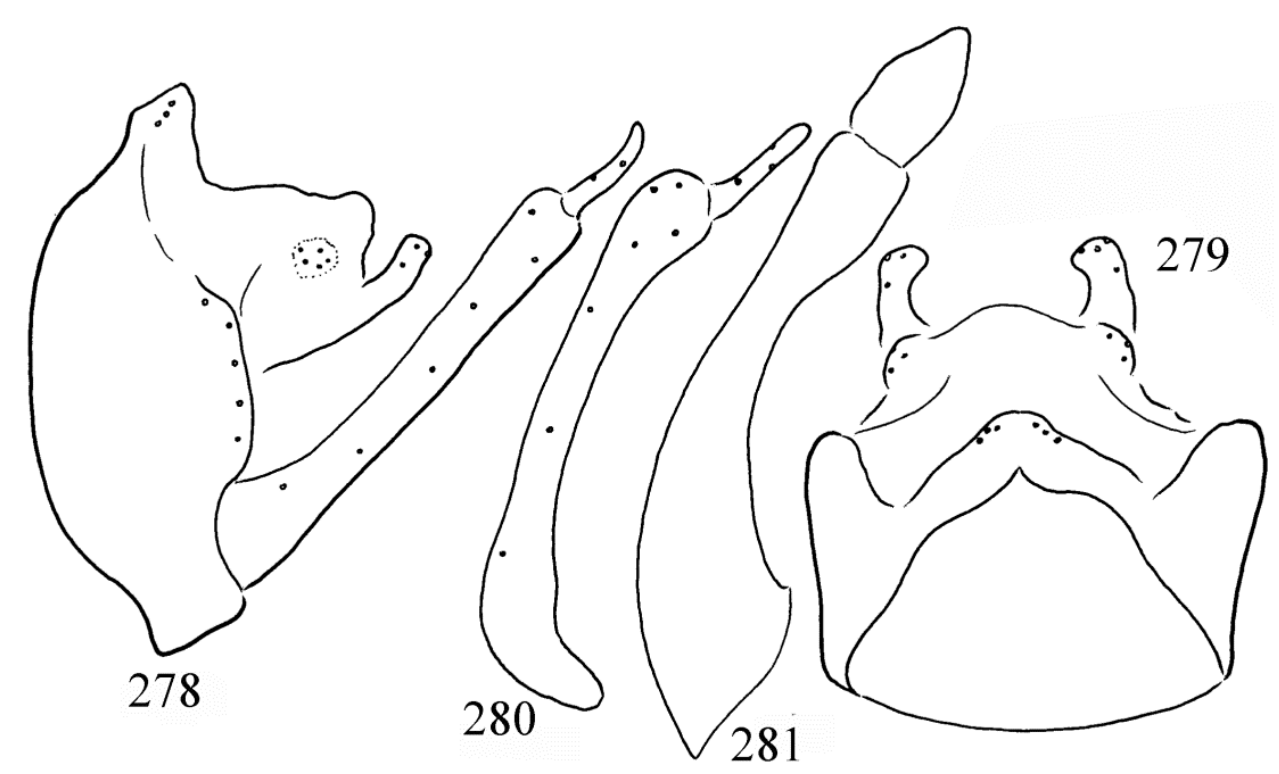

Figures 278-281. Cheumatopsyche mawprana sp. nov. Holotype: $278=$ male genitalia in left lateral view, $279=$ male genitalia in dorsal view, $280=$ left gonopod in ventral view, $281=$ phallic organ in left lateral view.

Male genitalia. Abdominal segment IX fused annular, short; anterior margin arciform, resulted in a short dorsum and short but little longer ventrum; the ventrum is without spiny ventrocaudal mesal lobe; apical margin straight, vertical, marked with a row of strong spines and ventrad terminated in a triangular lobe above the gonopods; intersegmental profile between the ninth and tenth segments present, very deep in lateral view. Body of segment $\mathrm{X}$ as long as high; circular lateral setose area (cerci) in subapical position; apicoventral setose lobe rather long discernible in lateral view and mesad turning in dorsal view. The basal segment of the gonopods straight almost parallelsided, without pronounced dilatation in lateral view; harpago, the terminal segment short digitate. Phallic apparatus with a pair of endothecal sclerites narrowing apicad.

Etymology. mawprana, named after the locus typicus of the holotype.

\section{Cheumatopsyche ningmapa Schmid, 1975}

(Map 6: $\mathrm{n}^{\circ}$ 31, Map 21)

Material examined. India, Manipur, Khangairim. It probably corresponds to Khangkhui
Khullen, $4145 \mathrm{ft}, 25^{\circ} 05^{\prime} 58.7^{\prime \prime} \mathrm{N} 94^{\circ} 23^{\prime} 35.8^{\prime \prime} \mathrm{E}, 29$. VI.1960, leg. F. Schmid (1 male, 1 female, CNC; 2 males, OPC). India, Manipur, Chattrik, $4500 \mathrm{ft}$., 23.VII.1960, leg. F. Schmid (1 male, CNC).

\section{Cheumatopsyche nonga sp. nov.}

(Figures 282-285, Map 5: n 50, 82, 84, Map 20)

Material examined. Holotype: India, Meghaláya (United Jaintia and Khasi Hills), Nongjri, 300 ft., $25^{\circ} 10^{\prime} 18.4^{\prime \prime} \mathrm{N} 91^{\circ} 466^{\prime} 54.9^{\prime \prime} \mathrm{E}, 1 . I V .1960$, leg. F. Schmid (1 male, CNC). Paratype: India, Assam, United District of Mikir and North Cachar Hills, Bandarkhal, $300 \mathrm{ft} ., 2^{\circ} 03^{\prime} 31.1^{\prime \prime} \mathrm{N} 92^{\circ} 48^{\prime}$ 02.5"E, 9. V. 1960, leg. F. Schmid (1 male, OPC). India, Assam, United District of Mikir and North Cachar Hills, Bangku [= Nangku $], 700 \mathrm{ft}$., 7.V.1960, leg. F. Schmid (2 males, CNC).

Diagnosis. This new species having bilobed segment $\mathrm{X}$ with shortened ventroapical lobe belongs to the $C$. costalis species group (Oláh et al. 2008a). According to the structure of segment $\mathrm{X}$, the gonopod, especially the harpago and the phallic organ, this small, delicate brown species is most close to the $C$. ningmapa but differs by location of cerci, shifted dorsad, not with middle 


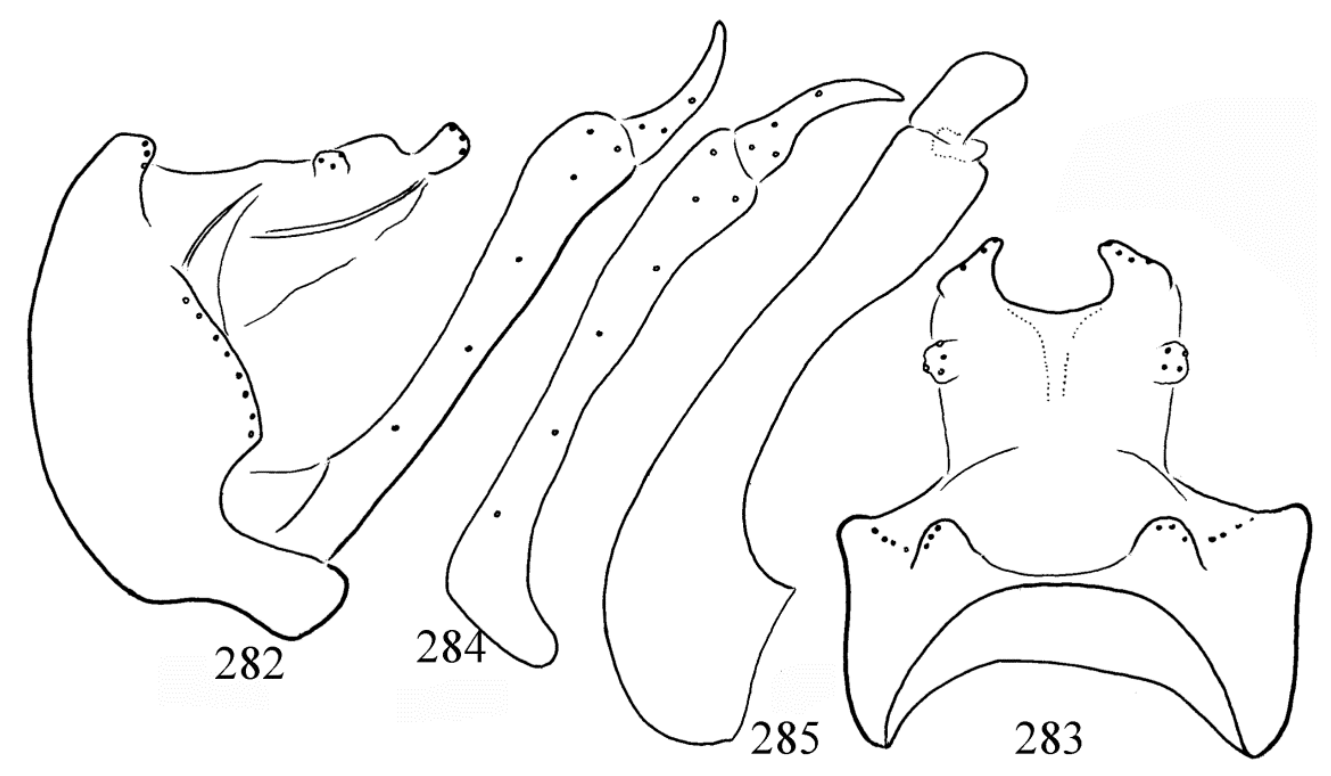

Figures 282-285. Cheumatopsyche nonga sp. nov. Holotype: $282=$ male genitalia in left lateral view, $283=$ male genitalia in dorsal view, 284 = left gonopod in ventral view, $285=$ phallic organ in left lateral view.

position; by the lateral profiles of segment X; its dorsum flat without the pronounced character state of the definite hump manifested by the elevated basal margin of the interlobular gap or excision; differs also by the abbreviated endothecal sclerite.

Description. A uniformly brown coloured small species with forewing length of $6 \mathrm{~mm}$.

Male genitalia. Abdominal segment IX fused annular, short; anterior margin arciform, resulted in a very short dorsum and short but little longer ventrum; the ventrum without spiny ventrocaudal mesal lobe; apical margin produced into a flat lobe above the gonopods, marked with a row of strong spines; intersegmental depression between the ninth and tenth segments oblique and low in lateral view. Body of segment X longer than high; circular lateral setose area (cerci) in dorsal position; apicoventral setose lobe discernible as a obliquely positioned slightly elongated structure as visible both in dorsal and lateral views. The basal segment of the gonopods straight dilating apicad in lateral view; harpago, the terminal segment, slender digitate arching in lateral and broad-based in ventral views. Phallic apparatus with constricted middle and broadening apico- ventrum; the pair of endothecal sclerites abbreviated, downward directed.

Etymology. nonga, coined from the name of the locus typicus of the holotype.

\section{Cheumatopsyche nongajra sp. nov.}

(Figures 286-289, Map 5: n 50, Map 20)

Material examined. Holotype: India, Meghaláya (United Jaintia and Khasi Hills), Nongjri [=Hat Nongiri], $300 \mathrm{ft}, 25^{\circ} 10^{\prime} 18.4^{\prime \prime} \mathrm{N}$ 91 46' 54.9"E, 1.IV.1960, leg. F. Schmid (1 male, CNC).

Diagnosis. This new species having bilobed segment X with shortened ventroapical lobe belongs to the Cheumatopsyche costalis species group (Oláh et al. 2008a). According to the structure of segment $\mathrm{X}$, the gonopod, especially the harpago and the phallic organ, this small, brown species most close to Cheumatopsyche nonga sp. nov. but differs by the lateral profile of segment $\mathrm{X}$; by the robust harpago especially discernible in ventral view, as well as by the lateral profile of the phallotheca with its broad, almost semicircular head in lateral view and by very low endothecal sclerites. 


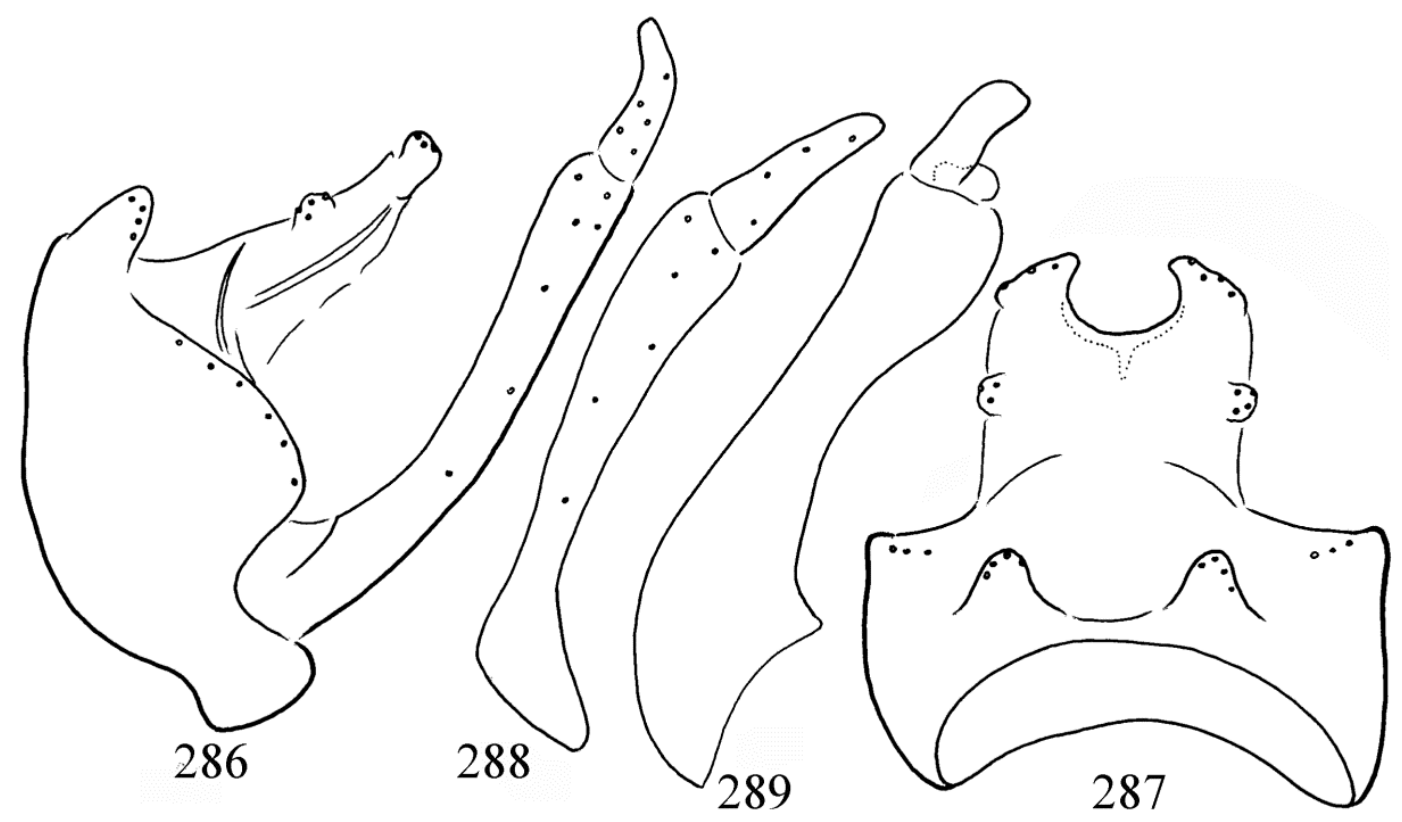

Figures 286-289. Cheumatopsyche nongajra sp. nov. Holotype: $286=$ male genitalia in left lateral view, $287=$ male genitalia in dorsal view, 288 = left gonopod in ventral view, 289 = phallic organ in left lateral view.

Description. A uniformly brown coloured small species with forewing length of $6 \mathrm{~mm}$.

Male genitalia. Abdominal segment IX fused annular, short; anterior margin arciform, resulted in a very short dorsum and short but slightly longer ventrum; the ventrum lacks spiny ventrocaudal mesal lobe; apical margin produced into a flat lobe above the gonopods, marked with a row of strong spines; intersegmental depression between the ninth and tenth segments oblique and low in lateral view. Body of segment $\mathrm{X}$ longer than high; circular lateral setose area (cerci) in dorsal position; apicoventral setose lobe discernible as a obliquely positioned slightly elongated structure as visible both in dorsal and lateral views. The basal segment of the gonopods straight dilating apicad in lateral view; harpago, the terminal segment broad, robust. Phallic apparatus with constricted middle and broadening, almost semicircular apicoventrum; the pair of endothecal sclerites low and elongated, slightly downward directed.

Etymology. nongajra, coined from the name of the locus typicus of the holotype.

\section{Cheumatopsyche oinamla sp. nov.}

(Figures 290-293, Map 6: near n 4, Map 21)

Material examined. Holotype: India, Manipur, (Oinamlong) Dinamlong, 300 ft., 22.-23.V.1960, this locality remains unknown but should be near the next locality on the Schmid's collecting road in Manipur: Kambiron, 24⒋46.9"N 93 ${ }^{\circ} 23^{\prime}$ 01.7"E, leg. F. Schmid (1 male, CNC). Paratypes: same as holotype (6 males, CNC; 1 male, OPC; 1 male, SMNH).

Diagnosis. This new species having bilobed segment $X$ with shortened ventroapical lobe belongs to the Cheumatopsyche costalis species group (Oláh et al. 2008a). According to the structure of segment $\mathrm{X}$, the gonopod, especially the harpago and the phallic organ, this small, delicate brown species is most close to the Cheumatopsyche dangchura sp. nov. but differs by the stout ventroapical setose lobe, by the very slender coxopodite, the spiraling harpago, and the low and robust phallic organ.

Description. A uniformly brown coloured small species with forewing length of $5 \mathrm{~mm}$. 


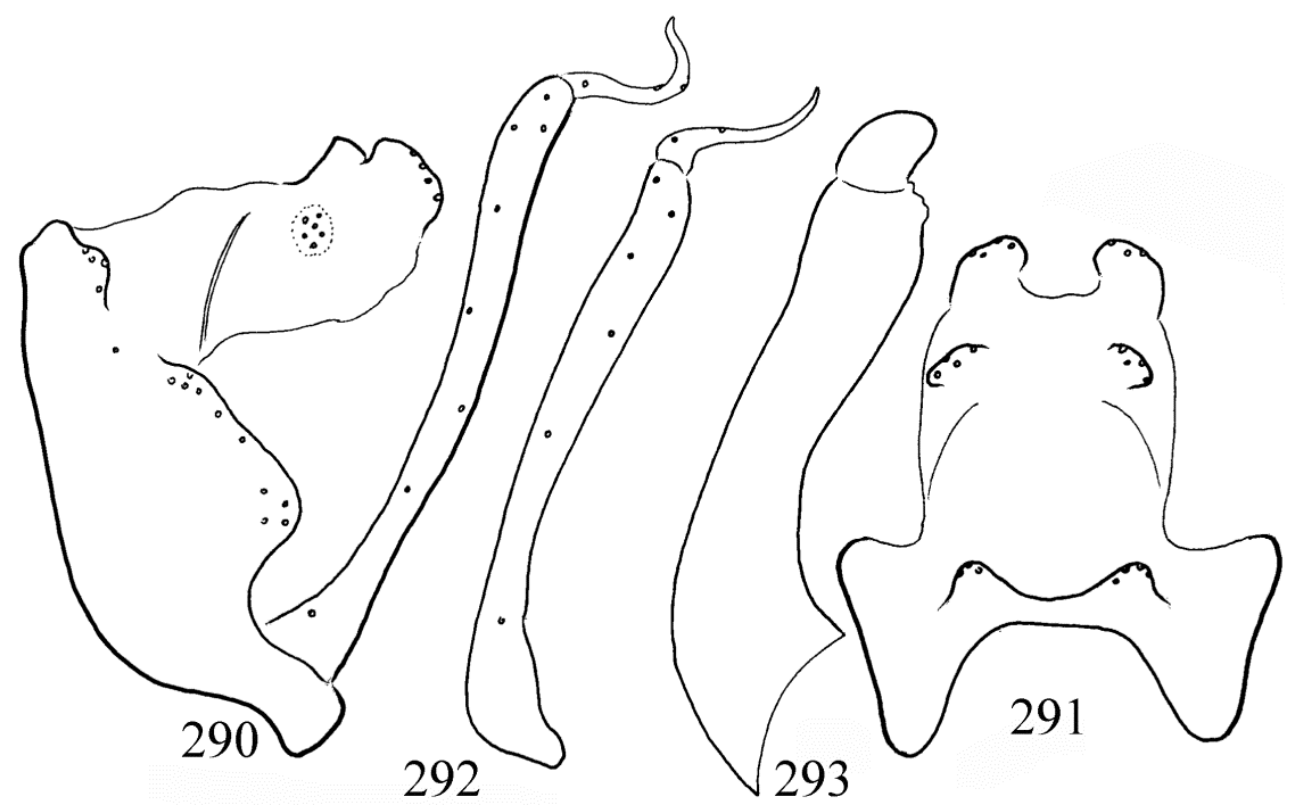

Figures 290-293. Cheumatopsyche oinamla sp. nov. Holotype: $290=$ male genitalia in left lateral view, $291=$ male genitalia in dorsal view, 292 = left gonopod in ventral view, 293 = phallic organ in left lateral view.

Male genitalia. Abdominal segment IX fused annular, short; anterior margin arciform, resulted in a very short dorsum and ventrum; the ventrum without spiny ventrocaudal mesal lobe; apical margin produced into a flat lobe above the gonopods, marked with a row of strong spines; intersegmental depression between the ninth and tenth segments low in lateral view. Body of segment $X$ longer than high; circular lateral setose area (cerci) in middle position; apicoventral setose lobe discernible as an obliquely positioned slightly elongated structure as visible both in dorsal and lateral views. The basal segment of the gonopods slim slender in lateral view; harpago, the terminal segment slim and somehow spiraling. Phallic apparatus robust with low phallobase; the pair of endothecal sclerites low, elongated, slightly downward directed.

Etymology. oinamla, coined from the name of the locus typicus of the holotype.

\section{Cheumatopsyche salaka sp. nov.}

(Figures 294-297, Map 5: n 72, Map 20)

Material examined. Holotype: India, Meghaláya (United Jaintia and Khasi Hills), Barato,
2500 ft., 2536'24.1"N 92²7'23.1"E, 24.IV.1960, leg. F. Schmid (1 male, CNC).

Diagnosis. This new species having bilobed segment $\mathrm{X}$ with shortened ventroapical lobe belongs to Cheumatopsyche costalis species group (Oláh et al. 2008a). According to the structure of segment $X$ and the phallic organ this small, delicate brown species is most close to Cheumatopsyche jaekam described from Thailand, but differs by the lateral profile of segment $\mathrm{X}$, by the longer subapical ventral broadening of the phallotheca and by the S-shaped formation on the head of the gonopod.

Description. A uniformly brown coloured small species with forewing length of $5 \mathrm{~mm}$.

Male genitalia. Abdominal segment IX fused annular, short; anterior margin arciform, resulted in a very short dorsum and short but slightly longer ventrum; the ventrum is without spiny ventrocaudal mesal lobe; apical margin is straight vertical, marked with a row of strong spines and ventrad terminated in a triangular lobe above the gonopods; intersegmental depression between the ninth and tenth segments present, shallow in lateral view. Body of segment X longer than high; 


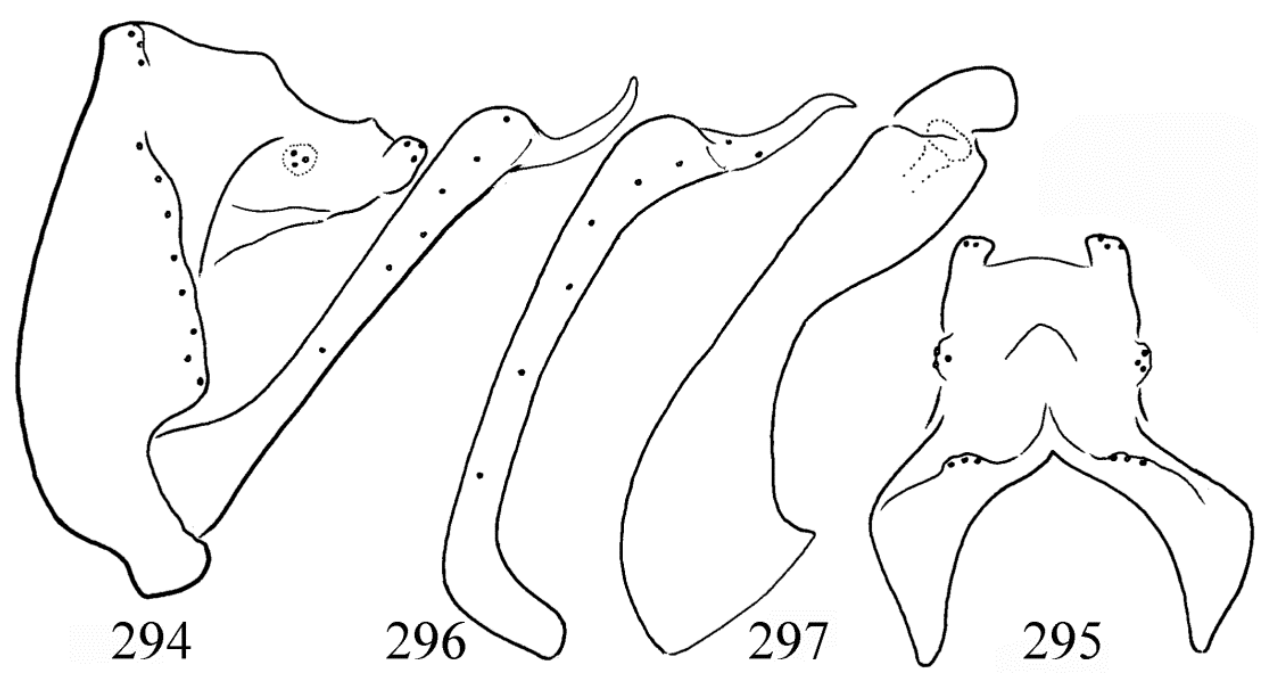

Figures 294-297. Cheumatopsyche salaka sp. nov. Holotype: $294=$ male genitalia in left lateral view, $295=$ male genitalia in dorsal view, 296 = left gonopod in ventral view, 297 = phallic organ in left lateral view.

circular lateral setose area (cerci) in middle position; apicoventral setose lobe discernible as incompletely fused to the apicoventrum of the segment and discernible as a small rectangular setose lobe as visible both in dorsal and lateral views. The basal segment of the gonopods straight dilating apicad, both in ventral and dorsal views; harpago, the terminal segment slender digitate Sforming in ventral view. Phallic apparatus with straight dorsum and broadening ventrum; the pair of endothecal sclerites rounded, slightly longer than high.

Etymology. salaka, coined from "S-alakú" Sshaped in Hungarian, refers to the S-shaped formation of the gonopod head in ventral view.

\section{Cheumatopsyche yunnana sp. nov.}

(Figures 298-301, Map 21)

Cheumatopsyche ningmapa Schmid, 1975. Oláh et al. 2020b: 201. Misidentification.

Material examined. Holotype: China, Yunnan Province, Tongbiguanxiang, Jinzhuzhai, $1450 \mathrm{~m}$, $24^{\circ} 36^{\prime} 55.8^{\prime \prime} \mathrm{N}$ 97³6'51.1"E, 3.V.2012, leg. Liu Yuanye (1 male, OPC). Paratype: same as holotype (50 males, DPP-HIST; 49 males, OPC).
Diagnosis. This new species having bilobed segment $\mathrm{X}$ with shortened ventroapical lobe belongs to the Cheumatopsyche costalis species group (Oláh et al. 2008a). According to the structure of segment $\mathrm{X}$, the gonopod, especially the harpago and the phallic organ this small, delicate brown species is most close to Cheumatopsyche ningmapa but differs by the more broad-based harpago, by the dorsal and lateral profiles of segment $\mathrm{X}$. The interlobular gap is deeper and wider in dorsal view as well as the setose ventroapical lobes are more developed and more oblique, not at the end of their stalk.

Description. A uniformly brown coloured small species with forewing length of $5 \mathrm{~mm}$.

Male genitalia. Abdominal segment IX fused annular, short; anterior margin arciform, resulted in a very short dorsum and short but slightly longer ventrum; the ventrum lacks spiny ventrocaudal mesal lobe; apical margin produced into a rounded lobe above the gonopods, marked with a row of strong spines; intersegmental depression between the ninth and tenth segments deep in lateral view. Body of segment $\mathrm{X}$ longer than high; circular lateral setose area (cerci) in middle position; apicoventral setose lobe discernible as a well produced rectangular setose lobe as visible both in dorsal and lateral views. The basal segment of the 


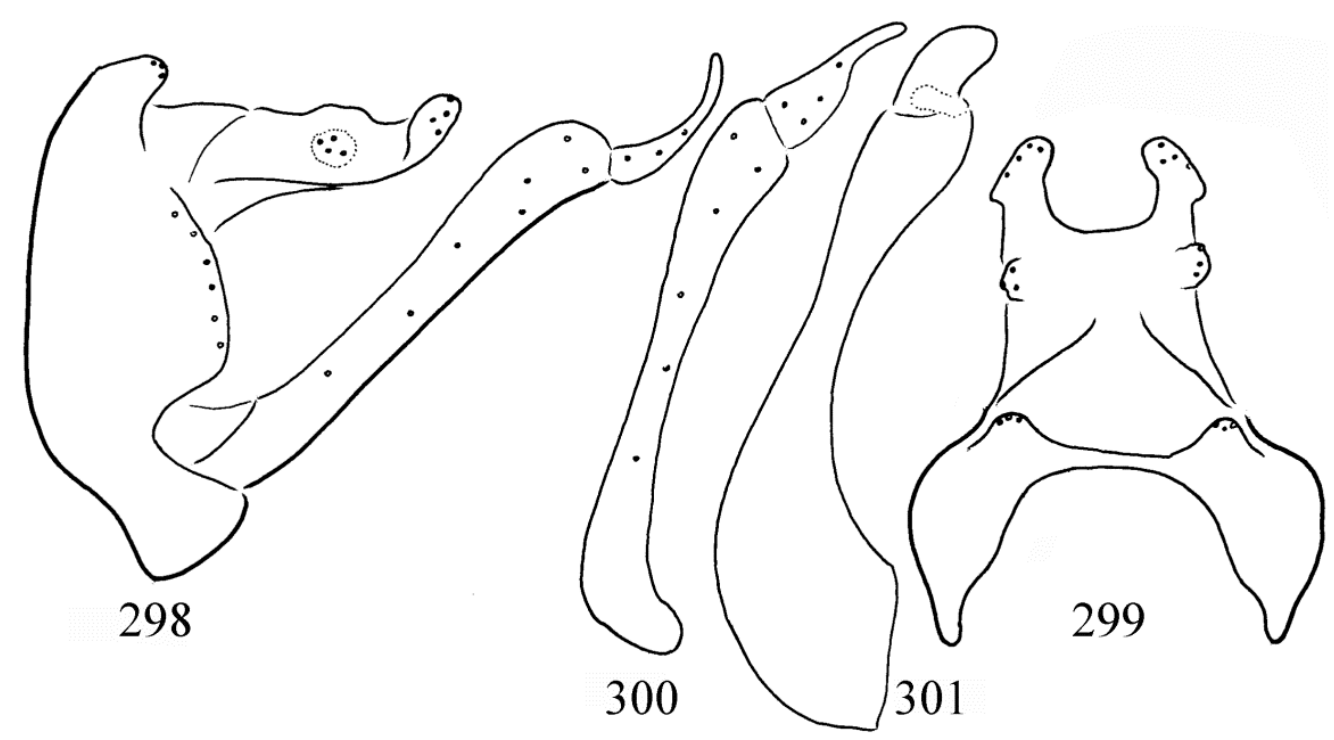

Figures 298-301. Cheumatopsyche yunnana sp. nov. Holotype: $298=$ male genitalia in left lateral view, $299=$ male genitalia in dorsal view, 300 = left gonopod in ventral view, 301 = phallic organ in left lateral view.

gonopods straight slightly dilating apicad in lateral and ventral views; harpago, the terminal segment with more develop basal broadening. Phallic apparatus with constricted middle and broadening apicodorsum and more apicoventrum; the pair of endothecal sclerites elongated, downward directed.

Etymology. yunnana, named after the locus typicus of the holotype.

\section{Cheumatopsyche concava species group}

Species group of monolobed segment $\mathrm{X}$ with almost fused ventroapical lobe. All the processes or lobes on segment $\mathrm{X}$ are fused, except the small wart-like, more or less elevated lateral setose surface area of cerci. The setose ventroapical lobe regularly fused to the apical margin of segment X and delineated only by its setose surface or by an abbreviated vestigium. As a result, both the dorsal and lateral interlobular gaps disappeared or very reduced. Wart-like lateral setose area, the vestigium of preanal appendages located centrally on segment X. Spiny ventroapical lobe on segment IX present or absent. Distributed in South and Southeast Asia, including the Southeast Asian Archipelago.

\section{Cheumatopsyche cressida Malicky, 1997}

(Map 5: $n^{\circ}$ 59, Map 22)

Cheumatopsyche cressida Malicky, 1997:1031. "Holotype: Nepal, Arun River Valley, 1600m, probably near this point: $27^{\circ} 32^{\prime} 52.2^{\prime \prime} \mathrm{N} 87^{\circ} 16^{\prime} 33.3^{\prime \prime E}$, 27.IV.8.V.1994."

Material examined. India, Meghaláya (United Jaintia and Khasi Hills), Mawpran [=Mawpran Nonglyndiang], $2000 \mathrm{ft}, 2^{\circ} 18^{\prime} 27.3^{\prime \prime} \mathrm{N} \quad 91^{\circ} 58^{\prime}$ 05.7"E, 9.IV.1960, leg. F. Schmid (2 males, CNC; 1 male, SMNH; 1 male, OPC).

\section{Cheumatopsyche haflonga sp. nov.}

(Figures 302-305, Map 5: nº 80, 85, Map 22)

Material examined. Holotype: India, Southern Assam, United District of Mikir and North Cachar

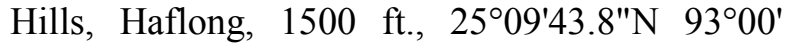
54.3"E, 5.V.1960, leg. F. Schmid (1 male, CNC). Paratype: same as holotype (4 males, $\mathrm{CNC}$; 1 male, OPC; 1 male, SMNH). India, Southern Assam, United District of Mikir and North Cachar Hills, Sirtrang (unknown locality between Rongbong Ronghang and Terang Gaon), $1400 \mathrm{ft}$., 28.IV.1960, leg. F. Schmid (1 male, CNC). India, 


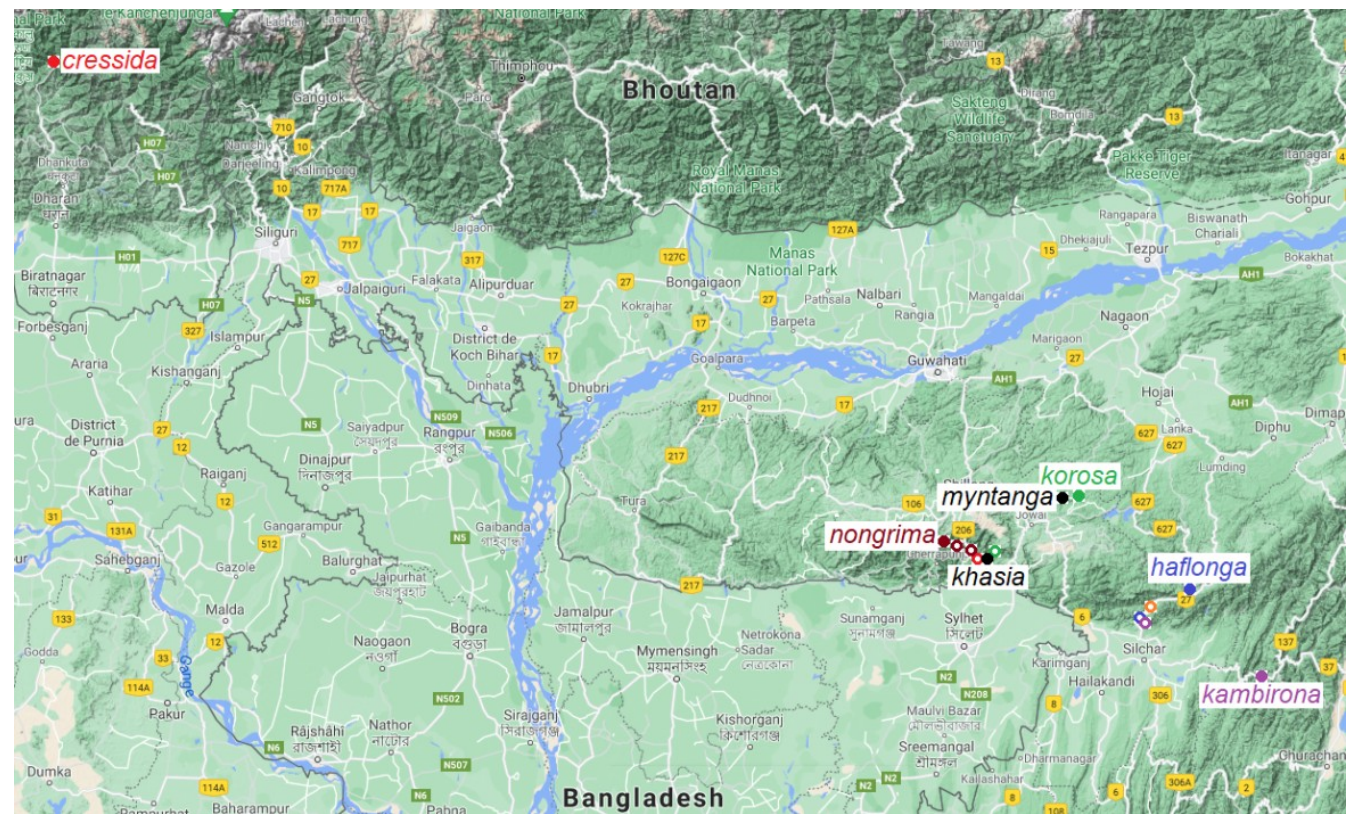

Map 22. Cheumatopsyche concava group.

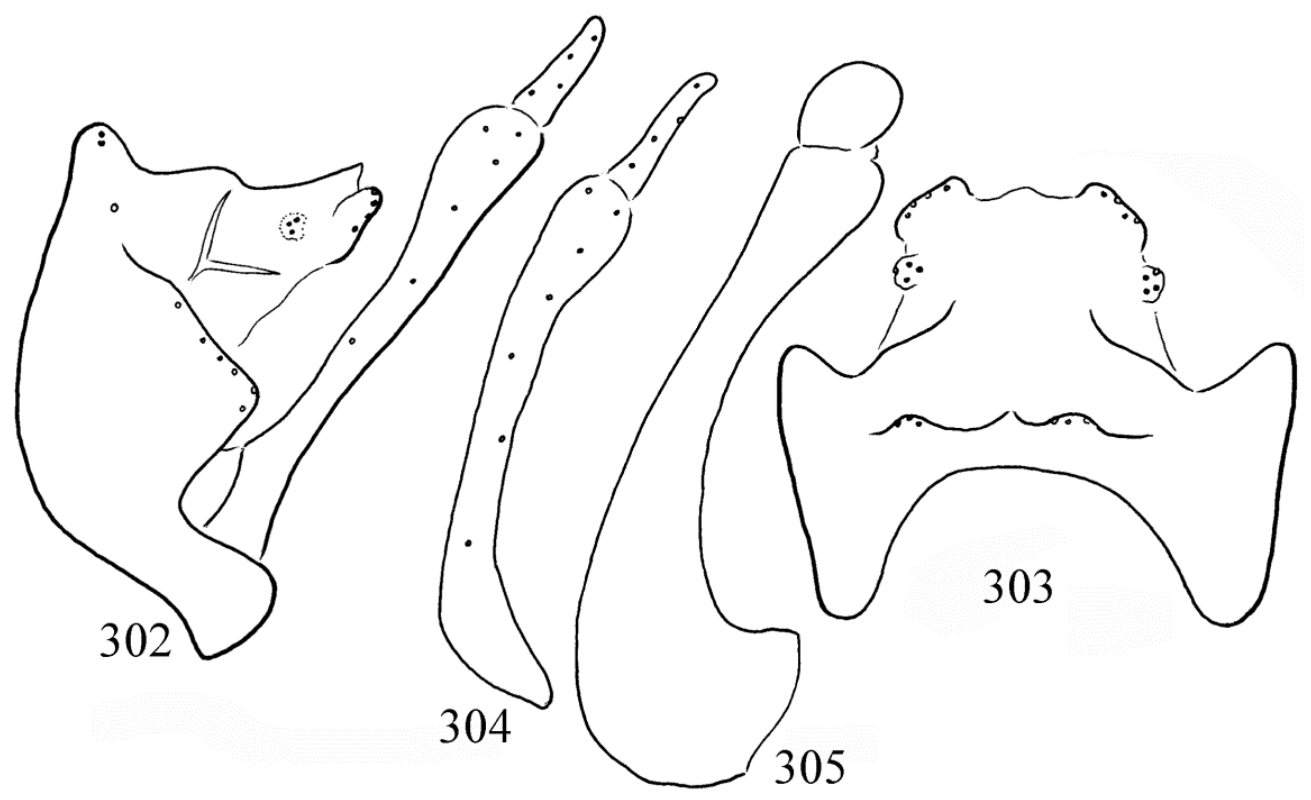

Figures 302-305. Cheumatopsyche haflonga sp. nov. Holotype: $302=$ male genitalia in left lateral view, $303=$ male genitalia in dorsal view, 304 = left gonopod in ventral view, $305=$ phallic organ in left lateral view.

Southern Assam, United District of Mikir and North Cachar Hills, Damchara, 250 ft., $25^{\circ} 00^{\prime}$ 44.8"N 9244'57.3"E, 10.V.1960, leg. F. Schmid (1 male, CNC).
Diagnosis. This new species having monolobed segment $\mathrm{X}$ that is the ventroapical pair of setose lobes fused to the body of segment $\mathrm{X}$ belongs to the Cheumatopsyche concava species 
group (Oláh et al. 2008a). According to the structure of segment $\mathrm{X}$ and the phallic organ this small, delicate brown species is most close to Cheumatopsyche myntanga sp. nov., but differs by the slightly light-spotted forwing; the triangular, not rounded triangular apical lobe of segment IX; the very slim middle of the gonopod; the shape and position of the fused ventroapical setose lobe, the rounded, not elongated endothecal sclerites of the phallic organ.

Description. A uniformly brown coloured small species with forewing length of $6 \mathrm{~mm}$.

Male genitalia. Abdominal segment IX fused annular, short; anterior margin arciform, resulted in a very short dorsum and short but slightly longer ventrum; the ventrum is without spiny ventrocaudal mesal lobe; apical margin is straight vertical, its dorsal region is marked with a row of strong spines and ventrad terminated in a triangular lobe above the gonopods; intersegmental depression between the ninth and tenth segments present, deep and step-wise in lateral view. Body of segment $\mathrm{X}$ longer than high; slightly elongated lateral setose area (cerci) in middle position; apicoventral setose lobe discernible as incompletely fused to the apicoventrum of the segment and discernible as a small setose lobe with shal- low excision middle as visible both in dorsal and lateral views. The basal segment of the gonopods straight dilating basad and apicad, slim between, especially in lateral view; harpago, the terminal segment slender digitate. Phallic apparatus with straight dorsum, posterad curving basad and broadening apicoventrum; the pair of endothecal sclerites rounded, slightly longer than high.

Etymology. haflonga, named after the locus typicus of the holotype.

\section{Cheumatopsyche kambirona sp. nov.}

(Figures 306-309, Map 5: n 84, Map 6: n 4, Map 22)

Material examined. Holotype: India, Manipur, Kambiron, 1500 ft., 244ㄴ $46.9^{\prime \prime} \mathrm{N} 93^{\circ} 23^{\prime} 01.7^{\prime \prime} \mathrm{E}$, 24.V.1960, leg F. Schmid (1 male, CNC). Paratypes: India, Assam, United District of Mikir and North Cachar Hills, Bandarkhal, $300 \mathrm{ft}$., $25^{\circ} 03^{\prime}$ 31.1"N 9248'02.5"E, 9.V.1960, leg. F. Schmid (13 males, CNC; 5 males, OPC; 5 males, SMNH). India, Assam, United District of Mikir and North Cachar Hills, Bangku [= Nangku], $700 \mathrm{ft}$., 7.V.1960, leg. F. Schmid (1male, CNC).

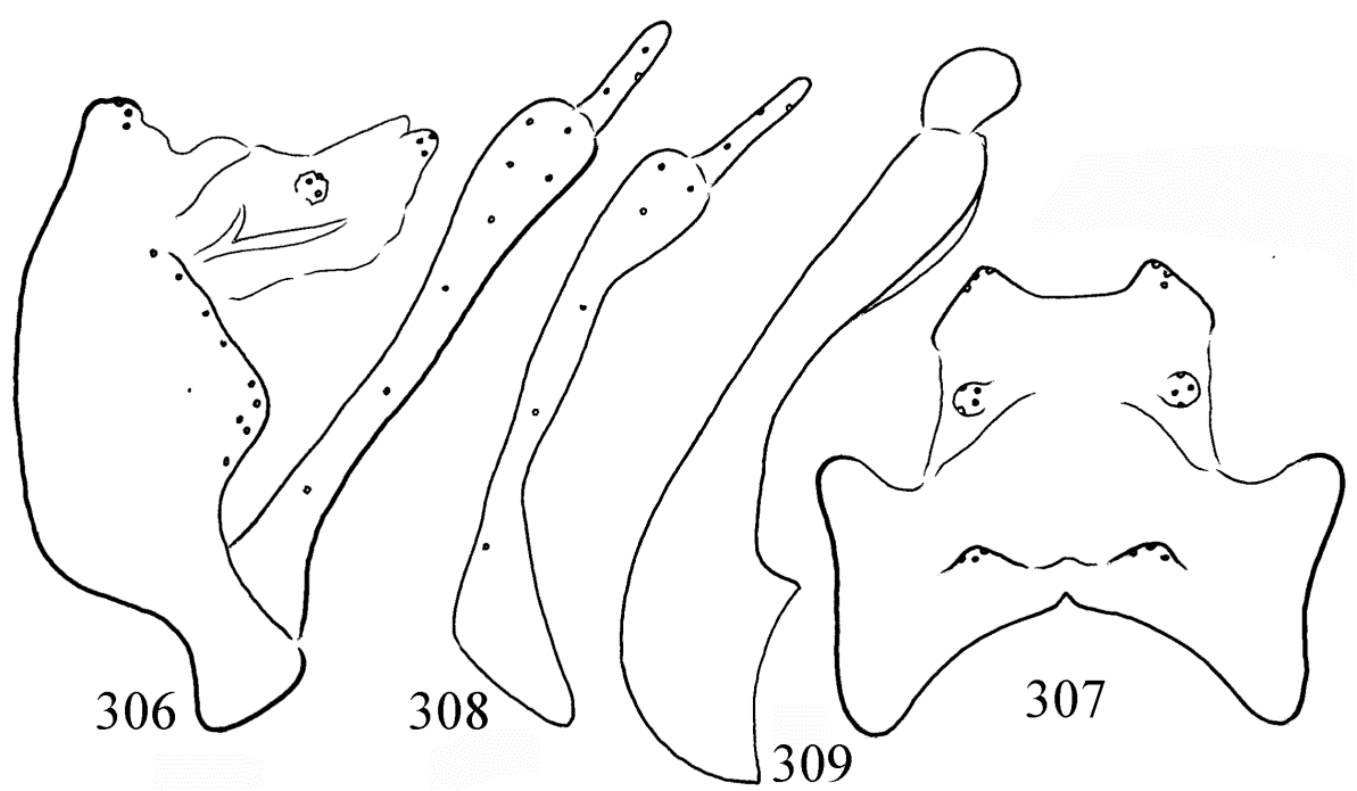

Figures 306-309. Cheumatopsyche kambirona sp. nov. Holotype: $306=$ male genitalia in left lateral view, $307=$ male genitalia in dorsal view, $308=$ left gonopod in ventral view, $309=$ phallic organ in left lateral view. 


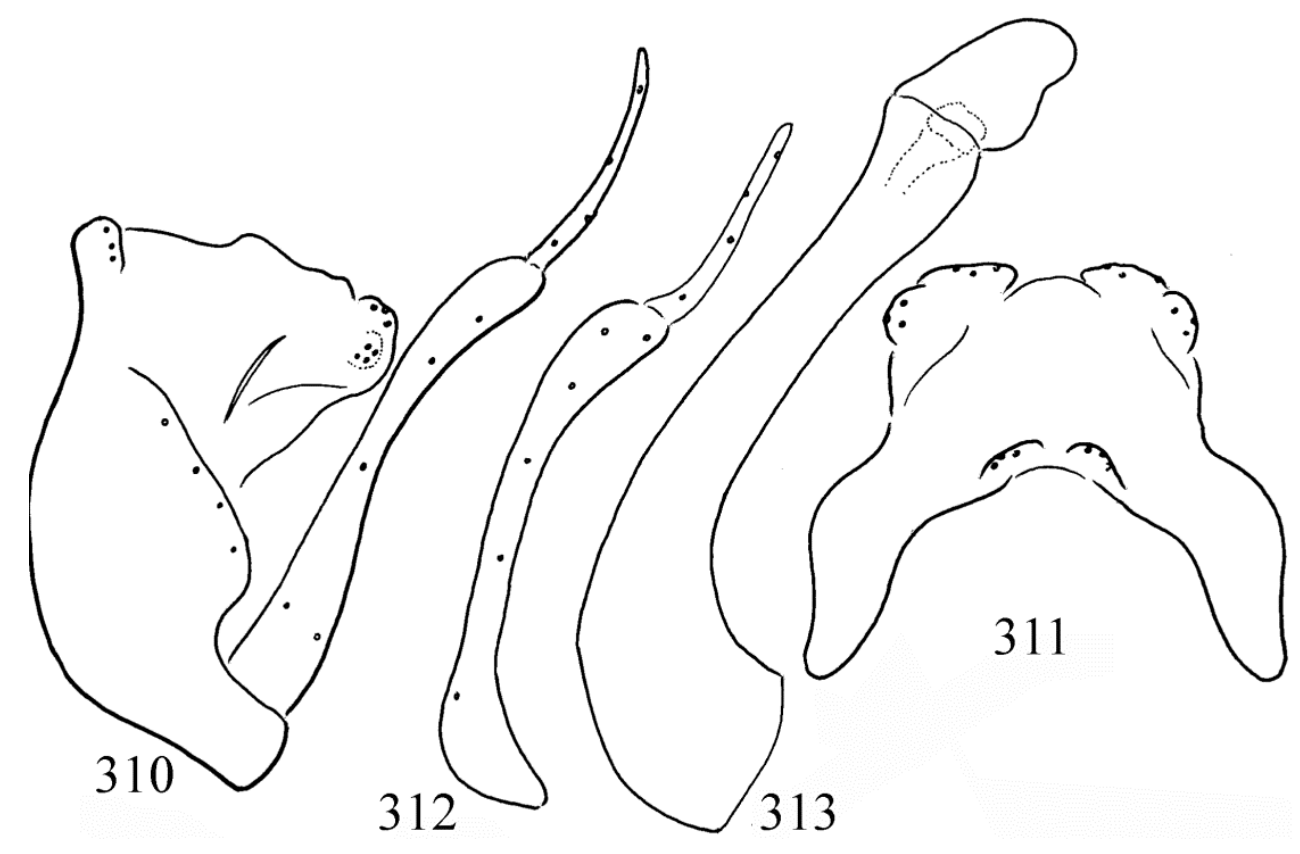

Figures 310-313. Cheumatopsyche khasia sp. nov. Holotype: $310=$ male genitalia in left lateral view, $311=$ male genitalia in dorsal view, 312 = left gonopod in ventral view, 313 = phallic organ in left lateral view.

Diagnosis. This new species having monolobed segment $\mathrm{X}$ that is the ventroapical pair of setose lobes fused to the body of segment $\mathrm{X}$ belongs to the Cheumatopsyche concava species group (Oláh et al. 2008a). According to the structure of segment $\mathrm{X}$ and the phallic organ this small, delicate brown species is the sibling species of Cheumatopsyche haflonga sp. nov., but differs by the rounded triangular, not sharp triangular apical lobe of segment IX; the almost regular triangular shape of the fused ventroapical setose lobe, as well as by the lateral profile of the phallic organ with short, not high phallobase and long, not short ventral subapical broadening.

Description. A uniformly brown coloured small species with forewing length of $7 \mathrm{~mm}$.

Male genitalia. Abdominal segment IX fused annular, short; anterior margin arciform, resulted in a very short dorsum and double long ventrum; the ventrum is without spiny ventrocaudal mesal lobe; apical margin is straight vertical, its dorsal region is marked with a row of strong spines and ventrad terminated in a rounded triangular lobe above the gonopods; intersegmental depression between the ninth and tenth segments present, deep and step-wise in lateral view. Body of segment $X$ longer than high; slightly elongated lateral setose area (cerci) in middle position; apicoventral setose lobe discernible as incompletely fused to the apicoventrum of the segment and discernible as a small setose triangular lobe with shallow middle excision as visible in dorsal view. The basal segment of the gonopods straight dilating basad and apicad, slim between, both in lateral and ventral views; harpago, the terminal segment slender, straight digitate. Phallic apparatus with straight dorsum, posterad curving basad and with broadening apicoventrum; the pair of endothecal sclerites rounded, slightly longer than high.

Etymology. kambirona, named after the locus typicus of the holotype.

\section{Cheumatopsyche khasia sp. nov.}

(Figures 310-313, Map 5: n 59, Map 22)

Material examined. Holotype: India, Meghaláya (United Jaintia and Khasi Hills), Mawpran [=Mawpran Nonglyndiang], $2000 \mathrm{ft}, \quad 25^{\circ} 18^{\prime}$ 27.3"N 9158'05.7"E, 9.IV.1960, leg. F. Schmid (1 male, CNC). 
Diagnosis. This new species having almost monolobed segment $X$ that is the ventroapical pair of setose lobes almost completely fused to the body of segment $\mathrm{X}$ belongs to the Cheumatopsyche concava species group (Oláh et al. 2008a). According to the structure of segment $X$ and the phallic organ this small, delicate brown species is most close to Cheumatopsyche lolo Oláh \& Johanson, 2008 but differs by mesad turning apex of the almost fused apicoventral setose lobe, simple at C. lolo; by the apicad shifted cerci and by the harpago very long and slender both in lateral and ventral views.

Description. A uniformly brown coloured small species with forewing length of $5 \mathrm{~mm}$. Male genitalia. Abdominal segment IX fused annular, short; anterior margin short arciform, resulted in a very short dorsum and short but little longer ventrum; the ventrum is without spiny ventrocaudal mesal lobe; apical margin is straight vertical, its dorsal region is marked with a row of strong spines and ventrad terminated in a rounded lobe above the gonopods; intersegmental depression between the ninth and tenth segments present, low and oblique in lateral view, filled partially by a pair of setose humps. Body of segment X shorter than high; the almost regularly circular lateral setose area (cerci) at apical position superimposed on the apicoventral setose lobes; apicoventral setose lobe discernible as incompletely fused to the apicoventrum of the segment and discernible as a small rounded setose lobe as visible in lateral view; its mesal free apex curving mesad. The basal segment of the gonopods downward arching only slightly dilating apicad in lateral view; harpago, the terminal segment long, slender and digitate both in lateral and ventral views. Phallic apparatus with straight dorsum upward curving apicad and slightly broadening ventrum; the pair of endothecal sclerites elongated with broadening ventrobasal region.

Etymology. khasia, named after the region of type locality.

\section{Cheumatopsyche korosa sp. nov.}

(Figures 314-317, Map 5: n 4, 71, Map 22)

Material examined. Holotype: India, Meghaláya (United Jaintia and Khasi Hills), Thangrain, 3000 ft., 2534'45.1"N 92²6'26.7"E, 22.IV.1960, leg. F. Schmid (1 male, CNC). Paratypes: India, Meghaláya (United Jaintia and Khasi Hills), Mawshun, $1500 \mathrm{ft} ., 25^{\circ} 14^{\prime} 46.7^{\prime \prime N} 91^{\circ} 58^{\prime 2} 21.2^{\prime \prime} \mathrm{E}$, 4.XII.1959, leg. F. Schmid (1 male, OPC; 1 male, SMNH).

Diagnosis. This new species having monolobed segment $X$ that is the ventroapical pair of setose lobes almost completely fused to the body of segment $\mathrm{X}$ belongs to the Cheumatopsyche concava species group (Oláh et al. 2008a). According to the structure of segment $\mathrm{X}$ and the phallic organ, this small, delicate brown species is most close to Cheumatopsyche myntanga sp. nov., but differs by the regular rounded lateral margin of the fused ventroapical setose lobe in dorsal view, not concave and the phallobase is more right angled.

Description. A uniformly brown coloured small species with forewing length of $6 \mathrm{~mm}$. Male genitalia. Abdominal segment IX fused annular, short; anterior margin short arciform, resulted in a very short dorsum and short but slightly longer ventrum; the ventrum is without spiny ventrocaudal mesal lobe; apical margin is straight vertical, its dorsal region is marked with a row of strong spines and ventrad terminated in a rounded lobe above the gonopods; intersegmental depression between the ninth and tenth segments present, low and oblique in lateral view. Body of segment X longer than high; the almost regularly circular lateral setose area (cerci) in middle position; apicoventral setose lobe discernible as incompletely fused to the apicoventrum of the segment and discernible as a small setose lobe rounded circular as visible both in dorsal and lateral views. The basal segment of the gonopods straight only slightly dilating apicad in lateral 


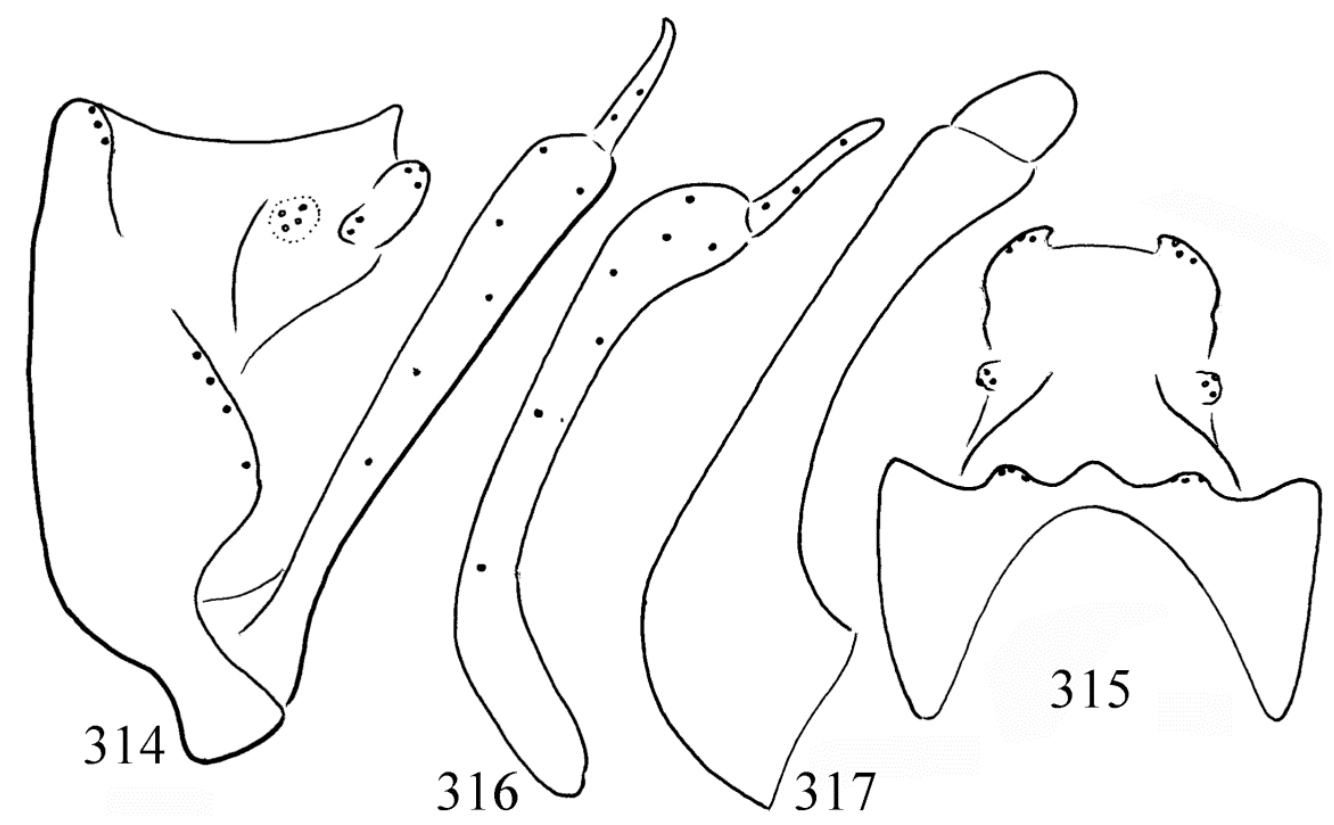

Figures 314-317. Cheumatopsyche korosa sp. nov. Holotype: $314=$ male genitalia in left lateral view, $315=$ male genitalia in dorsal view, $316=$ left gonopod in ventral view, 317 = phallic organ in left lateral view.

view; harpago, the terminal segment slender digitate. Phallic apparatus with straight dorsum and broadening ventrum; the pair of endothecal sclerites rounded, slightly longer than high.

Etymology. korosa, coined from "körös" circular in Hungarian, refers to the extremely regular round or circular slice of the almost fused ventroapical lobe in dorsal view.

\section{Cheumatopsyche myntanga sp. nov.}

(Figures 318-321, Map 5: n 70, Map 22)

Material examined. Holotype: India, Meghaláya (United Jaintia and Khasi Hills), Shilliang Myntang [=Shiliangmyntang], $3500 \mathrm{ft}, 25^{\circ} 33^{\prime}$ 55.6"N 92²1'32.5"E, 21.IV.1960, leg. F. Schmid (1 male, CNC). Paratypes: same as holotype (2 males, CNC; 1 male, OPC; 1 male, SMNH).

Diagnosis. This new species having monolobed segment $X$ that is the ventroapical pair of setose lobes fused to the body of segment $\mathrm{X}$ or very abbreviated belongs to the Cheumatopsyche concava species group (Oláh et al. 2008a). According to the structure of segment $\mathrm{X}$ and the phallic organ this small, delicate brown species is most close to the following species: $C$. cressida Malicky, 1997, Nepal; C. copia Malicky \& Chantaramongkol, 1997 Thailand; C. orthocercata Sun et al. 2011, China (Guangxi), C. ecsedii Oláh \& Johanson, 2008, Vietnam; C. lolo Oláh \& Johanson, 2008, Vietnam. This new species from India (Meghalaya) differs by the following character combination: lateral profile of segment $\mathrm{X}$ long, short at the other species except $C$. ecsedii; cerci elongated, circular at the other species except $C$. cressida; cerci in middle position, posterad position at the other species; fused apicoventral setose lobe with shallow middle excision lacking at the other species; harpago short and thin, longer and robust at the other species; endothecal sclerite short and rounded, downward hooked at C. cressida, C. copia, C. lolo, C. orthocercata and elongated low at $C$. ecsedii.

Description. A uniformly brown coloured small species with forewing length of $6 \mathrm{~mm}$.

Male genitalia. Abdominal segment IX fused annular, short; anterior margin arciform, resulted in a very short dorsum and short but slightly longer ventrum; the ventrum is without spiny ven- 


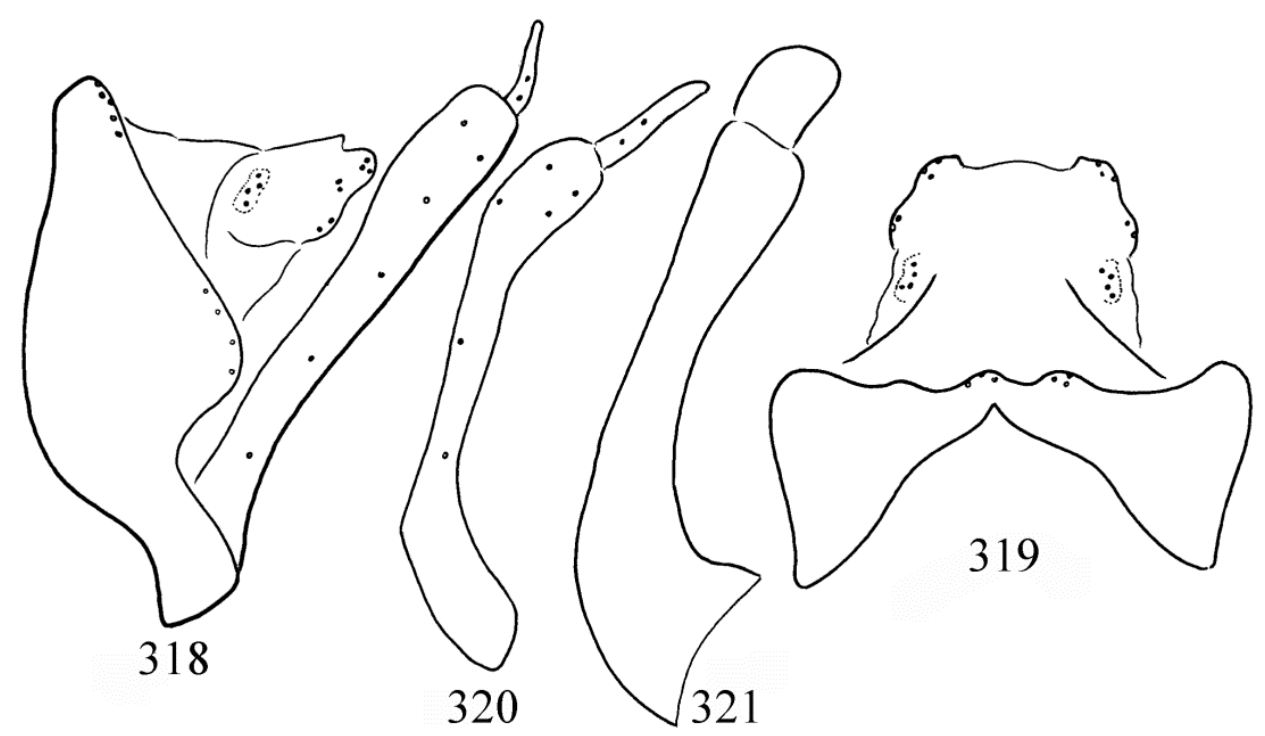

Figures 318-321. Cheumatopsyche myntanga sp. nov. Holotype: $318=$ male genitalia in left lateral view, $319=$ male genitalia in dorsal view, $320=$ left gonopod in ventral view, 321 = phallic organ in left lateral view.

trocaudal mesal lobe; apical margin is straight vertical, its dorsal region is marked with a row of strong spines and ventrad terminated in a triangular lobe above the gonopods; intersegmental depression between the ninth and tenth segments present, deep and step-wise in lateral view. Body of segment $\mathrm{X}$ longer than high; slightly elongated lateral setose area (cerci) in middle position; apicoventral setose lobe discernible as incompletely fused to the apicoventrum of the segment and discernible as a small setose lobe with shallow excision middle as visible both in dorsal and lateral views. The basal segment of the gonopods straight, only dilating apicad, especially in ventral view; harpago, the terminal segment slender digitate in ventral view. Phallic apparatus with straight dorsum and broadening ventrum; the pair of endothecal sclerites rounded, slightly longer than high.

Etymology. myntanga, named after the locus typicus of the holotype.

\section{Cheumatopsyche nongrima sp. nov.}

(Figures 322-325, Map 5: n², 42, 47, 84, Map 22)

Material examined. Holotype: India, Meghaláya (United Jaintia and Khasi Hills), Nongrim [according to the Schmid's route it probably corresponds to Nongtraw, $3000 \mathrm{ft}, 25^{\circ} 22^{\prime} 09.9^{\prime \prime} \mathrm{N}$ 914ㄴ'48.2"E, 28.III.1960, leg. F. Schmid] (1 male, CNC). Paratypes: India, Meghaláya (United Jaintia and Khasi Hills), Nongrim [=Nongtraw], 1800 ft, 27.III.1960, leg. F. Schmid (3 males, CNC; 1 male, OPC; 1 male, SMNH). India, Meghaláya (United Jaintia and Khasi Hills), Mawpran [=Mawpran Nonglyndiang], $2000 \mathrm{ft}$, $25^{\circ} 18^{\prime} 27.3^{\prime \prime N} 91^{\circ} 58^{\prime} 05.7^{\prime \prime E}, 9 . I V .1960$, leg. F. Schmid (1 male, OPC). India, Meghaláya (United Jaintia and Khasi Hills), Mawshuid (Mawshnid), 1400 ft, 29.III.1960, leg. F. Schmid (3 males, CNC). India, Meghaláya (United Jaintia and Khasi Hills), Rumkheng [= Ramkheng], $4500 \mathrm{ft}$, $25^{\circ} 23^{\prime} 07.2^{\prime \prime} \mathrm{N} 91^{\circ} 50^{\prime} 12.8^{\prime \prime} \mathrm{E}, 24 . \mathrm{III} .1960$, leg. F. Schmid (1 male, CNC). India, Assam, United District of Mikir and North Cachar Hills, Bandarkhal, $300 \mathrm{ft}, 25^{\circ} 03^{\prime} 31.1^{\prime \prime} \mathrm{N} 92^{\circ} 48^{\prime} 02.5^{\prime \prime} \mathrm{E}$, 9.V.1960, leg. F. Schmid (1 male, OPC).

Diagnosis. This new species having almost monolobed segment $\mathrm{X}$ that is the ventroapical pair of setose lobes almost completely fused to the body of segment $\mathrm{X}$ belongs to the Cheumatopsyche concava species group (Oláh et al. 2008a). According to the structure of segment $X$ and the phallic organ this brown species is most close to Cheumatopsyche khasia sp. nov. but 


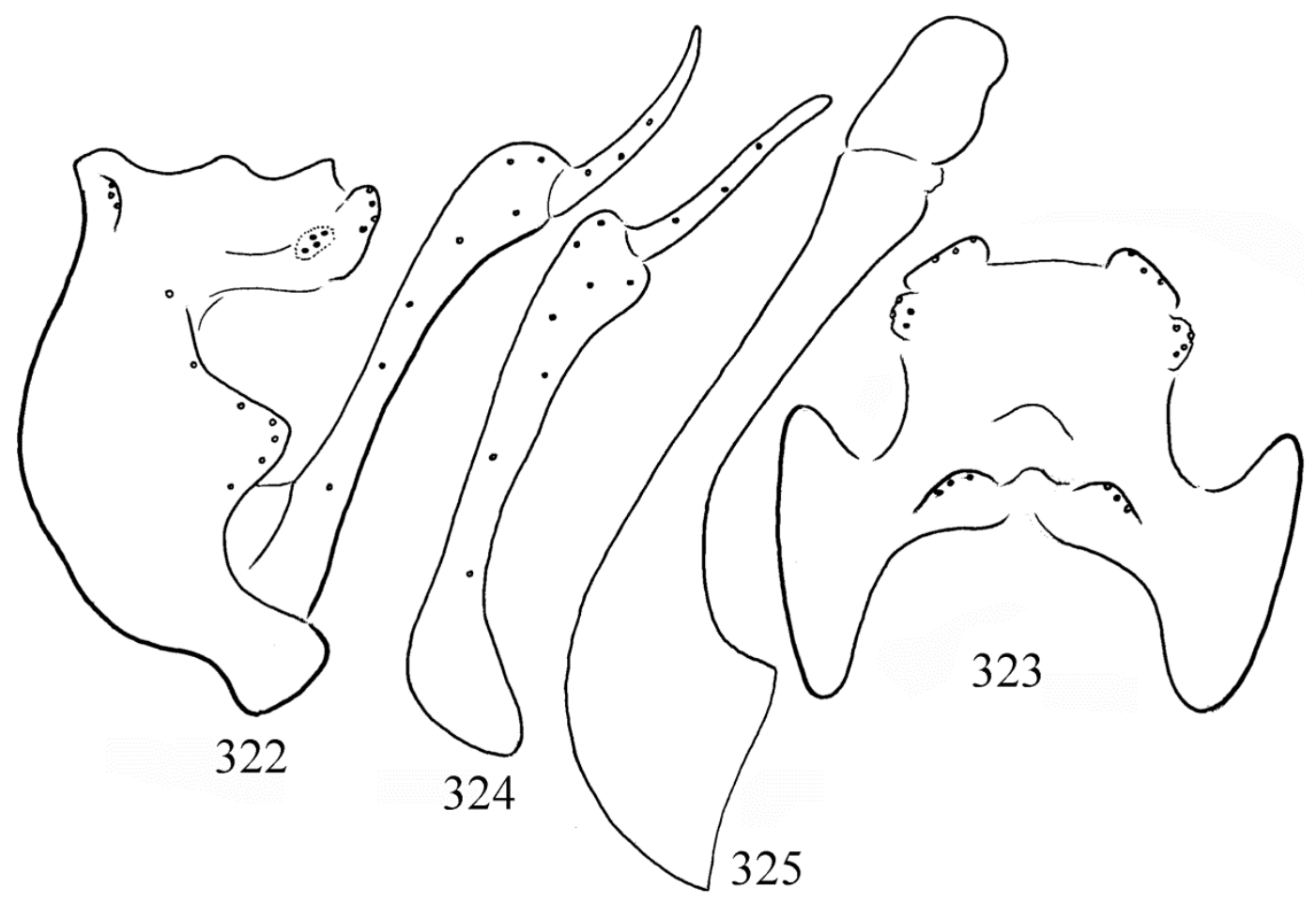

Figures 322-325. Cheumatopsyche nongrima sp. nov. Holotype: $322=$ male genitalia in left lateral view, $323=$ male genitalia in dorsal view, 324 = left gonopod in ventral view, 325 = phallic organ in left lateral view.

differs by the rather pronounced triangular shape of the apical lobe of segment IX; by the wide dorsal interlobular gap between the vestigial ventroapical setose lobe; by the subapical, not almost apical position of cerci; by the inflated head of the coxopodite; by the slender middle region of the phallic organ as well as by the lateral shape of the endothecal sclerites.

Description. A uniformly brown coloured species with forewing length of $7 \mathrm{~mm}$. Male genitalia. Abdominal segment IX fused annular, short; anterior margin short arciform, resulted in a very short dorsum and short but slightly longer ventrum; the ventrum is without spiny ventrocaudal mesal lobe; apical margin is dominated by the triangular lobe; intersegmental depression between the ninth and tenth segments present, low and oblique in lateral view; dorsoapical setose lobes of segment IX well separated. Body of segment X longer than high; the almost regularly circular lateral setose area (cerci) at subapical position superimposed near to the apicoventral setose lobes; apicoventral setose lobe discernible as incompletely fused to the apicoventrum of the segment and discernible as a small rounded setose lobe as visible in lateral view; its mesal free apex curving mesad. The basal segment of the gonopods downward arching; apex highly inflated; harpago, the terminal segment long, slender and digitate both in lateral and ventral views. Phallic apparatus with straight dorsum upward curving apicad and slightly broadening ventrum; the pair of endothecal sclerites elongated robust with broadening ventrobasal region.

Etymology. nongrima, named after the region of type locality.

\section{Cheumatopsyche chinensis species group}

Species group of fused monolobed segment $\mathrm{X}$ with upturning mostly spiny apices of the setose ventroapical lobes, variously distanced from each other. The fused setose ventroapical lobes with upturning apices dominate the genital structure; 
only the very spiny tip of the lobes remained separated. As a result segment $\mathrm{X}$ is nearly monolobed, except a very narrow and shallow dorsal interlobular gap remained between the upturning apices or a small convex unsetose mesal lobe developed as visible in dorsal view. The cerci form an elevated wart-like setose surface. The harpago mostly short and broad, frequently having apices with specific character states (Oláh et al. 2008a).

Seven species with character states of the Cheumatopsyche chinensis species group are described from the Afrotropical faunal region (Oláh et al 2008a,b). Here we list or treat only species from the Palaearctic and Oriental faunal regions: Cheumatopsyche amurensis Martynov, 1934, Russia, Amurland; C. bandarkhala sp. nov. India, Assam; C. banksi Mosely, 1942, China, Fujian; $C$. caieta Malicky \& Chantaramongkol, 1997, Thailand; C. chinensis (Martynov, 1930), China, Sichuan; $C$. delhia sp. nov., India, Delhi; $C$. diehli Malicky, 1997, Indonesia, Sumatra; C. hanoia sp. nov. Vietnam; $C$. hotaya sp. nov., Vietnam; $C$. junolahi Oláh \& Johanson, 2008, Vietnam; $C$. pega sp. nov. Myanmar; C. processuata (Martynov, 1927) North Iran; C. pulchripennis (Banks, 1939), Indonesia, Sumatra; C. quangchua sp. nov., Vietnam; C. rubachi Mey, 1995 Philippines; C. schwendingeri Malicky \& Chantaramongkol, 1997, Thailand; C. socia (Navás, 1927), Egypt; $C$. tamda sp. nov., Vietnam; C. tinjar (Kimmins, 1955), Malaysia, Sarawak; C. tongoma sp. nov., Laos.

Based on the "wide distribution with high variability" principles and practices of the lumpers which is widely applied and practiced in gross phenomics, the taxonomy of this species group is frequently contradictory and puzzling. Here we revise the unsettled species of the group applying the principles and procedures of our fine phenomics.

In species delineation the neutral trait of the first segment of the gonopod, the coxopodites has no real diagnostic value; one species $C$. amurensis has very robust coxopodite, another species $C$. delhia sp. nov. has very broadened almost capitate apical region on the coxopodite; all the other species have more slender coxopodite, especially on its basal half. The other neutral trait, the cerci are variously lobe-like and have some divergences in their location. The magnitude, direction and development of the spine formation on the ventroapical setose lobes of segment X, especially its lateral profile has high dianostic value; its dorsal profile is depending on the observation view that is highly unstable; very tiny change in the observation angle creates significant shape alterations. The lateral profile of the phallic organ has high diagnostic value; however, we have to take into consideration a unique feature of the subapical region of the phallotheca in this species group that is frequently less sclerotized, permitting some kind of functional wrist movement, resulted in a downward leaning apical region, a possible anchoring capacity for the post-copulatory sperm selection in the cryptic female choice producing rapid divergences of the reproductive gene sequence complexes.

The spine formation on the ventroapical setose lobes and the phallic organ as non-neutral adaptive traits are more diverse than the neutral traits of coxopodites and cerci. Another unique feature of this species group is the extremely high diversity of the head on the harpagones, similarly to the apices of harpago in the Hydromanicus luctuosus species complex. These tiny shape divergences on the harpago head is usually not recognised in gross phenomics. However, these divergences organised on the tip of harpagones are very stable as we have examined also in the Hydromanicus genus.

\section{Cheumatopsyche amurensis Martynov, 1934, stat. rest.}

(Figures 326-329, Map 23)

Cheumatopsyche amurensis Martynov, 1934:293. This species is described from the Amur River below Habarovsk, as very close to Cheumatopsyche processuata Martynov described from North Iran.

Cheumatopsyche chinensis (Martynov, 1930): Malicky 2013:48. synonymised with Cheumatopsyche chinensis (Martynov, 1930). 


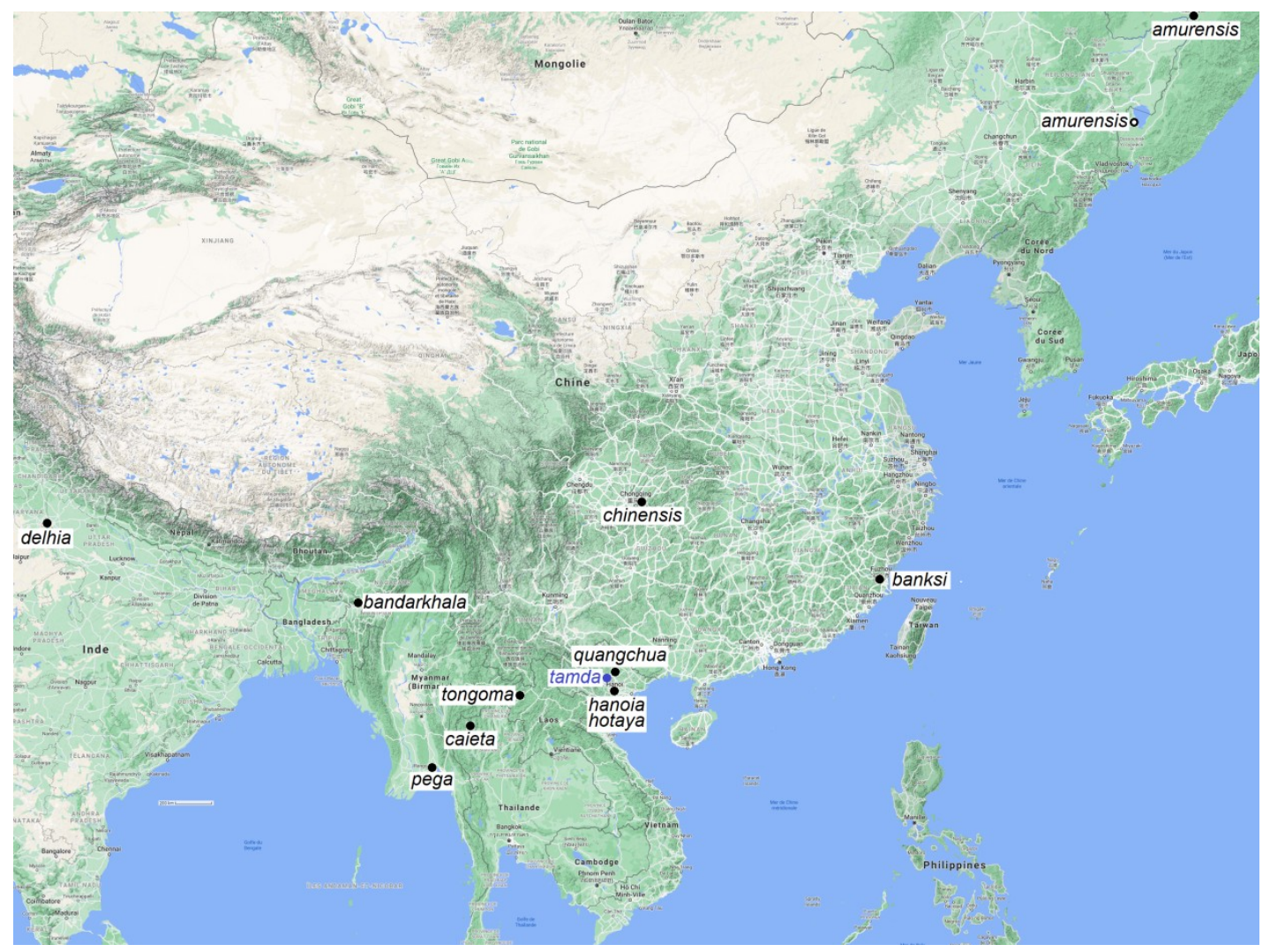

Map 23. Cheumatopsyche chinensis group.

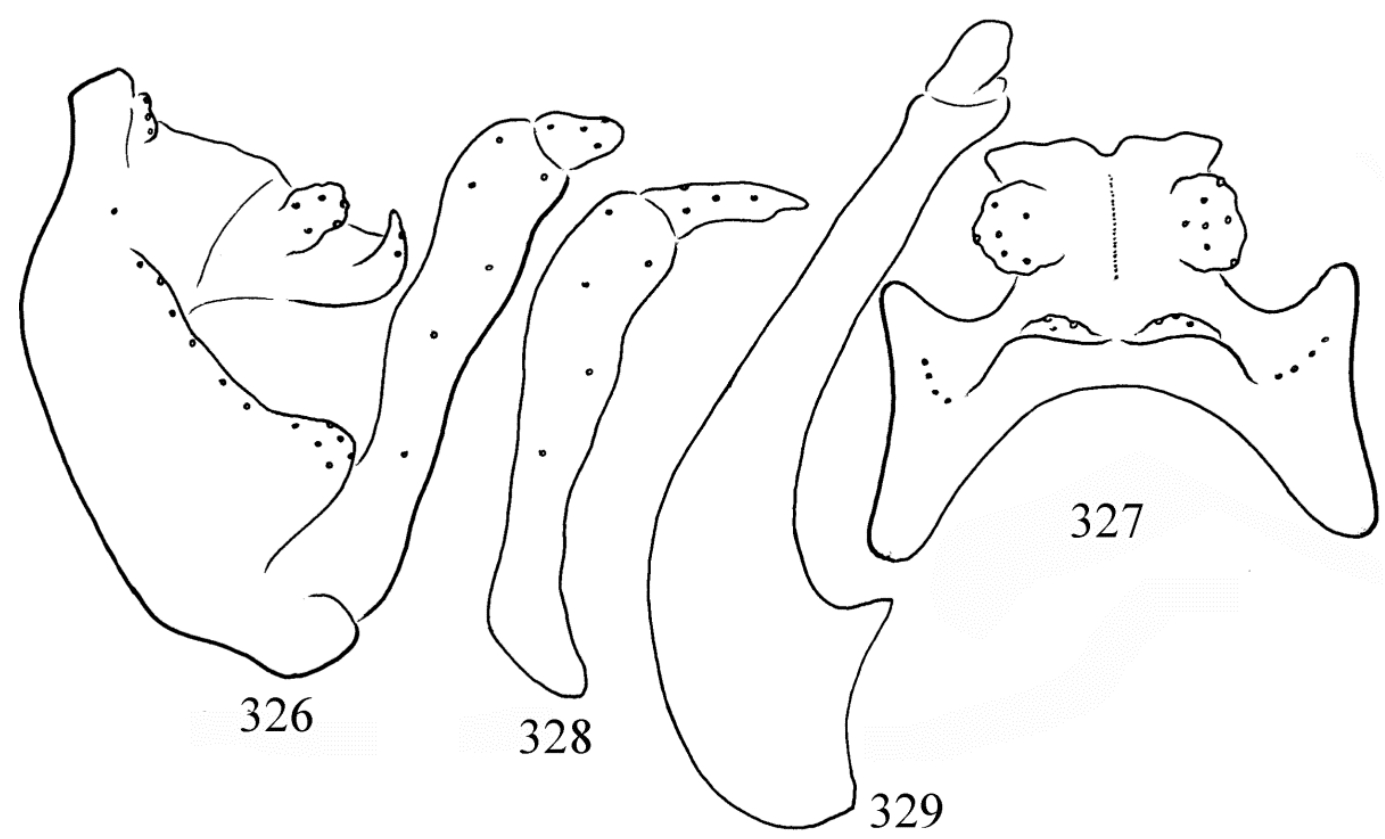

Figures 326-329. Cheumatopsyche amurensis Martynov, 1934. $326=$ male genitalia in left lateral view, $327=$ male genitalia in dorsal view, 328 = left gonopod in ventral view, 329 = phallic organ in left lateral view. 
Material examined. Russia, Khabarovsk Ter. Slavyanka at Amur, light trap, 17.VI.1994, light trap, leg. P. Lindskog \& B. Viklund (3 males NRM, 3 males OPC). Russia, Khabarovsk Ter. Slavyanka 5km E. Troitskoye, $44^{\circ} 49^{\prime} 32.7^{\prime \prime N} 132^{\circ}$ $02^{\prime} 07.2^{\prime \prime} \mathrm{E}$, bog margin in dec. forest, light trap, 18-19.VI.1993, leg. P. Lindskog \& B. Viklund (3 males NRM).

Remarks. Holotype was not available for examination. We have collected and studied nine specimens from the type locality. Cheumatopsyche amurensis Martynov, 1934 is far from all the members of the group and especially well differentiated from C. chinensis (Martynov, 1930), having cerci more lobe-like; gonopode extremely robust, not slender; ventroapical setose lobes shorter, phallic organ slender with horizontal, not arching phallothecal shaft. It is not a synonym of C. chinensis. Here we reinstate its species status.

\section{Cheumatopsyche bandarkhala sp. nov.}

(Figures 330-333, Map 5: n 83, Map 23)

Material examined. Holotype: India, Assam, United District of Mikir and North Cachar Hills, Bandarkhal, $300 \mathrm{ft} ., 25^{\circ} 03^{\prime} 31.1^{\prime \prime} \mathrm{N} 92^{\circ} 48^{\prime} 02.5^{\prime \prime} \mathrm{E}$, 8.V.1960, leg. F. Schmid (1 male, CNC).

Diagnosis. This new species having monolobed segment $X$ with spiny upward turning apices of the ventroapical pair of setose lobes belongs to the Cheumatopsyche chinensis species group (Oláh et al. 2008a). According to the structure of segment $\mathrm{X}$ and the phallic organ this small, delicate brown species is most close to $C$. hanoia sp. nov., but differs by having longer endothecal sclerites, more robust spiny formation on the ventroapical setose lobes and the digitate apices on harpago right angled.

Description. A uniformly brown coloured small species with forewing length of $7 \mathrm{~mm}$.

Male genitalia. Abdominal segment IX fused annular, short; anterior margin arciform, resulted in a very short dorsum and slightly longer ventrum; the ventrum is without spiny ventrocaudal mesal lobe; apical margin is straight vertical, its dorsal region is marked with a row of spines and ventrad terminated in a rounded triangular lobe above the gonopods; intersegmental depression between the ninth and tenth segments present, shallow and partially occupied by a pair of setose humps. Body of segment $\mathrm{X}$ as long as high, subtriangular; slightly elevated lateral setose area (cerci) in middle position; apicoventral setose lobe discernible as incompletely fused to the apicoventrum of the segment and armed with a pair of up and anterad turning spiny pointed lobes. The basal segment of the gonopods straight with dilating apical half; harpago, the terminal segment slender digitate with right angle in ventral view. Phallic apparatus with arching dorsum and broadening ventrum subapicad; the pair of endothecal sclerites elongated, longer than high.

Etymology. bandarkhala, named after the locus typicus of the holotype.

\section{Cheumatopsyche banksi Mosely, 1942 stat. rest.}

(Figures 334-336, Map 23)

Cheumatopsyche banksi Mosely, 1942:351-352. Described from a single male collected in Foochow [=Fuzhou], Fujian Province, China by M. S. Yang and deposited in the British Natural History $\mathrm{Mu}-$ sem.

Cheumatopsyche chinensis (Martynov, 1930): Oláh et al. 2008a: 150, synonymised with Cheumatopsyche chinensis (Martynov, 1930).

Cheumatopsyche chinensis (Martynov, 1930): Malicky, 2013:48. Listed as Cheumatopsyche chinensis (Martynov, 1930).

Remarks. After careful examination of details in the genitalia of the type of $C$. banksi and $C$. chinensis significant divergences was detected between the two species. The only known specimen of this species, the holotype has the spiny formation on ventroapical setose lobes anterad, not upward turning, the apical region of the phallotheca strait, not downward directed, the endothecal sclerites short, not long as well as there is an arching digitate process on the tip of harpago, lacking in $C$. chinensis. Here we reinstate the species status of Cheumatopsyche banksi Mosely, 1942. 


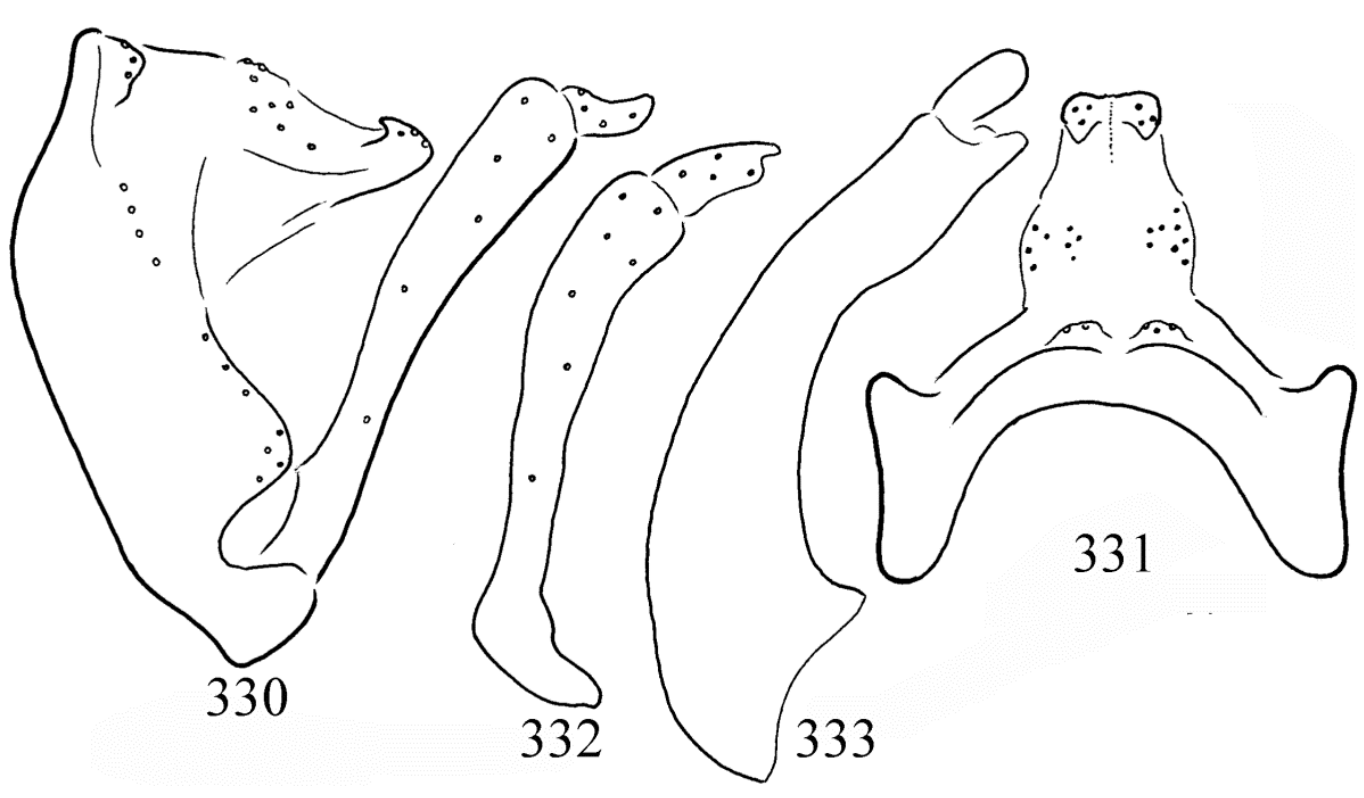

Figures 330-333. Cheumatopsyche bandarkhala sp. nov. Holotype: $330=$ male genitalia in left lateral view, $331=$ male genitalia in dorsal view, 332 = left gonopod in ventral view, 333 = phallic organ in left lateral view.

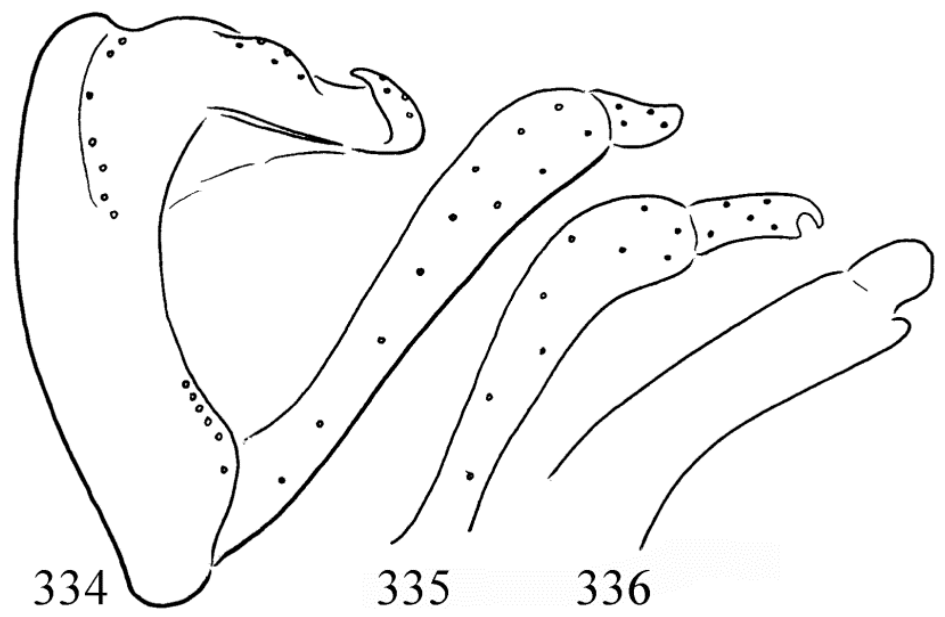

Figures 334-336. Cheumatopsyche banksi Mosely, 1942. $334=$ male genitalia in left lateral view, $335=$ left gonopod in ventral view, $336=$ phallic organ in left lateral view.

\section{Cheumatopsyche caieta Malicky \& Chantaramongkol, 1997}

(Map 23)

Cheumatopsyche caieta Malicky \& Chantaramongkol, 1997, in Malicky 1997:1032. Described from Thailand, Huai Nam Dang National Park as close to Cheumatopsyche banksi Mosely.

\section{Cheumatopsyche chinensis (Martynov, 1930)}

(Figures 337-340, Map 23)

Hydropsychodes chinensis Martynov, 1930: 80-81. Described from China, Chungking [=Chongqing], Sichuan.

Cheumatopsyche chinensis (Martynov, 1930); Mosely 1939: 27. 
Cheumatopsyche chinensis (Martynov, 1930): Oláh et al. 2008a: 150. Holotype is examined and deposited in the Natural History Museum, London, UK.

Remarks. The nominate species of the group, Cheumatopsyche chinensis (Martynov, 1930) differs from all the other species in the group by the simple rounded tip of the harpago without any specific pattern. That is the apomorphic character state in the species group.

\section{Cheumatopsyche delhia sp. nov.}

(Figures 341-344, Map 23)

Material examined. Holotype: India, New Delhi, 18.III.1967, light trap, leg. K. E. Gibson (1 male, OPC). Paratypes: same as holotype (12 males, 8 females, BMNH; 2 males, 1 female; OPC).

Diagnosis. This new species having monolobed segment $\mathrm{X}$ with spiny upward turning apices of the ventroapical pair of setose lobes belongs to the Cheumatopsyche chinensis species group (Oláh et al. 2008a). According to the structure of segment $\mathrm{X}$ and the phallic organ this small, delicate brown species is most close to $C$. pega sp. nov., but differs by having capitate coxopodite, more pointed spiny formation on the ventroapical setose lobes, broadening on the ventroapical region of the phallotheca, longer endothecal sclerites as well as blunt and short digitate process on the tip of the harpago.

Description. A uniformly brown coloured small species with forewing length of $7 \mathrm{~mm}$.

Male genitalia. Abdominal segment IX fused annular, short; anterior margin arciform with obliquely cut dorsum, resulted in a very short dorsum and much longer ventrum; the ventrum is without spiny ventrocaudal mesal lobe; apical margin is straight vertical, its dorsal region is marked with a row of spines and ventrad terminated in a rounded triangular lobe above the gonopods; intersegmental depression between the ninth and tenth segments present, shallow and partially occupied by a pair of setose humps. Body of segment $\mathrm{X}$ as long as high, subtriangular;

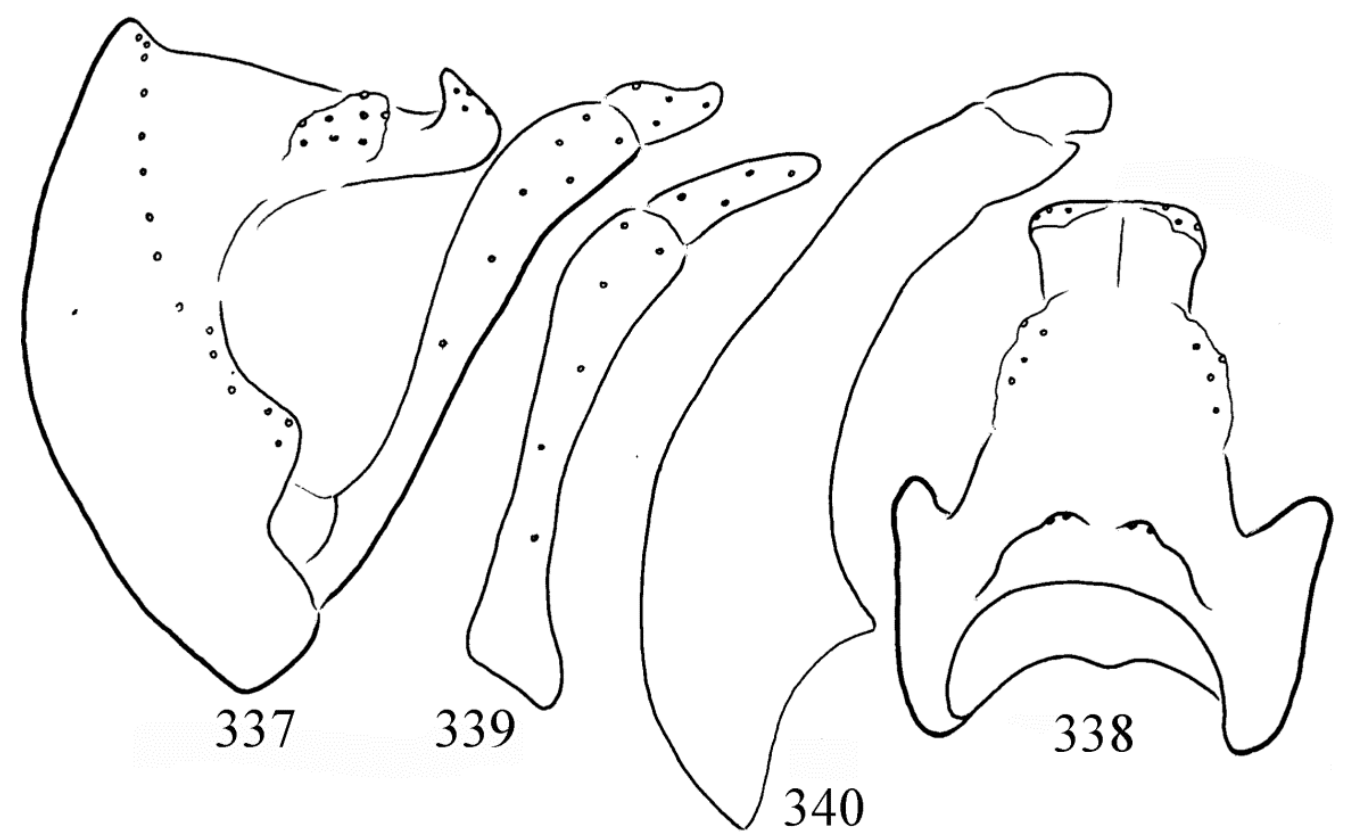

Figures 337-340. Cheumatopsyche chinensis (Martynov, 1930). $337=$ male genitalia in left lateral view, $338=$ male genitalia in dorsal view, $339=$ left gonopod in ventral view, 340 = phallic organ in left lateral view. 


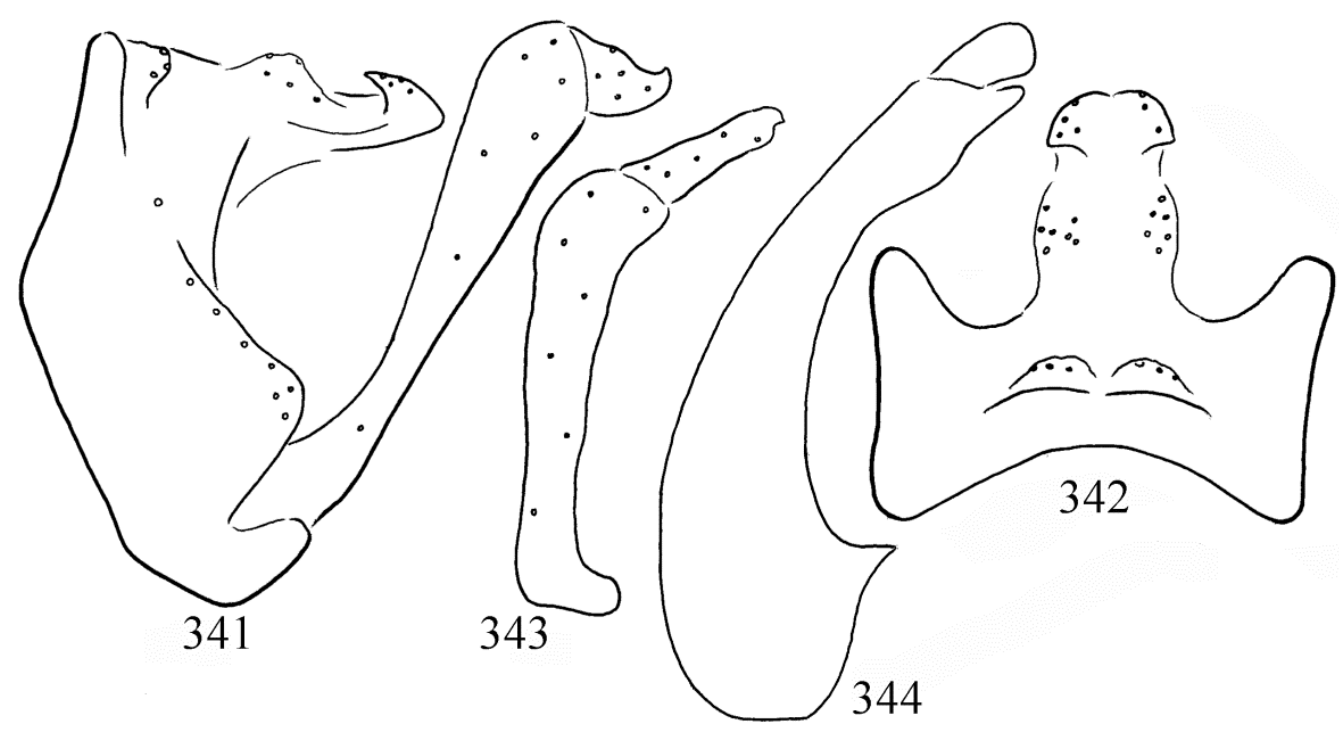

Figures 341-344. Cheumatopsyche delhia sp. nov. Holotype: $341=$ male genitalia in left lateral view, $342=$ male genitalia in dorsal view, 343 = left gonopod in ventral view, 344 = phallic organ in left lateral view.

elevated lateral setose area (cerci) in middle position; apicoventral setose lobe discernible as incompletely fused to the apicoventrum of the segment and armed with a pair of up and anterad turning spiny pointed lobes. The basal segment of the gonopods straight with highly dilating capitate apex; harpago, the terminal segment blunt digitate with mesad turning tiny tip in ventral view. Phallic apparatus with arching dorsum and broadening ventrum subapicad; the pair of endothecal sclerites elongated, longer than high.

Etymology. delhia, named after the locus typicus of the holotype.

\section{Cheumatopsyche hanoia sp. nov.}

(Figures 345-348, Map 23)

Material examined. Holotype: Vietnam, Hanoi, Ho Tay (West Lake), 28.X.1986, light leg. S. Mahunka \& J. Oláh (1 male, OPC). Paratypes: same as holotype (10 males, OPC).

Diagnosis. This new species having monolobed segment $\mathrm{X}$ with spiny upward turning apices of the ventroapical pair of setose lobes belongs to the Cheumatopsyche chinensis species group (Oláh et al. 2008a). According to the struc ture of segment $\mathrm{X}$ and the phallic organ this small, delicate brown species is most close to $C$. bandarkhala sp. nov., but differs by having shorter endothecal sclerites, less robust spiny formation on the ventroapical setose lobes and the digitate apices on harpago obtuse angled.

Description. A uniformly brown coloured small species with forewing length of $7 \mathrm{~mm}$.

Male genitalia. Abdominal segment IX fused annular, short; anterior margin arciform, resulted in a very short dorsum and slightly longer ventrum; the ventrum is without spiny ventrocaudal mesal lobe; apical margin is straight vertical, its dorsal region is marked with a row of spines and ventrad terminated in a rounded triangular lobe above the gonopods; intersegmental depression between the ninth and tenth segments present, shallow and partially occupied by a pair of setose humps. Body of segment $\mathrm{X}$ as long as high, subtriangular; slightly elevated lateral setose area (cerci) in middle position; apicoventral setose lobe discernible as incompletely fused to the apicoventrum of the segment and armed with a pair of up and anterad turning robust spiny pointed lobes. The basal segment of the gonopods straight with dilating apical half; harpago, the terminal segment slender digitate with obtuse angle in 


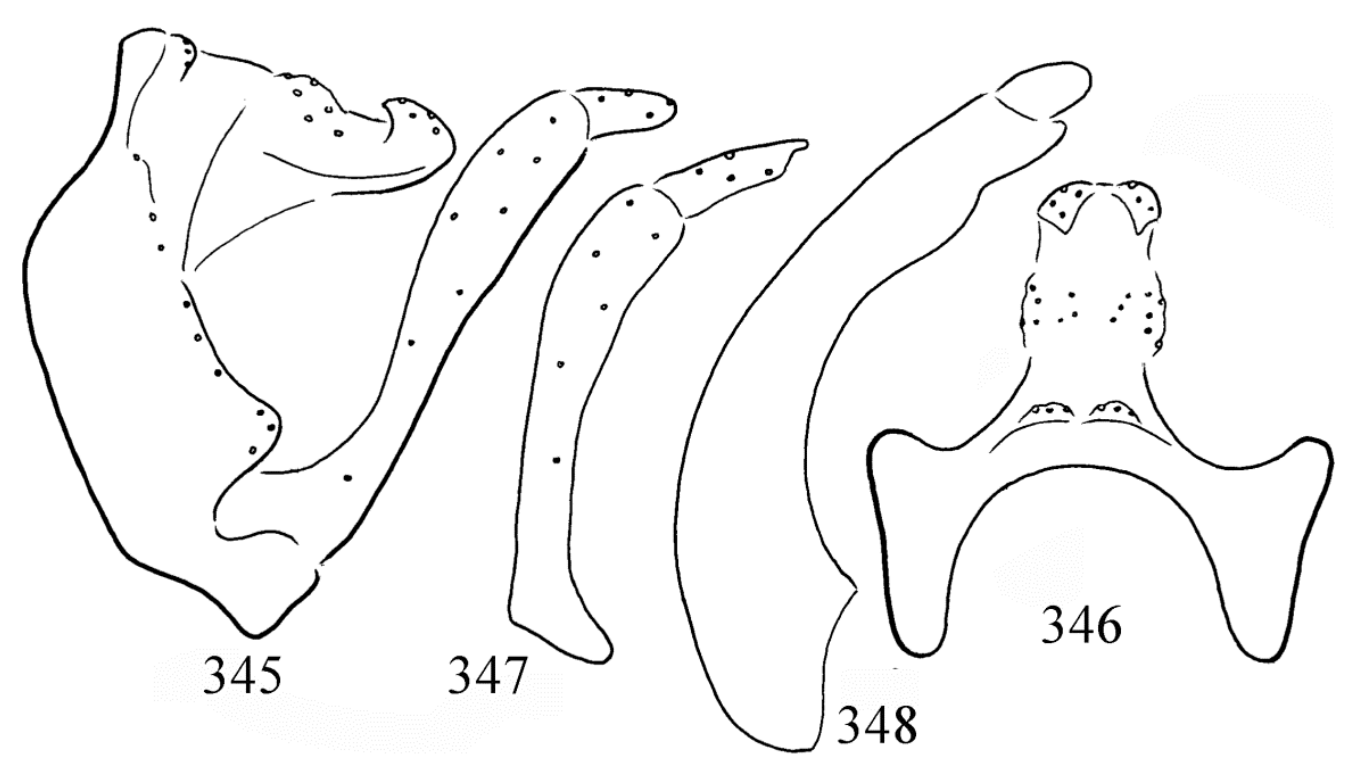

Figures 345-348. Cheumatopsyche hanoia sp. nov. Holotype: $345=$ male genitalia in left lateral view, $346=$ male genitalia in dorsal view, 347 = left gonopod in ventral view, $348=$ phallic organ in left lateral view.

ventral view. Phallic apparatus with arching dorsum and broadening ventrum subapicad; the pair of endothecal sclerites ovoid, longer than high.

Etymology. hanoia, named after the locus typicus of the holotype.

\section{Cheumatopsyche hotaya sp. nov.}

(Figures 349-352, Map 23)

Material examined. Holotype: Vietnam, Hanoi, Ho Tay (West Lake), 19.I.1986, light leg. S. Mahunka \& J. Oláh (1 male, OPC).

Diagnosis. This new species having monolobed segment $X$ with spiny upward turning apices of the ventroapical pair of setose lobes belongs to the Cheumatopsyche chinensis species group (Oláh et al. 2008a). According to the structure of segment $\mathrm{X}$ and the phallic organ this small, delicate brown species is most close to C. quangchua sp. nov., but differs by having hooked, not upward directed triangular spiny formation on the ventroapical setose lobes and the phallotheca low and straight, not high and not strongly arching.
Description. A uniformly brown coloured small species with forewing length of $7 \mathrm{~mm}$.

Male genitalia. Abdominal segment IX fused annular, short; anterior margin arciform, resulted in a very short dorsum and much longer ventrum; the ventrum lacks spiny ventrocaudal mesal lobe; apical margin straight vertical, its dorsal region marked with a row of spines and ventrad terminated in a rounded triangular lobe above the gonopods; intersegmental depression between the ninth and tenth segments almost disappeared, shallow and partially occupied by a pair of setose humps. Body of segment $\mathrm{X}$ as long as high, subtriangular; slightly elevated lateral setose area (cerci) in middle position; apicoventral setose lobe discernible as incompletely fused to the apicoventrum of the segment and armed with a pair of robust hookshaped spiny pointed lobes. The basal segment of the gonopods straight with dilating apical half; harpago, the terminal segment slender gradually digitate in ventral view. Phallic apparatus with slightly arching dorsum; the pair of endothecal sclerites ovoid, longer than high.

Etymology. hotaya, named after the locus typicus of the holotype. 


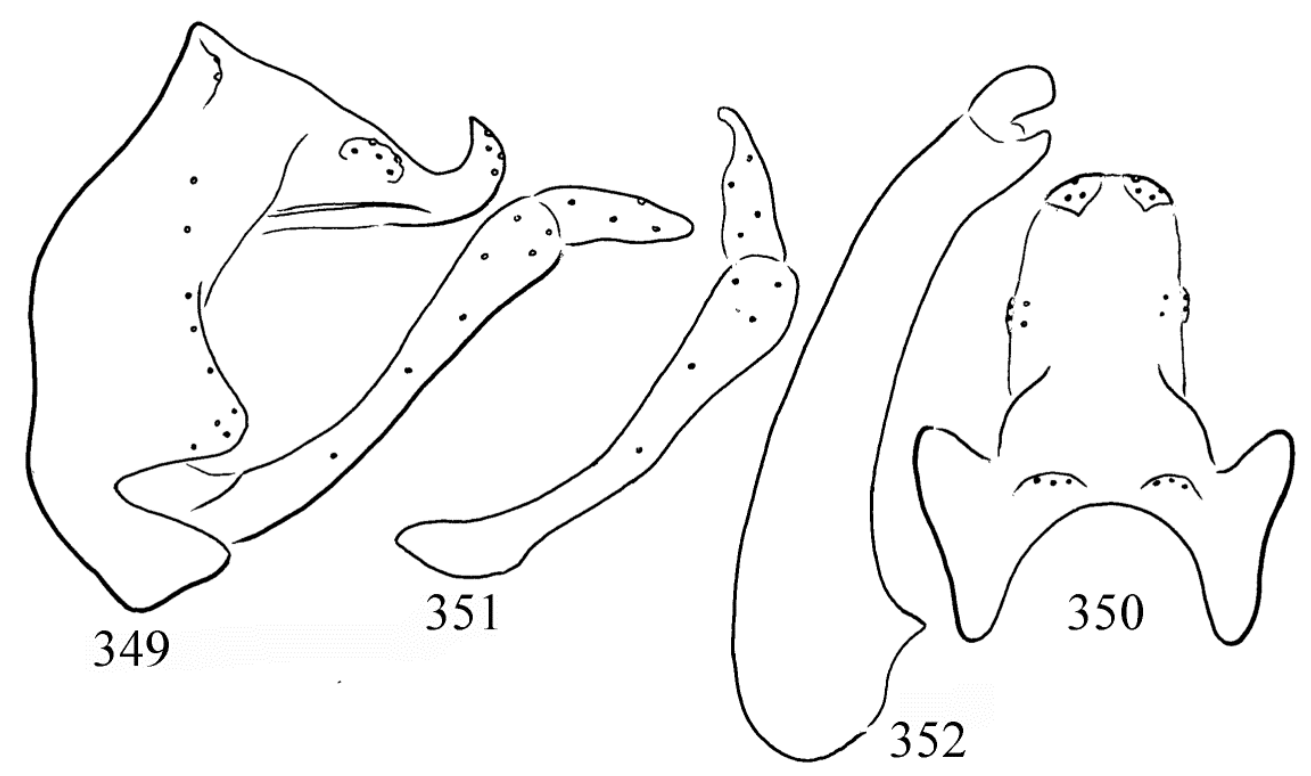

Figures 349-352. Cheumatopsyche hotaya sp. nov. Holotype: $349=$ male genitalia in left lateral view, $350=$ male genitalia in dorsal view, 351 = left gonopod in ventral view, 352 = phallic organ in left lateral view.

\section{Cheumatopsyche pega sp. nov.}

(Figures 353-356, Map 23)

Material examined. Holotype: Myanmar, Pegu, (Bago), 10.IX.1914, Fletcher collection (1 male, BMNH).

Diagnosis. This new species having monolobed segment $\mathrm{X}$ with spiny upward turning apices of the ventroapical pair of setose lobes belongs to the Cheumatopsyche chinensis species group (Oláh et al. 2008a). According to the structure of segment $X$ and the phallic organ this small, delicate brown species is most close to $C$. delhia sp. nov., but differs by having dilated, but not capitate coxopodite, less pointed spiny formation on the ventroapical setose lobes, without broadening on the ventroapical region of the phallotheca, shorter endothecal sclerites as well as falcate, not blunt and short digitate process on the tip of the harpago.

Description. A uniformly brown coloured small species with forewing length of $7 \mathrm{~mm}$.
Male genitalia. Abdominal segment IX fused annular, short; anterior margin arciform with obliquely cut dorsum, resulted in a very short dorsum and much longer ventrum; the ventrum is without spiny ventrocaudal mesal lobe; apical margin is straight vertical, its dorsal region is marked with a row of spines and ventrad terminated in a rounded triangular lobe above the gonopods; intersegmental depression between the ninth and tenth segments present, shallow and partially occupied by a pair of setose humps. Body of segment $\mathrm{X}$ as long as high, subtriangular; elevated lateral setose area (cerci) in middle position; apicoventral setose lobe discernible as incompletely fused to the apicoventrum of the segment and armed with a pair of up and anterad turning spiny pointed lobes. The basal segment of the gonopods straight with dilating apex; harpago, the terminal segment with falcate process in ventral view. Phallic apparatus with strait dorsum without broadening ventrum subapicad; the pair of endothecal sclerites short.

Etymology. pega, named after the locus typicus of the holotype. 


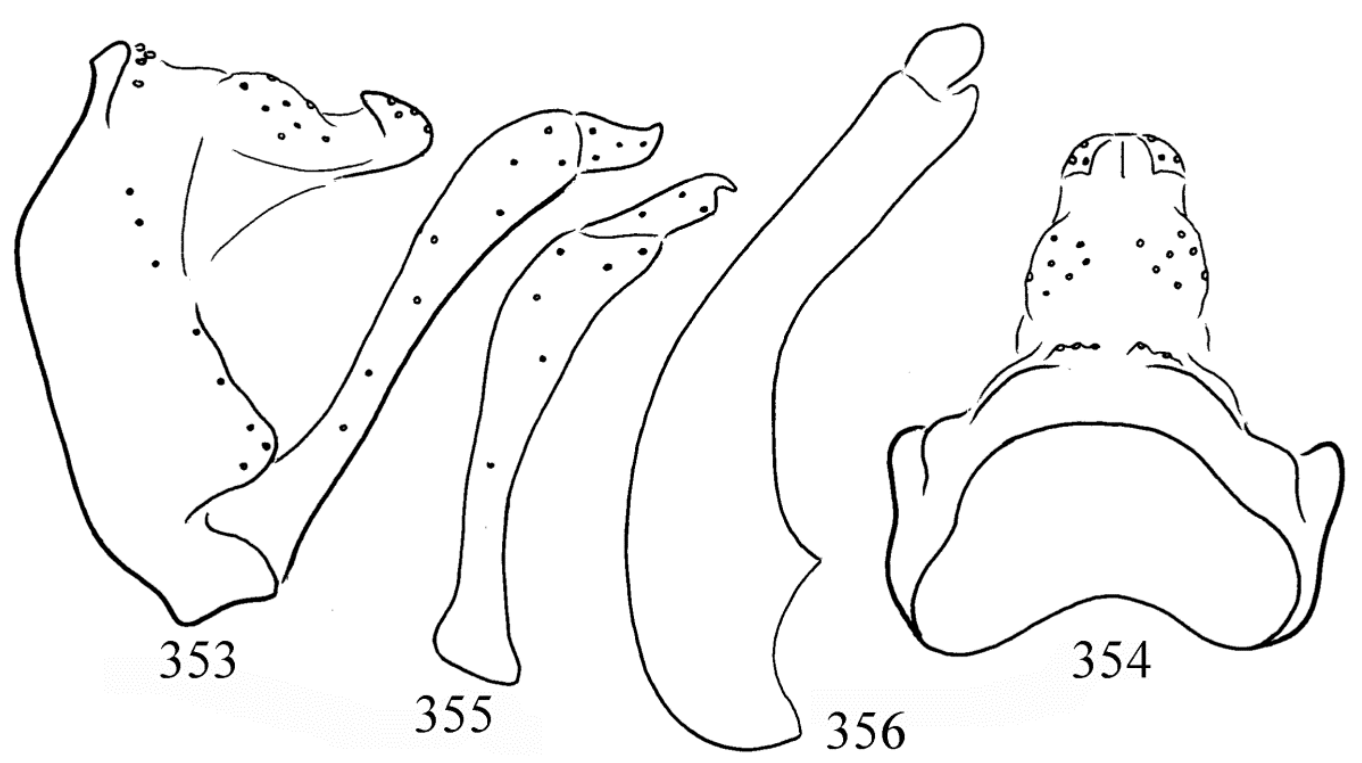

Figures 353-356. Cheumatopsyche pega sp. nov. Holotype: $353=$ male genitalia in left lateral view, $354=$ male genitalia in dorsal view, $355=$ left gonopod in ventral view, 356 = phallic organ in left lateral view.

\section{Cheumatopsyche processuata (Martynov, 1927)} stat. rest.

(Figures 357-359)

Hydropsyche processuata Martynov, 1927: 190-191. This species is described from Shellali, North Persia, as related to Hydropsyche asiatica Ulmer.

Cheumatopsyche chinensis (Martynov, 1930): Malicky, 2013: 48. Synonymised with Cheumatopsyche chinensis (Martynov, 1930).

Remarks. Holotype is lacking. Only the original drawings and the description are available for comparative study. However, Martynov's drawings are ultimate with their high resolution of precise details compared to the poor drawings of his comtemporary tricopterologists like Banks, Navas and Ulmer. Our previous reports of $C$. processuata (Martynov, 1927) from India, Myanmar, Pakistan and Vietnam are misidentifications (Oláh et al. 2008a,b). The synonymy between $C$. processuata and C. chinensis (Martynov, 1930) was suggested by Malicky (2013) with a question mark. In the same paper Malicky (2013) has published a new drawing of $C$. processuata from an unknown specimen without collecting data.
Probably it is modified from an idealised version of the original drawings of Martynov (1927).

The comparison of the holotype drawings of $C$. chinensis with the original drawings of $C$. processuata demonstrates the identity of both species. The shape of spiny formation on the ventroapical setose lobe and the tip of the harpago are clearly different. The spiny formation on ventroapical setose lobes anterad, not upward turning, and there is a mesad arching digitate process on the tip of harpago, lacking in $C$. chinensis. $C$. processuata have resemblance to $C$. banksi and $C$. pega, but both species have straight almost regular tube-like apical region of the phallotheca, clearly downward curving and wawing at $C$. processuata. Here we reinstate the species status of Cheumatopsyche processuata (Martynov, 1927).

\section{Cheumatopsyche quangchua sp. nov.}

(Figures 360-363, Map 23)

Material examined. Holotype: Vietnam, Back Kan province, Cho Moi District, Quang Chu Village, 25.X.1986, light leg. S. Mahunka \& J. 


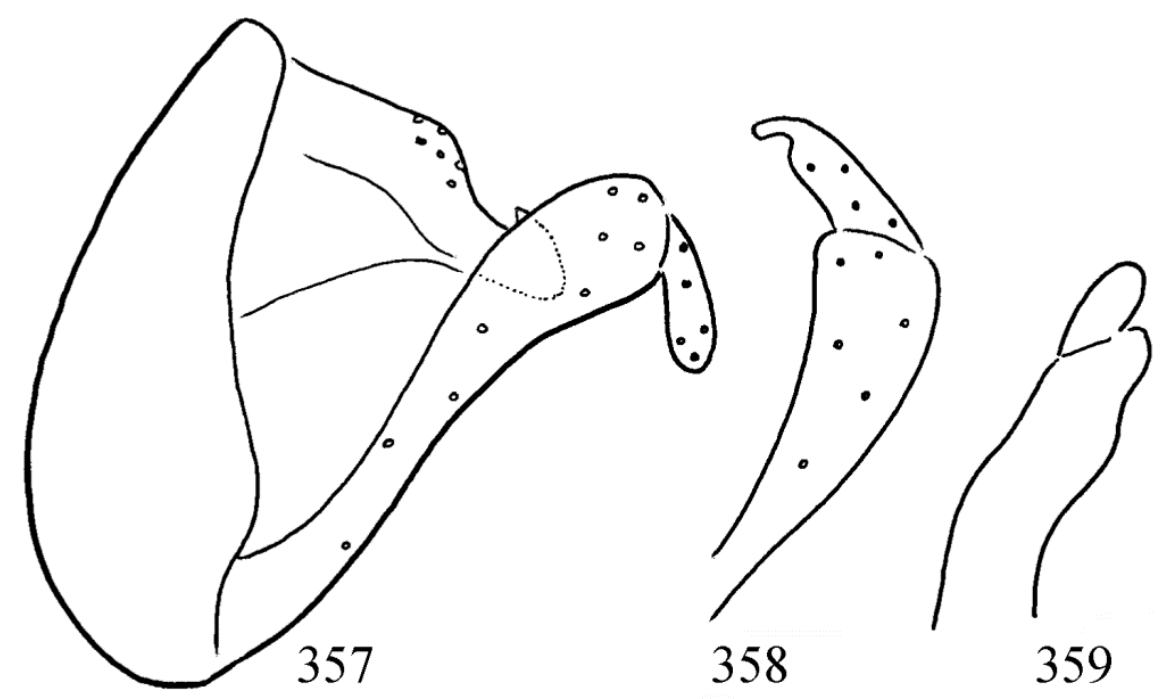

Figures 357-359. Cheumatopsyche processuata (Martynov, 1927). $357=$ male genitalia in left lateral view, $358=$ right gonopod in ventral view, 359 = phallic organ in left lateral view.

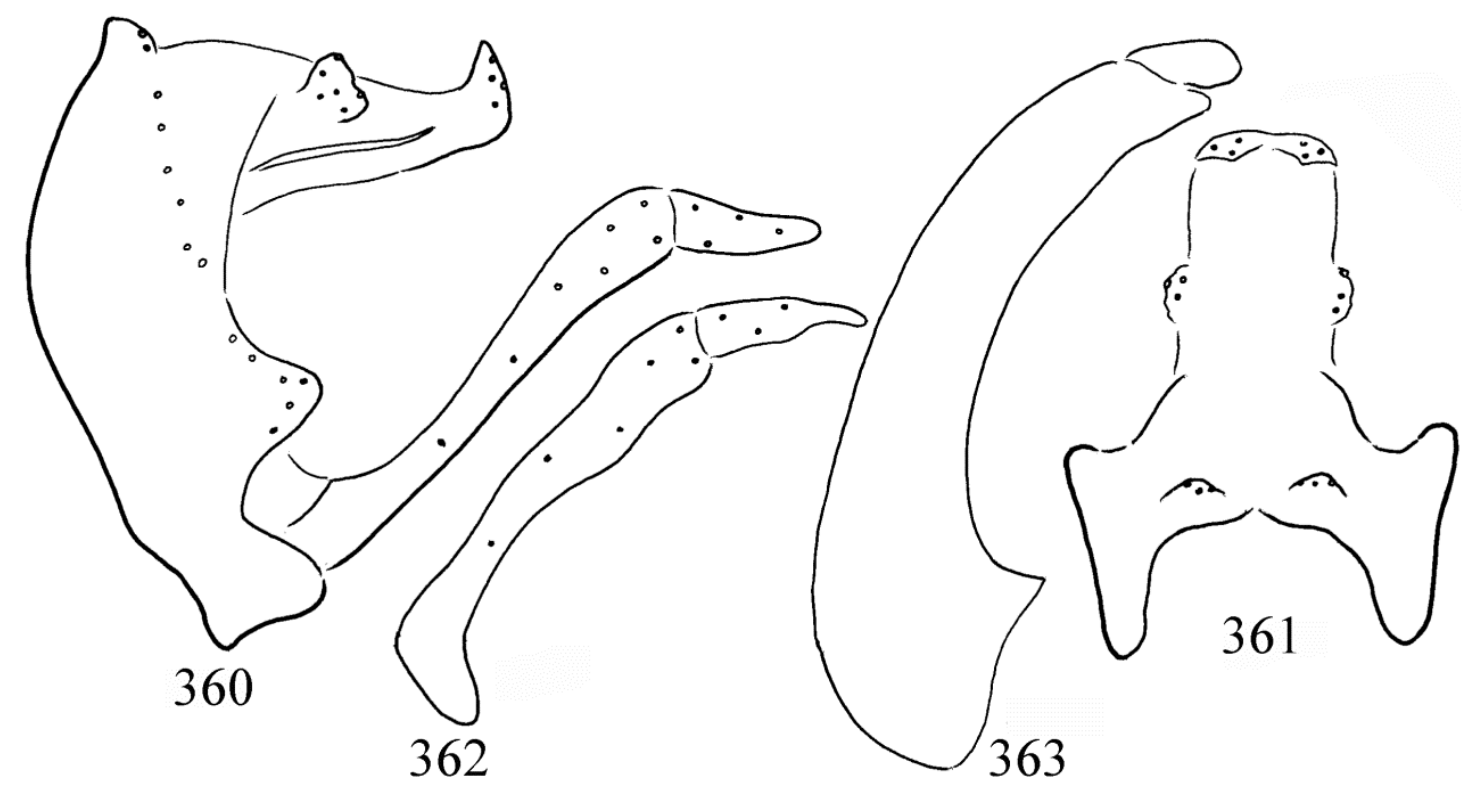

Figures 360-363. Cheumatopsyche quangchua sp. nov. Holotype: $360=$ male genitalia in left lateral view, $361=$ male genitalia in dorsal view, 362 = left gonopod in ventral view, 363 = phallic organ in left lateral view.

Oláh (1 male, OPC). Paratypes: same as holotype (2 males, OPC).

Diagnosis. This new species having monolobed segment $\mathrm{X}$ with spiny upward turning apices of the ventroapical pair of setose lobes belongs to the Cheumatopsyche chinensis species group (Oláh et al. 2008a). According to the structure of segment $\mathrm{X}$ and the phallic organ this small, delicate brown species is most close to $C$. hotayaa sp. nov., but differs by having upward directed triangular, not hooked spiny formation on the ventroapical setose lobes and the phallotheca high and strongly arching, not straigth and low. 
Description. A uniformly brown coloured small species with forewing length of $7 \mathrm{~mm}$.

Male genitalia. Abdominal segment IX fused annular, short; anterior margin arciform, resulted in a very short dorsum and much longer ventrum; the ventrum lacks spiny ventrocaudal mesal lobe; apical margin straight vertical, its dorsal region marked with a row of spines and ventrad terminated in a rounded triangular lobe above the gonopods; intersegmental depression between the ninth and tenth segments present, shallow and partially occupied by a pair of setose humps. Body of segment $\mathrm{X}$ as long as high, subtriangular; slightly elevated lateral setose area (cerci) in middle position; apicoventral setose lobe discernible as incompletely fused to the apicoventrum of the segment and armed with a pair of robust upward directed triangular spiny pointed lobes. The basal segment of the gonopods straight with dilating apical half; harpago, the terminal segment slender gradually digitate in ventral view. Phallic apparatus with arching dorsum; the pair of endothecal sclerites ovoid, longer than high.
Etymology. quangchua, named after the locus typicus of the holotype.

\section{Cheumatopsyche tamda sp. nov.}

(Figures 364-367, Map 23)

Material examined. Holotype: Vietnam, Tamdao, 200m, 21 $28^{\prime} 16.1^{\prime \prime} \mathrm{N} 105^{\circ} 33^{\prime} 55.6 " \mathrm{E}, 12 . \mathrm{X}$. 1986, light leg. S. Mahunka \& J. Oláh (1 male, OPC).

Diagnosis. This new species having monolobed segment $\mathrm{X}$ with spiny upward turning apices of the ventroapical pair of setose lobes belongs to the Cheumatopsyche chinensis species group (Oláh et al. 2008a). According to the structure of segment $\mathrm{X}$ and the phallic organ this small, delicate brown species differs from all the known members of the species group by the slender upward directed spiny formation of ventroapical setose lobes as well as by the very slender and regularly arching phallotheca.

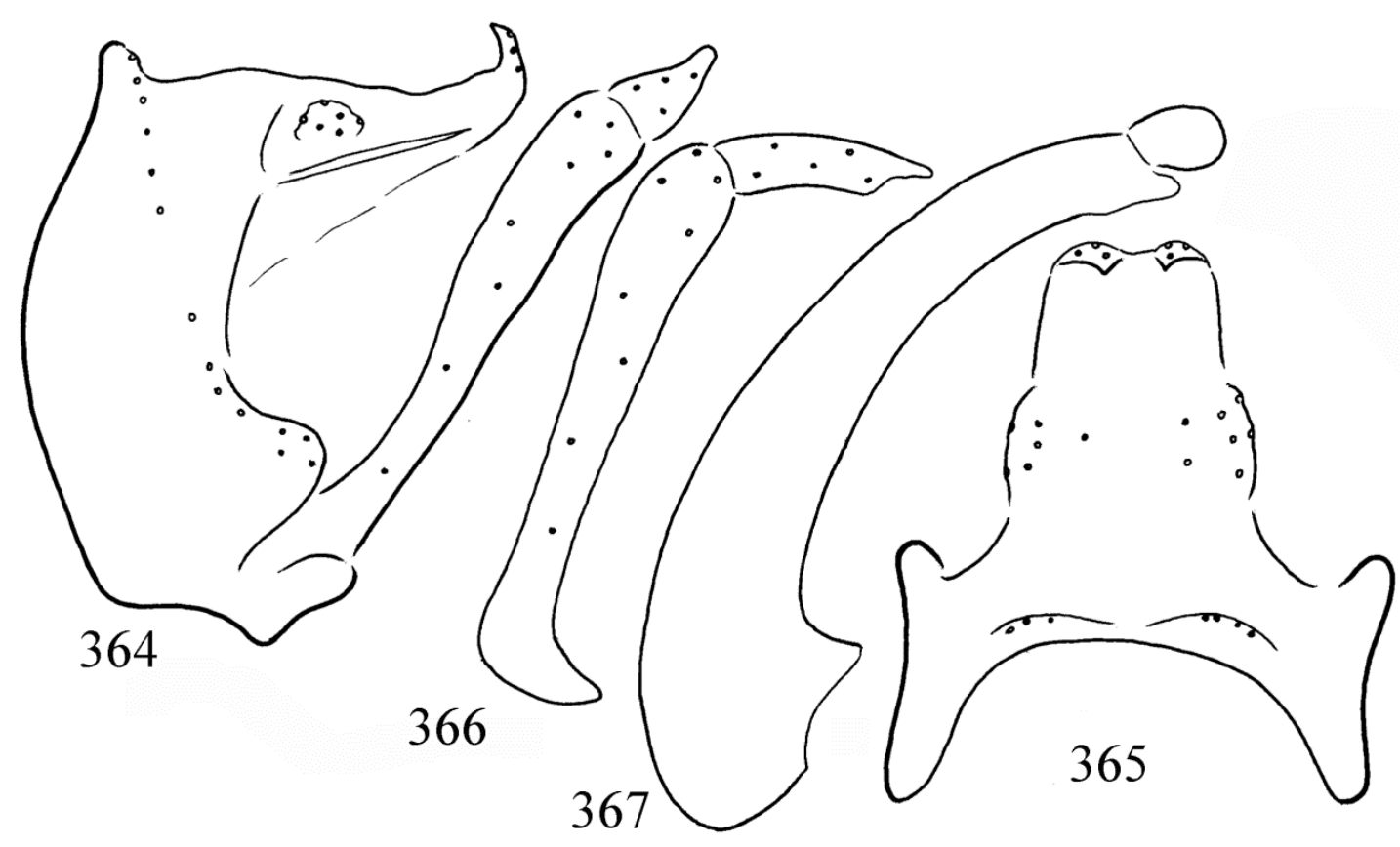

Figures 364-367. Cheumatopsyche tamda sp. nov. Holotype: $364=$ male genitalia in left lateral view, $365=$ male genitalia in dorsal view, $366=$ left gonopod in ventral view, 367 = phallic organ in left lateral view. 
Description. A uniformly brown coloured small species with forewing length of $7 \mathrm{~mm}$. Male genitalia. Abdominal segment IX fused annular, short; anterior margin arciform, resulted in a very short dorsum and much longer ventrum; the ventrum is without spiny ventrocaudal mesal lobe; apical margin is straight vertical, its dorsal region is marked with a row of spines and ventrad terminated in a rounded triangular lobe above the gonopods; intersegmental depression between the ninth and tenth segments present, deep and partially occupied by a pair of setose humps. Body of segment $\mathrm{X}$ as long as high, subtriangular; slightly elevated lateral setose area (cerci) in middle position; apicoventral setose lobe discernible as incompletely fused to the apicoventrum of the segment and armed with a pair of very slender upward directed spiny pointed lobes. The basal segment of the gonopods straight with dilating apical half; harpago, the terminal segment slender digitate with obtuse angle in ventral view. Phallic apparatus with slender arching dorsum; the pair of endothecal sclerites ovoid, just longer than high.

Etymology. tamda, named after the locus typicus of the holotype.

\section{Cheumatopsyche tongoma sp. nov.}

(Figures 368-371, Map 23)

Material examined. Holotype: Laos PDR, Luang Namtha Prov., Tong Om Village, 552mao, 47Q 0750111, UTM 2321825, 1.V.2005, light trap, loc 30 leg. N. Jönssson, T. Malm \& B. Viklund (1 male, SMNH).

Diagnosis. This new species having monolobed segment $\mathrm{X}$ with spiny upward turning apices of the ventroapical pair of setose lobes belongs to the Cheumatopsyche chinensis species group (Oláh et al. 2008a). According to the structure of segment $\mathrm{X}$ and the phallic organ this small, delicate brown species differs from all the known members of the species group by the robust plate-like spine formation of ventroapical setose lobes.

Description. A uniformly brown coloured small species with forewing length of $7 \mathrm{~mm}$. Male genitalia. Abdominal segment IX fused annular, short; anterior margin arciform, resulted in a very short dorsum and much longer ventrum; the ventrum is without spiny ventrocaudal mesal lobe;

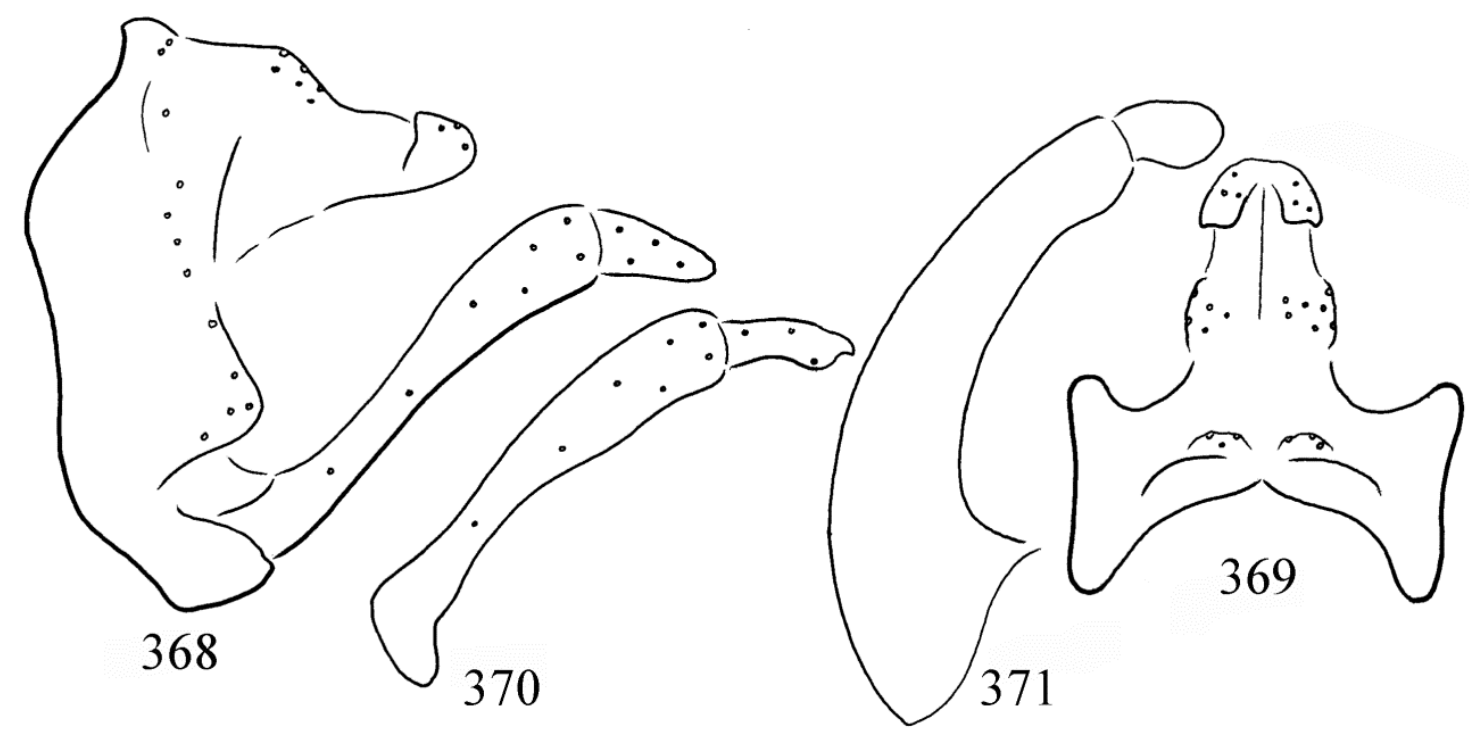

Figures 368-371. Cheumatopsyche tongoma sp. nov. Holotype: $368=$ male genitalia in left lateral view, $369=$ male genitalia in dorsal view, $370=$ left gonopod in ventral view, $371=$ phallic organ in left lateral view. 
apical margin is straight vertical, its dorsal region is marked with a row of spines and ventrad terminated in a rounded triangular lobe above the gonopods; intersegmental depression between the ninth and tenth segments present, shallow and partially occupied by a pair of setose humps. Body of segment $\mathrm{X}$ as long as high, subtriangular; slightly elevated lateral setose area (cerci) in middle position; apicoventral setose lobe discernible as incompletely fused to the apicoventrum of the segment and armed with a pair of plate-like upward directed pointed lobes. The basal segment of the gonopods straight with dilating apical half; harpago, the terminal segment with a tip of small hook in ventral view. Phallic apparatus with arching dorsum; the pair of endothecal sclerites ovoid, just longer than high.

Etymology. tongoma, named after the locus typicus of the holotype.

\section{Cheumatopsyche holzschuhi species group}

This species group includes species with elongated appendages or processes on segments IX or $\mathrm{X}$ of various origin. Usually, tergum IX or only the lateroapical corner of tergum IX and the dorsoapical and ventroapical setose lobes on segment $\mathrm{X}$ are elongated (Oláh et al. 2008a). It requires a detailed study to homologize these dorsal elongated lobes or processes. These elongated lobes are possibly plesiomorphic with dubious homology, and the elongation of the lateroapical corner of tergum IX is possibly an apomorphic state. This is a rather heterogeneous, possibly polyphyletic group of chimeric species. Most species have short and rather complex second segment of inferior appendages, and some species have unusual terminal structures on the phallotheca. The species group is distributed on the mainland and on islands of Southeast Asia, known from India, Thailand, Laos, Vietnam, Taiwan and the Philippines.

\section{Cheumatopsyche apuma new species complex}

This new species complex of the $C$. holzschuhi species group is the most apomorphic lineage of the Cheumatopsyche genus. The dorsum of segment IX and the entire segment $\mathrm{X}$ are completely restructured, due to drastic or even dramatic perturbation by stochastic internal or external effects and corrected in the protective processes of integrative organisation. The plesiomorphic, ancestral genital plan, with elongated cerci of the $C$. pali species group and the most complete processes on the apical region of segment $\mathrm{X}$ in the $C$. lepida species group (Oláh et al. 2008a) is so much modified that we have to turn to the structure of wing venation in order to reconstruct the geretic status of these caddisflies. The distance between crossveins $m-c u$ to $c u$ on forewing is close, a character state of the Cheumatopsyche and Potamyia genera in the Hydropsychinae subfamily. However, the stem of $M$ and $C u_{1}$ in hind wing is well separated, neither parallel nor close together and the crossvein $\mathrm{m}$-cu present and well visible, a character state of the Cheumatopsyche genus. In the Potamyia genus the stem of $M$ and $C u_{1}$ in hind wing is parallel and close together therefore, the crossvein $m-c u$ absent or obscure.

Cheumatopsyche apuma species complex is characterized by the posterad elongated, fused or subdivided tergite IX, the highly reduced almost vestigial unsetose mesocaudal lobe, by the hardly discernible setose surface of cerci, by the apicoventral setose lobes uniquely detached from the body of segment $\mathrm{X}$ as well as by the abbreviated coxopodite and harpago of gonopods. The following species belongs to this species complex: Cheumatopsyche admetos Malicky \& Chantaramongkol (Thailand), C. apuma sp. nov. (India, Manipur); C. automedon Malicky \& Chantaramongkol (Thailand), C. edom Malicky \& Chantaramongkol (Laos), C. meyi Malicky (Vietnam), C. nyukma sp. nov. (India, Arunachal Pradesh), C. saiyok Malicky \& Chantaramongkol (Thailand).

\section{Cheumatopsyche apuma sp. nov.}

(Figures 372-375, Map 6: $\mathrm{n}^{\circ}$ 18, Map 24)

Material examined. Holotype: India, Manipur,

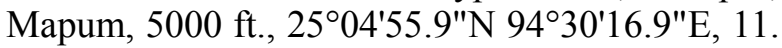
VI.1960, leg. F. Schmid (1 male, OPC). Paratype: same as holotype (1 male, OPC). 


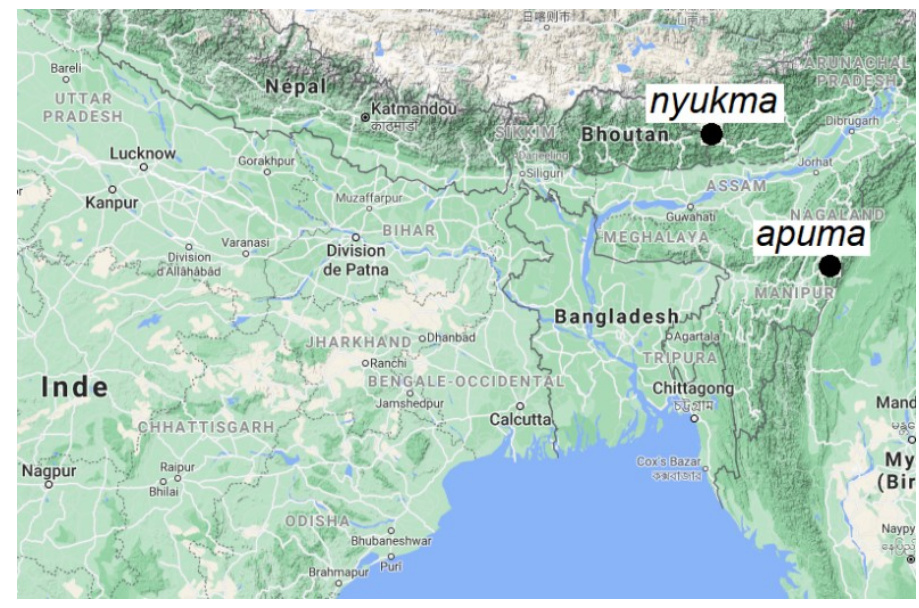

Map 24. Cheumatopsyche holzschuhi group.

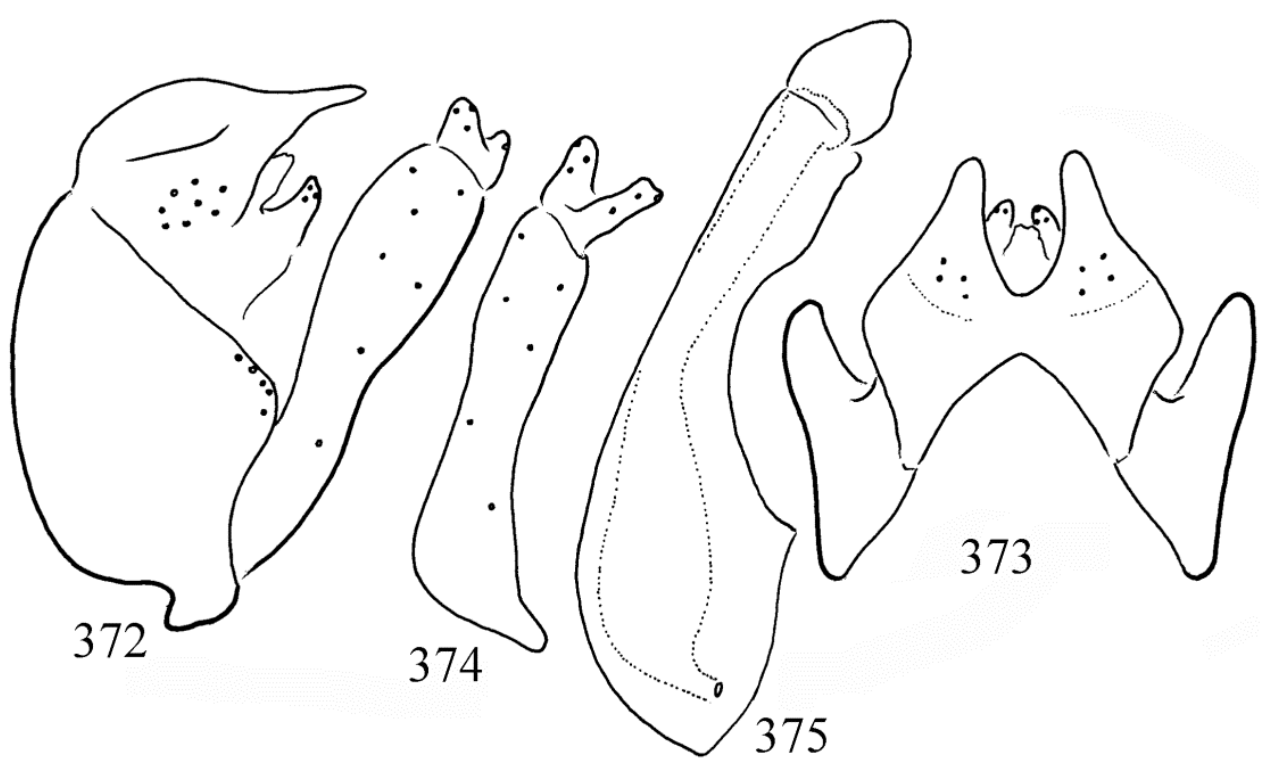

Figures 372-375. Cheumatopsyche apuma sp. nov. Holotype: $372=$ male genitalia in left lateral view, $373=$ male genitalia in dorsal view, $374=$ left gonopod in ventral view, 375 = phallic organ in left lateral view.

Diagnosis. This new species having highly restructured genital components belongs to the Cheumatopsyche holzschuhi species group (Oláh et al. 2008a). According to the structure of segment $\mathrm{X}$, the gonopod, especially the harpago and the phallic organ this small, delicate brown species gives the nominate species of the $C$. apuma species complex. Most close to C. edom Malicky, described from Laos, but differs by trapezoid shape of segment IX in dorsal view; the different shapes of the bilobed harpago as well as by the more robust phallic organ and the endothecal sclerites with narrowing apical region in lateral view.

Description. A uniformly brown coloured small species with forewing length of $7 \mathrm{~mm}$.

Male genitalia. Abdominal segment IX fused annular, medium long; anterior margin arciform, its tergite elongated posterad; the ventrum is without spiny ventrocaudal mesal lobe; apical margin is produced into a flat triangular lobe 
above the gonopods, marked with a row of strong spines. Body of segment X subdivided; elongated lateral setose area (cerci) in middle position; apicoventral setose lobe digitate and detached from the body of segment X. The basal segment of the gonopods the coxopodite is very short, stout; harpago, the terminal segment abbreviated with bilobed terminal pattern. Phallic apparatus with constricted middle and broadening apicoventrum; the pair of endothecal sclerites elongated, ovoid with narrowing apex.

Etymology. apuma, coined from the name of the locus typicus of holotype.

\section{Cheumatopsyche nyukma sp. nov.}

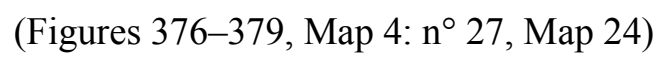

Material examined. Holotype: India, Arunachal Pradesh (Assam), Kameng, Nyukmadong, 6600-8000 ft., $27^{\circ} 24^{\prime} 32.5^{\prime \prime} \mathrm{N}$ 9207'57.3"E, 1. VIII.1961, leg. F. Schmid, (1 male, OPC).

Diagnosis. This new species having highly restructured genital components belongs to the Cheumatopsyche holzschuhi species group (Oláh et al. 2008a). According to the structure of segment $\mathrm{X}$, the gonopod, especially the harpago and the phallic organ this small, delicate brown species is a member of the C. apuma species complex. Most close to C. saiyok Malicky and Chantaramongkol, described from Thailand, but differs by posterad elongated tergite $\mathrm{X}$ without mesal excision, by the more elongated and detached apicoventral setose lobes, by the fine structure of harpago as well as by the lateral profile of the phallic organ.

Description. A uniformly brown coloured small species with forewing length of $7 \mathrm{~mm}$.

Male genitalia. Abdominal segment IX fused annular, medium long; anterior margin arciform, its tergite elongated posterad; the ventrum is without spiny ventrocaudal mesal lobe; apical margin is produced into a flat rounded lobe above the gonopods, marked with a row of strong spines. Body of segment $X$ subdivided; elongated lateral setose area (cerci) in middle position; apicoventral setose lobe digitate and detached from the body of segment X. The basal segment of the gonopods the coxopodite is very short, stout; harpago, the terminal segment abbreviated with small digitiform ventromesal process. Phallic apparatus with constricted middle and broadening apicodorsum and more apicoventrum; the pair of endothecal sclerites elongated, ovoid.

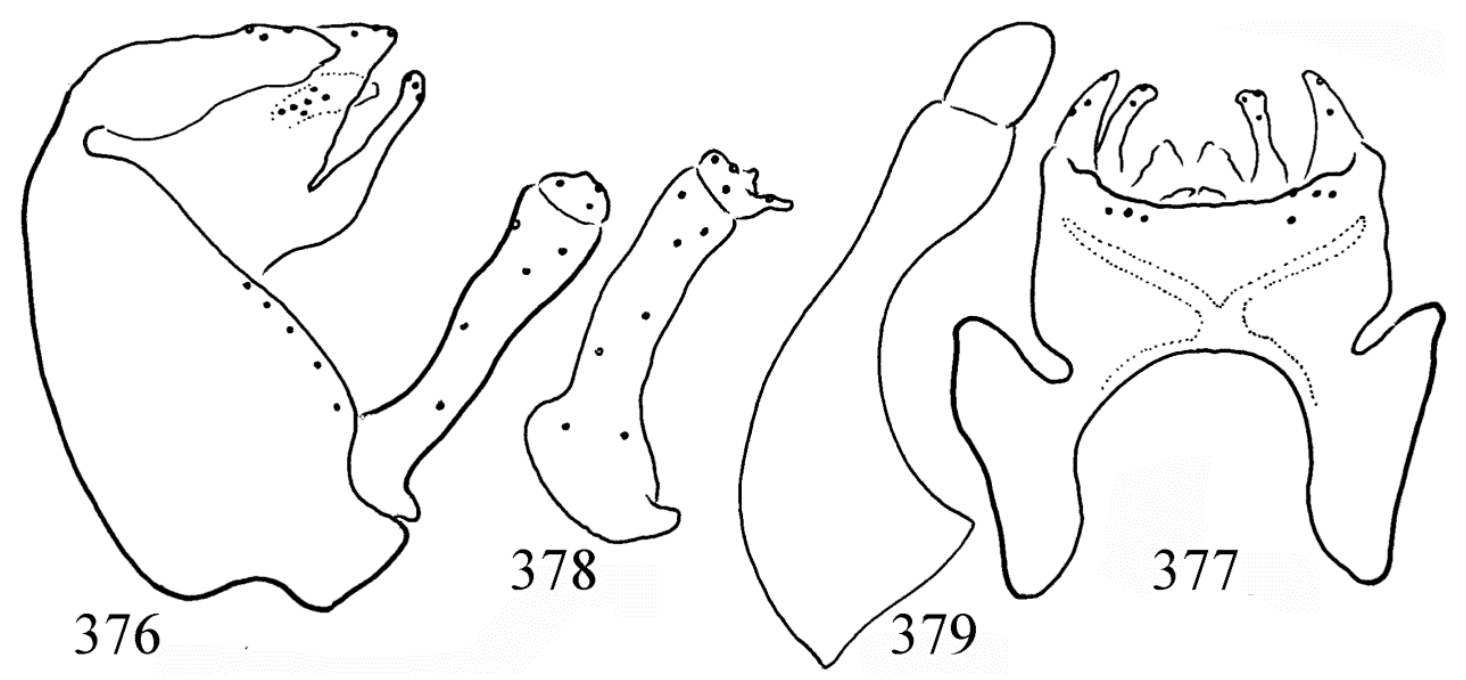

Figures 376-379. Cheumatopsyche nyukma sp. nov. Holotype: $376=$ male genitalia in left lateral view, $377=$ male genitalia in dorsal view, $378=$ left gonopod in ventral view, $379=$ phallic organ in left lateral view. 
Etymology. nyukma, coined from the name of the locus typicus of holotype.

\section{Potamyia Banks, 1900}

\section{Potamyia czekanovskii species group}

Tenth tergum developed with very characteristic upwardly directed pronounced hook formation: hook at least twice as long as wide, base narrow, situated at ventroapical corner (Oláh et al. 2006).

\section{Potamyia flavata new species complex}

This new species complex is characterized by the medium long upward directed hook formation. The tip of the ventroapically erected hooks reaches about half to the top of segment $\mathrm{X}$.

\section{Potamyia binhoa sp. nov.}

(Figures 380-381, Map 25)

Material examined. Holotype: Vietnam, Hoabinh [=Hòa Bình], 30.I.1986, light leg. J. Oláh (1 male, OPC).

Diagnosis. Potamyia binhoa sp. nov. with upward directed and very pronounced hook formation on segment $\mathrm{X}$ belongs to Potamyia czekanovskii species group (Oláh et al. 2006) and to the Potamyia flavata species complex. Having abbreviated hook formation most close to $P$. klakahana (Ulmer, 1951) described from East Java, but differs by having regularly curving hook reaching over, not below the half of the top of segment $\mathrm{X}$, as well as not angled; cerci lower.

Description. Body and wings light yellowish brown with brown pubescence. Forewing without any maculation. Antennae less than twice length of forewing. Abdominal segment $\mathrm{V}$ with very short pointed lobe only. Spur formula 144. Forewing $7 \mathrm{~mm}$. In forewing crossveins $m-\mathrm{cu}$ and $\mathrm{cu}$ close; $\mathrm{Cu} 2$ and $A$ joining well before wing margin; In hindwing stem of $M$ plus proximal part of $M 3+4$ almost touching and running parallel with $\mathrm{CuI}$; fork 1 present.
Male genitalia. Abdominal segment IX fused annular and short, tergum shorter than sternum; anterior margin of segment IX convex; apical lobe on posterolateral margin small above the narrow articulation cavity of the gonopod; spine row on the posterior margin of segment IX almost complete. Intersegmental step between segment IX and segment $\mathrm{X}$ low and oblique. The body of segment $\mathrm{X}$ as high as long; ventroapical hook formation reaching just above half of the top of segment $X$. The first segment of the gonopod with broadening apical and thiner ventral half angled and Sforming; harpago truncated. Phallotheca with moerately enlarged phallobase, the straight horizontal shaft with regular straight dorsum, with slightly upward directed apicodorsum; ventral broadening long; endophallus looks a narrow tube at the gonopore near to the bottom of the phallobase; the chitinized endothecal process circular, phallotremal sclerites broad vertical in lateral view.

Etymology. binhoa, named after the locus typicus of holotype.

\section{Potamyia chitwana sp. nov.}

(Figures 382-383, Map 25)

Material examined. Holotype: Nepal, Chit-

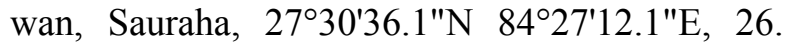
XII.1981-9.I.1982, subtropical deciduous forest (mainly Slorea robusta), swept from low vegetation, leg. L. Jessop (1 male, OPC). Paratypes: same as holotype ( 2 males, OPC).

Diagnosis. Potamyia chitwana sp. nov. with upward directed and very pronounced hook formation on segment $\mathrm{X}$ belongs to Potamyia czekanovskii species group (Oláh et al. 2006) and to the Potamyia flavata species complex. Having long hook formation most close to P. flavata (Banks, 1934) described from Malaysia, but differs by having hook formation less curving and forming a V-shaped, not a U-shaped bottom between cerci and hooks.

Description. Body and wings light yellowish brown with brown pubescence. Forewing without 


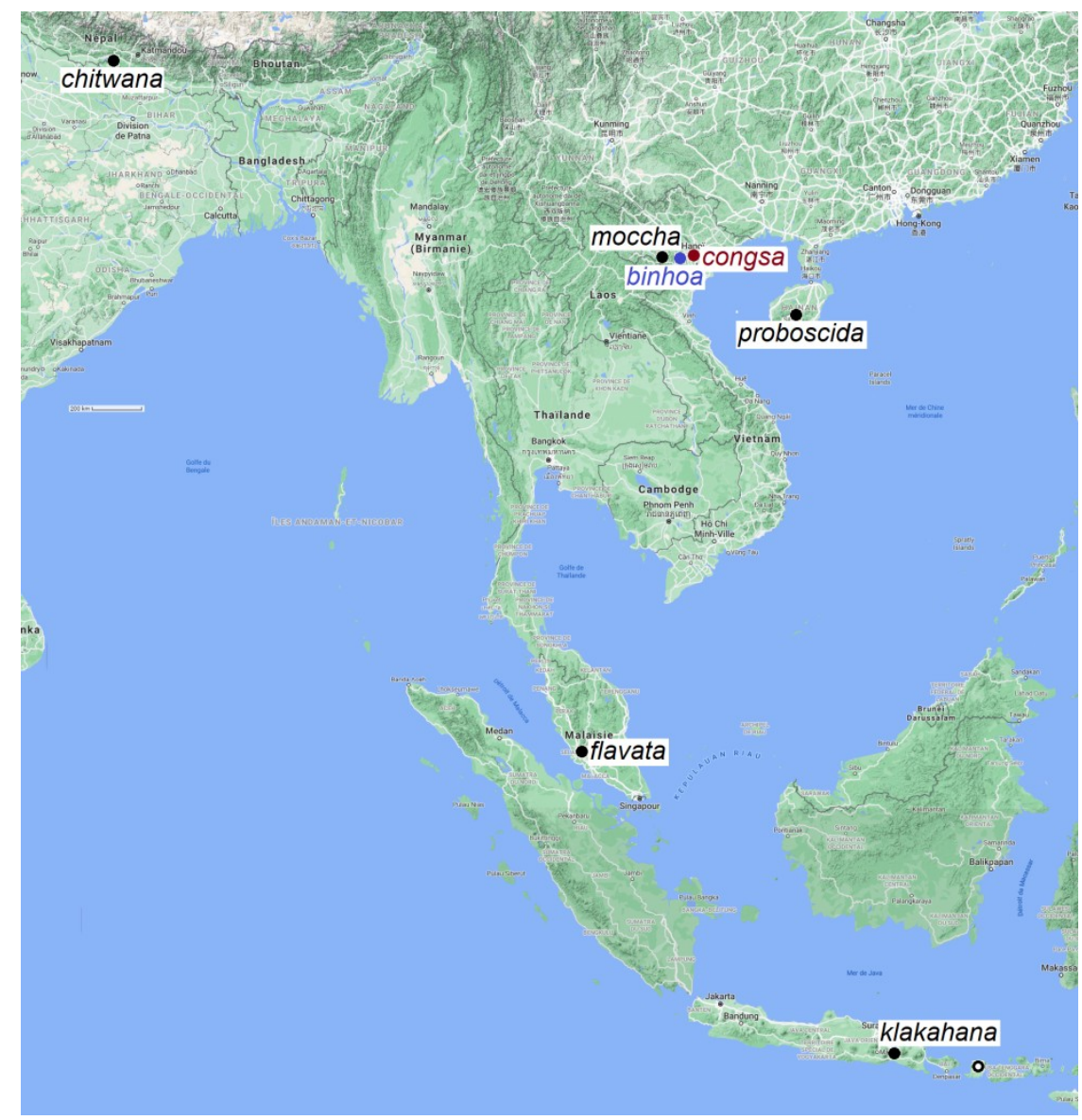

Map 25. Potamyia flavata species complex.

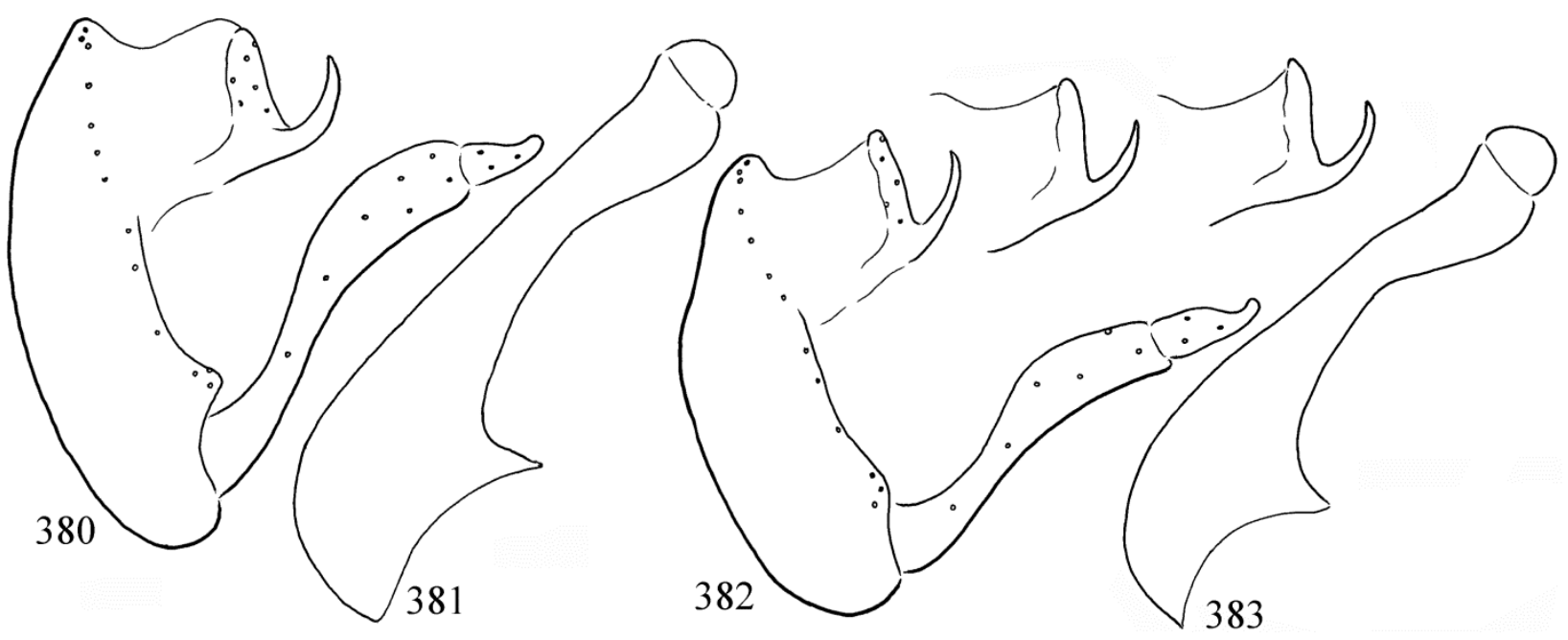

Figures 380-383. Potamyia binhoa sp. nov. Holotype: $380=$ male genitalia in left lateral view, $381=$ phallic organ in left lateral view. Potamyia chitwana sp. nov. Holotype: $382=$ male genitalia in left lateral view with the spine formation of the paratypes in lateral view, $383=$ phallic organ in left lateral view. 
any maculation. Antennae less than twice length of forewing. Abdominal segment $\mathrm{V}$ with very short pointed lobe only. Spur formula 144. Forewing $7 \mathrm{~mm}$. In forewing crossveins $m-\mathrm{cu}$ and $\mathrm{cu}$ close; $\mathrm{Cu} 2$ and $A$ joining well before wing margin; In hindwing stem of $M$ plus proximal part of $M 3+4$ almost touching and running parallel with $\mathrm{CuI}$; fork 1 present.

Male genitalia. Abdominal segment IX fused annular and short, tergum shorter than sternum; anterior margin of segment IX convex; apical lobe on posterolateral margin small above the narrow articulation cavity of the gonopod; spine row on the posterior margin of segment IX almost complete. Intersegmental step between segment IX and segment $X$ low and oblique. The body of segment $\mathrm{X}$ as high as long; ventroapical hook formation reaching just above half of the top of segment $\mathrm{X}$, enclosing a V-shaped bottom between cerci and hooks. The first segment of the gonopod with broadening apical and thiner ventral half angled and S-forming; harpago truncated. Phallotheca with moderately enlarged phallobase, the straight horizontal shaft with regular straight dorsum, with upward directed apicodorsum; ventral broadening long; endophallus looks a narrow tube at the gonopore near to the bottom of the phallobase; the chitinized endothecal process circular, phallotremal sclerites broad vertical in lateral view.

Etymology. chitwana, named after the locus typicus of holotype.

\section{Potamyia congsa sp. nov.}

(Figures 384-385, Map 25)

Material examined. Holotype: Vietnam, Hanoi, Red River, 28.X.1986, singled from below embankment stones on the shoreline, leg. J. Oláh (1 male, BMNH).

Diagnosis. Potamyia congsa sp. nov. with upward directed and very pronounced hook formation on segment $\mathrm{X}$ belongs to Potamyia czekanovskii species group (Oláh et al. 2006) and to the Potamyia flavata species complex. Having long hook formation most close to P. flavata (Banks, 1934) described from Malaysia, but differs by having hook formation more curving, even longer and slender and forming a deeper U-shaped bottom between cerci and hooks. The middle region of the phallotheca more constricted and its apicodorsum less curving upward.

Description. Body and wings light yellowish brown with brown pubescence. Forewing without any maculation. Antennae less than twice length of forewing. Abdominal segment $\mathrm{V}$ with very short pointed lobe only. Spur formula 144 . Forewing $7 \mathrm{~mm}$. In forewing crossveins $\mathrm{m}-\mathrm{cu}$ and $\mathrm{cu}$ close; $\mathrm{Cu} 2$ and $A$ joining well before wing margin; In hindwing stem of $M$ plus proximal part of $M 3+4$ almost touching and running parallel with $C u I$; fork 1 present.

Male genitalia. Abdominal segment IX fused annular and short, tergum shorter than sternum; anterior margin of segment IX convex; apical lobe on posterolateral margin small above the narrow articulation cavity of the gonopod; spines row on the posterior margin of segment IX almost complete. Intersegmental step between segment IX and segment $\mathrm{X}$ low and oblique. The body of segment X longer than high; ventroapical hook formation reaching well above half of the top of segment X, enclosing a U-shaped bottom between cerci and hooks. The first segment of the gonopod with broadening apical and thiner ventral half angled and S-forming; harpago truncated. Phallotheca with moderately enlarged phallobase, the straight horizontal shaft with waving dorsum, with slightly upward directed apicodorsum; ventral broadening pronounced and long; endophallus looks a narrow tube at the gonopore near to the bottom of the phallobase; the chitinized endothecal process circular, phallotremal sclerites broad vertical in lateral view.

Etymology. congsa, named after the locus typicus of holotype Red River Cong Sa in Vietnamese.

\section{Potamyia flavata (Banks, 1934)}

(Figures 386-387, Map 25)

Hydropsyche flavata Banks, 1934: 569. "Kuala Lumpur, 21 April, 2 April, 15 June." "The union of the anals before margin is unusual in this genus, but otherwise it is a normal Hydropsyche." 


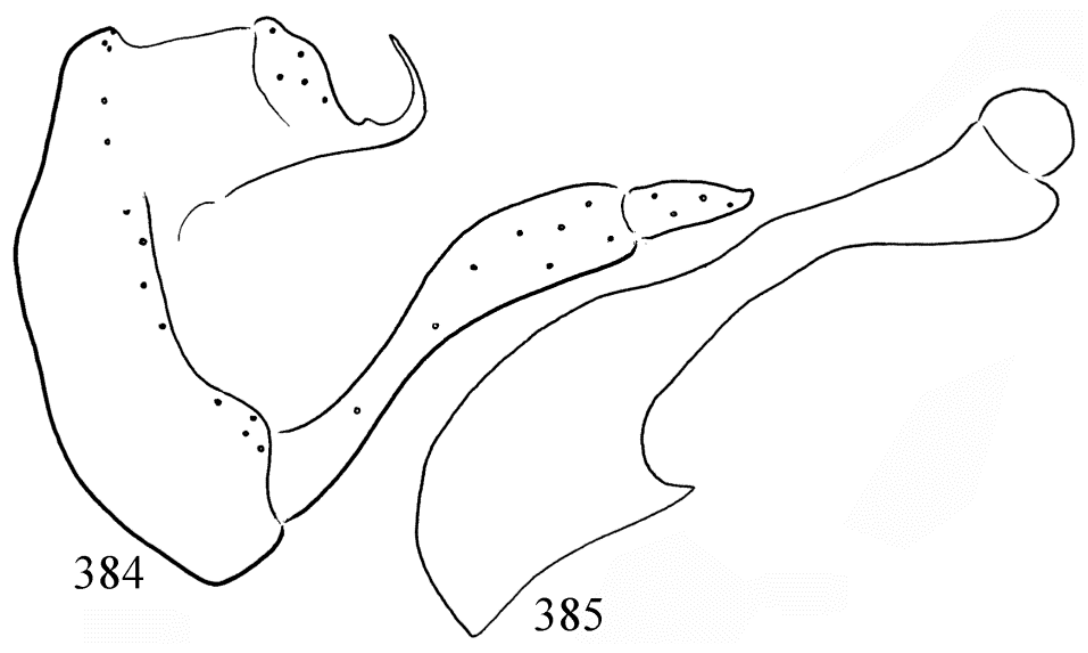

Figures 384-385. Potamyia congsa sp. nov. Holotype: 384 = male genitalia in left lateral view, $385=$ phallic organ in left lateral view.

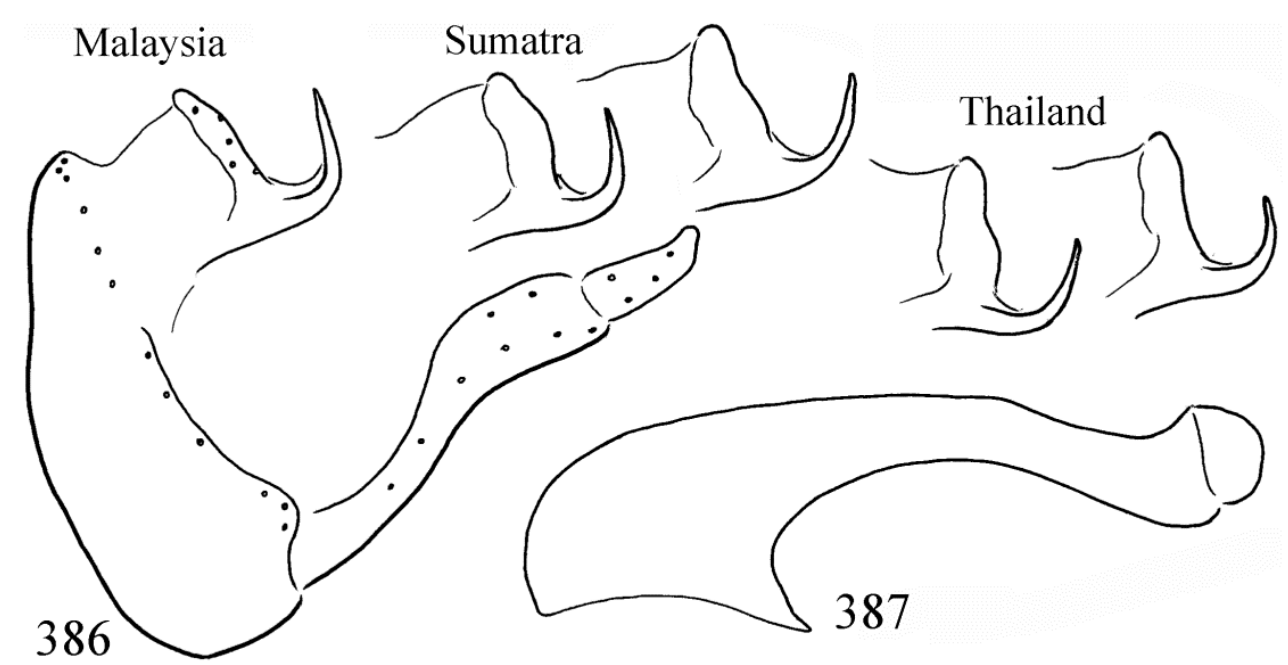

Figures 386-387. Potamyia flavata sp. nov. Holotype: 386 = male genitalia in left lateral view, with spine formation of specimens from Malaysia, Sumatra and Thailand, 387 = phallic organ in left lateral view.

Material examined. Malaysia, Kuala Lumpur, 27.X.1938, at light, leg. N. C. E. Miller (1 male, BMNH). Cheumatopsyche kraepelini Ulmer? det. by M. E. Mosely. Synaptopsyche klakahana U1mer, det. by D. E. Kimmins, 1961. Sumatra, North Sumatra, Dolok Merangir, 23.VII.1972, leg Malicky (6 males, OPC). Thailand, Phu Phan National Park, 18.IV.1996 leg. H. Malicky (1 male, 3 fermales; OPC). Thailand, Bamgsaen, 4.IV.1989, leg H. Malicky (12 males, OPC). Thailand, Chiangmai, 25.IV.1988, Leg. H. Malicky (2 males, OPC).
Potamyia klakahana (Ulmer, 1951), stat. rest.

(Figures 388-389, Map 25)

Synaptopsyhe klakahana Ulmer, 1951:254-255. "Material: $1 \hat{\delta}$, in spiritus, Klakah, Ost-Java, X. 1928, an der lampe, Thienemann leg., in meiner Samlung; dies die Type." "Am nächsten verwandt mit czeskanovskanovskii Martynov aus Sibirien."

Potamyia flavata (Banks, 1934): Malicky 1997:1035. "Mir liegen viele Exemplare von Bali, Sumatra und Thailand vor, und ich konnte den HT von KLakah (Java) aus dem Hamburger Museum untersuchen. 
Herr Dr. W. Mey sandte mir eine Zeichnung von HT der P. flavata aus Malaysia. Es besteht daher kein Zweifel an der Synonymie."

Material examined. Holotype: Indonesia, East Java, Klakah, X.1928, light leg. A. Thienemann (1 male, ZMB). Indonesia, Lombok, Narmada, leg. Rensch (1 male, ZMB).

\section{Potamyia moccha sp. nov.}

(Figures 390-391, Map 25)

Material examined. Holotype: Vietnam, Moc Chau, 26.X.1986, light leg. J. Oláh (1 male, $\mathrm{OPC})$.

Diagnosis. Potamyia moccha sp. nov. with upward directed and very pronounced hook formation on segment $\mathrm{X}$ belongs to Potamyia czekanovskii species group (Oláh et al. 2006) and to the Potamyia flavata species complex. Most close to $P$. binhoa sp. nov. described from Vietnam, but differs by having hook formation with very broad basement as well as the apical region of the phallotheca more upward directed.

Description. Body and wings light yellowish brown with brown pubescence. Forewing without any maculation. Antennae less than twice length of forewing. Abdominal segment $\mathrm{V}$ with very short pointed lobe only. Spur formula 144. Forewing $7 \mathrm{~mm}$. In forewing crossveins $\mathrm{m}$-cu and cu close; $\mathrm{Cu} 2$ and A joining well before wing margin; In hindwing stem of M plus proximal part of $\mathrm{M} 3+4$ almost touching and running parallel with CuI; fork 1 present.

Male genitalia. Abdominal segment IX fused annular and short, tergum shorter than sternum; anterior margin of segment IX convex; apical lobe on posterolateral margin small above the narrow articulation cavity of the gonopod; spines row on the posterior margin of segment IX almost complete. Intersegmental step between segment IX and segment X low and oblique. The body of segment $\mathrm{X}$ longer than high; ventroapical hook formation with very broad basement, reaching above half of the top of segment $X$. The first segment of the gonopod with broadening apical and thiner ventral half angled and S-forming; harpago truncated. Phallotheca with moderately enlarged phallobase, the straight horizontal shaft with slightly convex dorsum, with pronounced upward directed apicodorsum; ventral broadening long; endophallus looks a narrow tube at the gonopore near to the bottom of the phallobase; the chitinized endothecal process circular, phallotremal sclerites broad vertical in lateral view.

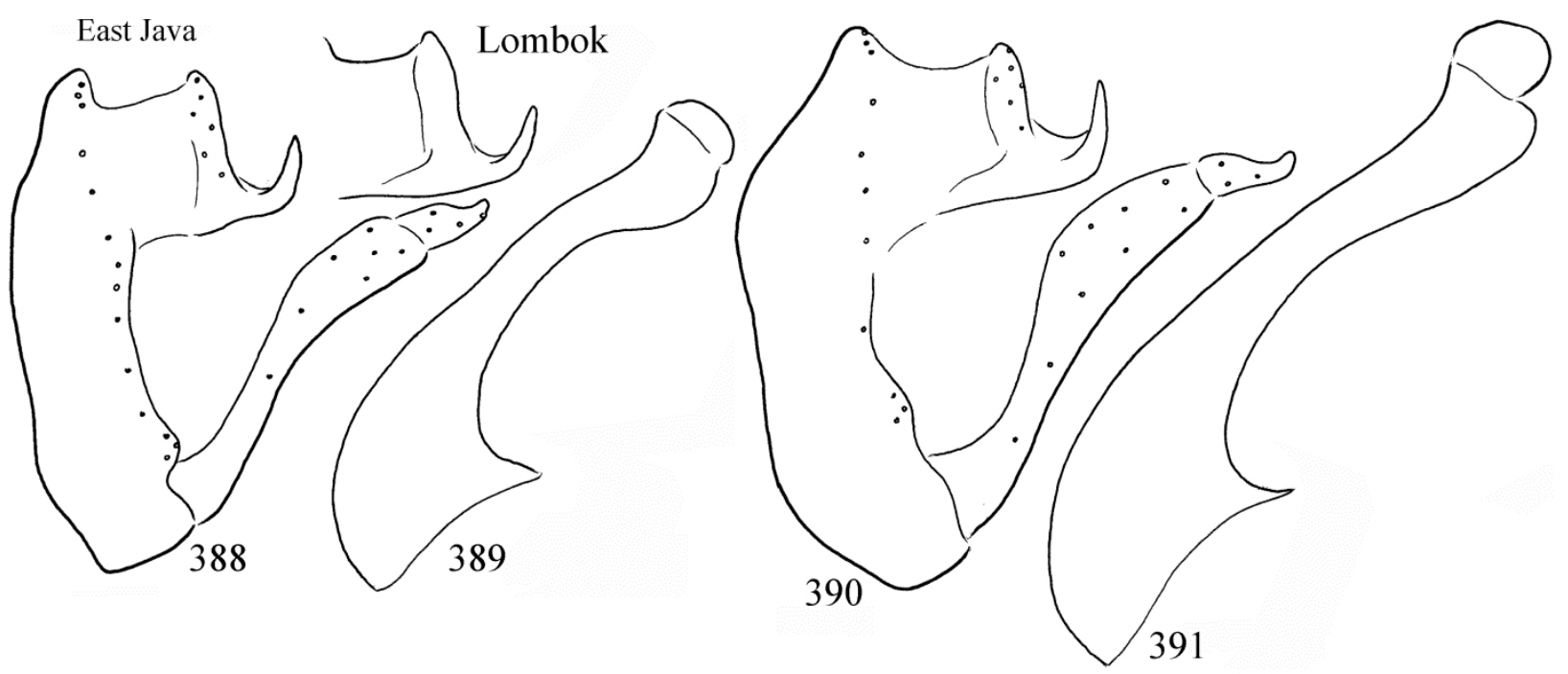

Figures 388-391. Potamyia klakahana (Ulmer, 1951). 388 = male genitalia in left lateral view, with spine formation of specimens from the type locality of East Java as well as from Lombok, $389=$ phallic organ in left lateral view. Potamyia moccha sp. nov. Holotype: $390=$ male genitalia in left lateral view, $391=$ phallic organ in left lateral view. 
Etymology. moccha, named after the locus typicus of holotype.

Potamyia proboscida Li \& Tian, 1996, stat. rest.

(Figures 392-393, Map 25)

Potamyia proboscida, Li et Tian, 1996 in Tian et al. 1996: 136-137 (Chinese), 185 (English): "Holotype ふै, Ba-wang-ling, Hainan, V-23, 1983, Ke Ming-hui. Allotype $\bigcirc$; paratypes $3 \hat{\jmath}$, Ba-wangling, Hainan, V-23, 1983, Ke Ming-hui."

Potamyia flavata (Banks, 1934): Oláh et al. 2006: 755. $P$. proboscida described from China Hainan Island is synonymised with $P$. flavata based on the statement of the third author that Potamyia flavata "is a somewhat variable species with wide distribution." tion.

Material. Drawings from the original descrip-

Remarks. The lateral profile of the speciation traits, both the segment $X$ and the phallic organ are excellently detailed permitting to delineate this incipient sibling species isolated in allopatric condition of the Hainan Island. Stat. Rest.

\section{Potamyia nikalandugola new species complex}

This new species complex is characterized by the very long upward directed hook formation. The tip of the ventroapically erected hook almost reaches or even surpasses the top of segment $\mathrm{X}$.

\section{Potamyia hasalaka sp. nov.}

(Figures 394-396, Map 26)

Material examined. Holotype: Sri Lanka, Hasalaka, $300 \mathrm{ft} ., 7^{\circ} 21^{\prime} 08.9^{\prime \prime} \mathrm{N} 80^{\circ} 56^{\prime} 50.2^{\prime \prime} \mathrm{E}, 23 . \mathrm{XI}$. 1970, leg. O.S. Flint, det. as Potymyia nikalandugola by O. S. Flint (1 male, BMNH).

Diagnosis. Potamyia hasalaka sp. nov. with upward directed and very pronounced hook formation on segment $\mathrm{X}$ belongs to Potamyia czekanovskii species group (Oláh et al. 2006) and to the Potamyia nikalandugola species complex. Close to P. nikalandugola (Schmid, 1958) described from Sri Lanka, but differs by having shorter and curving hook formation, unlike hook formation of $P$. nikalandugola reaching to the top of segment $\mathrm{X}$ and straight; the vertical region of hook formation broad middle narrowing apicad and basad, not evenly narrow. The ventral profile of harpago as well as the lateral profile of phallic organ also differs.

Description. Body and wings light yellowish brown with brown pubescence. Forewing without any maculation. Antennae less than twice length of forewing. Abdominal segment $\mathrm{V}$ with very short pointed lobe only. Spur formula 144. Forewing $8 \mathrm{~mm}$. In forewing crossveins $m-\mathrm{cu}$ and $\mathrm{cu}$ close; $\mathrm{Cu} 2$ and $A$ joining well before wing mar-

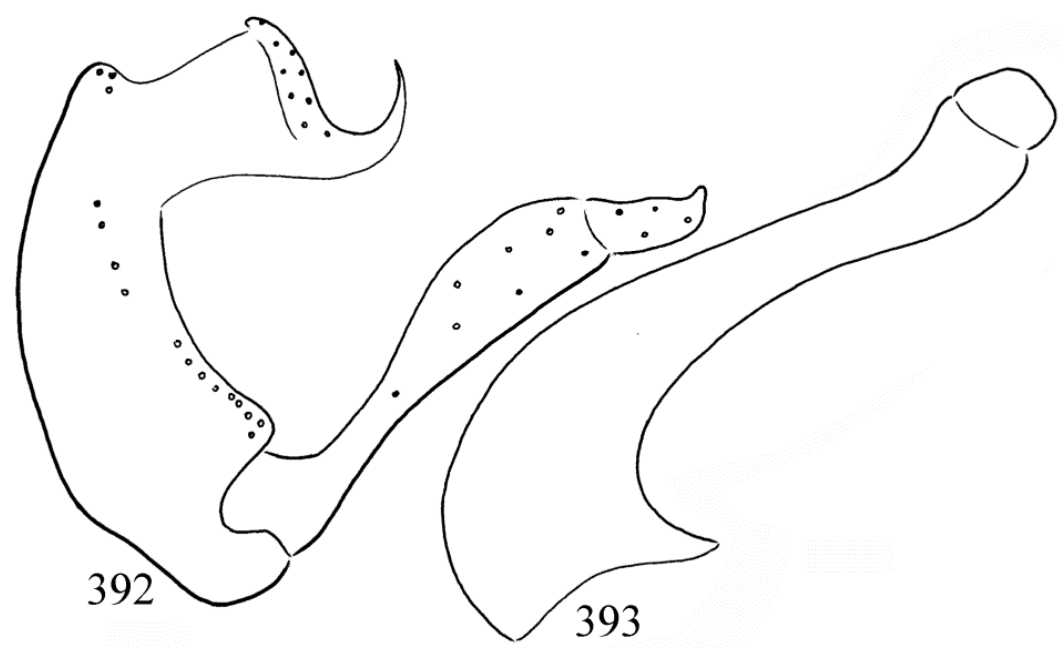

Figures 392-393. Potamyia proboscida Li \& Tian, 1996. 392 = male genitalia in left lateral view, $393=$ phallic organ in left lateral view. 


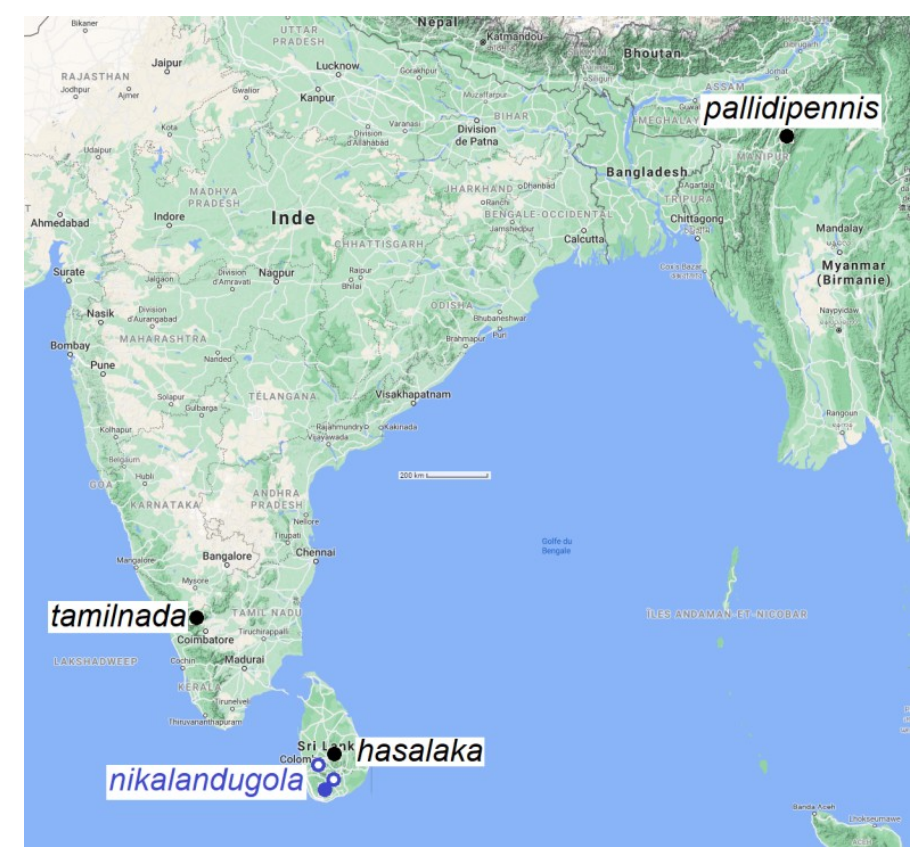

Map 26. Potamyia nikalandugola complex and chinensis group.

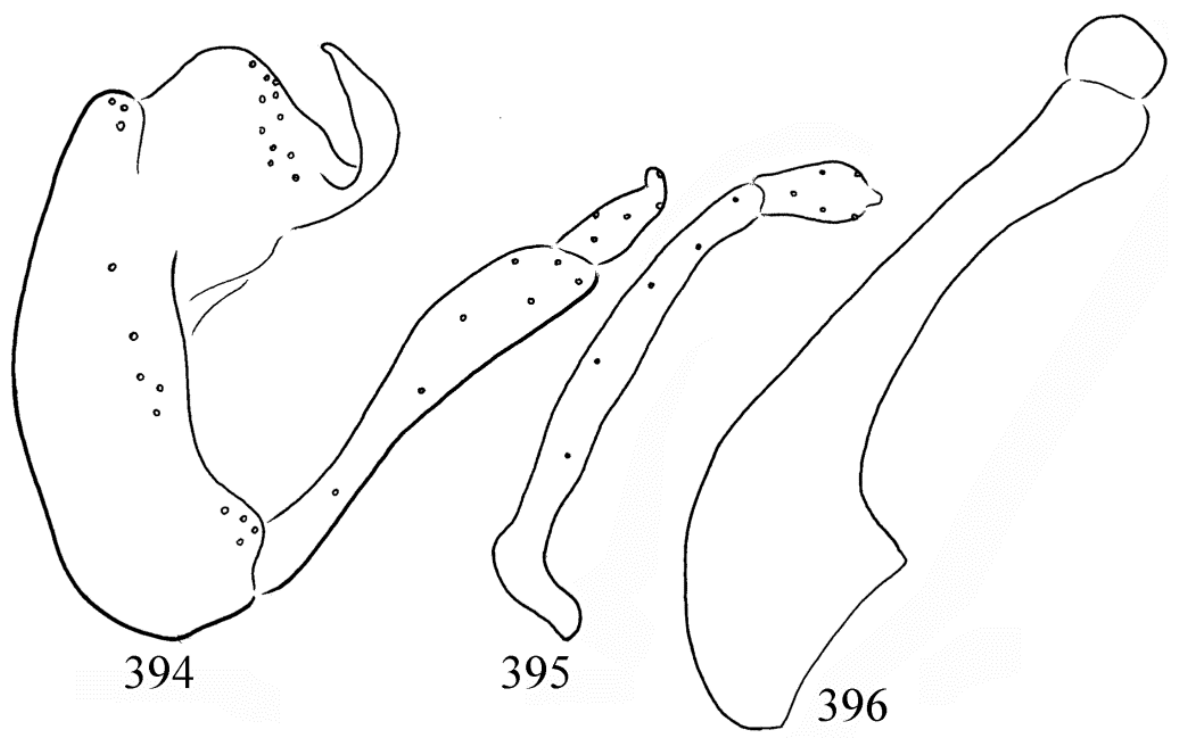

Figures 394-396. Potamyia hasalaka sp. nov. Holotype: 394 = male genitalia in left lateral view, $395=$ left gonopod in ventral view, $396=$ phallic organ in left lateral view.

gin. In hindwing stem of $M$ plus proximal part of $M 3+4$ almost touching and running parallel with $\mathrm{CuI}$; fork 1 present.

Male genitalia. Abdominal segment IX fused annular and short, tergum shorter than sternum; anterior margin of segment IX convex; apical lobe on posterolateral margin lacking above the narrow articulation cavity of the gonopod; spines row on the posterior margin of segment IX almost complete. Intersegmental step between segment IX and segment $\mathrm{X}$ low. The body of segment X higher than long; ventroapical hook formation 
long, reaching just below the top of segment X. The first segment of the gonopod with broadening apical and thiner ventral half; harpago broadening apicad in ventral view with mesad turning process. Phallotheca with moderately enlarged phallobase, the straight horizontal shaft with regular straight dorsum, the most striking feature is the short ventral subapical keel; endophallus looks a narrow tube at the gonopore near to the bottom of the phallobase; the chitinized endothecal process circular, phallotremal sclerites broad vertical in lateral view.

Etymology. hasalaka, named after the locus typicus of holotype.

\section{Potamyia nikalandugola (Schmid, 1958)}

(Map 26)

Synaptopsyche nikalandugola Schmid, 1958: 114-115. "Holotype $\delta^{\lambda}$ : Sri Lanka, Deniyaya, 6²0'33.8"N $80^{\circ} 33^{\prime} 36.5^{\prime \prime E}, 5-I I, 1 \delta^{\Uparrow}$; Beliul Oya [=Belihul Oya], $6^{\circ} 43^{\prime} 48.8^{\prime \prime} \mathrm{N} 80^{\circ} 49^{\prime 26.9 " E, 19-I I, ~} 1$ ふ઼; Kitulgala, $6^{\circ} 59^{\prime} 25.8^{\prime \prime N} \quad 80^{\circ} 25^{\prime} 12.2 " \mathrm{E}, \quad 4-\mathrm{IV}, 1$ 1. ." “Cette espèce très voisine de $S$. klakahana Ulm. de Java."

Potamyia nikalandugola (Schmid, 1958): Oláh et al. 2006:755. Transferred from Synaptopsyche to Potamyia, male redescribed in the Potamyia czekanovskii species group.

\section{Potamyia tamilnada sp. nov.}

(Figures 397-399, Map 26)

Potamyia nikalandugola (Schmid, 1958): Oláh \& Johanson, 2008b: 231-232. "India: Tamil Nadu, Nilgiri Hills, Doddabetta, $1000 \mathrm{~m}, 11^{\circ} 24^{\prime} 59.0^{\prime \prime} \mathrm{N} 76^{\circ}$ 43'52.5"E, 18.III.1980, on mossy tree, leg. Gy. Topan 2 males.” Misidentification.

Material examined. Holotype: India: Tamil Nadu, Nilgiri Hills, Doddabetta, $1000 \mathrm{~m}, 11^{\circ} 24^{\prime}$ 59.0"N 76²43'52.5"E, 18.III.1980, on mossy tree, leg. Gy. Topan (1 male, OPC). Paratype: Same as holotype (1 male, OPC).

Diagnosis. Potamyia tamilnada sp. nov. with upward directed and very pronounced hook formation on segment $\mathrm{X}$ belongs to Potamyia czekanovskii species group (Oláh et al. 2006) and to the Potamyia nikalandugola species complex. Close to P. nikalandugola (Schmid, 1958) described from Sri Lanka, but differs by having longer, over the top of segment $\mathrm{X}$, and slightly curving hook formation, unlike hook formation of $P$. nikalandugola reaching just to the top of segment $\mathrm{X}$ and straight. cerci lobe-like emerging over the top of segment $X$ in lateral view. The ventral profile of harpago monolobed, not bilobed due to the mesad turning narrowing lobes.

Description. Body and wings light yellowish brown with brown pubescence. Forewing without any maculation. Antennae less than twice length of forewing. Abdominal segment $\mathrm{V}$ with very short pointed lobe only. Spur formula 144. Forewing $6 \mathrm{~mm}$. In forewing crossveins $m-\mathrm{cu}$ and cu close; $C u 2$ and $A$ joining well before wing margin; In hindwing stem of $M$ plus proximal part of $M 3+4$ almost touching and running parallel with $\mathrm{CuI}$; fork 1 present.

Male genitalia. Abdominal segment IX fused annular and short, tergum shorter than sternum; anterior margin of segment IX convex; apical lobe on posterolateral margin lacking above the narrow articulation cavity of the gonopod; spine row on the posterior margin of segment IX almost complete. Intersegmental step between segment IX and segment $X$ low. The body of segment $X$ as high as long; cerci higher than the top of segment $\mathrm{X}$ in lateral view; ventroapical hook formation long, reaching above the top of segment $\mathrm{X}$. The first segment of the gonopod with broadening apical and thiner ventral half; harpago broadening apicad in ventral view with mesad turning process. Phallotheca with moderately enlarged phallobase, the straight horizontal shaft constricted middway; apicodorsum upward produced by wing-like broadenings; endophallus looks a narrow tube at the gonopore near to the bottom of the phallobase; the chitinized endothecal process circular, phallotremal sclerites broad vertical in lateral view.

Etymology. tamilnada, named after the locus typicus of the holotype. 


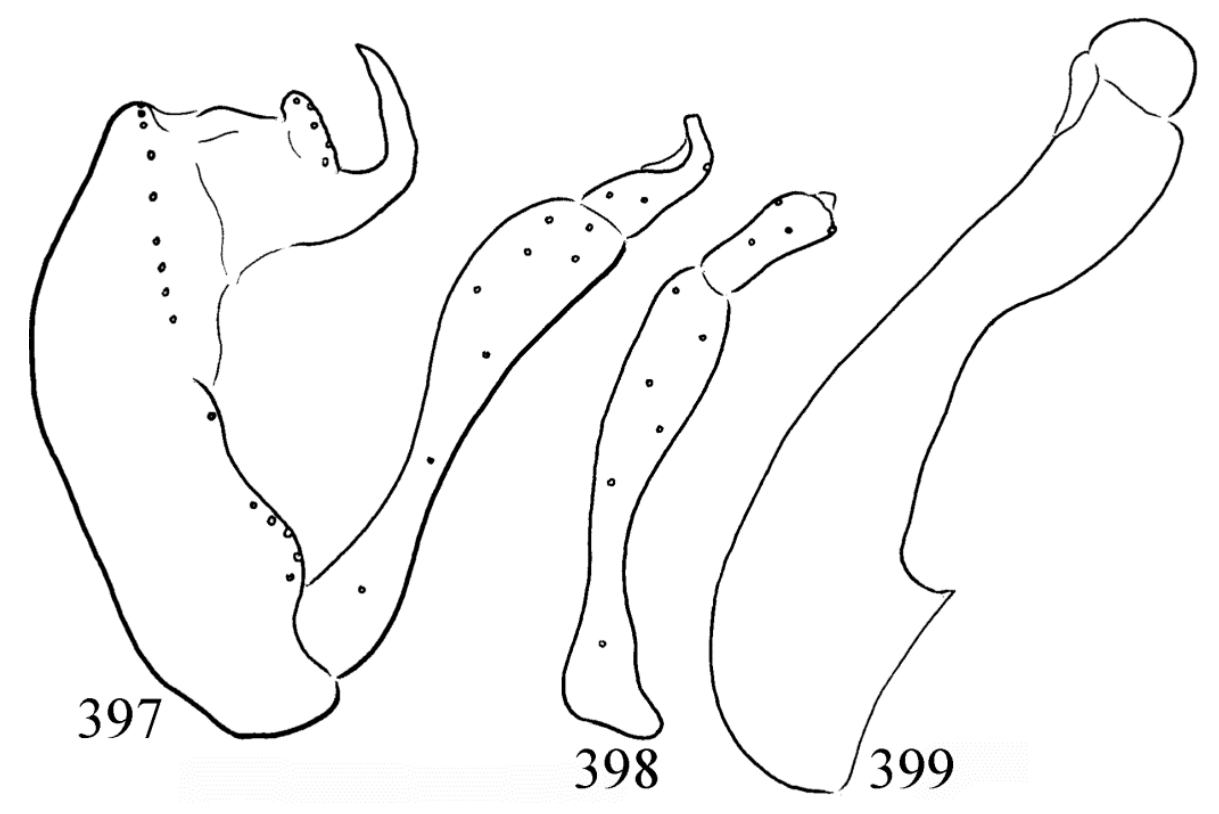

Figures 397-399. Potamyia tamilnada sp. nov. Holotype: 397 = male genitalia in left lateral view $398=$ left gonopod in ventral view, $399=$ phallic organ in left lateral view.

\section{Potamyia chinensis species group}

Tenth tergum long with pair of slightly upcurving small ventrocaudal hooks or rather small spines (Oláh et al. 2006).

\section{Potamyia pallidipennis (Martynov, 1935)}

(Figures 400-403, Map 6: $n^{\circ}$ 18, Map 26)

Material examined. India, Manipur, Mapum, $5000 \mathrm{ft.}$., 2504'55.9"N 94³0'16.9"E, 11.VI.1960, leg. F. Schmid (1 male, OPC). India, Manipur, Sihai Khullen, 4700 ft., $25^{\circ} 11^{\prime} 32.1^{\prime \prime N} 94^{\circ} 29^{\prime}$ 31.5"E, 25.VI.1960, leg. F. Schmid (1 male, $\mathrm{CNC})$.

\section{Potamyia flava species group}

Tenth tergum without any, or with very small hook formation, variable in position, or even with just the upward curving apices of the apical lobes (Oláh et al. 2006). Apical lobes of tergum X usually close mesally with short (narrow) interlobular gap, seldom wide or disappeared and the lobes are fused.

\section{Potamyia dinamla sp. nov.}

(Figures 404-407, Map 6: near n 4, Map 27)

Material examined. Holotype: India, Manipur, Dinamlong, $300 \mathrm{ft}$., unknown locality, probably near the next collecting site on the Schmid's road: Kambiron, 244ㄴ $46.9^{\prime \prime} \mathrm{N} 93^{\circ} 23^{\prime} 01.7^{\prime \prime} \mathrm{E}, 22 .-23$. V.1960, leg. F. Schmid (1 male, CNC).

Diagnosis. Potamyia dinamla sp. nov. with very small hook formation on segment $\mathrm{X}$ belongs to Potamyia flava species group (Oláh et al. 2006) and close to $P$. elektra Malicky \& Chantaramongkol, 2008 described from Thailand, but differs by having completely rounded and not excised ventroapical angle of the ventroapical lobe, by the anterad and not upward turning of the narrowing pointed process of the ventroapical setose lobe. The lateral profile of the phallic organ without waving dorsum and with much less developed phallobase.

Description. Body and wings light yellowish brown with brown pubescence. Forewing without 


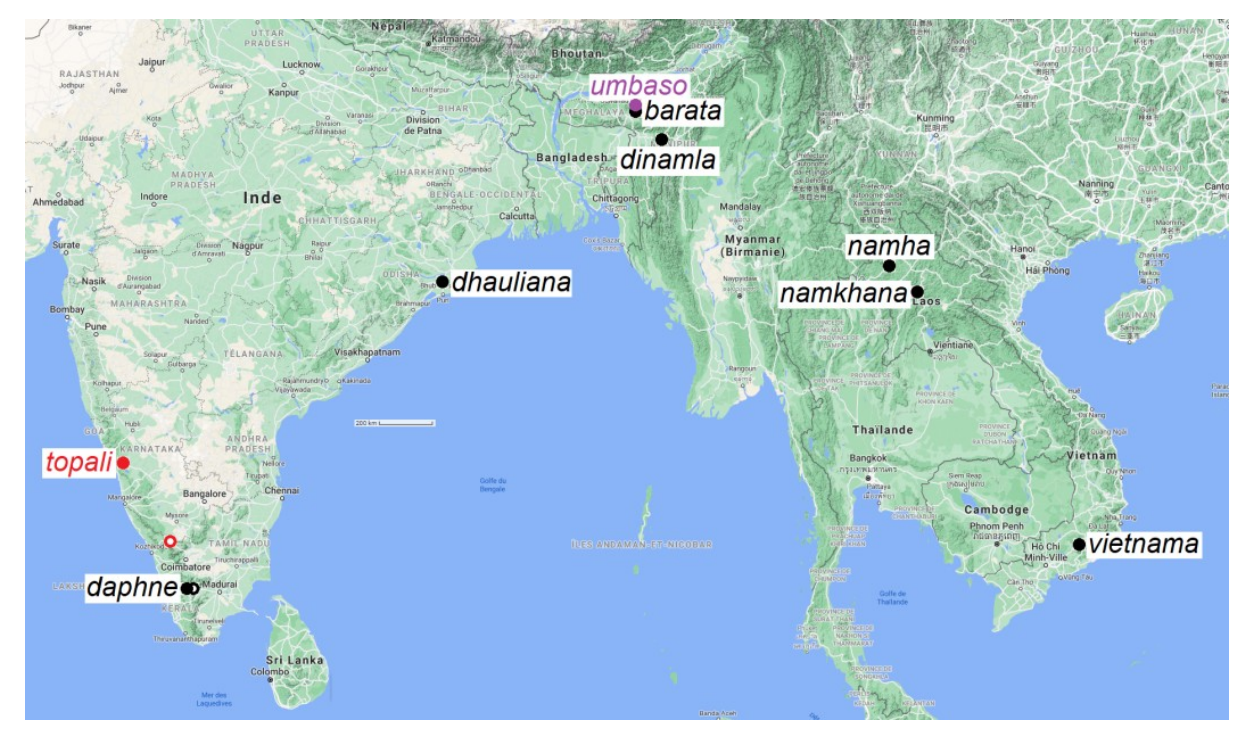

Map 27. Potamyia flava and trenhona groups.

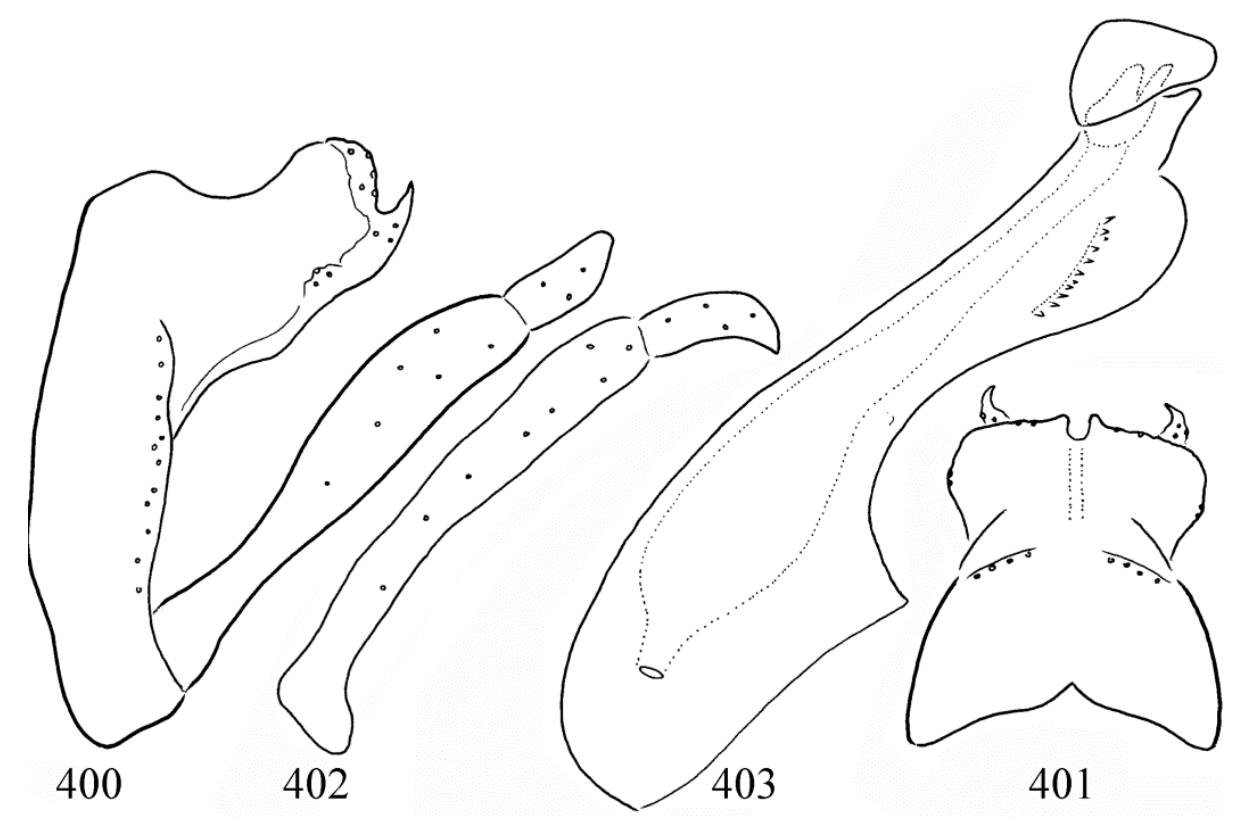

Figures 400-403. Potamyia pallidipennis (Martynov, 1935). $400=$ male genitalia in left lateral view, $401=$ male genitalia in dorsal view, 402 = left gonopod in ventral view, 403 = phallic organ in left lateral view.

any maculation. Antennae less than twice length of forewing. Abdominal segment $\mathrm{V}$ with very short pointed lobe only. Spur formula 144. Forewing $9 \mathrm{~mm}$. In forewing crossveins $m-\mathrm{cu}$ and $\mathrm{cu}$ close; $C u 2$ and $A$ joining well before wing margin; In hindwing stem of $M$ plus proximal part of $M 3+4$ almost touching and running parallel with $\mathrm{CuI}$; fork 1 present.
Male genitalia. Abdominal segment IX fused annular and short, tergum shorter than sternum; anterior margin of segment IX convex with posterad shifted dorsal and ventral sections in lateral view; apical lobe on posterolateral margin lacking above the narrow articulation cavity of the gonopod; spines row on the posterior margin of segment IX almost complete. Intersegmental step be- 
tween segment IX and segment X deep partly occupied by a pair of setose protuberances, appearing as the setose laterocaudal lobe. The body of segment $\mathrm{X}$ longer than high; rounded ventroapical setose lobes narrowing and pointed into an anterad curving apex visible both in lateral and dorsal views; ventroapical spiny hook lacking. The first segment of the gonopod with broadening apical and thiner ventral half; harpago digitate, mesad curving with blunt apex. Phallotheca with moderately enlarged phallobase, the straight horizontal shaft with regular straight dorsum, the most striking feature is the enlarged elongated ventral subapical keel; endophallus looks a narrow tube at the gonopore near to the bottom of the phallobase; the chitinized endothecal process semicircular, phallotremal sclerites broad vertical in lateral view.

Etymology. dinamla, coined from the name of the locus typicus of the holotype.

\section{Potamyia trenhona species group}

Tenth tergum produced into upward or backward curving hook formation with very broad bases (Oláh et al. 2006). This species group is composed of two new species complexes. Potamyia jinhongensis, a small species complex with obliquely posterad directed long spine formation on segment $\mathrm{X}$ and Potamyia yunnanica, a large species complex with upward and variously anterad directed hook formation of various length.

\section{Potamyia barata sp. nov.}

(Figures 408-411, Map 5: $\mathrm{n}^{\circ}$ 72, Map 27)

Material examined. Holotype: India, Meghaláya (United Jaintia and Khasi Hills), Barato, 2500 ft., 2536'24.1"N 92²7'23.1"E, 24.IV.1960, leg. F. Schmid (1 male, 1 associated female; CNC). Paratype: same as holotype (1 male, OPC).

Diagnosis. Potamyia barata sp. nov. belongs to Potamyia trenhona species group (Oláh et al. 2006) and close to $P$. umbaso sp. nov., but differs by having coxopodite slender, not dilating apicad; harpago short, not long; segment $\mathrm{X}$ broad-based and high, not narrow, constricted, and low; hook formation is also high, not low; lateral profile of the phallic organ that is the speciation trait has a more rounded, not elongated ventroapical keel.

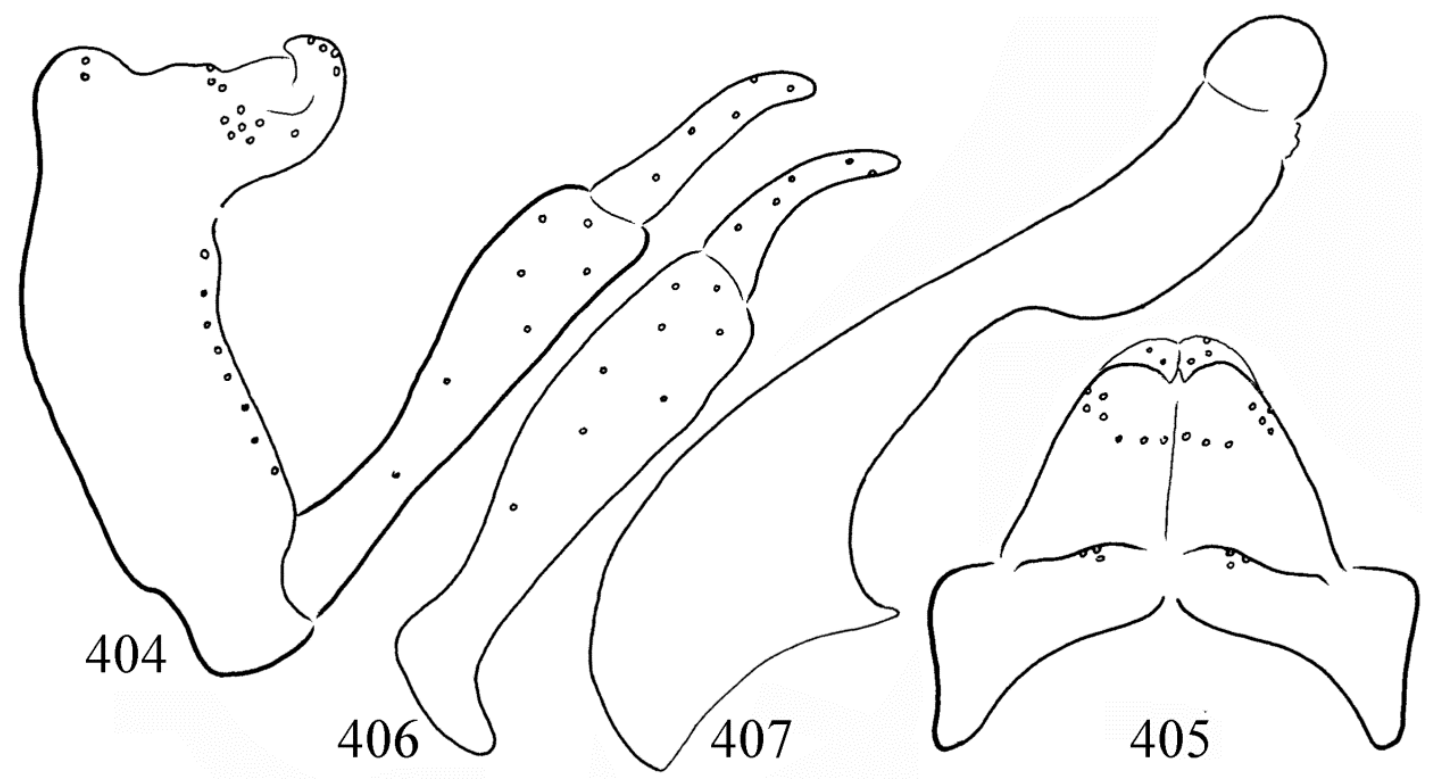

Figures 404-407. Potamyia dinamla sp. nov. Holotype: $404=$ male genitalia in left lateral view, $405=$ male genitalia in dorsal view, $406=$ left gonopod in ventral view, 407 = phallic organ in left lateral view. 


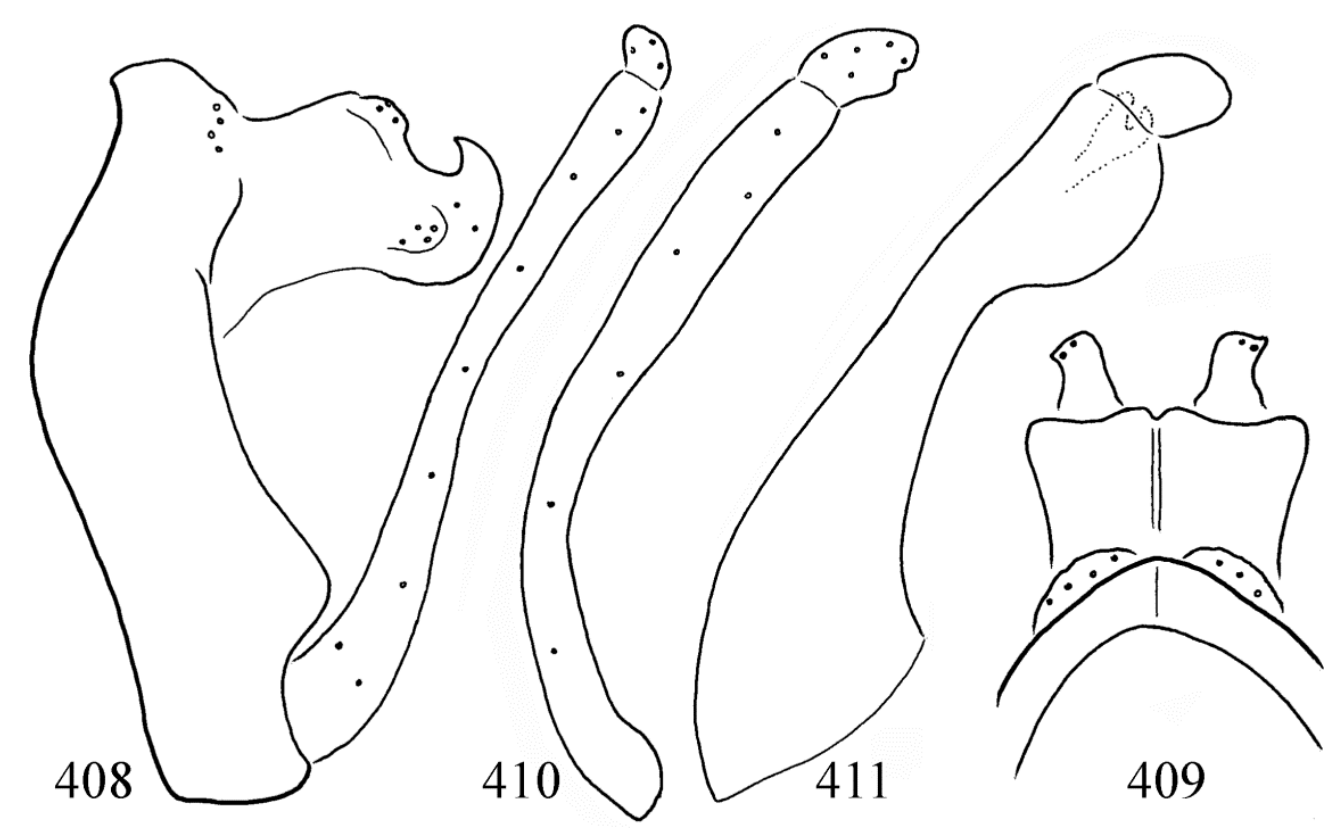

Figures 408-411. Potamyia barata sp. nov. Holotype: 408 = male genitalia in left lateral view, $409=$ male genitalia in dorsal view, $410=$ left gonopod in ventral view, $411=$ phallic organ in left lateral view.

Description. Body and wings light brown with brown pubescence. Forewing without any maculation. Antennae less than twice length of forewing. Abdominal segment $\mathrm{V}$ with very short pointed lobe only. Spur formula 144, single spur on foreleg tibia small. Protarsal claw asymmetrical with laterally flanked setal bundle, claws on the second and third legs also asymmetrical. Forewing $9 \mathrm{~mm}$. In forewing crossveins $m-c u$ and $c u$ close; $\mathrm{Cu} 2$ and A joining well before wing margin; In hindwing stem of $M$ plus proximal part of $M 3+4$ almost touching and running parallel with $\mathrm{CuI}$; fork 1 present.

Male genitalia. Abdominal segment IX fused annular and short, tergum twice shorter than sternum; anterior margin of segment IX convex with posterad shifted dorsal section in lateral view; apical lobe on posterolateral margin very small almost reduced and located at above the narrow articulation cavity of the gonopod; spine row on the posterior margin of segment IX almost complete. Intersegmental step between segment IX and segment $X$ deep partly occupied by a pair of setose protuberances, appearing as the setose laterocaudal lobe. The body of segment $\mathrm{X}$ subquadrangular; rounded ventroapical setose lobe pointed into an anterad curving spine in lateral view; this ventroapical spiny hook dominating on the distal part of segment X. The first segment of the gonopod, the coxopodite slender without pronounced apical broadening; harpago very short broad with small excision ventrally, subapicad in ventral view. Phallotheca with enlarged phallobase, the straight horizontal shaft with regular straight dorsum, but the most striking feature the very enlarged ventral subapical rounded broadening keel; endophallus looks a narrow tube at the gonopore near to the bottom of the phallobase; the chitinized endothecal process semicircular, phallotremal sclerites broad vertical in lateral view.

Etymology. barata, named after the locus typicus of the holotype.

\section{Potamyia jinhongensis new species complex}

Potamyia dhauliana sp. nov.

(Figures 412-415, Map 27)

Potamyia arachne Malicky, 1998: Oláh et al. 2006: 752. "New Records. India, Odisha, Bhubaneswar, Dhauli, $20^{\circ} 11^{\prime} 14.5^{\prime \prime N} 85^{\circ} 50^{\prime} 34.5^{\prime \prime} \mathrm{E}, 20-28$. February. 1987, 20ิ $\delta^{1} 1$ q light (J. Oláh) (Fig. 27). Misidentification. 


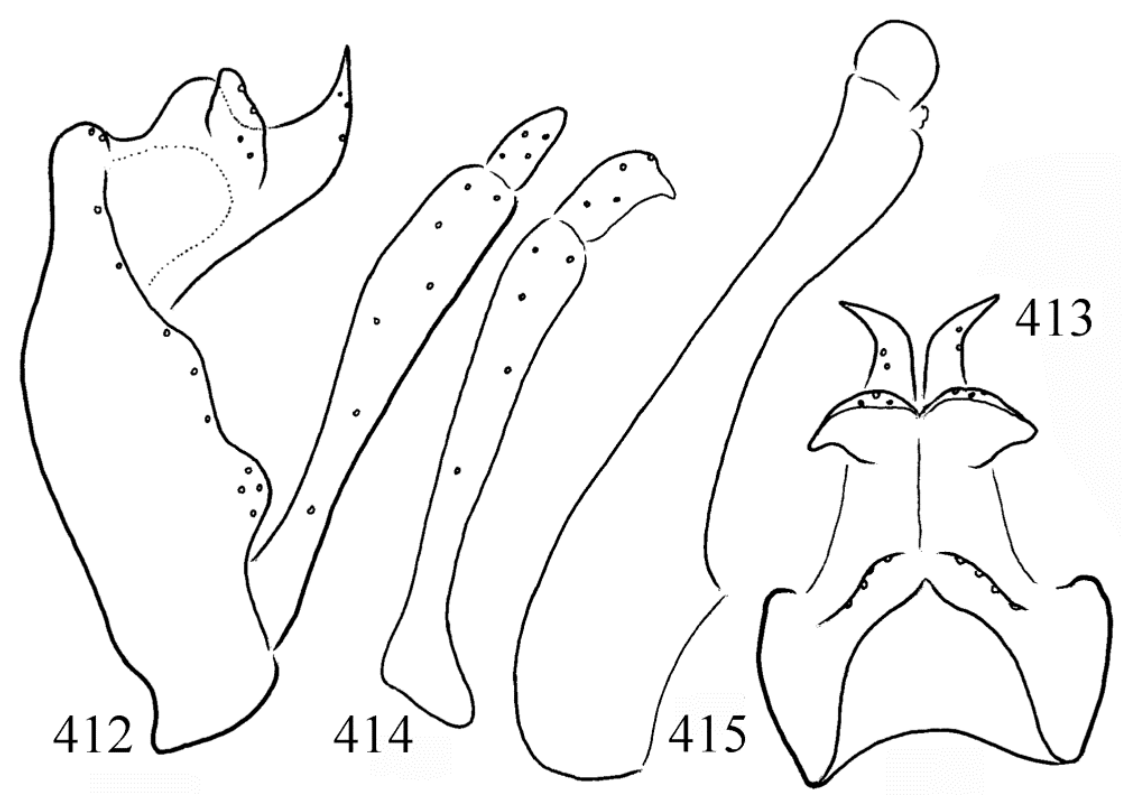

Figures 412-415. Potamyia dhauliana sp. nov. Holotype: $412=$ male genitalia in left lateral view, $413=$ male genitalia in dorsal view, $414=$ left gonopod in ventral view, $415=$ phallic organ in left lateral view.

Material examined. Holotype: India, Bhubaneswar, Dhauli, 20-28.II.1987, light leg. J. Oláh (1 male, OPC). Paratypes: same as holotype (1 male, 1 female; OPC).

Diagnosis. Potamyia dhauliana sp. nov. belongs to $P$. trenhona species group (Oláh et al. 2006) and close to $P$. arachne Malicky, 1998 described from Myanmar (Irrawady lowland) but differs by the lateral window (weakly sclerotized region) of segment $\mathrm{X}$ that is short at $P$. dhauliana sp. nov. and long at $P$. arachne; by the cerci tapering both in lateral and dorsal views, not rounded; by the higher dorsal hump on segment $\mathrm{X}$; by the ventroapical lobe having spiny hook formation with slender and longer basal half, clearly visible in dorsal view; by the apicomesal long tip on the harpago visible in ventral view as well as by the lateral profile of the phallic organ with short and low phallobase.

Description. Body and wings light brown with brown pubescence. Forewing without any maculation. Antennae less than twice length of forewing. Abdominal segment $\mathrm{V}$ with very short pointed lobe only. Spur formula 144, single spur on foreleg tibia small. Protarsal claw asymmet- rical with laterally flanked setal bundle, claws on the second and third legs also asymmetrical. Forewing $7 \mathrm{~mm}$. In forewing crossveins $m-c u$ and $c u$ close; $C u 2$ and $A$ joining well before wing margin; In hindwing stem of $M$ plus proximal part of $M 3+4$ almost touching and running parallel with $\mathrm{CuI}$; fork 1 present.

Male genitalia. Abdominal segment IX fused annular and short, tergum twice shorter than sternum; anterior margin of segment IX convex with posterad shifted dorsal section in lateral view; apical lobe on posterolateral margin small and located at above the narrow articulation cavity of the gonopod; spines row on the posterior margin of segment IX almost complete. Intersegmental step between segment IX and segment $X$ deep partly occupied by a pair of setose protuberances, appearing as the setose laterocaudal lobe. The body of segment $\mathrm{X}$ longer than high, cerci welldifferentiated into a tapering lobe; rounded ventroapical setose lobe pointed into an upward curving pointed spine in lateral view; this ventroapical spiny hook dominating on the distal part of segment $X$. The first segment of the gonopod with broadening apical and very thin ventral half; harpago short broad with small apicomesal pointed process in lateral view. Phallotheca with low 
and short phallobase, the straight horizontal shaft with regular straight dorsum, slightly upward bending; endophallus looks a narrow tube at the gonopore near to the bottom of the phallobase; the chitinized endothecal process circular, phallotremal sclerites broad vertical in lateral view.

Etymology. dhauliana, named after the locus typicus of the holotype.

\section{Potamyia yunnanica new species complex}

\section{Potamyia daphne Malicky, 1998}

(Map 27)

Potamyia daphne Malicky, 1998:20. "Holotype: Indien, Kerala, Kallar-Tal, 15 km SW Munnar, 1250m, $10^{\circ} 02^{\prime} 06.9^{\prime \prime} \mathrm{N} 76^{\circ} 59^{\prime} 12.7^{\prime \prime E}, 1-9 . V .1997 . "$

Material examined. India, Tamil Nadu (Madras), Kottagudi [=Kottakudi], $2500 \mathrm{ft}, 10^{\circ} 04^{\prime}$ 43.9"N 77¹5'44.4"E, 23.I.1962, leg. F. Schmid (1 male, OPC).

\section{Potamyia namha sp. nov.}

(Figures 416-419, Map 27)

Material examined. Holotype: Laos PDR, Luang Namtha Prov., Nam Ha NBCA, Lakkhammai Village, Nam Leung stream, 749mao, 47Q 0744602, UTM 2339873, 30.iv.2005, light trap, loc 29, leg. N Jönssson, T. Malm and B Viklund (1 male, SMNH).

Diagnosis. Potamyia namha sp. nov. belongs to Potamyia trenhona species group (Oláh et al. 2006) and to the Potamyia yunnanica species complex. However, cerci separated, not fused and the hook formation also not typical. Unique in the complex. Intermediate taxon between species groups of $P$. trenhona, $P$. flava and $P$. czekanovskii.

Description. Body and wings light brown with brown pubescence. Forewing without any maculation. Antennae less than twice length of forewing. Abdominal segment $\mathrm{V}$ with very short pointed lobe only. Spur formula 144, single spur on foreleg tibia small. Protarsal claw asymmetrical with laterally flanked setal bundle, claws on the second and third legs also asymmetrical. Forewing $10 \mathrm{~mm}$. In forewing crossveins $m-c u$ and $c u$ close; $\mathrm{Cu} 2$ and $A$ joining well before wing margin; In hindwing stem of $M$ plus proximal part of $M 3+4$ almost touching and running parallel with $C u I$; fork 1 present.

Male genitalia. Abdominal segment IX fused annular and short, tergum 4 times shorter than sternum; anterior margin of segment IX convex with slightly posterad shifted dorsal section in lateral view; apical lobe on posterolateral margin small and located at above the narrow articulation cavity of the gonopod; spines row on the posterior margin of segment IX almost complete. Intersegmental step between segment IX and segment X oblique partly occupied by a pair of setose protuberances, appearing as the setose laterocaudal lobe. The body of segment $\mathrm{X}$ longer than high, cerci separate setose lobes; hook formation thin, elongated; atypical for the complex. The first segment of the gonopod straight, robust; harpago elongated, with slightly mesad turning and tapering apex and mesad broadening basement in ventral view. Phallotheca with produced phallobase, constricted subapicad; endophallus looks a narrow tube at the gonopore near to the bottom of the phallobase; the chitinized endothecal sclerites semicircular, phallotremal sclerites broad vertical in lateral view.

Etymology. namha, named after the locus typicus of the holotype.

\section{Potamyia namkhana sp. nov.}

(Figures 420-423, Map 27)

Material examined. Holotype: Laos PDR, Luang Phrabang Prov., Nam Khan River, 500m upstr. Mekong River, 293mao, 48Q 0200517, UTM 2202237, 27.IV.2005, light trap, loc 14, leg. N. Jönssson, T. Malm and B. Viklund (1 male, SMNH).

Diagnosis. Potamyia namkhana sp. nov. belongs to $P$. trenhona species group (Oláh et al. $2006)$ and to the $P$. yunnanica species complex. 


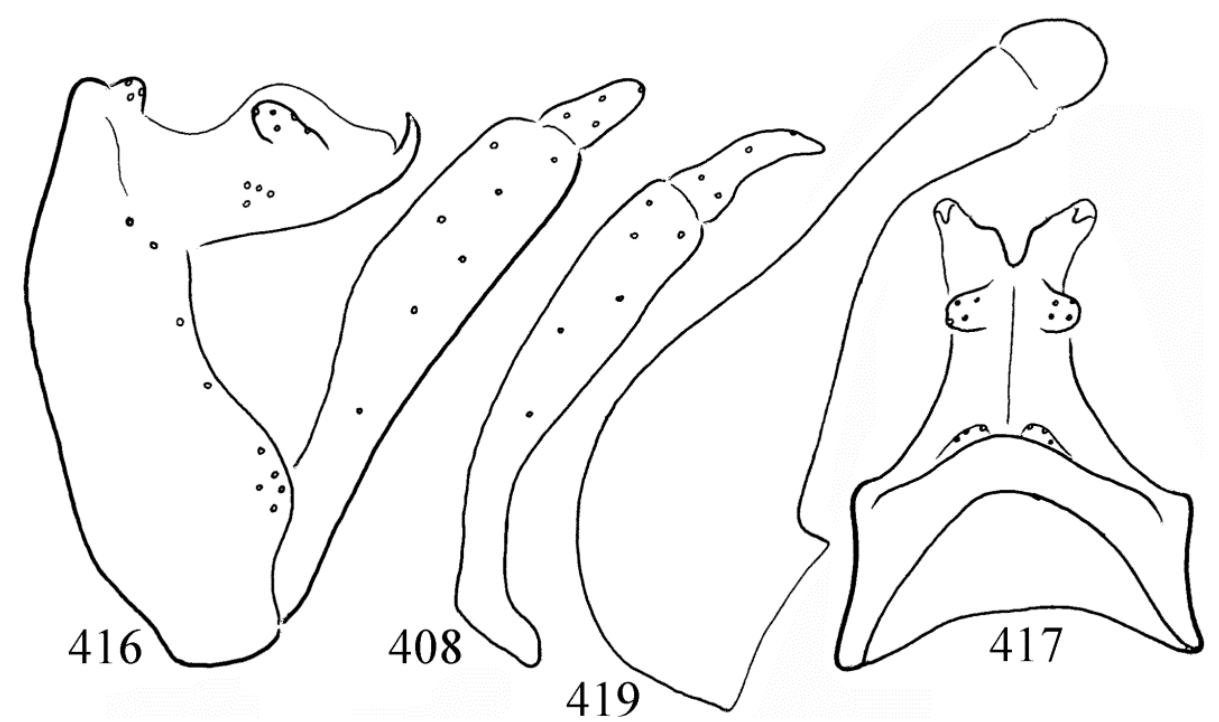

Figures 416-419. Potamyia namha sp. nov. Holotype: 416 = male genitalia in left lateral view, $417=$ male genitalia in dorsal view, 418 = left gonopod in ventral view, 419 = phallic organ in left lateral view.

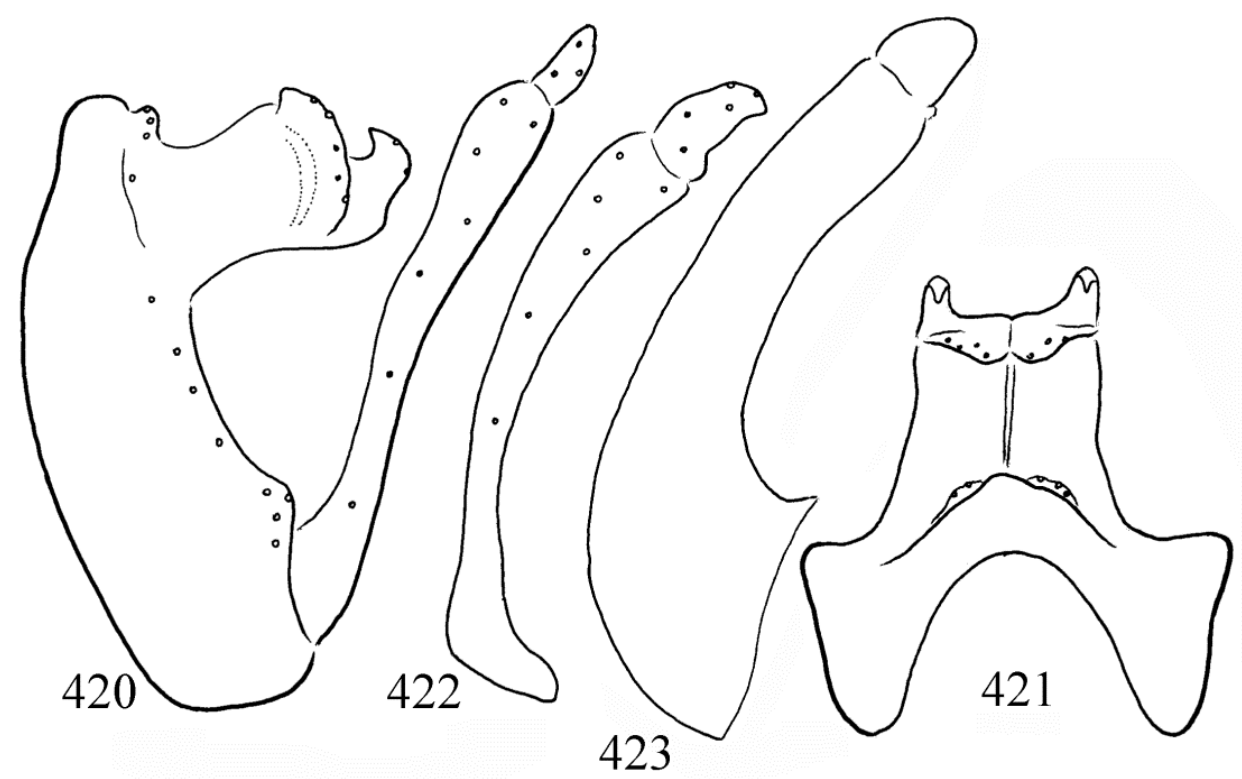

Figures 420-423. Potamyia namkhana sp. nov. Holotype: $420=$ male genitalia in left lateral view, $421=$ male genitalia in dorsal view, 422 = left gonopod in ventral view, 423 = phallic organ in left lateral view.

Most close to $P$. trenhona Oláh \& Barnard, 2006 described from Vietnam, but differs by having more pronounced hook formation of segment X; apical third of the phallotheca straight, not directed slightly downward, as well as the endothecal sclerites of the phallic organ narrowing apicad, not circular.
Description. Body and wings light brown with brown pubescence. Forewing without any maculation. Antennae less than twice length of forewing. Abdominal segment $\mathrm{V}$ with very short pointed lobe only. Spur formula 144, single spur on foreleg tibia small. Protarsal claw asymmetrical with laterally flanked setal bundle, claws on 
the second and third legs also asymmetrical. Forewing $7 \mathrm{~mm}$. In forewing crossveins $m-c u$ and $c u$ close; $\mathrm{Cu} 2$ and $A$ joining well before wing margin; In hindwing stem of $M$ plus proximal part of $M 3+4$ almost touching and running parallel with $\mathrm{CuI}$; fork 1 present.

Male genitalia. Abdominal segment IX fused annular and short, tergum shorter than sternum; anterior margin of segment IX convex with posterad shifted dorsal section in lateral view; apical lobe on posterolateral margin small and located at above the narrow articulation cavity of the gonopod; spines row on the posterior margin of segment IX almost complete. Intersegmental step between segment IX and segment X deep partly occupied by a pair of setose protuberances, appearing as the setose laterocaudal lobe. The body of segment $\mathrm{X}$ longer than high, cerci well-differentiated into a fused lobe; rounded ventroapical setose lobe with apical incision of concavity, pointed into an upward and anterad curving spine in lateral view; this ventroapical spiny hook dominating on the distal part of segment $\mathrm{X}$. The first segment of the gonopod almost straight and slightly broadening apicad; harpago slightly mesad turning apex and mesad broadening basement in ventral view. Phallotheca with low and short phallobase, the straight horizontal shaft with regular straight, slightly convex dorsum; endophallus looks a narrow tube at the gonopore near to the bottom of the phallobase; the chitinized endothecal sclerites narrowing apicad, phallotre- mal sclerites broad vertical in lateral view.

Etymology. namkhana, named after the locus typicus of the holotype.

\section{Potamyia topali sp. nov.}

(Figures 424-425, Map 27)

Potamyia daphne Malicky, 1998: 20. Oláh et al. 2006: 752. Misidentification.

Material examined. Holotype: India, Karnataka, Shimoga district, Jog Falls, 500m, 14 ${ }^{\circ} 13^{\prime}$ 45.4"N 7448'44.9"E, 2.III.1980, light leg. GY. Topál (1 male, HNHM). Paratypes: same as holotype (6 males, HNHM, 2 males, OPC). India, Tamil Nadu, Mudumalai, 1000m, $11^{\circ} 37 ' 26.2^{\prime \prime} \mathrm{N}$ 76³0'37.5"E, 19.III.1980, leg. Gy. Topál (1 male, HNHM).

Diagnosis. Potamyia topali sp. nov. belongs to Potamyia trenhona species group (Oláh et al. 2006) and close to $P$. assamana Oláh \& Schefter, 2008 and particularly to $P$. daphne Malicky, 1998 described from Kerala, but differs by having rounded and not straight ventroapical angle of the ventroapical lobe, by the upward and not dorsoapicad turning of the pointed spine-like process of the ventroapical setose lobe. The lateral profile of the phallic organ that is the speciation trait has a straight dorsum, not waving as well as the ventroapical keel is differently shaped.

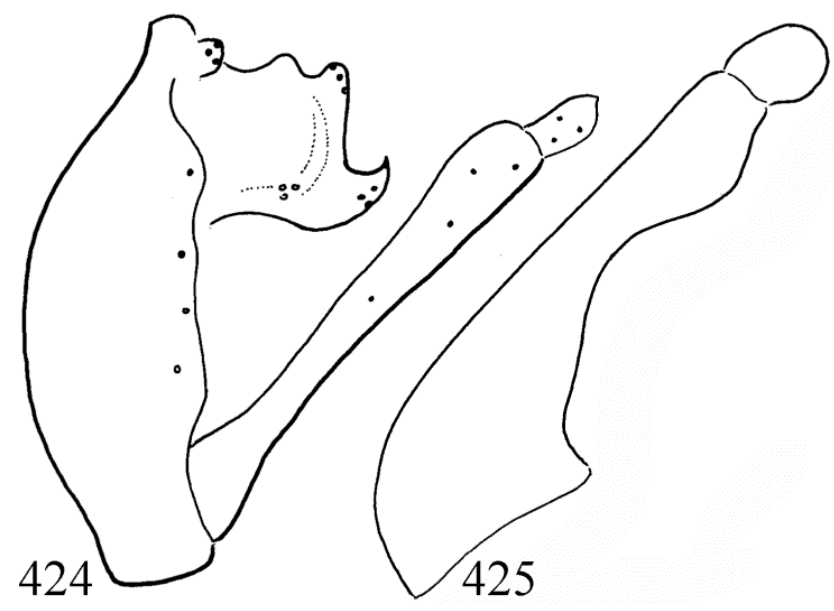

Figures 424-425. Potamyia topali sp. nov. Holotype: $424=$ male genitalia in left lateral view, $425=$ phallic organ in left lateral view. 


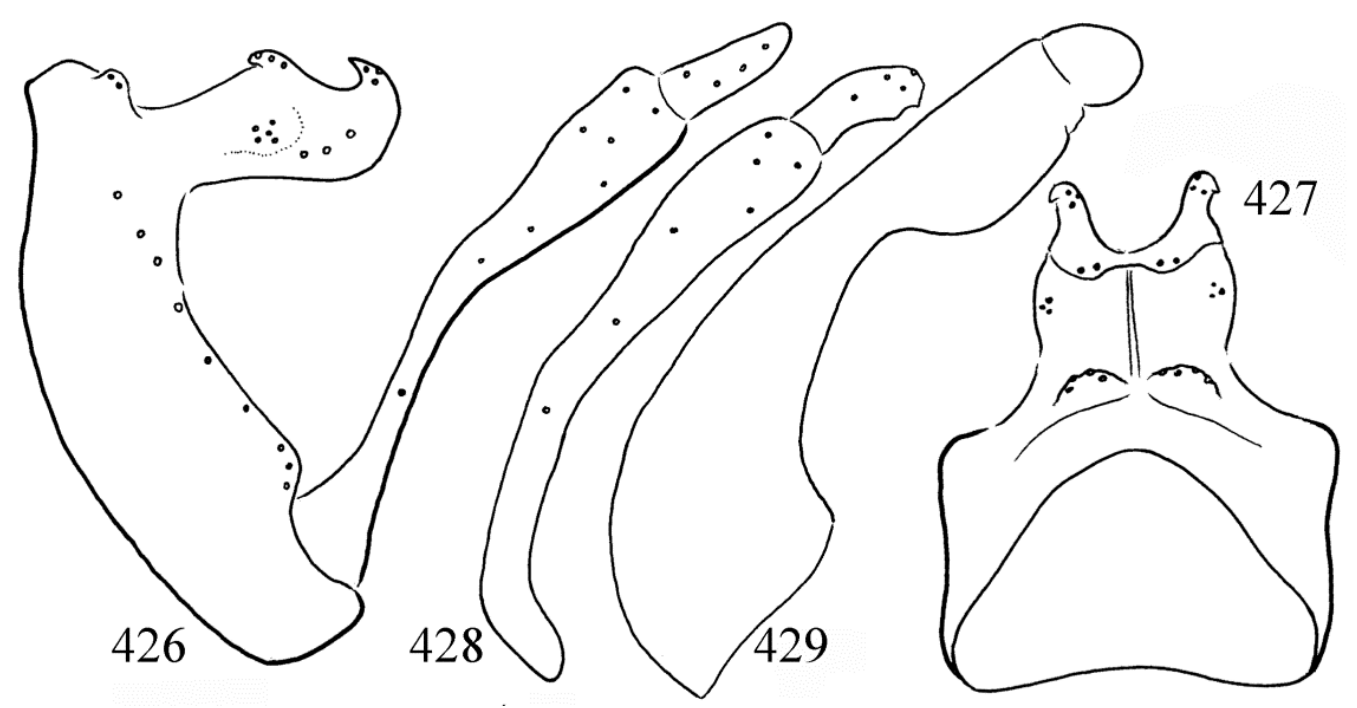

Figures 426-429. Potamyia umbaso sp. nov. Holotype: $426=$ male genitalia in left lateral view, $427=$ male genitalia in dorsal view, $428=$ left gonopod in ventral view, $429=$ phallic organ in left lateral view.

Description. Male (pinned). Body and wings light brown with brown pubescence. Forewing without any maculation. Antennae less than twice length of forewing. Abdominal segment $\mathrm{V}$ with very short pointed lobe only. Spur formula 144, single spur on foreleg tibia small. Protarsal claw asymmetrical with laterally flanked setal bundle, claws on the second and third legs also asymmetrical. Forewing $6 \mathrm{~mm}$. In forewing crossveins $m$ $\mathrm{cu}$ and $\mathrm{cu}$ close; $\mathrm{Cu} 2$ and $\mathrm{A}$ joining well before wing margin; In hindwing stem of $M$ plus proximal part of $M 3+4$ almost touching and running parallel with $\mathrm{CuI}$; fork 1 present.

Male genitalia. IX abdominal segment fused annular and short, tergum twice shorter than sternum; anterior margin of segment IX convex with posterad shifted dorsal section in lateral view; apical lobe on posterolateral margin very small almost reduced and located at above the narrow articulation cavity of the inferior appendages; spines row on the posterior margin of segment IX almost complete. Intersegmental step between segment IX and segment X deep partly occupied by a pair of setose protuberances, appearing as the setose laterocaudal lobe. The body of segment $\mathrm{X}$ as long as high, subquadrangular; rounded ventroapical setose lobe pointed into an upcurving spine in lateral view; this upturning ventroapical spiny hook dominating its distal part of segment X; dorsoapical setose lobe straight vertical. The first segment of inferior appendages significantly longer than the apex of tenth segment, rod-shaped and broadening to apicad; harpago short broad slightly tapering in lateral view. Phallotheca with enlarged phallobase, the straight horizontal shaft with regular straight dorsum, however, the most striking feature is the very enlarged ventral subapical broadening; endophallus looks a narrow tube at the gonopore near to the bottom of the phallobase; the chitinized endothecal process circular, phallotremal sclerites broad vertical in lateral view.

Etymology. Name was given in honour of the collector György Topál.

\section{Potamyia umbaso sp. nov.}

(Figures 426-429, Map 5: n 74, Map 27)

Material examined. Holotype: India, Assam, United District of Mikir and North Cachar Hills, Umbaso, $2300 \mathrm{ft}$., 2543'46.3"N 92³1'33.5"E, 26.IV.1960, leg. F. Schmid (1 male, CNC).

Diagnosis. Potamyia umbaso sp. nov. belongs to $P$. trenhona species group (Oláh et al. 2006), and is close to $P$. assamana Oláh \& Schefter, 2008 but differs by having completely rounded and not excised ventroapical angle of the ventro- 
apical lobe, by the anterad and not upward turning of the pointed spine-like process of the ventroapical setose lobe. The lateral profile of the phallic organ that is the speciation trait has a more elongated ventroapical keel, not subtriangular.

Description. Body and wings light brown with brown pubescence. Forewing without any maculation. Antennae less than twice length of forewing. Abdominal segment $\mathrm{V}$ with very short pointed lobe only. Spur formula 144, single spur on foreleg tibia small. Protarsal claw asymmetrical with laterally flanked setal bundle, claws on the second and third legs also asymmetrical. Forewing $9 \mathrm{~mm}$. In forewing crossveins $m-c u$ and $c u$ close; $C u 2$ and $A$ joining well before wing margin; In hindwing stem of $M$ plus proximal part of $M 3+4$ almost touching and running parallel with $\mathrm{CuI}$; fork 1 present.

Male genitalia. Abdominal segment IX fused annular and short, tergum twice shorter than sternum; anterior margin of segment IX convex with posterad shifted dorsal section in lateral view; apical lobe on posterolateral margin very small almost reduced and located at above the narrow articulation cavity of the gonopod; spines row on the posterior margin of segment IX almost complete. Intersegmental step between segment IX and segment $X$ deep partly occupied by a pair of setose protuberances, appearing as the setose laterocaudal lobe. The body of segment X longer than high, slightly downward directed; rounded ventroapical setose lobe pointed into an anterad curving spine in lateral view; this ventroapical spiny hook dominating on the distal part of segment $\mathrm{X}$. The first segment of the gonopod with broadening apical and very thin ventral half, angled middle; harpago short broad with small excision ventrally, subapicad in ventral view. Phallotheca with enlarged phallobase, the straight horizontal shaft with regular straight dorsum, however, the most striking feature is the very enlarged ventral subapical broadening keel; endophallus looks a narrow tube at the gonopore near to the bottom of the phallobase; the chitinized endothecal process semicircular, phallotremal sclerites broad vertical in lateral view.
Etymology. umbaso, named after the locus typicus of the holotype.

\section{Potamyia vietnama sp. nov.}

(Figures 430-433, Map 27)

Potamyia phaidra Malicky \& Chantaramongkol, in Malicky 1997: Oláh et al. 2006:753. "New Records. Vietnam, Lamdong, Baoloc, Loc chau, 24 October 1988, at light (Oláh).” Misidentification.

Material examined. Holotype: Vietnam, Lam-

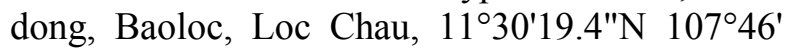
48.8"E, 24.X.1988, light leg. J. Oláh (1 male, OPC).

Diagnosis. Potamyia vietnama sp. nov. belongs to $P$. trenhona species group (Oláh et al. $2006)$ and to the $P$. yunnanica species complex. Most close to P. yunnanica (Schmid, 1959) described from China, Yunnan Province and to $P$. umbaso sp. nov. described here from India, Assam, but differs by the pattern of the broadbased hook formation of segment $\mathrm{X}$ and by the lateral profile of the phallotheca.

Description. Body and wings light brown with brown pubescence. Forewing without any maculation. Antennae less than twice length of forewing. Abdominal segment $\mathrm{V}$ with very short pointed lobe only. Spur formula 144, single spur on foreleg tibia small. Protarsal claw asymmetrical with laterally flanked setal bundle, claws on the second and third legs also asymmetrical. Forewing $6 \mathrm{~mm}$. In forewing crossveins $m-\mathrm{cu}$ and $c u$ close; $C u 2$ and $A$ joining well before wing margin; In hindwing stem of $M$ plus proximal part of $M 3+4$ almost touching and running parallel with $C u I$; fork 1 present.

Male genitalia. Abdominal segment IX fused annular and short, tergum little shorter than sternum; anterior margin of segment IX convex with posterad shifted dorsal section in lateral view; apical lobe on posterolateral margin small and located at above the narrow articulation cavity of the gonopod; spines row on the posterior margin of segment IX almost complete. Intersegmental 


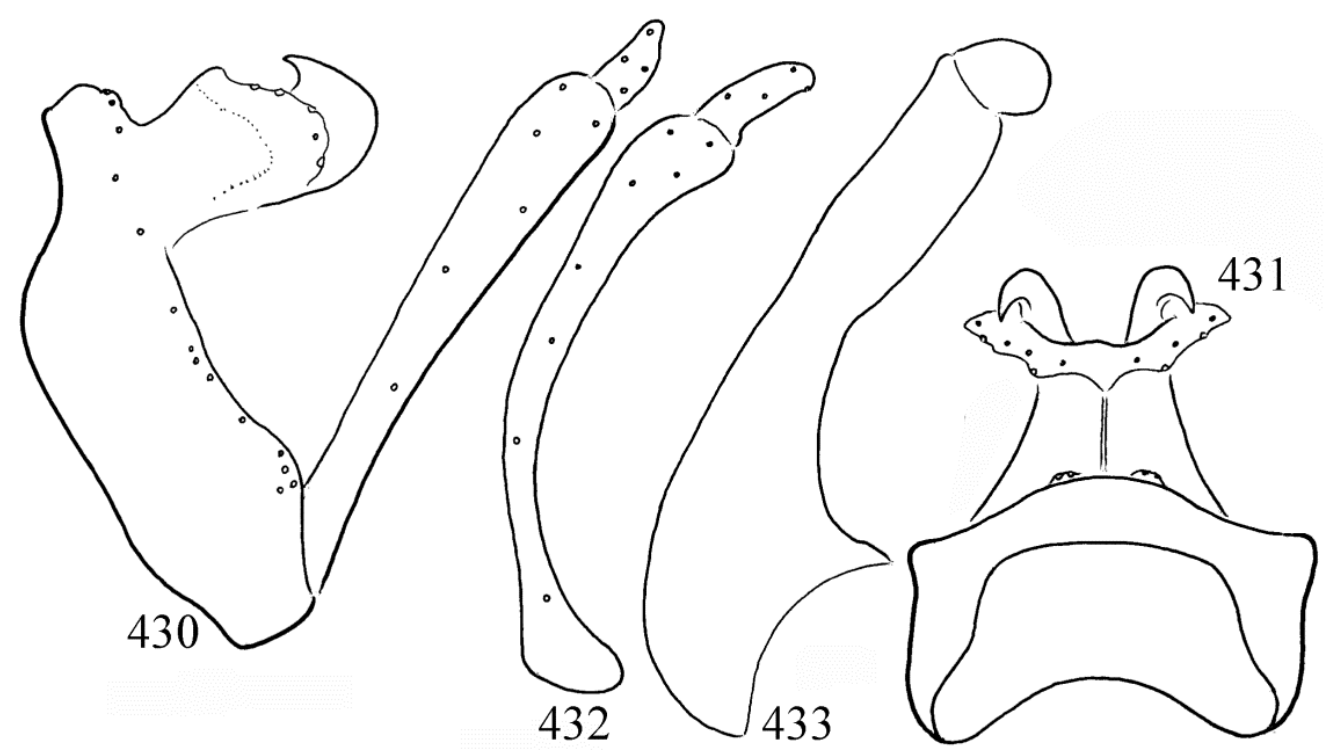

Figures 430-433. Potamyia vietnama sp. nov. Holotype: $430=$ male genitalia in left lateral view, $431=$ male genitalia in dorsal view, 432 = left gonopod in ventral view, 433 = phallic organ in left lateral view.

step between segment IX and segment $X$ deep partly occupied by a pair of setose protuberances, appearing as the setose laterocaudal lobe. The body of segment $\mathrm{X}$ longer than high, cerci welldifferentiated into a fused lobe pronouncedly directed laterad; rounded ventroapical setose lobe pointed into an upward and anterad curving pointed spine in lateral view; this ventroapical spiny hook dominating on the distal part of segment X. The first segment of the gonopod almost straight and slightly broadening apicad; harpago with slightly mesad turning apex in ventral view. Phallotheca with low and short phallobase, the straight horizontal shaft with regular straight dorsum, ventrum broader along apical half; endophallus looks a narrow tube at the gonopore near to the bottom of the phallobase; the chitinized endothecal process circular, phallotremal sclerites broad vertical in lateral view.

Etymology. vietnama, named after the locus typicus of the holotype.

\section{Hydromanicus}

\section{Hydromanicus hermosus species group}

Species group with the following character combination. (1) Short, narrow and subtriangular apical lobe on segment IX. (2) Long or mediumsized segment X. (3) Short, monolobed cerci. (4) Broad ventromesal subapical keel on the phallotheca absent, but ventromesal subapical hook formation developed on the phallotheca of the $H$. flavoguttatus species complex. Large species characterized with variously patterned forewing and rather long antennae (Oláh \& Johanson, 2008b).

\section{Hydromanicus flavoguttatus new species complex}

Having very short, abbreviated cerci this new species complex belongs to the Hydromanicus hermosus species group and diverged by the organisation of a peculiar apicoventral hook formation on the phallotheca. This small species complex is still known only from Java and Sumatra islands and represented by three species: $H$. bukit sp. nov., (Sumatra); H. flavoguttatus Albarda, 1881, (Java, Sumatra); H. sempit Chantaramongkol and Malicky, 1995, (Sumatra).

\section{Hydromanicus bukit sp. nov.}

(Figures 434-438, Map 28)

Hydromanicus flavoguttatus Albarda, 1881. Oláh \& Malicky, 2011:15: Indonesia, Sumatra, Danau Ranau, Bukit Barisan Selatan National Park, 950 m, 


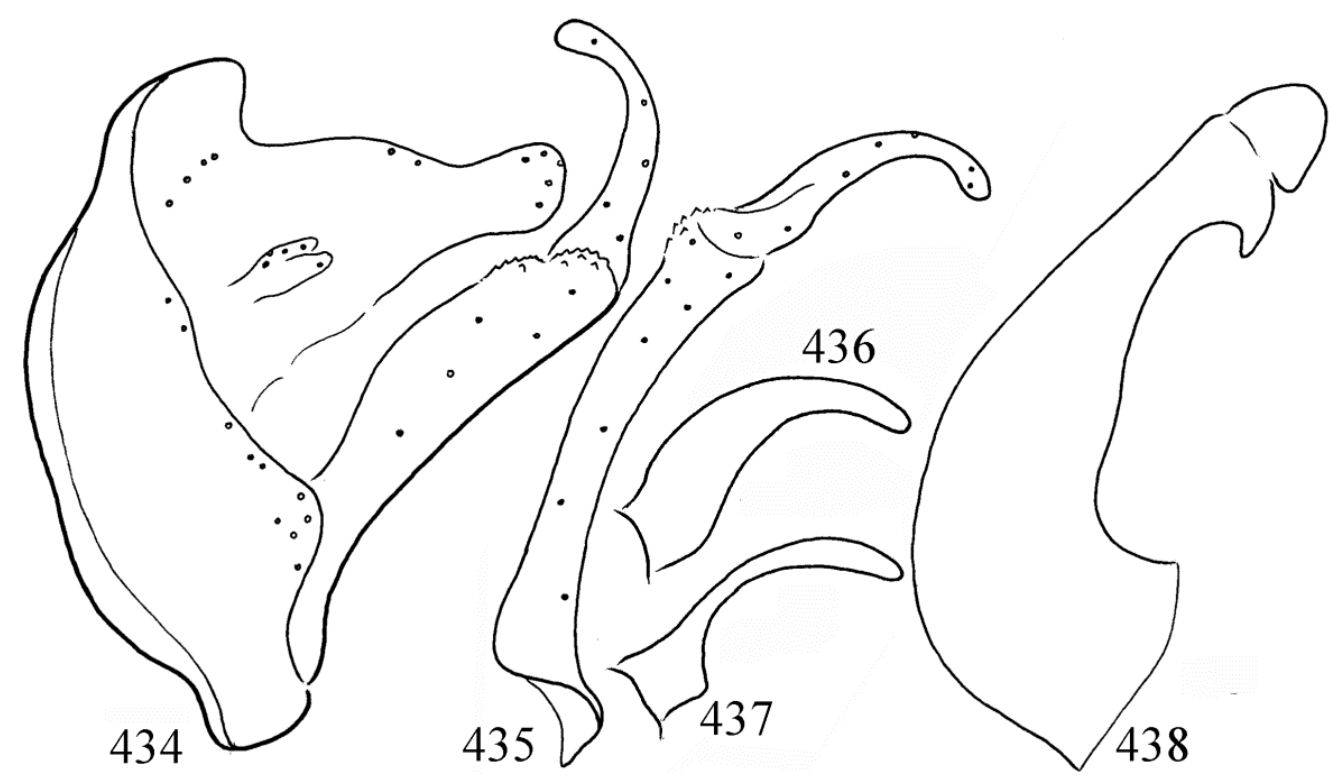

Figures 434-438. Hydromanicus bukit sp. nov. Holotype: $434=$ male genitalia in left lateral view, $435=$ left gonopod in ventral view, $436=$ harpago of $H$. flavoguttatus in ventral view, $437=$ harpago of $H$. sempit in ventral view, $438=$ phallic organ in left lateral view.

$4^{\circ} 50^{\prime} 31.8^{\prime \prime S} 103^{\circ} 53^{\prime} 15.7^{\prime \prime E}, 2 . V I I .2009$, light trap, leg. Z. Ecsedi (1 male, OPC). A single male specimen was originally determined as a new species by the first author, but it was considered as Hydromanicus flavoguttatus by the second author and it was published accordingly as $H$. flavoguttatus. Misidentification.

Material examined. Holotype: Indonesia, Sumatra, Danau Ranau, Bukit Barisan Selatan National Park, 950 m, 2.VII.2009, light trap, leg. Z. Ecsedi (1 male, OPC).

Diagnosis. This new species having abbreviated cerci belongs to the $H$. hermosus species group as well as having phallotheca supplied with subapical ventral hook it is a member of the small H. flavoguttatus species complex. According to the harpago has resemblance to H. flavoguttatus, but differs by the fine structure of the harpago that is more slender, clearly S-shaped, not C-shaped; as well as the ventral subapical hook-formation on the phallotheca is half as long as compared to the lectotype. The new species has forewing without any pattern; the other two species of the complex have patterned forewing.
Description. Dark brown coloured animal with forewing having not any pattern; membrane is evenly covered with dense recumbent short setae. Forewing length is $13 \mathrm{~mm}$.

Male genitalia. Abdominal segment IX with small apical lobe of rounded subtriangular shape; its median keel short and narrow; anterior margin arciform, resulted in a little longer dorsum and shorter ventrum; intersegmental depression between the ninth and tenth segments deep in lateral view. Body of segment $\mathrm{X}$ broad-based less sclerotized; broad in dorsal view; without anterad curving spiny process; dorsoapical setose lobes form a short bilobed apex; setose cerci short. The basal segment of the gonopods slightly curving with spiny head; terminal segment, the harpago slender, S-shaped in ventral view. Phallic apparatus robust, phallobase only slightly broadening; subapical ventral hook of the phallotheca present, blunt, less developed; endothecal sclerites slightly elongated regular semicircular, half ovoid.

Etymology. bukit, named after the locus typicus of the holotype. 


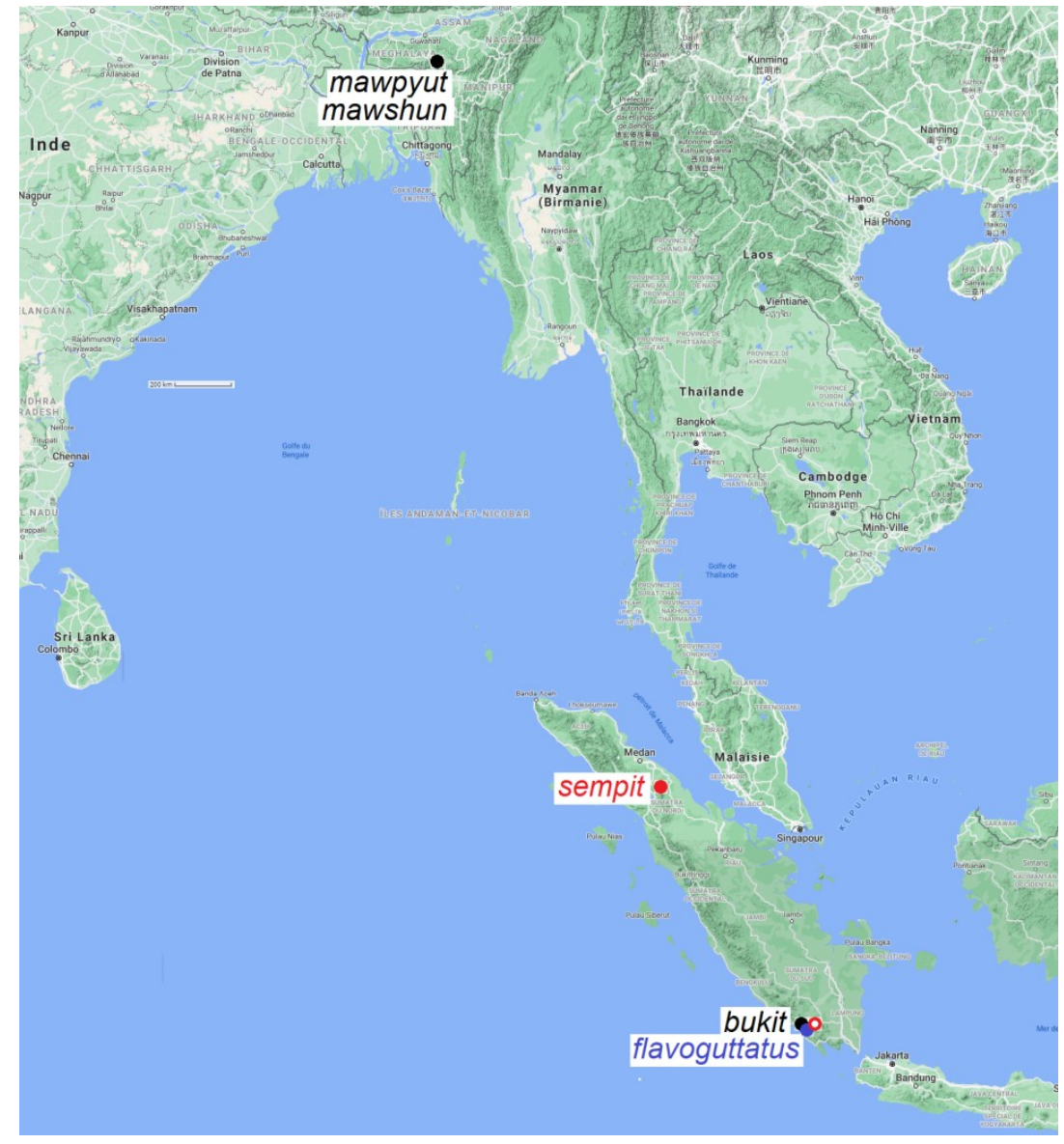

Map 28. Hydromanicus hermosus group.

\section{Hydromanicus flavoguttatus Albarda, 1881}

(Figure 436, Map 28)

Hydromanicus flavoguttatus Albarda, 1881. Neboiss, 1996:8-9. Nº/Museum Leiden, Hydromanicus flavoguttatus Alb./genitalia prep. PT-1623ð̄, A. Neboiss, 1986". "Described from Palembang and Ajer Boesoek, Sumatra."

Material examined. Indonesia, Sumatra, Bukit Barisan Selatan National Park, Way Titias, $5.068^{\circ} \mathrm{S}, 104.026^{\circ} \mathrm{E}, 850 \mathrm{~m}, 25 . \mathrm{VII}^{2} 2009$, light trap, leg. Z. Ecsedi (3 males, 1 female; OPC). Indonesia, Sumatra, Bukit Barisan Selatan National Park, Way Titias, $5.068^{\circ} \mathrm{S} 104.026^{\circ} \mathrm{E}, 950 \mathrm{~m}$, 26.VI.2009, light trap, leg. Z. Ecsedi (2 males, 2 females; OPC).

\section{Hydromanicus sempit Chantaramongkol and Malicky, 1995}

(Figure 437, Map 28)

Hydromanicus sempit Chantaramongkol and Malicky, 1995:94-95. "Holotypus đ̊: Sumatra, Aek Tarum, 180 m, 21.II.1994. Viele Paratypen von folgenden Orten auf Sumatra: Sipirok, Sodikalang, Dairi, Prapat, Sitahoan, Simarito, Pematang Siantar, Paritohan, Dolok Merangir, Huta Padang."

Material examined. Indonesia, Sumatra, Bukit Barisan Selatan National Park, Barisan Mts., Way Titias, $5.068^{\circ} \mathrm{S} 104.026^{\circ} \mathrm{E}, 800 \mathrm{~m}, 17-19 . \mathrm{VI} .2008$, light trap leg. J. Oláh jr. (2 males, SMNH). Indonesia, Sumatra, Kerinci National Park, "W" waterfall, $1500 \mathrm{~m}, 5$. VII.2008, light trap leg. J. 
Oláh jr., (1 male, OPC). Indonesia, Sumatra, Bukit Barisan Selatan National Park, Panyungkain, 950m, 24.VI.2009, light trap leg. Z. Ecsedi (2 males, OPC).

\section{Hydromanicus mawpyut sp. nov.}

(Figures 439-441, Map 5: n 64, Map 28)

Material examined. Holotype: India, Meghalaya (United Jaintia and Khasi Hills), Mawpyut, 4000 ft., 2522'20.7"N 9209'03.7"E, 14.IV.1960, leg. F. Schmid (1 male, CNC). Paratype: same as holotype (OPC).

Diagnosis. This new species belongs to the $H$. hermosus species group. According to the harpago has resemblance to $H$. mawshun described from Meghalaya, but differs by shorter segment IX and X, by the evenly very broad coxopodite; by the different forewing pattern as well as by the abbreviated almost reduced broad basement of harpago.

Description. Dark brown coloured animal with forewing of contrasted light pattern. The pattern is evenly small light spotted. Forewing length 14 $\mathrm{mm}$.

Male genitalia. Abdominal segment IX with pronounced apical lobe of rounded subtriangular shape; its median keel short and narrow; anterior margin arciform moved basad, resulted in a longer dorsum and shorter ventrum; intersegmental de- pression between the ninth and tenth segments deep in lateral view. Body of segment X broadbased less sclerotized; broad in dorsal view; anterad curving small spiny process present middle; dorsoapical setose lobes form a short bilobed apex; setose cerci short. The basal segment of the gonopods straight, evenly very broad; terminal segment, the harpago with very short broad basement and with capitate apex. Phallic apparatus robust, phallobase only slightly broadening; endothecal sclerites regular semicircular.

Etymology. mawpyut, named after the locus typicus of the holotype.

\section{Hydromanicus mawshun sp. nov.}

(Figures 442-445, Map 5: $\mathrm{n}^{\circ}$ 4, 84, Map 28)

Material examined. Holotype: India, Meghalaya (United Jaintia and Khasi Hills), Mawshun, $1500 \mathrm{ft} ., 25^{\circ} 14^{\prime} 46.7^{\prime \prime N} 91^{\circ} 58^{\prime} 21.2^{\prime \prime} \mathrm{E}, 6 . \mathrm{IV} .1960$, leg. F. Schmid (1 male, CNC). Paratype: India, Assam, United District of Mikir and North Cachar Hills, Bandarkhal, 300 ft., 9.V.1960, leg. F. Schmid (1 male, OPC).

Diagnosis. This new species belongs to the $H$. luctuosus species group. According to the harpago most close to $H$. abiud Malicky \& Chantaramongkol, 1993 described from Thailand, but differs by longer segment IX and X as well as by the different forewing pattern.

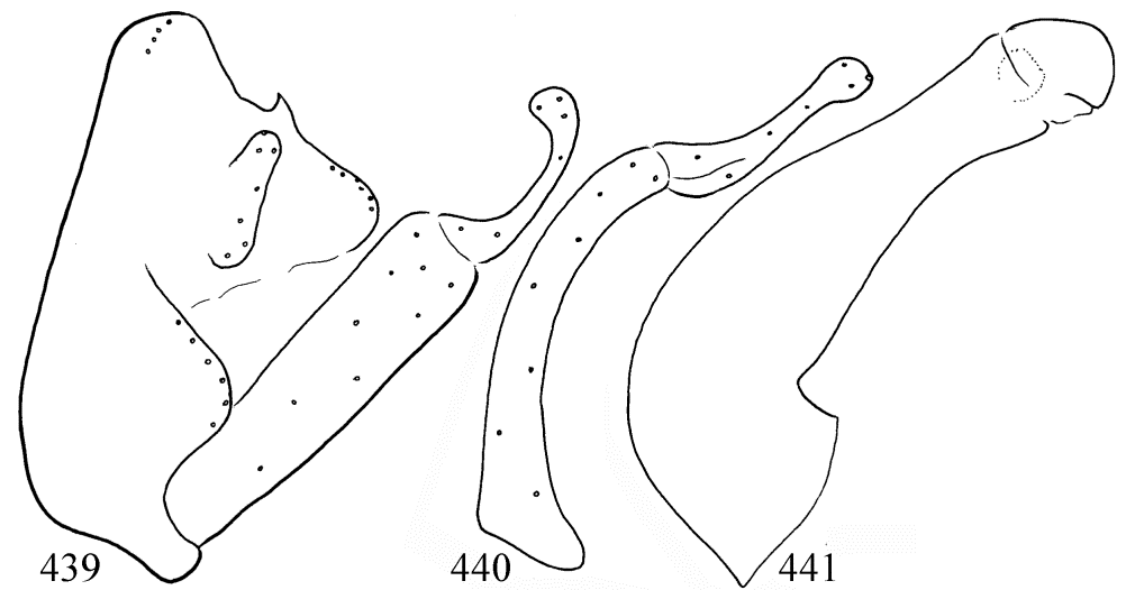

Figures 439-441. Hydromanicus mawpyut sp. nov. Holotype: $439=$ male genitalia in left lateral view, $440=$ left gonopod in ventral view, $441=$ phallic organ in left lateral view. 


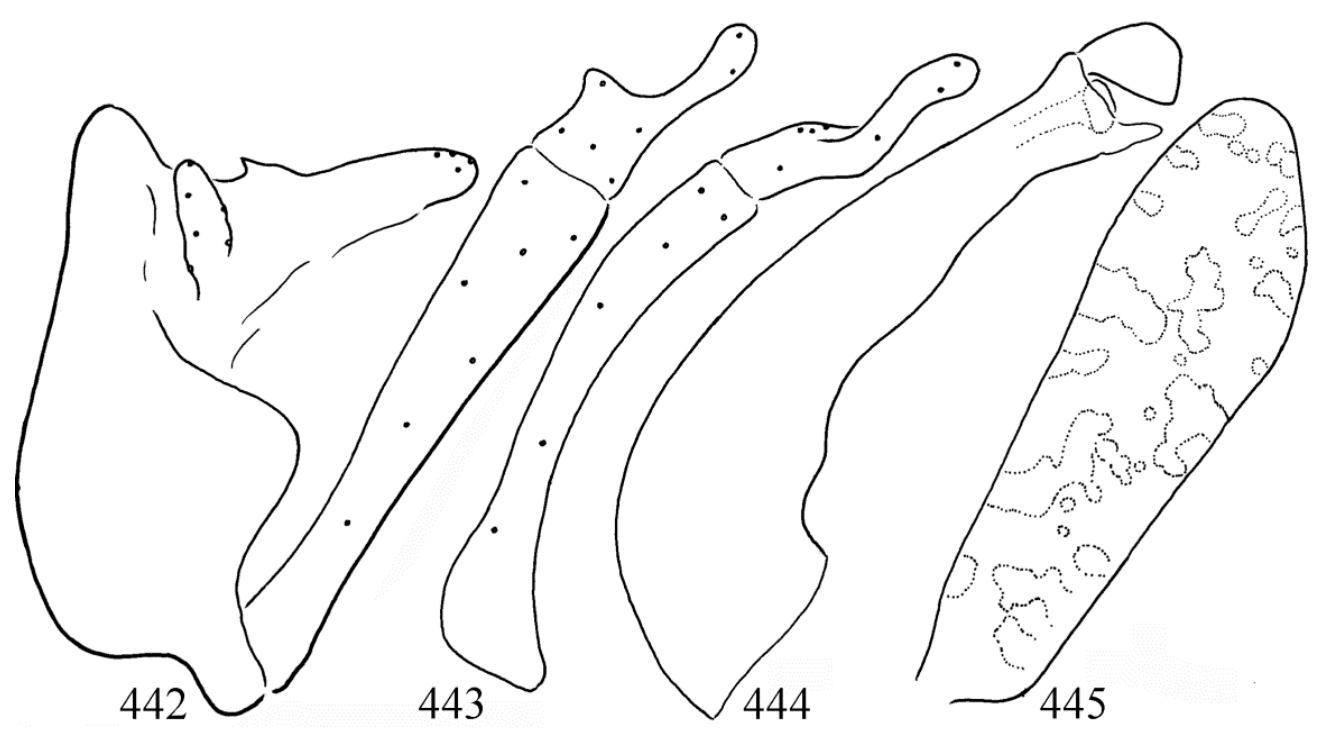

Figures 442-445. Hydromanicus mawshun sp. nov. Holotype: $442=$ male genitalia in left lateral view, $443=$ left gonopod in ventral view, $444=$ phallic organ in left lateral view, $445=$ forewing pattern.

Description. Dark brown coloured animal with forewing of contrasted light pattern. Forewing length $13 \mathrm{~mm}$.

Male genitalia. Abdominal segment IX with pronounced apical lobe of rounded subtriangular shape; its median keel short and narrow; anterior margin arciform, resulted in a very short dorsum and slightly longer ventrum; intersegmental depression between the ninth and tenth segments deep in lateral view. Body of segment X broadbased less sclerotized; broad in dorsal view; anerad curving small spiny process present middle; dorsoapical setose lobes form a long bilobed apex; setose cerci short. The basal segment of the gonopods straight, slightly and gradually broadening apicad; terminal segment, the harpago inverted L-shaped with long broad basal half. Phallic apparatus robust, phallobase only slightly broadening; endothecal sclerites regular semicircular.

Etymology. mawshun, named after the locus typicus of the holotype.

Remarks. The paratype from Assam is small, 9 $\mathrm{mm}$; its forewing is less pigmented, pattern indistinct. However, the harpago and phallic organ are similar, there is slight divergence discernible in the dorsal profile of the dorsoapical setose lobes.

\section{Hydromanicus luctuosus species group}

Hydromanicus truncatus species group in Oláh \& Johanson 2008: 25, established.

Hydromanicus luctuosus Ulmer, 1905 described from Kurseong, Annandale, West Bengal, India established as senior synonym of $H$. truncatus Betten, 1909 described from nearby Sikkim, India in Malicky 2009:41, 44.

We have established the $H$. truncatus species group by the following character state combination (Oláh \& Johanson 2008b): (1) A more or less pronounced longitudinal suture present on dorsolateral position of the segment IX, dividing it into a smaller dorsal and a larger ventral half as visible in lateral view. (2) Broad and rounded apical lobe on the segment X. (3) Elongated and narrow segment X. (4) Monolobed and long cerci. (5) Broad ventromesal subapical keel on the phallotheca.

Following the synonymy of $H$. truncatus with $H$. luctuosus, the species group name is modified here accordingly: H. luctuosus species group. Based on the organisation of the harpago, the terminal segment of the gonopod, the H. luctuosus 
species group is comprised of four species complexes: $H$. asor new species complex, $H$. eleasar new species complex, $H$. inferior new species complex, H. luctuosus new species complex.

\section{Hydromanicus asor new species complex}

(Map 29)

Hydromanicus asor species complex in the $H$. luctuosus species group is characterized by the most plesiomorphic harpago having the shape of single parallel-sided pattern with narrowing apex. The following species belong to this complex: $H$. almansor Malicky, 1993 (Myanmar); H. asor Malicky, 1993 (Myanmar); H. eliakim Malicky, 1993 (Thailand); H. punctosalis Mey, 1996 (Vietnam); H. shilliang sp. nov. (India, Meghalaya).

\section{Hydromanicus shilliang sp. nov.}

(Figures 446-449, Map 5: n 70, Map 29)

Material examined. Holotype: India, Meghaláya (United Jaintia and Khasi Hills), Shilliang Myntang [= Shiliangmyntang], $3500 \mathrm{ft}$., 25 ${ }^{\circ} 33^{\prime}$ 55.6"N 92²1'32.5"E, 21.IV.1960, leg. F. Schmid (1 male, CNC).

Diagnosis. This new species belongs to the $H$. luctuosus species group and to the $H$. asor species complex. Most close to $H$. inferior, but differs by the short and mesad directed dorsoapical setose lobes and by the lateral profile of the phallic organ; the apicoventral keel on the phallotheca is very long, not short.

Description. A brown coloured animal with light spotted forewing; forewing length is $9 \mathrm{~mm}$.

Male genitalia. Abdominal segment IX divided by suture into a smaller dorsal and a larger ventral part; its median keel short and narrow; anterior margin arciform, resulted in a very short dorsum and slightly longer ventrum; apical lobe on posterolateral margin robust semicircular, comprising the bulk of the segment; intersegmental depression between the ninth and tenth segments low in lateral view. Body of segment X broad-based less sclerotized; setose cerci elon- gated foliform with less setose digitiform apical part; dorsoapical setose lobes form the short mesad directed bilobed apex of segment X. The basal segment of the gonopods straight broadening apicad; terminal segment, the harpago parallel-sided with digitate apex. Phallic apparatus robust, subapical ventral keel long and shallow, endothecal sclerites quadrangular.

Etymology. shilliang, named after the locus typicus of the holotype.

\section{Hydromanicus eleasar new species complex}

(Map 29)

This small species complex is a member of $H$. luctuosus species group with broad ventromesal subapical keel on the phallotheca and characterised by a very short, pointed and slightly Sshaped harpago in ventral view.

There are divergences in the usually neutral periphallic organs that are in the shape of the bilobed head of segment $X$, in the length and shape of the cerci as well as in the lateral shape of the coxopodite and the ventral shape of the harpago. The terminal harpago, the second segment of the gonopods is particularly divergent with high diversity and with rather significant stability in the entire $H$. luctuosus species group including $H$. eleasar new species complex. Harpago has high diagnostic value to delineate species complexes inside the species group.

The delineation of the incipient sibling species in the $H$. eleasar species complex is based primarily on the lateral shape of the strongly chitinized pair of the endothecal sclerites supported by character combinations of periphallic organs. However, to draw exactly the comparable lateral shape of endothecal sclerites is not easy and practically impossible in dorsal, ventral or caudal view. Endothecal sclerites are an active movable structure capable to realise functional copulatory movements in almost all directions, downward, upward, laterad and mesad. Most of the published drawings were prepared without proper attention to the possibilities of such functional shape distortions. 


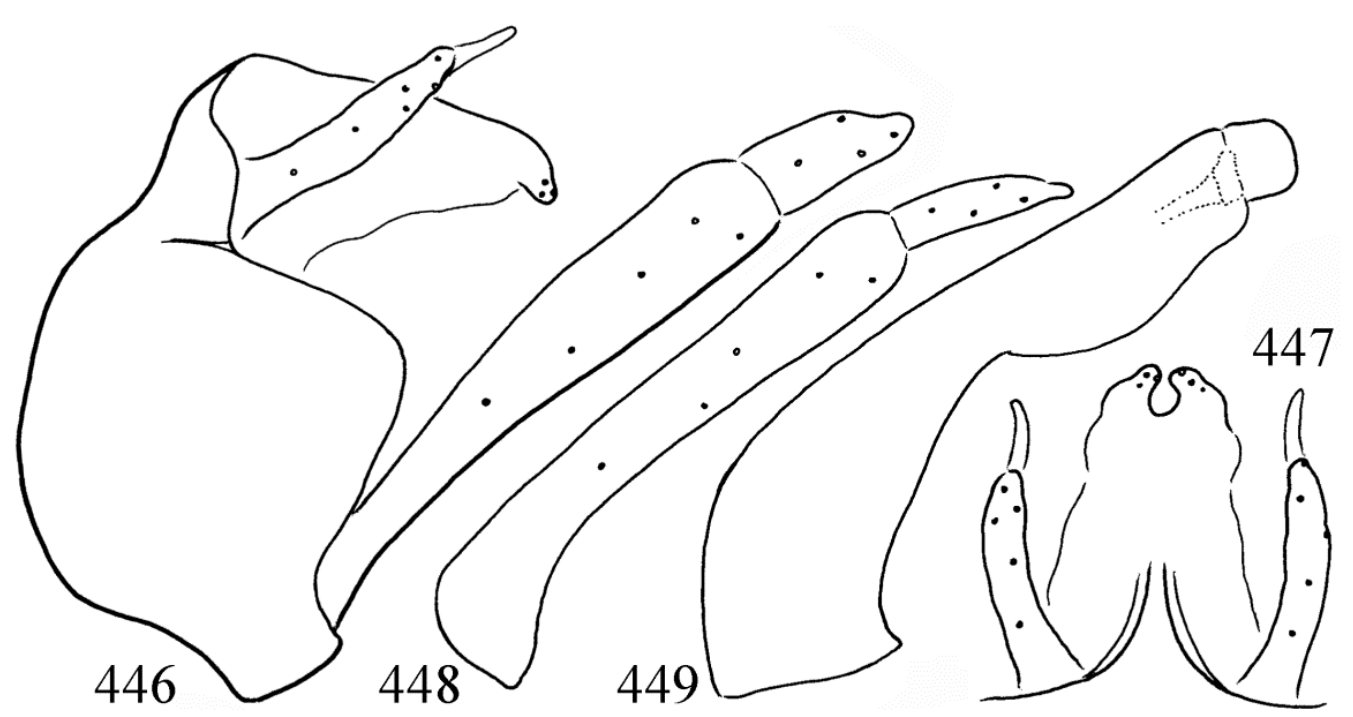

Figures 446-449. Hydromanicus shilliang sp. nov. Holotype: $446=$ male genitalia in left lateral view, $447=$ male genitalia in dorsal view, 448 = left gonopod in ventral view, 449 = phallic organ in left lateral view.

The following species belong to the $H$. eleasar species complex in the $H$. luctuosus species group: H. eleasar Malicky, 1993 (Nepal, Dhankuta), H. kambaitiensis sp. nov. (Myanmar), $H$ kamengensis sp. nov. (India, Assam, Kameng), $H$. kashong sp. nov. (India, Manipur), H. sikkimensis sp. nov. (India, Sikkim), H. tibetensis sp. nov. (China, Tibet).

\section{Hydromanicus eleasar Malicky, 1993}

(Map 29)

Hydomanicus eleasar Malicky, 1993:1123: "Holotypus त: Ost-Nepal, Dhankuta, Arun-Tal, SE des Makalu, Tashigaon, 2100m, 7.VI.1980."

\section{Hydromanicus kambaitiensis sp. nov.}

(Figures 450-452, Map 29)

Material examined. Holotype: Myanmar, Kambaiti [=Kan Paik Ti], 7000ft, 25 24'04.0"N 9806'55.4"E, 13-22.VI.1934, leg. R. Malaise (1 male, Coll. Malaise B.M. 1938-258, BMNH)

Diagnosis. This new species having broad ventromesal subapical keel on the phallotheca belongs to the H. luctuosus species group and having short, tapering, and slightly S-shaped har pago belongs to the H. eleasar species complex. Most close to H. kamengensis sp. nov., but differs by the character combination of the pronounced but obtuse-angled intersegmental depression, upward located and short head of segment X, short cerci, short and very stout coxopodite; The ventromesal subapical keel on the phallotheca is more circular than triangular. The shape of the endothecal sclerites is with pronounced constricted neck.

Description. A brown coloured animal with forewing without discernible light spotted pattern (old specimen!), forewing length is $11 \mathrm{~mm}$.

Male genitalia. Abdominal segment IX divided by suture into a smaller dorsal and a larger ventral part; its median keel medium-long and narrow; anterior margin arciform, resulted in a very short dorsum and slightly longer ventrum; apical lobe on posterolateral margin robust semicircular, comprising the bulk of the segment with long marginal setae; intersegmental depression between the ninth and tenth segments obtuseangled in lateral view. Body of segment X broadbased less sclerotized; its bilobed apex is upward positioned and short. Setose cerci short foliform, shorter than segment X. The basal segment of the gonopods straight, short and robust stout; terminal 


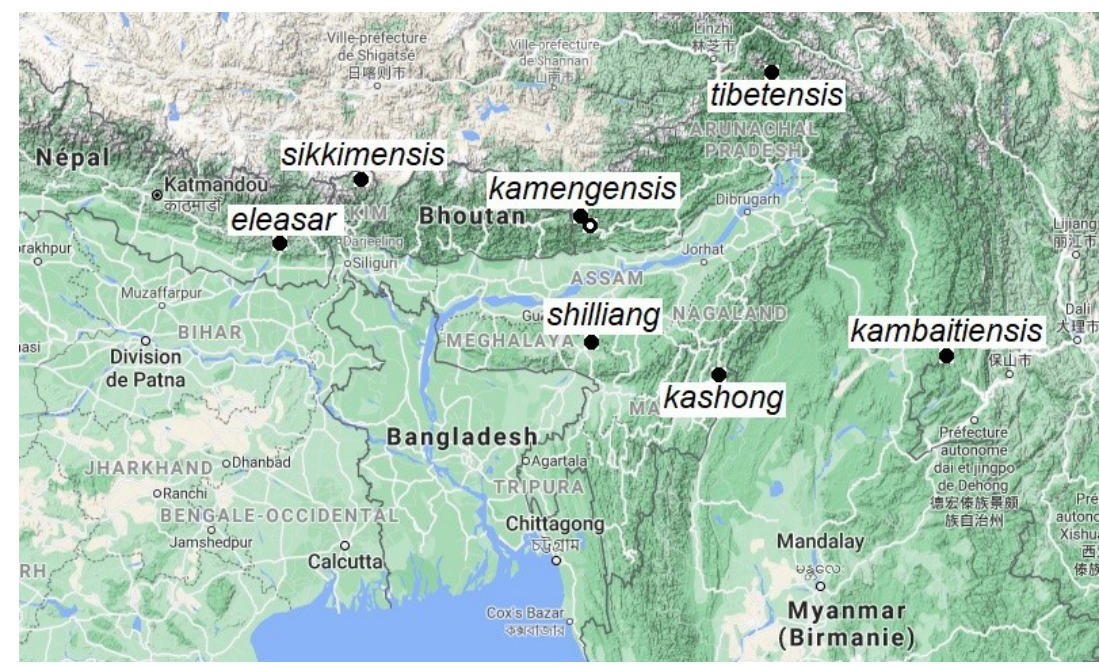

Map 29. Hydromanicus asor and eleasar complexes.

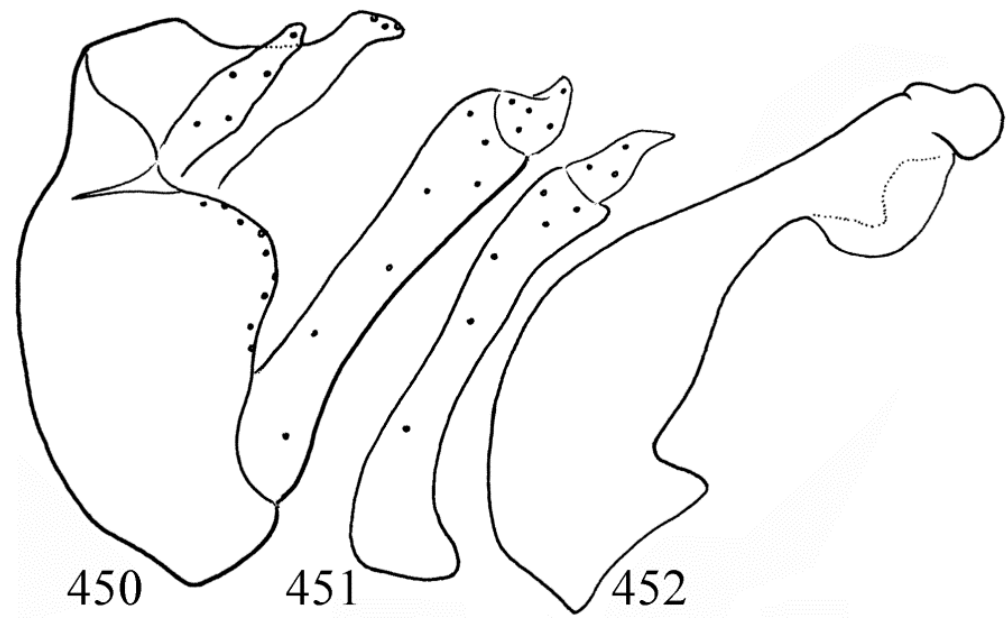

Figures 450-452. Hydromanicus kambaitiensis sp. nov. Holotype: $450=$ male genitalia in left lateral view, $451=$ left gonopod in ventral view, 452 = phallic organ in left lateral view.

segment, the harpago with mesad turning narrowing apex. Phallic apparatus robust, subapical ventral keel short semicircular, endothecal sclerites short with constricted neck.

Etymology. kambaitiensis, named after the locus typicus of the holotype.

\section{Hydromanicus kamengensis sp. nov.}

(Figures 453-455, Map 4: $\mathrm{n}^{\circ}$ 23, 69, 70, Map 29)

Material examined. Holotype: India, Arunachal Pradesh (Assam), Kameng District, Chug,
6800-7300 ft., $27^{\circ} 25^{\prime} 07.7^{\prime \prime} \mathrm{N} 92^{\circ} 14^{\prime} 01.0 " \mathrm{E}, 25-$ 31.VII.1961, leg F. Schmid (1 male, CNC). Paratype: same as holotype (1 male, OPC). India, Arunachal Pradesh (Assam), Kameng, Nyukmadong, 6600-8000 ft., 27²4'32.5"N 92 $07^{\circ} 57.3 " \mathrm{E}$, 5-8.VIII.1961, leg F. Schmid (1 male, CNC). India, Arunachal Pradesh (Assam), Kameng, Rahung, 6500-7000 ft., 27 $18^{\prime} 46.2^{\prime \prime} \mathrm{N} 92^{\circ} 23^{\prime} 43.8^{\prime \prime} \mathrm{E}$, 16.VII.1961, leg F. Schmid (1 male, SMNH).

Diagnosis. This new species having broad ventromesal subapical keel on the phallotheca belongs to the $H$. luctuosus species group and 
having short, tapering, and slightly S-shaped harpago belongs to the $H$. eleasar species complex. Most close to H. kambaitiensis sp. nov., but differs by the character combination of the pronounced almost right-angled intersegmental depression, upward located and elongated head of segment $\mathrm{X}$, longer cerci, longer and more slender coxopodite. The ventromesal subapical keel on the phallotheca more triangular, not circular. The shape of the endothecal sclerites lacks constricted neck.

Description. A brown coloured animal with forewing with just discernible light spotted pattern, forewing length $10 \mathrm{~mm}$.

Male genitalia. Abdominal segment IX divided by suture into a smaller dorsal and a larger ventral part; its median keel medium-long and narrow; anterior margin arciform, resulted in a very short dorsum and slightly longer ventrum; apical lobe on posterolateral margin robust semicircular, comprising the bulk of the segment with long marginal setae; intersegmental depression between the ninth and tenth segments right-angled in lateral view. Body of segment X broad-based less sclerotized; its bilobed apex is upward positioned. Setose cerci elongated foliform, as long as segment $\mathrm{X}$. The basal segment of the gonopods only slightly arching with less constricted middle; terminal segment, the harpago with mesad turning narrowing apex. Phallic apparatus robust, subapical ventral keel short triangular, endothecal sclerites short with small ventral lobe.

Etymology. kamengensis, named after the locus typicus of the holotype.

\section{Hydromanicus kashong sp. nov.}

(Figures 456-458, Map 6: $\mathrm{n}^{\circ}$ 14, Map 29)

Material examined. Holotype: India, Manipur, Sirohi Kashong [=Siruhi Kashong], 7000-7500 ft,

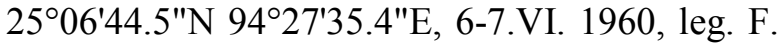
Schmid (1 male, CNC).

Diagnosis. This new species having broad ventromesal subapical keel on the phallotheca belongs to the H. luctuosus species group and having short, tapering, and slightly S-shaped harpago belongs to the $H$. eleasar species complex. Most close to $H$. kambaitiensis sp. nov., but differs by the character combination of the pronounced apical lobe with flat dorsum on the posterolateral margin of segment IX; of the more developed coxopodite with enlarged basal region; of the distinctly S-shaped harpago, the most pronounced curving in the species complex; of the very low, slender neck on the phallic shaft, behind the subapical ventral keel, of the differently patterned lateral profile of the endothecal sclerites.

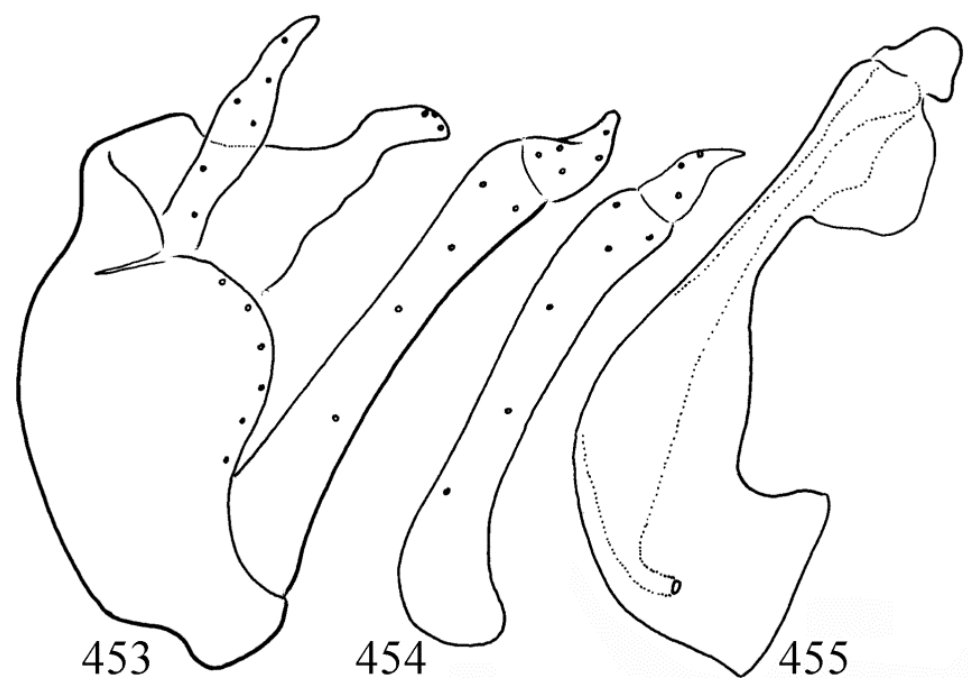

Figures 453-455. Hydromanicus kamengensis sp. nov. Holotype: 453 = male genitalia in left lateral view, $454=$ left gonopod in ventral view, 455 = phallic organ in left lateral view. 


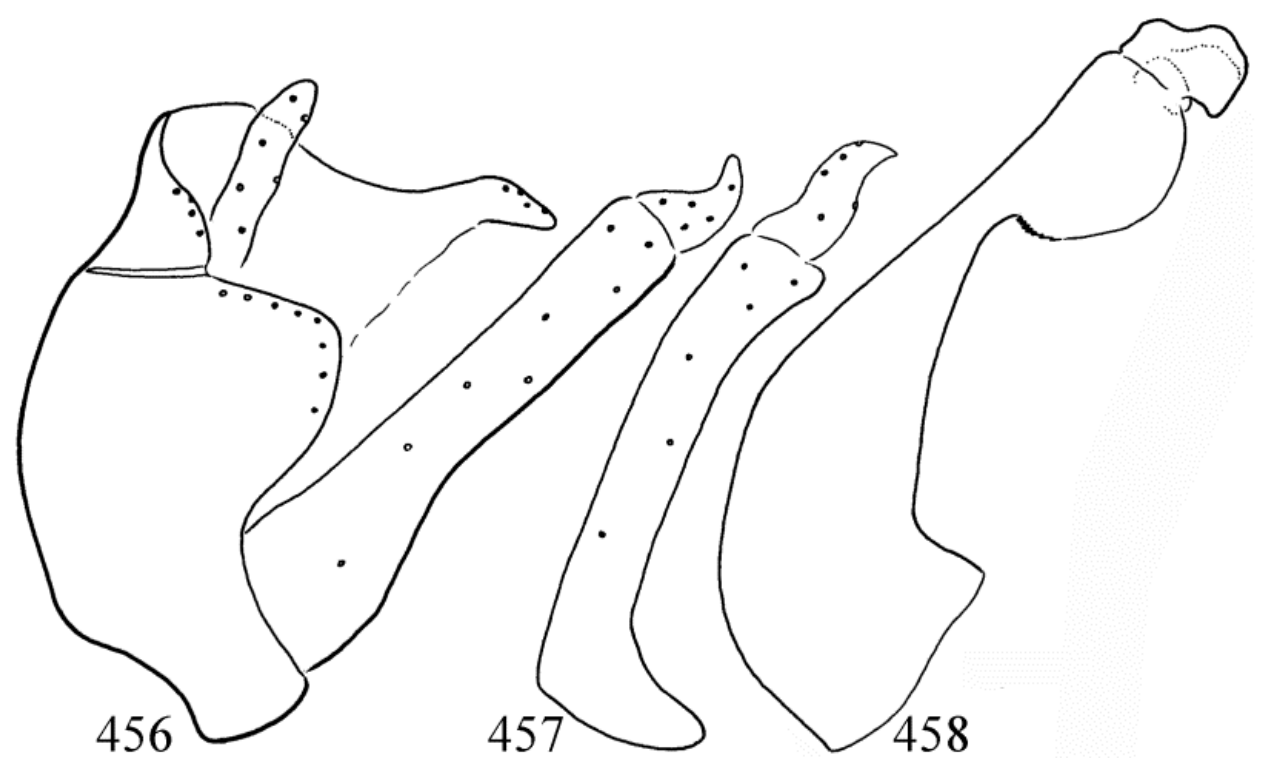

Figures 456-458. Hydromanicus kashong sp. nov. Holotype: 456 = male genitalia in left lateral view, 457 = left gonopod in ventral view, 458 = phallic organ in left lateral view.

Description. A brown coloured animal with forewing with just discernible light spotted pattern (old specimen!), forewing length $11 \mathrm{~mm}$.

Male genitalia. Abdominal segment IX divided by a suture into a smaller dorsal and a larger ventral part; its median keel medium-long and narrow; anterior margin arciform, resulted in a very short dorsum and longer ventrum; apical lobe on posterolateral margin robust semicircular with flat dorsum, comprising the bulk of the segment with long marginal setae; intersegmental depression between the ninth and tenth segments obtuse-angled in lateral view. Body of segment X broad-based less sclerotized; its bilobed apex upward positioned elongated and tapering. Setose cerci short foliform, shorter than segment $\mathrm{X}$. The basal segment of the gonopods straight, short and robust stout with enlarged basement; terminal segment, the harpago pronounced S-shaped in lateral view. Phallic apparatus robust with very low slender neck, behind the ventral keel; subapical ventral keel short semicircular, endothecal sclerites short with constricted neck.

Etymology. kashong, coined from the name of holotype locus typicus.

\section{Hydromanicus sikkimensis sp. nov.}

(Figures 459-461, Map 29)

Material examined. Holotype: India, Sikkim, Yoongn, could correspond to the Yumthang Val-

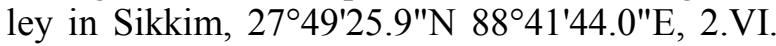
1928, leg. Lt. Col. F. M. Bailey, (1 male, B.M. 1928-409, BMNH).

Diagnosis. This new species having broad ventromesal subapical keel on the phallotheca belongs to the H. luctuosus species group and having short, tapering, and slightly S-shaped harpago belongs to the $H$. eleasar species complex. Most close to $H$. eleasar, but differs by the character combination of the low intersegmental depression, capitate head of segment X, long cerci, arching coxopodite, long harpago. The shape of the endothecal sclerites is short, not long.

Description. A brown coloured animal with forewing without discernible pattern (old specimen!), forewing length is $13 \mathrm{~mm}$.

Male genitalia. Abdominal segment IX divided by suture into a smaller dorsal and a larger ventral part; its median keel medium-long and 


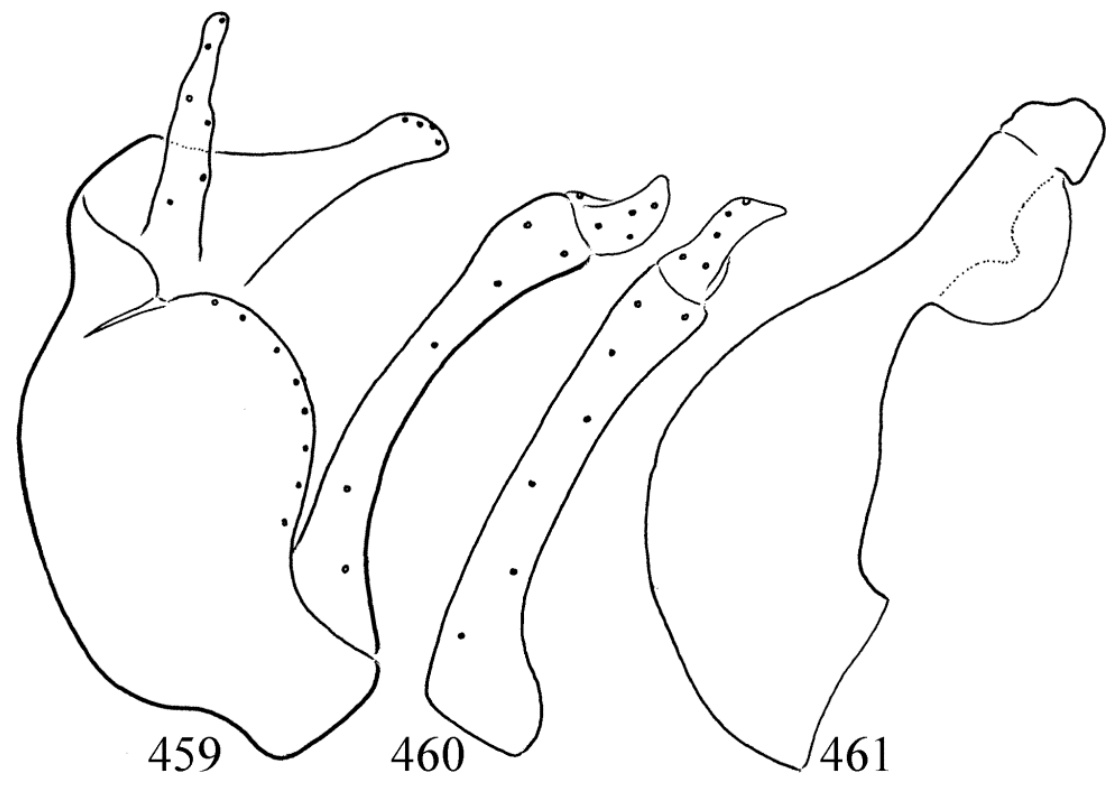

Figures 459-461. Hydromanicus sikkimensis sp. nov. Holotype: $459=$ male genitalia in left lateral view, $460=$ left gonopod in ventral view, $461=$ phallic organ in left lateral view.

narrow; anterior margin arciform, resulted in a very short dorsum and slightly longer ventrum; apical lobe on posterolateral margin robust semicircular, comprising the bulk of the segment with long marginal setae; intersegmental depression between the ninth and tenth segments low in lateral view. Body of segment X broad-based less sclerotized; its bilobed apex capitate, slightly upward directed. Setose cerci elongated foliform, as long as segment $\mathrm{X}$. The basal segment of the gonopods arching with constricted middle; terminal segment, the harpago with mesad turning narrowing apex. Phallic apparatus robust, subapical ventral keel short and high, semicircular, endothecal sclerites short.

Etymology. sikkimensis, named after the locus typicus of the holotype.

\section{Hydromanicus tibetensis sp. nov.}

(Figures 462-464, Map 29)

Hydromanicus luctuosus Ulmer, 1905. Oláh et al. 2020b: 169. Misidentification!

Material examined. Holotype: China, Tibet, Motuo, 80K 1000m, 29²0'05.3"N 95¹9'41.3"E,
24.VII.2012, leg. Li Wenliang (1 male, DPPHIST). Paratypes: same as holotype (3 males, DPP-HIST; 2 males, OPC).

Diagnosis. This new species having broad ventromesal subapical keel on the phallotheca belongs to the $H$. luctuosus species group and having short, tapering, and slightly S-shaped harpago belongs to the $H$. eleasar species complex. Most close to $H$. sikkimensis, but differs by the character combination of the more pronounced intersegmental depression, narrowing, not capitate head of segment $X$, long cerci, straight and very stout not slender and arching coxopodite, harpago differently shaped. The shape of the endothecal sclerites is short, with more pronounced anterad directed ventrobasal lobe.

Description. A brown coloured animal with forewing with discernible pattern of light spots on dark brown membrane. Forewing length $12 \mathrm{~mm}$. Male genitalia. Abdominal segment IX divided by suture into a smaller dorsal and a larger ventral part; its median keel short and narrow; anterior margin arciform, resulted in a very short dorsum and slightly longer ventrum; apical lobe on posterolateral margin robust semicircular, com- 


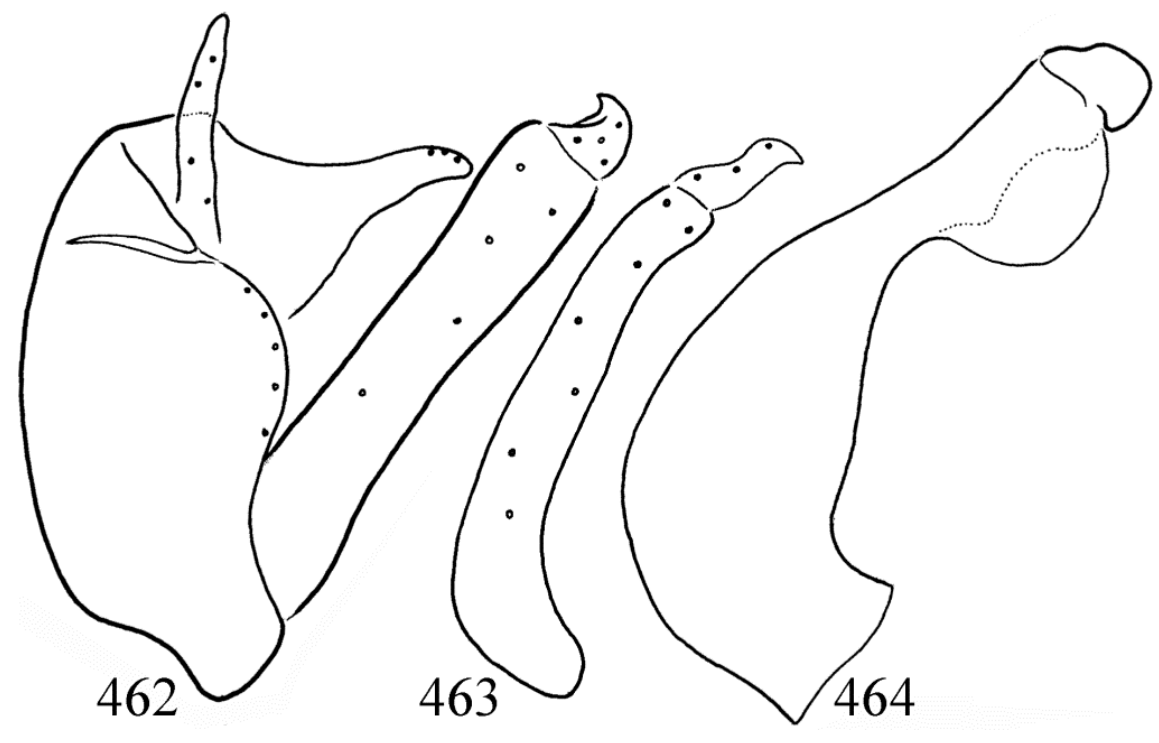

Figures 462-464. Hydromanicus tibetensis sp. nov. Holotype: $462=$ male genitalia in left lateral view, $463=$ left gonopod in ventral view, $464=$ phallic organ in left lateral view.

prising the bulk of the segment with long marginal setae; intersegmental depression between the ninth and tenth segments pronounced in lateral view. Body of segment $\mathrm{X}$ broad-based less sclerotized; its bilobed apex tapering, slightly downward directed. Setose cerci elongated foliform, as long as segment $\mathrm{X}$. The basal segment of the gonopods short, straight and very stout; terminal segment, the harpago with mesad turning narrowing apex of undulating external margin in ventral view. Phallic apparatus robust, subapical ventral keel short and high, semicircular, endothecal sclerites short with anterad turning ventrobasal small lobe.

Etymology. tibetensis, named after the locus typicus of the holotype.

\section{Hydromanicus inferior new species complex}

Hydromanicus inferior new species complex in the H. luctuosus species group is characterized with a finger-tipped harpago. It means that the very tip of harpago is suddenly narrowing into a slender finger-like straight or curving ending. Following species belong to this complex: $H$. angulatus Yang \& Yang, 2004 (China, Guangyi); H. fallax Mey, 1996 (Vietnam); H. hasad sp. nov.
(India, Manipur); H. heges Oláh, Oláh \& Li, 2020 (China, Tibet); H. hullamos Oláh, 2013 (Vietnam); H. inferior Chantaramongkol \& Malicky, 1995 (Thailand); H. jakhand sp. nov. (India, Uttarakhand, Teri Garhwal); H. mattiyang sp. nov. (India, Manipur); H. mynso sp. nov. (India, Meghaláya); $H$. nondeng sp. nov. (India, Meghaláya); H. serubel Malicky \& Chantaramongkol, 1993 (Thailand).

\section{Hydromanicus darban sp. nov.}

(Figures 465-467, Map 5: n 84, Map 30)

Material examined. Holotype: India, Assam, United District of Mikir and North Cachar Hills, Bandarkhal, $300 \mathrm{ft} ., 25^{\circ} 03^{\prime} 31.1^{\prime \prime} \mathrm{N} 92^{\circ} 48^{\prime} 02.5^{\prime \prime} \mathrm{E}$, 9.V.1960, leg. F. Schmid (1 male, CNC). Paratypes: same as holotype (1 male, OPC; 1 male, SMNH).

Diagnosis. This new species belongs to the $H$. luctuosus species group and to the $H$. inferior species complex. Having small finger-like apicomesal lobe on harpago in ventral view it has resemblance to $H$. nondeng sp. nov., but differs by the head of cerci having apex ventral digitate, not dorsal digitate in lateral view; by the lateral pro 


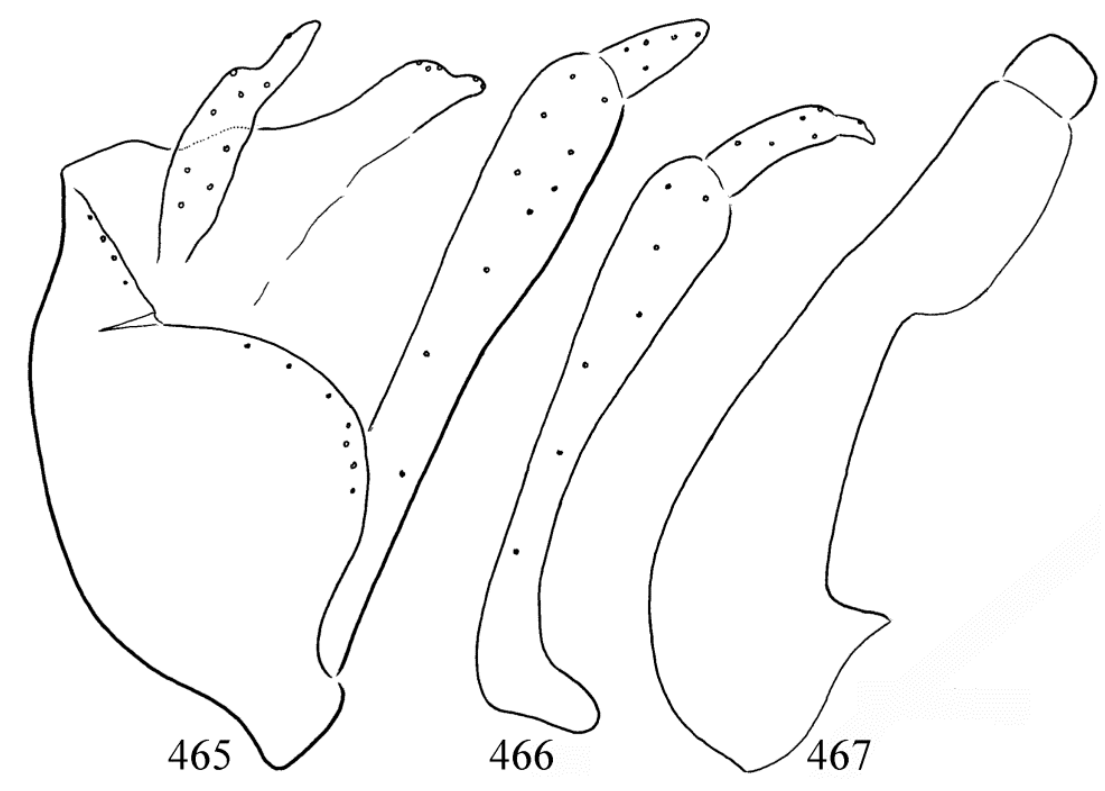

Figures 465-467. Hydromanicus darban sp. nov. Holotype: $465=$ male genitalia in left lateral view, $466=$ left gonopod in ventral view, $467=$ phallic organ in left lateral view.

file of segment $X$ that is its apex concave, not straight in lateral view; by the shape of the fingerlike apicomesal lobe on the harpago that is downward directed. The lateral shape of the subapical mesal keel on the ventrum not broadening anterad; endothecal sclerites regular quadrangular.

Description. A brown coloured animal; forewing distinctly light spotted, forewing length 10 $\mathrm{mm}$.

Male genitalia. Abdominal segment IX divided by a tiny suture into a smaller dorsal and a larger ventral part; its median keel medium-long and narrow; anterior margin arciform, resulted in a very short dorsum and longer ventrum; apical lobe on posterolateral margin rounded produced; intersegmental depression between the ninth and tenth segments low in lateral view. Body of segment X elongated, broad-based, less sclerotized ventrally; apex of segment $\mathrm{X}$ concave in lateral view; setose cerci elongated foliform with ventral digitate apex. The basal segment of the gonopods straight and constricted basally; terminal segment, the harpago with a broad finger-like apicomesal mesad curving lobe. Phallic apparatus slender with low curving basal half, subapical ventral keel long, not broadening anterad; endothecal sclerites short and quadrangular.

Etymology. darban, coined from the name of the holotype locus typicus.

\section{Hydromanicus hasad sp. nov.}

(Figures 468-470, Map 6: $\mathrm{n}^{\circ}$ 18, 23, 28, Map 30)

Material examined. Holotype: India, Manipur, Mapum, $5000 \mathrm{ft}, 25^{\circ} 04^{\prime} 55.9^{\prime \prime} \mathrm{N}$ 94³0'16.9"E, 11.VI.1960, leg. F. Schmid (1 male, CNC). Paratypes: same as holotype (1 male, CNC; 1 male, OPC; 1 male SMNH). India, Manipur, Loni [=Roni], $4500-5500 \mathrm{ft}, \quad 25^{\circ} 03^{\prime} 41.8^{\prime \prime} \mathrm{N} \quad 94^{\circ} 34^{\prime}$ 18.8"E, 16.VI.1960, leg. F. Schmid (3 males, CNC). India, Manipur, Sihai Khulen [=Sihai Khullen], 4700 ft, 25.V.1960, 2511'32.1"N 94²9'31.5"E, leg. F. Schmid (2 males, CNC).

Diagnosis. This new species belongs to the $H$. luctuosus species group and to the $H$. inferior species complex. Having curving finger-tipped harpago in ventral view it has resemblance to $H$. mattiyang sp. nov., but differs by the apical lobe on posterolateral margin less produced; by the 


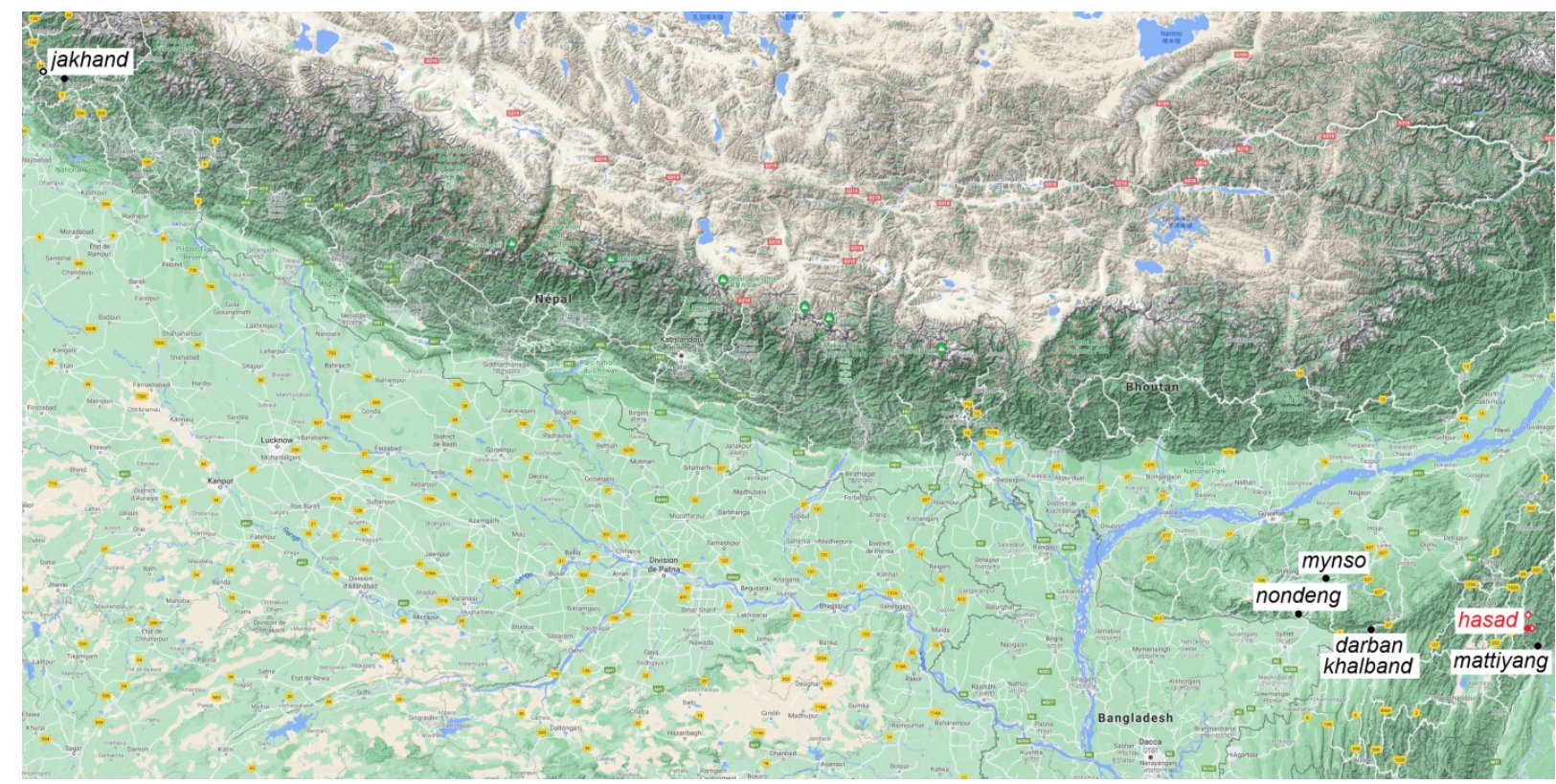

Map 30. Hydromanicus inferior complex.

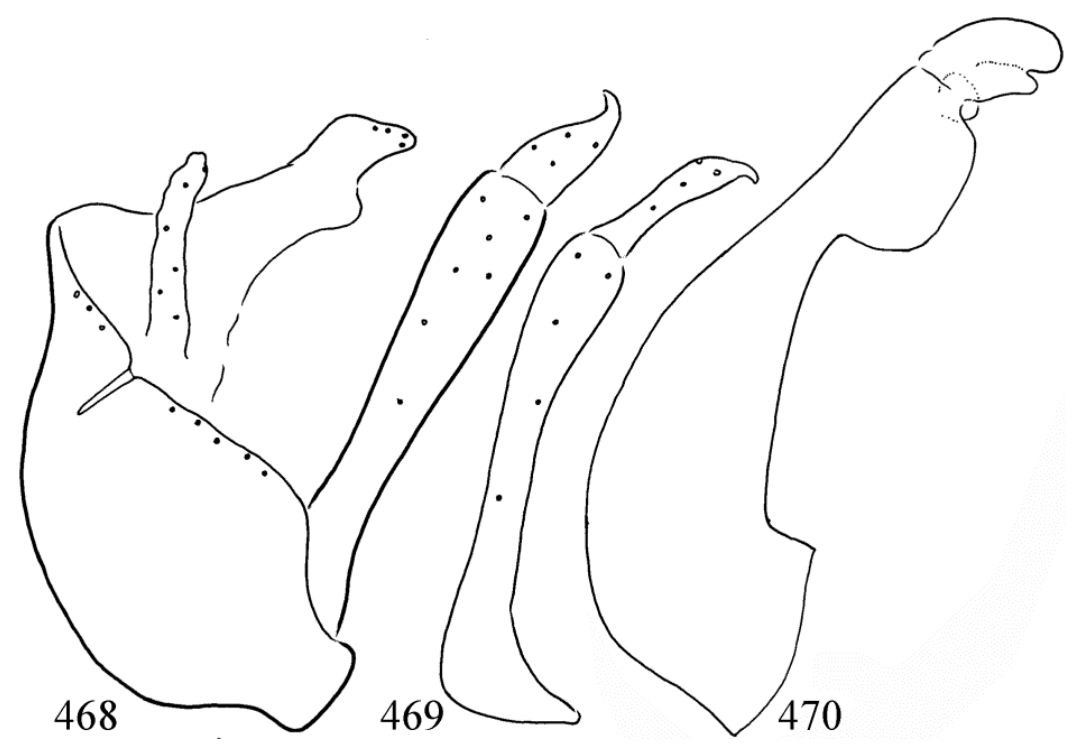

Figures 468-470. Hydromanicus hasad sp. nov. Holotype: $468=$ male genitalia in left lateral view, $469=$ left gonopod in ventral view, $470=$ phallic organ in left lateral view.

dorsoapical setose lobe that is bilobed both in dorsal and lateral views, by the shape of the longer finger-tipped harpago; by the shorter and more blunt finger-tip; as well as by the more produced and high ventroapical keel and the split endothecal sclerites of the phallic organ.
Description. A brown coloured animal with slightly light spotted forewing of length $15 \mathrm{~mm}$.

Male genitalia. Abdominal segment IX divided by suture into a smaller dorsal and a larger ventral part; its median keel medium-long and narrow; anterior margin arciform, resulted in a 
very short dorsum and slightly longer ventrum; apical lobe on posterolateral margin less produced; intersegmental depression between the ninth and tenth segments low in lateral view. Body of segment $\mathrm{X}$ broad-based less sclerotized; setose cerci elongated digitiform; dorsoapical setose lobes bilobed both in lateral and dorsal views. The basal segment of the gonopods robust; terminal segment, the harpago pronounced finger-tipped, visible especially in ventral view; the tip is curving and blunt. Phallic apparatus robust, subapical ventral keel high; endothecal sclerites elongated, downward curving and split apicad.

Etymology. hasad, coined from "hasadt" split in Hungarian, refers to the pair of endothecal sclerites of the phallic organ, split into a larger more sclerotized upper and a smaller less sclerotized lower region, subdivided apicad.

\section{Hydromanicus jakhand sp. nov.}

(Figures 471-473, Map 2: nº 12, 15, Map 30)

Material examined. Holotype: India, Uttarakhand, Tehri Garhwal, Jakhaur [= Jakhanr] according to Lonsdale (2020) [=Jahkand], $3500 \mathrm{ft}$., below the village, small river tributary of Alaknanda River, 30¹9'49.4"N 78³9'20.9"E, 24.IV. 1958, leg. F. Schmid (1 male, CNC). Paratype: India, Tehri Garhwal, Jaspur, 3500-4500 ft., 30 ${ }^{\circ}$ 23'34.7"N 78²5'21.4"E, 15.IV.1958, leg. F. Schmid (1 male, OPC).

Diagnosis. This new species belongs to the $H$. luctuosus species group and to the Hydromanicus inferior species complex. Having small finger-like apicomesal lobe on harpago in ventral view it has resemblance to $H$. mynso sp. nov. but differs by the head of cerci having apex slightly capitate, not digitate; by the lateral profile of segment $\mathrm{X}$ that is trilobed, not bilobed; by the shape of the fingerlike apicomesal lobe on the harpago that is not slender, rather broad. The lateral shape of the phallic organ rather different; subapical mesal keel on the ventrum very low, not high.
Description. A brown coloured animal; forewing slightly and indistinctly light spotted, forewing length $9 \mathrm{~mm}$.

Male genitalia. Abdominal segment IX divided by a tiny suture into a smaller dorsal and a larger ventral part; its median keel medium-long and narrow; anterior margin arciform, resulted in a very short dorsum and longer ventrum; apical lobe on posterolateral margin rounded produced; intersegmental depression between the ninth and tenth segments low in lateral view. Body of segment X elongated, broad-based, less sclerotized; dorsoapical setose lobes form a trilobed apex of segment $X$ with a ventral spine like process discernible in lateral view; setose cerci elongated foliform with slightly capitate apex. The basal segment of the gonopods slightly arching and constricted middle; terminal segment, the harpago with a broad finger-like apicomesal lobe. Phallic apparatus slender, subapical ventral keel low with serrated anterior half, endothecal sclerites short and semicircular.

Etymology. jakhand, coined from the name of holotype locus typicus.

\section{Hydromanicus khalband sp. nov.}

(Figures 474-476, Map 5: $\mathrm{n}^{\circ}$ 84, Map 30)

Material examined. Holotype: India, Assam, United District of Mikir and North Cachar Hills, Bandarkhal, $300 \mathrm{ft} ., 25^{\circ} 03^{\prime} 31.1^{\prime \prime} \mathrm{N} 92^{\circ} 48^{\prime} 02.5^{\prime \prime} \mathrm{E}$, 9.V.1960, leg. F. Schmid (1 male, CNC). Paratype: same as holotype (1 male, OPC).

Diagnosis. This new species belongs to the $H$. luctuosus species group and to the $H$. inferior species complex. Having pointed-tipped harpago in ventral view and short endothecal sclerites it has resemblance to $H$. mattiyang sp. nov., but differs by the apical lobe on posterolateral margin produced, rounded, not regularly triangular; by the slender coxopodite; the dorsoapical setose lobe with downward turning apex, not straight; the shorter pointed-tipped harpago; as well as by 


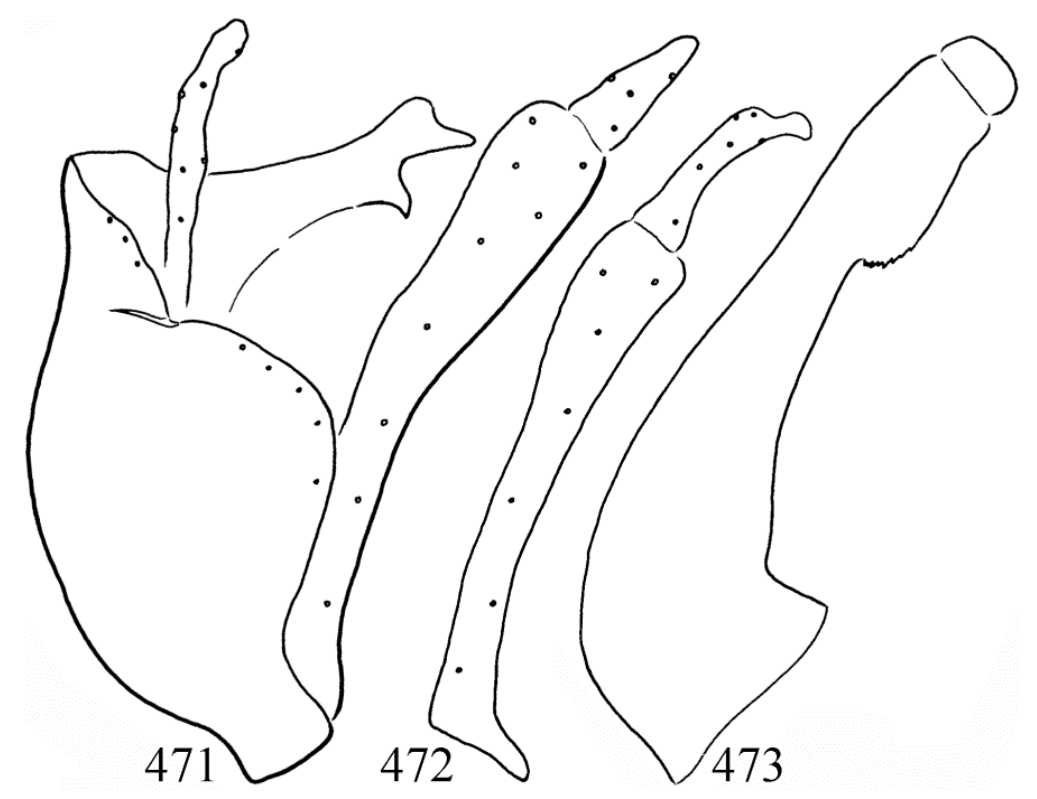

Figures 471-473. Hydromanicus jakhand sp. nov. Holotype: $471=$ male genitalia in left lateral view, $472=$ left gonopod in ventral view, $473=$ phallic organ in left lateral view.

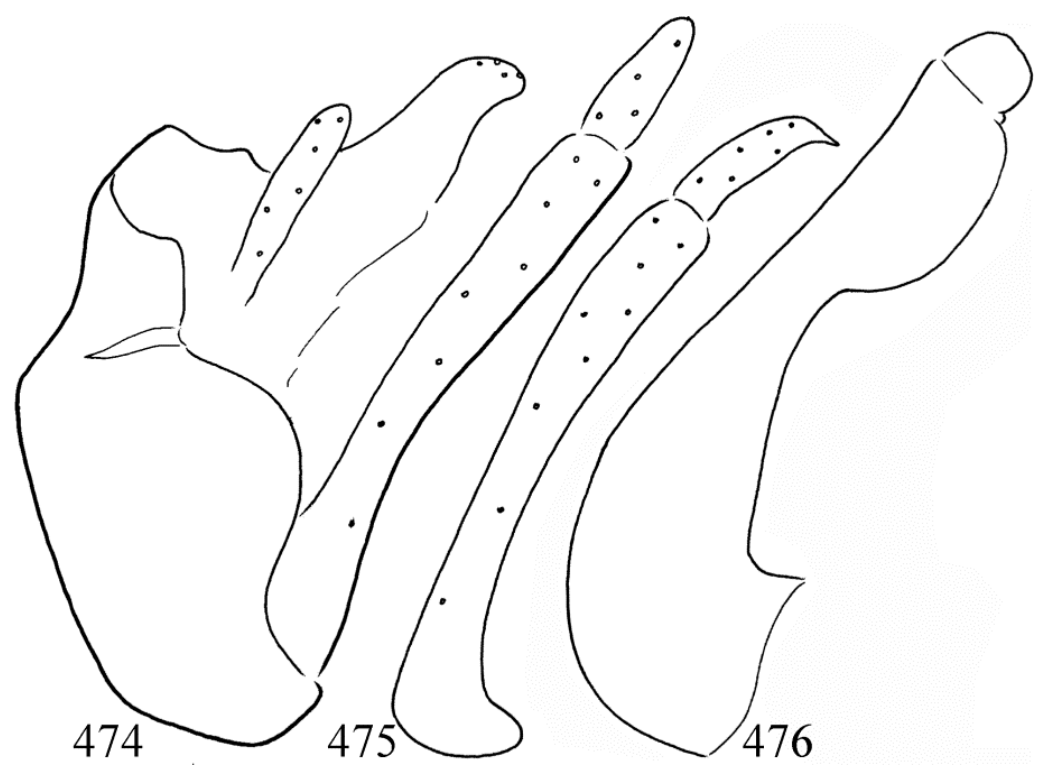

Figures 474-476. Hydromanicus khalband sp. nov. Holotype: $474=$ male genitalia in left lateral view, $475=$ left gonopod in ventral view, $476=$ phallic organ in left lateral view.

the rounded, not flat ventroapical keel of the phallic organ.

Description. A brown coloured animal forewing slightly light spotted, forewing length is 9 $\mathrm{mm}$.
Male genitalia. Abdominal segment IX divided by suture into a smaller dorsal and a larger ventral part; its median keel medium-long and narrow; anterior margin arciform, resulted in a very short dorsum and sligthtly longer ventrum; apical lobe on posterolateral margin produced, 
rounded; intersegmental depression between the ninth and tenth segments low in lateral view. Body of segment $\mathrm{X}$ broad-based less sclerotized; setose cerci elongated digitiform; dorsoapical setose lobes form a downward directed apex of segment $X$. The basal segment of the gonopods slender; terminal segment, the harpago short finger-tipped, visible especially in ventral view. Phallic apparatus robust, subapical ventral keel rounded; endothecal sclerites short and rounded.

Etymology. khalband, coined from the name of holotype locus typicus.

\section{Hydromanicus mattiyang sp. nov.}

(Figures 477-479, Map 6: near n² 24, Map 30)

Material examined. Holotype: India, Ukhrul, Manipur, Mattiyang, $2800 \mathrm{ft}$. [the Mattiyang Mount ( $1531 \mathrm{~m})$, probably $24^{\circ} 59^{\prime} 02.1^{\prime \prime} \mathrm{N} 94^{\circ} 36^{\prime}$ $31.9 " \mathrm{E}$, is the major peak of the range between the Mount Khayang Bung upto Chahang Khunou (Chahong Khunou)]. Remarks: The locality Mattiyang was not found but it should be along the road to the Mattiyang Mount near this point according to the altitude, $24^{\circ} 53^{\prime} 16.1^{\prime \prime} \mathrm{N} 94^{\circ} 36^{\prime}$
49.2"E, 17.VI.1960, leg. F. Schmid (1 male, CNC).

Diagnosis. This new species belongs to the $H$. luctuosus species group and to the Hydromanicus inferior species complex. Having finger-tipped harpago in ventral view it has resemblance to $H$. mynso sp. nov., but differs by the apical lobe on posterolateral margin produced, rounded triangular, not regularly rounded; by the dorsoapical setose lobe that is not bilobed nor in dorsal and lateral views, by the longer finger-tipped harpago, discernible both in lateral and ventral views; by the mesad turning finger-tip; as well as by the less produced and low ventroapical keel of the phallic organ.

Description. A brown coloured animal forewing slightly light spotted with length of $11 \mathrm{~mm}$.

Male genitalia. Abdominal segment IX divided by suture into a smaller dorsal and a larger ventral part; its median keel medium-long and narrow; anterior margin arciform, resulted in a very short dorsum and sligthtly longer ventrum; apical lobe on posterolateral margin produced, rounded triangular; intersegmental depression between the ninth and tenth segments low in lateral

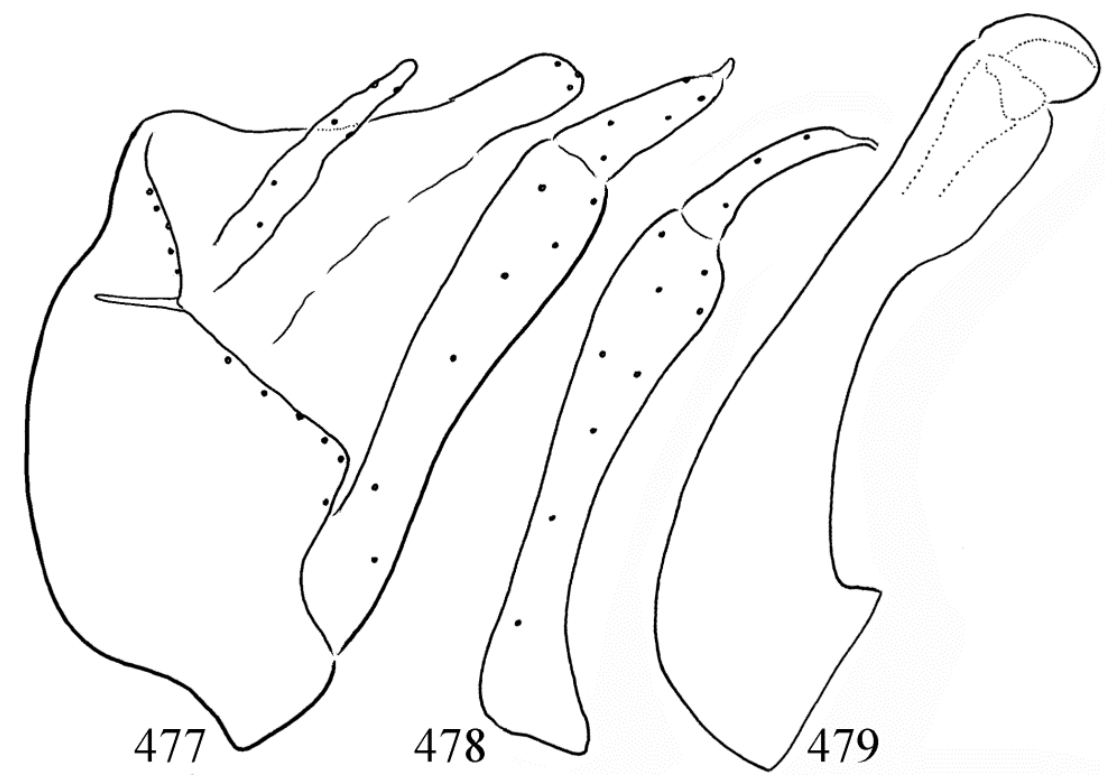

Figures 477-479. Hydromanicus mattiyang sp. nov. Holotype: $477=$ male genitalia in left lateral view, $478=$ left gonopod in ventral view, $479=$ phallic organ in left lateral view. 
view. Body of segment X broad-based less sclerotized; setose cerci elongated digitiform; dorsoapical setose lobes form a rounded apex of segment $\mathrm{X}$ both in lateral and dorsal views. The basal segment of the gonopods robust; terminal segment, the harpago pronounced finger-tipped, visible especially in ventral view. Phallic apparatus robust, subapical ventral keel low; endothecal sclerites short and rounded.

Etymology. mattiyang, named after the name of locus typicus the holotype.

\section{Hydromanicus mynso sp. nov.}

(Figures 480-483, Map 5: n 69, Map 30)

Material examined. Holotype: India, Meghaláya (United Jaintia and Khasi Hills), Mynso [=Mynsoo], $3500 \mathrm{ft}, 25^{\circ} 33^{\prime} 43.5^{\prime \prime} \mathrm{N} 92^{\circ} 19^{\prime} 37.5^{\prime \prime} \mathrm{E}$, 20.IV.1960, leg. F. Schmid (1 male, CNC).

Diagnosis. This new species belongs to the $H$. luctuosus species group and to the $H$. inferior species complex. Having finger-tipped harpago in ventral view it has resemblance to $H$. inferior, but differs by the dorsoapical setose lobe bilobed both in dorsal and lateral views, by the more pro nounced finger-tipped harpago, discernible both in lateral and ventral views; as well as by the more produced and serrated ventroapical keel of the phallic organ.

Description. A brown coloured animal forewing slightly light spotted with length of $11 \mathrm{~mm}$.

Male genitalia. Abdominal segment IX divided by suture into a smaller dorsal and a larger ventral part; its median keel medium-long and narrow; anterior margin arciform, resulted in a very short dorsum and ventrum; apical lobe on posterolateral margin produced, rounded; intersegmental depression between the ninth and tenth segments low in lateral view. Body of segment $X$ broad-based less sclerotized; setose cerci elongated foliform with apical digitiform ending; dorsoapical setose lobes form a bilobed apex of segment $X$ both in lateral and dorsal views. The basal segment of the gonopods robust; terminal segment, the harpago pronounced finger-tipped, visible especially in ventral view. Phallic apparatus robust, subapical ventral keel short and high with serrated anterior half, endothecal sclerites short and rounded.

Etymology. mynso, named after the locus typicus of the holotype.

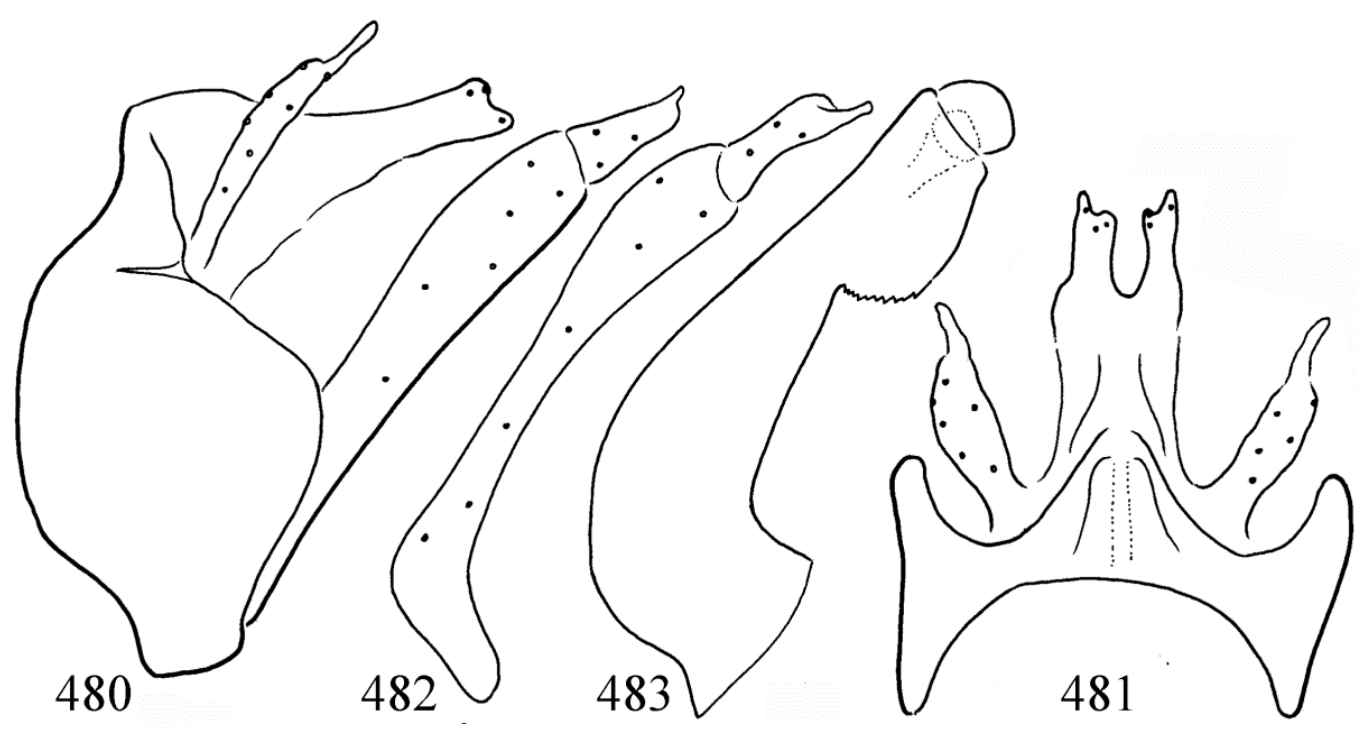

Figures 480-483. Hydromanicus mynso sp. nov. Holotype: $480=$ male genitalia in left lateral view, $481=$ male genitalia in dorsal view, $482=$ left gonopod in ventral view, 483 = phallic organ in left lateral view. 


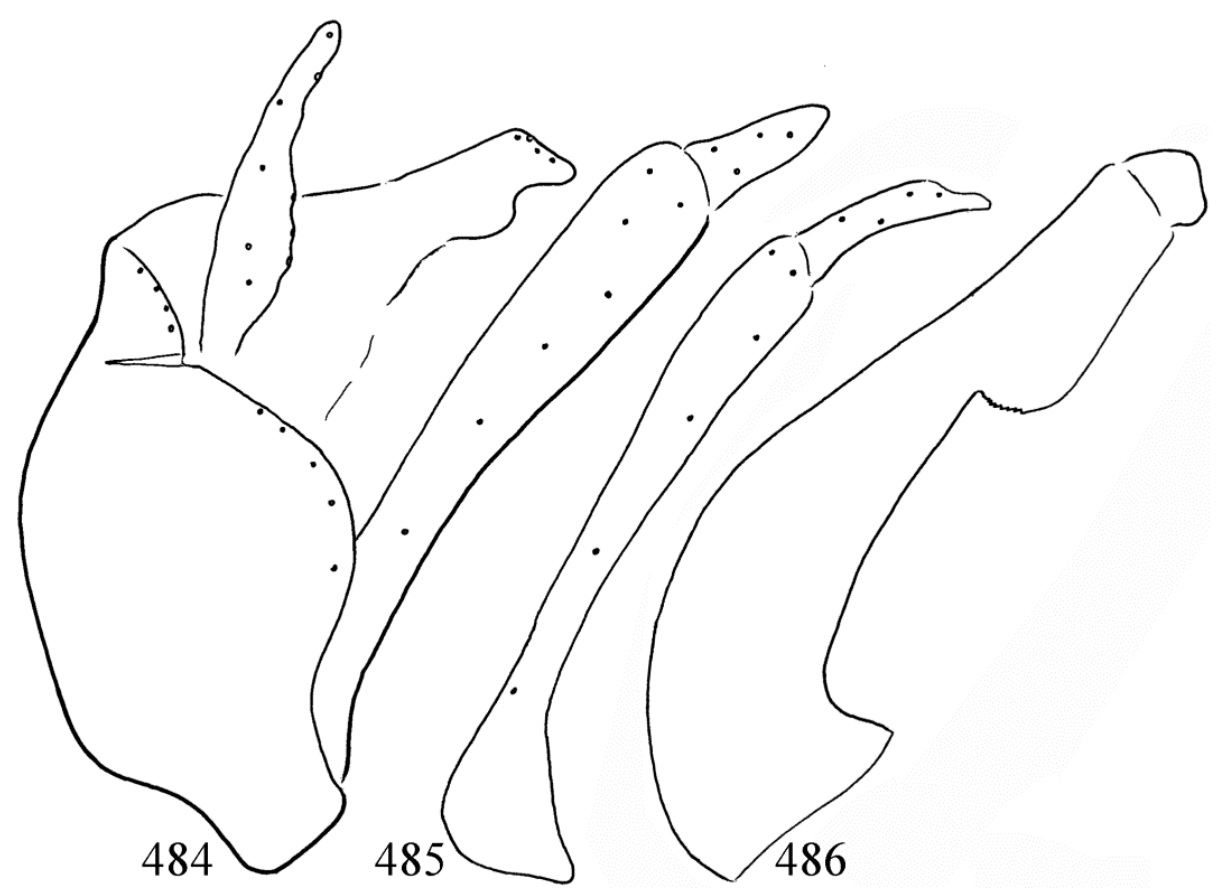

Figures 484-486. Hydromanicus nondeng sp. nov. Holotype: 484 = male genitalia in left lateral view, $485=$ left gonopod in ventral view, 486 = phallic organ in left lateral view.

\section{Hydromanicus nondeng sp. nov.}

(Figures 484-486, Map 5: n 5, Map 30)

Material examined. Holotype: India, Meghaláya (United Jaintia and Khasi Hills), Shnongpdeng, $1000 \mathrm{ft} ., 25^{\circ} 12^{\prime} 27.0^{\prime \prime} \mathrm{N} 92^{\circ} 00^{\prime} 28.4^{\prime \prime} \mathrm{E}, 7 . \mathrm{IV}$. 1960, leg. F. Schmid (1 male, CNC). Paratypes: same as holotype (1 male, OPC; 1 male, SMNH).

Diagnosis. This new species belongs to the $H$. luctuosus species group and to the $H$. inferior species complex. Having small finger-like apicomesal lobe on harpago in ventral view it has resemblance to $H$. jakhand sp. nov. but differs by the head of cerci having apex digitate, not slightly capitate and basal half broad in lateral view; by the lateral profile of segment $\mathrm{X}$ that is trilobed, but the lobes are blunt, not pointed; by the shape of the finger-like apicomesal lobe on the harpago that is not capitate. The lateral shape of the phallic organ rather different; basal half long curving, not short; subapical mesal keel on the ventrum broadening anterad; endothecal sclerites subtriangular, not semicircular.
Description. A brown coloured animal; forewing distinctly light spotted with legth of $10 \mathrm{~mm}$.

Male genitalia. Abdominal segment IX divided by a tiny suture into a smaller dorsal and a larger ventral part; its median keel medium-long and narrow; anterior margin arciform, resulted in a very short dorsum and longer ventrum; apical lobe on posterolateral margin rounded produced; intersegmental depression between the ninth and tenth segments low in lateral view. Body of segment X elongated, broad-based, less sclerotized ventrally; apex of segment $X$ trilobed in lateral view with blunt apices; setose cerci elongated foliform with digitate apex and widened basal half. The basal segment of the gonopods slightly arching and constricted basally; terminal segment, the harpago with a broad finger-like apicomesal lobe. Phallic apparatus slender with long curving basal half, subapical ventral keel low, broadening anterad with serrated anterior, endothecal sclerites short and subtriangular.

Etymology. nondeng, coined from the name of the holotype locus typicus. 


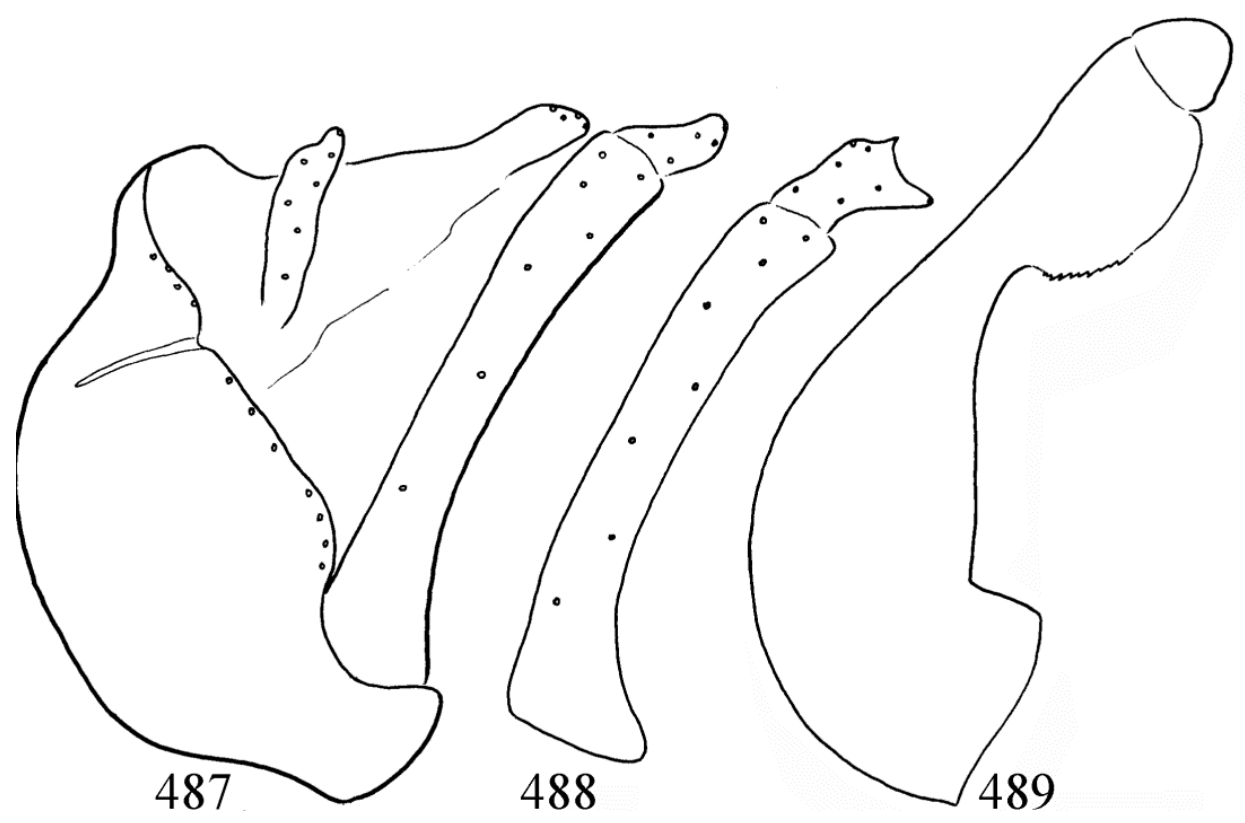

Figures 487-489. Hydromanicus fureses sp. nov. Holotype: $487=$ male genitalia in left lateral view, $488=$ left gonopod in ventral view, $489=$ phallic organ in left lateral view.

\section{Hydromanicus luctuosus species complex}

Hydromanicus luctuosus new species complex in the H. luctuosus species group is characterized with a bicuspid harpago. The apical ending of the harpago is diverging into an upper, apicodorsal and a lower, apicoventral variously produced corner in ventral view.

\section{Hydromanicus fureses sp. nov.}

(Figures 487-489, Map 5: n 69, Map 31)

Material examined. Holotype: India, Meghalaya (United Jaintia and Khasi Hills), Mynso [= Mynsoo], 3500 ft., 253' $43.5^{\prime \prime} \mathrm{N} 92^{\circ} 19^{\prime} 37.5^{\prime \prime} \mathrm{E}$, 20.IV.1960, leg. F. Schmid (1 male, CNC).

Diagnosis. This new species belongs to the $H$. luctuosus species complex of the H. luctuosus species group. Having bi-pointed harpago in ventral view it resembles to $H$. luctuosus, but differs by the needle pointed dorsoapical and mesoapical bifid apical ending of the harpago as well as by the serrated ventroapical keel and by the subtriangular endothecal sclerites of the phallic organ.
Description. A brown coloured animal forewing slightly light spotted with length of $12 \mathrm{~mm}$.

Male genitalia. Abdominal segment IX divided by suture into a smaller dorsal and a larger ventral part; its median keel medium-long and narrow; anterior margin arciform, resulted in a very short dorsum and slightly longer ventrum; apical lobe on posterolateral margin less produced; intersegmental depression between the ninth and tenth segments low in lateral view. Body of segment X broad-based less sclerotized; setose cerci elongated foliform; dorsoapical setose lobes form a bilobed apex of segment X. The basal segment of the gonopods slightly arching and constricted middle; terminal segment, the harpago bicuspidate in ventral view. Phallic apparatus robust, subapical ventral keel short with serrated anterior half, endothecal sclerites short and subtriangular.

Etymology. fureses, coined from "fürészes" serrated in Hungarian, refers to the serrated anterior half of the ventroapical keel of the phallic organ. 


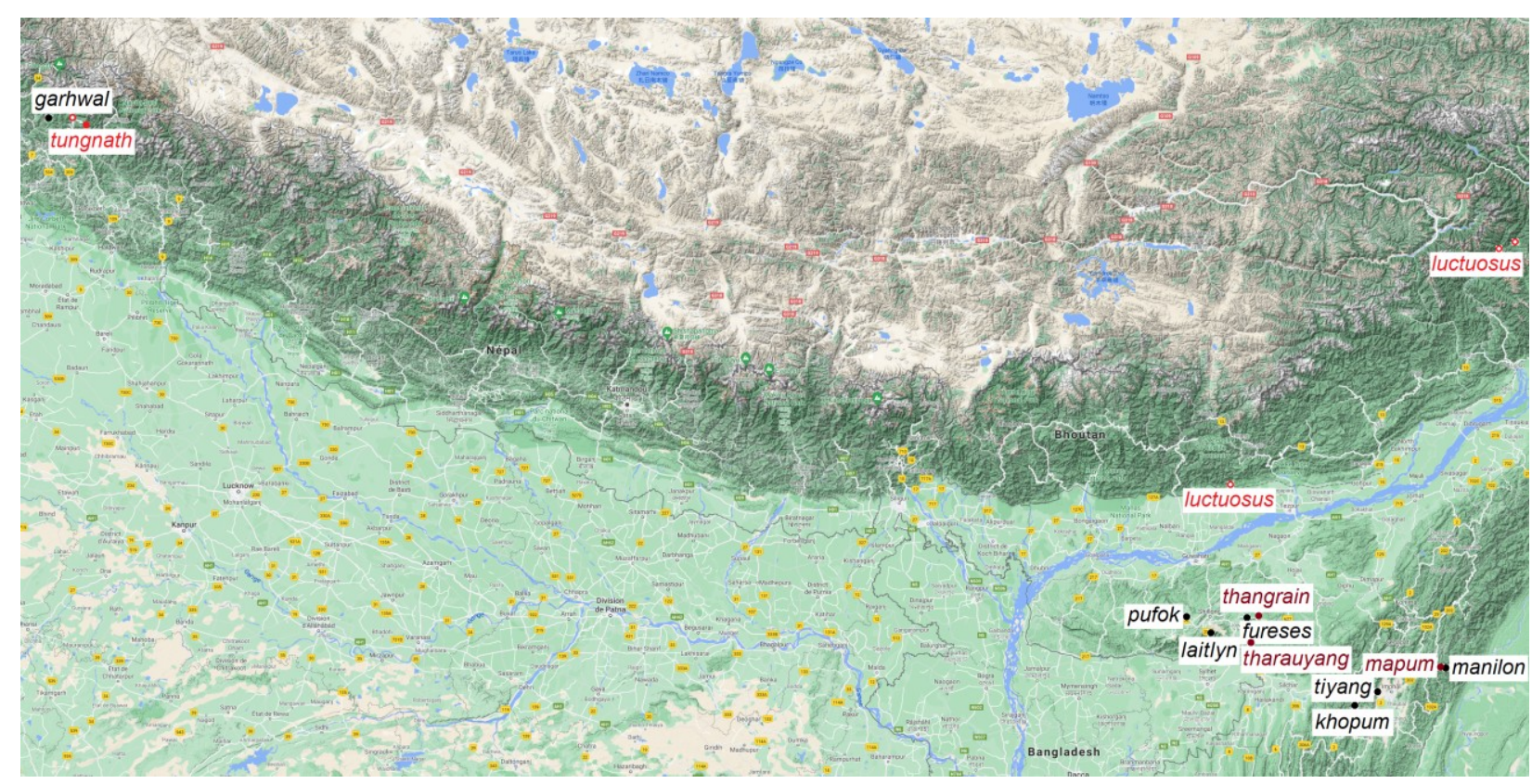

Map 31. Hydromanicus luctuosus complex.

\section{Hydromanicus garhwal sp. nov.}

(Figures 490-492, Map 2: n³4, Map 31)

Material examined. Holotype: India, Uttarakhand, Tehri Garhwal, Gawana Jaunpur [= Gawana Malla], $6000 \mathrm{ft}$, small river tributary of Bhichangana, 30³2'18.9"N 7848'35.9"E, 22-24.V. 1958, leg. F. Schmid (1 male, CNC).

Diagnosis. This new species belongs to the $H$. luctuosus species group and to the H. luctuosus species complex. Having bi-pointed harpago in ventral view it has resemblance to H. luctuosus, but differs by the flat without-corner dorsoapical and straight, not-turning-mesad mesoapical ending of the harpago as well as by the lateral profile of the phallic organ. H. luctuosus is a small species with 9-10 $\mathrm{mm}$ forewing; the new species $H$. garhwal is a large species having forewing of 15 $\mathrm{mm}$.

Description. A brown coloured animal; forewing slightly and indistinctly light spotted of 15 mm length.

Male genitalia. Abdominal segment IX divided by a suture into a smaller dorsal and a larger ventral part; its median keel medium-long and narrow; anterior margin arciform, resulted in a very short dorsum and longer ventrum; apical lobe on posterolateral margin rounded produced; intersegmental depression between the ninth and tenth segments low in lateral view. Body of segment $X$ broad-based less sclerotized; setose cerci elongated foliform; dorsoapical setose lobes form a bilobed apex of segment $X$. The basal segment of the gonopods slightly arching and constricted middle; terminal segment, the harpago bi-pointed in ventral view, the dorsoapical point moved mesad. Phallic apparatus robust, subapical ventral keel short with serrated anterior half, endothecal sclerites short and semicircular.

Etymology. garhwal, named after the locus typicus of the holotype.

\section{Hydromanicus khopum sp. nov.}

(Figures 493-495, Map 6: nº 7, Map 31)

Material examined. Holotype: India: Manipur, Khopum [ $=$ Khoupum Valley], $2500 \mathrm{ft}$., 24 ${ }^{\circ}$ $40^{\prime} 31.8^{\prime \prime} \mathrm{N}$ 93³1'07.3"E, 27.V.1960, leg. F. Schmid (1 male, CNC). 


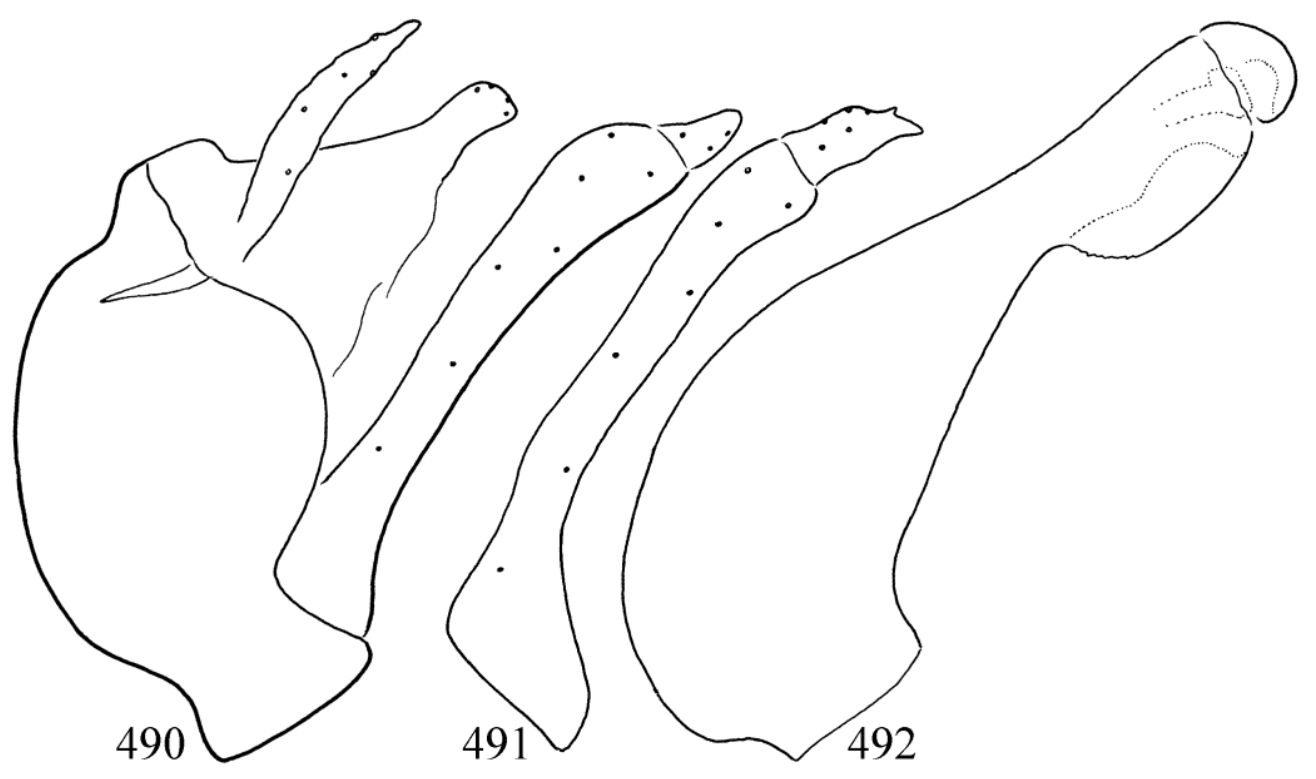

Figures 490-492. Hydromanicus garhwal sp. nov. Holotype: $490=$ male genitalia in left lateral view, $491=$ left gonopod in ventral view, 492 = phallic organ in left lateral view.

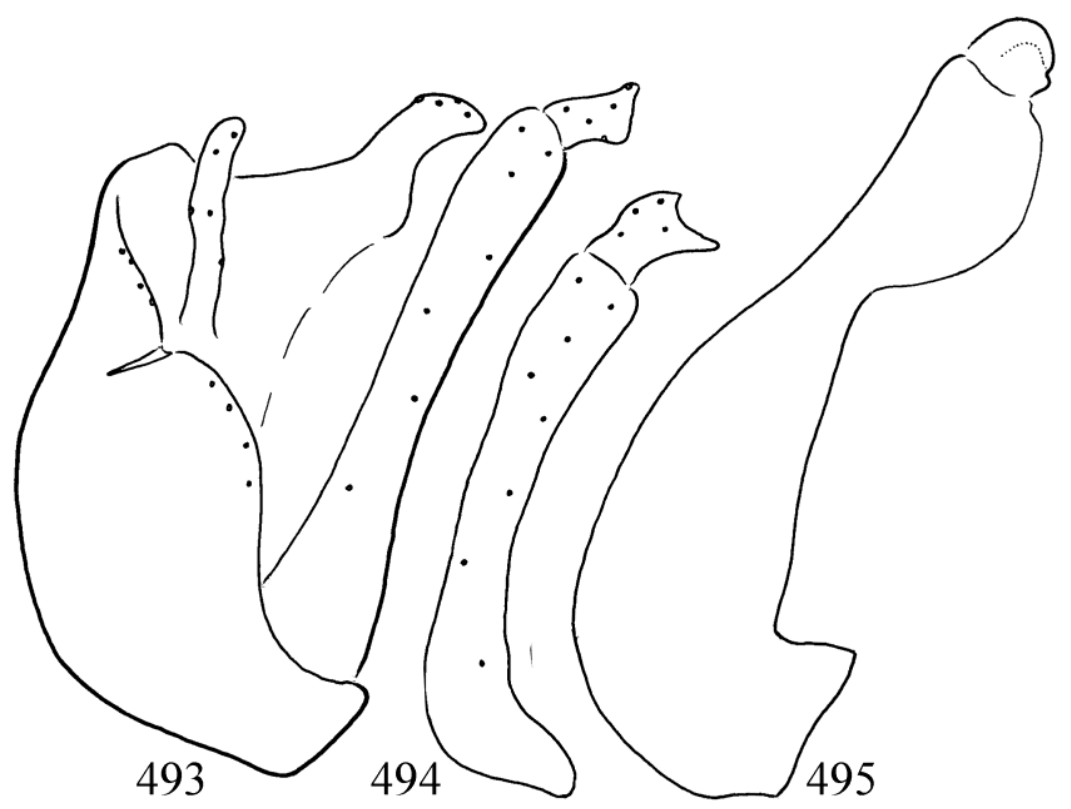

Figures 493-495. Hydromanicus khopum sp. nov. Holotype: 493 = male genitalia in left lateral view, $494=$ left gonopod in ventral view, $495=$ phallic organ in left lateral view.

Diagnosis. This new species belongs to the $H$. luctuosus species group and to the H. luctuosus species complex. According to the ventral profile of the harpago most close to $H$. pufok sp. nov. described from India, Meghaláya, but differs by the shorter harpago, aviform head of segment $\mathrm{X}$ in lateral view, and by the slender, not fat phallic organ.

Description. A brown coloured animal forewing with distinct light spotted pattern, forewing length is $10 \mathrm{~mm}$. 
Male genitalia. Abdominal segment IX divided by a suture into a smaller dorsal and a larger ventral part; its median keel short and narrow; anterior margin arciform, resulted in a very short dorsum and longer ventrum; apical lobe on posterolateral margin less produced; intersegmental depression between the ninth and tenth segments high and almost right angled in lateral view. Body of segment X broad-based less sclerotized ventrally; setose cerci elongated digitiform; dorsoapical setose lobes form a bilobed apex of segment $\mathrm{X}$ visible in dorsal view and aviform in lateral view. The basal segment of the gonopods slightly arching little constricted middle; terminal segment, the harpago bi-pointed in ventral view. Phallic apparatus slender, subapical ventral keel elongated, endothecal sclerites short and rounded with small bilobed ventrum.

Etymology. khopum, named after the holotype locus typicus.

\section{Hydromanicus laitlyn sp. nov.}

(Figures 496-498, Map 5: n 38, Map 31)

Material examined. Holotype: India: Meghaláya (United Jaintia and Khasi Hills), Laitlyngkot, 2000-2300 ft., 25²4'42.9"N 91 ${ }^{\circ} 54^{\prime} 35.4 " \mathrm{E}, 17 . \mathrm{III}$. 1960, leg. F. Schmid (1 male, CNC). Paratypes: same as holotype (1 male, OPC; 1 male, SMNH).
Diagnosis. This new species belongs to the $H$. luctuosus species group and to the H. luctuosus species complex. According to the ventral profile of the harpago most close to $H$. khopum sp. nov. described from India, Manipur, but differs by the tri-pointed harpago, one small pointed process has been shift to middle position on the apical margin of harpago, and by the more broad and more curving basal two thirds of the phallic organ as well as endothecal process shorter.

Description. A brown coloured animal forewing with distinct light spotted pattern of $10 \mathrm{~mm}$ length.

Male genitalia. Abdominal segment IX divided by suture into a smaller dorsal and a larger ventral part; its median keel short and narrow; anterior margin arciform, resulted in a very short dorsum and longer ventrum; apical lobe on posterolateral margin less produced; intersegmental depression between the ninth and tenth segments low and obtuse angled in lateral view. Body of segment $\mathrm{X}$ broad-based less sclerotized ventrally; setose cerci elongated digitiform; dorsoapical setose lobes form a bilobed apex of segment $\mathrm{X}$ visible in dorsal view and aviform in lateral view. The basal segment of the gonopods slightly arching little constricted middle; terminal segment, the harpago tri-pointed in ventral view, a small pointed process appears in middle position

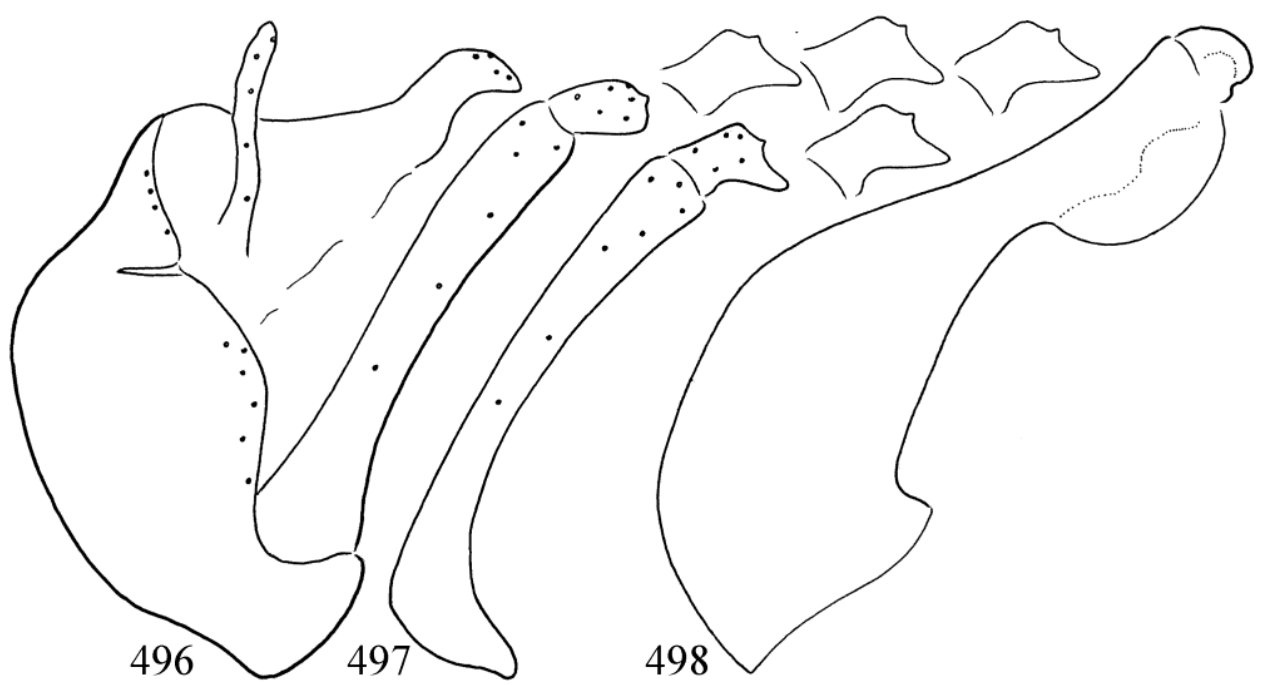

Figures 496-498. Hydromanicus laitlyn sp. nov. Holotype: $496=$ male genitalia in left lateral view, $497=$ left gonopod in ventral view with redrawn variations of the harpago in ventral view, $498=$ phallic organ in left lateral view. 
on the apical margin of harpago. Phallic apparatus with robust basal two thirds, subapical ventral keel elongated, endothecal sclerites short and rounded with small bilobed ventrum.

Etymology. laitlyn, coined from the name of the holotype locus typicus.

\section{Hydromanicus luctuosus Ulmer, 1905}

(Figures 499-502, Map 31)

Hydromanicus luctuosus Ulmer, 1905:92-93. Described from "Sikkim, (Himalaya)", India, deposited in Stettiner Musem.

Hydromanicus truncatus Betten, 1909:235-236. "corresponds closely to the description of H. luctuosus, Ulmer. Several specimens from Kurseong (Annandale, May, 1906)."

Hydromanicus truncatus Betten, 1909: Martynov 1935: 184-185. Kurseong, Darjeeling, Bengal, India.

Hydromanicus luctuosus Ulmer, 1905: Malicky 2009: 41, 44. Hydromanicus truncatus described from Kurseong, West Bengal, synonymised with H. luctuosus Ulmer, 1905 described from India (Sikkim).

Material examined. China, Tibet, Beibengxiang, $700 \mathrm{~m}, 29^{\circ} 14^{\prime} 44.6^{\prime \prime} \mathrm{N} 95^{\circ} 10^{\prime} 06.5^{\prime \prime} \mathrm{E}, 30$.VII. 2012, leg. W. Li (1 male, DPP-HIST). China, Tibet, Motuo, $1100 \mathrm{~m}, 29^{\circ} 19^{\prime} 40.8^{\prime \prime} \mathrm{N} 95^{\circ} 20^{\prime} 27.7^{\prime \prime}$ E, 26.VII.1912, leg. Li Wenliang (1 male, DPPHIST). China, Tibet, Motuo, $80 \mathrm{~K} 1000 \mathrm{~m}$, 29²0'05.3"N 95¹9'41.3"E, 24.VII.2012, leg. Li Wenliang (1 male, OPC). India, Arunachal Pradesh (Assam), Kameng, Amartala PWD Camp, $26^{\circ} 55^{\prime} 47^{\prime \prime} \mathrm{N} 92^{\circ} 7^{\prime} 18^{\prime \prime} \mathrm{E}, 1250-2000$ ft. 11.III. 1961, leg. F. Schmid (1 male, pinned with cleared abdomen in plastic genital vial, ROM).

Remarks. Examination of paratype from Sikkim, and specimens from nearby territories in Tibet and Assam has indicated stable lateral profile of the adaptive speciation trait, that is the phallic organ in the different populations. Even the non-adaptive, neutral structure of the ventral profile of the harpago seems rather stable in the examined populations.

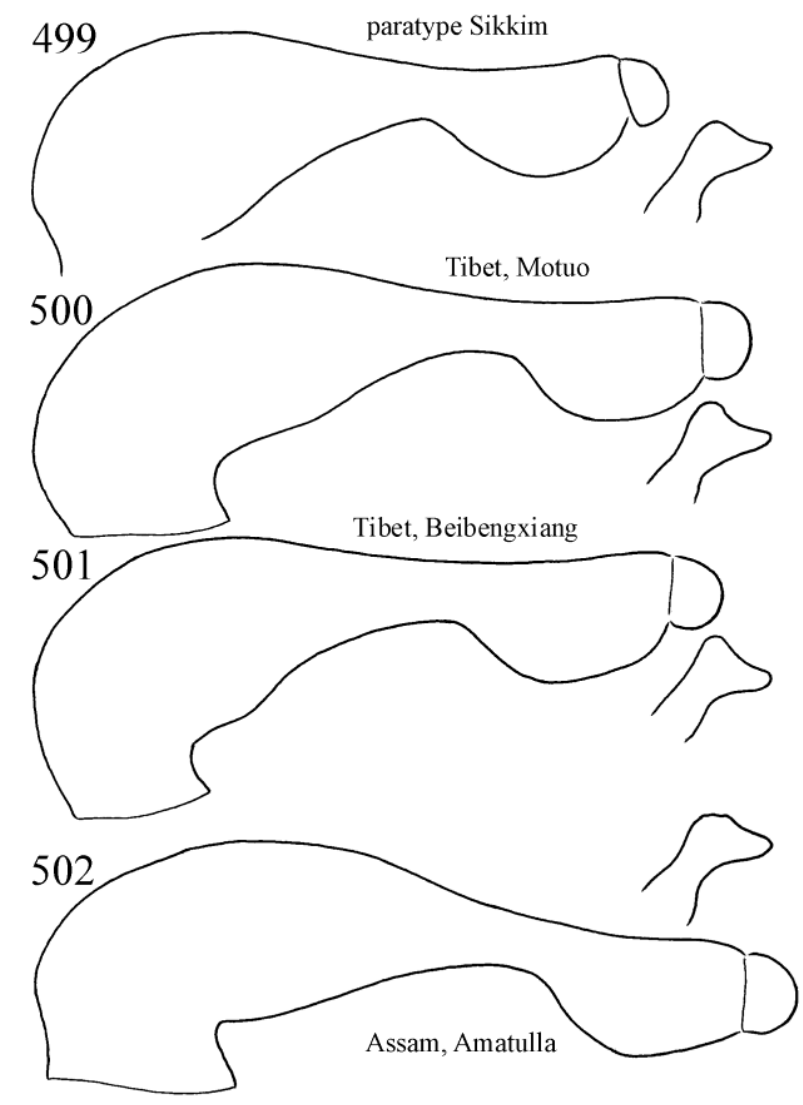

Figures 499-502. Hydromanicus luctuosus Ulmer, 1905. 499-502 = phallic organ in left lateral view and the apex of harpago in ventral view of the paratype and specimens from Tibet and Assam.

\section{Hydromanicus manilon sp. nov.}

(Figures 503-505, Map 6: n 23, Map 31)

Material examined. Holotype: India, Manipur, Loni [=Roni], 4500-5500 ft, $25^{\circ} 03^{\prime} 41.8^{\prime \prime} \mathrm{N} 94^{\circ} 34^{\prime}$ 18.8"E, 16.VI.1960, leg. F. Schmid (1 male, $\mathrm{CNC}$ ). Paratype: same data as for the holotype (1 male, OPC).

Diagnosis. This new species belongs to the $H$. luctuosus species group and to the H. luctuosus species complex. Having bicuspidate harpago in ventral view it has resemblance to $H$. fureses $\mathrm{sp}$. nov., but differs by the blunt, not needle-pointed dorsoapical and mesoapical bifid apical ending of 


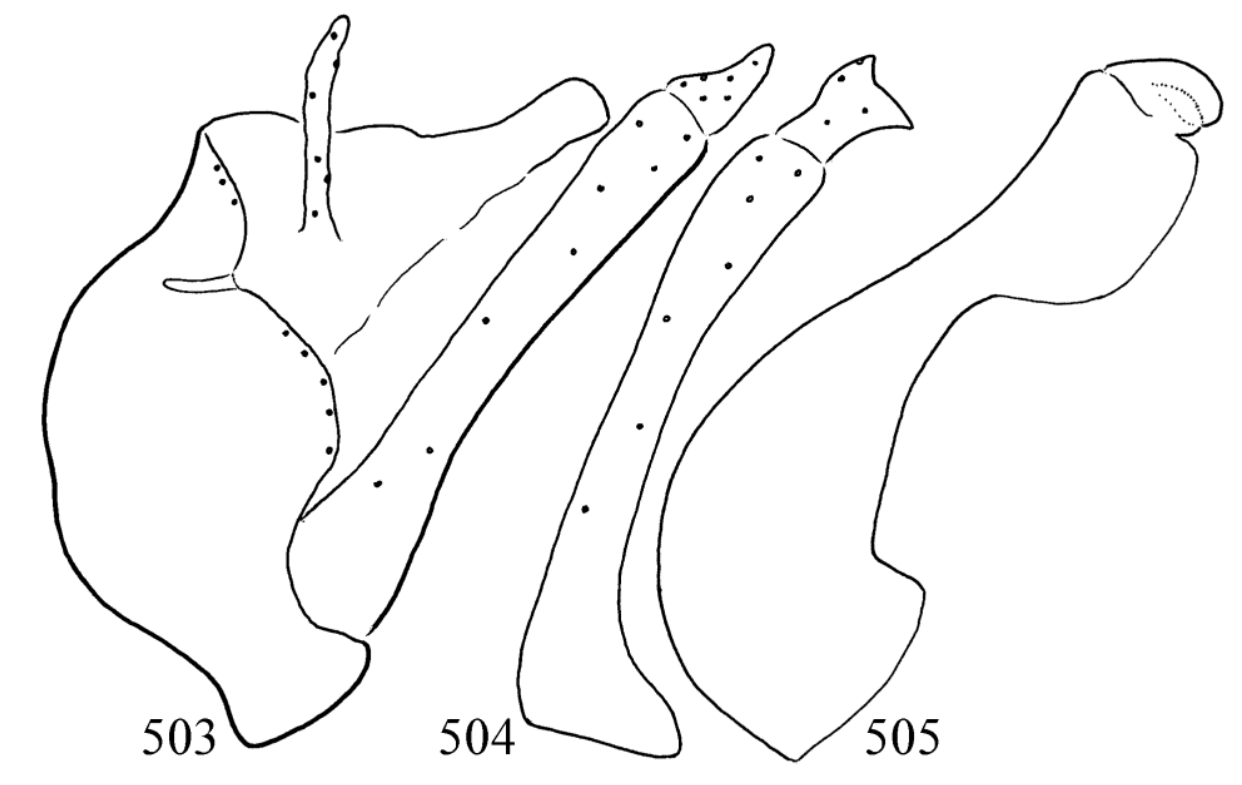

Figures 503-505. Hydromanicus manilon sp. nov. Holotype: 503 = male genitalia in left lateral view, $504=$ left gonopod in ventral view, $505=$ phallic organ in left lateral view.

the harpago as well as by the less serrated ventroapical keel and by the downward sloping, not subtriangular endothecal sclerites of the phallic organ.

Description. A brown coloured animal forewing slightly light spotted of $10 \mathrm{~mm}$ length.

Male genitalia. Abdominal segment IX divided by suture into a smaller dorsal and a larger ventral part; its median keel medium-long and narrow; anterior margin arciform, resulted in a very short dorsum and slightly longer ventrum; apical lobe on posterolateral margin less produced rounded; intersegmental depression between the ninth and tenth segments low in lateral view. Body of segment X broad-based less sclerotized ventrally; setose cerci elongated foliform; dorsoapical setose lobes form a bilobed apex of segment $\mathrm{X}$. The basal segment of the gonopods slightly arching and constricted middle; terminal segment, the harpago blunt bi-pointed in ventral view. Phallic apparatus robust, subapical ventral keel short with less serrated anterior half, endothecal sclerites short and downward directed.

Etymology. manilon, coined from the name of the locus typicus of holotype.

\section{Hydromanicus mapum sp. nov.}

(Figures 506-508, Map 6: n 18, Map 31)

Material examined. Holotype: India, Manipur, Mapum, 5000 ft., 250 $04^{\prime} 55.9^{\prime \prime} \mathrm{N} 94^{\circ} 30^{\prime} 16.9^{\prime \prime} \mathrm{E}, 11$. VI.1960, leg. F. Schmid (1 male, CNC). Paratype: same as holotype (1 male, OPC).

Diagnosis. This new species with its subapical ventral keel on the phallic organ belongs to the Hydromanicus luctuosus species group. Having double pointed harpago it is a member of the Hydromanicus luctuosus species complex. Most close to the nominate species of the group $H$. luctuosus, but differs by the apical region of segment X: its apex upward directed or produced, not downward; the harpago broader apicad and with two small apical outgrowths as visible in ventral view; phallic organ with high basal region and the subapical ventral keel high and subtriangular.

Description. A brown coloured animal forewing slightly light spotted of $10 \mathrm{~mm}$ length.

Male genitalia. Abdominal segment IX divided by suture into a smaller dorsal and a larger ventral part; the median keel of segment IX medium-long and narrow; anterior margin arciform, 


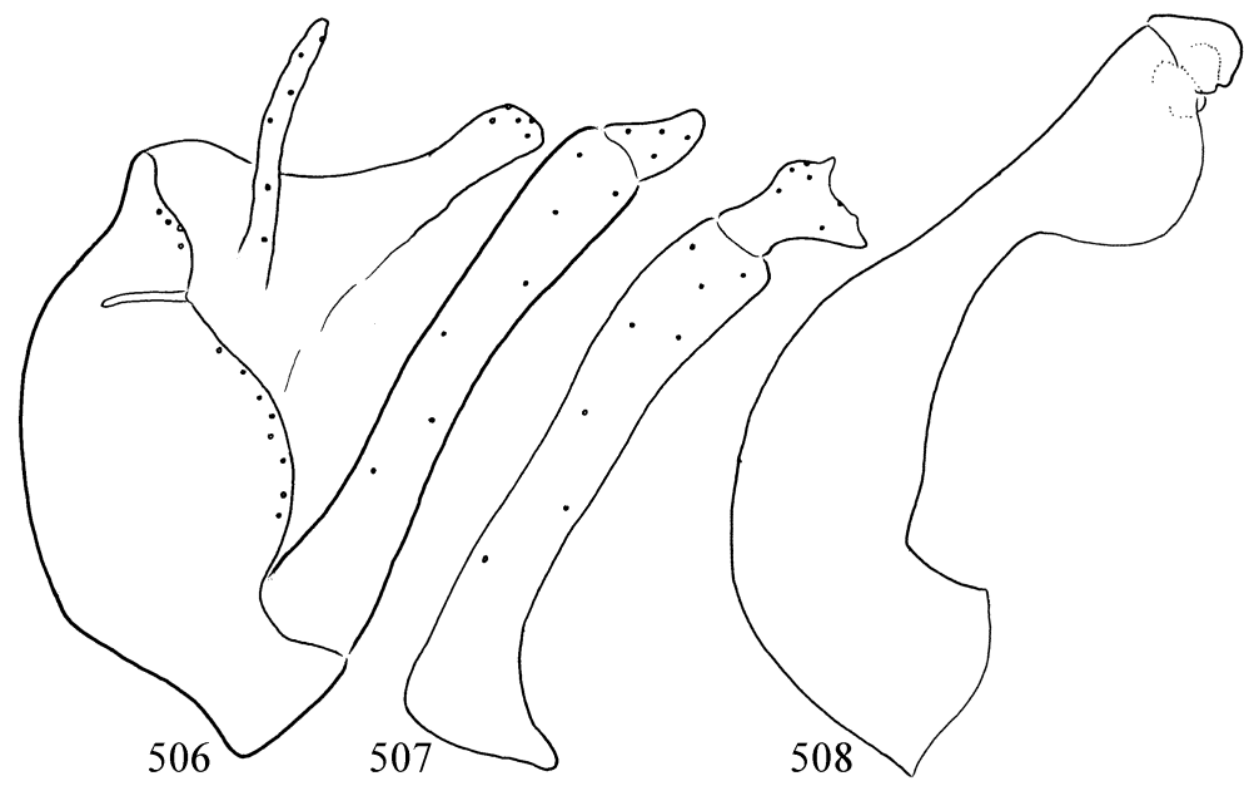

Figures 506-508. Hydromanicus mapum sp. nov. Holotype: $506=$ male genitalia in left lateral view, $507=$ left gonopod in ventral view, $508=$ phallic organ in left lateral view.

resulted in a very short dorsum and longer ventrum; apical lobe on posterolateral margin less produced, rounded; intersegmental depression between the ninth and tenth segments low in lateral view. Body of segment X broad-based less sclerotized ventrally; setose cerci elongated digitiform; dorsoapical setose lobes bilobed as visible in dorsal views and upward produced in lateral view. The basal segment of the gonopods robust; terminal segment, the harpago subtriangular in ventral view with two small apical outgrowths. Phallic apparatus slender, subapical ventral keel high, subtriangular; endothecal sclerites with flat dorsoapical region.

Etymology. mapum, named after the name of holotype locus typicus.

\section{Hydromanicus pufok sp. nov.}

(Figures 509-511, Map 31)

Material examined. Holotype: India: Meghaláya, Khasi Hills, 2534'56.9"N 91³7'57.6"E (1 male, Nat. Coll. McLachlan, Coll.B.M. 1938-674, $\mathrm{BMNH})$. Paratype: same as holotype (1 male, OPC).
Diagnosis. This new species belongs to the $H$. luctuosus species group and to the H. luctuosus species complex. This large sized new species differs from all the known species by the less developed apical lobe on the posterolateral margin of segment IX, by the bi-pointed harpago in ventral profile, by the enlarged phallobase of the phallic organ.

Description. A brown coloured animal forewing without any pattern (old specimen), forewing length $15 \mathrm{~mm}$.

Male genitalia. Abdominal segment IX divided by suture into a smaller dorsal and a larger ventral part; its median keel medium-long and narrow; anterior margin arciform, resulted in a very short dorsum and slightly longer ventrum; apical lobe on posterolateral margin less produced; intersegmental depression between the ninth and tenth segments low in lateral view. Body of segment X broad-based less sclerotized; setose cerci elongated foliform; dorsoapical setose lobes form a bilobed apex of segment X. The basal segment of the gonopods slightly arching and constricted middle; terminal segment, the harpago bi-pointed in ventral view. Phallic apparatus 


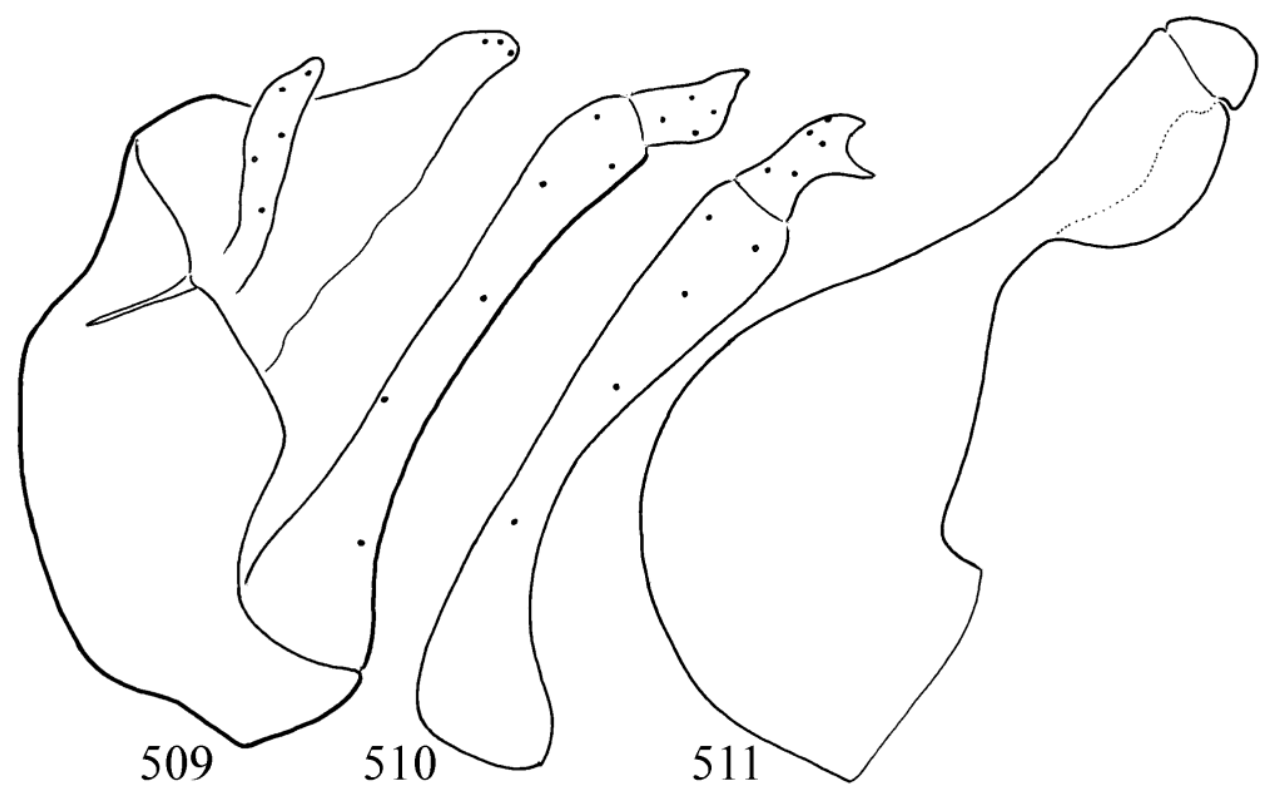

Figures 509-511. Hydromanicus pufok sp. nov. Holotype: $509=$ male genitalia in left lateral view, $510=$ left gonopod in ventral view, 511 = phallic organ in left lateral view.

robust, subapical ventral keel short, endothecal sclerites short and rounded.

Etymology. pufok, coined from "pufók" chubby in Hungarian, refers to the extremely enlarged phallobase of the phallic organ.

\section{Hydromanicus thangrain sp. nov.}

(Figures 512-514, Map 5: n 71, Map 31)

Material examined. Holotype: India, Meghaláya (United Jaintia and Khasi Hills), Thangrain, $3000 \mathrm{ft}$., 2534'45.1"N 92²6'26.7"E, 22.IV.1960, leg. F. Schmid (1 male, CNC).

Diagnosis. This new species belongs to the $H$. luctuosus species group and to the H. luctuosus species complex. Most close to H. luctuosus, but differs by the shape of harpago being fan-shaped with equal apicolateral and apicomesal corner, not with pronounced apicomesal lobe. The lateral profile of the phallotheca of the phallic organ is different. $H$. thangrain sp. nov. has the terminal ending tube of the phallobase low and long (wide), not high and short; its dorsoapical margin protruded posterad, not as long as the apical end- ing of the ventroapical keel; its ventroapical keel is flat ventrad, not rounded.

Description. In alcohol a brown coloured animal without discernible pattern on the forewing, forewing densely covered with thin recumbent setae; forewing length $10 \mathrm{~mm}$.

Male genitalia. Abdominal segment IX divided by suture into a smaller dorsal and a larger ventral part; its median keel short and narrow; anterior margin arciform, resulted in a very short dorsum and slightly longer ventrum; apical lobe on posterolateral margin robust flat rounded, comprising the bulk of the segment; intersegmental depression between the ninth and tenth segments low oblique in lateral view. Body of segment $\mathrm{X}$ broad-based less sclerotized, narrowing apicad; setose cerci elongated very thin filiform; dorsoapical setose lobes apicad directed bilobed apex of segment $X$. The basal segment of the gonopods straight almost parallel-sided; terminal segment, the harpago regular fan-shaped. Phallic apparatus robust, subapical ventral keel long and flat, endothecal sclerites semicircular.

Etymology. thangrain, named after the locus typicus of the holotype. 


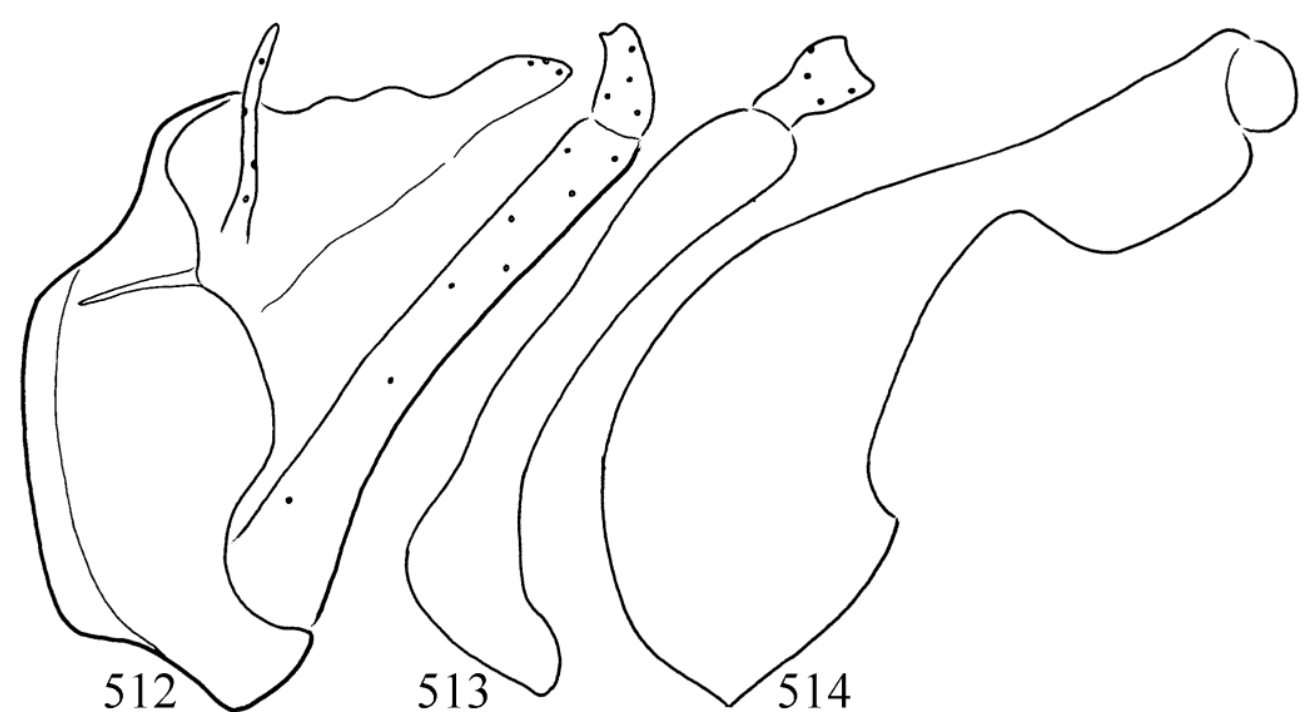

Figures 512-514. Hydromanicus thangrain sp. nov. Holotype: $512=$ male genitalia in left lateral view, $513=$ left gonopod in ventral view, $514=$ phallic organ in left lateral view.

\section{Hydromanicus tharauyang sp. nov.}

(Figures 515-517, Map 5: n 30, 39, Map 31)

Material examined. Holotype: India: Meghaláya (United Jaintia and Khasi Hills), Tharauyang, $2900 \mathrm{ft}$., this unknown locality is probably not far from the next locality on the Schmid's road: Byndihati, $3000 \mathrm{ft}, 25^{\circ} 19^{\prime} 09.4^{\prime \prime} \mathrm{N} 92^{\circ} 22^{\prime} 12.7^{\prime \prime} \mathrm{E}$, 10.I. 1960, leg. F. Schmid (1 male, CNC). Paratype: India: Meghaláya (United Jaintia and Khasi Hills), Mawkhap, 1500 ft., 18.III.1960, leg. F. Schmid (1 male, OPC).

Diagnosis. This new species belongs to the $H$. luctuosus species group and to the H. luctuosus species complex. According to the lateral profile of segment $X$, the ventral profile of the harpago as well as the lateral shape of the endothecal sclerites most close to H. khopum sp. nov. described from India, Mapipur, but differs by the less aviform head of segment $\mathrm{X}$ in lateral view, longer harpago with straight dorsal margin in ventral view, and by the shorter than high endothecal sclerites.

Description. A brown coloured animal forewing with indistinct light spotted pattern; forewing length $10 \mathrm{~mm}$.
Male genitalia. Abdominal segment IX divided by suture into a smaller dorsal and a larger ventral part; its median keel short and narrow; anterior margin arciform with dorsal excision in lateral view, resulted in a very short dorsum and longer ventrum; apical lobe on posterolateral margin less produced; intersegmental depression between the ninth and tenth segments high and right angled in lateral view. Body of segment $\mathrm{X}$ broadbased less sclerotized ventrally, its apex truncated; setose cerci elongated digitiform; dorsoapical setose lobes form a bilobed apex of segment $\mathrm{X}$ visible in dorsal view and less aviform in lateral view. The basal segment of the gonopods slightly arching not constricted middle; terminal segment, the harpago bi-pointed in ventral view. Phallic apparatus slender, subapical ventral keel elongated, endothecal sclerites short.

Etymology. tharauyang, named after the holotype locus typicus.

\section{Hydromanicus tiyang sp. nov.}

(Figures 518-520, Map 6: n 10, 24, Map 31)

Material examined. Holotype: India, Manipur, Mattiyang, $2800 \mathrm{ft}$, as explained for Hydro 


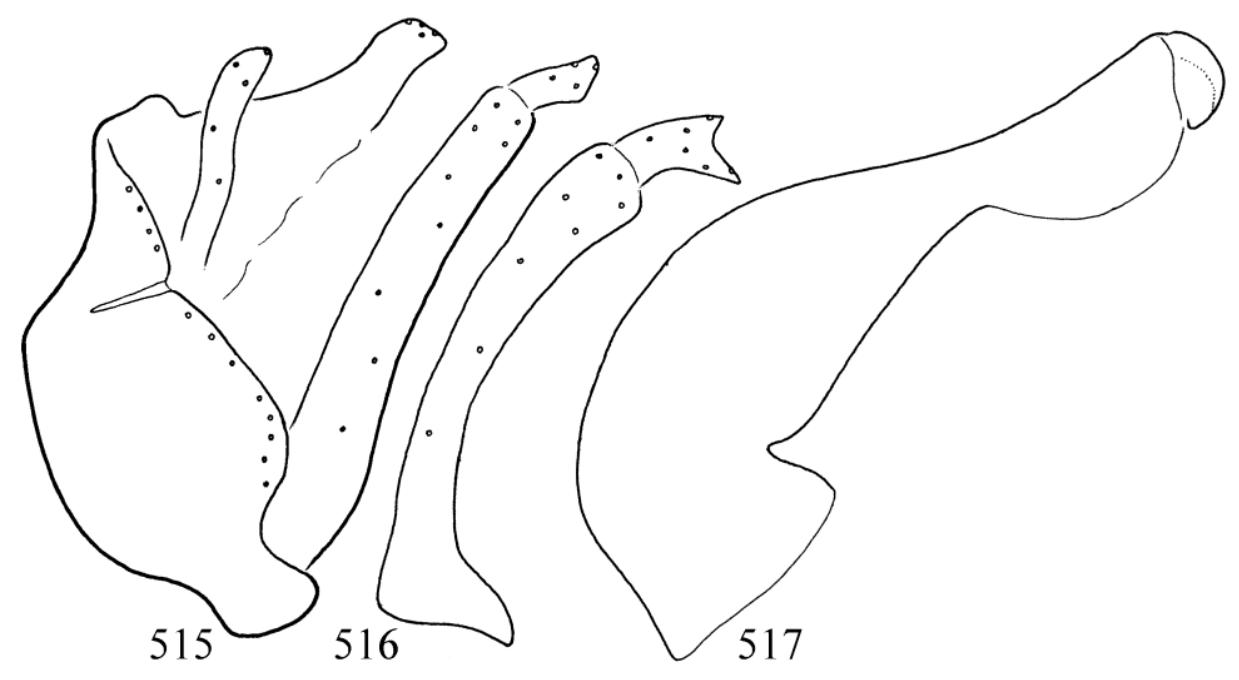

Figures 515-517. Hydromanicus tharauyang sp. nov. Holotype: $515=$ male genitalia in left lateral view, $516=$ left gonopod in ventral view, 517 = phallic organ in left lateral view.

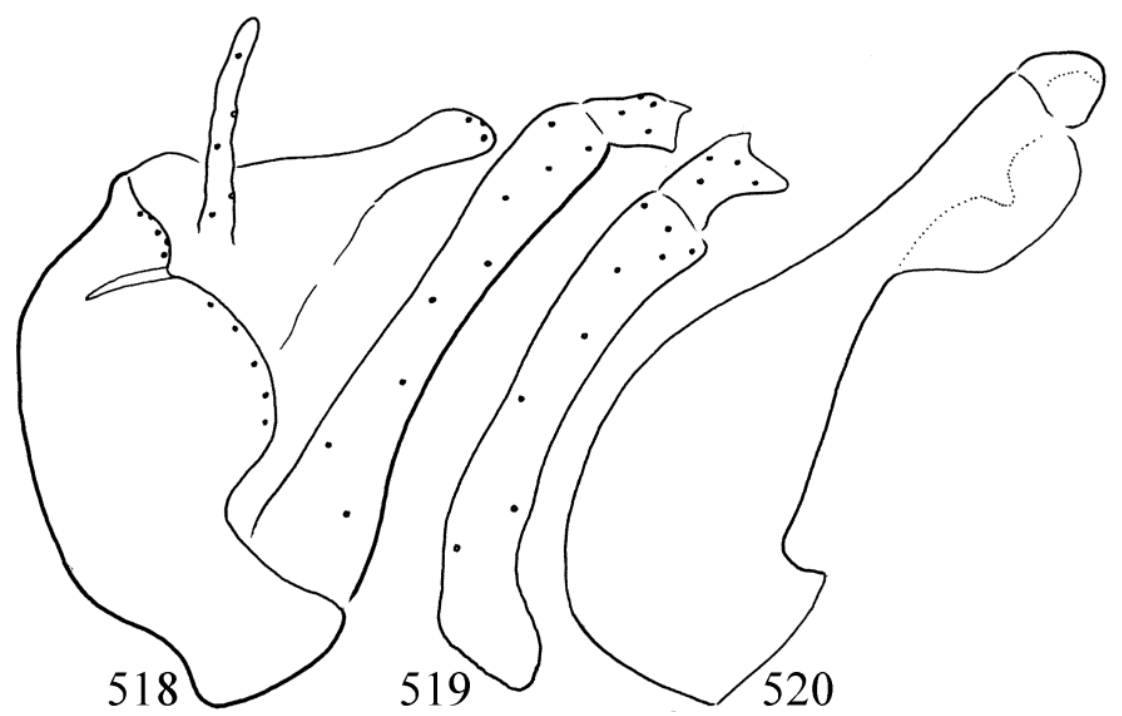

Figures 518-520. Hydromanicus tiyang sp. nov. Holotype: $518=$ male genitalia in left lateral view, $519=$ left gonopod in ventral view, $520=$ phallic organ in left lateral view.

manicus mattiyang sp. nov., it should be located near this point: $24^{\circ} 53^{\prime} 16.1^{\prime \prime} \mathrm{N} 94^{\circ} 36^{\prime} 49.2^{\prime \prime} \mathrm{E}, 17$. VI.1960, leg. F. Schmid (1 male, CNC). Paratype: India, Manipur, Tairenpokpi, 4000 ft., 2449' 36.7"N 9348'14.6"E, 31.V.1960, leg F. Schmid (1 male, OPC).

Diagnosis. This new species belongs to the $H$. luctuosus species group and to the H. luctuosus species complex. Having bi-pointed harpago in ventral view it has resemblance to $H$. luctuosus, but differs by the needle pointed dorsoapical and mesoapical bifid apical ending of the harpago as well as by the serrated ventroapical keel and by the subtriangular endothecal sclerites of the phallic organ.

Description. A brown coloured animal forewing slightly light spotted, forewing length 12 $\mathrm{mm}$. 
Male genitalia. Abdominal segment IX divided by suture into a smaller dorsal and a larger ventral part; its median keel medium-long and narrow; anterior margin arciform, resulted in a very short dorsum and slightly longer ventrum; apical lobe on posterolateral margin less produced; intersegmental depression between the ninth and tenth segments low in lateral view. Body of segment $\mathrm{X}$ broad-based less sclerotized; setose cerci elongated foliform; dorsoapical setose lobes form a bilobed apex of segment X. The basal segment of the gonopods slightly arching and constricted middle; terminal segment, the harpago bi-pointed in ventral view. Phallic apparatus robust, subapical ventral keel short with serrated anterior half, endothecal sclerites short and subtriangular.

Etymology. tiyang, coined from the name of the holotype locus typicus.

\section{Hydromanicus tungnath sp. nov.}

(Figures 521-523, Map 2: n² 22, 41, Map 31)

Material examined. Holotype: India, Uttarakhand, Pauri Garhwal, Tungnath, $9000 \mathrm{ft}$, brook with mosses in forest, $30^{\circ} 28^{\prime} 41.9^{\prime \prime} \mathrm{N} 79^{\circ} 12^{\prime}$ 43.9"E, 1.VI.1958, leg. F. Schmid (1 male, CNC). Paratype: India, Pauri Garhwal, Khumyara [=Khumera according to Lonsdale (2020)], 30 $33^{\prime}$ $15.4^{\prime \prime} \mathrm{N} 79^{\circ} 03^{\prime} 44.3^{\prime \prime} \mathrm{E}, 4300-5000 \mathrm{ft}, 27-28 . \mathrm{V}$. 1958, leg. F. Schmid (1 male, OPC).

Diagnosis. This new species belongs to the $H$. luctuosus species group and to the H. luctuosus species complex. Having bicuspidate harpago in ventral view it has resemblance to $H$. garhwal sp. nov. but differs by the ventral profile of the harpago with dorsoapical lobe very produced dominating on the harpago head and well visible both in lateral and ventral views; the lateral profile of the phallic organ also differs, that is the neck, the before-keel-region is very narrow and the keel is rounded-shaped.

Description. A brown coloured animal; forewing slightly but distinctly light spotted, forewing length $15 \mathrm{~mm}$.
Male genitalia. Abdominal segment IX divided by suture into a smaller dorsal and a larger ventral part; its median keel medium-long and narrow; anterior margin arciform, resulted in a very short dorsum and longer ventrum; apical lobe on posterolateral margin flatly rounded produced; intersegmental depression between the ninth and tenth segments low in lateral view. Body of segment $\mathrm{X}$ broad-based less sclerotized; setose cerci elongated foliform with blunt apex; dorsoapical setose lobes form a bilobed apex of segment X. The basal segment of the gonopods slightly arching and constricted middle; terminal segment, the harpago bi-pointed in ventral view, the dorsoapical lobe is well-developed. Phallic apparatus robust, subapical ventral keel short with serrated anterior half, endothecal sclerites short and semicircular.

Etymology. tungnath, named after the locus typicus of the holotype.

\section{Hydromanicus umbonatus new species complex}

Hydromanicus unbonatus new species complex in the H. luctuosus species group is characterized by a somehow and somewhat flat harpago in ventral view.

\section{Hydromanicus kover sp. nov.}

(Figures 524-526, Map 6: n 18, Map 32)

Material examined. Holotype: India, Manipur, Mapum, $5000 \mathrm{ft} ., 2^{\circ} 04^{\prime} 55.9^{\prime \prime} \mathrm{N}$ 94³0'16.9"E, 11. VI.1960, leg. F. Schmid (1 male, CNC).

Diagnosis. This new species belongs to the $H$. luctuosus species group. Having somehow flat harpago most close to the $H$. umbonatus species complex and the uniquely broad harpago and the very low subapical ventral keel on the phallic organ have resemblance to H. umbonatus Li, 1993 described from China (Yunnan), but differs by the lateral shape of segment IX, the double suture development dividing segment IX into dorsal and ventral regions; by the dorsoapical setose lobe that is capitate and upward directed, not elongated and downward directed; by the short and more 


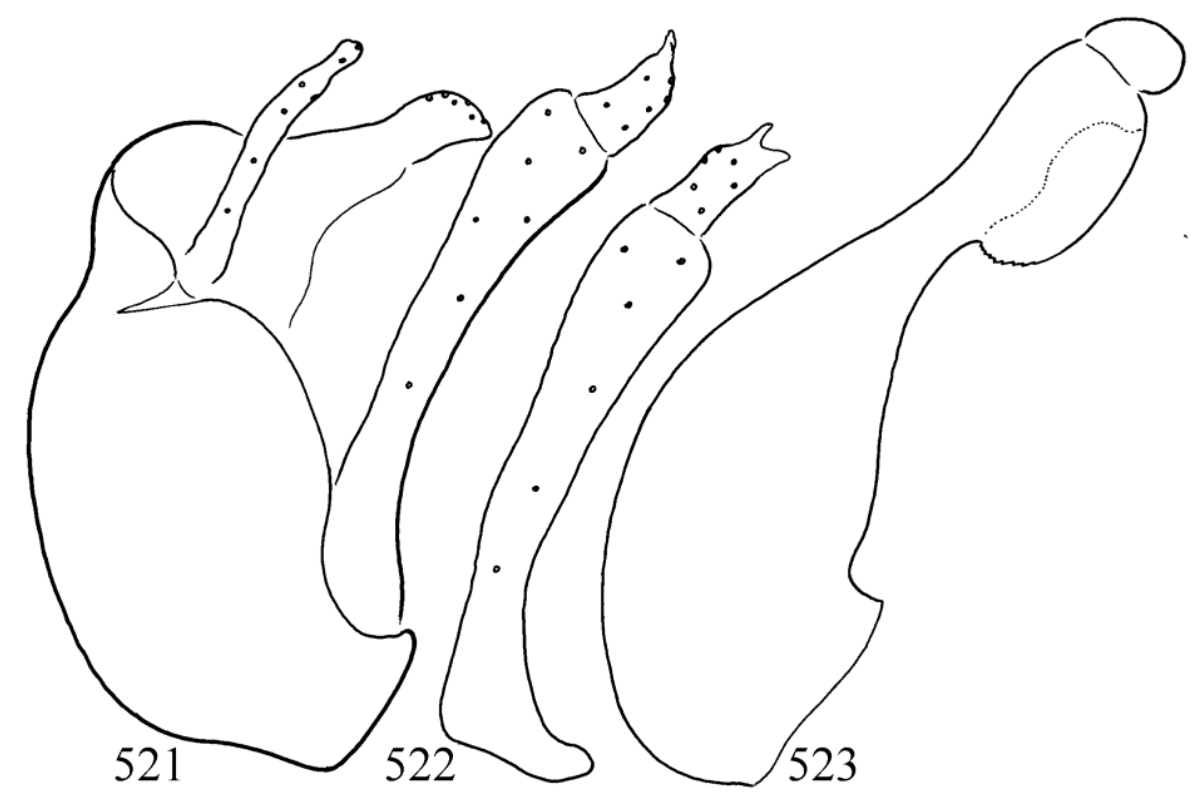

Figures 521-523. Hydromanicus tungnath sp. nov. Holotype: 521 = male genitalia in left lateral view, $522=$ left gonopod in ventral view, 523 = phallic organ in left lateral view.

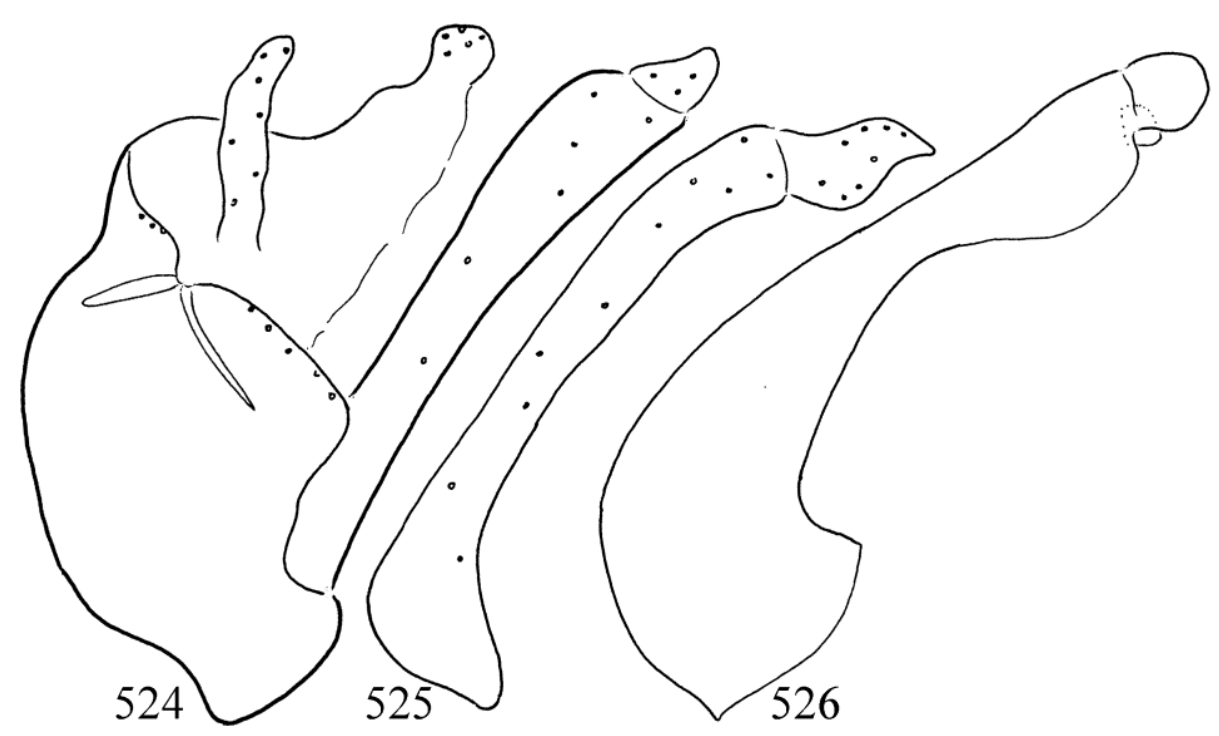

Figures 524-526. Hydromanicus kover sp. nov. Holotype: 524 = male genitalia in left lateral view, $525=$ left gonopod in ventral view, $526=$ phallic organ in left lateral view.

broad S-form harpago; as well as by the more slender phallobase and the less produced, low ventroapical keel.

Description. A brown coloured animal forewing slightly light spotted, forewing length is 10 $\mathrm{mm}$.
Male genitalia. Abdominal segment IX divided by suture into a smaller dorsal and a larger ventral part, a unique additional suture originates from this suture and directed ventrad; the median keel of segment IX medium-long and narrow; anterior margin arciform, resulted in a very short dorsum and slightly longer ventrum; apical lobe 
on posterolateral margin less produced, flat triangular; intersegmental depression between the ninth and tenth segments low in lateral view. Bo$\mathrm{dy}$ of segment $\mathrm{X}$ broad-based less sclerotized; setose cerci elongated digitiform; dorsoapical setose lobes bilobed as visible in dorsal views and capitate in lateral view. The basal segment of the gonopods robust; terminal segment, the harpago very unique in the genus with its broad fat Sforming shape. Phallic apparatus slender, subapical ventral keel low; endothecal sclerites circular.

Etymology. kover, coined from "kövér" fat in Hungarian, refers to the unique shape of the harpago, the short, broadly fat S-form shaped, especially visible in ventral view

\section{Hydromanicus manisir sp. nov.}

(Figures 527-529, Map 6: $\mathrm{n}^{\circ}$ 14, Map 32)

Material examined. Holotype: India, Manipur, Sirohi Kashong $[=$ Siruhi Kashong, $=$ Shirui Kashong (peak)], 7000-7500 ft, $25^{\circ} 07^{\prime} 16.8^{\prime \prime} \mathrm{N} 94^{\circ} 27^{\prime}$ 29.5"E, 6-7.VI. 1960, leg. F. Schmid (1 male,
CNC). Paratypes: same as holotype (1 male, CNC; 1 male, OPC, 1 male SMNH). India, Manipur, Sirohi Kashong, $7000-7500 \mathrm{ft}, 25^{\circ} 07^{\prime} 16.8^{\prime \prime} \mathrm{N}$ 94²7'29.5"E, 9.VI. 1960, leg. F. Schmid (1 male, CNC).

Diagnosis. This new species belongs to the $H$. luctuosus species group. Having sagitally somehow flat harpago most close to the H. umbonatus species complex and the uniquely broad shaped harpago has resemblance to $H$. sironis sp. nov. described from the same habitat, but differs by the rounded triangular apical lobe on the posterolateral margin of segment IX; by the longer harpago with middle located blunt pointed apical process in ventral view as well as by the lateral shape of the phallic organ and its endothecal sclerites.

Description. A brown coloured animal with forewing with just discernible light spotted pattern (old specimen!), forewing length is $11 \mathrm{~mm}$.

Male genitalia. Abdominal segment IX divided by suture into a smaller dorsal and a larger ventral part; its median keel medium-long and

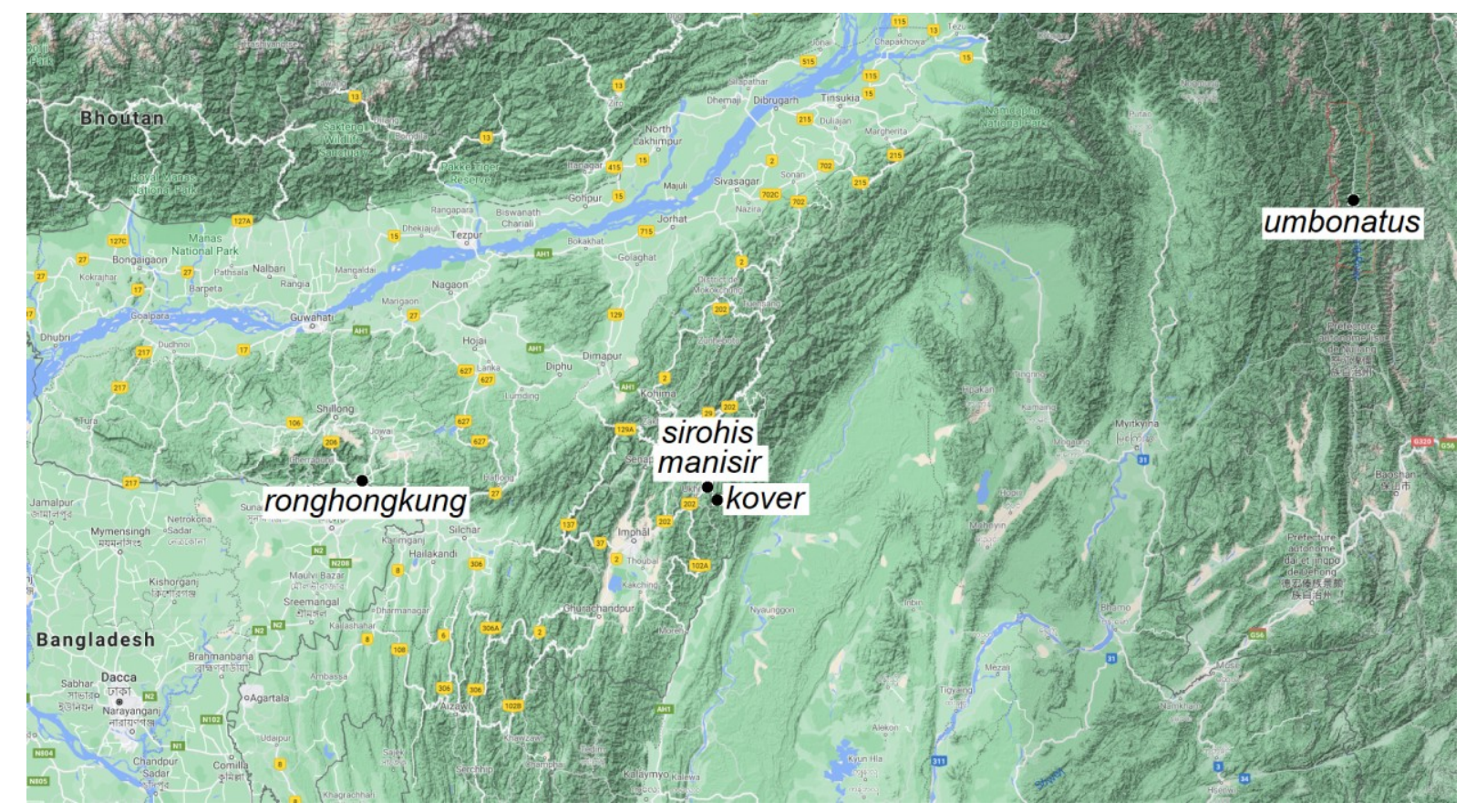

Map 32. Hydromanicus umbonatus complex. 


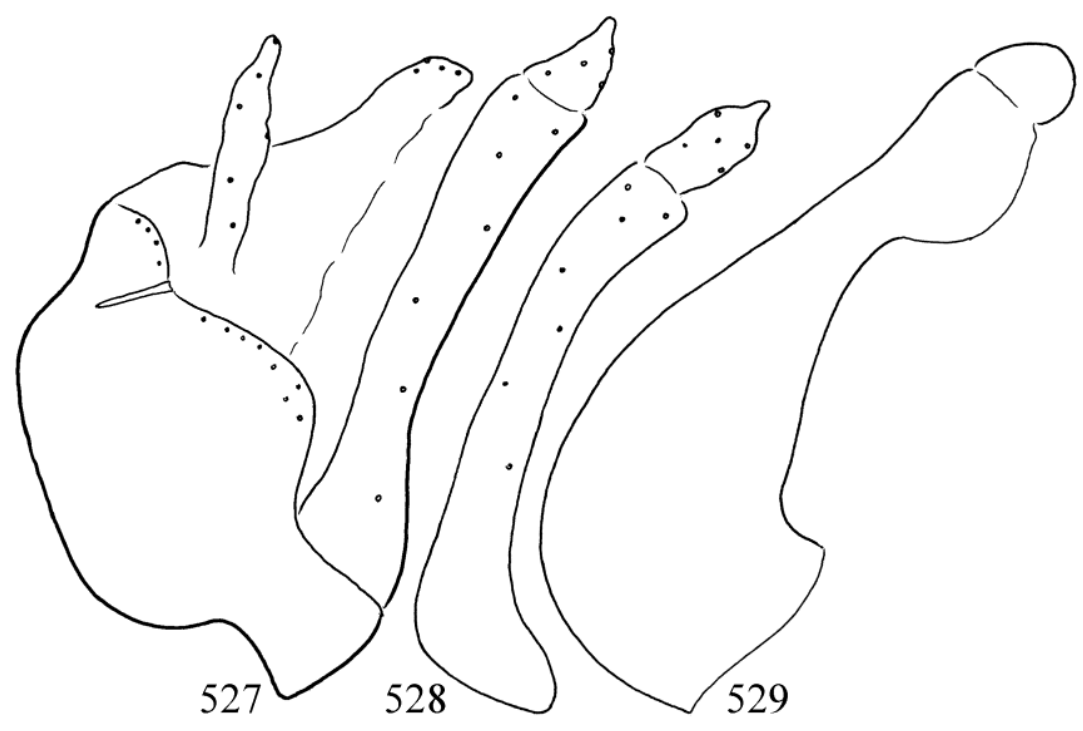

Figures 527-529. Hydromanicus manisir sp. nov. Holotype: 527 = male genitalia in left lateral view, $528=$ left gonopod in ventral view, $529=$ phallic organ in left lateral view.

narrow; anterior margin arciform, resulted in a very short dorsum and longer ventrum; apical lobe on posterolateral margin rounded triangular, comprising the bulk of the segment with long marginal setae; intersegmental depression between the ninth and tenth segments obtuse-angled in lateral view. Body of segment $\mathrm{X}$ broad-based less sclerotized; its bilobed apex upward positioned elongated and tapering. Setose cerci short foliform, shorter than segment $\mathrm{X}$. The basal segment of the gonopods straight, short and robust stout; terminal segment, the harpago sagitally flat with blunt middle located apical process in ventral view. Phallic apparatus robust with very low narrow neck, behind the ventral keel; subapical ventral keel short semicircular, endothecal sclerites short semicircular.

Etymology. manisir, coined from the name of holotype locus typicus.

\section{Hydromanicus ronghongkung sp. nov.}

(Figures 530-532, Map 5: n 9, Map 32)

Material examined. Holotype: India, Meghaláya (United Jaintia and Khasi Hills), Ronghongkung, [=Rhongkum], $200 \mathrm{ft}, 25^{\circ} 10^{\prime} 49.4^{\prime \prime} \mathrm{N} \mathrm{92^{ \circ } 0 5 ^ { \prime }}$ 01.5"E, 9.XII.1959, leg. F. Schmid (1 male, $\mathrm{CNC})$.
Diagnosis. This new species belongs to the $H$. luctuosus species group. Having sagitally somehow flat harpago most close to the H. umbonatus species complex and the uniquely broad shaped harpago have resemblance to $H$. sirohis sp. nov. described from Manipur, but differs by the shorter segment IX; the harpago without any dorsal spine-like process in ventral view; and by the low ventroapical keel on the phallic organ.

Description. A brown coloured animal with forewing with discernible light spotted pattern (old specimen!), forewing length $9 \mathrm{~mm}$.

Male genitalia. Abdominal segment IX short, divided by suture into a smaller dorsal and a larger ventral part; its median keel medium-long and narrow; anterior margin arciform, resulted in a very short dorsum and longer ventrum; apical lobe on posterolateral margin rounded flat, comprising the bulk of the segment with long marginal setae; intersegmental depression between the ninth and tenth segments sloping in lateral view. Body of segment $\mathrm{X}$ broad-based less sclerotized; its bilobate apex is upward positioned rounded. Setose cerci short foliform with constricted basal region, much shorter than segment $\mathrm{X}$. The basal segment of the gonopods slightly arching and robust stout with enlarged basement; terminal segment, the harpago sagitally flat and fan-like. 


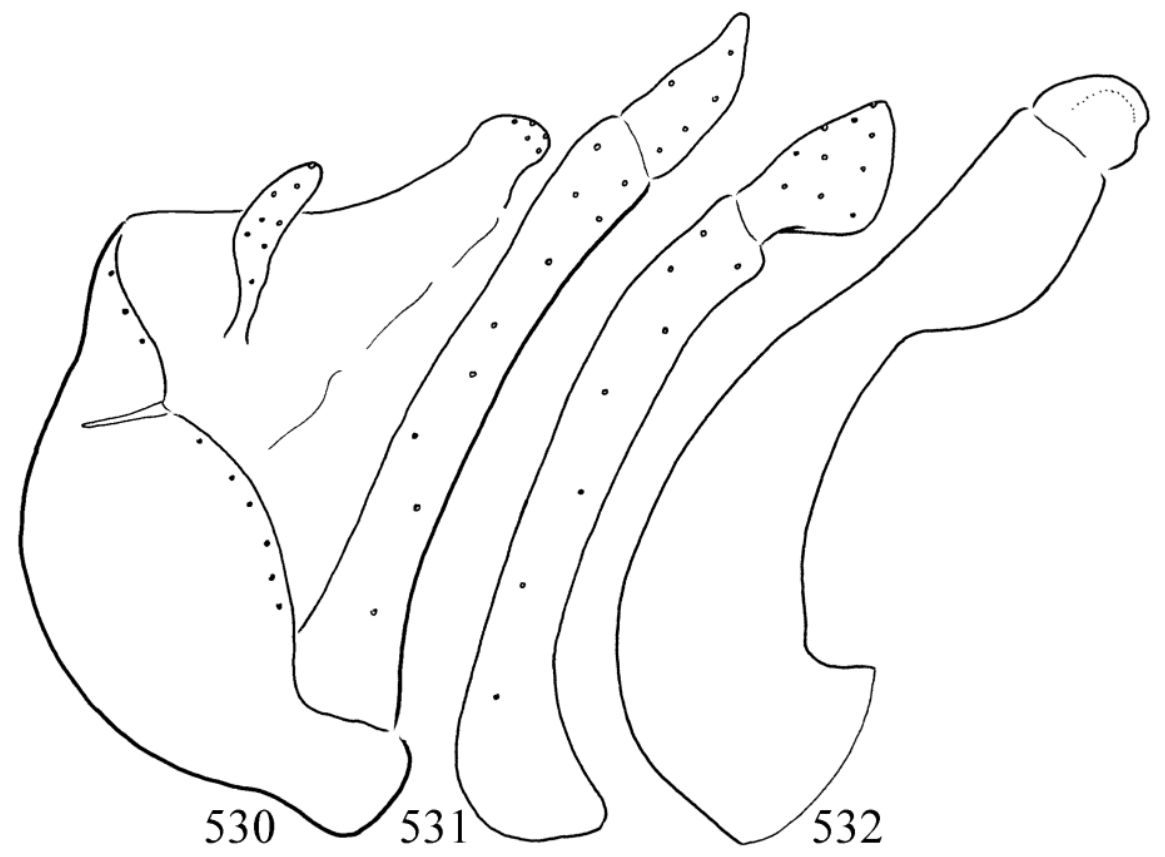

Figures 530-532. Hydromanicus ronghongkung sp. nov. Holotype: $530=$ male genitalia in left lateral view, $531=$ left gonopod in ventral view, 532 = phallic organ in left lateral view.

Phallic apparatus robust with low slender neck, behind the ventral keel; subapical ventral keel flat semicircular, endothecal sclerites short with bilobate ventrum.

Etymology. ronghongkung, named after the locus typicus of holotype.

\section{Hydromanicus sirohis sp. nov.}

(Figures 533-535, Map 6: $\mathrm{n}^{\circ}$ 14, Map 32)

Material examined. Holotype: India, Manipur, Sirohi Kashong [=Siruhi Kashong, =Shirui Kashong (peak)], 7000-7500 ft, $25^{\circ} 07^{\prime} 16.8^{\prime \prime} \mathrm{N} 94^{\circ} 27^{\prime}$ 29.5"E, 6.-7.VI. 1960, leg. F. Schmid (1 male, CNC).

Diagnosis. This new species belongs to the $H$. luctuosus species group. Having sagitally somehow flat harpago most close to the H. umbonatus species complex and the uniquely broad shaped harpago have resemblance to $H$. manisir sp. nov. described from the same habitat, but differs by the rounded flat apical lobe on the posterolateral margin of segment IX; by the shorter harpago with left located pointed apical process in ventral view as well as by the lateral shape of the phallic organ and its endothecal sclerites.

Description. A brown coloured animal with forewing with just discernible light spotted pattern (old specimen!), forewing length $11 \mathrm{~mm}$.

Male genitalia. Abdominal segment IX divided by suture into a smaller dorsal and a larger ventral part; its median keel medium-long and narrow; anterior margin arciform, resulted in a very short dorsum and longer ventrum; apical lobe on posterolateral margin rounded flat, comprising the bulk of the segment with long marginal setae; intersegmental depression between the ninth and tenth segments obtuse-angled in lateral view. Body of segment X broad-based less sclerotized; its bilobed apex is upward positioned elongated and tapering. Setose cerci short foliform, shorter than segment X. The basal segment of the gonopods straight, short and robust stout with enlarged basement; terminal segment, the harpago sagitally flat and short with left located pointed apical process. Phallic apparatus robust with very low slender neck, behind the ventral 


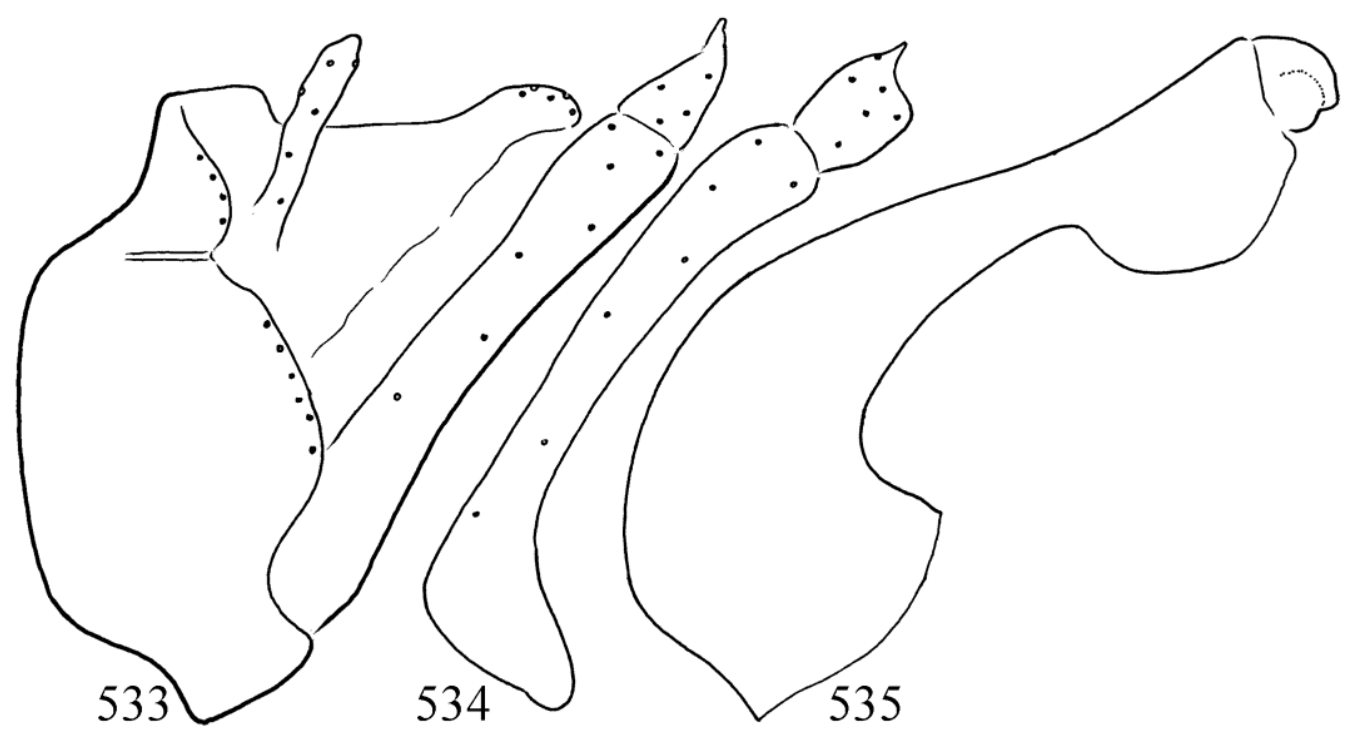

Figures 533-535. Hydromanicus sirohis sp. nov. Holotype: 533 = male genitalia in left lateral view, $534=$ left gonopod in ventral view, $535=$ phallic organ in left lateral view.

keel; subapical ventral keel long semicircular, endothecal sclerites short with bilobed ventrum.

Etymology. sirohis, coined from the name of holotype locus typicus.

\section{Hydomanicus umbonatus Li, 1992}

(Map 32)

Hydromanicus umbonatus $\mathrm{Li}, 1992$ in Tian et al. 1992:

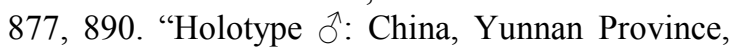
Hengduan Mountains, Fugong, Maji, 1196m."

\section{Hydromanicus spatulatus species group}

Species group with the following character combination. (1) Very narrow almost lacking or triangular apical lobe on segment IX. (2) Long or medium-sized segment $\mathrm{X}$ frequently with elongated processes. (3) Bilobed and long cerci. (4) Broad ventromesal subapical keel on the phallotheca is lacking, however uniquely developed sclerous endothecal lobes and phallotremal sclerites present or variously formed endothecal sclerous spines, plates or hooks accompanying the phallothecal apex (Oláh \& Johanson, 2008).

\section{Hydromanicus rahung sp. nov.}

(Figures 536-538, Map 4: $\mathrm{n}^{\circ}$ 23, Map 33)

Material examined. Holotype: India, Arunachal Pradesh (Assam), Kameng, Rahung, 65007000 ft., $27^{\circ} 18^{\prime} 46.2^{\prime \prime} \mathrm{N} 92^{\circ} 23^{\prime} 43.8^{\prime \prime} \mathrm{E}, 16$.VII. 1961, leg F. Schmid (1 male, CNC).

Diagnosis. This new species without produced rounded apical lobe on segment X, with bilobed cerci and with terminal phallothecal processes belongs to the $H$. spatulatus species group. Most close to $H$. diomedes Malicky described from Nepal and to $H$. makareus Malicky described from Bhutan, but differs by the subdivided formation of the cercal complex, the lateral profile of segment $\mathrm{X}$, by the broad based harpago as well as by the fine structure of the phallic head, that is the shape of endothecal and phallotremal sclerites as well as the subdivided terminal of the phallotheca.

Description. A brown coloured animal; forewing slightly but distinctly light spotted of $12 \mathrm{~mm}$ length.

Male genitalia. Abdominal segment IX convex anterad, its dorsal region the tergite very short, 


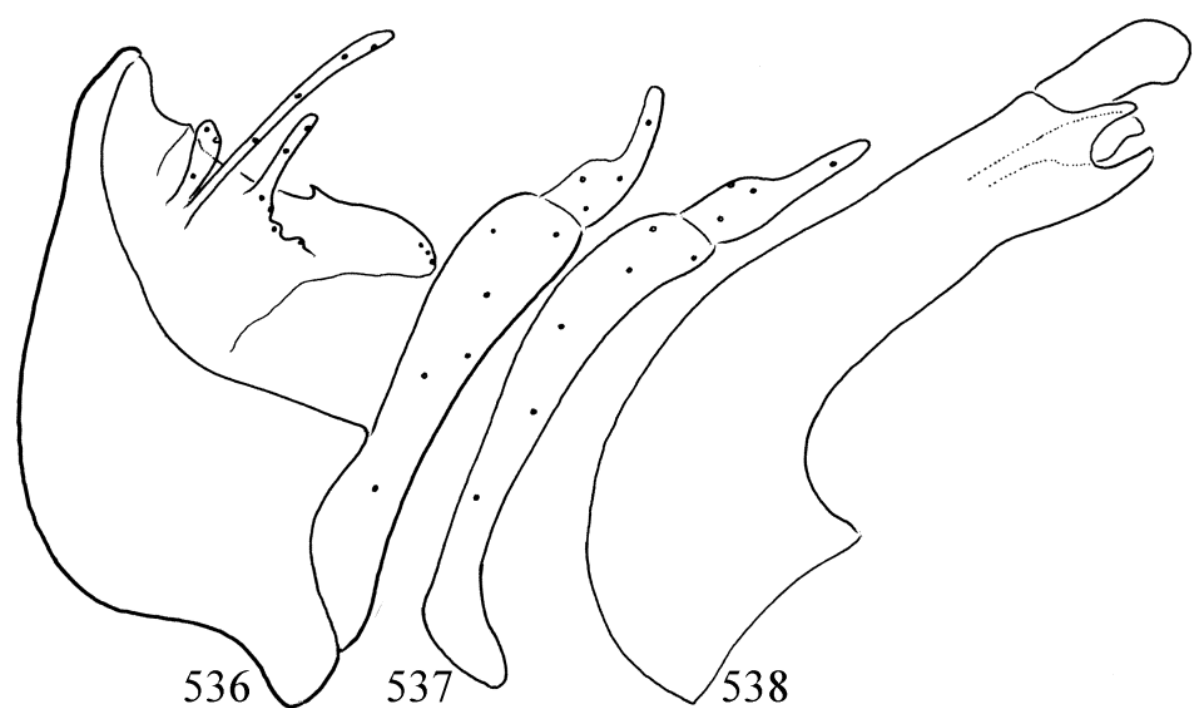

Figures 536-538. Hydromanicus rahung sp. nov. Holotype: $536=$ male genitalia in left lateral view, $537=$ left gonopod in ventral view, $538=$ phallic organ in left lateral view.

apical lobe triangular; its median keel short and narrow; anterior margin arciform, resulted in a very short dorsum and longer ventrum; intersegmental depression between the ninth and tenth segments high in lateral view. Body of segment X broad-based less sclerotized; dorsoapical setose lobes form a bilobed apex of segment X. Setose cerci subdivided and even separated; it is represented by a cercal complex characterized by the usual short, but broad and long and slim bilobed structure and the presence of a separated, posterad shifted setose digitiform process continuing into small setose humps. The basal segment of the gonopods broad robust; terminal segment, that is the harpago with broad basal half. Phallic apparatus robust, phallothecal terminal with a pair of ventral and a pair of lateral small digitiform processes; the pair of phallotremal sclerites rather produced as well as the endothecal sclerites elongated with rounded head.

Etymology. rahung, named after the locus typicus of the holotype.

\section{Hydromanicus spatulatus species cluster}

There is a small species cluster separated here in the H. spatulatus new species group with four closely related species distributed in South India. Their phallotremal sclerites and sclerous endothe- cal lobes are so peculiarly developed that we group them together in this cluster. Their phallotremal sclerites beaked and their sclerous endothecal processes cornuted (Oláh \& Johanson, 2008).

\section{Hydromanicus palnis Oláh \& Johanson, 2008}

$$
\text { (Map 7a: n²7, 30, Map 33) }
$$

Hydromanicus palnis Oláh \& Barnard, 2008: in Oláh \& Johanson 2008:46-48. "Holotype male: India, Tamil Nadu, Palnis, 7000 ft, Kodaikanal, 10 $10^{\circ}$

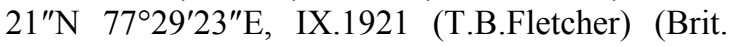
Mus. 1936-643, NHML)."

Material examined. India, Tamil Nadu (Madras), Swamp Hill, South Mannavanur, $7300 \mathrm{ft}$., $10^{\circ} 10^{\prime} 01.2^{\prime \prime} \mathrm{N} 77^{\circ} 22^{\prime} 36.1 " \mathrm{E}, 2 . I I .1962$, leg. F. Schmid (3 males, CNC; 1 male, OPC; 1 male, SMNH).

\section{Hydropsyche}

\section{Hydropsyche nevae species group}

Species of this group has phallotheca with membranous subapical dorsum, the modified endotheca, surmounted by a pair of more or less fused heavily pigmented dark ball-like phallotremal sclerites. Just behind the dominating structure of phallotremal sclerites arises a pair of long 


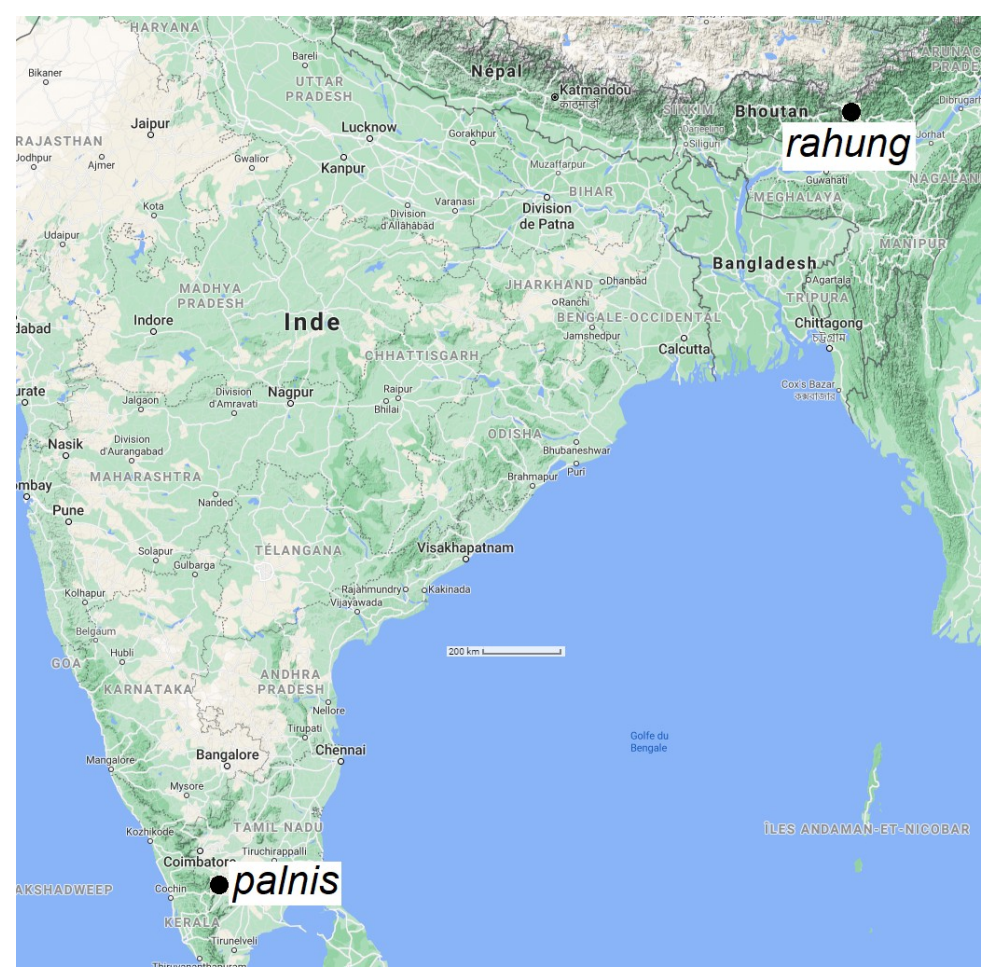

Map 33. Hydromanicus spatulatus group: only 2 species are shown.

membranous endothecal processes tipped by sclerous point, spicule or spine, sometimes replaced by rounded membranous spine-window in various position with sclerous point, spicule or spine. The lower ventral and apical portion of endotheca fused with the apex of the phallotheca (enlarged phallobase). Three apicoventral lobules of endotheca surrounded at the base by sclerous integument, each lobule membranous and eversible to some extent and tipped with a cluster of pale but sclerous spicules; sometimes these lobules fused into one or two larger lobules inverted deep into the sclerous apical portion of the endotheca (Oláh \& Johanson 2008b).

\section{Hydropsyche columnata lineage}

The basic hydropsychine profile of the phallic apparatus is modified into an inverse V-shaped meeting of the basal and terminal sections of the phallotheca, forming a triangularly sinuate bend or modified at least into a significant dorsal elevation of this meeting point, resulted in deep sloping to the shortened terminal section of the phallotheca (Oláh \& Johanson 2008b).

Hydropsyche yathetima Oláh \& Schefter, 2008

(Map 4: $n^{\circ} 21,69$ )

Hydropsyche yathetima Oláh \& Schefter, 2008: in Oláh \& Johanson 2008:134-136. "Holotype male: India, Assam, Kameng, Rupa, 5200-6000 ft, $27^{\circ}$ $12^{\prime} 10.6^{\prime \prime} \mathrm{N} 92^{\circ} 23^{\prime} 55.1$ "E, 26.VIII.1961 (F. Schmid)."

Material examined. India, Arunachal Pradesh (Assam), Kameng District, Chug, 6800-7300 ft., $27^{\circ} 25^{\prime} 07.7^{\prime \prime} \mathrm{N} 92^{\circ} 14^{\prime} 01 " \mathrm{E}, 25-31 . V I I .1961$, leg F. Schmid (1 male, CNC).

\section{Hydropsyche simulata lineage}

The basic hydropsychine profile of the phallic apparatus is modified into an inverse U-shaped meeting of the basal and terminal sections of the phallotheca, forming a rounded or rectangular sinuate bends. The dorsal side of the bend never 
acute, rather obtuse angled, forming a wide and flat dorsum of elevation. The basal section of the bend longer than the terminal section (Oláh \& Johanson 2008b).

\section{Hydropsyche keralana Oláh \& Barnard, 2008}

(Map 7a: $\mathrm{n}^{\circ} 12,23$ )

Hydropsyche keralana Oláh \& Barnard, 2008; in Oláh \& Johanson 2008:138-139. "Holotype male: India, Kerala, Road to Lamb's Rock, beyond Coonoor, $6000 \mathrm{ft}, 11^{\circ} 21^{\prime} 12.9^{\prime \prime} \mathrm{N}$ 76²49'55.5"E, 20.X. 1921 (T. B. Fletcher)."

Material examined. India, Tamil Nadu (Madras), Sothuparai dam, $1200 \mathrm{ft}, 10^{\circ} 07^{\prime} 48.8^{\prime \prime} \mathrm{N} 77^{\circ}$ 28'03.2"E, 22.I.1962, leg. F. Schmid (1 male, CNC). India, Tamil Nadu (Madras), Sothuparai dam, $1200 \mathrm{ft}, 10^{\circ} 07^{\prime} 48.8^{\prime \prime} \mathrm{N} 77^{\circ} 28^{\prime} 03.2^{\prime \prime} \mathrm{E}, 22 . \mathrm{I}$. 1962, leg. F. Schmid (1 male, SMNH; 1 male, OPC). India, Tamil Nadu (Madras), Old Kuttalam Falls [= Courtallam Falls], 200m, 8०54'04.3"N 77¹7'47.9"E, 15.I.1962 (2 males, CNC).

\section{Hydropsyche serpentina lineage}

The basic hydropsychine profile of the phallic apparatus modified into a ring-shaped meeting of the basal and terminal sections of the phallotheca, forming double sinuate bends. The ring-shaped bend continues into the horizontal terminal section with a right angle, at least on the dorsum. The length of the bend almost double of the horizontal terminal segment (Oláh \& Johanson 2008b).

\section{Hydropsyche shillonga Oláh \& Barnard, 2008}

$$
\text { (Map 5: } \mathrm{n}^{\circ} \text { 5, 7, 10, 72) }
$$

Hydropsyche shillonga Oláh \& Barnard, 2008; in Oláh \& Johanson 2008:150-152. "Holotype male: India, Assam, Shillong, 2534'43.8"N 91 ${ }^{\circ} 53^{\prime} 10.7 " \mathrm{E}$, IXX.1918 (T. B. Fletcher).”

Material examined. India, Meghaláya (United Jaintia and Khasi Hills), Barato, $2500 \mathrm{ft}$., $25^{\circ}$ 36'24.1"N 92²7'23.1"E, 24.IV.1960, leg. F. Schmid (1 male, CNC). Meghaláya (United Jaintia and Khasi Hills), Shnongpdeng, 500 ft., 6.XII.
1959, leg. F. Schmid (2 males, OPC). Meghaláya (United Jaintia and Khasi Hills), Sohkha, 200-300 ft., 7.XII.1959, leg. F. Schmid (1 male, SMNH). Meghaláya (United Jaintia and Khasi Hills), Sohkharim, 200 ft., 10.XII.1959, leg. F. Schmid (1 male, CNC).

Acknowledgement - We are grateful to Owen Lonsdale, Collections Manager, Canadian National Collection of Insects and National Identification Center (Entomology) in Ottawa, Canada. We acknowledge him for the cooperation and kind help provided during the entire procedure of our study.

\section{REFERENCES}

AUBERT, J. (1967): Les Nemouridae de l'Assam (Plécoptera). Mitteilungen der Schweizerischen Entomologischen Gesellschaft, 39(3-4): 209-253.

BANKS, N. (1934): XXXXVIII. Supplementary Neuropteroid insects from the Malay Peninsula, and from Mt. Kinabalu, Borneo. Journal of the Federated States Malay Museums, 17: 567-578.

BANKS, N. (1937): Philippine Neuropteroid Insects. The Philippine Journal of Science, 63(2): 125-172.

Chantaramongkol, P. \& Malicky, H. (1995): Drei neue asiatische Hydromanicus (Trichoptera: Hydropsychidae). Entomologische Zeitschrift, Essen, 105(5): 92-95.

FLINT, O.S. Jr. (2001): Diplectroninae of Sri Lanka (Trichoptera: Hydropsychidae). Proceedings of the Biological Society of Washington, 114(1): 91-103).

HuXLEY, J.S. (1940): The new systematics. Clarendon Press, Oxford, $583 \mathrm{pp}$.

Kimmins, D.E. (1955): Results of the Oxford University Expedition to Sarawak, 1932. Order Trichoptera. Sarawak Museum Journal, 6(5): 374-442.

KimminS, D.E. (1964): On the Trichoptera of Nepal. Bulletin of the British Museum (Natural History) Entomology 15(2): 35-55. doi: 10.5962/bhl.part.20534

LONSDALE, O. (2020): Name-bearing type specimens of Trichoptera (Insecta) in the Canadian National Collection of Insects, Arachnids \& Nematodes (CNC), with a biography of Fernand Schmid. $O$ puscula Zoologica Budapest, 51(Supplementum 1): 3-141. doi: 10.18348/opzool.2020.S1.3 
MALICKY, H. (1993): Ein Beitrag zur Kenntnis asiatischer Arten der Gattungen Cheumatopsyche Wallengren 1891 und Potamyia Banks 1900 (Trichoptera, Hydropsychidae). (Zugleich 22. Arbeit über thailändische Köcherfliegen). Linzer biologische Beiträge, 29(2): 1015-1055.

MALICKY, H. (1993): First speculations on the size of areas and the number of species of caddisflies (Trichoptera) in southeastern Asia. In: OTTO, C. (Ed.) Proceedings of the $7^{\text {th }}$ International Symposium on Trichoptera, p. 92.

MALICKY, H. (1997). Neue asiatische Köcherfliegen (Trichoptera: Philopotamidae, Polycentropodidae, Psychomyidae, Ecnomidae, Hydropsychidae, Leptoceridae). Linzer biologische Beiträge, 25(2): 1099-1136.

MalicKY, H. (1998): Neue Köcherfliegen (Trichoptera) aus Indien, Myanmar, Nepal und Palawan. Braueria (Lunz am See), 25: 20-22.

MalicKY, H. (2002): Ein Beitrag zur Kenntnis asiatischer Arten der Gattung Diplectrona Westwood, 1840 (Trichoptera, Hydropsychidae). Linzer biologische Beiträge, 34(2):1201-1236.

MALICKY, H. (2009): Beiträge zur Kenntnis asiatischer Trichopteren. Braueria (Lunz am See, Austria), 36: $11-58$.

MALICKY, H. (2013): Synonyms and possible synonyms of Asiatic Trichoptera. Braueria (Lunz am See, Austria), 40: 41-54.

MALICKY, H. (2017): Über die Unterscheidung einiger Chimarra- und Cheumatopsyche-Arten (Trichoptera: Philopotamidae, Hydropsychidae) und über ihre Variabilität. Braueria (Lunz am See, Austria), 44: 31-43.

Malicky, H. (2018): Notes by Fernand Schmid from his research trips to India 1958-1962. Braueria (Lunz am See, Austria), 45: 5-13.

MartynOV, A. (1927): Contributions to the aquatic entomofauna of Turkestan. I. Trichoptera annulipalpia. Annuaire du Musée Zoologique de l'Académie des Sciences de l'URSS, 28: 162-192.

MARTYNOV, A. (1930): On the trichopterous fauna of China and eastern Tibet. Proceedings of the Zoological Society of London, 100(1): 65-112. doi: 10.1111/j.1096-3642.1930.tb00967.x

MARTYNOV, A. (1934): Trichoptera Annulipalpia. Tableaux analytiques de la Faune de l'URSS. In- stitut Zoologique de l'Académie des Sciences Vol. 13, SSSR Academy of Science, Leningrad, 343 pp.

MARTYNOV, A. (1935): On a collection of Trichoptera from the Indian Museum. Records of the Indian Museum, 37(2): 93-209.

MAYR, E. (1942): Systematics and the origin of species. Columbia University Press, New York, 334 pp.

MEY, W. (1997): Revision of the type-species of Hydropsychinae and Diplectroninae described by $N$. Banks from the Philippines (Trichoptera: Hydropsychidae). In: HolzenTHAL, R.W. \& Flint, O.S. (Eds.) Proceedings of the $8^{\text {th }}$ International Symposium on Trichoptera. Ohio Biological Survey, p. 303-308.

Mosely, M.E. (1939): Trichoptera. Ruwenzori Expedition 1934-35. British Museum (Natural History), 3(1): $1-40$.

Mosely, M.E. (1942): Chinese Trichoptera: a collection made by Mr. M.S. Yang in Foochow. Transactions of the Entomological Society of London, 92(2): 343-362.

NeBoIss, A. (1996): Notes and illustrations of some Hydropsyche and Hydromanicus types (Hydropsychidae). Braueria (Lunz am See, Austria), 23: 7-9.

NimMO, A.P. (2000): Fernand Schmid: personal memories. Braueria (Lunz am See, Austria), 27: 9-10.

OLÁH, J. (1993): Seven new Trichoptera from the Gombak River system, Malaysia. Folia Entomologica Hungarica, 54: 93-100.

OlÁH J., BARnARD, P.C. \& MALICKY, H. (2006): A revision of the lotic genus Potamyia Banks 1900 (Trichoptera: Hydropsychidae) with the description of eight new species. Linzer biologische Beiträge, 38(1): 739-777.

OLÁH J., JOHANSON K.A. \& BARNARD P.C. (2008a): Revision of the Oriental and Afrotropical species of Cheumatopsyche Wallengren (Trichoptera: Hydropsychidae). Zootaxa, 1738: 1-171. doi: 10.11646/zootaxa.1738.1.1

OlÁH J. \& Johanson, K.A. (2008b): Generic review of Hydropsychinae, with description of Schmidopsyche, new genus, 3 new genus clusters, 8 new species groups, 4 new species clades, 12 new species clusters and 62 new species from Oriental and Afrotropical regions (Trichoptera: Hydropsychidae). Zootaxa, 1802: 1-248 doi: $10.11646 /$ zootaxa.1802.1.1 
OlÁH J., Morse, J.C. \& Sun, C. (2008c): Status of four Chineses species of Hydropsychinae (Trichoptera: Hydropsychidae). Braueria (Lunz am See, Austria), 35: 9-10.

OLÁH, J. \& MALICKY, H. (2011): Caddisflies (Trichoptera) from Sumatra (Indonesia), with description of eleven new species. Braueria (Lunz am See, Austria), 38: 15-22.

OlÁH, J. (2013): On the Trichoptera of Vietnam, with description of 52 new species. Annales HistoricoNaturales Musei Nationalis Hungarici, 105: 55134.

OlÁH, J. (2017): Is the genus Potamophylax (Trichoptera: Limnephilidae) highly polymorphic? Acta Entomologica Musei Nationalis Pragae, 57(1): 253-257. doi: 10.1515/aemnp-2017-007

OLÁH, J. (2018a): Species delineation and description in Aethaloptera Brauer genus by phallic head (Trichoptera, Macronematinae). Opuscula Zoologica, Budapest, 49(1): 3-16.

doi: $\underline{10.18348 / \text { opzool.2018.1.3 }}$

OLÁH J. (2018b): Revisiting the genus Aethaloptera Brauer (Trichoptera, Hydropsychidae, Macronematinae): new species and records. Opuscula Zoologica, Budapest, 49(2): 181-190. doi: $10.18348 /$ opzool.2018.2.181

Oláh, J., Andersen, T., Beshkov, S., Billali, A., COPPA, G., IBrahimi, H., JOHANSON, K.A., KoVÁCS, T., MEY, W., Musliu, M., OlÁH, J. JR., \& RUIZ-GARCIA, A. (2019): Lineage sorting by paramere in Limnephilinae subfamily (Trichoptera): with description of a new tribe, new genera and new species. Opuscula Zoologica, Budapest, 50(Supplementum 1): 3-98. doi: 10.18348/opzool.2019.S1.3

OlÁH, J. \& DE VRIES, P.J. (2019): New Baliomorpha species (Trichoptera, Hydropsychidae) from Papua, Indonesia, with plesiomorphic state of phallic organ. Suara Serangga Papua (SUGAPA digital), 11(2): 87-93. doi: 10.19269/sugapa2019.11(2).05

OlÁH J., Vinçon, G., Kerimova, I., Kovács, T. \& MANKO, P. (2020a): On the Trichoptera of the Caucasus with western and eastern relatives. Opuscula Zoologica, Budapest, 51(Supplementum 3): 3-174. doi: 10.18348/opzool.2020.S3.3

OlÁH, J., OlÁH J. JR. \& LI, W.-H. (2020b): On the Trichoptera of China with relatives of adjacent territories I. Opuscula Zoologica, Budapest, 51(2): 153-212. doi: $10.18348 /$ opzool.2020.2.153

SCHMID, F. (1958): Trichoptères de Ceylan. Archiv für Hydrobiologie, 54(1-2):1-173.

SCHMID, F. (1961): Trichoptères du Pakistan. 4me partie. Tijdschrift voor Entomologie, 104(9): 187230.

SCHMID, F. (1984): Essai d'Evaluation de la Faune mondiale des Trichoptères. In: MORSE, J.C. (Ed.) Proceedings of the $4^{\text {th }}$ International Symposium on Trichoptera, Junk, The Hague, Series Entomologica 30, p. 337.

SuN, C.-H. (2017): Eight new species of Diplectrona (Trichoptera: Hydropsychidae) from China. Journal of the Kansas Entomological Society, 90(2): 146-161. doi: $10.2317 / 0022-8567-90.2 .146$

TIAN, L., LI, Y., YANG, L. \& Sun, C. (1992): Trichoptera. Insects of the Hengduan Mountains Region, 2: 868-191.

TIAN, L., YANG, L. \& LI, Y. (1996): Trichoptera (1): Hydroptilidae, Stenopsychidae, Hydropsychidae, Leptoceridae. Economic Insect Fauna of China 49, Science Press, Beijing, 196 pp.

UlMER, G. (1905a): Zur Kenntniss ausseuropäischer Trichopteren. Stetteniner Entomologische Zeitung, 66(1): 3-119.

Ulmer, G. (1905b): Trichoptera aus Java. Mitteilungen aus dem Naturhistorischem Museum in Hamburg, 22: 89-100.

Ulmer, G. (1907): Trichoptera. In: WyTSMAN, P. (Ed.) Genera Insectorum, 60: 1-259.

UlMER, G. (1909): Einige neue exotische Trichopteren. Notes from the Leyden Museum, 31: 125-142.

Ulmer, G. (1913): H. Sauter's Formosa-Ausbeute. Trichopteren. Entomologische Mitteilungen, 2(2): $48-50$.

Ulmer, G. (1930): Trichopteren von den Philippinen und von den Sunda-Inseln. Treubia, 11(4): 373498.

UlMER, G. (1951): Köcherfliegen (Trichopteren) von den Sunda-Inseln (Teil I). Archiv für Hydrobiologie, Supplement 19: 1-528.

WEAVER, J.S. III, \& NimMO, A.P. (1999): Fernand Schmid. Braueria (Lunz am See, Austria), 26: 7-18. 